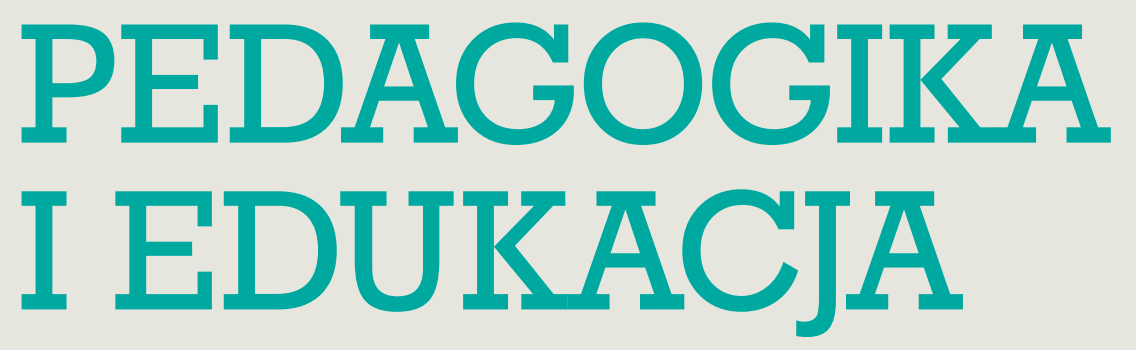
wobec kryzysu zaufania, wspólnotowości i autonomii

Redakcja naukowa Joanna Madalińska-Michalak Anna Wiłkomirska 


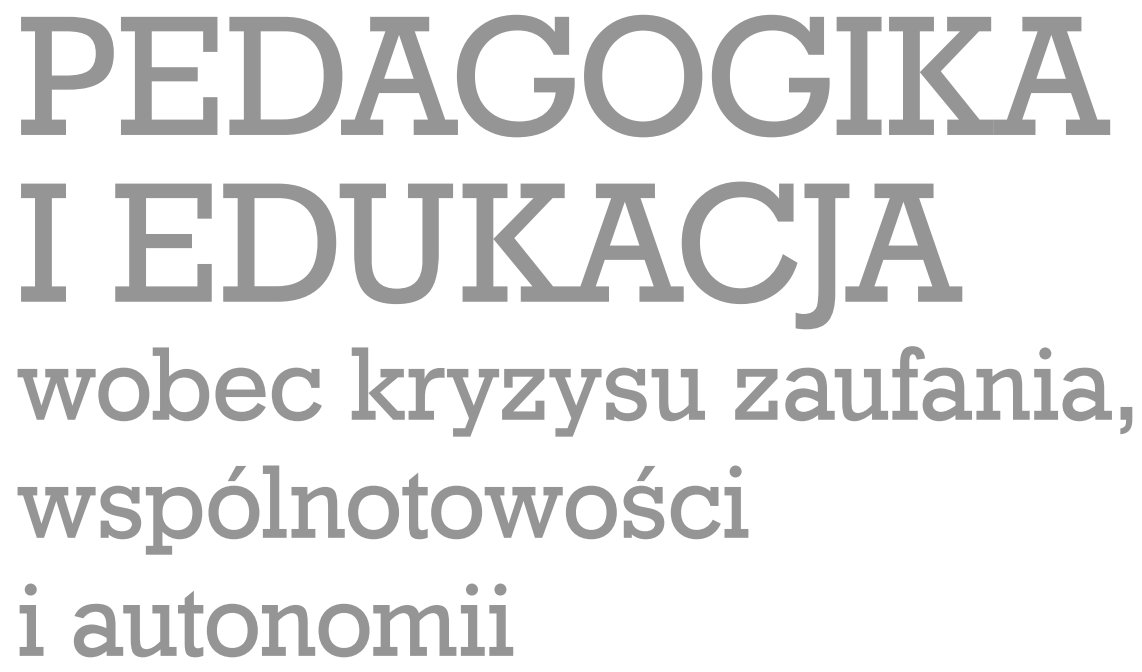





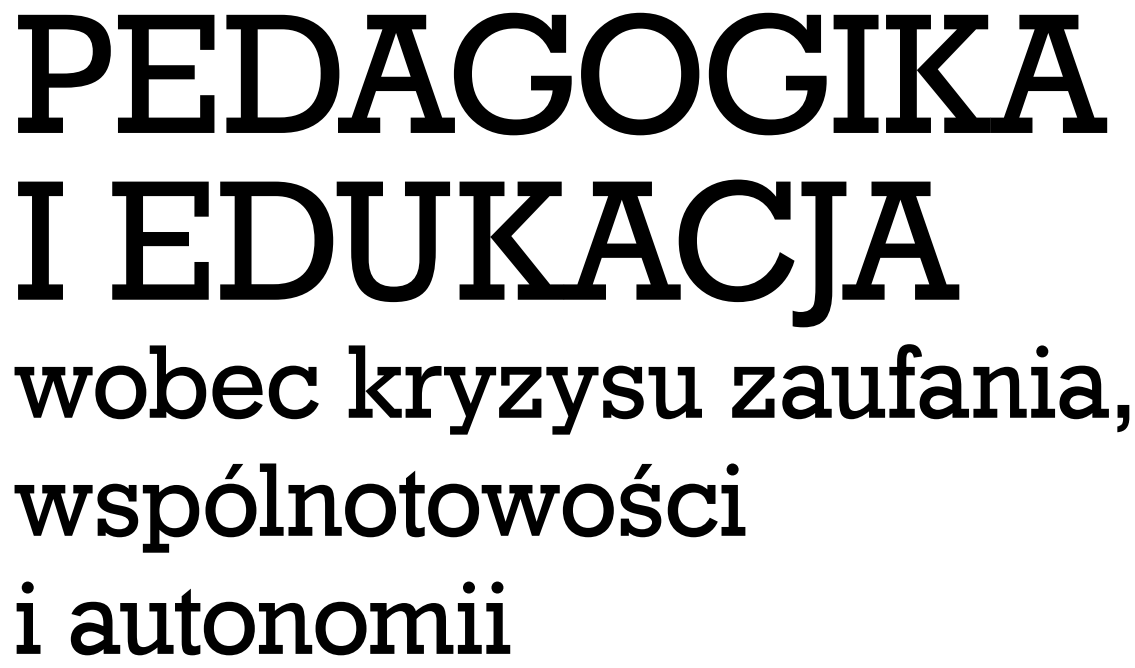

Redakcja naukowa

Joanna Madalińska-Michalak

Anna Wiłkomirska 
Recenzenci

Maria Czerepaniak-Walczak

Andrzej Radziewicz-Winnicki

Redaktor prowadzący

Ewa Wyszyńska

Redakcja

Monika Grucza-Nápoles

Korekta

Krystyna Komorowska

Projekt okładki i stron tytułowych

Anna Gogolewska

Ilustracja na okładce

SergeyZavalnyuk/istock

Skład i łamanie

Marcin Szcześniak

(C) Copyright by Wydawnictwa Uniwersytetu Warszawskiego, Warszawa 2020

Joanna Madalińska-Michalak ORCID 0000-0001-9980-6597

Anna Wiłkomirska ORCID 0000-0002-2413-245X

ISBN 978-83-235-4295-7 (druk) ISBN 978-83-235-4303-9 (pdf online)

ISBN 978-83-235-4311-4 (e-pub) ISBN 978-83-235-4319-0 (mobi)

Wydawnictwa Uniwersytetu Warszawskiego

00-838 Warszawa, ul. Prosta 69

e-mail:wuw@uw.edu.pl

księgarnia internetowa: www.wuw.pl

Wydanie 1, Warszawa 2020 


\section{Spis treści}

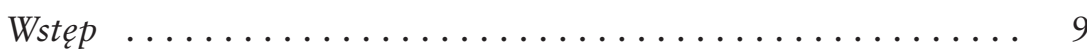

CZĘŚĆ PIERWSZA

\section{PEDAGOGIKA I EDUKACJA KU AUTONOMII, ZAUFANIU I WSPÓLNOTOWOŚCI}

Zbigniew Kwieciński „Wleczemy za soba dtugi ogon nie przezwyciężonej przesztości”. Pierwsza dekada . ............. 21

Joanna Madalińska-Michalak Odpowiedzialność za przyszte pokolenia: edukacja do autonomii . . . .............. 31

Andrzej Maciej Kaniowski Autonomia wyzwaniem dla naszej edukacji ...................... 48

Bogusław Śliwerski Pedagogika (braku) zanfania .......... 67

Urszula Ostrowska Edukacja wobec kryzysu zaufania. Spojrzenie $z$ perspektywy aksjologicznej .................. 79

Ryszard Maciej Łukaszewicz Edukacja wobec kryzysu zaufania, wspólnotowości i autonomii - która edukacja $i$ jaka? ...... 98

Teresa Hejnicka-Bezwińska Pamięć $i$ tradycja $w$ kulturze zaufania (vs. nieufności) ........................ 116

Krzysztof Maliszewski, Ewa Marynowicz-Hetka, Lech Witkowski Dziedzictwo idei i pęknięcia międzypokoleniowe w pedagogice polskiej (Postowie) .......................... 134

Tadeusz Pilch Myśl pedagogiczna i edukacja wobec anomii, bierności obywatelskiej, dysfunkcjonalności wtadzy i demokracji proceduralnej ........................ 153 
Małgorzata Kosiorek Pedagogiczno-spoleczne konteksty bierności obywatelskiej w III RP . . . . . . . . . . . . . . . . . . . . . 177

Renata Nowakowska-Siuta Odwaga dialogu, wspólnotowości $i$ sceptycyzmu. Uniwersytet $w$ obronie rudymentarnych wartości stanowiacych o jego (prze)trwaniu . . . . . . . . . . . . . 189

Stefan M. Kwiatkowski Prognozowanie rozwoju systemu edukacji w kontekście wyzwań natury globalnej . . . . . . . . . . . . 207

Anna Sajdak-Burska Budowanie kultury zaufania i wspólnotowości $w$ dydaktyce akademickiej . ................. 223

CZĘŚĆ DRUGA

\section{PODMIOTY EDUKACJI JAKO PRZEDMIOT BADAŃ I REFLEKSJI PEDAGOGICZNEJ}

Piotr Kostyło Leszka Kolakowskiego pojęcie charyzmatycznego nauczyciela . . . . . . . . . . . . . . . . . . . . . . . . . . 249

Rafał Piwowarski Czy praca nauczycieli jest ceniona? . . . . . . 267

Izabella Kust Misja nauczyciela szkoly zawodowej . . . . . . . . 287

Anna Zielińska Mtody nauczyciel w szkole. Problemy związane z rozwojem kompetencji i autonomii ............... 308

Marta Porembska Prawo dziecka do kontaktów z obojgiem rodziców a konflikt okotorozwodowy . . . . . . . . . . . . 326

Alicja Zagrodzka Rodzice $w$ kryzysie matżenskim na warsztatach umiejętności wychowawczych - szanse i zagrożenia ....... 346

Anna Gawel-Mirocha Twórcze dziatania w pracy z dziećmi z cechami osobowości narcystycznej izolowanymi rówieśniczo jako sprawcami i ofiarami przemocy rówieśniczej . . . . . . . . . . 380

Jacek Pyżalski, Agnieszka Cybal-Michalska, Natalia Walter, Mateusz Marciniak, Sylwia Jaskulska, Ewa Karmolińska-Jagodzik Picie alkoholu i zaburzenia zwiazane z piciem alkoholu u polskich studentów - kilka ważnych wyników reprezentatywnych badań . . . . . . . . . . . . . . . . . . . . . . . . . . . . . . . . . . 397

Małgorzata Orłowska Czas wolny jako środowisko życia . . . . 413

Katarzyna Białożyt Edukacja kobiet w okresie późnej starości . . 425 
CZĘŚĆ TRZECIA

\section{REFLEKSJE METODOLOGICZNE}

Dariusz Kubinowski Trajektorie legitymizacji naukowej innowacyjnych metod pedagogicznych badań jakościowych: badanie $w$ dziataniu, badanie przez sztuke, autoetnografia . . . . . 443

Jarosław Gara Problematyczność recepcji metody fenomenologicznej $i$ jej stosowalności $w$ badaniach pedagogicznych . . . . . . . 457

Rafał Włodarczyk Rozumienie jako przekład. Wokól koncepcji hermeneutyki George'a Steinera ................. 474

Stanowisko X Ogólnopolskiego Zjazdu Pedagogicznego wobec następstw zmian $w$ oświacie ................... 491 



\section{Wstęp}

Kryzys może być punktem zwrotnym zarówno w życiu człowieka, jak i w życiu instytucjonalnym, społecznym, politycznym czy gospodarczym. Kryzys oznacza zetknięcie się z nieznanymi okolicznościami, wymagającymi decyzji o podjęciu konkretnych działań, przy braku pewności czy będą skuteczne w przezwyciężaniu sytuacji kryzysowej. Kryzysy bywają nagłe, mogą być też rezultatem długotrwałych zaniechań, zaniedbań czy wielu skumulowanych błędnych decyzji. Kryzysy w życiu społecznym mają najczęściej trudno odwracalne skutki. Kryzysy w edukacji mogą mieć poważne konsekwencje odczuwane przez kolejne pokolenia. Dlatego badania i refleksja nad tym zjawiskiem są imperatywem dla przedstawicieli nauk humanistycznych i społecznych, a pedagogów w szczególności.

Dyskurs kryzysu ma długą historię w naukach humanistycznych i społecznych. Nadużywanie terminu kryzys może osłabiać jego dramatyczną konotację, wskazywać na pewną naturalność w makro-, mezo- i mikrostrukturach i tym samym w relacjach społecznych oraz stępiać wrażliwość społeczną, która powinna ujawniać się zarówno w dociekaniu przyczyn, przejawów, przebiegu, jak i następstw kryzysu. Brak tej wrażliwości może prowadzić do niedostrzegania zagrożeń i niebezpieczeństw płynących z kryzysu lub do świadomej rezygnacji ze zmierzenia się z wyzwaniami, które stawia nam sytuacja kryzysowa.

Traktujemy jednak używanie terminu kryzys jako uzasadnione w obecnej sytuacji społeczno-politycznej w Polsce (i nie tylko). Skutki każdego kryzysu, w szczególności społecznego, mogą być poważne. Często prowadzą do trudno odwracalnych lub wręcz nieodwracalnych zmian w wielu dziedzinach życia, do destrukcji 
porządku społecznego, a nierzadko do stanu anomii lub głębokich konfliktów. Negatywne konsekwencje sytuacji kryzysowej mogą dotyczyć też jednostek, które tracą oparcie w dotychczasowym ładzie. Pojawiają się niekorzystne dla ich funkcjonowania uczucia lęku, braku zaufania do innych oraz dezorientacji, rezygnacji czy nawet alienacji. $Z$ drugiej strony brak zgody na przyczyny bądź następstwa sytuacji kryzysowej może być bodźcem do działania na rzecz jej przezwyciężenia. Kryzys skłania przede wszystkim do namysłu nad wartościami, które zostają zakwestionowane. Obrona priorytetów moralnych wymusza działania o charakterze protestu, akceptacja zmiany prowadzić może do reorientacji etycznej jednostek i grup społecznych.

Wspólnotowość nie może istnieć bez więzi społecznej. Więzi opartej na przyjaźni, lojalności, solidarności i wzajemnej trosce. Klasycy socjologii, August Comte, Florian Znaniecki czy Stanisław Ossowski łączą jednoznacznie więź ze współdziałaniem. Pedagodzy są dzisiaj zgodni, że sztuka współdziałania to kluczowa umiejętność człowieka, a jej rozwijanie to jeden z najważniejszych celów edukacji. Uczenie się współdziałania może odbywać się tylko w warunkach wzajemnego szacunku, zaufania i dialogu, zakładającego autonomiczność współuczestników danej sytuacji.

Zarząd Główny Polskiego Towarzystwa Pedagogicznego podjął decyzję, aby jubileuszowy X Ogólnopolski Zjazd Pedagogiczny odbył się w dniach od 18 do 20 września 2019 r. w Warszawie. Zjazd został zorganizowany przez Polskie Towarzystwo Pedagogiczne we współpracy z Wydziałem Pedagogicznym Uniwersytetu Warszawskiego i Akademią Pedagogiki Specjalnej im. Marii Grzegorzewskiej w Warszawie. Wiodące hasło Zjazdu brzmiało „Pedagogika i edukacja wobec kryzysu zaufania, wspólnotowości i autonomii". Tak sformułowany temat orientował dyskusje podejmowane w trakcie obrad plenarnych, obrad w sekcjach problemowych i sympozjów. Postawiona w tytule Zjazdu teza o kryzysie zaufania, wspólnotowości i autonomii stanowiła wyraz głębokiej troski pedagogów o polskie społeczeństwo, a zwłaszcza jego młode pokolenia, które doświadczają, w sposób nie zawsze świadomy, życia w warunkach podziałów społecznych i destrukcji wspólnoty obywatelskiej w dyskursie, w którym pojawia się pogarda i nienawiść do innych. $Z$ jednej strony miała to więc być próba zdiagnozowania sytuacji, choć oczekiwania szły także w kierunku nakreślenia sposobów poradzenia sobie z sytuacją kryzysową w każdej z grup społecznych partycypujących w polskiej edukacji. 
Warto zaznaczyć, iż Polskie Towarzystwo Pedagogiczne zostało powołane do życia w 1981 r. i od początku swojego istnienia wpisuje się w działania społecznego ruchu naukowego, który jest integralną częścią systemu nauki polskiej. Niemal czterdziestoletnia działalność PTP potwierdza wartość przyjętego przez założycieli Towarzystwa kierunku działania, skoncentrowanego na inspirowaniu i prowadzeniu badań pedagogicznych zmierzających do poznania dorobku myśli pedagogicznej polskiej i obcej, rozwijaniu nauk pedagogicznych oraz doskonaleniu systemu edukacji $\mathrm{w}$ Polsce. U podstaw tego działania leży idea rozpowszechniania w szerokich kręgach społeczeństwa naukowych ustaleń dotyczących kształcenia i wychowania oraz promowania - nie tylko w środowisku pedagogicznym, ale w całym społeczeństwie - wartości demokratycznych, przyczynianie się do budowania dojrzałego społeczeństwa obywatelskiego, opartego na wzajemnej przychylności, szacunku i otwartości na dialog. Polskie Towarzystwo Pedagogiczne organizuje od 1993 r. Ogólnopolskie Zjazdy Pedagogiczne, które stały się trwałą instytucją i ważnymi punktami orientacji we współczesnej pedagogice. I Zjazd odbył się w dniach 10-12 luty 1993 r. w Rembertowie pod Warszawą i obradował pod hasłem: „Ewolucja tożsamości pedagogiki”. Został on zorganizowany przez Polskie Towarzystwo Pedagogiczne we współpracy z Wydziałem Pedagogicznym Uniwersytetu Warszawskiego i Akademią Obrony Narodowej.

Zjazdy są spotkaniami tematycznymi, dotyczącymi istotnych problemów edukacyjnych. Mają za zadanie nadać impet dalszemu rozwojowi pedagogiki oraz przybliżyć jej obraz szerokim kręgom odbiorców. Pokłosiem kolejnych Zjazdów są publikacje w postaci ksiąg zjazdowych, w których zamieszczane są teksty referatów reprezentatywne dla problematyki zjazdowej.

X Ogólnopolski Zjazd Pedagogiczny był Zjazdem jubileuszowym. Zjazdem, podczas którego w jednym miejscu spotkali się ci, których dorobek zapewnił im już miejsce w historii polskiej pedagogiki, wraz z tymi, którzy dopiero wchodzą w świat pedagogiki. Ten jubileuszowy Zjazd organizowany był z nadzieją, podobnie jak poprzednie, że przyczyni się do konsolidacji polskiego środowiska pedagogicznego i jego rozwoju, a także wniesie istotny merytoryczny wkład w rozwój pedagogiki, a tym samym w rozwój polskiej nauki. Zjazd niejako z założenia skłaniał do namysłu nad upływającym czasem, współczesnością i edukacją we współczesnym nam świecie - w świecie, w którym teraźniejszość 
jest rozciągnięta w czasie i stanowi przedmiot badań pedagogicznych - i nad tym, co niesie nam przyszłość. Wszakże człowiek żyje nie tylko dzięki historyczności, lecz także ją współtworzy, kształtując swoją rzeczywistość; człowiek może również kształtować myślenie o przyszłości i zmieniającym się świecie. Troska o przyszłość wymaga edukacji, u podstaw której leży pedagogika interakcji między rozbudzaniem mikroświatów ludzkich osobowości a uwrażliwianiem na odpowiedzialność wobec współtworzonego makroświata. Przeobrażenia, jakich jesteśmy świadkami, jeszcze bardziej akcentują oczywistą odpowiedzialność historyczną człowieka, który jest usytuowany w czasie - ma swoją przeszłość, teraźniejszość i przyszłość. W obliczu coraz większej złożoności otaczającego nas świata w sposób szczególny pojawia się aktualność pytania o odpowiedzialność za przyszłość.

Zarząd Główny Polskiego Towarzystwa Pedagogicznego przyjmując temat przewodni X Ogólnopolskiego Zjazdu Pedagogicznego, stał na stanowisku, iż w warunkach toczących się zmian $\mathrm{w}$ świecie społecznym, politycznym, ekonomicznym i kulturowym Polski, w kontekście pojawiających się kryzysów i konfliktów w coraz bardziej złożonej rzeczywistości, należy podjąć refleksję nad wyzwaniami, które stoją przed pedagogiką i edukacją, oraz namysł nad złożonymi uwarunkowaniami różnorodnych przejawów kryzysu zaufania, wspólnotowości i autonomii, jak i nad ich przezwyciężaniem. Źródła omawianego kryzysu niewątpliwie lokują się w sferze polityki i obozu władzy. Decyzje, które mają istotny wpływ na edukację, zapadają niezależnie od głosu ekspertów i wszystkich pracujących codziennie na rzecz edukacji. Edukacja - jako jeden z najistotniejszych obszarów życia społecznego - jest narażona szczególnie na erozję wynikającą z kryzysu. Obserwowane zawłaszczanie edukacji wynikające z interesów politycznych prowadzi do odzwierciedlania w niej symptomów kryzysu: podziałów, wrogości, nieufności, rozbicia więzi - które dla rozwoju młodych ludzi są szczególnie ważne. Oczywiście te same mechanizmy destrukcji pojawiają się w gronie nauczycieli, którym odbiera się autonomiczność (jak mają ją rozwijać u uczniów?), a których protesty traktuje się jako antyspołeczne (jak mają rozwijać postawy wspólnotowe i obywatelskie w szkole?).

Panoptyczne wizje instytucji edukacyjnych czy kulturalnych, charakterystyczne dla reżimów totalitarnych, są nie do zaakceptowania przez pedagogów. Powszechnie dziś znane i szeroko 
stosowane pojęcie przemocy symbolicznej Pierre'a Bourdieu (1990) należałoby sparafrazować, określając je jako polityczną przemoc symboliczną, zbliżając się tym samym do wizji foucaultowskiego represyjnego modelu instytucji nadzoru, jaką stałaby się wtedy szkoła. Nam zależy na edukacji rozwijającej kapitał społeczny, kapitał ludzki, współdziałanie, przyjacielskie więzi, troskę o siebie i innych, niezależnie od różnic nas dzielących.

U podstaw edukacji dążącej do tych celów powinny leżeć, jak trafnie pisze Zbigniew Kwieciński, „zdolności do samodzielnego wyboru i krytycznego osądu, do bycia odrębną osobą, odpowiedzialną za zgodność swoich zachowań wobec przyjętych uniwersalnych zasad etycznych, a zarazem działającą dla dobra wspólnot" (Kwieciński 2019: 43). Tak rozumiana edukacja powinna być postrzegana

jako zadanie i wyzwanie współczesności, zaś decydująca rola w realizacji tego zadania przypadać powinna nauczycielom, a dokładnie rzecz ujmując nam wszystkim. Przy czym jakość realizacji tego zadania z pewnością zależy w dużej mierze od postawy - od tego, czy pokolenie odpowiedzialne za przyszłe pokolenia będzie podejmowało działania, czy też będzie w przyszłości czynione odpowiedzialnym za zaniechania (zob. Madalińska-Michalak 2019a).

Zarząd Główny Polskiego Towarzystwa Pedagogicznego dla dobrej organizacji Zjazdu zarówno od strony merytorycznej, jak i organizacyjnej powołał Komitet Naukowy, Komitet Programowy i Komitet Organizacyjny Zjazdu. Komitet Naukowy tworzyli: prof. dr hab. Stefan M. Kwiatkowski, prof. dr hab. Zbigniew Kwieciński, prof. dr hab. Joanna Madalińska-Michalak, prof. dr hab. Bogusław Śliwerski i prof. dr hab. Anna Wiłkomirska. W skład Komitetu Programowego weszli: prof. dr hab. Maria Czerepaniak-Walczak, przewodnicząca, dr hab. Joanna Ostrouch-Kamińska, prof. UWM, wieceprzewodnicząca, oraz osoby odpowiedziane za prace poszczególnych Sekcji - obszarów problemowych, a byli to: prof. dr hab. Bogusław Śliwerski, prof. dr hab. Mirosław J. Szymański, prof. dr hab. Joanna Madalińska-Michalak, dr hab. Piotr Kostyło, prof. UKW, prof. dr hab. Agnieszka Cybal-Michalska, prof. dr hab. Maria Kolankiewicz, prof. dr hab. Ewa Ogrodzka-Mazur, prof. dr hab. Stefan M. Kwiatkowski, prof. dr hab. Magdalena Piorunek, prof. dr hab. Anna Wiłkomirska, prof. dr hab. Zbyszko Melosik, prof. dr hab. Krzysztof Rubacha i prof. dr hab. Dariusz Kubinowski. 
Zjazd odbył się dzięki jego sprawnej organizacji. Na czele Komitetu Organizacyjnego stała prof. dr hab. Anna Wiłkomirska. W skład Komitetu Organizacyjnego wchodzili: dr Marta Pietrusińska, dr Sylwia Galanciak, dr Dorota Jankowska, dr Halina Rotkiewicz, dr Katarzyna Białożyt, dr Monika Gromadzka i mgr Anna Szewczyk. X Ogólnopolski Zjazd Pedagogiczny został poprzedzony Akademią Młodych Naukowców Polskiego Towarzystwa Pedagogicznego. Akademia stanowiła część integralną Zjazdu. Obrady Akademii odbyły się 17 września 2019 r. Miejscem obrad była Akademia Pedagogiki Specjalnej im. Marii Grzegorzewskiej w Warszawie. Uczestnikami Akademii Młodych Naukowców byli adepci pedagogiki z polskich ośrodków naukowych oraz przedstawiciele Letniej Szkoły UNESCO, wśród której znaleźli się naukowcy z Indii, Albanii, Rosji, Argentyny, Mołdawii, Nigerii, Kanady, Stanów Zjednoczonych, Ukrainy, Turcji oraz Szwajcarii.

W ramach X Ogólnopolskiego Zjazdu Pedagogicznego przewidziano prezentacje w różnych formach. Zgodnie z tradycją Zjazdów zaproponowano wykłady plenarne, sesje tematyczne i sesję posterową oraz wprowadzono, jako nową formę debaty zjazdowej, sympozjum specjalne. W sumie wygłoszono 13 wykładów plenarnych, w tym trzy wykłady jubileuszowe, odbyły się obrady w 7 sesjach tematycznych i w 8 sympozjach specjalnych (zob. Madalińska-Michalak 2019: 173). Ponadto zrealizowana została interaktywna sesja posterowa. Pierwszego dnia Zjazdu wykłady jubileuszowe wygłosili: prof. dr hab. Zbigniew Kwieciński: „Wleczemy za sobą ogon nieprzezwyciężonej przeszłości. Pierwsza dekada”, prof. dr hab. Bogusław Śliwerski „Pedagogika (bez) zaufania” i prof. dr hab. Joanna Madalińska-Michalak „Odpowiedzialność za przyszłe pokolenia: edukacja do autonomii”. W trakcie drugiego i trzeciego dnia obrad uczestnicy Zjazdu mogli wysłuchać wykładów plenarnych, które odbywały się w dwóch równoległych sesjach. Wśród zaproszonych do wygłoszenia wykładów byli zarówno Profesorowie, którzy aktywnie uczestniczyli w tworzeniu historii Ogólnopolskich Zjazdów Pedagogicznych, w tym Profesorowie, którzy brali udział w I Ogólnopolskim Zjeździe Pedagogicznym w 1993 r., jak i przedstawiciele młodego pokolenia naukowców. W trakcie drugiego dnia Zjazdu swoje wykłady wygłosili: prof. dr hab. Zbyszko Melosik: „Książka jako ,złoty standard' w naukach humanistycznych i społecznych”, prof. dr hab. Tomasz Szkudlarek: „No Future. Drogi wyjścia, linie 
ucieczki i teraźniejszość jako międzywojnie”, prof. dr hab. Stefan Michał Kwiatkowski: „Prognozowanie rozwoju systemu edukacji w kontekście wyzwań natury globalnej”, prof. dr hab. Tadeusz Pilch: „Myśl pedagogiczna i edukacja wobec anomii, bierności obywatelskiej, dysfunkcjonalności władzy i demokracji proceduralnej” oraz prof. nadzw. dr hab. Andrzej Maciej Kaniowski: „Autonomia wyzwaniem dla naszej edukacji”. W trzecim dniu Zjazdu wykłady wygłosili prof. dr hab. Iwona Chrzanowska: „O czym się nie mówi w kontekście edukacji włączającej - perspektywa (nie tylko) pedagogiki specjalnej”, dr hab. Roman Dolata, prof. UW: „Czy genetyka zachowania trafnie szacuje wpływ szkoły na osiągnięcia szkolne, czyli o nieoczekiwanym pożytku poznawczym z gimnazjalnego eksperymentu", dr hab. Anna Sajdak-Burska: „Budowanie kultury zaufania i wspólnotowości w edukacji akademickiej”, prof. dr hab. Teresa Hejnicka-Bezwińska: „Pamięć i tradycja w przezwyciężaniu kryzysu zaufania i wspólnotowości w praktyce edukacyjnej” i prof. dr hab. Ryszard Maciej Łukaszewicz: „Edukacja wobec kryzysu zaufania, wspólnotowości i autonomii - która i jaka edukacja?”. Każdemu z wygłoszonych wykładów towarzyszyła dyskusja z udziałem uczestników Zjazdu. W ramach dyskusji stawiano nie tylko pytania służące poszerzeniu spektrum treści wykładów, ale też wskazywano na kolejne problemy związane $z$ wykładanymi zagadnieniami.

Z satysfakcją możemy uznać, iż Jubileuszowy X Ogólnopolski Zjazd Pedagogiczny, obradujący nad niezwykle ważnym tematem, wzywał do tego, aby z należytą wnikliwością i wrażliwością podjąć dyskusję nad edukacją i światem życia jednostki, jej otoczeniem społecznym, kulturowym oraz politycznym - na bliższą i dalszą skalę. Zjazd stanowił wyjątkową wręcz okazję do refleksyjnego i odpowiedzialnego rozprawiania o pedagogice i edukacji, o roli pedagogów we współczesnym, jakże złożonym świecie, z pełną świadomością pojawiających się różnic w podejściu do rozmaitych spraw dotyczących kondycji pedagogiki i edukacji w Polsce.

X Ogólnopolski Zjazd Pedagogiczny, podobnie jak poprzednie Zjazdy, stanowił wydarzenie o szczególnej randze. Był spotkaniem uczonych, przed którymi stoją tak istotne zadania, jak chociażby:

- „budowanie naukowych podstaw dla rozwiązywania problemów ważnych dla pedagogiki;

- uczestniczenie w umacnianiu intelektualnej debaty nad pedagogiką, jej statusem i prowadzonymi w jej obrębie badaniami; 
- rozwijanie wiedzy o edukacji i wzmacnianie praktyki edukacyjnej, wspieranie rozwoju edukacji - edukacji sprzyjającej autonomii i uspołecznieniu, samodzielności myślenia i zdolności do współdziałania" (Madalińska-Michalak 2019b: 175).

Zjazd, stanowiąc forum wymiany myśli naukowej oraz współdziałania ludzi nauki i oświaty, umożliwił czynny udział w dyskusji przedstawicielom wszystkich subdyscyplin pedagogicznych i nauk pokrewnych pedagogice z różnych ośrodków naukowo-badawczych oraz stworzył szansę spotkania i poznania znanych teoretyków i praktyków edukacji. Zjazd z pewnością sprzyjał integracji środowiska pedagogicznego, otwarciu się na różne środowiska oraz współpracy z nimi. Był wyjątkową okazją do pokazania dorobku naukowego oraz okazał się doskonałą przestrzenią dla głosu pedagogów w debacie publicznej - uczestnicy Zjazdu przyjęli Stanowisko wobec następstw zmian w oświacie. Stanowisko zgromadzonych na X Ogólnopolskim Zjeździe Pedagogicznym zostało skierowane do najwyższych władz Rzeczypospolitej Polskiej: Prezydenta, Parlamentu i Rządu z apelem o podjęcie działań uzdrawiających polską oświatę. Zamieszczamy je w tym tomie.

Niniejszy tom zatytułowany Pedagogika i edukacja wobec kryzysu zaufania, wspólnotowości i autonomii jest zbiorem tekstów, które były przedmiotem dyskusji podczas obrad Zjazdu. Wśród tekstów znajdują się przygotowane na potrzeby tej publikacji referaty jubileuszowe, wystąpienia plenarne oraz wybrane referaty z sekcji tematycznych, sympozjów, a także jeden referat wybrany z Akademii Młodego Naukowca Polskiego Towarzystwa Pedagogicznego.

W tomie, do którego lektury zapraszamy, Czytelnik znajdzie artykuły, które - jak zakładamy - w sposób interesujący i pogłębiony rozważają bardzo aktualne problemy nie tylko z zakresu pedagogiki, ale także nauk z nią pokrewnych. Artykuły te dobrze odzwierciedlają zainteresowanie środowiska naukowego dyskusją na temat kryzysu zaufania, wspólnotowości i autonomii, a wraz z tym kondycję teoretycznej refleksji nad pedagogiką i edukacją, nad prowadzonymi w ramach pedagogiki badaniami i sposobami naukowego poznawania świata. Kształtowanie życia wartościowego, życia, które łączy dobro własne i osobiste spełnienie z regułami przyzwoitości, troski i miłości wobec drugiego człowieka, czynienie naszego społeczeństwa bardziej spójnym, solidarnym i otwartym, wymaga badań naukowych, wymiany poglądów, uczenia się od siebie nawzajem, w tym nowego spojrzenia na tytułową problematykę niniejszej monografii. 
Tom składa się z trzech zasadniczych części. Pierwsza zawiera teksty napisane przez profesorów wygłaszających wykłady jubileuszowe, plenarne oraz zawierające analizy i refleksje nad kontekstami kryzysu zaufania, wspólnotowości i autonomii. W drugiej części znajdują się artykuły wybrane z poszczególnych sekcji. Obrazują one różnorodność zainteresowań pedagogów z wielu uczelni. Trzecia część poświęcona została refleksji metodologicznej nad badaniami jakościowymi stosowanymi w dyscyplinach humanistycznych, naukach o kulturze i filozofii oraz ich wykorzystaniem w pedagogice.

Mamy nadzieję, że niniejszy tom przyczyni się do lepszego zrozumienia stanu dzisiejszej refleksji z zakresu pedagogiki, jak również rzuci nowe światło na niezmiernie ważny problem kryzysu zaufania, wspólnotowości i autonomii oraz sposobów jego przezwyciężania we współczesnym świecie. Jeśli rzeczywiście tak się stanie, to nasze przedsięwzięcie uznamy za sukces. Ocena przedsięwzięcia zależy jednak już od wnikliwości i życzliwości tych, którzy poświęcą swój czas, by zapoznać się z prezentowanymi w tym tomie materiałami.

Bardzo gorąco dziękujemy wszystkim autorom tekstów niniejszego tomu za ich przygotowanie oraz za intensywną współpracę $\mathrm{z}$ nami nad ich publikacją.

Joanna Madalinska-Michalak, Anna Witkomirska, Stefan M. Kwiatkowski

Warszawa 2020

\section{Bibliografia}

Bourdieu P., Passeron J.-C. (1990), Reprodukcja. Elementy teorii systemu nauczania, tłum. E. Neyman, PWN, Warszawa.

Kwieciński Z. (2019), Edukacja w galaktyce znaczeń, [w:] Z. Kwieciński, B. Śliwerski (red.), Pedagogika. Podreccznik akademicki, PWN, Warszawa.

Madalińska-Michalak J. (2019a), Odpowiedzialność za przyszłe pokolenia. Edukacja do autonomii, Referat jubileuszowy wygłoszony w trakcie otwarcia X Ogólnopolskiego Zjazdu Pedagogicznego „Pedagogika i edukacja wobec kryzysu zaufania, wspólnotowości i autonomii”, 18 września 2019, Warszawa.

Madalińska-Michalak J. (2019b), X Ogólnopolski Zjazd Pedagogiczny „Pedagogika i edukacja wobec kryzysu zaufania, wspólnotowości i autonomii”, Warszawa, 18-20.09.2019 r., „Forum Oświatowe”, t. 31, nr 1, s. 169-176. 



\section{CZĘŚĆ PIERWSZA}

\section{PEDAGOGIKA I EDUKACJA KU AUTONOMII, ZAUFANIU I WSPÓLNOTOWOŚCI}





\title{
„Wleczemy za sobą długi ogon nie przezwyciężonej przeszłości”. Pierwsza dekada ${ }^{1}$
}

\author{
Abstract \\ We drag the long tail of the unconquerable \\ past behind us. The first decade
}

In the opening speech of the 10th National Pedagogical Congress, the activity of the Polish Educational Research Association was acknowledged. In the first decade after 1989, under the direction of Professor Mikołaj Kozakiewicz Polish Educational Research Association was to build education for the expected state's democratic system transformation. However, already in 1993, prof. M. Kozakiewicz warned against the possibility of a recurrence of totalitarianism as a result of the lack of social ability to overcome old habits of thinking and acting. The 10th Congress is a new call to continue efforts to shape critical and active citizenship.

Keywords: education for democracy, permanent mission of the Polish Educational Research Association

Słowa kluczowe: edukacja dla demokracji, stała misja Polskiego Towarzystwa Pedagogicznego

Polskie Towarzystwo Pedagogiczne powstało wiosną $1981 \mathrm{r}$. $\mathrm{Na}$ II posiedzeniu plenarnym Zarządu Głównego Polskiego Towarzystwa Pedagogicznego w dniu 23 października 1981 r. jego pierwszy przewodniczący prof. Mikołaj Kozakiewicz wygłosił obszerny referat programowy pt. Kryzys ekonomiczno-spoteczny Polski a problemy wychowania, po czym Zarząd Główny przyjął

1 Wystąpienie na otwarciu X Ogólnopolskiego Zjazdu Pedagogicznego 18 września 2019 r. Tytuł wystąpienia nawiązuje do sformułowania Mikołaja Kozakiewicza (Kozakiewicz 1994: 92). 
uchwałę, wykorzystującą treść tego wystąpienia. Dokumenty te zostały później opublikowane w pierwszym numerze Biuletynu Polskiego Towarzystwa Pedagogicznego z 1983 r. (s. 6-22).

Kozakiewicz mówił, że przeżywamy „katastrofalny kryzys społeczno-ekonomiczny kraju”, że znajdujemy się na „dnie ekonomicznego upadku":

Dokuczliwość życia z kryzysem czy życia w kryzysie jest tak wielka, iż kłopoty zaopatrzeniowe, materialne, wyżywieniowe przesłaniają większości ludzi rozmiary i niebezpieczeństwa kryzysu wychowawczego, którego skutki mogą okazać się długotrwalsze od braków mięsa, proszków do prania, czy rajstop.

Co więcej, kryzys ekonomiczny sprawia, że równolegle do walk i starań odnowieńczych (także o odnowę moralną), po sierpniu 1980 roku narastają procesy demoralizacji, wykolejania się młodych ludzi, rośnie przestępczość nieletnich, w twardej i coraz twardszej walce o byt i przetrwanie umacniają się postawy egoistyczne, kombinatorskie, coraz mniej życzliwe wobec słabszych, starych i niepełnosprawnych (Kozakiewicz 1983: 7).

Za ten kryzys wychowawczy nie można obwiniać ludzi i procesów odnowy. Został on wywołany polityką lat 70., w której „minimalną wagę przypisywano problematyce ideowo-moralnej, przy zachowaniu ideologicznego rytuału i ideowo-moralnej frazeologii” (Kozakiewicz 1983: 8), kiedy dominował „system działań oraz instytucji pozornych", a posunięcia władzy poddawane były pod „rzekomą ocenę społeczną” i „konsultacje”, których wynikiem było zawsze potwierdzenie słuszności wcześniej podjętych decyzji władz. Nasze naukowe diagnozy ostrzegawcze dotyczące możliwych głębokich skutków anomii moralnej i alienacji społecznej były cenzurowane i lekceważone - konkluduje Kozakiewicz (Kozakiewicz 1983: 11).

W „okresie gwałtownego zwrotu politycznego" zjawiska demoralizacji młodzieży nasiliły się, zwłaszcza że w naszym społeczeństwie zarysowały się głębokie podziały od makroskali aż do społeczności lokalnych i wewnątrz rodzin. Coraz częściej frustracje młodzieży przeradzają się w agresję, przestępczość, uzależnienia. Nauczyciele, mimo tego, iż wielu z nich zdobyło wyższe wykształcenie, okazali się w większości nieprzygotowani do tych nowych wyzwań wychowawczych. Kozakiewicz nawołuje zatem:

Jako PTP będziemy usilnie starać się szukać dróg wyjścia z kryzysu. Stawką jest młodzież, która znalazła się w wielorakim zagrożeniu 
materialnym, zdrowotnym, życiowym i moralnym. Tylko część z nich szuka rozwiązania własnych problemów poprzez włączanie się w różnych formach do działań na rzecz odnowy i naprawy rzeczywistości. Wielu z nich szuka raczej ucieczki od tych problemów. Jest to coraz częściej niestety fizyczna ucieczka najlepiej wykształconej i najbardziej rzutkiej młodzieży za granicę, w ramach emigracji zarobkowej (Kozakiewicz 1983: 17).

Polskie Towarzystwo Pedagogiczne, jak podkreśla jego przewodniczący, powinno skupić się na tworzeniu solidnych podstaw systemowych reform oświaty i wychowania, łącząc wysiłki badawcze z wykorzystaniem nowatorskich osiągnięć praktyków, a zarazem

przeciwstawiać się wszelkim pochopnym próbom reformowania wychowania bez dogłębnej naukowej zasadności projektów i propozycji wysuwanych w postaci postulatów i żądań przez różne kręgi społeczne, jak też podejmowanych przez władze szkolne w odpowiedzi na te postulaty. Uważamy bowiem, że cele i metody wychowania nie mogą być rezultatem doraźnych rozgrywek [politycznych - uzup. Z.K.] (Kozakiewicz 1983: 18).

W Uchwale II Plenum ZG PTP z 23 października 1981 r. powtórzone zostały w skrócie tezy wystąpienia Kozakiewicza z silnym zaakcentowaniem konieczności wspólnych działań naukowych i praktycznych na rzecz odnowy oświaty i wychowania w Polsce: "Jest oczywiste, że nie ma szans na radykalną poprawę szkolnictwa i wychowania szkolnego i rodzinnego bez radykalnej naprawy rzeczywistości społecznej, w której to wychowanie przebiega" (ZG PTP 1983b: 19). Zarazem jednak tak kultura, jak oświata i wychowanie „należą do podstawowych narzędzi wychodzenia z kryzysu, przywracania stosunkom społecznym równowagi, a ludziom poczucia godności i dumy z przynależności do własnego narodu” (ZG PTP 1983b: 19).

Środowiska pedagogów powinny upominać się o to, by

wszystkie poczynania reformatorskie i odnowicielskie stwarzały strukturalne i instytucjonalne gwarancje dla pełnego wcielania w rzeczywistości społecznej takich wartości jak: sprawiedliwość i równość, wolność jako niezbędna przesłanka wszechstronnego rozwoju ludzi, ich samorealizacji i ekspresji, tolerancja i poszanowanie prawa ludzi do odrębnego zdania, nieskrępowane prawo do szukania prawdy i dostęp do jej źródeł (ZG PTP 1983b: 20). 
Towarzystwo nasze apeluje zarówno do władz, jak i do ruchu związkowego o nadanie sprawom młodzieży priorytetowego charakteru we wszystkich programach wyjścia z kryzysu oraz o nieczynienie spraw młodzieży terenem przetargów i próby sił, lecz przeciwnie - intensywnego współdziałania i współpracy (ZG PTP 1983b: 21).

W początkowym okresie stanu wojennego, 22 kwietnia 1982 r., Zarząd Główny ogłosił List otwarty Polskiego Towarzystwa Pedagogicznego do pracowników nankowych i nauczycieli (ZG PTP 1983a), w którym powtórnie wezwaliśmy pracowników naukowych i nauczycieli do pracy nad założeniami systemowej reformy oświaty i wychowania, podkreślając, że „stan wojenny, sam przez się niczego nie rozwiązuje, bo nie może rozwiązać żadnego z nabrzmiałych w ciągu lat ekonomicznych, politycznych, społecznych i oświatowych problemów naszego kraju” (ZG PTP 1983a: 23).

„Sytuacja oświaty i wychowania jest zbyt poważna, aby sobie pozwolić na bierność i wyczekiwanie”, należy „robić wszystko, co można, aby przygotować się do wyjścia ze stanu wojennego i przygotować przedpole dla działalności dla dobra młodzieży, nauczycielstwa i nauki polskiej” (ZG PTP 1983a: 23).

W następnych latach Zarząd Główny PTP pozyskał środki na badania i studia $\mathrm{w}$ ramach problemu węzłowego $11.4 \mathrm{w}$ projekcie zatytułowanym Oświata i wychowanie wobec zmian spolecznych. Od 1985 r. organizowano coroczne dwudniowe krajowe konferencje towarzyszące Zjazdom PTP, wspomagane przez osoby i środki z Instytutu Rozwoju Wsi i Rolnictwa PAN. Odbywały się one w Sali Lustrzanej Pałacu Staszica w Warszawie, a gromadziły około 120-150 osób.

Wybrane referaty i rozwinięte głosy dyskusyjne z tych konferencji opublikowane zostały w trzech książkach: Ciagtość $i$ zmiana w systemie edukacji (Pęcherski [red.] 1985), Badania oświatowe a polityka oświatowa (Nowak [red.] 1987), Oświata i wychowanie $w$ okresie cywilizacyjnego przetomu (Nowak [red.] 1988). Referaty z konferencji pt. Wplyw przebudowy spoleczno-ekonomicznej na koncepcje reform szkolnictwa $i$ wychowania, zorganizowanej przez PTP i IRWiR PAN w 1988 r., ukazały się tylko w formie preprintów poszczególnych tekstów. Cykl tych spotkań domykało otwarte posiedzenie Zarządu Głównego PTP z konferencją na temat Oświata $i$ wychowanie wobec kryzysu w 1989 r., a referaty $\mathrm{z}$ niej opublikowane zostały $\mathrm{w}$ różnych czasopismach. Podczas konferencji Zarząd Główny uchwalił też stanowisko popierające 
propozycje reformy oświaty zaproponowane w raporcie Komitetu Ekspertów pod kierunkiem prof. Czesława Kupisiewicza Edukacja naszym narodowym priorytetem (1989).

Do przygotowania referatów na tych konferencjach zapraszani byli uczeni z wielu środowisk i pokoleń. W tomie Ciaggtość $i$ zmiana $w$ systemie edukacji Polski Ludowej (Pęcherski [red.] 1985) opublikowano referaty i wystąpienia następujących autorów (w kolejności przyjętej w tej publikacji): Mikołaj Kozakiewicz (dwukrotnie), Mieczysław Pęcherski, Heliodor Muszyński, Ryszard Borowicz, Zbigniew Kwieciński, Czesław Kupisiewicz, Wojciech Pasterniak, Krzysztof Konarzewski, Bogdan Suchodolski (dwukrotnie), Ryszard Maciej Łukaszewicz, Janusz Tymowski, Włodzimierz Michajłow, Stefan Wołoszyn i Roman Schulz. Artykuły te obejmowały analizami wszelkie aspekty kryzysu polskiego, ale też ważne przemiany i wyzwania globalne, a także podejmowały próby oceny stanu pedagogiki i wyznaczenia jej nowych horyzontów.

W tomie Oświata $i$ wychowanie $w$ okresie cywilizacyjnego przetomu (Nowak [red.] 1988) oprócz nestorów i klasyków takich jak: Bogdan Suchodolski, Wincenty Okoń, Jan Szczepański, Mikołaj Kozakiewicz i Krzysztof Konarzewski, referaty wygłosili przedstawiciele młodszego pokolenia naukowego, jak na przykład: Lech Witkowski, Jerzy Głuszyński, Andrzej Kaleta, Maria Dąbrowska-Bąk czy Anna Sawisz. W kilku wystąpieniach podniesiono edukacyjne implikacje rewolucji informatycznej.

Kozakiewicz był wierny swoim deklaracjom programowym z 1981 r. W referacie Nowe problemy badań oświatowych, w wymienionym tomie z roku 1988, pisał: „Trzeba na problemy szkolnictwa patrzeć z perspektywy ogólnego rozwoju kraju, a rozwojowe trudności polskiej szkoły oceniać także z perspektywy zjawisk światowych” (Kozakiewicz 1988: 268). „Kryzys ekonomiczny nie jest jedynym kryzysem uderzającym w oświatę. Trzeba badać wpływ polimorficznego kryzysu, który trapi świat współczesny, na oświatę i wychowanie” (Kozakiewicz 1988: 275).

„Dzieło unowocześnienia Polski zawiera w sobie również dzieło unowocześnienia szkoły i oświaty. Winno opierać się zarówno na określeniu całkiem nowych zjawisk, jak i na dogłębnej analizie niewcielonych w życie zaleceń i wskazań w okresie minionych lat" (Kozakiewicz 1988: 277).

Publikacja Kozakiewicza zarysowała rozległą „mapę” nowych problemów, które powinny stać się przedmiotem badań w naukach pedagogicznych. Niestety, wbrew konsekwentnym próbom 
konsolidowania przez Towarzystwo środowisk pedagogicznych wokół problemów systemowej odnowy oświaty i wychowania, do takiej wspólnoty działań nie doszło.

Nie zdołaliśmy też zaproponować uzgodnionego projektu zasadniczej odnowy polskiego systemu oświaty w przygotowaniach obrad Okrągłego Stołu i w czasie jego trwania.

Wiosenne przesilenie po 4 czerwca 1989 r. szeroko otwarło nadzieje - także na to, że budzące się społeczeństwo obywatelskie stanie się nowym wielkim wychowawcą publicznym, że przyniesie wyczekiwaną odnowę oświaty i wychowania. Dlatego I Zjazd Pedagogiczny podjął pytanie o naszą tożsamość, o stosunek pedagogów akademickich do przeszłości, teraźniejszości i przyszłości naszego kraju, nareszcie otwartego na demokrację, pluralizm, silną gospodarkę i na kulturę Zachodu.

W roku 1993, kiedy to odbył się I Ogólnopolski Zjazd Pedagogiczny w Rembertowie, prof. Kozakiewicz - już jako marszałek Sejmu i socjolog obserwujący od środka polską politykę - zabrał głos na temat zmian w polskiej oświacie. Głos ów opublikowany został w „Kwartalniku Pedagogicznym” nr 2/1994 (Wychowanie do demokracji $w$ okresie wielkiej zmiany). Treść tego artykułu zawiera niezwykle krytyczną ocenę przemian polskiej oświaty.

Autor podkreślił, że na początku okresu przejścia systemowego dokonano znaczących zmian oczyszczających programy i podręczniki szkolne z uprzedniej ich ideologizacji. Usunięto z nich zafałszowania historyczne, wprowadzono treści uprzednio przemilczanych lub zafałszowanych faktów historycznych, wypełniono „białe plamy” w historii najnowszej i w literaturze polskiej XX w. Zlikwidowano „naukę o społeczeństwie” według starych tendencyjnych programów, ale też faktycznie zlikwidowano „przysposobienie do życia w rodzinie" (stało się ono przedmiotem do wyboru), a do szkolnictwa wszystkich szczebli wprowadzono skądinąd w szczególnym trybie - katechezę. Zarazem jednak powstał ogromny zamęt nieustannego „reformowania oświaty” przez szybko zmieniające się ekipy rządzące, mimo iż w roku 1989 został opublikowany raport ekspertów pod kierunkiem Czesława Kupisiewicza Edukacja naszym narodowym priorytetem, który został zlekceważony. „Można powiedzieć” - napisał Kozakiewicz - „że mamy w tej chwili okres, w którym próbuje się dokonać reformy bez gruntownego przedyskutowania zasadniczych założeń psychologicznych, filozoficznych i socjologicznych przyszłego systemu. Jest to rzecz zdumiewająca i wprowadzająca 
dużą przypadkowość oraz zmienność podejmowanych decyzji w zakresie treści kształcenia” (Kozakiewicz 1994: 91).

Za tymi szybkimi zmianami nie nadążali nauczyciele, którzy nie dość, że mieli stare nawyki tradycyjnego autorytarnego charakteru szkoły, to nie znali dzieł literatury zalecanych w nowych programach i prac historycznych zawierających odnowione fakty i interpretacje naszych i europejskich dziejów. „Powstaje więc często ukryty program nauczania, który bynajmniej nie musi dowodzić wrogości nauczycieli wobec nowych idei i pomysłów, ale bardzo często oznacza tylko inercję, bezwład i brak entuzjazmu do zmieniania czegokolwiek w sposobie nauczania, do jakiego przywykli” (Kozakiewicz 1994: 97).

„Wleczemy za sobą ogon nie przezwyciężonej przeszłości, starych nawyków myślenia i starych przesądów" (Kozakiewicz 1994: 92; podr. Z.K.). „Istnieje zagrożenie, że jeden totalitaryzm może się zamienić w drugi totalitaryzm, tylko o odwróconych znakach matematycznych. Niebezpieczni dla kraju są ludzie, którzy są przekonani, że posiedli prawdę absolutną" (Kozakiewicz 1994: 94). Do tego dochodzi rozwarstwienie szkół państwowych, niezwykle nisko finansowanych, i szkół prywatnych, które stać na wysoki poziom i nowoczesne nauczanie przy podwójnym finansowaniu przez państwo i rodziców. W ruinę zapada się zasada równości społecznej. Państwo nie tylko wycofało się z wielu powszechnie dostępnych przywilejów socjalnych (opieka zdrowotna w szkołach, bezpłatne wczasy pracownicze, tanie mieszkania), ale zarazem w błyskawicznym tempie robią kariery finansowe ludzie sprytni i cyniczni, demonstrujący swoje bogactwo w postaci luksusowych willi, aut, wystawnych uczt.

Młodzież to obserwuje, podczas gdy szkoła wyposaża ją w zasób informacji do najbliższej klasówki czy do egzaminu. Kozakiewicz podkreślił potrzebę nacisku na kształcenie formalne, na kształtowanie zdolności do samodzielności krytycznego osądu i do wychowania ludzi o silnych osobowościach, którzy budują swoją odrębność i tożsamość, szanując przy tym myślących odmiennie oraz ich prawo do wyrażania własnych opinii.

W tym samym roku 1993 na I Ogólnopolskim Zjeździe Pedagogicznym wyłoniła się nowa formacja młodszego pokolenia pedagogów akademickich - dobrze wykształconych, otwartych na świat, sięgających do podstaw pedagogiki w innych dyscyplinach humanistyki i do nowych źródeł informacji naukowej.

Czy jednak ta nowa formacja zapewniła ciągłość z wielkimi osiągnięciami pedagogiki polskiej z pierwszych czterech dekad 
XX w.? - o co upominałem się w referacie na Zjeździe Pedagogicznym. Czy miała skuteczny wpływ na politykę oświatową i odnowę praktyk edukacyjnych? Czy okazała się zdolna do wspólnego zaprojektowania nowoczesnego, specyficznego dla naszego kraju systemu oświaty i wychowania? Czy mogła i może mieć wpływ na odrodzenie się porządnego społeczeństwa, zdolnego do powszechnego wychowywania swoich dzieci na ludzi przyzwoitych?

Zapewne nasz jubileuszowy Zjazd przyczyni się do odpowiedzi na te pytania.

W 1993 r. pierwszy prezes naszego Towarzystwa głosił: Polska już przegrała swoją historyczną szansę wielkiego odrodzenia i rozwoju i właśnie przeżywa w każdym swym aspekcie śmiertelny kryzys. W tym samym czasie, na I Zjeździe Pedagogicznym, młodzi akademicy pedagogiczni obwieszczali wielkie nadzieje pokładane w wychowanie i kształcenie nowych pokoleń. Takie były i są prawa młodzieży akademickiej. Zarazem znaczna część ich aktywnych poprzedników ze starego systemu długo jeszcze przekazywała młodzieży „skamieliny” ich (nie)wiedzy i przekonań. Nie udało nam się zbudowanie „porządnego społeczeństwa” (Avigai Margalit) złożonego ze wspólnot zaufania i ambitnych zadań, wspólnot zdominowanych przez ludzi przyzwoitych i życzliwych.

Jedno jest pewne i jaskrawo widoczne. Mamy nieodwracalny chaos w systemie oświaty publicznej. Na naszych oczach niszczy się kilkusetletnią harmonię badań i kształcenia na uniwersytetach. Mamy za to powrót czasów plemiennych (Ayn Rand), w których zaciekle broniono własnej terytorialności, odrębności i nienawiści do obcych, powrót do świadomości magiczno-plemiennej i wojowniczej (Ken Wilber, cyt. za Kielar 2012: 90-92), do „brudnych wspólnot” interesów grupowych kosztem innych szerszych społeczności (Podgórecki 1985: 57) oraz do fazy moralnego niemowlęctwa, w której oczekuje się, że wszystkie nasze pragnienia zostaną zaspokojone przez naszych opiekunów i przewodników.

Prawie sto lat temu nasz wielki humanista Florian Znaniecki w książce Upadek cywilizacji zachodniej (1921) napisał:

Niekiedy wszakże zdarza się, że jakaś katastrofa dziejowa zmiecie zupełnie arystokrację umysłową, a nie ma nowej arystokracji gotowej do przejęcia jej funkcji. Wynikiem tego jest ruina tej cywilizacji, istniejącej przed katastrofą, reprezentowanej przez arystokrację umysłową, która jest przedmiotem nienawiści mas, w których ręce przechodzi władza. [...] Ciągłość ewolucji społecznej jest przerwana, 
stracone stulecia odzyskać się nie dają i liczne pierwiastki, które zniszczona cywilizacja zawierała, nie mogą już być odtworzone (Znaniecki 1921: 5-6).

Przyczynami tej katastrofy, według tego myśliciela, są: powszechne panowanie człowieka nad przyrodą i samobójcze jej zniszczenie, wzrost materializmu oraz nienawiści rasowej, ochlokracja (tj. rządy motłochu) oraz fala bolszewizmu, która wynosi dyktatorów o nieograniczonej władzy.

Po 98 latach od publikacji Znanieckiego współczesny wybitny humanista Marcin Król wyraził pogląd, że „przeżywamy schyłek najwspanialszego okresu w naszych dziejach. Także schyłek nadziei, danej nam przez ,Solidarność', która była cudem historycznym" (Król 2019: 8-9). Wyraził przekonanie, że Polski już nie da się uratować, ale da się ocalić siebie i nadzieję na pogłębianie naszej duchowości, powiązanej z zaufaniem i życzliwością wobec wszystkich ludzi, których napotykamy, oraz okazywać trwałą aktywność w ochronie środowiska przyrodniczego i społecznego, w których żyjemy, a także aktywność polityczną, polegającą na codziennym współtworzeniu zdolności do współzarządzania naszym bliskim światem (Król 2019: 8-9).

Możemy i powinniśmy czynić stałe wysiłki w budowaniu $\mathrm{w}$ nas samych pełni człowieczeństwa. To jest warunek sine qua non i początek bycia pedagogiem, wspierającym młodzież w podobnym dążeniu.

\section{Bibliografia}

Kielar M.B. (2012), Integralna wizja Kena Wilbera i jej zastosowanie w edukacji, Wydawnictwo Akademii Pedagogiki Specjalnej, Warszawa.

Kozakiewicz M. (1983), Kryzys ekonomiczno-spoleczny Polski a problemy wychowania, „Biuletyn Polskiego Towarzystwa Pedagogicznego”, nr 1, s. 6-22.

Kozakiewicz M. (1988), Nowe problemy badań oświatowych, [w:] J. Nowak (red.), Oświata i wychowanie w okresie cywilizacyjnego przełomu, Wydawnictwo PTP i IRWiR PAN, Warszawa.

Kozakiewicz M. (1994), Wychowanie do demokracji w okresie wielkiej zmiany, „Kwartalnik Pedagogiczny”, nr 2, s. 89-98.

Król M. (2019), Mam nadzieję, „Gazeta Wyborcza”, nr 156, dodatek „Jakiej Polski potrzebujemy", s. 8-9.

Król M. (2019), Rozmowa w programie „Fakty po faktach” w TVN, 29.05.2019.

Nowak J. (red.) (1987), Badania oświatowe a polityka oświatowa, Wydawnictwo PTP i IWiR PAN, Warszawa. 
Pęcherski M. (red.) (1985), Ciągtość i zmiana w systemie edukacji, Wydawnictwo PTP i IRWiR PAN, Warszawa.

Margalit A. (1996), The Decent Society, Harvard University Press, Cambridge.

Nowak J. (red.) (1988), Oświata i wychowanie w okresie cywilizacyjnego przetomu, Wydawnictwo PTP i IRWiR PAN, Warszawa.

Podgórecki A. (1985), Całościowa analiza spoleczeństwa polskiego, [w:] J. Drewnowski (red.), Bieżace zagadnienia krajowe, P.I.N.O, t. II, Londyn.

Rand A. (2004), Powrót czlowieka pierwotnego. Rewolucja antyprzemystowa, tłum. Z.M. Czarnecki, Zysk i S-ka, Poznań.

ZG PTP (1983a), List otwarty Polskiego Towarzystwa Pedagogicznego do pracowników nauki i nauczycieli z 22 kwietnia 1982 r., „Biuletyn Polskiego Towarzystwa Pedagogicznego", nr 1, s. 22-23.

ZG PTP (1983b), Uchwata II Plenum Polskiego Towarzystwa Pedagogicznego z 23 października 1981 r., „Biuletyn Polskiego Towarzystwa Pedagogicznego", nr 1, s. 19-21.

Znaniecki F. (1921), Upadek cywilizacji zachodniej, Gebethner i Wolff, Warszawa. 
Joanna Madalińska-Michalak

ORCID 0000-0001-9980-6597

Uniwersytet Warszawski

Przewodnicząca Polskiego Towarzystwa Pedagogicznego

\title{
Odpowiedzialność za przyszłe pokolenia: edukacja do autonomii ${ }^{1}$
}

\author{
Abstract \\ Responsibility for future generations: \\ Education for autonomy
}

This paper considers the problem of autonomy of the individual in a democratic society, and the problem of education for autonomy, education seen as a challenge and our moral responsibility to the future generation. I assume that the decisive role in this task is for us all. The quality of our response to the call of responsibility to the future generation depends largely on our generation's attitude - whether the generation responsible to the future generations will take action or whether it will be made responsible for its inaction in the future.

Teachers and teacher education are placed in the centre of the presented analysis. I argue that teachers who do not focus on acquiring and expanding their autonomy competences, or do not use the autonomy assigned to them by law, are not able to create appropriate conditions for their students in the field of education. Education for autonomy depends, among other conditions, on the teachers' responsibility for their own professional development. A significant responsibility in this respect falls on universities that provide teacher education.

Keywords: responsibility to the future, generations, autonomy, competence to be autonomous, education for autonomy, teacher education

Słowa kluczowe: odpowiedzialność za przyszłość, pokolenia, autonomia, kompetencja do bycia autonomicznym, edukacja do autonomii, edukacja nauczyciela

1 Wystąpienie na otwarcie X Ogólnopolskiego Zjazdu Pedagogicznego 18 września 2019 r. 


\section{Wprowadzenie}

W niniejszym wystąpieniu podejmuję zagadnienie autonomii jednostki w społeczeństwie demokratycznym, a wraz z tym problem edukacji do autonomii, edukacji prowadzącej do - jak trafnie pokazuje Zbigniew Kwieciński - rozwoju przez jednostkę „zdolności do samodzielnego wyboru i krytycznego osądu, do bycia odrębną osobą, odpowiedzialną za zgodność swoich zachowań wobec przyjętych uniwersalnych zasad etycznych, a zarazem działającą dla dobra wspólnot (bliskich i dalszych)" (Kwieciński 2019: 43). Tak rozumiana edukacja powinna być postrzegana jako zadanie i wyzwanie dla współczesności. Decydująca rola w realizacji tego zadania przypada - jak zakładam - nam wszystkim. Jakość jego realizacji zależy w dużej mierze od naszej postawy od tego, czy współczesne pokolenie, „odpowiedzialne” za przyszłe pokolenia, będzie podejmowało odpowiednie działania, czy też będzie w przyszłości czynione odpowiedzialnym za zaniechania. Szczególna aktualność pytania o odpowiedzialność za przyszłość, za jutro, wynika przede wszystkim z coraz większej złożoności otaczającego nas świata.

Stojąc na stanowisku, że konieczna jest w naszym szkolnictwie dobrze przemyślana i funkcjonująca edukacja na rzecz autonomii, edukacja, która położy nacisk na rozwijanie kompetencji niezbędnych do bycia autonomicznym w świecie społecznym, zakładam, że należy też zgodzić się $\mathrm{z}$ warunkiem sine qua non: będzie bardzo trudnym, czy wręcz nierealnym, przedsięwzięcie edukowania do/dla autonomii ucznia przez nauczyciela, który sam tej autonomii nie rozumie, a tam, gdzie ma takie możliwości sam z niej nie korzysta; nauczyciela, który nie dba o nabywanie i poszerzanie swoich kompetencji do autonomii. Trudno otwierać horyzonty wolności ucznia, pomóc mu rozwijać się „w jestestwo autonomiczne" (Hessen 1997: 126), czynić go niezależnym, samodzielnym i odpowiedzialnym, budującym swoją odrębność i tożsamość, szanując przy tym ludzi odmiennie myślących i ich prawo do wyrażania swoich własnych opinii czy osądów, a zatem wychowywać do autonomii komuś, kto nie podejmuje należytego wysiłku kształcenia i uczenia się dla własnej samosterowności, spójności, rozwoju samodzielności, a jednocześnie dialogicznego bycia (zob. Aviram 1993), czy wręcz sam jest zniewolony. 


\section{Pokolenia - czas historyczny a zmiany wspólne}

Barbara Galas, ukazując znaczenie terminu „pokolenie” w Encyklopedii pedagogicznej XXI wieku, podkreśla, powołując się na ustalenia socjologa wiedzy Karla Mannheima (1893-1947), że termin ten oznacza „grupę ludzi o wspólnych postawach czy systemach wartości, które są efektem wspólnie przeżytego doświadczenia historycznego" (Galas 2005: 513).

W literaturze przedmiotu wśród różnych określeń terminu pokolenia na szczególną uwagę zasługuje propozycja rozumienia tego terminu wskazana przez Helenę Radlińską, która mówiła o „pokoleniu historycznym”, czyli jednostkach „w różnym wieku, przebywających w wyodrębnionej przestrzeni, których udziałem jest dany czas historyczny. Tak rozumiane pokolenia stoją w obliczu tych samych wydarzeń i tych samych zadań. Poszczególne generacje danego pokolenia różnią się przeżyciami, zasobem doświadczeń i możliwościami działania” (Radlińska 1961: 366). Ten sposób rozumienia pokolenia przyjmuję na potrzeby prowadzonych rozważań, gdyż propozycja Heleny Radlińskiej kładzie nacisk na wymiar czasu i przestrzeni, stanowiących ramy aktywności jednostki, oraz na fakt, że człowiek jest istotą relacyjną, rozwijającą się we wzajemnym związku ze środowiskiem społeczno-kulturowym. Takie rozumienie pokolenia pokazuje, że każdy z nas oprócz tego, że należy do jakieś grupy wiekowej, jest także członkiem grupy pokoleniowej.

Trafna wydaje się uwaga Ewy Marynowicz-Hetki, według której udziałem pokolenia w ujęciu Radlińskiej jest dany czas historyczny. Koncepcja pokolenia Radlińskiej jest silnie

powiązana z koncepcją człowieka i koncepcją wychowania, rozumianego jako pomoc w rozwoju, towarzyszenie rozwojowi, które może być udziałem jednostki w różnych okresach (w ciągu) jej życia. Co oznacza, że ta sama osoba, będąc przedstawicielem jednego pokolenia, może uczestniczyć w różnych jego konfiguracjach, w zależności od wieku biologicznego, fazy życia i ról społecznych, jakich wypełnienia się od niej oczekuje. Koncepcja ta jest pojemna. Obejmuje wszystkich, którzy w danym czasie historycznym uczestniczą, są obecni. Wprowadza ona istotny wymiar czasu i przestrzeni, stanowiących ramy aktywności (Marynowicz-Hetka 2007: 43). 
Warto zauważyć, że z punktu widzenia psychologii rozwojowej podleganie podobnym wpływom społecznym oraz poczucie wspólnoty działań i przeżyć owocują tym, iż osoby zaliczane do różnych, choć zbliżonych warstw wiekowych, zachowują się podobnie i podejmują podobne działania, czego wynikiem mogą być zbliżone osiągnięcia rozwojowe. Helen Bee (2004) w pracy Psychologia rozwoju człowieka takie zmiany określa jako wspólne.

W czasach radykalnych zmian społecznych większej wagi nabiera przynależność do określonego pokolenia niż grupy wiekowej. Można powiedzieć metaforycznie, iż w czasach rewolucji zegar społeczny przyspiesza i swym zasięgiem obejmuje więcej osób niż w czasach stagnacji czy stabilizacji społecznej (Brzezińska 2005: 24). W tym sensie możemy mówić o pokoleniu Wielkiego Kryzysu w Stanach Zjednoczonych w latach 30. XX w., a w Polsce o pokoleniu Kolumbów (zwanym pokoleniem apokalipsy spełnionej czy pokoleniem poetów podziemia), „pokoleniu '56” („Pokolenie Współczesności”), „pokoleniu marca 68”, „pokoleniu sierpnia 80”, „pokoleniu stanu wojennego”, „pokoleniu X”, „pokoleniu Y”, „pokoleniu JP II”, czy „pokoleniu Wielkiego Brata” itd. Aby zatem objąć szerszy krąg problemów etycznych dotyczących troski o przyszłość, np. troski o przyszłość szkoły, edukacji, czy pedagogiki jako nauki, tematem: „odpowiedzialność za przyszłe pokolenia”, należałoby mówić nie tylko o dalekiej przyszłości, przyszłości jeszcze nie narodzonych, ale także o tych przyszlych pokoleniach, które niejako już teraz sq czesściowo wspótczesne z własnym pokoleniem, co oznacza, że pokolenia dzieci byłyby już pokoleniem przyszłym² ${ }^{2}$.

\section{Autonomia i edukacja do autonomii - pierwsze przybliżenie}

Określenie interesującego nas pojęcia, jakim jest autonomia pojęcia, które jest współcześnie dość powszechnie wykorzystywane zarówno w języku naukowym, jak i potocznym, nie należy do

2 Dietrich Birnbacher (1999: 17) stawiając pytanie o to, jak „przyszłe są przyszłe pokolenia”, powołuje się na Martina Goldinga (1972: 86) i przyjmuje, że za przyszłe pokolenia należy uznać tylko te, które „w żadnym okresie nie żyją razem z pokoleniem mającym przejąć odpowiedzialność” (Birnbacher 1999: 18). Przyszłość, o jaką chodzi w problemie „odpowiedzialności za przyszłe pokolenia”, jest dla Birnbachera, podobnie jak dla Goldinga, przyszłością jeszcze nie narodzonych oraz przyszłością dzieci i dzieci dzieci (Birnbacher 1999: 18-19). 
łatwych zadań. Pomimo faktu, iż termin ten niejako zadomowił się tak w pedagogice, jak i w języku innych nauk - szczególnie wiele o autonomii piszą filozofowie, psychologowie i socjolodzy w literaturze naukowej trudno o jedną, powszechnie obowiązującą jego definicję. Na nieścisłość w jego definiowaniu i różnorodność jego ujęć wskazuje wielu autorów.

Współczesne słowniki języka polskiego traktują terminy autonomia i autonomiczność w zbliżonym sensie. Autonomia (auto nomos - „żyjący według własnych praw”) - w przeciwieństwie do anomii i heteronomii - to stan „przedmiotu”: cecha lub raczej zbiór przypisywanych mu cech. Oznacza ono pozytywnie prawo do samodzielnego rozstrzygania spraw wewnętrznych, osobistych lub pewnej zbiorowości: państwa, narodu, miasta, instytucji, a negatywnie - nie uleganie naciskom zewnętrznym. Do słów bliskoznacznych słowa autonomia należą: „samostanowienie”, „samodzielność”, „niezależnośc”, „samorządność”, „wolność”. Do antonimów: „podległość”, „zależność”, „niewola”.

W kulturze europejskiej autonomiczność (autonomia) jest zdecydowanie wartościowana pozytywnie i stanowi jedno z głównych haseł nowożytnej samoświadomości. Ceni się różne rodzaje autonomii, od czasów starożytnej Grecji zwłaszcza polityczną w sensie instytucjonalnego samostanowienia (samorządności) narodu. Średniowiecze nie zna pojęcia autonomii, ale pojawia się ono znowu w XVI w. w dyskusjach nad wolnością religijną i w XVII i XVIII w. w prawoznawstwie, by zyskać ogólniejsze znaczenie w filozofii Immanuela Kanta. Oznacza ono odtąd prawo do instytucjonalnego samostanowienia i możliwość samokonstytuowania się człowieka jako istoty rozumnej. I tylko możliwość samostanowienia umożliwia odpowiedzialne działanie. Szczególny rodzaj autonomii, jaką jest autonomia osobista - obok autonomii politycznej, autonomii instytucji - czy państwa, znajduje się obecnie w centrum dyskursu o liberalnej edukacji, o wartościach demokratycznych, a nawet o zasadach rynkowych.

W literaturze przedmiotu autonomia jest najczęściej przypisywana jednostce i traktowana jest jako jej pożądana cecha. Autonomia jest postrzegana jako zdolność jednostki do samostanowienia lub samorządności, jako zdolność do odpowiedzialnego kierowania swoim zachowaniem, podejmowania decyzji z uwzględnieniem własnych i cudzych potrzeb. Gerald Dworkin (1988) w książce poświęconej teorii i praktyce autonomii podkreśla wagę autonomii osobistej. Jej pojęcie jest czasami 
używane jako ekwiwalent wolności [...] czasami jako ekwiwalent samorządności lub suwerenności, czasem jest utożsamiane z wolną wolą. Bywa też utożsamiane z godnością, uczciwością, indywidualnością, niezależnością, odpowiedzialnością i samoświadomością. Bywa używane w celu wskazania na takie cechy, jak samowystarczalność, krytyczna refleksja, wolności od zobowiązań, brak przyczynowości zewnętrznej [...] Autonomia odnosi się do działań, przekonań, przyczyn działania, zasad, woli, czy myśli (Dworkin 1988: 6).

Wieloaspektowe i dość wyczerpujące spojrzenie na pojęcie autonomii proponuje $\mathrm{w}$ swoich rozważaniach teoretycznych Rainer Forst. W pracy Integrating Five Conceptions of Autonomy (Forst 2005) w sposób szczegółowy pokazuje zarówno różne sposoby opisywania, jak i idące za nimi postaci/wymiary autonomii, podkreśla też niezwykle złożoną naturę autonomii. Jedną z postaci, w jakich przejawia się autonomia, jest autonomia moralna, w której działająca jednostka może być uważana za autonomiczną o tyle, o ile działa ona na podstawie powodów, które biorą pod uwagę każdą inną władzę jednakowo i które są „uzasadnione na podstawie wzajemnych i ogólnie obowiązujących norm" (Forst 2005: 230). Tak rozumiana autonomia ma swoje znaczenie polityczne, ponieważ promuje wzajemny szacunek jednostek do siebie, wzajemny szacunek w działaniu instytucji, organizacji, co jest niezwykle potrzebne do wolności politycznej i idącej za nią autonomii politycznej. Autonomia etyczna dotyczy pragnień człowieka w dążeniu do dobrego życia, w kontekście jego wartości, zobowiązań, relacji i społeczności. Z kolei autonomia prawna pozwala na to, by działać zgodnie prawem, aby nie być zmuszanym do narzucanych poza prawem zachowań. Autonomia polityczna dotyczy prawa do uczestniczenia w zbiorowych rządach, wykonywanych z innymi członkami danej społeczności. Wreszcie autonomia społeczna dotyczy tego, czy jednostka ma środki, aby być równoprawnym członkiem danej społeczności. Uczestnictwo w autonomii społecznej pomaga wykazać odpowiedzialność członków społeczności za wzajemne uwzględnianie własnych potrzeb oraz ocenę struktur politycznych i społecznych pod kątem tego, czy służą one promowaniu społecznej autonomii wszystkich członków. Forst twierdzi, że ostatecznie

obywatele są politycznie wolni w takim stopniu, w jakim oni, jako dawcy wolności i użytkownicy wolności, są moralnie, etycznie, prawnie, politycznie i społecznie niezależnymi członkami wspólnoty 
politycznej [...] Prawa i wolności muszą zatem być uzasadnione nie tylko w odniesieniu do jednej koncepcji autonomii, ale ze złożonym zrozumieniem, co to znaczy być osobą autonomiczną (Forst 2005: 238).

Głoszenie poglądów, że obywatele są niezależni, mają prawo do głosowania, jeśli ich materialne potrzeby nie są zaspokojone lub jeśli nie mają swobodnego wyboru wartości lub zobowiązań etycznych, jest traktowane przez Forsta jako swoiste nadużycie. Autor, podobnie jak Marta Nussbaum (2006) czy Amartya Sen (1999), poszukuje teorii sprawiedliwości społecznej, która może poprowadzić nas do bogatszego, bardziej responsywnego podejścia do współpracy społecznej. Wszelkie dyskusje o autonomii we współczesnych społeczeństwach powinny mieć na uwadze podejście do praw człowieka w zakresie możliwości działania, w którym wzywa się społeczeństwa do zapewnienia wszystkim ludziom możliwości rozwinięcia ich zdolności, cech, właściwości - jednostki mają wówczas wybór, czy je rozwinąć, czy też nie. Autonomia podmiotu zależy od tego na ile edukacja, społeczeństwo, państwo wspierają rozwój jego możliwości działania, który z założenia powinien być właśnie wysoce autonomiczny.

\section{Problematyzacja autonomii - autonomia jako wartość, relacyjność autonomii}

W badaniach nad autonomią coraz częściej podkreśla się, że autonomia nie powinna być traktowana wyłącznie jako cecha jednostki, ale należy ją postrzegać jako wartość oraz w aspekcie relacyjnym, procesowym, co uwidacznia się chociażby w pracach przedstawicieli filozofii feministycznej zajmujących się „autonomią relacyjną" (Nedelsky 1989; Mackenzie, Stoljar 2000).

Wartość autonomii w pełni uwidacznia się w określonym kontekście społecznym, gospodarczym i politycznym. Profesor Mark Olssen z Uniwersytetu w Surrey, filozof polityki, analizując prace Jamesa Marshalla poświęcone myśli Michaela Foucault oraz autonomii osobistej jednostki i edukacji (zob. Olssen 2005), wykazał w swoich publikacjach, że warto poszerzyć proponowane przez Roba Reicha (2002) i Meiry Levinson (1999) - dwójkę współczesnych filozofów, którzy opowiadają się za modelami osobistej autonomii jako podstawy liberalnej edukacji - spojrzenie na autonomię jednostki poprzez zastosowanie filozoficznego 
podejścia Michaela Foucault właśnie do problemu autonomii oraz edukacji do autonomii jednostki.

Olssen dowodzi, że jednostka nie potrzebuje odkrywać/ wymyślać własnej autonomii w celu zabezpieczenia swoich praw i wolności. Prawa jednostki i jej wolność są ważnymi dla poczucia bezpieczeństwa każdej jednostki i jej dobrostanu, nawet wówczas, gdy nie wykorzystuje ona swojej autonomii. Kiedy prowadzimy dyskusje nad tym, czy w ogóle powinniśmy analizować autonomię, pojawiają się pytania, czy być może warto pozostać przy takich pojęciach, jak respekt, godność, dobrostan, wolność, integralność, prawa człowieka. Autor dowodzi, że właśnie teraz, bardziej niż kiedykolwiek wcześniej, należy - ze względu na powiązania, zależności i współzależności, w jakich funkcjonuje człowiek dokonać problematyzacji autonomii i odsłonić jej skomplikowaną naturę. Jednocześnie nie należy przeceniać progu, który wyznacza granice dla naszej niezależności i samostanowienia. Każda jednostka jest zależna od struktur społecznych i wsparcia instytucjonalnego $\mathrm{w}$ stopniu o wiele wyższym niż potencjalnie to sobie wyobraża, czy niż tradycyjnie głosili filozofowie liberalnej polityki. Nawet ci, którzy ostatecznie oceniają się jako wysoce kompetentni w osiąganiu celów życiowych i zawodowych, nie mogą orzec, że są „autonomiczni” w każdym swoim działaniu i podejmowanych decyzjach. Są oni raczej wysoce wykwalifikowani, mają duże możliwości działania. Ich potencjał i możliwości zależą od całego systemu, sieci powiązań, kompleksowych struktur i wsparcia. W odniesieniu do tego obywatele są w większym stopniu produktem normalizacji i socjalizacji niż wynikałoby to $\mathrm{z}$ ich samooceny. Kultura indywidualizacji i znormalizowane reprezentacje są modelami wyboru. Tam jednak, gdzie wybory osadzone są w kulturze dominacji pewnych marek, kolorów czy stylów, są one bardziej iluzoryczne. Edukacja ma przyczyniać się do utwierdzania jednostek w przekonaniu, że są one bardziej wolne gdyż mogą podejmować decyzje - i kreatywne niż ma to miejsce.

Olssen twierdzi, że autonomia w tym kontekście jest często mylona z przywilejami. Autor dowodzi, że powinniśmy kłaść nacisk na analizy autonomii na poziomie systemu, kultury i opisać autonomię jako swoisty aspekt społeczeństwa demokratycznego. Społeczeństwa, w którym podkreśla się partycypację, kulturę polityczną, pluralizm i swobody obywatelskie. I takie rozumienie autonomii wymaga rzeczywistej edukacji do niej i dla niej, gdyż - jak twierdzi Olssen za Foucault - możemy sobie wyobrazić 
demokrację, w której autonomia jest strategią dla zmniejszania roli państwa i zwiększania roli odpowiedzialności jednostek za jakość życia, pomyślność i dobrobyt. Zadaniem edukacji jest wzmacniać jednostki intelektualnie, sprzyjać rozwojowi ich możliwości dla rozwoju wartości ważnych dla demokracji. Człowiek jest ukonstytuowany historycznie, politycznie, i rozwija swój potencjał i zdolności do wolności oraz podejmowania decyzji bez pośpiechu, ale progresywnie.

\section{Autonomia jako cel edukacyjny - nabywanie kompetencji do autonomii}

Żywiołowy rozwój procesów społecznych oraz przemiany gospodarcze i polityczne ostatnich dziesięcioleci, jak pokazują różnego rodzaju diagnozy, uderzają w sieć ludzkich powiązań i zależności będących wynikiem swobodnych i świadomych decyzji mających budować autonomię i poczucie bezpieczeństwa jednostki i jej zakorzenienia w społeczności.

W sytuacji, której jesteśmy obecnie świadkami, mamy do czynienia z dość paradoksalnym układem - układem, w którym

jednostka nie tyle dojrzewa do autonomii przez rozwój wewnętrzny, który prowadzi ją do walki z ograniczającymi ją czynnikami zewnętrznymi, co zostaje niejako wrzucona w świat stanowiący dla niej wyzwanie i zagrożenie, niezależnie od jej dążeń i aspiracji.

Autonomiczność staje się, dla większości, nie tyle pożądanym celem wynikającym z poczucia własnej godności i siły, dążenia do usamodzielnienia się, ale nieuniknionym wyzwaniem, które może co prawda nieść ze sobą pewne doświadczenia pozytywne, jednak sprzyja koncentracji na potrzebach podstawowych, egoistycznych z natury (Ciążela 2001: 132-133).

Podejmując kwestię edukacji do autonomii, warto mieć zatem na uwadze czynniki makrospołeczne, które mogą rzutować na ograniczanie, bądź wyzwalanie autonomii jednostki i jej rozwoju, o czym była mowa także wcześniej. Jednocześnie, gdy spojrzymy na rozwój autonomii poprzez pryzmat szkoły, to warto rozważać ją jako cel edukacji, cel który można osiągnąć tylko wówczas, gdy dba się w pierwszej kolejności o rozwój kompetencji nauczyciela do bycia autonomicznym w toku jego całożyciowej edukacji.

Nauczyciele dużo mówią o autonomii ucznia, o jego niezależności, o tym by potrafił korzystać ze swojej wolności, przestrzegając 
przy tym zasad współżycia społecznego. Współczesne badania pokazują, że rozwojowi autonomii służą takie warunki uczenia się, które promują poczucie wyboru ucznia; uczenia się, które sprzyja rozwojowi podejmowania decyzji, rozwojowi kompetencji społecznych, emocjonalnych oraz interpersonalnych uczniów. Zatem z pewnością to, co istotne w procesie edukacyjnym w szkole, gdy zależy nam na wychowaniu do autonomii, to zwrócenie uwagi na zaprojektowanie środowiska uczenia się i oferowanie doświadczeń edukacyjnych sprzyjających promowaniu i rozwojowi uczniów, którzy potrafią m.in. kierować swoją nauką, własnym rozwojem, są samodzielni w wyborach i krytyczni w osądach, są odpowiedzialni za zgodność swoich zachowań z przyjętymi zasadami etycznymi.

Wydaje się, że mamy dziś do czynienia z ciągle jeszcze niezbadanym wystarczająco przez analityków i nieprzedyskutowanym przez filozofów swoistym wyalienowaniem jednostek, zwłaszcza młodych, ze społeczności, które można by określić mianem „izolacjonizmu”. Młodzi ludzie funkcjonują często na obrzeżach zespołów klasowych, grup podwórkowych czy innych wspólnot, zamykając się we własnym świecie, skorelowanym li tylko ze światem wirtualnym, do którego dostęp mają wyłącznie przez własnego smartfona. Nauczyciele tu i ówdzie dostrzegają tę alienację, nierzadko mówiąc o postawach aspołecznych - choć na ogół nie są to postawy antyspołeczne. Dzieci i młodzież starają się nie przeciwstawiać normom społecznym, raczej ignorują je, kontestują, uciekając w swój świat nawet podczas lekcji czy spotkań towarzyskich. Wydaje się, że model ten dostrzega kultura masowa - obserwując adresowane do młodych ludzi reklamy różnych produktów, można zauważyć te inności, nie rejestrowane przecież w poprzednich pokoleniach. Portale społecznościowe ułatwiają młodym (choć starszym także) tworzenie własnych wirtualnych grup „przyjaciół”, których łączy często jedynie ilość lajków pod opublikowanymi wpisami lub fotografiami. Komunikacja sprowadza się do demonstrowania swego „ja”, a potem szukania akceptacji (lub negacji) wśród ludzi, których często tak naprawdę nie znamy.

Pojawia się zatem pytanie, czy szkoła to dostrzega. Czy nauczyciele posiadają kompetencje, aby stać się przewodnikami uczniów „pokolenia smartfonu” w ich drodze do osobistej autonomii, by ów charakterystyczny „izolacjonizm” nie prowadził do zrywania więzi społecznych? Przeto w nowym układzie społecznym 
myślenie i mówienie o autonomii może stracić swój sens i jakąkolwiek rację bytu. Wydaje się, że wymaga to poważnego namysłu i poszukiwania rozwiązań, które pokażą uczniom w owej nowej formule ważne dla wszystkich więzi społeczne, a tym samym nowe rozumienie autonomii jednostki ery network.

Należy zwrócić baczną uwagę na obowiązujące przepisy prawa, aby zorientować się, jak definiowana jest autonomia szkoły, czy autonomia nauczyciela. Przykładowo w myśl przepisów ustawy Karta nauczyciela (Ustawa 1982, art. 12 ust. 1) nauczyciele zatrudnieni na podstawie mianowania nie podlegają podporządkowaniu służbowemu określonemu w innych przepisach prawnych dla mianowanych funkcjonariuszy państwowych. Zauważmy, że przepis ten nie dotyczy nauczycieli zatrudnionych $\mathrm{w}$ drodze umowy o pracę, czyli w większości rozpoczynających pracę w zawodzie. Dalej ustawa stanowi (Ustawa 1982, art. 12 ust. 2), że nauczyciel $\mathrm{w}$ realizacji programu nauczania ma prawo do swobody stosowania takich metod nauczania i wychowania, jakie uważa za najwłaściwsze spośród uznanych przez współczesne nauki pedagogiczne, oraz do wyboru spośród podręczników i innych pomocy naukowych zatwierdzonych do użytku szkolnego. Aby przepis nie był martwą literą z woli ustawodawcy, nauczyciel powinien podnosić swoją wiedzę ogólną i zawodową, korzystając z prawa pierwszeństwa do uczestnictwa we wszelkich formach doskonalenia zawodowego na najwyższym poziomie.

Jednocześnie ustawa Prawo oświatowe (Ustawa 2016, art. 5) postanawia, że nauczyciel w swoich działaniach dydaktycznych, wychowawczych i opiekuńczych ma obowiązek kierowania się dobrem uczniów oraz troską o ich zdrowie, postawę moralną i obywatelską, z poszanowaniem godności osobistej ucznia. Tak więc przywołana wcześniej autonomia jest uwarunkowana istotnymi pryncypiami polskiej edukacji, ale także czynnikami społecznymi i środowiskowymi. Jednocześnie tak ustalony program wychowania przedszkolnego lub program nauczania mogą obejmować treści nauczania wykraczające poza zakres ustalony w podstawie programowej.

Nauczyciel może zdecydować o realizacji programu nauczania z zastosowaniem podręcznika, materiału edukacyjnego bądź ćwiczeniowego, lub bez nich (Ustawa 1991, art. 22aa). Program nauczania może być realizowany również z wykorzystaniem urządzeń, sprzętu lub oprogramowania, przydatnych do 
realizacji tego programu, z uwzględnieniem potrzeb edukacyjnych i możliwości psychofizycznych uczniów (Ustawa 1991, art. 44 c ust. 1 i 2 ).

Można byłoby jeszcze mnożyć przykłady wzięte z polskiego prawa oświatowego, które odsłaniałyby obszary autonomii nauczyciela, nie taki jest jednak cel moich rozważań. Bardziej zależy mi na tym, by wykazać, że wraz z wyposażeniem nauczyciela w swobodę podejmowania decyzji w obszarach kształcenia winna wzrastać jego odpowiedzialność za własny rozwój zawodowy i rozwijanie w sobie poczucia autonomii - autonomii rozumianej za Davidem Bridgesem jako kompetencji osobistej (1997)3', która powinna być przez nauczycieli wykorzystywana w praktyce zawodowej i rozwijana na terenie szkoły i poza nią.

Podejście kompetencyjne $\mathrm{w}$ analizie pracy nauczycieli i związanej z nią odpowiedzialności pozwala na odsłonięcie konkretnych oczekiwań kierowanych pod adresem edukacji i rozwoju zawodowego nauczycieli oraz ich pracy zawodowej. Swoistym zaproszeniem do rozwijania tego podejścia jest proponowane przeze mnie spojrzenie na naturę kompetencji nauczyciela, a zwłaszcza na jedną z zasadniczych jej właściwości, jaką jest dwoistość (zob. Madalińska-Michalak 2019). Z jednej strony kompetencje nauczyciela, w tym kompetencja do działania autonomicznego, odsłaniają obszar możliwości jego działania. Kierują naszą uwagę w stronę tego, co nauczyciel potrafi; są niejako miernikiem jego zawodowej wiedzy, umiejętności, zdolności stawiania czoła danym sytuacjom zawodowym. Mogą być wykorzystywane do określania standardów dla zawodu nauczyciela w celu zapewnienia wysokiej jakości jego pracy. Z drugiej zaś strony kompetencje nauczyciela pokazują, jakie ma/powinien mieć potrzeby w zakresie rozwoju zawodowego. Tak rozumiane kompetencje eksponują odpowiedzialność nauczyciela wobec siebie i innych podmiotów za własną sprawczość zawodową. Nauczyciel powinien umieć dokonać krytycznego oglądu własnej pracy i swoich możliwości. Badanie własnej praktyki w celu wzmocnienia działania winno

3 Samo słowo kompetencja kieruje naszą uwagę w stronę wyboru języka, który ma szczególny charakter, i może mieć kontrowersyjny rezonans w kontekście toczących się dyskusji odnoszących się do efektów kształcenia, które to dyskusje są bardziej bezpośrednio związane z potrzebami rynku pracy, miejsc pracy lub, szerzej, szczególnych obowiązków instytucji kształcących wobec wyzwań rynku pracy. Stąd pojawia się tendencja do postrzegania języka kompetencji $\mathrm{w}$ rozdziale z językiem autonomii jednostki. 
być zakotwiczone $\mathrm{w}$ głęboko przemyślanej i dobrze funkcjonującej edukacji nauczyciela.

Opowiedzenie się za dwoistością natury kompetencji nauczyciela pozwala nie tylko koncentrować się na byciu nauczycielem i określaniu wykazu jego kompetencji wraz ze wskazywaniem na konieczność ciągłego uzupełniania niedoborów, ale zachęca do skupienia się na problematyce stawania się nauczycielem. Implikuje ono konieczność ciągłego rozwoju zawodowego nauczyciela, który należy postrzegać jako część (element) szerszego procesu, jakim jest całościowy rozwój człowieka.

Ten sposób myślenia koresponduje z myślą Davida Bridgesa, który dowodzi, że na autonomię jednostki nie może wyłącznie składać się opanowanie wiedzy, zrozumienie głównych pojęć opisujących autonomię, podejście krytyczno-twórcze, znajomość i zrozumienie sposobów życia i działania, które moglibyśmy wybrać my sami, czy też refleksyjna wiedza o nas samych i źródłach naszego zrozumienia oraz motywacja (zob. Bridges 1997: 158). Z pewnością wszystko to jest ważne, ale najistotniejsze jest niejako praktykowanie autonomii. W edukacji, w tym edukacji i pracy nauczyciela, należy przejść od wiedzy o autonomii do podejmowania autonomii, do autonomicznego działania w określonym kontekście społecznym czy polityczno-prawnym.

Dbałość nauczycieli o to, aby poprzez realizację programu nauczania pomóc uczniom w rozwijaniu ich zdolności do samooceny, krytycznego podejścia do siebie, bycia niezależną jednostką świadomą zakresu wyborów i podejmowanych decyzji, jak i motywów własnego działania, jednostką aktywną dla dobra wspólnot, tych bliższych, np. w szkole i jej otoczeniu, i dalszych - wszystkie te aspekty są niezbędne $\mathrm{w}$ procesie edukacji i wpisują się w warunki uzyskania osobistej autonomii. Wydaje się, że istnieje realne ryzyko, na którym opiera się edukacja lub program nauczania oparty na tych założeniach, że dążenie do rozwoju autonomii ucznia przyczyniłoby się do rozwijania niezwykle refleksyjnych, krytycznych osób, które mogą mimo to być całkowicie niezdolne do podejmowania działań niezbędnych do ich dobrego funkcjonowania, nie mówiąc już o działaniach w sytuacjach nagłych, jakie mają miejsce w świecie gospodarczym, społecznym i politycznym, w świecie pełnym zmian. Rozwijanie wiedzy o autonomii sprzyja samej autonomii, niemniej jednak o autonomii jednostki świadczy zdolność jej działania, to, czy potrafi odnaleźć się w określonej sytuacji, aby móc dokonywać niezależnych i autentycznych wyborów. 


\section{Uwagi końcowe}

Wiek XX, z jego niezwykłym rozwojem kultury, cywilizacji, technologii, szybkością zachodzących zmian, z pewnością przyczynił się do poszerzenia horyzontów możliwości człowieka i stworzył nadzieję na nową jakość życia, odsłaniając poszerzający się zakres odpowiedzialności człowieka za siebie i jego świat. Obecnie - to znaczy tu i teraz w Polsce, pod koniec drugiej dekady XXI w. - wciąż zmieniający się kształt świata, pojawiające się kryzysy i wyzwania o charakterze globalnym, przeobrażenia ekonomiczne i społeczne wymagają istotnych i gruntownych zmian w myśleniu o rzeczywistości, w jej wyjaśnianiu, w postawach ludzkich mających znaczny wpływ na przyszłość społeczeństw i przyszłość świata. W procesie odkrywania odpowiedzialności, jej poszukiwania i jednocześnie realizowania (bycie odpowiedzialnym), granice odpowiedzialności człowieka wyznaczają granice świata, w którym jest obecny i granice identyfikacji z tym, za co czuje się on odpowiedzialny (poczucie wspólnoty z przedmiotem odpowiedzialności). Nie są one wyznaczone z góry, lecz zależą od indywidualnego nastawienia każdego z nas i od naszego afektywnego zaangażowania.

Skupiając swoje rozważania nad ideą autonomii jako jednej z kluczowych idei naszej cywilizacji, należy niewątpliwie podjąć zagadnienie współczesnej kondycji autonomii jednostki i edukacji do/dla autonomii w świetle odpowiedzialności. Wysiłki w tym zakresie powodują, że stajemy przed zadaniem, jakim jest diagnoza współczesności, i jeśli już nie zaproponowanie własnego stanowiska, to chociażby rzetelna prezentacja współczesnego stanu dyskusji o szkole, nauczycielu, społeczeństwie i perspektyw przez nie otwieranych jest konieczna.

Teraźniejszość dowodzi, że wciąż różnimy się w ocenie czasu minionego. Mamy trudności w trafnym odczytaniu zarówno przeszłości, jak i teraźniejszości oraz ich ocenie w obliczu toczących się wręcz fundamentalnych sporów, pokoleniowych obrachunków, rywalizacji środowisk lub instytucji, czy wręcz pojawiającej się świadomej marginalizacji jednych postaci życia społecznego, politycznego czy naukowego, a ustanawiania dominacji innych ich postaci poprzez działania osób sprawujących władzę i mających zasadniczy wpływ na kształt nadmienionych form życia. Niemniej jednak sytuacja, w jakiej się znajdujemy, nie może być usprawiedliwieniem na to, by nie stawiać pytań o przyszłość oraz by nie 
dążyć do przełamywania podziałów, które niefortunnie odciskają swoje piętno na klimacie i poziomie społecznego, publicznego i politycznego traktowania kwestii edukacji w Polsce.

Jako naukowcy zajmujący się pedagogiką jesteśmy moralnie zobowiązani do służenia dobremu życiu i badania warunków jemu sprzyjających. Odpowiedzialność za przyszłość rodzi się z „troski o przyszłe dobro i zło, które można spowodować i któremu można zapobiec z pozycji teraźniejszości” (Brinbacher 1999: 21-22).

Pytanie o stosowne normy odpowiedzialności za przyszłość należy zatem poprzedzić pytaniem o stosowną ocenę teraźniejszych i przyszłych stanów świata. Wydaje się, że postawione przez Henrykę Ciążelę w roku 2001 pytania:

Czy propozycja społeczeństwa obywatelskiego jako sposobu życia może okazać się atrakcyjna dla rywalizujących jednostek zmagających się ze swoimi codziennymi problemami? Czy wobec wyzwań walki o byt bardziej atrakcyjne od dobrowolnych zrzeszeń autonomicznych jednostek nie okazują się korporacje, klany, mafie i inne układy niedobrowolne tworzące społeczeństwo jednostek niesamodzielnych, ale zakorzenionych? Czy samo społeczeństwo obywatelskie ze swoimi gwarancjami autonomii jednostki jako propozycja na przyszłość nie może zostać odrzucone jako nierealna utopia? (Ciążela 2001: 133)

są wciąż aktualne.

Punktem wyjścia do podjęcia odpowiedzi na te i inne pytania powinna być ponowna analiza podstaw naszego społeczeństwa i propozycji odnoszących się do współczesnych realiów życia społeczno-gospodarczego, życia politycznego i kulturowego w naszym kraju. W poszukiwaniu odpowiedzi na te pytania warto pamiętać, że tym, co powinno nas spajać jako naukowców zajmujących się szeroko rozumianą edukacją, są: po pierwsze, poszukiwania związków pedagogiki i edukacji z przemianami społeczeństwa zmierzającego ku liberalnej demokracji, gospodarce rynkowej, ku pluralizmowi i tolerancji dla różnic; po drugie, niezależnie od zasadniczych obiekcji natury teoretycznej, przyszłość może być przewidywana w wymiarze określonego doświadczalnie horyzontu, przynajmniej $\mathrm{w}$ zakresie pozwalającym na budowę modeli teoretycznych, umożliwiających prognozowanie dalszego rozwoju wydarzeń (warto odwoływać się w tym zakresie do teorii globalizacji); po trzecie, uznanie wagi etyki odpowiedzialności za przyszłość edukacji i pedagogiki jako nauki. Współczesność i przyszłość wymagają powszechnego dążenia do 
edukacji rozumianej jako sprzyjającej nabywaniu kompetencji do autonomii i pełni człowieczeństwa (zob. Kwieciński 2019: 43). Tak rozumiana edukacja nie powinna być odnoszona wyłącznie do ucznia, ale w pierwszej kolejności do osób, które zajmują się jego rozwojem. Dlatego warto mówić o edukacji do autonomii i skupić swoją uwagę badawczą zwłaszcza na edukacji w szkole oraz na nauczycielach, którzy mają prowadzić uczniów do wzrastania i pomóc im w rozwoju ich autonomii. Troska o rozwój autonomii nauczyciela - rozumianej jako wartość, ideał, czy wręcz kompetencję w jej ujęciu relacyjnym, a nie tylko rozumianej jako cecha osobowości - powinna być traktowana jako wręcz konstytutywna dla rozwoju autonomii ucznia, bez niej trudno o realizację podstawowych zadań nauczyciela.

Biorąc pod uwagę znaczenie zasygnalizowanej problematyki, a równocześnie kierując się przekonaniem, że edukacja, w tym edukacja nauczyciela, to sprawy szczególnej wagi i nie należałoby pozostawiać ich w gestii polityków, biurokratów, ekonomistów i przedstawicieli biznesu, zachęcam do prowadzenia badań w zakresie podejmowanego tutaj tematu poprzez podjęcie namysłu chociażby nad następującymi kwestiami: Co dziś oznacza autonomia szkoły i jej podmiotów - uczniów, rodziców, nauczycieli, dyrektorów szkól, władz samorządowych? Jakie wymiary autonomii szkoły i jej podmiotów można wyróżnić, i w czym się wyraża ta autonomia w poszczególnych wymiarach? Jakie jest znaczenie edukacji do autonomii? Jakie są szanse jej rozwijania? Jakie są jej ograniczenia? Co narusza autonomię, a co jej zagraża? Jak można ograniczać czy niwelować owe zagrożenia?

\section{Bibliografia}

Aviram A. (1993), Personal Autonomy and The Flexible School, "International Review of Education", nr 39 (5), s. 419-433.

Bee H. (2004), Psychologia rozwoju czlowieka, Zysk i S-ka, Warszawa.

Bridges D. (1997), Personal Autonomy and Practical Competence: Developing Politically Effective Citizens, [w:] D. Bridges, Education, Autonomy and Democratic Citizenship. Philosophy in a Changing World, Routledge, London-New York.

Birnbacher D. (1999), Odpowiedzialność za przyszte pokolenia, tłum. B. Andrzejewski, P. Jackowski, Oficyna Naukowa, Warszawa.

Brzezińska A.I. (2005), Jak przebiega rozwój czlowieka?, [w:] A.I. Brzezińska (red.), Psychologiczne portrety człowieka, Gdańskie Wydawnictwo Psychologiczne, Gdańsk. 
Ciążela H. (2001), Obecny renesans idei spoleczeństwa obywatelskiego a autonomiczność jednostki, [w:] M. Orłowska, M. Jaworowska, H. Ciążela, Różne oblicze podmiotowości we współczesnej Polsce. Analiza wybranych problemów $w$ aspekcie pedagogicznym, socjologicznym $i$ aksjologicznym, Wydawnictwo Akademii Pedagogiki Specjalnej, Warszawa.

Dworkin G. (1988), The Theory and Practice of Autonomy, Cambridge University Press, Cambridge.

Galas B. (2005), Pokolenie, [w:] T. Pilch, Encyklopedia pedagogiczna XXI wieku, t. 4, Wydawnictwo Akademickie „Żak”, Warszawa.

Golding M.P. (1972), Obligations to Future Generations, "Monist”, nr 56, s. 85-99.

Forst R. (2005), Political Liberty: Integrating Five Conceptions of Autonomy, [w:] J. Christman, J. Anderson, Autonomy and the Challenges to Liberalism, Cambridge University Press, Cambridge.

Hessen S. (1997), Podstawy pedagogiki, Wydawnictwo „Żak”, Warszawa.

Kwieciński Z. (2019), Edukacja w galaktyce znaczeń, [w:] Z. Kwieciński, B. Śliwerski (red.), Pedagogika. Podręcznik akademicki, PWN, Warszawa.

Levinson M. (1999), The Demands of Liberal Education, Oxford University Press, Oxford.

Mackenzie C., Stoljar N. (red.) (2000), Relational Autonomy, Oxford University Press, New York-Oxford.

Madalińska-Michalak J. (2019), Kompetencje nauczyciela. Między dziataniem zgodnie z możliwościami a koniecznościq rozwoju zawodowego, [w:] I. Kopaczyńska, M. Magda-Adamowicz (red.), Dziecko w ksztatceniu instytucjonalnym. Idee - refleksje - badania, Wydawnictwo Uniwersytetu Zielonogórskiego, Zielona Góra.

Marynowicz-Hetka E. (2007), Pedagogika społeczna. Podrecznik akademicki, t. 1, PWN, Warszawa.

Nedelsky J. (1989), Reconceiving Autonomy: Sources, Thoughts and Possibilities, "Yale Journal of Law and Feminism", nr 1, s. 7-36.

Nussbaum M. (2006), Frontiers of Justice: Disability, Nationality, Species Membership, Belknap Press, Cambridge, MA.

Olsen M. (2005), Foucault, Educational Research and the Issue of Autonomy, "Educational Philosophy and Theory", nr 37(3), s. 365-389.

Radlińska H. (1961), Pedagogika społeczna, Zakład Narodowy im. Ossolińskich - Wydawnictwo, Wrocław-Warszawa-Kraków.

Reich R. (2002), Bridging Liberalism and Multiculturalism in American Education, Chicago University Press, Chicago.

Sen A. (1999), Development as Freedom, Oxford University Press, Oxford.

Ustawa z 26 stycznia 1982 r. - Karta Nauczyciela; Dz.U. z 2018 r., poz. 967 ze $\mathrm{zm}$.

Ustawa z 7 września 1991 r. o systemie oświaty; Dz.U. z 2018 r., poz. 1457 ze $z m$.

Ustawa z 14 grudnia 2016 r. - Prawo oświatowe; Dz.U. z 2019 r., poz. 1148 ze zm. 


\section{Autonomia wyzwaniem dla naszej edukacji}

\section{Abstract \\ Autonomy as a challenge for our education}

The idea of autonomy can be considered "one of three or four innovations throughout the history of philosophy", following Jürgen Habermas. We owe today's understanding of this idea, which has always been related to the idea of freedom, to Immanuel Kant, but this idea has been forged both in the course of intellectual - particularly philosophical - reflection and in the social, political and economic struggle for its realization in concrete historical conditions. Autonomy based on one's own doing, that is, on being the author of one's own actions, can be understood in various ways. However, this diversity can be put in order. The model for the development of moral thinking, elaborated by Lawrence Kohlberg, is helpful here. The autonomy in its Kantian understanding is only attainable at the post-conventional level of development of this thinking. At this level of development of moral thinking, the measure of the rightness of one's own conduct, that is to say, the measure of how good or bad one's conduct is, is the norm that we can present to ourselves as the norm that governs the will or the freedom, both internal and external, of every single rational being. Subjecting one's will and freedom to such a norm is nothing else but autonomy, or "one's own norm-giving”. The aim of the considerations conducted in the article is, first of all, to show against the background of various possible variations of the understanding of autonomy - Kantian concept of autonomy as a particularly important way of understanding it, having fundamental significance for our perception of ourselves, both as individuals, i.e., unique individuals, and as creating our own political order of communities. The idea of autonomy, this particular product of Greek-Latin thinking and the centuries-long struggle to make it a reality, is particularly threatened in today's world. Because of these threats, it is the idea of autonomy - as an idea which is also to be adopted in the process of education and upbringing - that is a particular challenge for our education, both Polish and European.

Keywords: autonomy, Kant, natural law, the Good, freedom, Kohlberg

Słowa kluczowe: autonomia, Kant, prawo naturalne, dobro, wolność, Kohlberg 


\section{Wstęp: dwa słowa o filiacjach}

Głównymi obszarami moich zainteresowań naukowych były i są nadal: filozofia społeczna, etyka, filozofia polityczna, a także pewna kwestia bardziej szczegółowa i mająca znaczenie praktyczne, a mianowicie edukacja szkolna w zakresie etyki. $\mathrm{Z}$ racji takich właśnie naukowych zainteresowań bliskie mi oczywiście były zarówno badania, jak i refleksja nad edukacją. Niemal u początków mojej akademickiej drogi miały już miejsce kontakty, jak również wspólpraca z naukowcami prowadzącymi podobne badania - badania, którym towarzyszył szerszy namysł nad tym ważnym obszarem społecznej praxis. Na trwale zapisało się w mej pamięci uczestniczenie (w połowie lat 80 .) w zebraniach naukowych w Toruniu i pracach tamtejszego zespołu kierowanego przez prof. Zbigniewa Kwiecińskiego. Przykładem z ostatnich kilku lat konwergowania ze sobą moich zainteresowań naukowych i zainteresowań badaczy zajmujących się edukacją była realizacja - w szerokiej współpracy z prof. Madalińską-Michalak - projektu NPRH „Etyka w systemie edukacji w Polsce i w wybranych krajach świata zachodniego (Niemcy, Wielka Brytania, Hiszpania, Portugalia, Francja, USA, Norwegia, Finlandia)"1. Czasów toruńskich sięga też spojona admiracją dla myśli i dokonań Jürgena Habermasa współpraca z prof. Lechem Witkowskim, za którego sprawą miałem też przyjemność wystąpić podczas Zjazdu Pedagogicznego w Lublinie, w roku 2007, którego hasłami przewodnimi były: „Edukacja - moralność - sfera publiczna”.

Moje wystąpienie w Lublinie, zatytułowane: Dyskurs publiczny a podstawy nowoczesnej kultury: kryzys jako wyzwanie, poświęcone było jednemu z takich wyzwań, jednej z postaci kryzysu kultury, mianowicie fenomenowi, który nader trafnie zdiagnozowany został - przed niemal stu laty - przez José Ortegę y Gasseta, a który określić można za tym wnikliwym diagnostą jako „zawłaszczenie wymiaru publicznego i zagarnięcie władzy” przez - jak nazwany on zostaje przez Ortegę y Gasseta - „człowieka pośledniego” czy „przeciętnego”, pod którym to określeniem - co chcę mocno podkreślić, by usunąć źródło ewentualnych

${ }^{1}$ Jednym $\mathrm{z}$ istotnych efektów realizacji tego projektu jest zawierające bogaty materiał empiryczny, wraz z jego analizami, opracowanie autorstwa Joanny Madalińskiej-Michalak, Antoniego J. Jeżowskiego i Szymona Więsława zatytuowane Etyka w systemie edukacji w Polsce (Wolters Kluwer, Warszawa 2017). 
dezinterpretacji myśli Ortegi y Gasseta - rozumie on „[człowieka], któremu obcy jest trud dokonywania przemyśleń"2.

Można powiedzieć, że tematyka mojego dzisiejszego wystąpienia będzie pod pewnym względem kontynuacją problematyki podjętej w Lublinie, jako że pośrednio będzie ona poświęcona także pewnego typu „człowiekowi”, a mianowicie takiemu, który jest zaprzeczeniem owego „człowieka przeciętnego”, jest to bowiem człowiek, któremu ex definitione „winien być nieobcy trud dokonywania przemyśleń”. O ile tego „człowieka przeciętnego" znamy dobrze z doświadczenia, o tyle człowiek, któremu winien być nieobcy trud dokonywania przemyśleń, jest raczej ideałem, do którego chcielibyśmy, by człowiek dany nam empirycznie możliwie dalece dostawał. Przedmiotem dzisiejszego wystąpienia jest idea autonomii jako jednej z kluczowych idei naszej cywilizacji, cywilizacji łacińskiej, czyli cywilizacji grecko-zachodniochrześcijańskiej. Przy tej okazji chciałbym pogratulować Organizatorom Zjazdu, Komitetowi Naukowemu i Komitetowi Programowemu wyboru tematyki X Ogólnopolskiego Zjazdu Pedagogicznego, świadczącego o uznaniu przez Gremia decydujące o wyborze wiodącej tematyki Zjazdu ogromnej doniosłości idei autonomii.

\section{Idea autonomii i jej urzeczywistnianie}

Idea autonomii - podobnie, jak i inne fundamentalne idee cywilizacji łacińskiej (takie, jak idea wolności, idea równości, idea demokracji, a także idea rządów prawa) - wykształcała się w długim procesie przebiegającym mnogimi drogami, zawsze też w konkretnych, swoistych warunkach. Tę różnorodność można jednak w istocie sprowadzić do dwu zasadniczych sposobów wykształcania się tych idei i nabierania przez nie realnego

2 W swoim wystąpieniu na Zjeździe w roku 2007 tak diagnozowałem genezę i charakter pojawiającego się zagrożenia: „Zagrożenie to źródło swe ma w określonych własnościach mentalnych i w określonym wyobrażeniu o sobie owego ,człowieka pośledniego', ale przede wszystkim [...] w mobilizowaniu i wykorzystywaniu tego typu mentalnego przez pewne kręgi elit politycznych do zwalczania politycznej i ideowej opozycji w celu całkowitego zawłaszczenia dla siebie całej sfery publicznej. Dokonywać się to ma poprzez mobilizowanie owego typu mentalnego, jako kontrolowane aktywizowanie i kontrolowane powierzanie temu typowi mentalnemu władzy (czy częściej surogatów władzy)" (zob. Kaniowski 2008: 78). 
znaczenia. Wykształcanie się idei autonomii, wiodące do jej dzisiejszego, zachodniego pojmowania, przebiegało, po pierwsze, na drodze społecznej, politycznej, religijnej, jak też ekonomicznej walki, która była walką o to, by idea autonomii - podobnie jak i pewne inne fundamentalne idee czy zasady tej cywilizacji (jak na przykład idea równości wszystkich ludzi jako istot stworzonych na podobieństwo Boże) - mogła stać się składową historycznej rzeczywistości, czyli żeby się zrealizowała (jeśli nawet nie w chwili, kiedy wypisywana była na sztandarach, jako że walka w danym historycznym momencie mogła nie zakończyć się powodzeniem, to przynajmniej by mogła urzeczywistnić się w przyszłości). Taką walkę, nie tylko o rząd dusz, ale i będące jego drugą stroną władztwo ekonomiczne i instytucjonalne - i oczywiście o urzeczywistnienie idei autonomii $\mathrm{w}$ pewnym przynajmniej zakresie i w pewnej konkretnej formie - stoczyło, przed niemal dwoma tysiącami lat, chrześcijaństwo. Rewolucyjnym etapem na drodze urzeczywistniania i konkretyzowania idei autonomii była także reformacja. Oczywiste jest, że takim historycznym urzeczywistnianiem kilku idei fundamentalnych dla zachodniej cywilizacji, w tym również idei autonomii - urzeczywistnianiem okupionym jednakże ogromnymi kosztami i nie natychmiast nadającym ucieleśnieniom tych idei pożądany kształt - była rewolucja francuska. Jak widać z powyższych przykładów, walka, nierzadko z użyciem bezpośredniej przemocy, była jak dotąd narzędziem wprowadzania w życie i konkretyzowania fundamentalnych idei zachodniochrześcijańskiej cywilizacji. Druga droga wykształcania się danej idei (i jej późniejszego przenikania do organizacyjnych i instytucjonalnych, tudzież ustrojowych form życia społecznego), to droga namysłu - namysłu filozoficznego, namysłu teologicznego, ogólnie: namysłu teoretycznego (nierzadko też: akademickiego) nad daną ideą; jest to zarazem droga, na której dochodzi do pojęciowego precyzowania danej idei, jej cyzelowania, treściowego krystalizowania, a to znaczy również nadawania jej niejednokrotnie coraz to bardziej uabstrakcyjnionego kształtu, ale też i kształtu przekładalnego historycznie i społecznie na skonkretyzowane rozwiązania polityczne, organizacyjne czy instytucjonalne. Nie bez znaczenia w tym procesie ma też oczywiście publiczne deliberowanie na temat danej idei.

Temu aspektowi kształtowania się idei autonomii - jakim jest wykształcanie się i wykrystalizowywanie się idei w drodze teoretycznego namysłu - poświęcić by należało chwilę uwagi; 
zamierzam też tego dokonać, jednak uczynię to przede wszystkim w sposób poniekąd pośredni, pokazując pewną logikę rozwoju moralnego myślenia, zgodnie z którą przebiegał też historyczny rozwój teoretycznego namysłu nad autonomią i poprzedzającymi ją formami myślenia o wolności, jak też wolnej woli oraz wyznaczający generalne ramy dla myślenia na temat wolności, wolnej woli i autonomii - rozwój form pojmowania i widzenia świata. Idąc śladem tej logiki rozwoju moralnego myślenia, będzie można wydobyć to, co winniśmy - moim zdaniem - uznać za najistotniejszą treść idei autonomii, a co wydobyte i wyłożone zostało przez Immanuela Kanta ${ }^{3}$ (co jednak pozostaje nadal treścią jedynie fragmentarycznie i w sposób - niestety - nieciągły urzeczywistnianą w konkretnych historycznych, społecznych i politycznych warunkach) ${ }^{4}$.

\section{Autonomia wyzwaniem}

Nim jednak przedstawiona zostanie ta logika oraz kantowskie rozumienie autonomii, wyjaśnię pokrótce, w jakim sensie i z jakich powodów - uznałem, iz „autonomia” jest wyzwaniem dla naszej edukacji. Przy czym przez „naszą” edukację rozumiem nie tylko edukację realizowaną w ramach rodzimego systemu edukacji, lecz także edukację realizowaną w ramach świata cywilizacyjnie podążającego okcydentalną ścieżką rozwoju, świata kształtującego się $\mathrm{w}$ toku wielowiekowego procesu okcydentalnej racjonalizacji, której jednym z wytworów - obok zachodniej nauki, opartego na rachunku ekonomicznym gospodarowania, jak też biurokracji oraz ustroju politycznego, wyznaczonego przez konstytucję i określanego jako rządy prawa - jest idea autonomii, która nie tylko dla wyobrażenia na temat jednostki, ale także dla wyobrażenia

3 Autonomia jest dla Kanta „wolnością w rozumieniu pozytywnym”, czyli jest to „własne [...] prawodawstwo czystego i jako taki praktycznego rozumu” (Kant 1984: 58). Z autonomią woli, bo o nią tutaj chodzi, mamy do czynienia wówczas, kiedy „[w]ola [...] nie tylko podlega prawu, ale podlega mu tak, że należy ją uważać także za nadającą sobie samej prawa i właśnie dlatego podległą prawu (za którego twórcę może sama się uważać)" (zob. Kant 1953: 65-66).

${ }^{4}$ Nie należy tych stwierdzeń rozumieć jako wyrazu złudnych oczekiwań, że idea może w porządku empirycznym - czyli w świecie, jaki jest nam konkretnie dany - w pełni niejako się urzeczywistnić. Chodzi tylko o to, że stopień oddalenia od ideału może być relatywnie mały, ale może też to oddalenie być przeogromne i może się - przynajmniej przez pewien czas - jeszcze powiększać. 
o urządzonym mocą konstytucji porządku politycznym oraz rządach prawa ma znaczenie fundamentalne.

Mówiąc o „autonomii” jako „wyzwaniu dla naszej edukacji” mam na uwadze przede wszystkim takie oto kwestie. Pierwszą rzeczą, jakiej należy dokonać, to przynajmniej dobrze zrozumieć ustalenia, do jakich dochodzili ci, którzy zadawali sobie wiele umysłowego trudu, by dotrzeć do najtrafniejszego ujęcia badanych przez nich idei - w tym idei wolności i autonomii - chyba że jest się jednym z tych nielicznych, którzy z największą dokładnością i krytycznym oglądem własnych stwierdzeń sami są w stanie dokonać niezbędnej pracy, pozwalającej dociec, co też winniśmy rozumieć przez „autonomię”. Zarówno jedno, jak i drugie - praca własna, jak i dobre zrozumienie pracy intelektualnej dokonanej przez innych - jest już wyzwaniem. Dalsza rzecz, sprawiająca, iż idea autonomii jest dla nas wyzwaniem, to to, że w naszym cywilizacyjnym, okcydentalnym rozwoju doszliśmy do przekonania, iż idea autonomii winna być transferowana do społeczeństwa m.in. poprzez system edukacji. Nie sprostawszy pierwszemu wyzwaniu rzetelnego zrozumienia dociekań nad autonomią stajemy wobec kolejnych wyzwań: idea autonomii może, po pierwsze, jawić się jako pewna niejasna idea, po drugie, może budzić fałszywe skojarzenia, przez co traktowana może być niekiedy podejrzliwie, po trzecie, może też być traktowana jako idea niezbyt istotna albo całkowicie odstająca od realiów ludzkiego świata (i znanych człowiekowi porządków politycznych), a po czwarte, może uchodzić za ideę, której przekazywanie nie wiadomo komu miałoby być powierzone: rodzicom, wychowawcy, nauczycielowi języka polskiego, a może nauczycielowi religii? W tym sensie jest owa autonomia wyzwaniem, któremu nie całkiem wiadomo jak sprostać. Dodatkową okolicznością, którą w szczególności mam w tym wystąpieniu na uwadze, są wyzwania związane z zagrożeniami dla samej idei autonomii.

Możemy mówić o dwojakiego rodzaju cywilizacyjnych zagrożeniach dla samej idei autonomii: jedne $\mathrm{z}$ nich są zagrożeniami endogennymi (i na nich należy się skupić), drugie zaś są zagrożeniami egzogennymi (o nich z kolei nie można zapominać). Zdiagnozowanie tych zagrożeń winno być, jak mniemam, pierwszym krokiem przy poszukiwaniu sposobów mogących sprzyjać zarówno przekształcaniu postaw i nastawień mentalnych, jak też kształtowaniu instytucji i form organizacyjnych mających służyć temu, by idea mogła nabierać konkretnego społecznego i instytucjonalnego kształtu. 


\section{Dzieje pojęcia autonomii i sposoby jego rozumienia}

Dzisiejsze rozumienie autonomii, w znacznym stopniu urzeczywistniane w warunkach świata zachodniego poprzez ustrój polityczny i przyjęte formy życia, a w procesie socjalizacji i poprzez system edukacji przekazywane kolejnym pokoleniom, jest oczywiście efektem obydwu procesów: długotrwałego procesu walki, jak i procesu namysłu, a to znaczy również: efektem wspomnianego okcydentalnego procesu racjonalizacji, który to proces można pojmować jako urzeczywistnianie - modyfikowanych wciąż - form rozumności. O urzeczywistnianiu poprzez walkę nie zamierzam tu mówić. Skupię się tylko na formach myślenia o autonomii bądź przynajmniej formach możliwego myślenia na ten temat.

Najprzód jednak krótka bardzo relacja na temat historii pojęcia. W antycznej Grecji termin autonomia (av̉iovouía) oddawał treści podstawowej wówczas kategorii politycznej i oznaczał - będącą głównym obiektem dążeń każdego z greckich państw-miast możność samodzielnego decydowania przez te miasta o swoich wewnętrznych i zewnętrznych sprawach. Były pomiędzy autorami - takimi jak Herodot, Tukidydes czy Ksenofont - pewne drobne odmienności w rozumieniu pojęcia autonomii, gdy chodzi o zasadniczą treść, panowała tu jednak zgoda: autonomia rozumiana była jako kategoria polityczna, wyrażająca możność zagwarantowania sobie przez państwo-miasto prawa decydowania o swoich sprawach. Głównego znaczenia i kontekstu posługiwania się tym terminem nie zmienią pojawiające się odmienne użycia - jak na przykład użycie przez Sofoklesa terminu autonomia dla określenia wewnętrznej postawy Antygony, która postępując zgodnie ze swym wewnętrznym prawem zajęła postawę odznaczającą się „autonomią” (Pohlmann 2007: 701-719). Rzymianie nie przejęli greckiego terminu, oddawali tę samą treść słowem potestas (władza, możność). Również własny termin mieli dla oddania tego, co nam może się kojarzyć z autonomią, a na oddanie czego również Grecy mieli odrębny termin - chodzi oczywiście o „wolność”. Tak jak Grecy, mówiąc o wolności, posługiwali

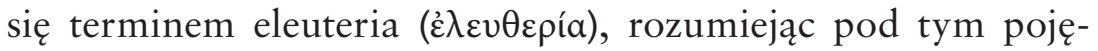
ciem przywilej obywatela polegający na możności swobodnego poruszania się, tak Rzymianie posługiwali się dla oddania tego uprawnienia terminem libertas. Zatem zarówno dla Greków, jak 
i dla Rzymian, autonomia i wolność nie znaczyły tego samego, stąd też i odmienne terminy, jakimi się posługiwali.

Średniowiecze nie zna terminu autonomia. Nie oznacza to jednak, że w epoce tej nie zajmowano się problemem, który nam jawi się jako bliski kwestii oddawanej terminem autonomia, czyli problemem „wolności”. Dopiero w czasach nowożytnych, w wieku XVII i XVIII, pojęcie autonomii nabiera ponownie znaczenia, przy czym jest ono przedmiotem zainteresowania i analiz przede wszystkim $w$ naukach prawnych. Staje się ono natomiast doniosłym pojęciem filozoficznym za sprawą Kanta i jego teorii autonomii. Poprzez nawiązania do Kanta trafia ono też do innych nauk, w których pod to pojęcie podkładane będą nie zawsze takie same treści i znaczenia.

Do Kantowskiego rozumienia autonomii dojdziemy tu drogą pośrednią, czyli nie poprzez rekonstruowanie XVII- i XVIII-wiecznych rozważań prowadzonych przez jurystów czy filozofów - jak Locke czy Rousseau - lecz poprzez wskazanie na nasze potoczne rozumienia autonomii, a następnie poprzez ukazanie transformacji szerszych ram naszego myślenia o świecie, rzeczywistości i człowieku, w których obrębie kształtować się będzie takie bądź inne - w tym również Kantowskie - rozumienie autonomii.

W obiegowym jej rozumieniu - ale też na przykład w rozumieniu przyjmowanym zazwyczaj w rozważaniach na temat tzw. autonomii pacjenta - ,autonomia” to tyle samo, co możliwość stanowienia o sobie. Takie „skrótowe” rozumienie może stać się źródłem różnorakich nieporozumień. Nie budzi specjalnych kontrowersji to, że pacjent może „stanowić o sobie” i że bez jego zgody (bądź osób prawnie do tego upoważnionych) nie można czynić mu czegokolwiek wbrew jego wolis.

\section{Autonomia i jej „obiektywna miara”}

Takiemu rozumieniu autonomii zdaje się być bliskie jej pojmowanie jako stanowienia o sobie wedle własnej woli - by nie powiedzieć: wedle swego „widzi mi się". Jednak z wyjątkiem może głosicieli jakiś skrajnych poglądów, apoteozujących

5 Rzecz oczywiście nie wygląda tak prosto. Brane są wszak niekiedy pod uwagę pewne szczególne okoliczności. Ze względu na nie udziela się pozwolenia na działanie, które zdaje się naruszać autonomię pacjenta. Nie miejsce tu jednak na rozwijanie tego pobocznego - z punktu widzenia niniejszych rozważań - wątku. 
„jednostkę” bądź jej „wolę mocy”, wszyscy inni interpretatorzy pojęcia autonomii (a także wolności) będą przyjmowali przynajmniej jedno z wymienionych założeń lub obydwa założenia, w których zawarte są określone warunki ograniczające skrajnie indywidualistyczne rozumienie autonomii. W myśl pierwszego założenia autonomia polega oczywiście na wolności czynienia tego, co się pragnie, pod warunkiem, że nie godzi to w autonomię innej jednostki, czyli możliwość czynienia również przez tę drugą jednostkę tego, co z kolei jest jej pragnieniem. Dalej idące założenie nakłada na autonomię ograniczenie, jakim jest warunek zgodności „autonomicznego” działania podmiotu (przez co może też być rozumiany wybór przez jednostkę sposobu życia) z pewną „obiektywną” miarą. Oczywiście wyobrażenia na temat owej „obiektywnej miary” będą - w szczególności w warunkach dzisiejszego, pluralistycznego świata - rozmaite. Okoliczność ta sprawia, że wszyscy ci, którzy nie są rzecznikami skrajnego indywidualizmu, ani też apologetami „woli mocy”, stają wobec problemu, jakim miarom i ze względu na jakie "racje” przypisać można, bądź należy przypisać charakter „obiektywny”, czyli powszechnie wiążący - innymi słowy charakter "racjonalny”.

Problemem oczywiście jest rozumienie owej „obiektywności”, a w szczególności wyobrażenie na temat tego, co jest podstawą „obiektywności” i w czym owa „obiektywność” jest ufundowana. Zadając takie pytanie - na które odpowiedź może wydawać się niektórym oczywista, acz dla wielu taką właśnie nie jest wkraczamy w obszar sporów filozoficznych, którym przy okazji rozważań na temat rozumienia autonomii poświęcić by warto było dłuższą chwilę uwagi. Te bowiem właśnie filozoficzne sposoby pojmowania podstaw obiektywności rzutują na rozumienie autonomii, a swoje odbicie znajdują również w wyobrażeniach

${ }^{6}$ Przyjmuję do wiadomości, że dość szeroko dyskutowane są dziś koncepcje głoszące, że za „racjonalne” winniśmy uznawać wszystko to, co dana jednostka uznaje za „racjonalne”, a co z kolei rozumiane jest jako odpowiadające jej preferencjom bądź będące - wedle jej wyobrażeń - w jej interesie. Takie skrajnie „indywidualistyczne" rozumienie racjonalności dalece odchodzi od pojmowania racjonalności i rozumności w ramach tradycji, w której rozumienie tych pojęć się kształtowało (podlegając oczywiście w toku rozwoju europejskiego myślenia kolejnym transformacjom). W niniejszych rozważaniach pomijam całkowicie takie skrajnie „indywidualistyczne” rozumienie racjonalności, uznając je za pozbawiające pojęcie racjonalności resztek jego elementarnej treści, czyli odwracające całkowicie podstawowy sens tego pojęcia. 
na jej temat żywionych przez zwykłych ludzi - o ile oczywiście nie są oni z góry przeświadczeni, że autonomia to jakaś chimera, nie ma bowiem dla niej miejsca w świecie, w którym rządzi $\mathrm{w}$ istocie prawo silniejszego, a imperatywy przetrwania każą podporządkowywać się jego woli (zwłaszcza, że może to bezwolnie podporządkowującemu się przynieść też wymierne dlań korzyści). Koncepcjom filozoficznym nie zamierzam tu jednak poświęcać nazbyt wiele uwagi, raczej chciałbym objaśnić wspomniane problemy z rozumieniem autonomii i obiektywności oraz rozumieniem miar owej obiektywności, odwołując się do koncepcji znanej doskonale pedagogom i psychologom, pozwalającej w sposób bardzo przejrzysty uporządkować różne sposoby moralnego myślenia, a tym samym myślenia o autonomii. Taką koncepcją jest kohlbergowska koncepcja logiki rozwoju moralnego.

Nawet jeśli człowiek - obojętne, czy nader młody czy dorosły - kierujący się swoim przede wszystkim interesem, kierowanym ku niemu oczekiwaniom co do jego zachowania czyni zadość jedynie wówczas, gdy jest to właśnie w jego interesie, a zatem urzeczywistniając „w praktyce” autonomię rozumianą jako postępowanie dobrze służące realizowaniu przezeń jego interesów, nie zastanawia się nad swą autonomią, to ją oczywiście, zgodnie ze wskazanym tu jej rozumieniem - a właściwie jej dezinterpretacją - praktykuje. "Słuszne” z tej perspektywy - i można w tym wypadku powiedzieć, że jest to dezinterpretacja „słuszności” jest to, co służy interesom działającego, a miarą tej „słuszności” jest on sam. Trudno tu zatem mówić o „obiektywnej” mierze. Można zatem takie rozumienie i praktykowanie autonomii uznać za nieodpowiadające poszukiwanemu i rekonstruowanemu tu pojęciu autonomii i korespondującemu z nim wyobrażeniu na temat „obiektywności”.

Kiedy jednak człowiek baczy już na oczekiwania swego - empirycznie mu danego - otoczenia, czyli rodzinę, grupę rówieśniczą, wspólnotę religijną, naród, którego czuje się częścią i do którego przynależność swą również emocjonalnie przeżywa, to wówczas ma poczucie dysponowania obiektywnymi miarami słuszności swego postępowania bądź wyboru sposobu życia. Taką miarą są oczekiwania żywione przez którąś z tych wspólnot czy przez któreś z nich. Nie musi to zawsze być ta faktycznie, empirycznie dana wspólnota i nie muszą to być oczekiwania jej empirycznie danych członków - niekiedy wszak żywiących oczekiwania nieprzystające do normatywnego wyobrażenia o tym, jaką ta 
wspólnota jest, czyli jaką wedle jej idealnego obrazu winna być - niemniej jednak takiej miary słuszności dostarcza realna bądź idealna wspólnota, która jest wspólnotą zespoloną czy to więzami krwi, wspólną wiarą, doznawanymi w przeszłości krzywdami czy też innymi zapisanymi w kolektywnej pamięci przeżyciami. Ktoś, kto postępuje w sposób przystający do oczekiwań żywionych przez członków tej wspólnoty, czy też w sposób przystający do jej idealnego o sobie wyobrażenia - mimo wszelkich przeszkód i przykrości, jakie mogą go spotkać ze strony „wrogów”, czyli krytyków czy przeciwników tejże wspólnoty będzie miał poczucie, iż jego postępowanie jest autonomiczne, to znaczy nie poddające się presji wywieranej przez krytyków jego postępowania, jego przeciwników czy wrogów. Możemy zatem wyobrazić sobie takie rozumienie autonomii, które polega na postępowaniu zgodnie z pewnymi „obiektywnymi” miarami słuszności postępowania i to pomimo przeszkód, na jakie działający podmiot natrafia.

Nieco bardziej wysubtelnioną formą podobnego myślenia o autonomii i obiektywności jest myślenie moralne odwołujące się do bardziej już abstrakcyjnej miary słuszności i obiektywności, jaką jest porządek ról i funkcji wyznaczonych przez system społeczny. Miarą słuszności nie są w tym wypadku oczekiwania wspólnoty tego rodzaju, jaką jest wspólnota dana „z krwi i kości” (czy też ta, za jaką się ona ma w swych własnych o sobie wyobrażeniach), lecz miarą słuszności są oczekiwania wpisane w system społeczny, który urządzony jest według pewnych - bynajmniej nie arbitralnych - praw. W rekonstruowanej przez Kohlberga logice rozwoju moralnego ta forma moralnego myślenia określona jest jako law and order orientation, czyli logika orientowania się w swym postępowaniu podług tego, co jest czymś oczekiwanym czy wymaganym nie ze strony takiej czy innej wspólnoty, której jest się członkiem, lecz ze strony systemu społecznego, który jest postrzegany przez reprezentantów takiego myślenia moralnego jako porządek urządzony według pewnych „obiektywnych” i „słusznych” praw (zob. Kohlberg, Hersh 1977: 55).

Owe „obiektywne” prawa mogą mieć swoją podstawę w tym, że dzięki urządzeniu podług nich porządku społecznego funkcjonowanie społeczeństwa jest efektywne, przez co rozumie się w tym przypadku to, iż dobre funkcjonowanie systemu społecznego przysparza jego członkom pożytków. Myślenie uznające za rzecz słuszną, by człowiek w swym postępowaniu orientował się 
na „prawo i porządek”, czyli kierował się „oczekiwaniami” ze strony "systemu" - które to oczekiwania mogą niekiedy wymagać nawet daleko idących poświęceń (w skrajnym wypadku, na przykład, poświęcenia życia przez rzetelnie wypełniającego swą rolę społeczną policjanta) - to myślenie każące się orientować podług oczekiwań i wymagań ze strony tworu o wiele bardziej abstrakcyjnego, aniżeli jakaś „wspólnota” (Kohlberg, Hersh 1977: 96); człowiek w ten właśnie sposób myślący uzasadnia uznanie dla obiektywnej słuszności owego porządku - który jest urządzony podług pewnych praw i stawia wobec członka systemu społecznego określone wymagania - przeświadczeniem, iż to efektywność funkcjonowania tej całości, jaką jest tu „system społeczny”, jest owym „dobrem”, będącym obiektywną miarą słuszności.

Strukturalnie, pod pewnym oczywiście tylko względem, acz bardzo istotnym, dalece podobny do tego sposobu rozumowania jest sposób myślenia o porządku urządzonym w zgodzie z prawem naturalnym, czyli myślenia, którego klasycznej wykładni dokonał św. Tomasz z Akwinu. Również w tej wersji myślenia o „prawie i porządku” uznaje się, że porządek ten jest urządzony podług praw pochodzących od człowieka, jednakże inaczej niż w wersji kohlbergowskiej ten pochodzący od człowieka porządek ma inną zupełnie, „obiektywną” podstawę, będącą też źródłem i miarą jego słuszności. Wprawdzie człowiek - a dokładnie prawodawca (a nie poddany - bo taki podział, na prawodawców i poddanych, jest właśnie zgodny, według św. Tomasza, z porządkiem naturalnym) ustanawia prawo, jednak prawowitość tego prawa wynika nie tyle z rozumności stanowiącego to prawo, co ze zgodności stanowionego prawa z „obiektywnym porządkiem rzeczywistości”, z porządkiem (celowo zorganizowanej) „natury”. Oczywiście nie chodzi tu o „naturę" i „stan natury” w nowożytnym rozumieniu tych terminów. „Natura” jest tu rozumiana metafizycznie jako porządek bytów i działań, które zawsze i w każdym wypadku zorientowane są na pewien właściwy sobie cel, czyli na swego rodzaju „dobro”, które widziane jest jako wpisujące się w całość w ten oto sposób, że właściwe danemu bytowi czy danemu działaniu dobro jest zarazem środkiem do dobra wyższego, które z kolei jest środkiem do kolejnego wyższego dobra, kresem zaś tych mnogich ciągów środków i celów jest dobro najwyższe, czyli Bóg, a w wypadku takiego podobszaru całego porządku natury, jak społeczeństwo i państwo, takim celem najwyższym, czyli dobrem najwyższym, jest „dobro wspólne”. Nie dość zatem, że 
mamy obiektywną miarę, to jeszcze na dodatek jest ona miarą „dobra”. Zgodnie z takim myśleniem i obrazem świata działanie człowieka - z tej racji, że człowiek jest istotą wyposażoną w rozum i zdolną rozeznać się w „porządku natury” - powinno być zorientowane na „obiektywne” dobro, a autonomia (św. Tomasz mówi tu o działaniu wolnej woli) będzie polegała właśnie na realizowaniu tego, co według tego obrazu świata jest pojmowane jako „obiektywne dobro".

Również w wypadku tego myślenia - które można by określić jako pewną wersję law and order orientation - jest miejsce na „autonomię”, acz ma ona tu raczej (a) postać skłonionej przez rozum ku obiektywnemu dobru „wolnej woli”, bądź (b) pewnego obszaru swobody, zagwarantowanej pomniejszym wspólnotom (jak rodzina) czy członom całości, w obrębie którego będzie możliwe urzeczywistnianie owego właściwego temu bytowi dobra bez całkowitego zdominowania przez - skądinąd według św. Tomasza niezbędny do sprawnego funkcjonowania całości władczy autorytet.

Nie jest to jednak rozumienie autonomii, jakie stopniowo wykształcało się z nowożytnego rozumienia wolności i nowożytnego pojmowania rozumu oraz prawa. Droga, na której będzie wykształcało się to pojęcie autonomii, wiedzie od Hobbesowskiego rozumienia wolności do Kantowskiego pojęcia autonomii. Oczywiście, również po Kancie, jak i we współczesnej myśli, nadal ma miejsce praca nad jak najbardziej trafnym ujęciem tego, co ma stanowić istotną treść pojęcia autonomii; żeby jednak móc w sposób sensowny nad tymi współczesnymi wariantami namysłu nad autonomią prowadzić jakiekolwiek rozważania - czego jednak nie zamierzam tu czynić - należy najpierw uchwycić istotną treść Kantowskiego pojęcia autonomii, o którym Jürgen Habermas w wygłoszonym w czerwcu 2019 r. wykładzie podczas konferencji na Uniwersytecie we Frankfurcie nad Menem, zorganizowanej z okazji jego 90. urodzin, powie, że jest ono „jedną z trzech bądź czterech wielkich innowacji na przestrzeni całych dziejów filozofii”.

Jak rozumiana jest ta autonomia? $\mathrm{Na}$ czym polega ta wielka innowacyjność pojęcia autonomii, którego prostej acz rewolucyjnej wykładni dostarczył Kant? Autonomia - czyli zgodnie z greckim źródłosłowem: „własne prawodawstwo” - to pewna szczególna, najwyższa postać wolności, której Kant rozróżnia jeszcze dwie inne odmiany. Mamy więc wolność empiryczno-psychologiczną, czyli 
wolność polegającą na niezależności aktów woli od czynników zewnętrznych i determinowaniu woli przez własne, wewnętrzne przedstawienia i odczucia. Obok takiego, znanego nam dobrze pojęcia wolności, możemy także przynajmniej pomyśleć sobie wolność jako całkowitą niezależność od przyczynowości rządzącej przyrodą zmysłową, czyli rządzącej w porządku empirycznym; tak rozumianą wolność nazywa Kant wolnością w rozumieniu transcendentalnym. Wolność w tym jej rozumieniu jest pojęciem wyznaczonym przez negację, a mianowicie przez negację podlegania przyczynowości rządzącej światem danym nam w doświadczeniu - światem, w którym na przykład silniejszy dyktuje swoją wolę słabszemu, pragnący uzyskać jakąś korzyść daje się skorumpować, szantażowany składa zaś fałszywe oskarżenia, a lękający się mąk piekielnych wystrzega się popełnienia grzechu ciężkiego. Pozytywną formą tejże wolności transcendentalnej, wolności możliwej do pomyślenia, jest właśnie autonomia. Autonomia, czyli wolność w sensie ściśle moralnym, polega na nieuleganiu przez wolę presji popędów i pożądań, czyli nieuleganiu „skłonności”, oraz na determinowaniu woli (chcenia) jedynie przez „rozum praktyczny”, który przez Kanta pojmowany jest nie jako rozum rozpoznający, co jest „obiektywnym dobrem”, tylko rozum przedstawiający sobie prawo moralne, a jest nim prawidło, które możemy sobie pomyśleć - bez popadania w wewnętrzną sprzeczność - jako rządzące wolą każdej jednej istoty rozumnej. Działanie woli z szacunku dla tak pojętego prawa moralnego jest niczym innym jak właśnie autonomią, czyli „sprawczością z wolności" - wola nie jest determinowana ani przez czynniki zewnętrzne, ani przez jakiekolwiek przedstawienia i odczucia, a jedynie przez „powszechną normę”, czyli normę dającą się pomyśleć jako rządzącą wolą każdej jednej istoty rozumnej.

Rewolucyjność tej postaci myślenia moralnego, a zarazem myślenia o człowieka, o świecie, jak też o właściwym ustroju politycznym (bowiem i dla myślenia o ustroju politycznym to pojęcie autonomii ma znaczenie podstawowe), polega na tym, że zupełnie inna - aniżeli w wypadku koncepcji mówiących, iż miarą obiektywności jest dobro, na które zorientowany ma być człowiek i wszelkie jego działanie - jest miara, podług której orzekać ma człowiek o swoim działaniu, w czym innym miara ta ma swoją podstawę i na czym innym zupełnie polega „obiektywność" porządku, który stanowić ma w tym wypadku punkt odniesienia. Ów „porządek”, podług którego mierzona jest słuszność czynu, to 
porządek ustanowiony mocą woli działającej w każdym jednym wypadku podług jednego i tego samego prawa, czyli na przykład prawa zakazującego składania fałszywych oskarżeń. Miarą obiektywności i punktem odniesienia jest przedstawiana przez ów prawodawczy rozum rzeczywistość, która jest rzeczywistością, którą prawodawczy rozum może sobie przedstawić jako taką, która może i powinna istnieć, natomiast działający ze względu na ową rzeczywistość, czyli z szacunku dla normy (prawa) podług której winna ona być urządzona, jest działającym moralnie, a jego działanie jest autonomiczne, czyli determinowane przez prawo, które rozum może sobie przedstawić, jako rządzące wolą każdej jednej istoty rozumnej. Podporządkowanie się temu właśnie prawu - tak rozumianemu „prawu powszechnemu”, któremu z racji właśnie tej powszechności przysługuje też obiektywność (prawu, któremu każe się podporządkować nie jakaś inna wola, tylko moja własna wola, wola działającego) - jest właśnie niczym innym jak autonomią.

Za sprawą Kanta pojęcie moralności i pojęcie autonomii jako wiązania własnego arbitralnego chcenia własnym, kierowanym przez rozum, normodawstwem - stają się pojęciami ze sobą sprzężonymi: nie jest się autonomicznym, jeśli swego arbitralnego chcenia nie podporządkowuje się prawu mogącemu i mającemu rządzić chceniem każdej jednej istoty rozumnej.

Fundamentem owego prawa, któremu przysługuje powszechna ważność, jest nie niezależny od podmiotu „obiektywny porządek rzeczywistości”, tylko porządek ustanowiony wolą działającego podmiotu, która zarazem jest i ma być tożsama z wolą każdej jednej istoty, a zatem niejako jedną wolą, bowiem działającą - to znaczy winną działać - tak samo w wypadku każdej jednej istoty, którą wyróżnia to, że jest w stanie determinować swoje chcenie chceniem, jakie może i winno być chceniem każdej jednej istoty rozumnej, na przykład chceniem tego, by nikt nigdy i nigdzie nie uzyskiwał tego, co jest przedmiotem jego arbitralnego chcenia poprzez krzywdę wyrządzaną innym.

Jakie szczególne właściwości tego Kantowskiego pojęcia autonomii czynią je tak wyjątkowym, i tak doniosłym cywilizacyjnie? Tak pojęta autonomia każe patrzeć człowiekowi na swoje działanie przez pryzmat mającej mieć powszechną ważność normy. Innymi słowy nakazuje taką samą miarą mierzyć własne postępowanie, jak i postępowania każdego innego człowieka, stosując zarazem do tej oceny nie „empiryczną” miarę, jaką mogłaby być 
na przykład statystyczna częstotliwość danego sposobu postępowania i faktyczne społeczne przyzwolenie na takie postępowanie, lecz normę mówiącą, jakie postępowanie winno mieć miejsce $\mathrm{w}$ świecie istot rozumnych, czyli zdolnych związać swoje arbitralne chcenie prawem powszechnym. W myśl tego pojęcia autonomii również porządek polityczny nie może być uznany za urządzony w sposób w pełni prawowity, jeśli każdy z przynależących do tego porządku nie miałby takiego samego prawa stanowić o rządzących tym porządkiem prawach i nie byłby zarazem zobowiązany do tego, by z własnej woli tym ustanowionym też mocą jego woli prawom się podporządkowywać.

Istotną własnością Kantowskiego pojęcia autonomii jest to, że niesie ono ze sobą zarówno określoną wizję człowieka, jak też wizję urządzenia porządku politycznego. Człowiek winien być zdolny stawić czoła presjom świata empirycznego i zachować się tak, jak dyktuje prawo moralne, mimo wszelkich presji ze strony empirycznie danej rzeczywistości. Gdy zaś chodzi o myślenie o porządku politycznym, jest to z kolei porządek pomyślany jako porządek inkluzywny, czyli nie wykluczający, lecz włączający wszystkich. Porządek, który urządzony jest mocą wspólnej woli wszystkich, którzy podlegać mają stanowionym w jego ramach prawom.

Człowiek autonomiczny - w myśl Kantowskiego rozumienia autonomii - to człowiek, który jest zdolny sprzeciwić się presjom zewnętrznym, jak również patrzeć na sprawy z perspektywy każdego innego, zdolny zatem do zachowania obiektywności, gdyż do wszystkich, w tym i do siebie, stosuje te same miary. Odpowiadające warunkom współczesnego świata jest też jego myślenie o porządku politycznym. Nie może to być porządek kogokolwiek dyskryminujący, musi to być porządek, w którym każdy winien się móc odnaleźć jako prawodawczy podmiot przynajmniej potencjalnie.

\section{Zakończenie: o zagrożeniach raz jeszcze}

Autonomia w rozumieniu odziedziczonym po Kancie jest wystawiona - jak powiedzieliśmy na początku - na różne zagrożenia. Zagrożenia te są nie tylko zagrożeniami zewnętrznymi, jakim jest na przykład wywierana z zewnątrz presja pewnej wizji sposobu urządzenia życia społecznego i politycznego, która jest wizją społeczeństwa zapewniającego pewien satysfakcjonujący 
daną społeczność poziom dobrobytu i bezpieczeństwo, za co $\mathrm{w}$ istocie ceną jest jednak ubezwłasnowolnienie członków społeczeństwa. Wizja ta realizowana jest w Chinach i niesiona jest w świat wraz z ekspansją ekonomiczną tego kraju. Nie tylko społeczeństwa Afryki, w bardzo wielu już wypadkach, zaakceptowały tego typu porządek. Również w społeczeństwach Zachodu obserwować można gotowość do rezygnowania z wolności, jeśli zapłatą ma być bezpieczeństwo i dobrobyt.

Istotne jednak są też zagrożenia wewnętrzne. Ponieważ życie w warunkach autonomii jest o wiele trudniejsze niż w warunkach gwarantującego pewien dobrobyt zniewolenia, jako że życie w warunkach autonomii wymaga poszukiwania wspólnych, akceptowalnych dla wszystkich członków społeczności, regulacji i rozwiązań, wymaga tym samym aktywnego uczestniczenia $\mathrm{w}$ publicznym deliberowaniu, wytaczania racji i reagowania na racje wytaczane przez oponentów; z tych to m.in. powodów gotowość do rezygnacji z autonomii nie jest bynajmniej zjawiskiem marginalnym, tak jak marginalnym jest pragnienie autonomii w społeczeństwie Chińskiej Republiki Ludowej.

Jednym z poważniejszych zagrożeń i przeszkód w urzeczywistnianiu autonomii w rozumieniu, jakie uzyskała w wyniku Kantowskiego nad nią namysłu, jest tkwienie znacznej liczby członków społeczeństwa w myśleniu, któremu trudno jest pogodzić się z faktem aksjologicznego, światopoglądowego pluralizmu. Myślenie, dla którego miarą „obiektywności” czy „słuszności” jest porządek rzeczywistości urządzony zgodnie z prawem naturalnym, nie może się pogodzić z innymi wyobrażeniami na temat spraw, które mają charakter światopoglądowy. Nie jest też myślenie to gotowe szukać rozwiązań akceptowalnych także przez inaczej myślących, z którymi przychodzi im żyć w ramach jednego porządku politycznego i prawnego. Myślenie w kategoriach prawa naturalnego jest takim wewnętrznym zagrożeniem dla autonomii w rozumieniu Kanta. Ponieważ to właśnie to Kantowskie pojęcie autonomii jest wyobrażeniem o nas samych, lepiej przystającym do dzisiejszej kondycji świata zachodniego - i tym m.in. różni się od myślenia dominującego poza okcydentem więc jego zachowanie i implementowanie jest przedsięwzięciem cywilizacyjnie doniosłym.

Jest to zarazem wyzwanie, również wyzwanie dla systemów edukacji. Jak bowiem „uczyć” tej rozumianej w tradycji kantowskiej autonomii? W przełożeniu na praktykę edukacyjną oznaczać 
to bowiem winno kształcenie przede wszystkim w otwartości na możliwe odmienne od naszego sposoby widzenia i interpretowania świata, kształcenie w umiejętności zajmowania krytycznego stanowiska wobec własnych poglądów i samemu głoszonych twierdzeń, jak też kształcenie $\mathrm{w}$ umiejętności patrzenia na te twierdzenia oczami drugiej strony. Kształcenie takie nie oznacza wcale hołdowania kulturowemu czy światopoglądowemu relatywizmowi. Otwartość nie oznacza bezrefleksyjnej afirmacji, oznacza tylko gotowość poddawania krytyce własnego poglądu, ale jednocześnie domaganie się od drugiej strony gotowości poddania namysłowi i dyskursowi przez nią głoszonych twierdzeń i poglądów. Tylko poprzez gotowość obydwu stron do wymiany racji (w tym też dyskusja nad tym, dlaczego to, co na poparcie swych twierdzeń przytacza któraś ze stron jako „rację”, może bądź nie może zostać zaakceptowane jako „racja”) możliwe jest w warunkach współczesnego świata urzeczywistnianie autonomii. Świadectwem zniewolenia - i to zniewolenia, w które samemu się popadło za sprawą braku otwartości, jak też z racji tkwienia w przeświadczeniu, że ma się monopol na prawdę, prawdę „obiektywną” jest właśnie całkowite odrzucenie sporu na argumenty i operowanie w tej rzekomej „dyskusji” insynuacjami, inwektywami i krzykiem. Wyzwaniem jest więc edukowanie, które wyposaży wychowywanych w takie ramy widzenia i pojmowania świata, które będą sprzyjały autonomii, a nie wyżej scharakteryzowanemu zniewoleniu.

Wyzwanie jest poważne. Pozostaje działać i wierzyć, że zdołamy mu sprostać, mimo że zawtaszczenie wymiaru publicznego i zagarnięcie władzy przez człowieka, o którym Ortega y Gasset powiedział, że obcy jest [mu] trud dokonywania przemyśleń, zdaje się czynić ogromne postępy. Od tego, czy uda się temu zjawisku postawić tamę, zależeć będzie przyszłość zarówno nasza, jak i przyszłość całej cywilizacji zachodniej.

\section{Bibliografia}

Habermas J. (2019), Moralität und Sittlichkeit, https://www.normativeorders. net/media/images/Programme/2019_Programme/Juergen\%20Habermas_ Moralitaet\%20und\%20Sittlichkeit.pdf (dostęp: 09.02.2020).

Garz D. (2009), Lawrence Kohlberg - An Introduction, Opladen, Budrich.

Kaniowski A.M. (2008), Dyskurs publiczny a podstawy nowoczesnej kultury: kryzys jako wyzwanie, [w:] M. Jaworska-Witkowska, Jaka kultura? Jaki dyskurs? Sfera publiczna a spory o edukacje, pedagogike i zarzadzanie, Wyższa 
Szkoła Humanistyczna Towarzystwa Wiedzy Powszechnej w Szczecinie, Szczecin.

Kant I. (1953), Uzasadnienie metafizyki moralności, tłum. M. Wartenberg, przekład przejrzał R. Ingarden, PWN, Warszawa.

Kant I. (1984), Krytyka praktycznego rozumu, tłum. J. Gałecki, PWN, Warszawa. Kohlberg L., Hersh R.H. (1977), Moral Development: A Review of the Theory, “Theory Into Practice”, vol. 16, nr 2, s. 53-59.

Madalińska-Michalak J., Jeżowski A.J., Więsław S. (2017), Etyka w systemie edukacji we Polsce, Wolters Kluwer, Warszawa.

Ortega y Gasset J. (2008), Bunt mas, tłum. P. Niklewicz, Muza, Warszawa.

Pohlmann R. (2007), hasło: Autonomie, [w:] G. Bien, J. Ritter (red.), Historisches Wörterbuch der Philosophie, Bd. 1, unter Mitw. von mehr als 700 Fachgelehrten, Schwabe, Basel-Stuttgart. 


\title{
Pedagogika (braku) zaufania ${ }^{1}$
}

\author{
Abstract \\ Pedagogy of (the lack) of confidence
}

The phenomenon of decreasing confidence and trust in academic environments is the subject-matter of my analysis. I observe one of the reasons for that in the fights of political elites, which tend to drag scientists into their political games. The instrumental utilisation of worldview disparities, religious activity, ideological and political preferences split scientific and academic staff, becoming the cause of antagonism among the representatives of social sciences and humanities. I write about pedagogy which is dependent on state affairs and included in activities firstly concentrating on gaining political power by a specific political formation, secondly - on maintaining it thanks to the system of national education, care, and upbringing.

Keywords: university, pedagogy, worldview, political battle, politics, political power, democracy, conflicts, science

Słowa kluczowe: uniwersytet, pedagogika, światopogląd, walka polityczna, polityka, władza, demokracja, konflikty, nauka

\section{Wstęp}

Umówiliśmy się w gronie organizatorów X Zjazdu Pedagogicznego, że podejmiemy w plenarnym referacie po jednej $\mathrm{z}$ trzech podstawowych kategorii zawartych w wiodącym temacie naszych obrad. Mnie przypadła kwestia zaufania, co początkowo budziło mój dyskomfort, bo jakże mówić o czymś tak oczywistym i dobrze opisanym w literaturze naukowej (Sztompka 2007), by nie powtarzać znanych już zagadnień. Doszedłem jednak do wniosku, że warto dokonać odsłony tego fenomenu w odniesieniu do

1 Wystąpienie na otwarcie X Ogólnopolskiego Zjazdu Pedagogicznego 18 września 2019 r. 
jego zanikania także w pedagogice akademickiej - tak w sensie instytucjonalnym (kulturowym, prawnym), jak i jego (nie-)obecności w przestrzeni publicznej. Jubileusz zjazdów pięknie zbiega się z mijającym trzydziestoleciem, które określam za Erichem Frommem ucieczką od wolności (Fromm 2014) - ze względu na podważanie przez część nauczycieli akademickich (różnych dziedzin naukowych) podstaw kulturowych i naukowych pedagogiki jako wspólnoty poznawczej oraz moralnej. Będzie to mój głos, a nie mojego pokolenia, który wcale nie musi nikogo do niczego zobowiązywać, a już na pewno nie moje młodsze koleżanki i kolegów, bo - jak śpiewa czeski bard Karel Kryl: „każda generacja ma swoją rewolucję, i własną emigrację, i własnych męczenników" (Kryl 2019).

\section{Zaufanie jako coraz mniej obecny w uniwersytetach fakt społeczny}

Zaufanie jest faktem społecznym, którego nie można zredukować do zjawiska dotyczącego jednostki, stanowi bowiem pochodną stosunków międzyludzkich, wpisując się w nasze działania i codzienność. Mam również świadomość, że nie dotyczy ono tylko akademickiej pedagogiki, skoro w innych naukach społecznych można spotkać się z podobnymi zjawiskami. Przykładowo, Patryk Słowik tak pisze o sytuacji na Wydziale Prawa i Administracji Uniwersytetu Warszawskiego: „od jakiegoś czasu jest zabawnie. Coraz więcej pracowników nie mówi sobie ,dzień dobry', a dawni koledzy zaczynają sobie grozić pozwami. Wszystko przez politykę i to, że wielu naukowców zaczęło ją stawiać na piedestale" (Słowik 2019: B8). Istotnie, mamy pierwszy, chociaż nie jedyny, czynnik braku zaufania, a zatem i spadku kapitału społecznego wśród naukowców tej samej jednostki akademickiej. Polityka i odkrywane przez samych zainteresowanych różnice światopoglądowe, które są rozwarstwione m.in. na „swoich” i „obcych”, „lojalnych” i „zdrajców”, „lewoskrętnych” i „prawoskrętnych”, „wierzących” i „niewierzących”, a wśród nich „hetero- i homoseksualnych”, afirmantów partii władzy i opozycyjnych wobec niej, sprawiają, że w aktywności naukowej i dydaktycznej to one zaczynają ważyć. Nauka ułatwia taki sposób uwikłania pedagogiki w politykę, kiedy wskazuje na pedagogikę jako światopogląd. Tak rozumiana pedagogika jako „nauka” 
światopoglądowa może być wykorzystywana do aplikacji myśli społecznej (religijnej, ideologii społecznej, doktryny politycznej, manifestu opinii publicznej) w praktyce rządzenia:

Pedagogika światopoglądowa to taki typ dyskursu (stawiania pytań i udzielania na nie odpowiedzi), który polega na formułowaniu ideowych założeń, podstaw światopoglądowych: ontologicznych, epistemologicznych i aksjologicznych dla bezpośredniej praktyki edukacyjnej oraz dla działań nadbudowujących się nad nią, tzn. dla kierowania edukacją, dla poznawania jej, dla rozwijania jej itp. (Schulz 2003: 66).

Polityka i odkrywane przez samych zainteresowanych różnice światopoglądowe, ich własne preferencje ideologiczne czy polityczne, dzielą akademików, stając się powodem zróżnicowania pedagogicznej społeczności, która - jak z tego wynika - nigdy nie była i nie będzie wspólnotą tych samych celów i ideałów, a tym samym otwartej, pluralistycznej wizji kształcenia i wychowywania młodych pokoleń. Zawsze bliższa będzie ciału koszula, a więc dbałość o własny interes. „Ludzie robią to, co przynosi im największe korzyści jak najmniejszym kosztem” (Haidt 2012: 177). Pedagogia bywa podporządkowywana interesom władzy państwowej i włączana w działania związane ze zdobywaniem przez określoną formację polityczną władzy, a następnie z jej sprawowaniem w dziedzinie m.in. kształcenia, opieki i wychowania:

Sferą polityki jest sfera walki, rywalizacji, ścierania się celów, wartości, dążeń i wysiłków. Ale w określonych okolicznościach jest ona także sferą współdziałania, współpracy, uzgadniania i kojarzenia postaw i wysiłków. O tym, czy mamy do czynienia z walką, czy ze współpracą w sferze polityki, decyduje zgodność bądź sprzeczność interesów, reprezentowanych przez określone siły społeczne. Walka i rywalizacja w sferze polityki mają swoje źródło w tym, że nie wszystkie interesy i dążenia mogą być zaspokojone, że występują antagonistyczne wobec siebie interesy i dążenia (Łopatka 1978: 172).

Im bardziej naukowcy angażują się w swoim osobistym życiu w upełnomocnienie elektoratu partii rządzącej lub partii opozycyjnych, tym trudniej jest o zaufanie do nich jako kierujących się wyłącznie standardami badań naukowych, a nie politycznymi więziami, ukrytymi lub jawnymi zobowiązaniami czy podejmowaniem przez nich aktywności stricte partyjnej. Po publicystycznej, także w internetowej sieci, obecności nauczycieli akademickich można usytuować ich na mapie politycznych wspólnot, z którymi się 
identyfikują i promują ich wartości. Oby nie zaistniała po wyborach parlamentarnych w 2019 weryfikacja politycznych afiliacji wśród naukowców, w tym recenzentów w postępowaniach na stopnie naukowe i tytuł naukowy, skoro prawidłowością psychologiczną jest obdarzanie sympatią i zaufaniem tych ludzi, którzy „kołyszą się w tym samym rytmie” (Haidt 2012: 92). Gorliwe zaangażowanie po jednej ze stron politycznych antagonistów może rzutować na odrzucenie czyichś dokonań pomimo ich naukowej wartości. Poglądy polityczne przedstawiciela odmiennej orientacji politycznej mogą wydawać się dziwaczne, sprzeczne z preferowanymi przez nas teoriami czy podejściami badawczymi, a nawet niedopuszczalne $\mathrm{z}$ racji zajmowanej $\mathrm{w}$ akademickim środowisku pozycji. Wówczas „nie szuka się prawdy, lecz argumentów przemawiających za słusznością własnych poglądów” (Haidt 2012: 130).

Dlaczego wolimy godzić w czyjś naukowo uzasadniony autorytet i pozbawiać daną osobę zaufania? Leczymy własne kompleksy? Uciekamy od prawdy o niezdolności do naukowej pracy z pasją, którą posiadają inni? Czy może coś innego dławi naszą naukę, zabijając ducha poznawczego uczciwie w nią zaangażowanych uczonych? Jak się okazuje, dla wielu bowiem nie to jest istotne, co stanowi dzieło naukowych dokonań, a zatem - co powinno być przedmiotem naszych dociekań, analiz, co świadczy o jakości postępowania badawczego i o poziomie wiarygodności (także $\mathrm{w}$ procesie awansowym). Stajemy się coraz bardziej stronniczy, ponieważ nie chcemy czy nie potrafimy dostrzec, że tak liberalizm, jak i konserwatyzm mogą być równie szczerymi wizjami dobrego społeczeństwa i życia w nim jednostek ludzkich.

Pojawia się pytanie, czy uczony ma prawo do odsłony osobistych celów życia i wychowywania innych? Czy może funkcjonować w uczelni jako zwolennik określonej formacji politycznej czy religijnego wyznania? Wzajemna wrogość zaczyna się od przypisywania jednym zaburzeń (społecznych, osobowościowych, kulturowych itp.), a innym ortodoksyjnego zaangażowania. Skoro jesteśmy coraz bardziej podzieleni, to nie możemy sobie ufać, gdyż uczestniczymy w mniej lub bardziej jawnej formie walki, rywalizacji, a nasza twórczość i/lub także pozycja społeczna i/ lub akademicka mają jeszcze wzmacniać dezaprobatę dla „onych”, „innych”, a nawet prowadzić do ich marginalizowania czy wreszcie wykluczenia (moralnego, etosowego, pracowniczego, społecznego) z akademickiej wspólnoty. Narzędziem wykluczania staje się ocena identyfikacji politycznej naukowca z jakąś formacją i jej ideologią 
polityczną. Być może jest on/ona oświecony/a, ale nieprzyzwoity, no bo jak można popierać, wspierać czy afirmować obcych, a nie swoich. W przypadku nauczycieli akademickich ich stopień przynależności do partii władzy lub opozycji, czy jej afirmacji raczej nie ma nic - a jeśli nawet, to niewiele - wspólnego z bezrefleksyjną uległością i/czy przynależnością wobec przywództwa politycznego po jednej lub drugiej stronie barykady.

Niektórzy nawet pytają, jak to jest możliwe, że ktoś jest profesorem, a mimo to jest lewakiem czy prawakiem? Jeśli nie jest członkiem partii politycznej, to trzeba wyszukać w jej/jego życiorysie członkostwo w partii władzy minionego ustroju lub jakieś z nią powiązania, np. z tytułu takiej przynależności chociaż jednego z rodziców lub rodzeństwa. Partyjniactwo jest przecież zaraźliwe i niegodne. Co innego dzisiaj, w wolnej III RP, w której wraz ze zmianą $\mathrm{w}$ rządzie po kolejnych wyborach parlamentarnych można afirmować czy wspierać jedną ze stron politycznych podziałów. Nie jest to bez znaczenia dla pracy naukowo-badawczej takich osób, bo jakże mają dociekać prawdy o badanych zjawiskach, skoro mają głosić czyjąś (chociaż zinternalizowaną już) politycznie poprawną prawdę lub ją kontestować. Czyżby świat uczonych został dotknięty cechami syndromu autorytarnego, w świetle którego świat postrzegany jest jako swego rodzaju dżungla, w której obowiązują zasady bezwzględnej rywalizacji, opartej na introjekcji podziałów i postrzeganiu innych uczonych w kategoriach „my” i „oni”, „lepsi” i „gorsi”?

Jak zaufać drugiemu uczonemu, skoro z powodów politycznej i ideologicznej afiliacji wzbudza w nas wrogość, niechęć, pogardę czy zawiść? Badacz postaw politycznych Anglików Hans Jürgen Eysenck doszedł do następujących wniosków:

Radykalizm stanowił tu biegun lewicowy z aprobatą dla takich idei jak komunizm, pacyfizm i swobody obyczajowe; konserwatyzm obejmował hasła należące do programu politycznego prawicy: patriotyzm, religijność, punitywność, wiarę w nieuchronność wojen. Drugi wymiar rozciągał się pomiędzy dwoma biegunami, od ,miękkości' do ,twardości', definiowanymi jako dwa przeciwstawne zbiory cech osobowości (za: Radkiewicz 2012: 32).

Jak się okazało zwolennicy zarówno partii socjalistycznej, jak i konserwatywnej przejawiali relatywnie wysoki poziom radykalizmu, przy czym najwyższy rozpoznano u zwolenników lewicy. Zwolenników obu skrajnych partii politycznych cechowała 
twardość umysłowa, a więc „wysoki stopień agresywności i skłonności do dominacji w kontaktach społecznych" (Radkiewicz 2012: 34).

Wystarczy sięgnąć do rozpraw naukowych profesorów filozofii, socjologii, a nie tylko pedagogiki, w całym okresie ich akademickiej aktywności, by przekonać się, że wielu zaczynało od pedagogiki liberalnej czy lewicowej, a po kilkunastu czy kilkudziesięciu latach kończyło na radykalnie konserwatywnej. Są też odwrotne przypadki, kiedy to naukowiec odchodzi z biegiem lat od pedagogii konserwatywnej, prawoskrętnej w swej młodości (zdarza się wśród nielicznych - umocnionej posługą kapłańską), by stać się jej antagonistą lub afirmantem pedagogiki liberalnej, czy lewicowej polityki i moralności. Amerykański psycholog kulturowy i antropolog Jonathan Haidt, chociaż sam był wychowywany w rodzinie żydowskiej, wiernej Partii Demokratycznej, a w czasie studiów na Uniwersytecie Yale fascynował się liberalizmem, którego zwolennicy także popierali w wyborach powyższą partię, po podróży do Indii, gdzie zderzył się jego kod kulturowy z odmienną dla jego socjalizacji konserwatywną moralnością, zapewne z wrodzoną sobie empatią dla odmienności zrozumiał, że „wszystkie ideologie i wizje moralne są równie dobre albo równie skuteczne $\mathrm{w}$ tworzeniu humanitarnych, moralnych społeczeństw. Nie jestem relatywistą" - pisze. „W tym miejscu pragnę tylko wyrazić przekonanie, że w odwiecznych walkach ideologicznych prawie zawsze uczestniczą ludzie oddani pewnej wizji moralnej, w którą szczerze i żarliwie wierzą. Często mamy skłonność do przypisywania naszym przeciwnikom ukrytych motywów, takich jak chęć zysku. Na ogół to nieprawda" (Haidt 2012: 153).

Nie ma nic złego $\mathrm{w}$ otwieraniu się środowisk naukowych na różnice między badaczami ze względu na ich zaangażowanie w politykę, aktywność religijną, społeczną czy akademickie doświadczenia, gdyż kryją się za nimi odmienne antropologie pedagogiczne, ideologie czy filozofie wychowania, inne podejście do kształcenia i rozumienia ludzkich praw. Zdaniem Haidt'a: „monizm moralny - próba oparcia całej moralności na jednej zasadzie - rodzi społeczeństwa, które są niezadowalające dla większości ludzi i z dużym prawdopodobieństwem mogą stać się niehumanitarne, ponieważ lekceważą wiele innych zasad moralnych” (Haidt 2012: 158). To czynniki różnic kulturowych i mechanizmy permanentnej walki politycznej zdegenerowanych 
częściowo „elit” III RP wiele znaczą także w aktywności naukowej i dydaktycznej. Jednak - jak trafnie pisze Józef Górniewicz:

Nie zdławił systemu nauki ani faszyzm, ani komunizm, ani żaden inny system totalitarny. Czynniki polityczne, zewnętrzne wobec segmentu nauki, nie zdołały zmienić też badaczy. Ale czyha inne niebezpieczeństwo. Tkwi ono w samej Akademii rozumianej tutaj jako cały świat nauki i kształcenia wyższego, tkwi w ludziach Akademii. Można bowiem powiedzieć, że takie są akademie, jakimi bywają akademicy (Górniewicz 2019: 9).

Także my-pedagodzy doprowadzamy do tego, że osób z politycznego krańca nie zaprasza się na konferencje naukowe, które są organizowane przez jego/jej politycznych oponentów, nie publikuje się jego/jej rozpraw w czasopiśmie czy kwestionuje się zasadność wniosku grantowego, bowiem wywołany przez niego/nią wstręt moralny wpływa na oceny moralne akademickich decydentów. Opowiedzenie się po jednej ze stron naraża uczonych na nienawiść u zwolenników drugiej strony. W sporach politycznych umysł człowieka przełącza się na tryb walki, a nie poszukiwania konsensusu, kompromisu czy troski o dobro wspólne. Słusznie zatem nawołuje Jonathan Haidt:

Jeżeli naprawdę pragniesz zmienić czyjąś opinię w kwestii moralnej lub politycznej, to musisz spojrzeć na ów problem zarówno z pozycji tej osoby, jak i z własnej perspektywy. A jeśli przyjrzysz mu się z punktu widzenia drugiej osoby - wnikliwie i intuicyjnie - to może się okazać, że i Twój umysł się otworzy. Empatia jest antidotum na naszą skłonność do moralizatorstwa, chociaż niezwykle trudno jest zdobyć się na empatię ponad podziałami moralnymi (Haidt 2012: 82).

Niezależnie od ówczesnej krytyki modelu postaw politycznych Hansa J. Eysencka możemy dostrzec, jak silne, a więc „twarde”, są przejawy wzajemnej wrogości także w naszym środowisku akademickim, jeśli owe afiliacje ideowo-polityczne są z jednej strony komunikowane przez samych zainteresowanych, a z drugiej strony są rozpoznawalne przez obserwatorów. „W sytuacjach codziennych ocena moralna decyduje o tym, z kim przestajemy, a od kogo stronimy, w sytuacjach krańcowych zaś może decydować o życiu lub śmierci ocenianej osoby" (Wojciszke 2012: 9). O ocenie naukowca czy jego pracy eksperckiej przestają decydować jego/jej osiągnięcia naukowe, ale przypisywane mu/ 
jej oceny moralne z racji ideowo-politycznego zaangażowania. Klasycznym tego dowodem jest odmowa nadania tytułu naukowego profesora Andrzejowi Zybertowiczowi, który w jednej ze swoich rozpraw pisze:

Ponieważ kultura jest dynamiczna, bywa tak, że reguły różnych pod/ przestrzeni niejako ,dialogują, negocjują ze sobą, pozostając w niekiedy trwałych ,konfliktach'. To dialogowanie i konflikty różnych części kultury znajdują swoje odbicie (można rzec: przełamują się) także w losach i psychice jednostek. Jest tak np. wtedy, gdy badacz stoi w obliczu konfliktu między np. przestrzeganiem reguł poprawności metodologicznej (nakazującej np. jak najściślejsze odróżnianie hipotez od ustaleń faktycznych), a presją reguł środowiskowej poprawności politycznej (sugerujących np. niepodejmowanie pewnych tematów uznawanych za drażliwe). Środowisko to niekiedy oczekuje, by badaczka zajęła (lub odwrotnie: nie uczyniła tego) publiczne stanowisko w sprawie, w której ma/nie ma ona wiedzy dostatecznej dla wygłoszenia pewnych tez, np. by coś skrytykowała lub pochwaliła (Zybertowicz 2015: 370).

Zawieszenie w ubiegłym tygodniu wybitnego Uczonego - prof. Aleksandra Nalaskowskiego na trzy miesiące w Jego akademickich prawach przez rektora UMK w Toruniu (jak się okazuje - bezprawnie przez prorektora) jest nie tylko zdumiewające i oburzające, ale przede wszystkim staje się z końcem drugiej dekady XXI w. niepokojącym dowodem na to, że nie każdy sprawujący władzę w uniwersytecie i nie każdy nauczyciel akademicki włączający się w poparcie tej skandalicznej kary rozumie, czym są prawa człowieka, obywatela w państwie demokratycznym, pluralistycznym, rzekomo otwartym na prawdę i wartości osobiste. „Elastyczny system prawny może być rozciągany według woli przede wszystkim organów jednoosobowych. Środowisko akademickie - dotąd w znacznym stopniu samorządne - musi zmierzyć się z nowymi wyzwaniami” (Górniewicz 2019: 9).

Część środowiska daje się wciągać w charakterystyczną dla mediów ludyczność i agonistyczność, chociaż powinna była być świadoma tego, że media celowo łapią interlokutorów czy autorów felietonów za słówka, dobierając je tendencyjnie lub wręcz przetwarzając je, nie mówiąc już o abstrahowaniu od kontekstów, by włączyć uczonych z prawej czy lewej strony do swojej manipulacji dla zdezorientowania odbiorcy. Jerzy Bralczyk analizując język polityki wskazuje - w przypadku jego konserwatywnej odmiany - na przejawianie przez autorów 
tendencji do wyrazistego nazywania rzeczy, często prowadzącego do zachowań konfrontacyjnych. Może to być określane jako język twardy. [...] Aprioryczne przeświadczenie o własnej racji ,z nadania' owocuje swobodą w arbitralnym opisywaniu rzeczywistości i przeradza się w woluntarystyczne mieszanie zasad ze stanem faktycznym (Bralczyk 2007: 328).

Nacechowana retorycznie populistyczna wypowiedź publicystyczna może mniej respektować porządek logiczny czy naruszać porządek gramatyczny, podtrzymując stan konfliktu jako uzasadnionego rywalizacją obozów politycznych „odstępstwa od idealnej komunikacji społecznej” (Bralczyk 2007: 345). To, że oceniamy innych w kategoriach moralnych, jest czymśs naturalnym, natomiast łącząc się ze sobą ze względu na podzielanie tej samej narracji politycznej, z jednej strony „stajemy się ślepi na inne światy moralne” (Haidt 2012: 25), z drugiej zaś strony napędzamy agresję językową.

Takie napędzanie języka jest chętnie nagłaśniane i wykorzystywane przez media [...]. Atrakcyjność medialnych tekstów rośnie w miarę zwiększania poziomu inwektyw. Nastawienie na walkę jest też dobrym sposobem promocji polityka, który może zaistnieć właśnie przez bulwersujące sformułowania, a stygmatyzujące powszechne potępienie nie jest ani tak bardzo potępieniem, ani nie może prowadzić do eliminacji z życia publicznego. Wręcz przeciwnie (Bralczyk 2007: 350).

Zanim zatem zabierzemy głos w sprawie języka populistycznej wypowiedzi politycznej któregoś z naukowców z dowolnej strony jego politycznych afirmacji, sięgnijmy najpierw do analiz językoznawczych, naukowych. Nie wikłajmy się w akceptację czy negację potoczności, która z zasady w okresie walki politycznej nacechowana jest wulgarnością, agresją słowną, etykietowaniem, stygmatyzowaniem przeciwnika czy drwiącym humorem. Zdaniem Bralczyka metafory leksykalizujące się i poszerzające sferę polisemii językowej wzbogacają swoistym neosemantyzmem słownik polityczny (Bralczyk 2007: 334). Taki jest język polityki w swoim perswazyjnym wymiarze, by w okresie wyborczym sprzyjać pozyskaniu aprobaty wyborców dla określonej formacji politycznej.

Socjolog Michel Wieviorka wieńczy koniec politycznej koncepcji zaangażowania badaczy nauk społecznych w zmiany społeczno-polityczne, gdyż ich bezpośredni wpływ polityczny i tak jest bardzo ograniczony. Działalność „polityczna należy do innego rejestru niż działalność naukowa i powołanie polityka nie jest 
takie samo, jak powołanie uczonego [...] polityka prowadzi nieuchronnie do kompromisów z , diabolicznymi siłami', jest ściśle związana z władzą i przemocą, czego nauka próbuje uniknąć” (Wieviorka 2011: 62). Podobnie jak „naiwnością jest myślenie, że analizy socjologiczne mogą trwale i skutecznie zaważyć na decyzjach politycznych" (Wieviorka 2011: 62), tak i wyniki badań pedagogicznych nie są już od początku pierwszej reformy ustroju szkolnego w 1999 r. w ogóle brane pod uwagę przez ministrów edukacji.

Jako pedagodzy zostaliśmy pozbawieni zaufania władz politycznych III RP, gdyż nie chcieliśmy uczestniczyć w pseudonaukowej destrukcji polskiej edukacji, tak za rządów SLD-PSL, AWS, PO i PSL czy PiS. Powód tego był słuszny. Jak analizuje Wieviorka:

Próbując wywierać wpływ polityczny, badacz podejmuje znaczące ryzyko, w tym ryzyko zatracenia swojej duszy [...] stania się ideologiem, intelektualistą organicznym, ,psem łańcuchowym' poprzez podporządkowanie swojego działania żądaniom i wymaganiom księcia albo opozycji. Jednak odmawiając udziału w debatach, które ożywiają sferę publiczną, badacz, którego działalność jest we współczesnym świecie często finansowana ze środków publicznych, a więc teoretycznie na rzecz społeczności, izoluje się, nie informując [o swoich badaniach] nikogo poza naukowym środowiskiem i nie zastanawiając się nawet nad tym, jak można się posłużyć wiedzą, jaką wytwarza (Wieviorka 2011: 63).

Wydawałoby się, że wraz ze zmierzchem ustroju socjalistycznego elity władzy rozstaną się z takim rozumieniem polityki i pedagogiki, w tym szczególnie z tak rozumianymi relacjami między nimi. Skoro bowiem o powodzeniu lub zmierzchu polityki decydować miały przede wszystkim interesy klasowe i narodowe, to upadek klasy panującej formacji socjalistycznej wraz z jej interesami klasowymi i narodowymi powinien być równoznaczny nie tylko z upadkiem pedagogiki socjalistycznej, ale i z zanikiem tak rozumianego uprawniania pedagogiki. Niestety. Trwało to zaledwie 4 lata. Jedyną formacją polityczną w okresie postsocjalistycznym, która uwolniła się od tak rozumianej roli nauk pedagogicznych, był rząd Tadeusza Mazowieckiego i kierowany przez Henryka Samsonowicza resort edukacji. Przejęcie władzy w 1993 r. przez rząd postkomunistyczny SLD-PSL spowodował powrót do typowej dla minionego ustroju roli polityki i podporządkowanej jej pedagogiki. Wprawdzie nauka mogła się z tego 
procesu wyrwać dzięki ustawowo zagwarantowanej autonomii szkół wyższych, a więc już nie można było jej poddać ideologicznej dominacji interesów władzy państwowej, ale oświata pozostała niestety sferą oddaną na żer polityków. Powrócono do podstawowego przesłania, iż państwo, jako „główny podmiot polityki, formułując cele, które chce osiągnąć, oraz poszukując środków i dróg ich realizacji, aczkolwiek jest suwerenne, nie może postępować dowolnie" (Łopatka 1978: 173). Spostrzeżenie to $\mathrm{w}$ jeszcze wyższym stopniu odnosi się do innych podmiotów polityki - w tym pedagogiki.

Pedagogia jako nauka nie powinna być podporządkowana interesom władzy państwowej i włączona w działania związane ze zdobywaniem przez określoną formację polityczną (a następnie z utrwalaniem przez nią) władzy, z jej wykonywaniem w postaci wytyczania programu państwa $\mathrm{w}$ dziedzinie m.in. kształcenia, opieki i wychowania.

Jubileuszowy Zjazd Pedagogiczny może być przełomem pokoleniowej zmiany, i oby do takiej doszło, byle to, na co pracowali nasi Mistrzowie, minione pokolenia, nie zostało zaprzepaszczone w imię zaspokajania pozanaukowych interesów przez część pedagogów, niekiedy nawet pełniących kluczowe funkcje w zarządzaniu, lub raczej pomiataniu, nauką we własnych środowiskach. Podzielam opinię Józefa Górniewicza: „Być naukowcem to uczestniczyć w tworzeniu wiedzy o sobie samym, świecie, który nas otacza, o przeszłości i przyszłości. To wyjątkowa misja i posłannictwo jednych wobec innych, ale nie przeciwko nim" (Górniewicz 2019: 133). Mogę co najwyżej zaapelować do młodych pokoleń - nie niszczcie tego, co jest metodologicznym fundamentem trwania polskiej nauki, mimo czynienia tego przez część starszego czy nawet średniego pokolenia, a pozbawionego już etosu pracy naukowej. Stosując wobec was ingracjację zapewne sądzą, że historyczna ocena ich ominie. Idźcie pod prąd zawłaszczenia i degradowania istoty nauki przez polityków, pomimo finansowych pokus i moralnych zdrad w klimacie zawiści, intryg, pomówień adeptów pseudonaukowych praktyk. Nie pozwólcie odebrać sobie pasji prowadzenia badań naukowych przez tych, którzy jej nie mają, bo inaczej zaufanie stanie się jeszcze jedną pustą wartością. Kształćcie piękne i mądre umysły, bądźcie intelektualnie nieposłuszni a jednoznaczni moralnie, a zostaniecie obdarzeni autentycznym zaufaniem osób z tzw. „genem nauki”, zatroskanych o kapitał naukowy naszej ojczyzny. 


\section{Bibliografia}

Fromm E. (2014), Ucieczka od wolności, tłum. O. Przekład, A. Zimilski, Czytelnik, Warszawa.

Górniewicz J. (2019), De dignitate Academiae - constanter firmiterque. O dostojeństwie Akademii - nieustannie i stanowczo, Wydawnictwo Uniwersytetu Warmińsko-Mazurskiego w Olsztynie, Olsztyn.

Haidt J. (2012), Prawy umyst. Dlaczego dobrych ludzi dzieli religia i polityka?, tłum. A. Nowak-Młynikowska, Wydawnictwo Smak Słowa, Sopot.

Kryl K., Pasažová revolta, https://www.google.com/search?q=karel+kryl+ pasazova+revolta+text\&rlz=1C1CAFA_plPL828PL828\&oq=Karel+Kryl++Pas\%C3\%A1\%C5\%BEov\%C3\%A1+revolta\&aqs=chrome.4.69i57j014. 3529j0j4\&sourceid = chrome\&ie=UTF-8 (dostęp: 17.09.2019).

Łopatka A. (1978), Nauki polityczne a pedagogika, [w:] M. Godlewski (red.), Pedagogika. Podrecznik akademicki, PWN, Warszawa.

Radkiewicz P. (2012), Autorytaryzm a brzytwa Ockhama, Wydawnictwo Naukowe Scholar, Warszawa.

Schulz R. (2003), Wyklady z pedagogiki ogólnej. Perspektywy światopoglądowe $w$ wychowaniu, t. 1, Wydawnictwo Naukowe UMK, Toruń.

Słowik P. (2019), Ministrze, czy ci nie żal... atakować kolege z sal?, „Dziennik Gazeta Prawna”, nr 145 (5047), 29.07.2019.

Sztompka P. (2007), Zaufanie. Fundament społeczeństwa, Wydawnictwo Znak, Kraków.

Wojciszke B. (2012), Przedmowa, [w:] J. Haidt, Prawy umyst. Dlaczego dobrych ludzi dzieli religia i polityka?, tłum. A. Nowak-Młynikowska, Wydawnictwo Smak Słowa, Sopot.

Wieviorka M. (2011), Dziewięć wykładów z socjologii, tłum. A. Trąbka, Zakład Wydawniczy „Nomos”, Kraków.

Zybertowicz A. m.in. (2015), Samobójstwo oświecenia? Jak neuronauka i nowe technologie pustosza ludzki świat, Wydawnictwo Kasper, Kraków. 


\title{
Edukacja wobec kryzysu zaufania. Spojrzenie z perspektywy aksjologicznej
}

\author{
Abstract \\ Education in the face of crisis of trust. \\ A look from an axiological perspective
}

This text deals with the issue of education in the face of the crisis of trust. I consider these issues from an axiological perspective, following the trail of the triad: education-trust-crisis. These three key categories belong to the universal and basic for man as an individual and a person fulfilling himself in various social communities. Education is deeply rooted in the world of the axiological anthroposphere. Man is the creator of meanings, which he gives to personal and social experiences.

Keywords: education, axiological perspective, crisis, trust

Słowa kluczowe: edukacja, aksjologiczna perspektywa, kryzys, zaufanie

\section{Uwagi wstępne}

Podjętą w niniejszym tekście problematykę edukacji wobec kryzysu zaufania rozważam z perspektywy aksjologicznej, podążając tropem triady: edukacja - zaufanie - kryzys, która została wytyczona przez Jubileuszowy X Ogólnopolski Zjazd Pedagogiczny Polskiego Towarzystwa Pedagogicznego. Owe trzy kluczowe kategorie zaliczają się do powszechnych i podstawowych dla człowieka jako indywiduum oraz osoby spełniającej się w różnych zbiorowościach społecznych.

Perspektywa aksjologiczna została przyjęta $w$ niniejszych rozważaniach jako zasadna z tej oczywistej racji, że od swego zarania edukacja jest procesem głęboko i rozlegle zakorzenionym w świecie wartości universum antroposferycznego i poza nim nie 
jest możliwa do spełnienia. Ów wartościujący stosunek człowieka do świata dany jest osobie ludzkiej jako zadanie na całe życie i zarazem jako wyzwanie ustawicznie ewoluujące w toku jej rozwoju $\mathrm{w}$ świecie przemian.

Natomiast zaufanie pośród bogactwa elementów universum antroposferycznego stanowi kluczową dla człowieka wartość nie tylko w procesie edukacji. Również kluczowe słowo kryzys jest pojęciem wartościującym w tym zwłaszcza sensie, że przede wszystkim służy do określenia stanu niepożądanego z punktu przyjętej perspektywy. Domagając się wszakże przezwyciężenia zaistniałego status quo, skłania do wprowadzenia istotnych zmian, które mają na celu nie tylko uwolnienie od piętna kryzysu, lecz także rokują pozytywne perspektywy na przyszłość.

\section{Edukacja}

Waga i znaczenie edukacji na przestrzeni dziejów okazują się oczywiste przede wszystkim z tego względu, że procesy edukacyjne $\mathrm{w}$ postaci rozmaitych konfiguracji w różnym stopniu i zakresie towarzyszą homo educandus od początku jego rozumnego istnienia aż po kres życia z racji:

- uczestnictwa ludzi w edukacji obligatoryjnej oraz poza nią w równoległych jej formach;

- pełnienia przez osoby posiadające stosowne uprawnienia profesjonalnej roli nauczyciela, wychowawcy, opiekuna, pedagoga;

- wykonywania tychże powinności poza sferą zawodową, np. w roli matki, opiekunki, ojca itd.;

- edukowania siebie w trakcie autorsko kreowanych procesów samokształcenia i samowychowania.

W toku dziejów myśli ludzkiej w jej rozwoju procesy edukacyjne ewoluują wielorako, obrastając różnorodnymi interpretacjami. Niejednokrotnie $\mathrm{w}$ dociekaniach istoty i znaczenia tej podstawowej kategorii pedagogicznej, jaką stanowi termin edukacja, wywodzący się - jak wiadomo - z łacińskich słów $\bar{e}$ dŭcātǐ̄o - wychowanie i $\bar{e} d \bar{u} c \bar{o}$ - wyprowadzić, wyciągnąć, poprowadzić, wychować, ujawniają się rozmaite zawiłości lingwistyczne z powodu wyprowadzenia rozważanego terminu z trzech różnych pojęć, takich mianowicie, jak: educare, educere i edocere. Wyartykułowanie owych dystynkcji znaczeniowych (każdy z trzech terminów różnicuje zaledwie jedna literka, tj. według wskazanej tu kolejności owych słów są to samogłoski: $\boldsymbol{a}$-e-o-) 
uwrażliwia na złożoność oraz potencjalność kreowania procesu edukacji i zarazem skłania ku eliminowaniu ewentualności nierozważnego wypaczania jego istoty, a zwłaszcza kieruje uwagę na kwestię nieodzowności w tym procesie conditio sine qua non fenomenu zaufania postrzeganego jako zjawisko egzystencjalnie znaczące (zob. Ostrowska 2018: 17-33).

Zasygnalizowane dystynkcje znaczeniowe znajdują poniekąd swoje odzwierciedlenie $\mathrm{w}$ prezentowanych przez pedagogiczne kompendia wiedzy koncepcjach rozumienia edukacji (por. np. Milerski, Śliwerski [red.] 1999; Pilch [red.] 2003, 2004, 2005, 2006, 2007, 2008, 2009, 2010; Chałas, Maj [red.] 2016), odwołujących się do ogółu międzygeneracyjnych zabiegów służących kształtowaniu i rozwijaniu oraz doskonaleniu zdolności życiowych człowieka - poznawczych, wolicjonalnych, moralnych i duchowych, mających wymiar dialogiczny, w którym to rozumieniu nauczyciel i uczeń, korzystając z dotychczasowego dorobku i własnych doświadczeń, koncentrują swoją aktywność nie tylko wokół przekazywania oraz opanowania wiedzy, lecz również ujawniają i urzeczywistniają świat wartości transgresyjnie zorientowany $\mathrm{w}$ istocie swej na prowadzeniu - wyprowadzaniu:

- od dzieciństwa do dojrzałej dorosłości;

- od egocentryzmu do socjalizacji i uspołecznienia;

- od ignorancji do wiedzy;

- od swobody do wolności i odpowiedzialności;

- od realności do uszlachetniania pragnień, kierowania się ku ideałom i versus;

- od bycia człowiekiem do zaświadczania człowieczeństwa.

Nie ma potrzeby specjalnie uzasadniać, że w toku edukacji realizację każdego z wymienionych międzygeneracyjnych - a także intrapersonalnych (w przypadku autoedukacji/samoedukacji) zabiegów służących kształtowaniu i rozwijaniu oraz doskonaleniu zdolności życiowych człowieka - warunkuje stanowiący wartość konstytutywną fenomen zaufania, któremu przeznaczam kolejną część niniejszych rozważań. Zaufaniu przypisuję walor egzystencjalnie znaczący z tej zwłaszcza racji, że stanowi ono fundamentalny element pomyślnej egzystencji we wszystkich sferach i wymiarach życia człowieka. Gdy bowiem „ufamy sobie nawzajem, możemy więcej ryzykować, być bardziej innowacyjni, inwestować” (Sztompka 2007: 444), jednocześnie jesteśmy bardziej odważni i zmotywowani do działania, mamy większe poczucie sprawstwa oraz wyższy optymizm w projektowaniu przyszłości. 


\section{Zaufanie}

Zaufanie jest pojęciem wielowymiarowym i okazuje się bardzo trudne do jednoznacznego zdefiniowania. Być może właśnie dlatego niektóre kompendia wiedzy - w tym Encyklopedia PWN $w$ trzech tomach (2006) czy Leksykon PWN Pedagogika (Milerski, Śliwerski [red.] 1999) - nie ujmują tego terminu w swoim wykazie. Również blurb zamieszczony na tylnej okładce obszernej pracy zbiorowej pt. Wspótczesny język polski pod redakcją Jerzego Bartmińskiego, zachęcający do przeczytania tego dzieła, w pierwszym zdaniu rekomendujący następująco ową książkę: „Tom WSPÓŁCZESNY JĘZYK POLSKI (wyróżnienie źródłowe) daje całościowy obraz stanu polszczyzny końca XX wieku w kontekście kultury narodowej” (zob. Bartmiński [red.] 2001) - niestety nie zawiera terminu zaufanie.

Natomiast w Stowniku języka polskiego PWN (2009) zaufanie sprowadzone zostało do „przekonania” (tj. do sądu, zdania opartego na przeświadczeniu o prawdziwości, słuszności czegoś). Objaśniając hasło zaufanie, wskazano w tym źródle na trzy następujące ewentualności:

1. przekonanie, że jakiejś osobie lub instytucji można ufać;

2. przekonanie, że czyjeśs słowa, informacje itp. są prawdziwe;

3. przekonanie, że ktoś posiada jakieś umiejętności i potrafi je odpowiednio wykorzystać.

Wynika stąd, że zaufanie to przekonanie podmiotu obdarzającego zaufaniem osoby i/lub instytucje, że jego oczekiwania dotyczące preferowanych wartości oraz realizacji zamierzeń zostaną spełnione, że można zawierzyć osobie czy instytucji.

Słowo pokrewne „zaufać” według tego źródła (tamże) oznacza:

1. powierzyć swoje sprawy osobie lub instytucji, której się ufa;

2. uznać, że czyjeś słowa, informacje są prawdziwe;

3. uznać, że ktoś posiada jakieś umiejętności i potrafi je odpowiednio wykorzystać.

Natomiast w ujęciu encyklopedii pedagogicznej „zaufanie” rozumiane jest jako wiara w szczerość ludzkich intencji i opisane zostało w kategoriach wartości, uczuć, potrzeb, ludzkich postaw, intencji a także $\mathrm{w}$ aspekcie norm moralnych służących potrzebie zaufania (Michalik-Surówka 2008: 823-831).

Zasygnalizowane ujęcie słownikowe „przekonania” i „powierzenia” oraz encyklopedyczne „wiary” zawarte zostało w stanowisku zaprezentowanym przez amerykańskiego politologa 
i socjologa Russella Hardina (2009: 25) w następujący sposób: „Zaufanie to przekonanie (podkreślenie - U.O.), że czyjeś słowa, informacje, czyny, umiejętności, zdolności itp. są prawdziwe, dobre, wartościowe i pożyteczne. Obecność zaufania wiąże się z wiarygodnością - z wiarą (podkreślenie - U.O.), że spełnione zostaną oczekiwania oraz zobowiązania”.

Współcześnie zaufanie zazwyczaj traktowane jest jako społeczny aspekt relacji, który może być aktywnie kształtowany przez różne podmioty i w różnych okolicznościach. W literaturze przedmiotu zaufanie na ogół ujmowane jest jako zbiór określonych oczekiwań wobec partnera, czy instytucji bazujących na zgodzie w kwestii pozostawania w stosunku współzależności lub zależności, jako wartość dynamiczna, cechująca się tymczasowością, rozwijająca się, lecz możliwa do utracenia oraz bardzo trudna do odzyskania.

Trzeba wszakże zauważyć, że w źródłach leksykalnych i encyklopedycznych, w których ujęto termin zaufanie, definiendum pojęcia zostało zubożone o jeden ważny definiens, a mianowicie dotyczący aspektu intrapersonalnego, to jest ufania sobie, zaufania do siebie, dotyczący tego, co stanowi konstytutywną podstawę nabywania kompetencji do darzenia zaufaniem innych, do ufania innym. Otóż, aby autentycznie i odpowiedzialnie wzbudzać zaufanie do innych, bądź obdarzać innych zaufaniem, wskazane jest zaufać najpierw samemu sobie, być wiarygodnym w odniesieniu do siebie samego - w układzie intrapersonalnym, w procesie kontaktowania się z samym sobą, w celu zdawania sobie sprawy z doświadczanych w sferze myśli, uczuć, działań treści otaczającej rzeczywistości. Uzupełnienie definiendum terminu zaufanie o tenże aspekt umożliwia wyłonienie kilku kategorii tego fenomenu, uobecniającego się zarówno w relacjach intrapersonalnych, jak i w relacjach interpersonalnych dwu- i wieloczłonowych, a mianowicie takich, jak:

- człowiek ujmowany w relacji do samego siebie, czyli układ pomiędzy dwoma sprzężonymi ze sobą aspektami indywiduum jaźni (self), pomiędzy ja subiektywnym (I) i zrelatywizowanym $(M e)$ - ja podmiotowe i ja przedmiotowe - (I to Me - ja do siebie samej/samego) (zob. Mead 1934, 1975);

- człowiek ujmowany w relacji do drugiego człowieka: układ ja - drugi/inny;

- człowiek ujmowany w relacji do innych ludzi, do zbiorowości społecznych: układ ja - grupa/inni; 
- zbiorowości społeczne/społeczeństwa we wzajemnych relacjach pomiędzy sobą: układ zbiorowość społeczna - inna zbiorowość (zob. Ostrowska [red.] 2002).

Ważnym aspektem zaufania będącego stanem, czynnością, procesem jest świadomość, iż nie można go zdobyć raz na zawsze, jako że charakteryzuje się ono dynamicznością, toteż zmienia się w czasie i w różnych okolicznościach, a to oznacza, że w każdej chwili może być utracone. Trudno je zdobyć, łatwo stracić, jeszcze trudniej odzyskać. Ponadto jest ono budowane w oparciu o doświadczenia i wiedzę nie tylko podmiotu, który chce zaufać, bądź darzyć innych zaufaniem, ale również innych podmiotów.

Dość powszechnie funkcjonuje przekonanie, że w przypadku społeczeństwa polskiego istnieje problem z zaufaniem. Większość Polaków od wielu lat w badaniach sondażowych wyraża przekonanie, że nie ufa innym, zaświadczając w tenże sposób jeden z najniższych poziomów zaufania w Europie. Tymczasem wśród na przykład mieszkańców krajów skandynawskich proporcje w tym zakresie bywają odwrotne - około $80 \%$ obywateli wierzy innym ludziom. O ile nieufność w odniesieniu do nieudolnego państwa, czy władzy, tudzież nieprzewidywalnych polityków albo miernych urzędników można w miarę racjonalnie wytłumaczyć, o tyle nieufność Polaków wobec siebie nawzajem - zwłaszcza w edukacji - wymaga bez wątpienia wnikliwego rozpoznania. Na podstawie prowadzonych od 2006 r. przez CBOS badań stwierdzono m.in., że: „Trzy czwarte Polaków zachowuje daleko idącą ostrożność w kontaktach z ludźmi. Ponad połowa z nieufnością traktuje nieznane sobie, spotkane po raz pierwszy osoby. Postawa nieufności w kontaktach międzyludzkich nigdy, odkąd prowadzimy badania dotyczące tej kwestii [...], nie była w deklaracjach Polaków tak silna” (CBOS 2018: 14).

W istocie przyznać trzeba, iż we współczesnych realiach niejednokrotnie można odnieść wrażenie, że w Polsce wręcz dominuje kultura nieufności. Zdaniem Piotra Sztompki:

Od środowiska nieufności, w którym przypadki braku zaufania i zawodu zaufania są nagminne, prosta droga prowadzi do przekonania, że należy unikać zaufania i nie warto starać się sprostać oczekiwaniom innych. Pojawia się wtedy uogólniona reguła nakazująca podejrzliwość i nieufność, patrzenie wszystkim na ręce, doszukiwanie się haniebnych zamiarów, a także nieliczenie się z innymi, zrywanie zobowiązań, lekceważenie oczekiwań, wykorzystywanie partnerów. Paradoksalnie, ufnych, rzetelnych i uczciwych dotykają sankcje (Sztompka 2007: 271). 
Kultywowanej kulturze nieufności bez wątpienia sprzyjają niedeklarowane reguły zachowania społecznego, wyzwalające chaos oraz skłaniające do podporządkowania egoistycznym interesom. Deficyt transparentności w tym zakresie prowadzi do braku rozumienia zasad funkcjonowania zbiorowości społecznych, a nawet może sprzyjać wyzwalaniu różnej proweniencji tzw. teorii spiskowych. Przejawy nieufności mogą wzmacniać tendencje arbitralne w funkcjonowaniu zbiorowości, doprowadzając do niedostrzegania przez jej członków szans na jakiekolwiek zaufanie, w tym możliwości zaufania komukolwiek i ufania czemukolwiek. W takim stanie rzeczy zazwyczaj dochodzi do pogłębienia bierności, wycofywania się, pojawia się skłonność do apatii oraz rezygnacji z poszukiwania dróg wyjścia z istniejącego stanu rzeczy. Zdaniem przywoływanego już Sztompki: "Jeżeli gwarancja praw jednostki leży wyłącznie w jej rękach ponieważ godni zaufania arbitrzy nie istnieją, są niedostępni lub mają opinię stronniczych i nieuczciwych - ludzie czują się bezradni. Podejrzliwość i nieufność stają się naturalną reakcją" (Sztompka 2016: 171).

$\mathrm{Z}$ analizowanej literatury przedmiotu na temat kultury zaufania wynika, że wyłanianiu się na przeciwległym biegunie kultury nieufności sprzyja nieprzejrzystość działania w odniesieniu osób, do których kierowane jest zaufanie, jak również poczucie obcości wobec nich, a także brak transparentnych norm i zasad regulujących relacje w tym zakresie, zwłaszcza jeśli są one sytuowane w warunkach chaosu oraz niepokojów nurtujących zbiorowości społeczne (Sztompka 2007). Warto wszakże zaznaczyć, że przeciwieństwem zaufania nie jest postrzegana jako jego lustrzane odbicie nieufność (zob. Giddens 2008: 70-71), lecz brak zaufania, czyli neutralna sytuacja, w której osoba powstrzymuje się zarówno przed okazaniem zaufania, jak i wyrażenia nieufności (Sztompka 2007: 73; Giddens 2008: 26).

Niemniej w dociekaniu przyczyn kultury nieufności najczęściej wskazuje się na intensywne i rozległe procesy o narastającej złożoności i nieprzewidywalności, które zdominowały życie społeczne od przełomu stuleci i osiągnęły apogeum w ostatnich latach, zwłaszcza takie, jak globalizacja czy informatyzacja. Rzecz oczywista owe przetaczające się przez świat procesy wpisujące się w działania edukacyjne, tudzież stanowiące dla nich kontekst, mają charakter ambiwalentny: z jednej strony przynoszą wielkie korzyści, z drugiej natomiast strony stanowią źródło problemów, 
które niekiedy konstytuują podstawy doświadczania kryzysu, kategorii zapowiadającej kolejną część niniejszych rozważań.

\section{Kryzys}

Słowo kryzys współcześnie zdaje się nabierać coraz większej popularności, a nawet aspirować do rangi terminu modnego, niemal wszędobylskiego, w tym dla jego entuzjastów nadto wręcz magicznego. Termin kryzys wydaje się być jednym z najczęściej używanych w naszych czasach pojęć $\mathrm{w}$ odniesieniu do niemal wszystkich sfer życia. Wystarczy nawiązać kontakt z jakimkolwiek środkiem „masowego przekazu”, by doświadczyć konfrontacji ze zdarzeniami, którym przypisywane jest miano kryzysowych. Zapewne codzienność dostarcza wielu okazji do tego, by sądzić, że czas, w którym żyjemy, jest w istocie swej rzeczywiście kryzysowym. Tymczasem bywa wszakże i tak, że niejednokrotnie dochodzi do swoistych manipulacji rozmaitych wydarzeń indywidualnych i społecznych, polegających nie tylko na tworzeniu fałszywych podpowiedzi dla owego określanego mianem kryzysu status quo, ale przede wszystkim na wybiórczym przedstawianiu przejawów tego, co określane jest jako kryzysowe. Oto bowiem za sprawą nadużywania czy nadinterpretacji tego słowa niejednokrotnie bywają podejmowane próby wyjaśniania i usprawiedliwiania wszelkich braków, słabości, niepowodzeń, czy ułomności, które mają niewiele, albo wręcz nic wspólnego ze stanem kryzysowym. Niemniej jednak tego typu przedsięwzięcia stają się główną przyczyną kształtowania kryzysu społecznego zaufania tudzież kreowania kultury kryzysu zaufania. Zwłaszcza w języku potocznym - w przeciwieństwie do oryginalnego greckiego desygnatu pojęcia kryzys - termin ten służy określaniu różnych sytuacji, których wspólnym mianownikiem jest wyraźnie ewokowana jego pejoratywna konotacja dotycząca stanu zagrożenia, a w ślad za tym oznajmiania o kryzysie wartości, rodziny, edukacji, szkoły, finansów publicznych, nauki, kryzysie demograficznym, migracyjnym, globalnym, intelektualnym, innowacyjności, klimatycznym, takiej czy innej tożsamości itp. ${ }^{1}$ zarówno w perspektywie indywidualnej, społecznej, jak i instytucjonalnej.

1 Okazuje się, iż grupa 500 naukowców z całego świata wystosowała list do Sekretarza Generalnego ONZ, w którym przekonują oni, że zjawisko zwane „kryzysem klimatycznym” nie istnieje. Zob. portal „Do rzeczy” (dostęp: 15.10.2019). 
Tymczasem grecka etymologia pojęcia kryzys nie wskazuje wszakże na kreowanie dla owego stanu rzeczy zgoła pejoratywnego charakteru. Czasownik krinein oznacza bowiem odsiewać, rozdzielać, wybierać, decydować, czy też sądzić, pochodzący zaś od niego rzeczownik krisis znaczy odsiew, wybór, a także rozstrzygnięcie (zob. Kopaliński 1988: 285).

W światowych źródłach słownikowych ${ }^{2}$, np. w The Webster's Encyclopedic Dictionary of the English Language (1988), hasło crisis objaśnione zostało jako „punkt zwrotny w chorobie, decydujący moment szczególnie $\mathrm{w}$ tragedii, czas zagrożenia, punkt kulminacyjny".

Rzecz oczywista, każde doświadczane poważne zagrożenie, tudzież nieoczekiwane zakłócenie normalnego biegu wydarzeń w życiu jednostki lub społeczności, a także każdy stan nierównowagi mający znaczenie przełomowe, zwrotne - wymaga odpowiedniego do zaistniałego stanu rzeczy działania poprzedzonego wnikliwą diagnozą oraz dogłębną oceną owego status quo, po czym podjęcia decyzji dotyczących wyboru należnych przedsięwzięć i wreszcie przystąpienia do adekwatnych działań w tej mierze. Słowem niezbędne jest stosowne zajęcie stanowiska oraz konieczna jest właściwie dobrana do zaistniałego stanu rzeczy odpowiednia interwencja.

W systematycznie wzbogacającej swój zasób literaturze przedmiotu na temat kryzysu wskazywane są takie zwłaszcza aspekty określanego tym mianem stanu rzeczy, jak: przeszkoda na drodze do ważnych celów życiowych, jej nieusuwalność za pomocą zwyczajowo stosowanych sposobów radzenia sobie z trudnościami, narastający okres dezorganizacji, czasowe załamanie, bezskuteczne wysiłki podejmowane dla przezwyciężenia trudności. Przy tym sygnalizowane są takie przyczyny kryzysu, jak

2 Adam Nobis (2010) w rozważaniach pt. Chiny i globalny kryzys, przywołując przemyślenia André Gundera Franka, wskazuje na funkcjonujące w literaturze przedmiotu interpretacje znaczenia słowa kryzys, a mianowicie: „chińskie znaczenie słowa ,kryzys' jest kombinacją niebezpieczeństwa i możliwości” (Nobis 2010: 111). Dalej Nobis powołuje się na Victora H. Mair, pokazując, że może być inaczej, gdyż mandaryńskie słowo oznaczające kryzys wēijī „składa się z dwóch sylab, które zapisywane są dwoma różnymi znakami, wēi (危) oraz ji (forma tradycyjna 機, forma uproszczona 机)” (Nobis 2010: 111). O ile wèi oznaczać ma „niebezpieczeństwo” to „jī w wēijī oznacza coś w rodzaju ,początkowy moment, rozstrzygający punkt (gdy coś się zaczyna lub zmienia)"” (Nobis 2010: 111). 
poczucie niemożności świadomego kontrolowania własnego życia zdominowanego przez strach, zagrożenie, dystres itp. (zob. np. Badura-Madej 1996, Chesney 2014, Domański [red.] 2010, Gielarowski 2016, Łuczewski 2010, Tight 1994).

Na zakończenie tej części rozważań - z uwagi na ograniczoność miejsca nie wyczerpującej rzecz oczywista rozległej problematyki kryzysu - warto zauważyć, że w literaturze przedmiotu podjęto próbę syntezy funkcjonujących ujęć definicyjnych tego terminu i stwierdzono, że kryzys jest sposobem postrzegania zdarzenia lub sytuacji, która jest trudnością niemożliwą do wytrzymania, przekraczającą zasoby i mechanizmy radzenia sobie z nią przez człowieka takiego stanu rzeczy doświadczającego. Podkreśla się przy tym, że zwłaszcza długotrwałe doświadczanie niemożliwości uwolnienia się od kryzysu może stanowić przyczynę poważnych zaburzeń funkcjonowania ludzi w różnych sferach i wymiarach (James, Gilliland 2012).

\section{Edukacja wobec kryzysu zaufania}

Zagadnienie kryzysu zaufania w edukacji stanowi istotny przedmiot zainteresowań z tej oczywistej racji, że fenomen zaufania warunkuje jakość realizacji zadań i celów edukacyjnych - owych międzygeneracyjnych zabiegów służących kształtowaniu, rozwijaniu i doskonaleniu zdolności życiowych człowieka - poznawczych, wolicjonalnych, moralnych i duchowych mających wymiar dialogiczny, w których nauczyciel, wychowawca, rodzic, opiekun uczeń, wychowanek, dziecko, podopieczny koncentrują swoją aktywność nie tylko wokół przekazywania oraz opanowania wiedzy, lecz również ujawniają i urzeczywistniają swój zorientowany transgresyjnie świat preferowanych wartości.

$\mathrm{Z}$ analizy prezentowanych $\mathrm{w}$ literaturze przedmiotu poglądów na temat kryzysu można wyprowadzić przekonanie, że realność takiego stanu rzeczy wydaje się być jedną z najbardziej podstawowych w świecie ludzkim. Niemal każdy człowiek w ciągu swojego życia doświadcza rozmaitych, trwających krócej bądź dłużej, sytuacji kryzysowych. Jakoby w sposób naturalny kryzysy wpisują się zatem w bieg życia ludzkiego. Niemniej jednak okazuje się, iż niezwykle trudno poddać ów stan rzeczy satysfakcjonującemu anagnoryzmowi oraz opisowi przyczynowo-skutkowemu z tej zwłaszcza racji, że na powstanie kryzysu nakłada się zazwyczaj wiele różnorodnych czynników zarówno intrapersonalnych, jak 
i interpersonalnych, a także środowiskowych wywierających wpływ na różne sfery i wymiary funkcjonowania człowieka. Zazwyczaj wymagane jest wieloaspektowe zajęcie stanowiska w tej mierze, kompleksowo uwzględniające sfery i wymiary, w których funkcjonuje człowiek, nie ograniczające pola problemowego wyłącznie do tych, których doświadczany kryzys dotyczy, lecz także uwzględniające jego konteksty, tj. zwłaszcza zespół wspólistniejących czynników powiązanych z kryzysem, stanowiących układ odniesień niezbędnych do jego zrozumienia.

Zaufanie $\mathrm{w}$ relacjach interpersonalnych $\mathrm{w}$ edukacji zakłada, że członkowie owej społeczności cechują się życzliwością, otwartością, uczciwością, przestrzegają określonych norm, a przy tym łączy ich wspólnota zadań oraz realizowanych celów. Jakkolwiek nawet bez niczyjej nagannej intencji $\mathrm{w}$ zaufaniu sytuują się w różnym stopniu i zakresie elementy ryzyka oraz niepewności - zgodnie z tym, jak dowiódł Sztompka, pisząc, że „zaufanie jest mostem nad morzem niepewności”, a także „zakładem podejmowanym na temat niepewnych, przyszłych działań innych ludzi” (zob. Sztompka 2007: 157) - to jednak właśnie edukacja oparta na zaufaniu okazuje się być strategią najlepszą z możliwych, z tego zwłaszcza względu, że pozwala redukować lęk, eliminować niepewność, a także dlatego, że stwarza możliwości bardziej swobodnego i umocowanego wsparciem podejmowania działań przynoszących oczekiwane rezultaty. Inaczej mówiąc, jeśli komuś - nie tylko w edukacji - ufa się, oznacza to, że oczekiwane rezultaty jego postępowania i działań nie tylko nie będą przynosić szkody, ale okażą się wielorako korzystne. Natomiast niedostatek czy brak zaufania stanowi źródło poczucia lęku, zagubienia, osamotnienia, samotności, trudności w przystosowaniu się do zmieniających się warunków, w tym braku aktywnego zaangażowania w przedsięwzięcia na rzecz indywidualnego i społecznego rozwoju.

Trzeba wszakże zastrzec, że jedną z podstawowych charakterystyk kryzysu, w tym kryzysu zaufania w edukacji, czy do edukacji, jest jego subiektywność. Otóż nie trzeba specjalnie uzasadniać, że ta sama sytuacja określana mianem kryzysu może być przez różne osoby postrzegana jako:

- będąca w ogóle bez znaczenia;

- przemijająca, charakteryzująca się umiarkowanym nasileniem, możliwa do rozwiązania;

- będąca problemem niełatwym do rozwiązania, stresująca, zwłaszcza w przypadku doświadczania krzywdy, straty, zagrożenia, 
odczuwania szkody czy urazu i stanowiąca wyzwania dotyczące oceny własnych możliwości poradzenia sobie z zaistniałą sytuacją;

- przybierająca postać absolutnej katastrofy, stanowiąca „utratę gruntu pod nogami";

- albo też zgoła przeciwnie - niezależnie od powyższej gradacji - jako okoliczność przede wszystkim sprzyjająca kreatywnie zorientowanym mobilizacjom do nowych przedsięwzięć, do zmian.

W istocie swej rzeczywistość ludzkich kryzysów okazuje się być ogromnie zróżnicowana i niejednakowo przez wszystkich postrzegana oraz doświadczana. Konstytutywną cechą kryzysu jest bowiem jego idiosynkrazja, tj. niepowtarzalność wynikająca z unikatowych splotów interakcji danej osoby przypisującej doświadczanemu zjawisku odmiennych znaczeń w powiązaniu z innymi osobami oraz konkretnymi sytuacjami. Nie jest zatem uprawnione orzekanie o kryzysie w edukacji w ogóle i przykładanie jednakowej miary owego stanu kryzysowego do wszystkich okoliczności oraz wszystkich uczestników tego procesu.

Niemniej spośród pięciu powyżej wymienionych ewentualności, którym bywa przypisywane miano kryzysowych, bądź orzekanie o zaistnieniu kryzysu, dwie z nich, a mianowicie te usytuowane na drugiej i trzeciej pozycji od dołu, jawią się jako najbardziej niepożądane, niebezpiecznie zakłócające proces edukacji, toteż wymagające kompleksowej interwencji w celu zwłaszcza eliminacji poczucia zagrożenia, tudzież towarzyszącego przekonania o konfrontacji z niebezpiecznym czasem i miejscem postrzeganym jako wrogie otoczenie wśród nieprzyjaznych osób w obliczu braku bądź niedostatku zasobów niezbędnych dla poradzenia sobie z owymi przeszkodami na drodze do odzyskania poczucia bezpieczeństwa oraz konieczności zmian i rozwoju.

Natomiast ostatnia z wymienionych ewentualności, tj. postrzeganie przejawów kryzysu jako okoliczności mobilizujących do nowych przedsięwzięć i kreatywnych zmian, wskazuje na obecność w tym wielorako skomplikowanym i trudnym zjawisku nie tyle wyłącznie swoistego zagrożenia, co przede wszystkim szansy zmian i rozwoju, a zwłaszcza wyłaniających się symptomów pozytywnie zorientowanych przemian.

Owo zagrożenie, szczególnie w warunkach odczuwanych jako ekstremalnie niesprzyjające, może być przyczyną dekompensacji, tzn. przekroczenia granicy zdolności przystosowania się do zwiększonych obciążeń, co objawia się niewydolnością zwłaszcza 
w sytuacjach jawiących się jako niezwykle trudne czy wręcz nie do rozwiązania. Następstwem takiego stanu rzeczy bywają zaburzone reakcje i zachowania oraz niesprawne pełnienie ról społecznych i wadliwe relacje interpersonalne. Zdarza się też skłonność do wycofania się z postrzeganej jako niemożliwa do tolerowania sytuacji, bądź też może dojść do zachowań agresywnych albo autoagresywnych, niekiedy wiodących do nadużywania przez ludzi substancji psychoaktywnych.

Doświadczanie kryzysu może stanowić szansę na zmianę istniejącego stanu rzeczy oraz zainicjowanie pozytywnych transformacji, zwłaszcza jeśli w owych przedsięwzięciach uzyskuje się wsparcie i pomoc osób znaczących. Racjonalne skorzystanie ze wsparcia i pomocy osób, które nie są w stanie samodzielnie przezwyciężyć owych trudności, stanowić może początek nowej drogi do rzeczywistego rozwiązania zaistniałej sytuacji problemowej i przełomowej, niepomyślnej i stresogennej oraz do otwarcia nowych możliwości rozwoju.

W procesy edukacyjne wpisane są z natury rzeczy sytuacje kryzysowe $\mathrm{z}$ racji napotykanych $\mathrm{w}$ toku pokonywania poszczególnych szczebli edukacyjnych rozmaitej proweniencji trudności, na które nakładają się w różnym stopniu i zakresie splatające się z nimi kryzysy rozwojowe podmiotów edukacyjnych, stanowiące konieczny warunek rozwoju osobowości człowieka przechodzącego przez pewne krytyczne etapy swej egzystencji. Warto nawiązać w tym miejscu do poglądów Ericha Eriksona, postrzegającego teorię kryzysu jako nieodzowny warunek rozwoju osobowości człowieka, kryzysu spełniającego rolę rozwojową i twórczą z racji poszukiwania rozstrzygnięć pomiędzy postępem a regresją (Hall, Lindzey, Campbell 2002: 202-204).

W literaturze przedmiotu prezentowane są różne teorie występowania kryzysów, w tym m.in. teorie egzogeniczne/zewnętrzne, teorie endogeniczne/wewnętrzne, tzw. teorie mieszane czy rozszerzona teoria kryzysu. W obrębie tej ostatniej sytuują się - oprócz psychodynamicznego - takie nurty, jak teoria systemowa, teoria adaptacyjna (uczenia się) oraz podejście Carla Rogersa, określane mianem teorii interpersonalnej (zob. James, Gilliland 2012). Do wskazanych podejść należy jeszcze dodać m.in. teorię stresu i radzenia sobie Richarda S. Lazarusa $(1990,1993,2001)$ - opisującą kryzys z pozycji psychologii poznawczej.

Każda z teorii - w zależności od napotykanych sytuacji, przyjętych kryteriów oraz założonych celów - może służyć jako 
podstawa do przeciwdziałania, bądź pokonywania czy radzenia sobie z przejawami kryzysu zaufania w edukacji.

Należy zauważyć, że w literaturze przedmiotu znacznie więcej uwagi i miejsca poświęca się teoriom kryzysu niż sposobom pokonywania sytuacji kryzysowych czy radzenia sobie z nimi, wychodzeniu z kryzysu, tudzież zapobieganiu kryzysowi - zwłaszcza w sferze edukacyjnej.

\section{Kilka uwag podsumowujących}

Zaufanie w edukacji można postrzegać z perspektywy zarówno potrzeby, jak i strategii działania, a przede wszystkim wartości egzystencjalnie znaczącej, wiążącej się z poczuciem bezpieczeństwa, stabilności, pewności, akceptacji, empatii i autentyczności, stwarzającej podwaliny do uruchomiania wewnętrznych możliwości, autonomii oraz zdolności do racjonalnego kontrolowania siebie a także otaczającej rzeczywistości. Darzenie kogoś zaufaniem, podobnie jak uznanie instytucji za godną zaufania z racji preferowanych w niej wartości oraz zaświadczany profesjonalizm i etos, stanowi podstawowy składnik we wszystkich aspektach życia społecznego, a także niezbędny czynnik uczestniczenia ludzi w konstruktywnych relacjach interpersonalnych. Zwłaszcza w sytuacjach trudnych zaufanie jest zasobem umożliwiającym ich pokonywanie zarówno w sferze prywatnej, jak i publicznej wpływając przy tym na optymizm i satysfakcję z życia.

Zaufanie $\mathrm{w}$ edukacji nabiera charakteru wartościującego, swoistego rodzaju zobowiązania przekraczającego zasady zadekretowane w umowach, systemach prawnych, regulaminach, przepisach etc. i odnosi się do bycia człowiekiem czy instytucją, na których można polegać, jest miernikiem jakości moralnych więzi międzyludzkich oraz szans dla rozwoju i doskonalenia osobowości podmiotów edukacji.

Tymczasem rzeczywistość kryzysu wydaje się być jedną z najbardziej podstawowych ludzkich realności. Jakkolwiek zazwyczaj jest dyskomfortowa oraz bywa bolesna, to jednak może okazać się istotnym źródłem potencjału dla rozwoju człowieka i zaświadczania człowieczeństwa zarówno w odniesieniu do tych, którzy doświadczają kryzysu, jak i tych, którzy starają się ich wspierać na drodze pokonywania niesprzyjających kryzysowych okoliczności.

W przypadku przejawów kryzysu zaufania w edukacji istotne jest, aby wszelkie przedsięwzięcia związane z tym stanem rzeczy 
nie ograniczały się li tylko do identyfikowania ich z perspektywy negatywnych konsekwencji, ale przede wszystkim stanowiły drogę poszukiwania możliwości konstruktywnego rozwiązywania i eliminowania tego, co może doprowadzać do kryzysu, tudzież nieść następstwa destruktywne. Szczególnie istotne jest zwłaszcza poszukiwanie metod radzenia sobie z przejawami kryzysu w taki sposób, aby owe przedsięwzięcia prowadziły do rozumienia, w jaki sposób doświadczana sytuacja może w toku pokonywania jej ograniczeń przybierać przesłanki konstruktywne wytyczające nowe możliwości.

Warto uwzględniać w owych przedsięwzięciach wyłonioną według typów oczekiwań $\mathrm{w}$ relacjach interpersonalnych gradację „zakładów” wyrażających ów fenomen zaufania. Przy czym przywołany termin „zakład” eksponuje kwestię podejmowania decyzji obarczonej ryzykiem, bez możliwości jej odwrócenia (zob. Sztompka 2007: 67-70).

Przyjmując, iż esencją zaufania jest oczekiwanie, Sztompka wyróżnił trzy kategorie oczekiwań (owe zakłady tworzą pewną gradację, w zależności od typu oczekiwań wobec partnerów oraz rosnącego ryzyka niespełnienia), a mianowicie: efektywnościowe, aksjologiczne i opiekuńcze. Podążając wytyczonym przez socjologa tropem rozważań, w odniesieniu do kwestii edukacji wobec kryzysu zaufania można rozwinąć owe kategorie z perspektywy stanowienia ważnych przesłanek w zakresie konstruowania kultury zaufania w edukacji, a mianowicie:

1. oczekiwania efektywnościowe - dotyczące instrumentalnych właściwości działań podejmowanych przez podmioty edukacji, $\mathrm{w}$ relacjach interpersonalnych, w odniesieniu do systemu edukacji jako całości i poszczególnych jego elementów, w istotny sposób wiążą się z zaufaniem do organizacyjnego aspektu funkcjonowania;

2. oczekiwania aksjologiczne - ten rodzaj oczekiwań związany jest z zaufaniem do etycznej sfery funkcjonowania systemu edukacji i jego podmiotów; dotyczą one szczególnych, humanistycznych właściwości działań w edukacji z uwzględnieniem założenia, że obdarzając kogoś zaufaniem tego rodzaju, oczekuje się, że będzie on działał odpowiedzialnie, sprawiedliwie, pryncypialnie, prawdomównie, moralnie nienagannie itp. (zakład tego rodzaju jest o wiele mocniejszy od oczekiwań efektywnościowych z uwagi na przyjęcie, że większość ludzi na ogół kieruje się przede wszystkim kalkulacją, znacznie rzadziej natomiast przesłankami moralnymi);

3. oczekiwania opiekuńcze (usytuowane najwyżej w hierarchii) - wiążą się z działaniami powierniczymi, w ramach których 
uobecnia się bezinteresowna dbałość o wspólne sprawy podmiotów edukacji, natomiast w relacjach interpersonalnych doświadczana jest pomoc, wsparcie, altruizm oraz szlachetność.

Tymczasem silniejsze i bardziej ryzykowne okazuje się pesymistyczne stwierdzenie, że inni będą działać amoralnie, stronniczo, kłamliwie, oportunistycznie. Za przesadne należy jednak uznać oczekiwanie, że inni będą działać irracjonalnie, przypadkowo, chaotycznie. Natomiast szansa, że nieufność okaże się bezzasadna, rośnie w miarę odmawiania partnerom cech - od opiekuńczych poprzez aksjologiczne do efektywnościowych. Analiza obu przeciwstawnych typów „zakładów” prowadzi do bardzo ważnych wniosków. Jak zauważa Sztompka:

Jeśli inni zawiodą pokładane w nich zaufanie, stanowi to dla nas zdarzenie destruktywne, które łatwo może doprowadzić do ugruntowania się uogólnionej nieufności, rozszerzyć na inne osoby czy instytucje. Jeśli natomiast nie sprawdzi się wyrażona innym nieufność, stanowi to doświadczenie pozytywne, które może prowadzić do wytworzenia się uogólnionego zaufania, wiary w rzetelność innych ludzi i instytucji (Sztompka 2002: 311).

Na przestrzeni dziejów zaufaniu przypisywano wielką rangę. Jednakże już Stagiryta, zwracając uwagę na kwestię nieufności, przestrzegał przed wykorzystywaniem zaufania w celach manipulacyjnych, tudzież do negatywnej perswazji przez „człowieka niegodziwego”, który w przeciwieństwie do „człowieka prawego” ,jest nieufny i złośliwie nastawiony względem wszystkich, gdyż własną miarę stosuje do innych. Dlatego łatwiej oszukać ludzi dobrych, chyba że z powodu doświadczenia nie ufają" (Arystoteles 1996: 461-463).

Również rzymski myśliciel Lucjusz Anneusz Seneka (4-65 n.e.) zalecał ostrożność przed skrajnościami, pisząc w listach moralnych do Lucyliusza, iż błędnym jest ufać wszystkim i nie ufać nikomu (Seneka 2019: 7).

Uzasadnionej nieufności trzeba jednak przypisać pozytywne funkcje, jeśli oczywiście jest ona poznawczo ugruntowana. Nieufność wobec niegodnych zaufania jest racjonalna - pozwala uniknąć niekorzystnych działań, zabezpieczyć się przed zagrożeniem, przygotować na ewentualne szkody. Niemniej jednak zarówno zaufanie, jak i nieufność stają się dysfunkcjonalne wtedy, gdy brak dla nich poznawczego uzasadnienia. Jeśli ufa się niegodnym zaufania, wykazuje się nieracjonalną niedbałość (nie czyni starań $\mathrm{w}$ zakresie pozyskania niezbędnych informacji o partnerze i działa 
na zasadzie metody prób i błędów) lub naiwność (bagatelizuje posiadane niekorzystne informacje). Trzeba jednak również pamiętać, że odmawiając zaufania tym, którzy na zaufanie zasługują, przynosi się szkody zarówno sobie, jak i innym. Sztompka zwraca uwagę na to, że nieracjonalne, paranoiczne obawy ignorujące wszelkie przeciwne dowody paraliżują działania, przekreślają szansę potencjalnie korzystnych interakcji, ograniczają spontaniczne, otwarte, swobodne kontakty z innymi. Z kolei godny zaufania partner doświadczający nieufności odczuwa frustrację, niesprawiedliwość, rozżalenie mogące przerodzić się w niechęć czy wrogość. Takie reakcje partnera stają się dodatkowym „dowodem” jego niewiarygodności, utwierdzając w stanie nieufności. W następstwie tego zainicjowane zostaje błędne koło pogłębiającej się wzajemnej alienacji. Kumulacja podobnych przypadków może prowadzić do rosnącej atomizacji i do rozbicia więzi społecznych oraz do kryzysu wspólnot. Nieuzasadniona nieufność może okazać się dysfunkcjonalna nie tylko dla partnerów, ale i dla całego społeczeństwa (Sztompka 2002: 344).

Z przeprowadzonych rozważań płynie przesłanie dotyczące przestrogi przed fascynowaniem się wszelakiego rodzaju symptomami kryzysu, torującymi drogę do kryzysu w edukacji, w tym niekiedy wręcz wyimaginowanymi zagrożeniami - nie każda wszak napotykana trudność ma od razu wymiar kryzysu. Natomiast wyczulenie na tropienie nade wszystko złych informacji, a niedostrzeganie dobrych stron, złudnie prowadzić może do przekonania, że ma się do czynienia z kryzysem.

Fundamentalne dla edukacji zaufanie $-\mathrm{z}$ jednej strony bezcenne, z drugiej obarczone ryzykiem z racji niemożności zagwarantowania jego trwałości - w istocie swej rozpościera przed ludźmi posiadającymi zdolność do ufania innym, bycia obdarzonymi zaufaniem oraz czynienia starań, aby trwać w tym fenomenie, ogromne możliwości doświadczania satysfakcji i nowych jakości $\mathrm{w}$ relacjach wobec siebie samego, z innymi oraz z otaczającym światem, których zapewne nie da się porównać z innym doznaniem, ani czymkolwiek - na miarę oczekiwań i aspiracji - zastąpić.

\section{Bibliografia}

Arystoteles (1996), Dziela wszystkie, t. 5, thum. zbiorowe, PWN, Warszawa. Badura-Madej W. (wybór i oprac.) (1996), Wybrane zagadnienia interwencji kryzysowej: poradnik dla pracowników socjalnych, Interart, Warszawa. 
Bartmiński J. (red.) (2001), Wspótczesny język polski, Wydawnictwo Uniwersytetu Marii Curie-Skłodowskiej, Lublin.

CBOS (2018), O nieufności i zaufaniu, „Komunikat z badań”, nr 35, s. 1-14.

Chałas K., Maj A. (red.) (2016), Encyklopedia aksjologii pedagogicznej, Polskie Wydawnictwo Encyklopedyczne POLWEN, Radom.

Domański H. (red.) (2010), Legitymizacja w Polsce. Nieustajacy kryzys w zmieniajacych sie warunkach?, Wydawnictwo IFiS PAN, Warszawa.

Encyklopedia PWN w trzech tomach (2006), PWN, Warszawa.

Foster J.B., Mc Chesney R.W. (2014), Kryzys bez końca, tłum. G. Konat, Instytut Wydawniczy Książka i Prasa, Warszawa.

Giddens A. (2008), Konsekwencje nowoczesności, tłum. E. Klekot, Wydawnictwo Uniwersytetu Jagiellońskiego, Kraków.

Gielarowski A. (2016), Kryzys kultury - kryzys czlowieka. Fenomenologiczna krytyka kultury: Hessel, Levinas, Henry, Akademia Ignatianum w Krakowie, Wydawnictwo WAM, Kraków.

James R.K., Gilliland B.E. (2012), Crisis Intervention Strategies, Cengage Learning, Inc, Belmont, CA, United States.

Hall C.S., Lindzey G., Campbell J.B. (2004), Teorie osobowości, tłum. J. Kowalczewska, J. Radzicki, M. Zagrodzki, PWN, Warszawa.

Hardin R. (2009), Zaufanie, tłum. A. Gruba, Wydawnictwo Sic!, Warszawa.

Lazarus R.S. (1990), Theory-Based Stress Measurement, "Psychological Inquiry", nr 1, s. 3-11.

Lazarus R.S. (1993), From Psychological Stress to the Emotions: A History of Changing Outlooks, "Annual Review of Psychology”, nr 44, s. 1-21.

Lazarus R.S. (2001), Conservation of Resources Theory (COR): Little more than words masquerading as a new theory, "Applied Psychology: An International Review", nr 50, s. 381-391.

Kopaliński W. (1988), Stownik wyrazów obcych i zwrotów obcojęzycznych, Wiedza Powszechna, Warszawa.

Łuczewski M. (2010), Socjologia narodu w kryzysie. Krytyczne wprowadzenie, „Studia Socjologiczne”, t. 199, nr 4, s. 7-35.

Michalik-Surówka J. (2008), Zaufanie, [w:] T. Pilch (red.), Encyklopedia pedagogiczna XXI wieku, t. VII, V-Ż, Wydawnictwo Akademickie Żak, Warszawa.

Mead G.H. (1934), Mind self and Society from the Standpoint of Social Behaviorist, University of Chicago, Chicago.

Mead G.H. (1975), Umyst, osobowość i spoleczeństwo, tłum. Z. Wolińska, PWN, Warszawa.

Milerski B., Śliwerski B. (red.) (1999), Pedagogika. Leksykon, PWN, Warszawa.

Nobis A. (2010), Chiny i globalny kryzys, „Kultura - Historia - Globalizacja”, nr 8, s. 111-119.

Ostrowska U. (2002), Relacje interpersonalne jako problem edukacyjny, [w:] U. Ostrowska (red.), Aksjologiczne aspekty relacji interpersonalnych $w$ edukacji, Oficyna Wydawnicza Impuls, Kraków.

Ostrowska U. (2018), Edukacja wobec wyzwań wspólczesności. Refleksje aksjologiczne - między zwątpieniem a nadzieja, „Pedagogika Przedszkolna i Wczesnoszkolna”, nr 2(12), s. 17-33. 
Ostrowska U. (red.) (2002), Aksjologiczne aspekty relacji interpersonalnych w edukacji, Oficyna Wydawnicza Impuls, Kraków.

Seneka A. (1960), Listy moralne do Lucyliusza, Edycja komputerowa: www. zrodla. historyczne.prv.pl, MMIII, s. 7 (dostęp: 30.11.2019).

Stownik języka polskiego PWN, https://sjp.pwn.pl/lista/a;202.html (dostęp: 30.10.2019).

The New Lexicon Webster's Encyclopedic Dictionary of the English Language (1988), Lexicon Publications, Inc. New York.

Tight M. (1994), Crisis, What Crisis? Rhetoric and Reality in Higher Education, "British Journal of Educational Studies", vol. 42, nr 4 (grudzień 1994), s. 363-374.

Sztompka P. (2002), Socjologia. Analiza spoleczeństwa, Wydawnictwo Znak, Kraków.

Sztompka P. (2007), Zaufanie. Fundament spoleczeństwa, Wydawnictwo Znak, Kraków.

Sztompka P. (2016), Kapitat spoleczny. Teoria przestrzeni międzyludzkiej, Społeczny Instytut Wydawniczy Znak, Kraków.

Sztompka P. (2007), Zaufanie, nieufność i dwa paradoksy demokracji, [w:] P. Sztompka, M. Kucia (red.), Socjologia. Lektury, Wydawnictwo Znak, Kraków.

Pilch T. (red.) (2003-2010), Encyklopedia pedagogiczna XXI wieku, t. I-VII oraz Suplement, Wydawnictwo Żak, Warszawa.

https://dorzeczy.pl/ (dostęp: 15.10.2019). 


\title{
Edukacja wobec kryzysu zaufania, wspólnotowości i autonomii - która edukacja i jaka?
}

\author{
Abstract \\ Education in the face of crises of: trust, commonality \\ and autonomy - what education?
}

Various attempts to solve crises, as well as the reform of education by the Ministry of National Education in Poland - are a constant promise of winners after losers. Another / new school should have been supported in the richness and diversity of the school's innovations and experiments. There is an observable need for social and academic release of education alternatives by practicing them, and at the same time the need for humanistic alternatives (Irena Wojnar's term) for education and school. Wrocław School of the Future, is the only example in the last twenty-five years that that better is possible.

Keywords: educational crises, educational reforms, political games, anachronistic interpretations of early school education, narrative model - Wrocław School of the Future, alternative education provocations, future of the school

Słowa kluczowe: kryzysy oświatowe, reformy oświatowe, gry polityczne, anachroniczne interpretacje wczesnej edukacji, model narracyjny - Wrocławska Szkoła Przyszłości, prowokacje edukacji alternatywnej, przyszłość szkoły

W 1959 r. fizyk Richard Feynman podczas jednego z wykładów wypowiedział słynne zdanie: Na dnie jest mnóstwo miejsca. To było na swój sposób zaproszenie do nowej rzeczywistości, do tworzenia jej na poziomie atomów, gdzie wcześniej człowieka nie było. Dziś wiara w sztuczną inteligencję jest jednocześnie wiarą w przekształcenie świata, ufnością że będzie można wyprodukować każdą rzecz, z każdego rodzaju tworzywa, przy niewielkim zużyciu energii. W 2016 r. Nagrodę Nobla odebrali chemicy tworzący roboty molekularne pomagające budować świat z cząstek zaczynają się spełniać „dziecięce” życzenia nanotechnologii. Ale 
już dość dawno temu profesor Józef Kozielecki - w małej, ale jakże mądrej książeczce pt. Smutek spetnionych baśni - ironizował na temat spełniania życzeń uczonych. Przychodzi nam zatem boleśnie konfrontować wielorakie nadzieje z miejscem... na dnie:

\begin{abstract}
Sto tysięcy lat temu - homo sapiens - osiągnął szczyt łańcucha pokarmowego, dwanaście tysięcy lat temu - pozycję jedynego gatunku ludzkiego, od czterystu lat żyjemy w antropocenie, jesteśmy najważniejsi i zdołaliśmy w tym czasie zmienić skład atmosfery, podnieść temperaturę, zakwasić oceany, zredukować rafę koralową o połowę, spowodować wyginięcie wielu gatunków lokalnych i błyskawiczną migrację oraz umocnienie innych, nagle wyrastających na globalnych dominatorów. Nasza historia jest równoznaczna z wprowadzeniem dramatycznych modyfikacji w otoczeniu, umocnieniem własnej pozycji i przynoszeniem zagłady roślinom czy zwierzętom (Wilk 2017: 332).
\end{abstract}

Struktura niniejszego tekstu podyktowana została swobodnym wyborem kilku kwestii, które z perspektywy mojego kilkudziesięcioletniego doświadczenia w praktykowaniu edukacji na etapie przedszkolnym oraz szkół podstawowych uznałem za szczególnie ważne. Być może jest to perspektywa właśnie zaledwie kilku „węzłów” w wielkiej sieci systemu edukacji. Nie są one ani najważniejsze, ani jedynie słuszne. Cóż, jak zaznaczyłem, są moim wyborem. Mamy zatem do czynienia z następującym porządkiem owej struktury: MEN - ciągte próby unieważniania się: teza Ignorowanie ztotego czasu wczesnej edukacji; teza Symbolicznego uwięzienia ruchu - klasy i tawki; teza Mizeria innowacji $i$ eksperymentów - „Nowe szaty cesarza”; Prowokowanie edukacji narracjami wyobraźni: teza Edukacja jako możliwości kreowania możliwości ludzi; teza Opowieści o Rodzinie Człowieczej i metoda PROedukacja; teza Nauczyciel jako imaginator-prowokator; Przysztość jako praktykowanie możliwości: teza Pewna zmiana perspektywy; teza Kreatywne podazanie $w$ novum; teza Dlaczego warto być czlowiekiem z tyczka?

\title{
MEN - ciągłe próby unieważniania się
}

Już od dość dawna noszę w sobie tezę - oby nie była drastycznie prawdziwa do końca - że zarówno kryzysy, reformy oświatowe, jak i niekiedy ich buńczuczne zapowiedzi, to po prostu... nieustanne obiecywanie wygranych po przegranych, innymi słowy ciągłe próby unieważniania się MEN-u; jak w czasie strajku nauczycieli 
w 2019 na „tle” Stadionu Narodowego. W „Dużym Formacie” obszerny tekst pod tytułem: To już moja szósta reforma, a jeden z wielu wypowiadających się mówił tak: „Wie pan, ja pracuję już piętnaście lat, to jest szósta reforma. W związku z tym nie ma czegoś takiego, że ja sobie przygotuję za swoje pieniądze zestaw pomocy i on będzie mi służył przez dziesięć lat. Co dwa, trzy lata muszę wszystko zmieniać" (Kwaśniewski 2019).

\section{Ignorowanie złotego czasu wczesnej edukacji (teza 1)}

Czytam z nieukrywanym uznaniem dla odwagi i wyzwania Francji: Francuskie trzylatki pójda do szkoly (Bassets 2019). Jak relacjonuje z Paryża Marc Bassets w EL PAIS francuski prezydent Emmanuel Macron wraz z ministrem edukacji narodowej Jeanem-Michelem Blanquerem zintensyfikowali działania mające na celu wzmocnienie edukacji podstawowej i przedszkolnej. Jednym z najważniejszych środków, po który sięgnęli, jest ustawa obniżająca wiek rozpoczęcia obowiązkowej edukacji z sześciu do trzech lat. Prawo przewiduje, że proces kształcenia nie może się zakończyć przed ukończeniem 16 lat. Termin „kształcenie” ma wymiar oficjalny, ponieważ uczniowie mogą pobierać nauki poza instytucjami szkolnymi, na przykład w domu (Bassets 2019). A równocześnie właśnie mija 20 lat od wydania głośnej pracy Gordona Drydena i Jeannette Vos pt. Rewolucja w uczeniu (w Polsce publikacja ukazała się po raz pierwszy w roku 2000). Książkę rozpoczyna kilkadziesiąt krótkich komentarzy zawierających ocenę jej wartości, których autorami są specjaliści z różnych dziedzin, światowe autorytety nauki i kultury - wśród nich m.in. Charles Handy, który opiniuje: „Obecnie bardziej niż kiedykolwiek konieczna jest zmiana całej koncepcji edukacji i uczenia się. Ta książka wspaniale pokazuje nam, jak tego dokonać” (Dryden, Vos 2000). Colin Rose pisze zaś: „Bez wątpienia wyjątkowa. Książka w niezwykle inspirujący i wyczerpujący sposób zbiera w jedno pasmo wszystkie nitki badań dotyczących edukacji” (Dryden, Vos 2000: 31). Sami autorzy Rewolucji w uczeniu już na początku swojego dzieła prezentują wyniki analiz przeprowadzonych przez wielu badaczy w kardynalnej kwestii szans rozwoju zdolności uczenia się. Piszą m.in.: „Pięćdziesiąt procent naszych zdolności uczenia się rozwija się w ciągu pierwszych czterech lat życia. W związku z tym rodzice są najważniejszymi nauczycielami dziecka. Mimo to żaden rząd nie wydaje nawet jednego procenta budżetu szkolnictwa na ich szkolenie" (Dryden, Vos 2000: 97). I dalej: 
Skoro pięćdziesiąt procent zdolności do nauki rozwija się w ciągu pierwszych czterech lat życia, a kolejne trzydzieści procent do ukończenia ośmiu lat, to programy rozwojowe dla okresu wczesnego dzieciństwa powinny być traktowane jako najwyższy priorytet. Tymczasem w większości krajów wcale tak nie jest. Średni wydatek na studenta uczelni wyższej jest znacznie większy niż na ucznia szkoły podstawowej lub średniej, a te z kolei i tak o wiele wyższe niż na dziecko w przedszkolu. Odwrócenie tych proporcji powinno stać się priorytetem w każdym państwie (Dryden, Vos 2000: 97).

Zróbmy zatem choćby mocno uproszczoną symulację, w której owe $80 \%$ rozwoju zdolności uczenia zajmuje pierwszych osiem lat życia, a umowna średnia długość życia to 80 lat. Przy takim założeniu pierwsze 10\% lat życia w sposób zasadniczy rzutuje na pozostałe $90 \%$. Jaka wobec tego strategia? Jakie programy innowacyjne i eksperymentalne? Jakie kształcenie nauczycieli? Jakie realne, podwyższone nakłady na wczesną edukację?

\section{Symboliczne uwięzienie ruchu - klasy i tawki (teza 2)}

Nie trzeba być złośliwym, aby pomyśleć/powiedzieć: wieki leca, tawki zostaja!? A tak przy okazji: chyba we wszystkich przekazach telewizyjnych w czasie strajku nauczycieli wiosną 2019 r. „niezastępowalnym” tłem do rozmów i dyskusji były klasy i ławki, czasami nawet z krzesłami na ławkach do góry nogami. W wielu prezentacjach marketingowych centrów konferencyjnych możemy znaleźć przykłady organizacji przestrzeni ze względu na usytuowanie stolików i krzeseł. Poniżej pokazuję przykład wzięty z prospektu hotelowego.

Cóż, tradycja „szkolna” trzyma się mocno.

Krytyka takiej organizacji przestrzeni szkolnej - czy nawet szerzej edukacyjnej - sięga jeszcze Trzeciej fali Alvina Tofflera i innych badaczy z końca lat 60. i 70. ubiegłego wieku; była mocna i trafna, nie będę tu już jej przywoływał, obnażała wiele kłopotliwych kontekstów natury psychologicznej, socjologicznej czy edukacyjnej, ale także wskazywała na ignorowanie funkcji przestrzeni, które postulowali także architekci.

W pracach nad projektem specjalnym Wrocławska Szkoła Przyszłości od początku w zespole byli architekci. I to nie tylko ze względu na wymagania profesjonalnego projektowania i budowania szkól, ale także z powodu ich odmiennego punktu widzenia oraz poszukiwania kreatywnych inspiracji (od 1972 r.). We Wrocławskiej Szkole Przyszłości wypracowaliśmy własne, oryginalne 
Rodzaje ustawienia mebli
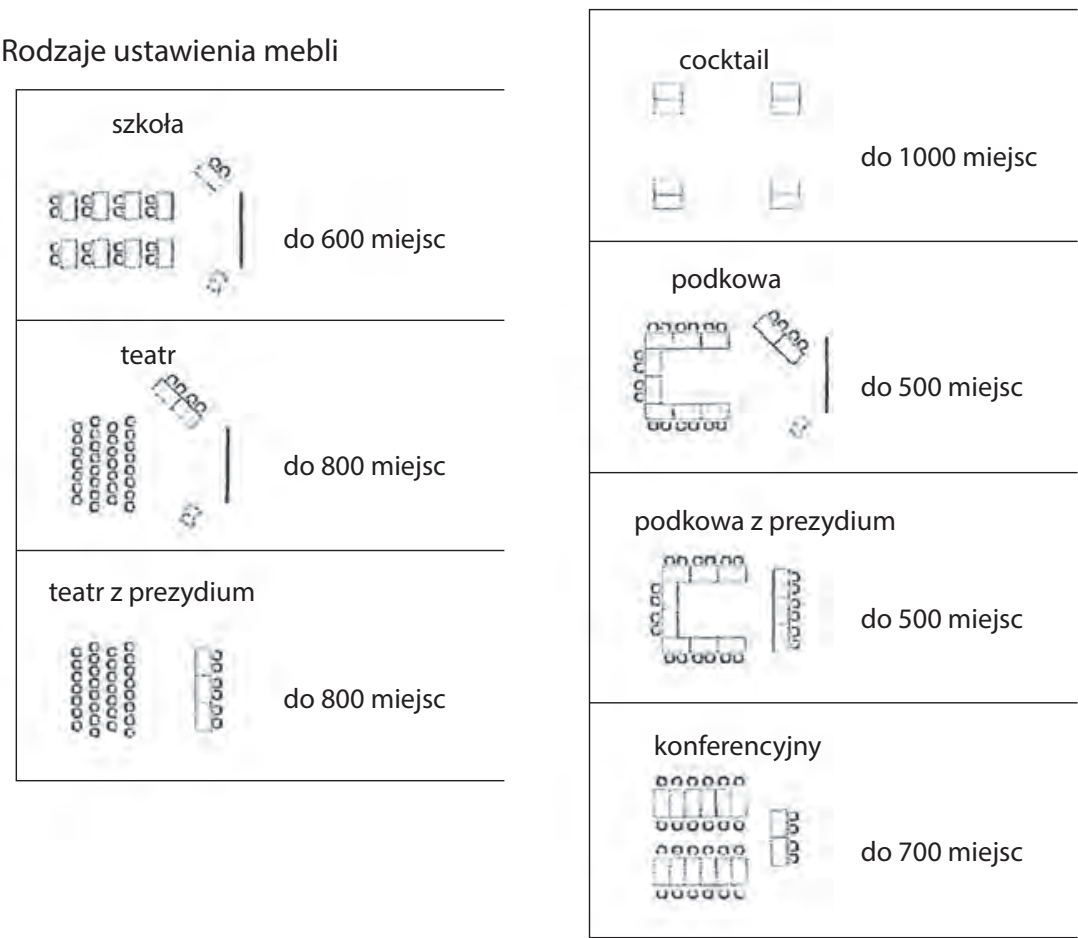

założenia i rozwiązania praktyczne dotyczące wartości i sensów organizacji przestrzeni (zob. Łukaszewicz 2010: 119-154).

Zaczęliśmy od przełamywania tradycyjnych wyobrażeń o przestrzeni edukacyjnej, która najczęściej zostaje zredukowana do klasycznych funkcji użytkowych, standardów mierzonych w metrach kwadratowych, wymogów bezpieczeństwa i higieny. Wszystko ważne, ale daleko niewystarczające. Przyjęliśmy zatem, że w każdym miejscu rozwiązania przestrzenne $\mathrm{i}$ ich konteksty aranżacyjne wspierają i animują aktywność dzieci; że uczą się poprzez to, co widzą, słyszą, co wyczuwają intuicyjnie, co je emocjonuje, zaciekawia i potrafi rozkołysać wyobraźnię; że jednocześnie jest to czas przeżywany, doświadczany, w którym istotne są nie tylko receptory przestrzenne - oczy, uszy, nosy - lecz także receptory bezpośrednie, czyli skóra i mięśnie, gdyż budują doświadczenia ruchowe, dotykowe, wizualne, ale równocześnie mnożą doświadczenia estetyczne, wyobrażeniowe, konceptualne.

W każdej sali organizacja przestrzeni oparta jest na założeniu zdecentrowanego porządku i kreowania światów niezredukowanych w swej złożoności poza kontekstami oczywistymi, czyli 
architektonicznymi z ich sensami funkcjonalnymi i użytecznościami. Odnajdujemy $\mathrm{w}$ nich owe wymiary antropologiczne, owe związki duchowe - wymiary symboliczne, metaforyczne, wyobrażeniowe, doświadczalne, kameralne czy nieformalne. To przestrzenne i aranżacyjne oddziaływanie różnych świadomości trwających w stanie niedopełnienia, jest nie tylko znaczące dla procesów edukacyjnych, ale jednocześnie pozwala każdemu doświadczać i tego, że miejsce może być pytające, prowokujące, odpowiadające, akceptujące, polemiczne czy kontemplujące. Tak dzieje się na przykład wówczas, gdy na półpiętrze, na ściennej półce, widzimy jak odchodzą wakacyjne wspomnienia falujące w odpływającej i przypływającej muszelce i garści kamyków, a na ich miejsce razem z październikiem wtoczą swoje opowieści kasztany, parkowa ławeczka zostanie przeznaczona na jesienny przystanek „dziada i baby”, krajobraz zaś wypełniają zapomniane, zaśniedziałe mechanizmy starych zegarów i dotknięte zaszłościami cyferblaty, dla których czas jest już tylko niemym trwaniem.

Kontekst symbolicznego uwięzienia ruchu nie do końca jest tylko symboliczny; oczywiste jest i to, że ciekawość świata wymaga także fizycznych możliwości ruchowych, reaktywności i muskulatury; sięganie po coś, chwytanie, bieganie, chodzenie, wydawanie dźwięków - wszystkie te umiejętności zdobywamy dzięki poruszaniu się. Ale szczególnie ważne jest to, iż ruch JEST FUNKCJĄ „JA” niezbędną do wzrostu i rozwoju (wykreowaliśmy przestrzenie - otwartą, warsztatową, kameralną i imaginującą... w każdej sali).

\section{Mizeria innowacji i eksperymentów - „Nowe szaty cesarza” (teza 3)}

Wydając pierwszy zeszyt pt. Drożdze dla edukacji - prowokowanie zmian (zob. Łukaszewicz 2014) miałem - chyba nieskromną - nadzieję, że pojawią się w naszym akademickim i nie tylko akademickim środowisku głosy wspólnej mobilizacji. Pomyliłem się!? Nadal jestem przekonany, iż właśnie w naszych „rękach i głowach” tkwi największy potencjał mobilizacyjny i... realizacyjny w kontekście innowacji i eksperymentów (Łukaszewicz 2014).

„Ostrzegam” przed uważnym - boleśnie wnikliwym i trafnym - czytaniem/studiowaniem raportu: Szkota dla innowatora. Ksztattowanie kompetencji proinnowacyjnych, który został przygotowany na zlecenie Ministerstwa Przedsiębiorczości i Technologii 
w roku 2017; co to: afirmacja kreatywności nad inteligencją; co to: rozróżnienie pomiędzy inteligencją a kreatywnością; co to: nacisk na sam proces uczenia się; nauczyciele stawiają przed uczniami zadania, które w większym stopniu umożliwiają im (...) wykonywanie powtarzalnych procedur i wykorzystywanie wiedzy w sytuacjach typowych...; co to: nauczanie kompetencji proinnowacyjnych jest związane $\mathrm{z}$ umożliwianiem podejmowania ryzyka poprzez eksperymentowanie; co to: obowiązująca podstawa programowa wyrasta $\mathrm{z}$ ideologii transmisji kulturowej (Arendt 2019).

A gdyby tak popatrzeć na kontekst innowacji i eksperymentów jeszcze inaczej. Spróbujmy:

- KAIZEN oznacza udoskonalanie, ciągłe udoskonalanie;

- Każdego roku TOYOTA wprowadza 8 mln. usprawnień;

- Polska: nauczyciel pracuje rocznie 18 godz. $\times 30$ tyg., czyli 540 godz.; 540 godz. $\times 40$ lat $=21.600$ godzin .

$21.600 \times 100$ tys. nauczycieli $=\mathbf{2} .160 .000 .000 \ldots$ ? taką liczbę godzin mamy do dyspozycji dla innowacji i eksperymentów (choćby przy 100 tys. nauczycieli).

I co? A przecież w oświacie pracuje nie sto tysięcy nauczycieli, a 600 czy 700 tys.?

Drozdze dla edukacji - prowokowanie zmian to wyzwanie, a zarazem zaproszenie do kreatywnego działania/współdziałania - w każdym miejscu, w każdym czasie, na każdy sposób, który otwie r a nowe możliwości, nowe drogi, nowe inspiracje i motywacje.

Może i nie ma musu, może i nie ma konieczności, ale jak ciągle powtarzam - są możliwości, i dlatego warto. Warto, albowiem w edukacyjnej perspektywie mamy zawsze do czynienia z... czującymi, wrażliwymi, czasami opornymi, ale chłonnymi stworzeniami - dziećmi; dla nich edukacja jest nie tylko „ziemią obiecaną”, czy żeglowaniem ku „trafnym utopiom”, lecz także wielkim kęsem życia; potrafią spontanicznie i z niecierpliwością, z uwagą i wytrwałością, używać rąk i rozumu, aby doświadczać, bezpośrednio dotykać, a nie jedynie ogarniać myślami zamienionymi na czynności pozorne; to one chcą ciągle od nowa stawiać znak równości pomiędzy twórczością i zmianą, a nie odtwarzać dany ład; potrzebują doświadczania siebie jako części świata, aby intuicją, fantazją, kreacją i zabawą, ekspresją i emocjami sprzyjać ekologicznemu porządkowi życia (zob. Łukaszewicz, Leksicka 2018). 


\section{Prowokowanie edukacji narracjami wyobraźni}

Prowokowanie edukacji narracjami wyobrazni to jedna z trzech głównych tez - obok tezy dotyczącej MEN-u jako ciagtej próby unieważniania się i tezy o przyszłości jako praktykowaniu możliwości - i dotyczy wprost długich i dobrych doświadczeń tworzenia szkół alternatywnych, w tym przypadku Wrocławskiej Szkoły Przyszłości (25 lat praktycznej realizacji tego modelu). Ma ona bogatą literaturę, ale tu zwrócę uwagę na dwie najnowsze pozycje: Ryszard Łukaszewicz, Krystyna Leksicka: Skrypt dydaktyczny struktury modelu i rozwiazań praktycznych eksperymentalnego i innowacyjnego projektu Wroctawska Szkoła Przyszłości (Wrocław 2018) i Łukaszewicz (2019): „Wroctawska Szkoła Przyszłości Plus”, czyli lepsze jest możliwe. Dziatania praktyczne, wizje i projekcje nowego - innego - twórczego.

Zupełnie od niedawna posługuję się czymś w rodzaju „super syntezy”, która próbuje ująć prawdopodobnie siedem najważniejszych kontekstów znaczeniowych sensów i wartości modelu Wrocławskiej Szkoły Przyszłości (w skrócie WSP). Nazwałem ową „całość” Elementarzem dla nowej/innej edukacji(?). Ten zapis nie był dotychczas nigdzie publikowany.

\section{ELEMENTARZ DLA NOWEJ/INNEJ EDUKACJI}

Po pierwsze: nowatorskie zinterpretowanie rozumienia edukacji w kontekście uczenia/uczenia się i rozwoju każdego człowieka/ dziecka, co oznacza, że: edukacja to perspektywy kreowania ludzkich możliwości; to - używając metafory - sięganie/wydobywanie na jaw diamentów z nieskończenie bogatej „kopalni” ludzkiego potencjału. W procesie edukacji - jak diamenty w rękach zmyślnych jubilerów - ów potencjał zyskuje radykalnie na wartości. A to, ile zyskuje, zależy właśnie od tego, z jaką edukacją mamy/ możemy mieć do czynienia?

Po drugie: w procesie eksperymentów i prób realizacyjnych została skutecznie wypracowana innowacyjna formuła kreatywnego powiązania potęgi umysłu jako samoorganizującego się systemu z heurystyczną metametodą projektowanych okazji edukacyjnych; oznacza to, że: mamy do czynienia $\mathrm{z}$ wartością synergiczną wedle której „możliwości pierwotne” potencjału 
każdego są transformowane w nowe i nazwane „możliwościami edukacyjnymi plus”; ów dosłowny i symboliczny plus jest/staje się trudny do przecenienia, a czasami - wręcz rozstrzygający?

Po trzecie: żyjemy w świecie kreatywnego podążania w novum, dysponujemy nieskończonym teatrem własnej wyobraźni, a nauka i edukacja stają się rewolucyjnym bogactwem; w tym kontekście jest oczywisty zmierzch edukacji reaktywnej/instrumentalnej, zdominowanej naśladowaniem wpisanym w użyteczność. Alternatywa polega na tym, że: edukacja jest/staje się sztuką i praktykowaniem prowokowania potencjału ludzi; staje się uczeniem, uczeniem się i rozwijaniem możliwości każdego $\mathrm{w}$ wieloraki sposób i na wszelkie okazje po to, aby zmieniać świat na lepsze i przekraczać siebie?

Po czwarte: tradycyjny układ i dobór treści edukacyjnych należy zastąpić „przewrotem kopernikańskim” polegającym na wprowadzaniu opowieści O RODZINIE CZŁOWIECZEJ; trzeba tworzyć porządki konstruowania owych narracji; trzeba przyjąć „antyszkolną tezę", iż dla edukacji dzieci ważniejsze są pytania od odpowiedzi, wiedza bowiem jest odmienianiem pytań w podróży (pytać - od/o/powiadać - pytać...)?

Po piąte: należy przyjąć paradygmat zmiany świadomości, który nie tylko dotyczy odejścia od paradygmatu Oświecenia paradygmatu odzwierciedlenia, ale pozwala nam rozumieć, że ani człowiek, ani świat nie są po prostu dane z góry, ale raczej istnieją w kontekstach $\mathrm{i}$ tłach, mają własną historię i własny rozwój, a więc w tym procesie rozwoju człowiek będzie przedstawiał świat bardzo różnie, w zależności m.in. od tego, co sam wnosi do jego obrazu; umysł kształtuje świat bardziej niż świat kształtuje umysł? (zob. Wilber 1997: 13-69).

Po szóste: „tajemnica” dobrej roboty nauczyciela leży w tym, czy chce i umie być/stawać się imaginatorem-prowokatorem; czy potrafi uczyć się prowokowania inwencji w sobie oraz czy potrafi przekładać ją na prowokowanie dzieci poprzez projektowane okazje edukacyjne. Tak, prowokowanie inwencji - inwencja prowokowania. Wówczas mamy do czynienia z autentycznym zaproszeniem do wszechświata możliwości?

Po siódme: to nade wszystko warsztaty aktywności niekonwencjonalnej są posłańcami sensów edukacyjnych, zawsze najlepszymi, jakie potrafimy kreować; są dla wyobraźni, wrażliwości, refleksji, mądrości - dla doświadczenia, dla stawiania pytań, dla rozwoju i duchowości, ale także dla wzruszenia pięknem, 
dla chwil zadumy, dla radości po nic, czy wreszcie - dla poetyckiej siły tworzącej rzeczywistość i dla nieodgadnionego. Zawsze mają przemyślaną strukturę sensów konstruowanej przypowieści, sekwencyjny porządek realizacji, sztafaż utkany z metafor i/lub symboli, magię rąk artystów i nauczycieli przemieniających mówiąc umownie - działania w „skuteczne zdziwienie” (określenie Jerome’a Brunera). Ale potrzebują też szczypty przypadku, odrobiny szaleństwa i wsparcia... ludzi dobrej woli?

\section{Przyszłość jako praktykowanie możliwości}

Ta trzecia główna teza prezentacji jest na swój sposób ogólniejszą próbą spojrzenia poza czas teraźniejszy - poza „tu i teraz”. Jakkolwiek trzeba mieć świadomość tempa biegu zdarzeń chciałoby się powiedzieć rosnącego z dnia na dzień - i potrzeby naszych człowieczych, autonarracyjnych odniesień do owego stanu rzeczy.

\section{Pewna zmiana perspektywy (teza 7)}

Mam przekonanie, że nie tylko w pedagogice i edukacji triada: przeszłość - teraźniejszość - przyszłość „rządziła i rządzi” niepodzielnie; takie podejście temporalne było i jest na swój sposób oczywiste i powszechnie zrozumiałe oraz akceptowane. Podzielam je i nie protestuję, ale, ale...?

Czytam Brunera Kulture edukacji - mojego guru od czasów Szkiców pisanych na lewa rękę - i w rozdziale czwartym znajduję Nauczanie Teraźniejszego, Przesztego i Możliwego. Cóż, można powiedzieć „możliwe, czyli przyszłe, czyli właściwie to samo”. Może, ale nie u Brunera, i teraz u mnie „oświeconego". Przyjmuję, że to chyba nie jest spór o słowa, a zdecydowanie raczej o kontekst interpretacyjny, to po pierwsze, a po drugie - o swoista zmianę sensów i wartości edukacji w jej praktykowaniu. Rozdział otwiera następująca refleksja:

To dziwne i w pewnym sensie deprymujące, jak niewiele uwagi poświęcono wewnętrznemu charakterowi nauczania i nauki szkolnej w debatach nad edukacją, które rozgorzały w latach osiemdziesiątych XX wieku. Debaty te przeważnie zogniskowane wokół rezultatów i standardów kształcenia najczęściej nie dostrzegały środków, z pomocą których zarówno nauczyciele, jak uczniowie zajmują się swoimi zadaniami w realnych klasach szkolnych - tego, jak nauczyciele nauczają, a uczniowie się uczą (Bruner 2006: 125). 
Profesor konstatuje poniekąd samokrytycznie, choć nie odnosi tego tylko do siebie, iż właśnie owa wewnętrzna perspektywa przeanalizowana przez Ann Brown - nie została należycie wykorzystana w debatach o edukacji w końcu XX w., a wnosi nad wyraz wiele znaczących inspiracji (zob. Bruner 2006: 26, 126).

Bruner zwraca tu uwagę na cztery zasadnicze pojęcia: pierwszym z nich jest idea sprawstwa; zwiększania stopnia zarządzania własną aktywnością umysłową. Drugim jest refleksja: nie mechaniczne „wkuwanie na pamięć”, ale pojmowanie sensu przyswajanego przedmiotu, uczenie się ze zrozumieniem. Trzecim jest współpraca; dzielenie się wiedzą przez osoby zaangażowane w nauczanie i uczenie się. Umysł znajduje się w głowie - dodaje autor Kultury edukacji - ale także w interakcji z innymi. Czwarte to kultura, sposób życia i myślenia, który konstruujemy, negocjujemy, poddajemy instytucjonalizacji, by wreszcie (ustaliwszy wszystkie te sprawy) - dla własnego pokrzepienia nazwać go „rzeczywistością” (Bruner 2006: 126).

„Chwilę później” czytam krytyczną refleksję, która chyba przez całe dziesięciolecia była na swój sposób „przemilczana lub omijana” w głównych nurtach dyskusji o szkole, a mianowicie, że rozważania o kondycji ludzkiej budzą nie tylko sprzeczne namiętności - a także wymagają nieco innych umiejętności, odmiennej wrażliwości i większej odwagi - jednak namiętności tych nie można zracjonalizować poprzez rozlokowanie ich po samowystarczalnych oazach poszczególnych „przedmiotów”, czego uczymy się obecnie - płacąc za to wysoką cenę (Bruner 2006: 127).

Warto także przytoczyć sarkastyczne słowa Brunera o trzeźwo myślących profesorach nauk przyrodniczych:

którzy potępiali miękkość ,miękkich przedmiotów', gdy Europa po raz kolejny maszerowała na wojnę - urzeczywistniając historyczno-socjologiczno-literackie opowieści, które jak przypuszczano miały tylko,wzbogacić umysł'. Zapewne mogliśmy wówczas lepiej rozumieć samych siebie i nasze szaleństwa, a gaz bojowy i grube berty' mogły okazać się śmiertelnymi owocami weryfikowalnej nauki (Bruner 2006: 129).

Czy nie powinniśmy zatem - pyta, choć z goryczą, wielki guru psychologii, prekursor kształcenia wspomagającego rozwój, jak określiła go profesor Anna Brzezińska - „postarać się lepiej zrozumieć, jak opowieści i przekazy historyczne są łączone, 
by ujrzeć, co mają w sobie takiego, że skłaniają ludzi albo do wspólnego życia, albo do wzajemnego okaleczania się i zabijania" (Bruner 2006: 129).

I dalej konkluduje (co warto z namysłem, spokojnie przeczytać niejeden raz):

W pierwszej ćwierci XX stulecia ludzie myślący byli świadkami pewnego rozstrzygającego zdarzenia. Nazwijmy go ,zwrotem interpretacyjnym'. Zwrot ten wyraził się początkowo w dramacie i literaturze, następnie $\mathrm{w}$ historii, naukach społecznych, wreszcie - w epistemologii. Obecnie uwidacznia się $\mathrm{w}$ edukacji. Przedmiotem interpretacji jest rozumienie, a nie wyjaśnianie; jej instrumentem zaś jest analiza tekstu. Rozumienie to rezultat organizowania i kontekstualizowania zasadniczo spornych, niezupełnie sprawdzalnych twierdzeń w zdyscyplinowany sposób. Jednym z istotnych sposobów ich rygorystycznego ujmowania jest układanie narracji: opowiadanie ,o czymś' historii. Jednak, jak niegdyś podkreślał Kierkegaard, tworzenie opowieści w celu zrozumienia świata to nie tylko sposób wzbogacania umysłu: bez nich zostalibyśmy zredukowani do, by użyć jego sformułowania, bojaźni i drżenia (Bruner 2006: 129-130).

Wyodrębnienie kategorii „możliwości” z magmy i jej nieokreśloności - jak mi się wydaje - którą powszechnie i potocznie nazywamy „przyszłością”, jest za każdym razem niezwykłym zaproszeniem do niezwykłych podróży; podróży przystosowywania się do nowych faktów/okoliczności POPRZEZ radykalną zmianę konstrukcji teoretycznych i praktycznych. Czytam/ rozumiem to jako na swój sposób permanentne „wykreślanie” trajektorii kreatywności. Trudno chyba o lepsze otwarcie edukacji na „najlepsze i największe” - na MOŻLIWOŚCI!? Pamiętajmy, to umysł konstruuje.

\section{Kreatywne podązanie $w$ novum (teza 8 )}

Jej sensy i wartości wiążą się bezpośrednio z ową zmianą perspektywy, którą zaproponował właśnie Bruner - nauczanie możliwego. Natomiast samo sformułowanie tej tezy pochodzi od Alfreda Northa Whitehead'a - wybitnego myśliciela matematyka i filozofa profesora Cambridge (1861-1947); „Whitehead [...] wymienił jedynie trzy ,ostateczne kategorie' - pojęcia, które są potrzebne, żebyśmy mogli w ogóle o czymś myśleć. Są to: kreatywność, jedno, wiele" (cyt. za Wilber 1997: 43-44).

Znawcy uprawy winorośli twierdzą, że spośród wszystkich odmian drożdży, jakie istnieją w przyrodzie, odpowiedni gatunek 
pojawia się spontanicznie na winnych gronach tuż przed winobraniem; w okresie dojrzewania gron pojawiają się w wielkiej obfitości, gotowe rozpocząć proces fermentacji. Analogia - jakkolwiek pewnie ułomna i być może banalna - pozwala odnieść ten opis do czytania/zobaczenia młodych na progu owej fermentacji ich inwencji i inicjatywy w eksplodującym bogactwie i różnorodności nurtów oraz ścieżek rozwojowych naszego czasu. Jednocześnie nabieram przekonania, iż owa niezwykła eksplozja drożdży stała się/staje manifestacją takiego czasu, w którym coraz bardziej zaczyna dominować to, co możliwe nad tym, co konieczne, stała się/staje - eksplozją aktywnych, trwałych praktyk zmieniających społeczne i kulturowe doświadczenia świata, w którym żyjemy, stała się/staje - poprzez wyobraźnię i edukację - permanentnie otwierającą się przestrzenią możliwości, a metapozytywne myślenie i kreatywność stanowią koło zamachowe: konteksty praktyczne wymuszają wzrastającą moc inwencji, a wzrastająca moc inwencji przemienia wizje - misje presje w łańcuchy czy bąble nowego - innego - twórczego... (zob. Łukaszewicz 2012a).

Świat zawsze się zmienial. Jednak teraz zdaje się zmieniać inaczej. Wcześniej człowiek z jego potęgą wyobraźni pokonywał opór materii i głód ciekawości, ale ciągle wśród zagadek miał do czynienia ,jedynie” ze Wszechświatem. Teraz zaś za sprawą komputera, czyli „maszyny stworzenia”, ofiarował nam jeszcze jeden, ale już cyfrowy wszechświat. „Cały rozszerzający się cyfrowy, komputerowy wszechświat, w którym jesteśmy zanurzeni, narodził się 60 lat temu we wnętrzu jednego komputera - w małym miasteczku w stanie New Jersey" (Łukaszewicz 2012b: 48).

Może daleko od tej nowej, tajemniczej i nieprzewidywalnej jeszcze drogi „mlecznej”, a może zupełnie blisko, rozwija się myśl, inwencja, energia, pola morfogenetyczne Sheldrake'a, przestrzeń, która zmienia, czy raczej próbuje zmienić „morze starego”. Edukacja - nie po raz pierwszy - zdaje się jednak konserwować status quo mimo hakerów i prowokatorów alternatyw. Nie wydaje się być wystarczającym i satysfakcjonującym sojusznikiem ludzi na drogach wśród znaków niepewności.

\section{Dlaczego warto być „cztowiekiem z tyczka” (teza 9)}

To ostatnia z dziewięciu „małych” tez, które przedstawiam w niniejszym tekście. W jakimś sensie „finalizuje” rozważania, zostawiając nam, ludziom... wszechświat możliwości i wyborów. 
Niezrównanymi sojusznikami w owej podróży są dla mnie autorzy Sztuki możliwości (Rosamund Stone Zander i Benjamin Zander). To oni - jak sami piszą - wciągają ludzi w swą pasję życia w sposób szczodry i otwarty, choć ani oni, ani my, nie mamy żadnych gwarancji... (Stone Zander, Zander 2005).

Już dawno temu „postawiłem/obstawiłem” w owej grze z możliwościami na „człowieka z tyczką”, choć wtedy ani go tak nie nazywałem, ani nie znałem przemyśleń i argumentów wielu znakomitych autorów. Kim jest zatem „człowiek z tyczką”?

„Człowiek z tyczką" jest symbolem człowieka drogi nieskończonej wielości... dróg. Inspiracją była dla mnie frapująca i przejmująca opowieść naszego rodaka - Jacoba Bronowskiego (1988), przedstawiona w pracy pod tytułem Potega wyobraźni. Z pasją śledził historię umysłu ludzkiego polegającą na ujawnianiu się jego rozmaitych talentów. W tej niezwyczajnej wędrówce ukazuje, jak człowiek wznosi się poprzez odkrywanie pełni własnych uzdolnień (talentów, umiejętności), to zaś, co tworzy po drodze, to pomniki kolejnych stadiów jego rozumienia przyrody i samego siebie (Bronowski 1988: 25). I właśnie tam, na kartach opowieści, „znalazłem” owego „człowieka z tyczką”: czarno-biała fotografia, na niej fragment obrazu tyczkarza, ręce na tyczce, twarz uniesiona lekko ku górze, jakby zapatrzona w niebo, pogodna, może nawet nastawiona optymistycznie(?), odrobinę uchylone usta i podpis Jacoba Bronowskiego: „Myśl skoczka wybiega naprzód współtworząc jego wyczyn: w wyobraźni swej skacze on w przyszłość" (Bronowski 1988: 34-35).

Jest tu pouczająca mądrość, a jednocześnie swoista metafora narracyjna powiązania człowieka z drogą poprzez myśli, które wybiegają naprzód i współtworzą cywilizacyjne koleje losu ludzkiej rodziny. A nieskończona wielość dróg oznacza otwartość i dialog człowieka z przyrodą, ale znaczy także wolność wyboru. Jednak to zawsze jest osobisty wybór (moje życie jest moim dziełem). Jest wędrowcem drogi odkrytej/odkrywanej w sobie!

„Człowiek z tyczką” jest Ikarem i Dedalem - marzy i jednocześnie tworzy. Sam wybiera zadania także wtedy, gdy wymagają kooperacji, a takie potrzeby są dziś coraz powszechniejsze. Stara się unikać więzi zinstytucjonalizowanych, sprzyja niezinstytucjonalizowanym i wspólnotom sieciowym. Najczęściej preferuje wizje ponadosobiste, a tym samym zadani a p on ad os ob is te, które integrują w związki człowieka ze światem, gratyfikując zarówno osobiste interesy podmiotu, jak i stany świata możliwego i/lub 
pożądanego. Takie wizje i takie zadania wymagają jednocześnie bycia sprawczymi, rozwojowymi i otwartymi (Łukaszewicz 2012: 35-48). Jest tym, który dobrowolnie chce i potrafi zmieniać świat na lepsze i przekraczać siebie!

„Człowiek z tyczką” jest prowokatorem rzeczywistości potencjalnej. Jego żywiołem jest niepewność i ryzyko. Jest pasjonatem „gry z zadaniem” i to takiej gry, której parametrów - ze względu na konsekwencje działania i/lub wynik - nie można określić w sposób pewny. Ponadto, formuła "gry z zadaniem” zawiera założenie, że poziom aspiracji i motywacji jest wyznaczany przez pryzmat antycypacji własnych możliwości; stawką owej gry jest wysoki wynik, a kryterium jego zdobycia - poziom wykonania. Innymi słowy: jego inwencję animują nade wszystko zadania, które są nie tylko przekraczaniem kolejnych granic, ale są jednocześnie lokowane w nie do końca zidentyfikowanych przestrzeniach; są frapującym wdzieraniem się w przyszłość poprzez... jej tworzenie. Jest więc kreatorem nowych jakości!

„Człowiek z tyczką” jest praktykującym wyznawcą permanentnego rozwoju i uczenia się. Docenia w tym kontekście smak sukcesów, ale również porażek; docenia dobrodziejstwa uczenia się po drodze; docenia pragmatyczne korzyści uczenia się poprzez robienie czegoś; docenia sensy i wartości wyobraźni i prowokowania $\mathrm{w}$ edukacji. Wybiera chętnie ścieżki sekwencji niewypróbowanych, w których działanie/rozwiązywanie jest zaangażowane poczucie własnej wartości. Otwarty, sam jest ścieżką samorozwoju, uczenia i uczenia się!

"Człowiek z tyczką" jest już coraz częściej Cyfrowym Tubylcem, a nie Imigrantem (Small, Vorgan 2011: 45-77). Oznacza to zasadniczą zmianę w kształtowaniu się sieci neuronalnej - Gary Small i Gigi Vorgan nazywają to iMózgiem - i wskazują na dynamiczną, permanentną jej modyfikację, a także na wzrastającą plastyczność, która na przestrzeni jednego pokolenia dokonuje skoku ewolucyjnego wywołanego postępem technologicznym (Small, Vorgan 2011: 40-43). Ta duża liczba potencjalnie wykonanych połączeń odpowiada za ową plastyczność mózgów i staje się jednym ze źródeł obniżania się wieku startu „człowieka z tyczką” - im większe poczucie panowania nad własnym życiem, tym większy jest hipokamp (Small, Vorgan 2011: 38). Jednocześnie z postępami kultury cyfrowej rośnie jego zdolność do wielozadaniowości, obrazowania oraz umiejętności skuteczniejszego dostrzegania szans i zagrożeń na obrzeżach „pola widzenia” galopującej cywilizacji. 
W świecie wirtualnym jest zatem łowcą płodnych memów, które karmią wyobraźnię nowymi/innymi ideami.

"Człowiek z tyczką" ma moc tworzenia „bąbli” nowego w morzu starego (Nowak, Lebenstein, Szamrej 1993: 296-308). Tak podpowiada dynamiczna psychologia społeczna, która jednocześnie wskazuje, że zmiany w jakichkolwiek układach mogą zachodzić dwojako: mogą być stopniowe bądź niejednostajne; ten ostatni rodzaj zmian - zachodzący czasem wolno, a czasem gwałtownie - przypomina niektóre przejścia fazowe w fizyce. Wówczas „bąble nowego” pojawiają się właśnie w morzu starego, rosną i łączą się ze sobą, tworząc grona. Model „bąbli” wskazuje, iż ludzie w różnym stopniu są zdolni do wpływania na zmianę opinii innych osób. Najsilniejszy wpływ wywierają ci, którzy są najbliżej: rodzina, przyjaciele, współpracownicy, sąsiedzi (Nowak, Lebenstein, Szamrej 1993: 298). „Człowiek z tyczką” grupuje w grona czy bąble przede wszystkim tych, z którymi kooperuje przy realizacji pasji-wizji-misji, jak i z tymi, którzy wspierają go prospołecznie w przełamywaniu starego. Dzięki czemu jako mniejszość potrafią przetrwać, tworząc właśnie zwarte skupiska... innego. W ten sposób bąble mniejszości - skupione wokół „człowieka z tyczką" - mogą stać się/stają się zarodnikami nowego w starym zarówno w kontekście profesjonalnym, jak i społecznym.

"Człowiek z tyczką" przekracza... horyzont zastanego. W terminologii sportowej można powiedzieć, że przeskakuje nad poprzeczką; unosi się ponad poziom tego, co wyznaczają standardy „tu i teraz” i nadal skacze. Wydaje się, iż jego filozofię najlepiej oddaje paradygmat psycho-transgresjonizmu Józefa Kozieleckiego (2009: 330-346). W jego rozumieniu działania transgresywne - ekspansywne, twórcze, ekspresyjne - to działania, które przekraczają istniejący stan rzeczy, a których wyniki wychodzą poza granice osiągnięć materialnych, poznawczych i społecznych (Kozielecki 2009: 333). Dzięki temu nie tylko przezwycięża swoje ograniczenia, ale tworzy nowe wartości, nowe idee, nowe ścieżki rozwoju przestrzeni profesjonalnej, nowe wyzwania cywilizacyjne, odsłaniając jednocześnie nowe/inne horyzonty świata możliwego i/ lub pożądanego, ciągle jednak nieznanego. Poczynania „człowieka z tyczką” są ambitną i odpowiedzialną „rywalizacją” osiąganych wyników z wynikami, o których myślimy jako o niemożliwych. To frapujące i porywające. Owa rywalizacja wymaga odwagi, uporu, cierpliwości porażek i drogi nadziei w powodzenie. To czujemy, rozumiemy, wiemy. Ale w tym wszystkim jest jeszcze coś, 
co wykracza poza wymiary profesjonalne i kreatywne. „Człowiek z tyczką" jest bowiem żywym symbolem prowokacji wyobraźni i ruchu do przodu, aby niemożliwe stało się możliwe, aby wiał wiatr wyzwań, zmian, aby „heurystyki żagla” (określenie Nosala) ogarniały innych śmiałków także i wtedy, gdy lądu jeszcze nie widać, aby edukacja w „rękach żeglarzy” była niezawodnym wsparciem jak busola!?

Potrafi także wspomagać, inspirować, animować tych, którzy jeszcze nie do końca odnaleźli drogę w sobie, a którzy być może jednak zdecydują, aby stawać się/stać „człowiekiem z tyczką”, albowiem to on jest:

Wędrowcem drogi odkrywanej w sobie

Animatorem zadań ponadosobistych

Prowokatorem rzeczywistości potencjalnej

Łowcą memów dla wyobraźni nowych/innych idei

Ścieżką samorozwoju, uczenia i uczenia się

„Bąblem” lokalnej grupy przemian społecznych

Sprawcą dokonań „niemożliwych” z pasji-wizji-misji.

W tej metaforze „człowieka z tyczką” edukacja nie jest ową tyczką, ale bez niej nie ma ani tyczki, ani myśli skoczka, która wybiega naprzód, współtworząc jego wyczyny.

\section{Bibliografia}

Arendt M. (2019), Szkola dla innowatora. Ksztattowanie kompetencji proinnowacyjnych (raport), Ministerstwo Przedsiębiorczości i Technologii (serwis polskiego rządu, opublikowano 29.03.2019).

Bassets M. (2019), Francuskie trzylatki pójda do szkoly. Tak Macron walczy $z$ nierównościami, EL PAIS, https://wyborcza.pl/naszaeuropa/7,168189,24 597348,francuskie-trzylatki-pojda-do-szkoly.html?disableRedirects $=$ true (dostęp: 20.08.2019).

Bronowski J. (1988), Potęa wyobraźni, PIW, Warszawa.

Bruner J. (2006), Kultura edukacji, tłum. T. Brzostowska-Tereszkiewicz, Universitas, Kraków.

Dryden G., Vos J. (2000), Rewolucja w uczeniu. Chcesz myśleć sprawniej niż inni?, tłum. B. Jóźwiak, Zysk i S-ka, Poznań.

Kozielecki J. (2009), Psychotransgresjonizm - zarys nowego paradygmatu, [w:] J. Kozielecki (red.), Nowe idee w psychologii, Gdańskie Wydawnictwo Psychologiczne, Gdańsk.

Kwaśniewski T. (2019), To już moja szósta reforma, Duży Format, sobotaponiedziałek 20-22 kwietnia 2019, Magazyn Świąteczny, Gazeta Wyborcza. 
Łukaszewicz R. (2010), Wroctawska Szkoła Przyszłości. Dla duchowości - dla wyobraźni - dla praktyki, Fundacja Wolne Inicjatywy Edukacyjne, Wrocław.

Łukaszewicz R. (2012a), Inna edukacja - biografia drogi, Fundacja Wolne Inicjatywy Edukacyjne, Wrocław.

Łukaszewicz R. (2012b), Ucieczka za... horyzont zastanego, [w:] I. Wojnar (red.), Alternatywy $i$ zobowiazania, Komitet Prognoz Polska 2000 Plus przy Prezydium PAN, Warszawa.

Łukaszewicz R. (2014), Projekt „Wroctawska Szkoła Przyszłości Plus”. Drożdze dla edukacji - prowokowanie zmian, Fundacja Wolne Inicjatywy Edukacyjne, Wrocław.

Łukaszewicz R. (2019), „Wroctawska Szkola Przysztości Plus”, czyli lepsze jest możliwe. Dziatania praktyczne, wizje i projekcje nowego - innego - twórczego, Fundacja Wolne Inicjatywy Edukacyjne, Wrocław.

Łukaszewicz R., Leksicka K. (2018), Skrypt dydaktyczny struktury modelu $i$ rozwiqzań praktycznych eksperymentalnego $i$ innowacyjnego projektu Wroctawska Szkola Przysztości, Fundacja Wolne Inicjatywy Edukacyjne, Wrocław.

Nowak A., Lebenstein M., Szamrej J. (1993), „Bąble” - modelem przemian spolecznych, „Świat Nauki”, nr 12, s. 16-25.

Small G., Vorgan G. (2011), iMózg - jak przetrwać technologicznq przemiane wspólczesnej umystowości, Wydawnictwo Vesper, Poznań.

Stone Zander R., Zander B. (2005), Sztuka możliwości. Jak przeksztatcić życie zawodowe i osobiste, tłum. G. Łuczkiewicz, MT Biznes, Warszawa.

Wilber K. (1997), Krótka historia wszystkiego, tłum. H. Smagacz, Jacek Santorski \& Co Agencja Wydawnicza, Warszawa.

Wilk P. (2017), Pojutrze. O miastach przyszłości, Wydawnictwo Literackie, Kraków. 
Teresa Hejnicka-Bezwińska

ORCID 0000-0002-2648-0415

em. prof. zw. Uniwersytetu Kazimierza Wielkiego w Bydgoszczy

\title{
Pamięć i tradycja w kulturze zaufania (vs. nieufności)
}

\author{
Abstract \\ Memory and tradition in a culture of trust \\ (vs. culture of mistrust)
}

Reflection upon pedagogical memory and tradition of the last century warrants a conclusion that entire generations of Polish pedagogues who participated in significant cultural changes (transitioning from a democratic, market-oriented culture to a real socialism culture and then transitioning back) failed to transform personal and generational memory into historical memory. There is even evidence that in post-World War 2 Poland the process of organised forgetting of the educational practices of the past was initialised. This could be considered one of the underlying factors for the weakening and breaking of the relationship between pedagogy and teaching practice (education).

The phobia of confronting personal and generational memory of pedagogues with historical memory after 1989 perpetuates and deepens the culture of mistrust between the educational entities. This reduces the likelihood of constructing a culture of trust, especially in the institutional and systemic context. Furthermore, refraining from building an educational tradition rooted in historical memory undermines any efforts to implement pedagogical consistency in consecutive educational reforms. This consistency should be defined as strengthening the willingness of people to take up action for the benefit of all.

Keywords: memory (personal - generational - historical), pedagogical tradition, trust (personalised - institutional - systemic), teaching practice/educational practice, culture of trust (vs. culture of mistrust)

Słowa kluczowe: pamięć (jednostkowa - pokoleniowa - historyczna), tradycja pedagogiczna, zaufanie (spersonalizowane - instytucjonalne - systemowe), praktyka oświatowa/edukacyjna, kultura zaufania (vs. nieufności) 


\section{Wprowadzenie}

Jubileuszowy charakter X Ogólnopolskiego Zjazdu Pedagogicznego oraz wcześniej obchodzone jubileusze wydziałów, instytutów i katedr tworzą dzisiaj korzystny klimat, aby uruchomić namysł nad wiedzą o czasie minionym. Moja propozycja namysłu nad pamięcią i tradycją inspirowana jest słowami Piotra Sztompki, który powiedział: „[...] dla ludzi przeszłość jest przedmiotem pamięci [...]. Teraźniejszość jest przedmiotem żywego doświadczenia. Przyszłość jest przedmiotem wyobraźni, zamiarów, planowania" (Sztompka 2002: 477).

Autor ten podpowiada, że celem przekształcenia żywego doświadczenia (pamięci jednostkowej i pamięci pokolenia) w pamięć historyczną (możliwą do przyjęcia przez wielu oraz przekazania następnym pokoleniom) jest uczynienie ludzkich działań, nakierowanych na zmianę, bardziej racjonalnymi. Przekonuje też, że dzięki przekształceniu pamięci w tradycję będziemy wiedzieli nie tylko „Dokąd idziemy? (Dokąd chcemy iść?)”, ale także „Skąd idziemy?”, a dzięki temu bardziej realne stanie się osiągnięcie zamierzonych celów.

Odpowiadając na zaproszenie do wygłoszenia wykładu starałam się odczytać zamysł Rady Programowej, która zaproponowała debatę na temat Pedagogika i edukacja wobec kryzysu zaufania, wspólnotowości i autonomii. W świetle mojej wiedzy kontekstem dla omawiania problemów pamięci i tradycji mogą być nie tylko teorie kryzysu zaufania, ale także teorie kultury zaufania. Zjawisko kryzysu identyfikowane jest głównie przez badaczy kultury Zachodniej i w związku z tym teoriami kryzysu zaufania posługują się przede wszystkim zwolennicy ujęć bardziej globalnych, uczestniczący $\mathrm{w}$ sporach ostatnich dziesięcioleci związanych z krytyką modernizmu i/lub afirmacją tzw. „postmodernizmu”. Ten nurt krytycznego myślenia o praktyce edukacyjnej został dobrze rozpoznany przez "nową formację młodszego pokolenia pedagogów akademickich” - jak pisze o nich Zbigniew Kwieciński

${ }^{1}$ Przyjmuję za Andrzejem Szahajem, że terminem tym określamy „nurt filozoficzny i - szerzej - kulturowy” (Szahaj 2004: 935). Nazwy tej po raz pierwszy użył Federico de Onís w 1934 r. do opisu poezji hiszpańskiej i południowo-amerykańskiej. Do słownika nauk społecznych wszedł w latach 70. za sprawą m.in. Daniela Bella, Jeana-Françoisa Lyotarda. Nurt ten łączony jest z ponowoczesnością rozumianą jako przejście od społeczeństwa industrialnego do społeczeństwa postindustrialnego, np. według Daniela Bella. 
w wystąpieniu jubileuszowym. ${ }^{2}$ Dzieła tego pokolenia pedagogów polskich znalazły się po 1989 r. w głównym nurcie polskiej pedagogiki współczesnej i mają zasadnicze znaczenie nie tylko dla jej rozwoju, ale także dla tego, co jest pomijane, marginalizowane, zapominane, a nawet zafałszowywane.

Czyniąc kontekstem rozważań teorię kultury zaufania i wykorzystując wyniki badań nad elementami strukturalnymi zaufania uogólnionego (szczególnie zaufaniem osobistym, instytucjonalnym i systemowym), które zostały zrealizowane w dłuższej perspektywie czasowej (ostatniego pięćdziesięciolecia w Polsce), chcę zwrócić uwagę na pewne osobliwości procesu kontynuacji i zmian.

Stefan Nowak (1979) już w latach 70. zidentyfikował zjawisko „próżni socjologicznej”. Pojęciem tym opisał społeczeństwo polskie PRL-u zorganizowane na zasadzie federacji grup pierwotnych, które swoją wspólnotę odnajduje jedynie w tradycji narodowej, szczególnie tej, która nie została historycznie zweryfikowana, ponieważ jej zadaniem było podtrzymywanie „ducha narodowego". Zjawisko próżni socjologicznej korespondowało z faktem wycofywania się ludzi z wielu płaszczyzn życia społecznego szerszych niż grupy pierwotne. Powodowało też wyraźne rozdzielanie przez ludzi sfery prywatnej od publicznej. Opisane to zostało jako zjawisko „dymorfizmu społecznego” przez Edmunda Wnuk-Lipińskiego (1991). Redaktorzy Diagnozy społecznej (Czapiński, Panek 2015) $)^{3}$ ujawniają kontynuację tych stanów oraz pokłady różnych resentymentów związanych z PRL-em.

Odwołując się do wspomnianych wyników badań (i wielu innych), skłonna jestem uznać, że nie mamy do czynienia z kryzysem $^{4}$ zaufania. Utrzymujący się od wielu dziesięcioleci wysoki

2 https://zjazd2019.pedagog.uw.edu.pl/index.php/program/wyklady-jubileuszowe/ (dostęp: 15.05.2019).

3 Odwołam się jedynie do projektu badawczego realizowanego przez Radę Monitoringu Społecznego. W ramach tego projektu w latach 2000-2015 zrealizowano osiem edycji badań nad uwarunkowaniami i jakością życia Polaków, które są dostępne pod wspólnym tytułem Diagnoza społeczna. W raporcie (Czapiński, Panek 2015) mamy dane z lat 1992-2015.

4 Pojęcie „kryzysu” (Michalski 1990) stosowane jest w języku potocznym, w publicystyce, w polityce, ale także w nauce. Tym, co łączy różne zastosowania tego pojęcia, jest przekonanie, że w stanie kryzysu mamy do czynienia z zakłóceniem znanego nam dotąd stanu rzeczy, załamaniem stanu dotąd poznawczo i pragmatycznie oswojonego. Pierwszy etap kryzysu rozumiany jako załamanie może kończyć się destrukcją (zapaścią, unicestwieniem, śmiercią) lub być początkiem możliwego przesilenia i potencjalnego przełomu. 
poziom zaufania spersonalizowanego (osobistego), które nie przekłada się na zaufanie zgeneralizowane wobec wszystkich ludzi, koresponduje $\mathrm{z}$ bardzo niskim poziomem zaufania w stosunku do instytucji, a szerzej z niskim poziomem „zaufania systemowego"5. Stan ten nie jest stanem charakteryzującym tylko naszą współczesność, nie pojawił się ani dzisiaj, ani w ostatnich latach, ani nawet w III Rzeczypospolitej. W świetle przywołanych wyników badań trwa on co najmniej 50 lat, a w świetle badań historyków i kulturoznawców jest to stan, którego genezy można poszukiwać w minionych stuleciach. Nie powoduje on jednak obniżonego poczucia satysfakcji i szczęścia u Polaków jako jednostek.

Ta konstatacja stanowi uzasadnienie rezygnacji z teorii kryzysu zaufania na rzecz teorii kultury zaufania vs. kultury nieufności Piotra Sztompki (2002, 2007) jako kontekstu rozważań nad pedagogiką jako dyscypliną naukową, której zadaniem jest m.in. wspieranie weryfikacji pamięci jednostkowej i społecznej oraz przekształcanie jej w tradycję edukacyjnych praktyk społecznych, możliwych do afirmacji, akceptacji, naśladowania, twórczego przekształcania, ale także krytyki, marginalizacji i odrzucenia z powodu zmiennej rzeczywistości naszego świata. W ten sposób wiedza o edukacji, uznawana za naukową, może przyczyniać się do lepszego kształcenia profesjonalistów do tej dziedziny praktyki społecznej oraz wspierać zmiany, którym możemy przypisać wyższy poziom racjonalności nie tylko instrumentalnej, ale także aksjologicznej (Walczak 2006).

\section{Kultura jako kontekst rozważań nad pamięcią i tradycją pedagogiczną}

Proponuję na wstępie przyjęcie definicji kultury jako praxis (Bauman 2012). W tej teorii kultury szczególnie ważne dla sformułowanego tematu wydają się następujące twierdzenia:

1. Każda kultura ma swoją historię;

2. W jej rozwoju „nie obowiązuje zasada ciągłego i kumulatywnego poszerzania wiedzy, mamy raczej do czynienia z procesem nieustannego zapominania i odzyskiwania" (Bauman 2012: 9-10). Zgodnie z tym twierdzeniem należy pytać nie tylko o to,

5 „ZAUFANIE SYSTEMOWE: poczucie bezpieczeństwa egzystencjalnego oparte na przekonaniu o efektywności, rzetelności, sprawiedliwości systemu społeczno-politycznego czy ustroju w obrębie którego żyjemy” (Sztompka 2002: 327). 
co pedagodzy opisali, wyjaśnili i zinterpretowali z zakresu pedagogiki i jej związków z praktyką edukacyjną, ale także o to, co zostało zmarginalizowane, zafałszowane, unieważnione, zapomniane. Bardzo ważne jest też odkrycie tego, co jest nadal pomijane i tego, co jesteśmy ewentualnie skłonni sobie przypomnieć i oczyścić z deformacji poznawczych;

3. Ten sam autor twierdzi też, że: „Nowoczesności nie da się opisać jako stanu dokonanego i skończonego, o trwałym kształcie; nowoczesność nie jest stanem, ale procesem, i na owym ,byciu procesem' polega jej istota” (Bauman 2004: 904). Zasadne zatem jest przyjęcie założenia, że „zaufanie” jest kluczową wartością każdej kultury i jednym z ważnych wymiarów kultury określonych społeczności. Z tego powodu każdą z kultur określonego miejsca i czasu historycznego (określonej społeczności) możemy umieścić na kontinuum, którego jeden kraniec stanowi „kultura zaufania”, pojmowana jako „uogólnione zaufanie przenikające całą zbiorowość i traktowane jako obowiązująca reguła postępowania (metaforycznie: klimat czy atmosfera zaufania w społeczności)" (Sztompka 2002: 326), a drugim krańcem tego wymiaru kultury jest „kultura nieufności”: „(inaczej: kultura cynizmu): rozpowszechniona i uogólniona podejrzliwość w stosunku do osób i instytucji, nakazująca nieustannie monitorować ich działania w obawie przed oszustwami, nadużyciami, kłamstwami, nierzetelnością, spiskami i konspiracją” (Sztompka 2002: 326).

\section{Pamięć i tradycja w kontekście teorii kultury zaufania vs. nieufności}

Zdaniem autora tej teorii nie da się mówić o zaufaniu w sposób ahistoryczny. Celem pracy nad pamięcią o pedagogice i edukacji oraz związkach łączących te dwie dziedziny kultury powinno być osiągnięcie pewnego poziomu zgody na to, co skłonni bylibyśmy uznać za tradycję $\mathrm{w}$ myśleniu i działaniu uzasadniającym nasze aktualne wartościowania kulturowe, decydujące o zmianach $\mathrm{w}$ pedagogice i edukacji. Uzasadnione w związku z powyższym wydają się twierdzenia, że przekształcanie doświadczenia i pamięci ludzi i pokoleń w tradycję: 1) wiąże się z kulturą i historycznym procesem jej zmiany, 2) dotyczy wszystkich dziedzin kultury, 3) pełni funkcję stabilizacyjną w warunkach zmian ewolucyjnych, 4) przestaje wspierać obowiązujące standardy myślenia, 
mówienia i działania w sytuacjach zmian radykalnych, rewolucyjnych, kryzysowych.

Doświadczenie edukacyjne pokoleń (także pokoleń i generacji uczestniczących w procesie pierwszej instytucjonalizacji i dyscyplinaryzacji pedagogiki) ${ }^{6}$, które są uczestnikami X Ogólnopolskiego Zjazdu Pedagogicznego, jest dla każdego z nas przedmiotem indywidualnej pamięci. W niewielkim stopniu pamięć Polaków o własnym doświadczeniu edukacyjnym w ostatnim 100-leciu została przekształcona w tradycję, ponieważ nie dysponujemy uznawanymi powszechnie wielkimi narracjami (syntezami) naukowo zweryfikowanymi, które byłyby efektem pracy nad pamięcią. Celem ich musiałoby być bowiem zdejmowanie kolejnych deformacji powstałych w pamięci jednostkowej i zbiorowej. Jeżeli przyjmiemy, że istotą tradycji jest przekształcanie pamięci przy użyciu wiedzy naukowo zweryfikowanej, to szczególnie ważną rolę $\mathrm{w}$ tym procesie trzeba przypisać wiedzy historycznej. Skłonna jestem bronić tezy, że nie zrobiliśmy tego w stopniu satysfakcjonującym, i dlatego uzasadniony wydaje mi się tytuł jubileuszowego wystąpienia Zbigniewa Kwiecińskiego: Wleczemy za soba dtugi ogon nie przezwyciężonej przeszłości.

Zawierzając filozofom i ludziom nauki, że teraźniejszość jest przedmiotem naszego doświadczenia, a przeszłość jest przedmiotem pamięci, to wykorzystanie nauki do przetworzenia doświadczenia i pamięci w historię może być źródłem najbardziej wiarygodnej wiedzy o tym: 1) Skąd idziemy? 2) Dokąd chcemy i możemy dojść? (a po drodze: Jakie przeszkody mamy do pokonania? Jakie zagrożenia musimy zneutralizować? Z jakimi ograniczeniami musimy się zmierzyć? Czego nie uda nam się przezwyciężyć?).

Doświadczenie ludzi zajmujących się czasem minionym pokazuje, że czas historyczny może być różnie opisywany: 1) przez dokonania (wytwory, dzieła i czyny) konkretnych osób - wielkich pedagogów i działaczy oświatowych, 2) przez monografie instytucji, których zadaniem było dokonywanie zmian w praktyce edukacyjnej - uniwersytety i instytucje systemu oświatowego (jubileusze do tego zachęcają), 3) przez procesy społeczne, które zachodziły $\mathrm{w}$ określonym czasie historycznym i w określonym miejscu, tworząc ramy zmian możliwych i pożądanych, np. procesy

${ }_{6}$ Zależnie od przyjętej definicji i kryteriów konstruowane mogą być różne typologie pokoleń. Zajmowałam się tym zagadnieniem w kilku swoich pracach (zob. m.in. Hejnicka-Bezwińska 2015). 
modernizacji, kolonizacji, globalizacji, centralizacji-decentralizacji $\mathrm{i}$ inne. Ciągle powstają nowe prace dotyczące osób i instytucji, ale zdecydowanie brakuje syntez, których autorzy chcieliby konstruować narrację historyczną poprzez usytuowanie osób i instytucji w wielkich procesach społecznych i kulturowych. O trudnościach związanych z pisaniem syntez jako tekstów kulturowych napisałam w ostatniej swojej monografii (Hejnicka-Bezwińska 2015: 52-56).

W tym roku mija 100 lat od powstania pierwszej katedry pedagogiki oraz 30 lat od transformacji ustrojowej, która uruchomiła przechodzenie od "kultury realnego socjalizmu” do „kultury demokratycznej i rynkowej” (Sztompka 2002: 279). To dobry czas, aby uruchomić namysł nad przekształcaniem pamięci o pedagogice i praktyce edukacyjnej w tradycję. Pracę nad tym zagadnieniem zaczęłam wydaniem książki zatytułowanej W poszukiwaniu tożsamości pedagogiki. Świadomość teoretyczno-pedagogiczna wspótczesnej pedagogiki polskiej (geneza i stan) (1989), a zakończyłam monografią Praktyka edukacyjna $w$ warunkach zmiany kulturowej (2015). Pierwsza z tych publikacji pokazuje problemy związane z przejściem od polskiej pedagogiki tradycyjnej II RP do pedagogiki nazwanej "naukową pedagogiką socjalistyczną" (Hejnicka-Bezwińska 2019) oraz próbą obrony pedagogiki przez „pedagogów z marginesu”. Druga z nich pokazuje ostatnie stulecie „praktyki edukacyjnej”, którą - zgodnie z teorią transgresji historycznej - pojmuję jako złożony układ relacji pomiędzy: pedagogiką jako dyscypliną naukową - kształceniem w zakresie pedagogiki systemem oświatowym (edukacyjnym). Moim doświadczeniem $\mathrm{w}$ pracy nad czasem minionym (weryfikowaniem pamięci i przekształcaniem jej w tradycję) chciałabym się z Państwem podzielić.

Czynię to, ponieważ mam poczucie, że tworzy się korzystny klimat dla wznowienia namysłu nad czasem minionym, i to jest zasadniczy powód zaprezentowania kilku uwag dotyczących przekształcania pamięci osób oraz pokoleń w wiedzę historyczną o czasie minionym.

W kontekście ustaleń poczynionych przeze mnie w kolejnych publikacjach o tożsamości pedagogiki polskiej oraz jej związkach z praktyką edukacyjną sformułowałam następujące twierdzenia:

1. Niewiele wiemy o genezie i rozwoju pedagogiki w ostatnim 100-leciu, chociaż dysponujemy licznymi monografiami działalności osób i instytucji. Brakuje jednak syntez;

2. Uogólnioną i ważną przyczyną tego stanu wydaje się to, że uruchomiony został po II wojnie światowej proces, który 
nazwałabym „procesem zorganizowanej niepamięci”. Ten proces został przeze mnie opisany. Wiele faktów wskazuje także na to, że z procesem zorganizowanej niepamięci mamy również do czynienia po roku 1989. Ten proces nie został jeszcze chyba dostrzeżony, a więc trudno oczekiwać, aby został opisany;

3. Rozumiem niechęć współczesnych pedagogów do zajmowania się czasem minionym i rozumiem niecierpliwość ujawnioną po roku 1989, która wyrażała się w przekonaniu, że trzeba koncentrować się na procesie transformacji ustrojowej i przełomie kulturowym oraz wspierać dokonującą się zmianę. Szczególną rolę $\mathrm{w}$ procesie przechodzenia od kultury realnego socjalizmu do kultury demokratycznej i rynkowej przypisywano „pedagogice krytycznej"7;

4. Nie godzę się jednak na trwałe marginalizowanie i stałą rezygnację z odsłaniania prawdy o czasie minionym, ponieważ nie zrealizujemy wtedy zadania odcięcia się od „starych nawyków myślenia i starych przesądów”, które Zbigniew Kwieciński, powołując się na sformułowanie Mikołaja Kozakiewicza, określił zasadną metaforą „wleczenia ogona nie przezwyciężonej przeszłości”. ${ }^{8} \mathrm{Nie}$ przyczynimy się też do przezwyciężenia skutków zawłaszczania pamięci i nie wykażemy należytej troski o zakończenie trwającej wojny kulturowej, której jesteśmy nie tylko świadkami, ale także mniej lub bardziej zaangażowanymi uczestnikami.

Po przedstawieniu pewnego kontekstu rozważań nad pamięcią i tradycją związków pedagogiki z edukacją oraz uzasadnieniu, że w odniesieniu do naszego polskiego doświadczenia uzasadnione jest raczej mówienie o potrzebie budowania kultury zaufania (niż o kryzysie zaufania), zasadne wydaje się poszukiwanie odpowiedzi na pytanie o to: Jak zmieniały się relacje pedagogiki z edukacją kreowane przez kolejne pokolenia pedagogów?

7 „Pedagogika krytyczna (pedagogika emancypacyjna): nurt badań edukacyjnych, rozwijający się głównie w USA od połowy lat 70., skoncentrowanych na analizie mechanizmów dominacji w oświacie i kulturze oraz na projektowaniu działań nastawionych na zmianę społeczeństwa w kierunku zwiększenia zakresu społecznej wolności i sprawiedliwości. Pedagogika krytyczna wyłoniła się z szeregu analiz prowadzonych w ramach socjologii edukacji, teorii programu szkolnego, kulturoznawstwa [...] oraz inspiracji filozoficznych związanych z teorią krytyczną szkoły frankfurckiej; znaczące są również związki z tradycją pragmatyzmu” (Milerski, Śliwerski [red.] 2000: 150-151).

8 Odwołanie do artykułu Zbigniewa Kwiecińskiego zawartego w niniejszym tomie. 


\section{Zmienność związku pedagogiki z edukacją w doświadczeniu kolejnych pokoleń polskich pedagogów}

W sformułowaniu pytania o związek pedagogiki z edukacją w doświadczeniu kolejnych pokoleń polskich pedagogów ograniczę się do ostatniego stulecia (1919-2019), a więc okresu, w którym mamy do czynienia z procesem instytucjonalizacji i dyscyplinaryzacji pedagogiki. Procesy te dokonywały się głównie w ramach uniwersytetów - odpowiedzialnych od stuleci za stan i rozwój nauki.

\subsection{Uwarunkowania, które uruchomiły proces instytucjonalizacji i dyscyplinaryzacji pedagogiki}

Odwołując się do tradycji pedagogiki jako dyscypliny naukowej możemy przyjąć, że narodziła się ona w obszarze niemieckojęzycznym, na przełomie XVIII i XIX w., doskonale wpisując się $\mathrm{w}$ projekt modernizacyjny świata nowoczesnego oraz oświeceniową koncepcję nauki. Możemy zatem uznać, że jedyną racją dla zaistnienia pedagogiki były potrzeby praktyki edukacyjnej, a szczególnie potrzeby tworzonych $\mathrm{w}$ krajach naszej cywilizacji (oraz na obszarach kolonizowanych) systemów oświatowych, których rola miała być kluczowa w procesach modernizacji. Muszę przyznać, że niewiele znajdziemy prac, których autorzy uważaliby problem genezy i rozwoju pedagogiki w Polsce za ważny i wart badań oraz dyskursu. W swoich pracach starałam się koncentrować na tym problemie i przedstawiać, jak zmieniał się związek pedagogiki jako dyscypliny naukowej z edukacją (szczególnie z praktyką oświatową) w doświadczeniu i pamięci kolejnych pokoleń polskich pedagogów.

Dodam też jeszcze, że pomimo administracyjnego wpisania pedagogiki do nauk społecznych, to literalne respektowanie tego postulatu eliminowałoby z kręgu zainteresowań wiele problemów, m.in. problem podjęty w tym wystąpieniu. Uznając, że pedagogika pomimo zmiany swojej przynależności dziedzinowej jest nadal nauką humanistyczną, przyjmuję także, że jest ona w Polsce spadkobierczynią i powierniczką oryginalnej polskiej tradycji humanistycznej wykreowanej przez Szkołę Lwowsko-Warszawską, co skłania do poważnego potraktowania słów Marii Janion, według której podstawą humanistyki jest opowieść: „Nie 
wystarczy coś zobaczyć, przeżyć lub nawet pojąć. Trzeba to jeszcze umieć opowiedzieć” (Janion 2016: 9). Taką opowieść tworzy się nieustannie - każde pokolenie na nowo - zarówno w odniesieniu do społecznej praktyki edukacyjnej, jak i pedagogiki. Niektórym pedagogom wydaje się, że możemy poczuć się zwolnieni z obowiązku „budowania opowieści” o swojej dyscyplinie naukowej, edukacji oraz związkach pedagogiki ze zmianami w praktyce edukacyjnej, szczególnie po wyodrębnieniu się z pedagogiki specjalistów od historii wychowania. W moim przekonaniu tak nie jest, ponieważ takiej syntezy nie da się napisać w orientacji historiograficznej (bliżej uzasadniałam to w kilku swoich publikacjach). Pojawia się $\mathrm{w}$ związku z tym pytanie: Czy istnieje satysfakcjonująca nas opowieść (narracja o czasie minionym) dotycząca zmienności związku między pedagogiką a edukacją (praktyką oświatową)?

\subsection{Diagnoza stanu}

Inspiracją do napisania mojej ostatniej monografii (Hejnicka-Bezwińska 2015) były m.in. słowa Krzysztofa Pomiana traktujące o związku historii politycznej z historią kultury. Pisze on tak: „wychodzi się od teraźniejszości i następnie zdejmuje jedna po drugiej warstwy wspomnień, nim dojdzie się do zjawisk usytuowanych w punkcie wyjścia, by - jeśli to możliwe - odsłonić znaczenie początkowe oraz ustalić, w jakiej mierze wyznaczyło ono wszystkie znaczenia nadawane później” (Pomian 2006: 218).

Diagnozując stan współczesny związków pedagogiki z edukacją - a szczególnie ze zmianami w systemie oświatowym skłonna byłaby dowodzić, że:

1. Nie umieliśmy scalić wiedzy pedagogicznej z wiedzą historyczną (a może nie wykazaliśmy dobrej woli i determinacji w działaniu);

2. Z tego powodu w procesie kształcenia nauczycieli i pedagogów nie została zweryfikowana pamięć jednostkowa i społeczna o społecznej praktyce oświatowej (szerzej edukacyjnej) ostatniego stulecia. W umysłach studentów i absolwentów pedagogiki nie zaistniały kategorie pojęciowe, narzędzia i kompetencje, które umożliwiałyby krytyczną ocenę reform oświatowych i zmian w oświacie przeprowadzonych po roku 1989;

3. Polacy dzisiaj nie wiedzą i nie rozumieją, dlaczego - pomimo masowego kształcenia pedagogów i nauczycieli (począwszy od 
1973 r.) - mogły zostać przeprowadzone dwie imitacyjne reformy oświatowe: pierwsza zapoczątkowana w roku 1999 i nawiązująca do reformy z 1932 r., druga natomiast zainicjowana na przełomie lat 2016/2017 i nawiązująca do reformy oświatowej z roku 1961. Oddziela je od siebie zaledwie kilka lat, ponieważ pełna realizacja pierwszej z nich zakończyła się w 2011 r., a wyniki osiągnięć uczniów (szczególnie gimnazjum) były niezwykle satysfakcjonujące i skłaniały jedynie do troski o dalsze podnoszenie jakości kształcenia;

4. Polacy nie rozumieją zatem, dlaczego została przeprowadzona destrukcja i demontaż systemu oświatowego - zwany „reformą/deformą minister Anny Zalewskiej”;

5. W dwóch imitacyjnych reformach oświatowych przeprowadzonych po 1989 r. zabrakło zdecydowanie kontekstu wiedzy historycznej, czego niepożądanym skutkiem jest pogłębienie niewiary w to, że pedagogika może mieć w ogóle znaczenie dla praktyki edukacyjnej i zmian dokonywanych w systemie oświatowym.

Jeżeli ta diagnoza znajduje uzasadnienie, to jest ona wskaźnikiem rozchwiania związku między dyscypliną naukową, której przedmiotem badań jest edukacja a społeczną praktyką edukacyjną. Mówiąc słowami Marii Janion - nie umieliśmy Polakom opowiedzieć o genezie i rozwoju pedagogiki oraz jej związkach z praktyką edukacyjną jako przedmiotem badań. Nie umieliśmy przekonać, że wysoki poziom wiarygodności wiedzy naukowej (wyższy niż wiedzy potocznej) ma znaczenie i jest wartością, z którą powinny liczyć się (a nawet jej bronić) wszystkie podmioty odpowiedzialne za dokonywanie zmian w systemie oświatowym, lub szerzej - w praktyce edukacyjnej (pojmowanej zgodnie z teorią transgresji historycznej). Pora zatem zapytać o proces destrukcji tego związku?

\subsection{Poszukiwanie przyczyn destrukcji związku pedagogiki z edukacją (praktyką oświatową)}

Odwołując się do twierdzeń teorii kultury oraz twierdzeń teorii kultury zaufania (vs. kultury nieufności) - przywołanych w części 1. i 2. z zamiarem wskazania kontekstu rozważań skłonna byłabym (w świetle swojej wiedzy o kulturowych uwarunkowaniach praktyki edukacyjnej) sformułować hipotezę, że:

Jedną z ważnych przyczyn destrukcji związku zdiagnozowanego w obszarze praktyki edukacyjnej (pojmowanej zgodnie 
z teorią transgresji historycznej) jest to, że nie mogliśmy lub nie umieliśmy zachować ciągłości międzypokoleniowej i przekształcić doświadczenia i pamięci kolejnych pokoleń polskich pedagogów w tradycję. W tym momencie należy zapytać: Jaki wkład mają poszczególne pokolenia polskich pedagogów w to dzieło?

\subsection{Ciągłość i zmiana międzypokoleniowa w polskiej pedagogice ostatniego stulecia}

Stosując w sposób radykalny kryterium historyczne można by wyodrębnić w ostatnim stuleciu trzy pokolenia pedagogów. Każde $\mathrm{z}$ nich tworzyło pedagogikę jako dyscyplinę naukową $\mathrm{z}$ innym nurtem głównym ${ }^{9}$. I tak:

1. Pokolenie II Rzeczypospolitej zapoczątkowało proces instytucjonalizacji i dyscyplinaryzacji pedagogiki w strukturach akademickich, otwierając kolejne katedry pedagogiki w polskich uniwersytetach. W ten sposób w głównym nurcie uprawiania pedagogiki znalazła się pedagogika wpisująca się w oryginalną tradycję uprawiania nauk humanistycznych, wypracowaną przez Szkołę Lwowsko-Warszawską Kazimierza Twardowskiego. Modele kształcenia zawodowego - realizowane w szkołach zawodowych średnich i wyższych - wykorzystywały bardziej osiągnięcia wpisujące się w orientację pedologiczną ${ }^{10}$. Obydwa te nurty zakładały włączenie Polaków w europejskie procesy modernizacyjne związane z uprawianiem nauki oraz realizowaniem zadań oświatowych w ścisłym powiązaniu ze sobą. Mówiąc krótko, największym osiągnięciem pokolenia polskich pedagogów II RP było utworzenie katedr pedagogiki we wszystkich polskich uniwersytetach oraz zorganizowanie systemu kształcenia zawodowego do praktyki oświatowej. Był to wkład w tworzenie i umacnianie struktur państwa polskiego, które w wyniku zakończenia I wojny światowej i rozpadu imperiów, zbiegu korzystnych okoliczności oraz mądrej polityki liderów uzyskało niepodległość.

${ }^{9}$ Opisując dokonania kolejnych pokoleń wykorzystuję ustalenia poczynione w moich wcześniejszych pracach, a szczególnie w monografii Praktyka edukacyjna w warunkach zmiany kulturowej (w poszukiwaniu logiki zmian) (2015).

${ }_{10}$ Pedagogika uprawiana w orientacji pedologicznej wykorzystywała wyniki badań empirycznych innych nauk o dziecku, szczególnie psychologii i nauk medycznych, aby wytwarzać możliwie najbardziej wiarygodną wiedzę o dziecku, dającą się zastosować w praktyce edukacyjnej. 
2. Pokolenie Polskiej Rzeczpospolitej Ludowej (PRL-u) do nurtu głównego uprawiania pedagogiki w Polsce wprowadziło tzw. „naukową pedagogikę socjalistyczną” (Hejnicka-Bezwińska 2019: 189-201) wpisującą się w radziecką koncepcję uprawiania nauki, która została przedstawiona przez delegację ZSRR w 1931 r. na Zjeździe Historii Nauki w Londynie. Zgodnie z tą koncepcją jedna doktryna wychowania (pedagogia nazwana „systemem wychowania socjalistycznego”) mogła wyznaczyć nowy sens i strukturę uprawiania pedagogiki jako dyscypliny naukowej włączonej w procesy modernizacji służącej ekspansji komunizmu (w Polsce nazywano to dzieło budowaniem społeczeństwa socjalistycznego lub „realnym socjalizmem”). Mamy tu do czynienia z odwrotnym procesem niż udział nauki w budowaniu struktur II RP. Demontaż instytucji państwa oraz przejęcie władzy przez Polską Zjednoczoną Partię Robotniczą (PZPR) wyprzedziło walkę z kulturowym dziedzictwem Polaków ( $w$ tym także z pedagogiką i praktyką oświatową II RP). Na walkę z tym dziedzictwem i powstanie nowej koncepcji pedagogiki władza potrzebowała około 20 lat, zaliczając po drodze raczej nieudaną próbę narzucenia praktyk wypracowanych w Związku Socjalistycznych Republik Radzieckich (ZSRR).

3. Pokolenie III Rzeczypospolitej do nurtu głównego uprawiania pedagogiki wprowadziło „pedagogikę krytyczną” (Szkudlarek 2019: 571-584). Łatwo zauważyć, że dzięki temu pokoleniu, które do pedagogiki weszło po roku 1989, nastąpiło przesunięcie do głównego nurtu pedagogiki uprawianej w Polsce problemów świata Zachodniego (dyskursów edukacyjnych i dyskursów o edukacji). Wypełniona w ten sposób została „próżnia” po tzw. „naukowej pedagogice socjalistycznej”, której jawnych obrońców zabrakło już na I Zjeździe Pedagogicznym. To jest nasza teraźniejszość i o niej trudno mówić w sposób jednoznaczny. Jedni określają ten stan jako realizację zasady pluralizmu w nauce, inni mówią o procesie kolonizacji. Nie podejmuję się rozstrzygnięcia sporu. Wydaje mi się jednak, że zasadne byłoby zadanie sobie kilku pytań, np.: Czy dzięki szerokiemu otwarciu i zafascynowaniu problemami świata Zachodniego lepiej rozumiemy zmiany w polskiej praktyce edukacyjnej dokonane w ostatnim 30-leciu? Czy skuteczniej przeciwstawiamy się demontażowi systemu oświatowego? Czy potrafimy lepiej bronić pedagogicznego sensu szkoły i uniwersytetu, w tym także kształcenia nauczycieli i pedagogów? Śmiem wątpić. 


\section{Interpretacja zmienności związku pedagogiki z praktyką edukacyjną/oświatową}

W opisie zmian zaistniałych w związku pedagogiki z praktyką edukacyjną/oświatową znajduje potwierdzenie teza sformułowana przez Krzysztofa Pomiana o związku historii politycznej z historią kultury. W II RP relacje pedagogiki z praktyką wygenerowane zostały potrzebami budowania państwa (Polski niepodległej), którego obywatele mieli wolę włączenia się w procesy modernizacyjne Zachodu. W PRL-u związek ten był kreowany wolą polityczną ustanowioną przez traktaty międzynarodowe, że mamy być częścią obozu państw socjalistycznych, budujących oryginalną kulturę komunizmu, nazwanego w Polsce „realnym socjalizmem”. Powinniśmy zatem zapytać: Z jakim dziedzictwem weszliśmy po roku 1989 w proces przechodzenia od kultury realnego socjalizmu do kultury demokratycznej i rynkowej?

Przyjmując definicję kultury jako społecznej praxis starałam się pokazać, że w zmianach kulturowych, które dokonały się w Polsce w ostatnim stuleciu, możemy zauważyć dwukrotne zerwanie z tradycją. Najpierw było to przejście od kultury demokratycznej i rynkowej do realnego socjalizmu, w wyniku którego w nurcie głównym uprawiania pedagogiki znalazła się tzw. naukowa pedagogika socjalistyczna. Po roku 1989 z kolei mieliśmy do czynienia z przechodzeniem od kultury realnego socjalizmu do kultury demokratycznej i rynkowej, czego skutkiem jest dzisiejsze doświadczenie, które niektórzy są skłonni wiązać $\mathrm{z}$ realizacją zasady pluralizmu $\mathrm{w}$ pedagogice, a inni przekonują, że mamy do czynienia z procesem kolonizacji pedagogiki przez jedną orientację (naukową - paradygmatyczną - ideologiczną). Te procesy przejścia są - w moim przekonaniu - najbardziej interesujące i jednocześnie najmniej zbadane, a tym samym opisane, wyjaśnione i zinterpretowane. Szczególnie interesujące (a jednocześnie bardzo trudne do odkrycia, opisania i ujawnienia) w tym procesie wydają się działania wpisujące się $\mathrm{w}$ zorganizowaną niepamięć (marginalizację, zapomnienie, przewartościowanie). Optymizmem zaś napawa fakt, że powstały w ostatnich latach dzieła, o których można powiedzieć, że celem ich jest nie tylko przywracanie pamięci, ale także jej weryfikacja.

Brak ciągłości kulturowej możemy traktować jako jedną z ważnych przyczyn małego zainteresowania pedagogów pracą 
nad przekształcaniem pamięci w tradycję, z powodów, o których Krzysztof Pomian pisze jak następuje:

Nieunikniona jest przeto konfrontacja prac historyków teraźniejszości z ciągle bolesną pamięcią i uprzedzeniami ideologicznymi mogącymi wywoływać silne namiętności. Konfrontacja dramatyczna, ponieważ historii nie można sprowadzić do zapisu pamięci, co sprawia, że konflikt między nimi wybucha natychmiast, gdy okazują się mieć ten sam przedmiot. Albowiem rolą historyka nie jest przejmowanie punktu widzenia ofiar, choćby solidaryzował się z nimi w całej pełni. Jego rolą jest przede wszystkim ustalenie faktów zgodnie z regułami krytyki historycznej, a potem - próba ich zrozumienia, co nieuchronnie prowadzi do wypracowania perspektywy odmiennej od tych, które mają protagoniści badanych przez niego wydarzeń, a więc do wywołania ogólnego niezadowolenia (Pomian 2006: 219-220).

Z tego względu okresy przejścia są dość długie, a w doświadczeniu Polaków ostatniego stulecia wiązały się, i wiążą nadal, z wymianą pokoleniową przełomu lat 60. i 70. XX w. oraz ostatnich kilkunastu lat.

Lęk przed konfrontacją pamięci z historią może skłonić pedagogów do kontynuacji i umacniania procesu zorganizowanej niepamięci, ale wtedy należy liczyć się z zagrożeniem, że czas miniony będziemy oglądać przez okulary (perspektywę poznawczą) „postpamięci”. Jest to szczególny rodzaj zagrożenia w procesie przekształcania doświadczenia jednostkowego i pokoleniowego w „tradycję kulturową"11. Prawdą jest, że przedrostek post- jest współcześnie nadużywany w nauce i publicystyce. Nie jest to jednak powód, aby się nim nie posługiwać. Termin „postpamięci” do nauk humanistycznych wprowadziła Marianne Hirsch ${ }^{12}$. To w jej ujęciu „postpamięć” jest pamięcią dziedziczoną, czyli pamięcią potomków pokolenia (narracją o tym pokoleniu), które przeżyło zbiorową traumę, ale nie mogło, nie umiało lub nie chciało zbudować rzetelnej narracji o niej. Tak rozumiana postpamięć odnosi się do dwóch pokoleń polskiej pedagogiki: 1) pokolenia, które wprowadzało pedagogikę w struktury akademickie II Rzeczypospolitej i walczyło o jej przetrwanie do przełomu lat 60 .

11 „TRADYCJA KULTUROWA: skumulowany, odziedziczony historycznie dorobek kulturowy danej zbiorowości” (Sztompka 2002: 256).

12 Marianne Hirsch jest profesorem Uniwersytetu Columbia. Zajmuje się takimi problemami, jak pokoleniowa transmisja pamięci, feministyczna teoria pamięci, holokaust $\mathrm{i}$ inne. 
i 70. oraz 2) pokolenia, którego doświadczeniem była z jednej strony „zorganizowana niepamięć” o pedagogice akademickiej II RP oraz zorganizowana "produkcja” innej pamięci, znajdującej swoje punkty oparcia w ideologii marksistowskiej i praktyce oświatowej (indoktrynacyjnej) ZSRR.

Mając świadomość nie tylko tego zagrożenia, chciałabym zakończyć interpretację - pomimo wszystko - optymistycznie. Powołując się na wypowiedź Krzysztofa Pomiana (2006), filozofa, historyka idei i eseisty, zajmującego się historią kultury europejskiej, autora książki zatytułowanej Historia. Nauka wobec pamięci (2006), z przekonaniem opowiadam się za tym, że przeszłość może być przedmiotem wiary lub przedmiotem wiedzy, ale tylko historia może być terenem spotkania i przezwyciężania konfliktów wynikających $\mathrm{z}$ różnic $\mathrm{w}$ pamięci o czasie minionym.

\section{Uwagi końcowe}

Odwołując się z kolei do twierdzeń teorii kultury zaufania (Sztompka 2002, 2007) chciałabym zwrócić uwagę na fakt, że zaufanie jest wartością i wymiarem każdej kultury. Pojęcie zaufania we współczesnych teoriach nie jest jednak redukowane tylko do zaufania jednego człowieka względem drugiego. Piotr Sztompka wyróżnia następujące odmiany zaufania: osobiste, pozycyjne, komercyjne, technologiczne, instytucjonalne i systemowe (Sztompka 2002: 312). Badacze publikujący wyniki badań empirycznych natomiast najczęściej odwołują się do zaufania występującego na trzech poziomach: 1) spersonalizowanym (stosunku ludzi do siebie nawzajem, który ujawnia się wobec rodziny, przyjaciół i znajomych), 2) zgeneralizowanym (społecznym, o którym decyduje nasze doświadczenie w relacjach z innymi, także nieznajomymi i obcymi), 3) instytucjonalnym (stosunku ludzi do instytucji formalnych). Osobliwością zaufania w społeczeństwie polskim - uzasadnioną historycznie i ujawnioną w wynikach badań ostatnich dziesięcioleci (co najmniej 50 lat) - jest to, że: 1) Polaków charakteryzuje wysoki poziom zaufania spersonalizowanego (do osób spokrewnionych i znajomych), czego skutkiem jest duża skłonność do upowszechniania się nepotyzmu i klientelizmu, 2) zaufanie na tym poziomie nie przekłada się jednak i nie koresponduje ze zgeneralizowanym zaufaniem do ludzi w ogóle (także obcych, innych i nieznanych), 3) bardzo niski 
jest natomiast poziom zaufania systemowego (do systemu i jego instytucji, m.in. do ustroju państwa, jego zasad).

Wielu myślicieli przekonuje, że uchylone zostały dotychczasowe punkty odniesienia i oparcia obecne np. w tzw. wielkich narracjach, kwestionowana jest wartość nauki, dotychczasowe autorytety upadają. Doświadczenie złożoności i skomplikowania świata współczesnego sprawia, że dobrze by było, abyśmy chcieli i mogli zaufać ekspertom i zdepersonalizowanym systemom, aby nasze decyzje były bardziej racjonalne. Coraz bardziej rośnie też świadomość, że człowiek jako twórca kultury wygenerował ryzyko, które może mieć charakter uniwersalny i globalny. Ludzie przyjmują różne postawy wobec zagrożeń aktualnych i przewidywanych. Jedni przyjmują postawę pragmatycznej akceptacji i przystosowania do tego, co jest. Inni zarażają konsekwentnym optymizmem, że jakoś to będzie. Cyniczni pesymiści chcą hedonistycznie wykorzystać wszystko, co jest tu i teraz. Nieliczni podejmują radykalną walkę ze źródłami zagrożeń przez budzenie świadomości i zaangażowania opinii społecznej.

Jeżeli uznamy, że współcześnie pedagogiczny sens edukacji związany być musi z umacnianiem ostatniej $\mathrm{z}$ wymienionych strategii radzenia sobie człowieka ze światem, to postulatem staje się włączenie uczestników procesu edukacji w kulturę zaufania, ponieważ tylko umacnianie kultury zaufania, szczególnie na poziomie zaufania zgeneralizowanego i instytucjonalnego, sprzyjać może angażowaniu się ludzi w imię dobra wspólnego.

Rola pedagogiki rehabilitującej historyczny wymiar badań i refleksji nad czasem minionym wydaje się kluczowa w podjęciu wskazanego wyzwania.

\section{Bibliografia}

Bauman Z. (2004), Ponowoczesność, s. 902-914, [w:] B. Szlachta (red.), Stownik spoleczny, WAM, Kraków.

Bauman Z. (2012), Kultura jako praxis, PWN, Warszawa.

Czapiński J., Panek T. (2015) (red.), Diagnoza społeczna 2015. Warunki i jakość życia Polaków, Rada Monitoringu Społecznego, Warszawa.

Hejnicka-Bezwińska T. (1989), W poszukiwaniu tożsamości pedagogiki. Świadomość teoretyczno-metodologiczna wspólczesnej pedagogiki polskiej (geneza $i$ stan), WSP, Bydgoszcz.

Hejnicka-Bezwińska T. (2015), Praktyka edukacyjna w warunkach zmiany kulturowej (w poszukiwaniu logiki zmian), PWN, Warszawa. 
Hejnicka-Bezwińska T. (2019), Pedagogika socjalistyczna, s. 189-201, [w:] Z. Kwieciński, B. Śliwerski (red.), Pedagogika. Podręcznik akademicki, PWN, Warszawa.

Janion M. (2016), Niesamowita Stowiańszczyzna. Fantazmaty, Wydawnictwo Literackie, wyd. III, Kraków.

Michalski K. (red.) (1990), O kryzysie, Res Publica, Warszawa.

Milerski B., Śliwerski B. (red.) (2000), Leksykon PWN. Pedagogika, PWN, Warszawa.

Nowak S. (1979), System wartości spoleczeństwa polskiego, „Studia Socjologiczne”, nr 4, s. 155-173.

Pomian K. (2006), Historia. Nauka wobec pamięci, Wydawnictwo UMCS, Lublin.

Szahaj A. (2004), Postmodernizm, [w:] B. Szlachta (red.), Stownik Społeczny, Wydawnictwo WAM, Kraków.

Szkudlarek T. (2019), Pedagogika krytyczna, [w:] Z. Kwieciński, B. Śliwerski (red.), Pedagogika. Podrecznik akademicki, PWN, Warszawa.

Sztompka P. (2002), Socjologia. Analiza spoleczeństwa, Wydawnictwo ZNAK, Kraków.

Sztompka P. (2007), Zaufanie. Fundament spoleczeństwa, Wydawnictwo ZNAK, Kraków.

Walczak M. (2006), Racjonalność nauki. Problemy, koncepcje, argumenty, Towarzystwo Naukowe KUL, Lublin.

Wnuk-Lipiński E. (1991), Rozpad polowiczny. Szkice z socjologii transformacji ustrojowej, Instytut Studiów Politycznych PAN, Warszawa. 
Krzysztof Maliszewski

ORCID 0000-0001-9044-8156

Uniwersytet Śląski

Ewa Marynowicz-Hetka

ORCID 0000-0002-4036-8876

Uniwersytet Łódzki

Lech Witkowski

ORCID 0000-0002-9940-5096

Akademia Pomorska w Słupsku

\title{
Dziedzictwo idei i pęknięcia międzypokoleniowe w pedagogice polskiej (Posłowie)
}

\author{
Abstract \\ The heritage of ideas and intergenerational gaps \\ in Polish pedagogy (The postscript)
}

The text consists of three integrated parts, accepted reciprocally but written separately by the above authors as coordinators of the debates and editors of the book prepared for the Vth Special Symposium of the 10th Polish Pedagogical Congress. In the Introduction we start with recalling the detailed list of problems inserted into this framework of debates. Part One puts forward the issue of "modern tradition" as the object of a new research perspective, postulated for the history of the Polish pedagogical thinking. The purpose is defined as revitalization of the tradition of ideas in their modern applications but without just a sentimental approach or purely historical intention. We want to regain access to new ideas through old categories as defining valuable places within the symbolic heritage of pedagogy. The basic instruments contain reference to concepts of generation, duality turn-over, recognition and permit discussing political contents for contemporary democratic education. The Second Part of the paper deals with ways of preservation of the past achievements in the practical and theoretical consciousness of new generations of researchers and teachers. We deal with the concepts of memory and forgetting as interlinked within mentality, affectivity and activities. References to Ricoeur, Freud and Radlińska are among the most crucial ones here. Then the tools for analysis of links between these three dimensions are discussed in depth. The basic inspirations stem here from Bachelard. Then we treat conclusive remarks as a new opening for future discussions. We stress the necessity to settle accounts 
with activity of various important Polish pedagogists like Bogdan Suchodolski in the "Stalinist era" in Poland and in its follow up, e.g. by a prolonged insistence upon the concept of the "bourgeois" tradition, as disqualifying and putting aside an important part of pre-war heritage, which was basic for installing education in Poland after regaining independence in 1918 and was disqualified by the orthodox Marxist domination after 1945. We stress that some practices of exclusion and contempt are present in the contemporary pedagogical literature as well.

Keywords: modernity, tradition, revitalization, memory, forgetting, Stalinism, the "bourgeois" tradition, applications of categories

Słowa kluczowe: nowoczesność, tradycja, rewitalizacja, pamięć, zapominanie, stalinizm, „burżuazyjna” tradycja, aplikacje kategorii.

\section{Wstęp}

Jako współkoordynatorzy Sympozjum V przeprowadzonego na X Zjeździe Pedagogicznym postanowiliśmy zredagować wspólnie komentarz do tej inicjatywy z perspektywy uwzględniającej odbytą debatę i nowo rodzące się refleksje. Było to możliwe i celowe przede wszystkim ze względu na fakt, że jako jedyne forum debaty zjazdowej mieliśmy przygotowaną i opublikowaną na obrady książkę przynoszącą plon propozycji autorskich wszystkich aktywnych uczestników Sympozjum pt. Dziedzictwo idei i pęknięcia międzypokoleniowe w pedagogice polskiej. Wprowadzenie do problemu (2019). Treść tej książki jest tu zatem naturalnie zakładana i przywoływana, jako już udostępniona, z nadzieją, że poniższe uwagi skłonią zainteresowanych problematyką dziedzictwa idei do sięgnięcia po nią oraz podjęcia nowych inicjatyw badawczych. Chcąc podkreślić wagę tej próby „wprowadzenia do problemu" nieciągłości poznawczych i strat z tym związanych (obok krzywd wyrządzonych wielkim historycznym propozycjom na styku teorii i praktyki edukacji) ${ }^{1}$, sądzimy, że celowe

1 W autorskim zamyśle Sympozjum akcentowane były także dramaty egzystencjalne wybitnych postaci polskiej pedagogiki jako ofiar prześladowań czy marginalizacji akademickiej; tego ludzkiego wymiaru nowych odczytań losu tradycji międzywojennej w PRL-u nie sposób pomijać ani lekceważyć. Pozostaje do podjęcia zadanie rekonstrukcji krytycznej zachowań czołowych eksponentów środowiska akademickiego pedagogiki, nie wyłączając Bogdana Suchodolskiego i to nie tylko w okresie stalinizmu. Dotyczy to w szczególności długotrwałego stosowania w publikacjach tego pedagoga kategorii „pedagogika burżuazyjna” w odniesieniu do okresu międzywojennego. Niektóre ustalenia w tym zakresie znaleźć można w tomie B. Nawroczyńskiego (2019). 
jest jednak przeglądowe przytoczenie - dla osób nieznających tej książki - jej ramowej zawartości, jako że tytuły zebranych w niej prac tworzą „mapę” podjętej problematyki i postulowanej perspektywy kontynuowania i rozszerzania dalszych badań. Oto ona, podana w kolejności, w jakiej pojawia się w tomie: Lech Witkowski: Wstęp. Co i jak pozostaje żywe z tradycji polskiej pedagogiki?, Część A: Problem pokoleń pedagogicznych. Lech Witkowski: Relacje międzypokoleniowe jako wyzwanie poznawcze dla historii myśli pedagogicznej w Polsce (zarys problematyki), Łukasz Michalski: Odprawa kohort, czyli granice stosowania pojęcia „pokolenie” (w kontekście analiz dziejów polskiej myśli pedagogicznej i projektu jej archiwum); Część B: Rewitalizacja, wspólnota, ciągłość jako zadanie rozwojowe. Krzysztof Maliszewski: Pedagogika jako filozofia stosowana. Gtos $w$ sprawie rewitalizacji formuty Sergiusza Hessena, Ewa Marynowicz-Hetka: Helena Radlińska i jej pokolenie historyczne: uwspólnianie doświadczeń i wzajemność oddziatywań, Zbigniew Kwieciński: Przywrócona ciagtość. Nieodrobiona lekcja. Dwa przypadki (komunikat); Część C: Margines i dwoistość. Michał Kruszelnicki, Wojciech Kruszelnicki: Afirmacja versus reakcja marginesu (nowe uwagi do Lecha Witkowskiego), Małgorzata Kaliszewska: Wyzyskiwanie $w$ praktyce akademickiej impulsów „przetomu dwoistości”. Gtos $w$ dyskusji; Część D: Pogłębianie rozumienia tradycji i współczesności. Magdalena Archacka: O problemie „pęknięcia” pomiędzy praktykq a teoriq pedagogiczna (refleksje na marginesie), Szymon Dąbrowski: Józef Tischner a tradycja tomistyczna (w kontekście edukacji religijnej), Izabela Kamińska-Jatczak: „Nigdy nie pisatam tak wiele jak w dniach i bezsennych nocach tej epoki”. Analiza dziatalności pisarskiej Heleny Radlińskiej w okresie okupacji; Część E: Zamiast podsumowań - nowe otwarcie. Lech Witkowski: Pora na „Oddech myśli”. Próba nowego otwarcia przestrzeni badań międzypokoleniowych w polskiej pedagogice, Lech Witkowski: Bogdan Nawroczyński - „ojciec chrzestny” polskiej pedagogiki (przeciw niespożytkowaniu dorobku).

Nie negując wartości dotychczasowych, różnorodnych prób refleksji historyczno-teoretycznej, także autorów nieobecnych w tomie, którzy z różnych zapewne powodów nie podjęli zaproszenia do wspólnej refleksji na Sympozjum, mamy nadzieję na przyszłą dyskusję nad przedłożoną propozycją w zderzeniu różnych perspektyw. Warto też odnotować najnowsze, okołozjazdowe publikacje, jak tom esejów Zbigniewa Kwiecińskiego 
Grzęawisko. Eseje z pedagogiki społecznej i krytycznej socjologii edukacji (2019). Zasługuje także na przywołanie fakt, iz w tle merytorycznym samej inicjatywy sympozjalnej - jak i w ramach niektórych wypowiedzi w debacie - istotne miejsce zajmowała przygotowywana do druku w Oficynie Wydawniczej Impuls (udostępniona w wersji roboczej pdf przez redaktora tomu na potrzeby Sympozjum) praca: Bogdan Nawroczyński, Oddech myśli. Archiwalia główne: Polska myśl pedagogiczna. Pamiętnik starego pedagoga. "Ojciec chrzestny” pedagogiki polskiej, wybór, opracowanie i wstęp Lech Witkowski (ukazanie się książki na Zjazd opóźniła przedłużona, żmudna - na materiale historycznym - korekta autorska).

$$
* * *
$$

Niniejszy tekst ma charakter uzgodnionego trójgłosu autonomicznych autorów, zespolonych wspólnym przekonaniem o wadze podjętej tematyki i uznających konieczność jej kontynuacji w badaniach teoretycznych, analitycznych, krytycznych, wymagających także peregrynacji archiwalnych, a zwłaszcza wypracowania dojrzałej perspektywy badawczej, świadomej metodologicznie złożoności odnoszonej do historii, która ma nas jeszcze czegoś nauczyć, do czegoś zainspirować. Warunkiem jednak jest zmiana jakości rozumienia tego, co działo się w XX w. w relacjach międzypokoleniowych w polskiej pedagogice, pełnej pęknięć w jakości percepcji tradycji myśli, nie tylko międzywojennej. W szczególności niezbędna jest świadomość ceny owych pęknięć jako warunku odzyskania dostępu do treści zwykle zdominowanych iluzorycznymi zwycięstwami, spłyconymi interpretacjami, także wpisanymi w afirmację „klasyków” i wykładnie podręcznikowe, przedłożone przez niektórych z ich krytyków, jak i następców. Konieczna jest nowa świadomość metodologiczna, ale także odwaga i dojrzałość zmierzenia się z rozmaitymi przesądzeniami, wpisanymi w toczącą się w części pedagogiki polskiej, i to jeszcze długo po okresie stalinowskiej, „walką z myślą burżuazyjną”. Jak potwierdzał Bogdan Suchodolski z pozycji „postępowej myśli pedagogiki socjalistycznej" - cena tej walki dotąd nie wydaje się oszacowana, a szkody z nią związane wszechstronnie opanowane, a tym bardziej naprawione.

Wstęp i zakończenie tego projektu przygotował Lech Witkowski, rozważania rozpoczyna tekst autorstwa Krzysztofa Maliszewskiego, kolejny fragment napisała Ewa Marynowicz-Hetka. 
W Dziedzictwie idei postulujemy innowacyjną strategię i nową metodologię badań pedagogicznych - choć mających już solidne zaplecze humanistyczne - które wyrosły z szeregu podjętych studiów i badań, również archiwalnych. Tekst ten w całości, jako zespołowe wystąpienie, został uzgodniony między autorami. Punktem wyjścia są oczywiście nasze głosy autorskie, zawarte w książce Dziedzictwo idei... (Witkowski 2019). Obok podziękowań dla Honorowego Przewodniczącego PTP Zbigniewa Kwiecińskiego za autorski i aktywny udział w Sympozjum, a także dla pozostałych autorów tekstów już opublikowanych w w/w książce, pragniemy dołączyć wyrazy wdzięczności dla gości naszej debaty, zwłaszcza w osobach profesorów Barbary Galas, Dariusza Kubinowskiego oraz Tomasza Szkudlarka. Dziękujemy także za życzliwość współdziałania w kontekście samej inicjatywy Sympozjum oraz niniejszej publikacji prof. Marii Czerepaniak-Walczak oraz prof. Annie Wiłkomirskiej.

\section{I \\ Nowoczesna tradycja - o możliwej perspektywie badań (nad) polską myślą pedagogiczną (Krzysztof Maliszewski)}

Na X Ogólnopolskim Zjeździe Pedagogicznym (18-20.09.2019) w ramach V Sympozjum Specjalnego („Dziedzictwo idei i dramat losów czołowych postaci pedagogiki polskiej w XX w.: historia, analiza i krytyka więzi i pęknięć międzypokoleniowych”), prowadzonego przez prof. Lecha Witkowskiego i zaprojektowanego przez niego wraz z przygotowaniem wyprzedzającej spotkanie publikacji², podjęliśmy (wszyscy uczestnicy tego wydarzenia) próbę zakreślenia horyzontu rewitalizacji badań polskiej myśli pedagogicznej.

Oparciem dla tego przedsięwzięcia jest płynący z dotychczasowych doświadczeń badawczych wniosek, że „historia idei polskiej pedagogiki w XX wieku zasługuje na znacznie głębsze poznanie i szersze uznanie w polskiej humanistyce i naukach społecznych niż się wydaje także samym pedagogom, nie mówiąc o przedstawicielach innych dyscyplin” (Witkowski 2019a: 23).

${ }^{2}$ Dziedzictwo idei i pęknięcia międzypokoleniowe w pedagogice polskiej. Wprowadzenie do problemu (2019), L. Witkowski (red.), Wydawnictwo Adam Marszałek, Toruń. 
Pedagogika ma w zasięgu bogatą, wielowarstwową oraz teoretycznie zaawansowaną tradycję myślenia o kluczowych z naukowego i społecznego punktu widzenia kwestiach: własnym statusie metodologicznym, tworzeniu systemu oświaty na bazie najnowszej wiedzy, nowoczesnym kształceniu nauczycieli i integrowaniu środowisk pedagogicznych, krytyce społecznej oraz sprzęganiu życia społecznego z wartościowymi dokonaniami kulturowymi itd. Rzadko jednak potrafimy uruchomić ten potencjał w projektach reform i konkretach życia codziennego. Pęknięcia między tzw. trzecim światem zasobów symbolicznych (znaczeń, wartości, doświadczeń skumulowanych w tekstach) a stanem ich recepcji oraz komunikacji społecznej (także międzypokoleniowej) i wreszcie zdolnościami do ich wykorzystania w aranżacji życia zbiorowego pozostają ogromne. Potencjał polskiej pedagogiki jest zbyt wielu nieznany i nazbyt często niespożytkowany, co odbija się negatywnie na jakości debat publicznych, praktyk edukacyjnych, kondycji kultury, a przede wszystkim zdolności jednostek do radzenia sobie $\mathrm{z}$ trudnymi egzystencjalnie sytuacjami i prowadzenia refleksyjnego, etycznego życia.

Pomysł na „nowy oddech” w badaniach myśli pedagogicznej rodzi się nie bez związku z tłem społeczno-kulturowym. Kontekstem różnego rodzaju pęknięć, zerwań, pominięć i spłyceń tradycji pedagogiki jest po pierwsze przemożny nacisk na praktycyzm i uzawodowienie edukacji. Niezależnie od oficjalnych deklaracji i maskującej retoryki polityka oświatowa na poziomie organizacji kształcenia promuje wyłącznie doraźną skuteczność rankingowego sukcesu. Jakość odniesień kulturowych, refleksyjność i etyczność wypadają z horyzontu społecznej troski. Myśl (nie tylko ta z przeszłości) przestaje się liczyć. Tym bardziej - dla nas - liczyć się musi. Po drugie, sferą odniesienia dla próby odnowienia żywotności polskiej myśli pedagogicznej jest stalowa klatka racjonalizatorskich pomysłów, w której nauka i edukacja traci oddech coraz bardziej, wygodnie dla urzędników, ale ze szkodą dla radzenia sobie człowieka w złożonej rzeczywistości. Padamy ofiarą administracyjnych uproszczeń, tymczasem:

Wbrew rygoryzmom biurokratycznym zależeć nam powinno na integrowaniu kręgów dyscyplinarnych i przeciwdziałaniu sztucznym i destrukcyjnym rozgraniczeniom na nauki humanistyczne i społeczne, nauki o kulturze i nauki o edukacji, w kierunku zespalania przestrzeni integralnie się rozwijającej, humanistyki stosowanej', zdolnej 
i zobowiązanej do głębokich inspiracji z całej przestrzeni refleksji

kulturowej, a także cywilizacyjnej (ibidem: 22).

Po trzecie, kontekstem projektu pogłębionych badań nad tradycją pedagogiki są odziedziczone dyskursywne uproszczenia, historyczne wykładnie osiągnięć pedagogiki, które w zmienionym horyzoncie (przemian ustrojowych i społeczno-kulturowych, nowych dokonań humanistycznych) domagają się rewizji. Po II wojnie światowej nastąpiło zerwanie ciągłości myśli pedagogicznej rozwijanej w okresie międzywojennym i odcięcie od pedagogiki zachodniej. W efekcie postawy ignoranckie (wręcz analfabetyzm pedagogiczny) rozprzestrzeniły się i uległy normalizacji. Jednostkowe wysiłki takich postaci, jak: Helena Radlińska, Sergiusz Hessen, Bogdan Nawroczyński, Kazimierz Sośnicki, Jan Konopnicki, Karol Kotłowski i inni, nie były w stanie przeszkodzić degradacji świadomości pedagogicznej, odciętej od najwartościowszych dokonań skumulowanych w tradycji ${ }^{3}$. Badania myśli pedagogicznej w zmienionym kontekście ustrojowym, gdy ustała presja potępiania „burżuazyjnej” przeszłości, trwają oczywiście od wielu lat, ale przywracanie zerwanych połączeń to proces długotrwały, nie zawsze też zmierza w dobrym kierunku. Łatwo jest - nawet bezwiednie - powielać utrwalone przez dziesięciolecia klisze, nie każde też przywołanie dawnego dorobku jest równie wartościowe.

W próbie, jaką podjęliśmy w odniesieniu do myśli pedagogicznej, chodzi o - to słowo nie pada przypadkowo - rewitalizacje, czyli przywrócenie energii, odnowienie żywotności.

Rewitalizacja to nowy impuls. Tradycję trzeba podjąć, a nie po prostu przywołać czy powtórzyć. W grę wchodzi ujęcie na nowo, raz jeszcze, w optyce łączącej to, co stare, z tym, czego wcześniej nie było (Marynowicz-Hetka 2019a: 109-110). To jest kluczowy punkt tego, co mamy do zaproponowania. W eksploracji polskiej myśli pedagogicznej nie chodzi o konserwatywną nostalgię za tym, co minione i wielkie. Nie duma narodowa czy dyscyplinarna stanowi tu stawkę. Przeciwnie, w projekt nowych badań nad myślą pedagogiczną wpisana jest niezgoda na sentymentalizację przeszłości. Uczuciowe uwznioślenie, odświętność recepcji, pomnikowe usztywnienie, rytualne wzmiankowanie tłumią zdolność wnikliwego i złożonego odniesienia do klasyki

\footnotetext{
3 Por. Kwieciński 2019a: 124.
} 
jako myśli aktualnej, ważnej teraz i wspomagającej punktowo rozwiązywanie współczesnych problemów. To nie sentyment bądź resentyment skłaniają do penetracji tradycji, lecz afirmatywne odkrywanie $\mathrm{w}$ tekstach skarbów interpretacyjnych i groźba (a raczej już doświadczenie) degradacji jakości kształcenia i dyskursu edukacyjnego.

Rewitalizacja to określenie perspektywy, jaką proponujemy. Bardziej niż o badania nad myślą pedagogiczną, chodzi o badania myśla pedagogiczna. Michał Paweł Markowski opisuje degradującą kolonizację dyskursu publicznego (w tym sfery edukacji) przez opinie wypierające interpretacje. Opinia, jak tłumaczy, to wyraz odczuć, impresji, preferencji - każdy ma prawo do swojej. Jednak gdy chcemy, aby ktoś nasze stanowisko rozumiał i podzielał, musimy przejść na wyższy poziom komunikacji i sformułować argument, czyli dokonać interpretacji (Markowski 2019: 26-27). $\mathrm{Z}$ podobnym efektem marginalizowania argumentacji mamy niekiedy do czynienia $\mathrm{w}$ badaniach tradycji. W historii myśli pedagogicznej daje o sobie znać toksyczna strategia wpisywania dziedzictwa w horyzont doxa (mniemań, opinii, przekonań, poglądów): „Takie rekonstrukcje nie mają mocy ani nadwyżki epistemologicznej, gdzie interesuje odbiorcę konstrukcja poznawcza, konstelacja kategorii, wypracowanie pojęć, opozycji, zgłoszenie hipotezy czy rozpracowanie narracyjnego toposu albo analiza złożoności idei” (Witkowski 2019a: 29).

W rewitalizacji myśli pedagogicznej celem nie jest sama dokumentacja tego, że coś zostało napisane, powiedziane (czasem drobiazgowa dokumentacja staje się wręcz przeszkodą w dotarciu do poziomu budowania argumentu i konstruowania interpretacji). Tutaj celem jest odnalezienie (lub inspirowana konstrukcja) istotnej kategorii, teoretycznego rozwiązania jakiejś kwestii, otwarcie dostępu wartościowego miejsca w zasobach kultury symbolicznej.

W ramach przedzjazdowej publikacji i sympozjalnego spotkania uruchomiliśmy - wstępnie, ilustracyjnie i zapraszająco do wspólmyślenia - kilka kategorii, jakie można i warto odnosić do sprzężenia tradycji i nowoczesności. Pojęcia: pokoleniowość, z kontekstem m.in. kultury jako „gleby” symbolicznej (charakterystycznym dla Heleny Radlińskiej) (Michalski 2019); praktyka zarówno w horyzoncie formuły Sergiusza Hessena „filozofii stosowanej” (Maliszewski 2019), jak i postheideggerowskiej dialogiczności (Archacka 2019); uznanie, z Nietzscheańskim zapleczem 
odmowy zabiegania o nie (Kruszelnicki, Kruszelnicki 2019); przełom dwoistości, w odniesieniu do dydaktyki akademickiej (Kaliszewska 2019); pedagogika polityczna, z przywołaniem zapomnianych analiz Kazimierza Sośnickiego (Kwieciński 2019a) to tylko niektóre narzędzia myślowe, jakie mamy do dyspozycji w próbach pogłębionej penetracji polskiej myśli pedagogicznej.

I książka, i sympozjum stanowią ledwie szkic, wstęp do ewentualnego projektu badań szerzej zakrojonego, ale przede wszystkim budują już teraz perspektywę rewitalizacji myśli pedagogicznej - nadawania jej głębszego i szerszego oddechu poprzez energetyzujące sprzęganie z własną klasyką i osiągnięciami nowoczesnej humanistyki.

\section{II \\ O przechowywaniu dorobku przeszłości - głos w dyskusji (Ewa Marynowicz-Hetka)}

\section{Uwagi wstępne}

Pytanie, które wybrzmiewa w refleksji po dyskusji prowadzonej na tym interesującym sympozjum, brzmi następująco: gdzie szukać racjonalnych argumentów uzasadniających podejmowanie trudu przechowywania dorobku przeszłości, który określamy jako dziedzictwo kulturowe? Odpowiedź na to pytanie nie powinna budzić wątpliwości, a jednak niekiedy wywołuje je także w środowisku akademickim, narażonym w dużym stopniu na doświadczanie wyzwań życia chwilą i czasem teraźniejszym. Taka aura nie sprzyja namysłowi nad przeszłością i wiązaniu jej z teraźniejszością i przyszłością. Większość uzasadnień i orientacji podejmowanego działania wpisuje się $\mathrm{w}$ dość powszechną postawę „tu i teraz”, „wymogu chwili”.

$\mathrm{Na}$ tym tle ważny staje się namysł nad procesami pamięci i niepamięci (zapomnienia), które można postrzegać jako splot aktywności mentalnej, afektywnej i działaniowej (Barbier 2016: 148). Zastanówmy się więc nad mechanizmami tych procesów, które w skrócie nazywamy pamięcią i nie-pamięcią (zapomnieniem). Oba te procesy w sensie indywidualnym stanowią podstawy tożsamościowe (tamże), natomiast $\mathrm{w}$ sensie zbiorowym mogą stanowić podstawy tożsamości zbiorowej. Ważny też może być namysł nad narzędziem analizy związków między przeszłością, 
teraźniejszością i przyszłością, które dawałoby tropy argumentacji dla pozytywnej odpowiedzi na postawione pytanie o znaczenie dbałości o dziedzictwo kulturowe.

\section{Pamięć, zapomnienie: sploty aktywności mentalnej, afektywnej, działaniowej}

Zagadnienie pamięci i zapomnienia znajdujemy $\mathrm{w}$ pracach Paula Ricoeura, opracowane w ujęciu epistemologicznym, omawiane kilkakrotnie (np. 2000, 2003, 2006, 2012) i modyfikowane. Ostatnie wystąpienie Ricoeura (2006) na ten temat miało miejsce w Budapeszcie, gdzie na Uniwersytecie Europy Centralnej ${ }^{4}$ powrócił do swych przemyśleń opublikowanych w roku $2000 \mathrm{w}$ pracy La Mémoire, l'Histoire, l'Oubli, krytycznie ustosunkowując się do tez tamże sformułowanych.

Z uwagi na tytuł tego wystąpienia Ricoeura (a może i miejsce) wybrzmiała w nim ważna teza, odnosząca się do związków między pamięcią a jej dyskursywnym opisem, czyli historią. Należy tu rozumieć to pojęcie $\mathrm{w}$ znaczeniu indywidualnych narracji, jak też opracowania zdarzeń w badaniach historycznych. Ich cechą jest to, że nie są linearne, ale cyrkularne, czyli wyrażają powroty, jak gdyby „zniesienie początku i końca” (Kuźma 2002: 47). W takim rozumieniu tych związków Ricoeur (2012) wyszczególnia cechy, powiązane wzajemnie w sposób paradoksalny, które prowadzą do konstatacji, że pamięć kształtowana jest przez opis zdarzeń (czyli historię rozumianą przez Ricoeura jako „travail littéraire”) i tę lekturęs. Na tym tle powstają, zdaniem Ricoeura (2006), główne wątpliwości, które możemy zaadaptować do poszukiwania uzasadnień na pytanie sformułowane na wstępie. Oceniając tych, którzy „tworzą” pamięć (zbiorową), a więc historyków, przypomina jednak, że „to obywatele tworzą historię - a historycy jedynie o niej mówią [...] i jako odpowiedzialni obywatele

${ }^{4}$ Miało to miejsce 8 marca 2003 r. Wystąpienie w języku angielskim Haunting Memories? History in Europe after Authoritarianism opublikowane zostało w języku francuskim w czasopiśmie „Esprit” (Ricoeur 2006), a następnie w zbiorze wystąpień Paula Ricoeura (2019).

5 Jest to utrwalone stanowisko w dyskursie frankofońskim autorów odwołujących się do filozofii Ricoeura. Np. Jean-Marie Barbier (2016) tak omawia ten problem: „Pojęcie pamięci jest stosowane również w dyskursywnym przywoływaniu przeszłości; funkcjonuje wówczas jako wzorzec, który jest u podstaw tożsamości deklarowanej” (tamże: 148). 
powinni być uważni na to, co i o czym mówią, zwłaszcza jeśli chodzi o te bolesne aspekty pamięci (zdarzeń)" (tamże)

Ricoeur (2006) konstatuje, że „pamięć nie tylko jest kształtowana poprzez historię, ale może być też przez nią zraniona", z uwagi na to, co i jak się mówi oraz pisze. Aspekt moralny jest tu wyraźnie obecny i wydaje się, że wskazanie Ricoeura może być śmiało rozszerzone na wiele analiz zdarzeń, pod których wpływem konstytuuje się pamięć indywidualna i zbiorowa.

Również moralny wymiar ma kategoria obowiązku pamięci/ pamiętania (devoir de mémoire), natomiast wymiar psychologiczny (psychoanalityczny) ma inna kategoria wprowadzona przez Freuda - Erinnerungsarbeit, czyli praca nad pamięcią (travail de la mémoire), która w pewnych sytuacjach może stawać się melancholijną pracą nad stratą (travail de deuil).

$\mathrm{Z}$ punktu widzenia problematyki sympozjum ważne jest to, że te wszystkie wymiary pracy nad pamięcią, innymi słowy stosunku do jej opisu w historycznych analizach, mogą się łączyć i przecinać oraz w rezultacie tworzyć kompleksowo zarysowany obraz analizowanego zagadnienia usytuowanego w kontekście społecznym, kulturowym i politycznym. Ten węzeł/warkocz wynika nie tylko ze złożoności samej kategorii pamięci, ale także, a może i przede wszystkim, ze złożoności kontekstów, w których usytuowane są jednostki doświadczające zdarzeń.

Praca na pamięcią jest często bolesna i wymaga odwagi, a niekiedy wyważenia jej efektów. Jednym z przykładów takiego procesu może być obraz obserwowany w środowisku pedagogów społecznych, w powojennym pokoleniu historycznym, które niosło w dziedzictwie traumę likwidacji w latach 1950-1952 Zakładu Pedagogiki Społecznej Uniwersytetu Łódzkiego, kierowanego przez założycielkę dyscypliny Helenę Radlińską. W sensie nadawanym tym procesom przez Ricoeura nie została przeprowadzona w tym środowisku dogłębna praca nad pamięcią indywidualną tych, którzy bezpośrednio doświadczyli wieloletniego wykluczenia ze zbiorowości akademickiej (by przypomnieć tylko Helenę Radlińską, Aleksandra Kamińskiego, Irenę Lepalczyk), a także praca na pamięcią zbiorową całej społeczności.

Jak przypomina Ricoeur (2006), tę trudną i bolesną niekiedy pracę można przeprowadzić w toku narracji, opowiadania o zdarzeniach, opisach. Pewne próby podjęła Irena Lepalczyk (2003),

6 Warto zwrócić uwagę na tytuł tego wygłoszonego w roku 2003 wykładu. 
ale raczej z punktu widzenia instytucji, a nie doświadczeń indywidualnych. Trauma wojenna, chęć zapomnienia i w ten sposób trwania/przechowania idei, ale i niesprzyjający kontekst społeczno-polityczny, wszystko to miało znaczenie dla budowania „nowego" (po reaktywacji Zakładu w roku 1962). Dokonywało się ono poprzez zapominanie $\mathrm{w}$ pamięci indywidualnej tego, co bolesne, i przechowywanie w pamięci zbiorowej tego, co trwałe i świadczące o tożsamości pedagogiki społecznej. W rezultacie, rekonstruując procesy instytucjonalizacji i dyscyplinaryzacji pedagogiki społecznej, coraz to nowi przedstawiciele pokolenia historycznego długo nie mieli świadomości doświadczeń przeszłych, ale dzięki przechowywaniu w pamięci tego, co cenne i mogące stanowić zaczyn dla rozwoju, byli wyposażeni w główne tropy kulturowe umożliwiające budowanie tożsamości indywidualnej i zbiorowej pedagoga społecznego. Oceniając z dystansu tę strategię, wpisującą się też $\mathrm{w}$ progresywny wymiar społeczno-pedagogicznej perspektywy, można stwierdzić, że ten sposób radzenia sobie z dramatycznymi zdarzeniami pamięci okazał się słuszny z punktu widzenia instytucjonalnego. Z pewnością nadal wywołując emocje indywidualne ${ }^{7}$.

W tym procesie tworzenia (la filiation) łańcucha spraw i ludzi w pokoleniu historycznym i transmisji międzygeneracyjnej raczej skupiono się, odwołując się znowu do epistemologii Ricoeura, na kategorii tropów zapomnienia (la trace et loubli), których cechą wspólną jest zacieranie śladów pamięci i jej destrukcja. Kategoria ta, zwłaszcza gdy odniesiemy się do przesłanek psychoanalitycznych, na które powołuje się Ricoeur (2006), cytując Freuda, jest bardzo dwoista. Narracje o zdarzeniach są często selektywne, co może być powodem „ideologizacji pamięci” i - jak wskazuje Ricoeur (2006) - „różnych rodzajów manipulacji” w następstwie swoistej pracy nad konfiguracją opisu o zdarzeniach (le travail de configuration narrative). Wyraża się ona często w pomijaniu, unikaniu, czy wręcz ucieczce od tych doświadczeń.

${ }^{7} \mathrm{Na}$ symboliczne 70-lecie Katedry Pedagogiki Społecznej Uniwersytetu Łódzkiego Zespół podjął wiele aktywności i przygotował publikacje, por. m.in.: Pedagogika spoleczna: wstępy i kontynuacje (2015). Warto przypomnieć, że w grudniu 1950 r. profesor Helena Radlińska została zwolniona (formalnie: urlop naukowy). Podobnie zwolnieni zostali ówcześni adiunkci, w tym Aleksander Kamiński i Irena Lepalczyk. Ta ostatnia przez wiele lat była bezrobotna (o czym dowiedziałam się wiele lat po śmierci Pani Profesor - co niewątpliwie świadczy o stopniu tej rany i o głębokim zapomnieniu). 
W związku z kategorią zapomnienia, które dokonuje się w wymiarze jednostkowym/indywidualnym i społecznym, istotne jest, kontynuuje Ricoeur (2006) w swym ważnym wykładzie wygłoszonym w Budapeszcie, ponowne przyswojenie przeszłości (réappriopriation du passé historique). Wcześniej, w 1995 r., w wywiadzie z François Azouvim i Markiem de Launay, badacz dodaje: „jest to pamięć podlegająca temu, co Freud określił mianem ,przymusu powtarzania', bardzo trafnie ujmowanym jako przejście do działania, kiedy brakuje pracy wspomnienia” (Ricoeur 2003: 180). Ricoeur ostrzega jednak, by w tym procesie ponownego odczytywania przeszłości historycznej dbać o równowagę, nie nadużywać nadmiernie pamięci i nie pogłębiać zapomnienia. Wymiar moralny takiej pracy nad sobą jako uczestnikiem pokolenia historycznego, i nad nim samym, jest tu wyraźnie obecny. Szczególnie widać to przy podejmowaniu próby ustalenia jakiejś linii demarkacyjnej między tymi zdarzeniami i ich opisami a ich zapominaniem, czy też przechowywaniem w pamięci indywidualnej i zbiorowej. Raz jeszcze Ricoeur przypomina o złożoności pracy nad pamięcią, obowiązku niezapominania i mówienia o przeszłości - nawet wówczas, gdy jest bolesna.

\section{Narzędzie analizy związków między tymi procesami}

Te procesy pamiętania, przypominania, zapominania, w końcu wybaczania przebiegają w długim trwaniu (Braudel 1999) i są narażone na zerwania i nieciągłości (Bachelard 2002). Równocześnie jednak zapomnienie sprzyjać może trwaniu i przechowywaniu splotu idei (wartości), które składają się na tożsamość danej struktury instytucjonalnej, często stanowiącej zręby tożsamości indywidualnej (myślimy tu bowiem o zapominaniu odnoszonym do bytu placówki, ale wyrażanym przez ludzi z nią związanych). Zapomnienie nieprzepracowane nie może stać się wybaczeniem (Ricoeur 2003), ale sprzyja rozpoznawalności i trwaniu. Można je analizować przy pomocy narzędzia uwzględniającego progi oraz fazy procesów instytucjonalizacji i dyscyplinaryzacji, które proponowałam we wcześniejszych pracach, poświęconych analizie kontekstów historycznych rozwoju pedagogiki społecznej (ostatnio [w:] Marynowicz-Hetka 2019).

Można spróbować dokonać analizy, jak teza o zerwaniu i nieciągłości rozwoju przejawia się w procesualności związków 
między przeszłością, teraźniejszością i przyszłością. Przyjęcie tej perspektywy rozwoju poprzez zerwanie i nieciągłość wymaga odejścia od bardzo oczekiwanego obecnie, szybkiego, linearnego wzrostu, pozwala na spojrzenie z dystansu na tak ukierunkowaną analizę naszej aktywności. Można w niej wyodrębnić wyraźne kryzysy, duże i małe porażki, wielkie sukcesy oraz drobne powodzenia w codziennej pracy. Cechą szczególną tak pomyślanego narzędzia analizy jest szczególna jego złożoność/dwoistość

widziana tu jako cecha nasycania sytuacji społecznych znamionami złożoności, powstającego z przenikania się odmiennych wpływów, ze zderzania tego, co mija i odchodzi, z tym, co zapowiada swoje nadejście, co wręcz znamionuje nową epokę, mimo jeszcze braku gotowego dla niej kształtu i dojrzałości przejawów (Witkowski 2013: 99).

Tak pojmowany paradygmat dwoistości sprzyja więc postrzeganiu złożoności, ale co najważniejsze w myśleniu o kształceniu/ edukacji, podkreślając znaczenie orientacji w odkrywaniu znaczeń, także symbolicznych. Jego realizacja wymaga więc „upominania się o sytuację uwzględniającą typ złożoności strukturalnej niedający szansy ani na jednoznaczność, ani na rozłączność; nie ma tu miejsca na klasyczny ,złoty środek', widziany po Arystotelesowsku, wyznaczający jedną właściwą miarę (dawkę, normę)" (tamże: 583), oraz uwrażliwienia „na nieustanny proces dynamiki i napięcia, skazujący na nieredukowalną naprzemienność (oscylację), w której wahanie nie jest - jak w duchu psychologicznym - brakiem stanowiska, ale wyraża jego złożony charakter, respektujący złożoność samego odniesienia przedmiotowego" (Witkowski 2013: 99).

Podkreślając te trzy wymiary temporalne pamiętamy o zaleceniu Gastona Bachelarda, aby dbając o dokonania przeszłości, czynić to z perspektywy teraźniejszości i przyszłości. Taka postawa pozwala na zmaganie z teraźniejszością, zachowując przeszłość i projektując przyszłość. Chroni też przed pułapką oddziaływania wychowawczego na jakąś formę ideologizacji czy nawet indoktrynacji. Taką perspektywę zrównoważenia znaczenia tych trzech przestrzeni temporalnych $\mathrm{w}$ działaniu edukacyjnym, formacyjnym, kształceniowym staramy się urzeczywistniać w codziennej aktywności zorientowanej na rozwój pedagogiki społecznej. Z tym złożonym procesem wiąże się wiele pytań. Jedno z tych szczególnie ważnych odnosi się do sposobu „oglądania” zmian - jeśli ma to być sposób krytyczny, a zarazem zdystansowany. Podobnie warto 
dociekać, czy i jak możliwe jest zastosowanie podejścia Bachelarda do innych obszarów (pól) praktyki niż twórczość naukowa? Wydaje się, że odniesienia psychologiczne (np. E. Erikson) na to pozwalają. Bachelard (2002) mówiąc o uprawianiu twórczości naukowej, a zatem o pewnej formie praktyki, przypomina, że „to, co dawne musi być myślane w zależności od tego, co nowe” (tamże: 323). Tak więc zwracamy się do przeszłości z perspektywy teraźniejszości. Warto zauważyć, że taka wskazówka może stać się, z jednej strony, poważną pułapką w kierunku wybiórczego traktowania przeszłości, ale z drugiej może też być odczytywana jako wzmocnienie dla rozumienia/pojęcia teraźniejszości i jej relacji z przeszłością i przyszłością, jeśli będziemy pamiętać, że cechą procesów rozwoju są zerwania i nieciągłości.

\section{Podsumowanie}

W zakończeniu tego przyczynku chciałabym wyrazić pochwałę interdyscyplinarnych i interkulturowych seminariów, które wzbogacają nasze doświadczenie indywidualne i sprzyjają procesowi nabywania tożsamości. Przestrzeń ta sprzyja kształtowaniu postawy otwartości na wielość, inność, na postrzeganie danej dyscypliny $\mathrm{w}$ sposób wielowymiarowy i procesualny, a niekiedy także na jej przekraczanie. Stanowi kontekst formowania badaczy i dopomagania im w odkrywaniu własnej tożsamości naukowej, konstruowania podzielanej przez środowisko kultury akademickiej. Myśląc więc o związkach relacyjnych między przeszłością - teraźniejszością - przyszłością oraz narzędziu ich analizy w perspektywie społeczno-pedagogicznej odnajdujemy podstawowe znaczenie złożoności tych związków, które sprzyjają procesowi rekonstrukcji i integracji doświadczenia indywidualnego i zbiorowego, a w rezultacie stawania się członkiem społeczności. Co jest niezbywalnym celem każdej aktywności edukacyjnej.

\section{III \\ Zakończenie jako nowe otwarcie (Lech Witkowski)}

Może warto podkreślić, nie siląc się na żadne podsumowania, że troska dotycząca zmiany „złej obecności” tradycji polskiej myśli pedagogicznej w analizach współczesnych (najnowszych) nie ma 
jedynie, ani przede wszystkim, charakteru rozliczeniowego. Nie dotyczy to więc głównie orientacji na sprawiedliwość dziejową, zawieszoną zwłaszcza w okresie walki ideologicznej w PRL-u, czy choćby utrudnioną uszkodzeniami pamięci poprzez interwencje w instytucje akademickie (likwidowanie zakładów, odsuwanie od dydaktyki i publikacji kluczowych postaci, przemilczenia lub spłycenia podręcznikowe). Oczywiście nie wolno takiego nowego bilansu lekceważyć. Powtórzmy zatem. Nadal pozostaje do zrekonstruowania realna postawa poszczególnych postaci, dominujących w różnych okresach w przestrzeni pedagogicznej wobec tradycji myśli, nie wyłączając Bogdana Suchodolskiego, zarówno w latach 50., jak i długo potem. W końcu przecież zawstydzająca dziś fraza o „myśli burżuazyjnej” i o słabościach rzekomo „przyrodzonych” innym nurtom niż „socjalistyczny” w pedagogice polskiej pojawiała się także w latach 70. i później, jak świadczą o tym prace także tego ostatniego. Gwoli ilustracji przytoczyć warto sformułowanie B. Suchodolskiego opublikowane jeszcze w roku 1986: „Główny front walki w latach czterdziestych i pięćdziesiątych przebiegał między burżuazyjnymi i socjalistycznymi koncepcjami” (Suchodolski 1986, s. 342). Tymczasem jednak najważniejsza wydaje się troska o „pamięć teoretyczną myśli pedagogicznej” (Witkowski 2009), jako że współczesna pedagogika (także najnowsza) staje się często ofiarą - a tym bardziej nieświadomym wspólnikiem złego pod względem poziomu odczytania i przyswojenia, a dalej braku twórczego przetworzenia, idei rozwijanych przez czołowe postaci z historii myśli pedagogicznej w Polsce. Zadania tego nie da się pozostawić samym historykom, wymaga ono nowej jakości świadomości historycznej teoretyków, jak też nowej dojrzałości teoretycznej kręgów historyków. Kwestia ta także nie da się wpisać w subdyscypliny pedagogiczne. Podobnie nie wystarczy jedynie zamiar współpracy między tymi środowiskami, składającymi się z osób zbyt często i zbyt mocno rozdzielonych między sobą, wręcz izolowanych i izolujących się, tak jak nie ma wystarczającego przejścia w praktyce dydaktyki w ramach studiów pedagogicznych między historią wychowania i myśli pedagogicznej a teorią czy filozofią wychowania, jak również pedagogiką ogólną i badaniami nad recepcją myśli z wykorzystaniem studiów na materiałach archiwalnych. Archiwa nadal nie są wystarczająco doceniane, a tym bardziej spenetrowane i udostępnione w niezbędnych inicjatywach badawczych i edytorskich. Mamy tu do wykorzystania z jednej strony materiały często niekompletne, rozproszone czy zmarginalizowane, 
z drugiej strony pokutuje brak dojrzałego odnoszenia się pedagogów do refleksji nad historią myśli czy historią idei w rozmaitych innych dyscyplinach współczesnej humanistyki i poszczególnych dyscyplin nauk społecznych - podlegających w czasach nam współczesnych jeszcze bardziej skrajnej segregacji i separatyzmowi niż miało to miejsce w przeszłości. Pozostaje zatem do wykonania praca organiczna i to wbrew gratyfikowanym strategiom adaptacji do obecnie lansowanych biurokratycznych prób konstytuowania szkodliwych wizji „doskonałości” w uprawianiu profesji akademickich. Tego żmudnego zajęcia nie da się przeprowadzić $\mathrm{w}$ inny sposób niż poprzez podjęcie wysiłku przygotowania monografii, wielowymiarowej teoretycznie i archiwalnie, bez oglądania się na kryteria zainteresowania „czołowych” czasopism międzynarodowych środowisk pedagogicznych i nie tylko. Praca ta musi być adresowana do obecnych oraz przyszłych pokoleń badaczy w dziedzinie pedagogiki, aby w ten sposób uchronić się od powielania uproszczonych ocen i wizji znaczenia dorobku w tradycji myśli pedagogicznej. Chodzi też o to, by nie dochodziło do dominacji sposobów tworzenia myśli najnowszej ze stosowaniem najgorszych praktyk okresów wcześniejszych - nie do końca minionych, zwłaszcza pod względem iluzji mentalności władczej w ustanawianiu prawdy historycznej, czy presji zwykłej gry interesów instytucjonalnych, funkcji sztywnych podziałów dyscyplinarnych i braku świadomości wagi historycznej refleksji dla jakości współczesności.

\section{Bibliografia}

Archacka M. (2019), O problemie „pęknięcia” między praktyka a teoria pedagogiczna, [w:] L. Witkowski (red.), Dziedzictwo idei i pęknięcia międzypokoleniowe w pedagogice polskiej. Wprowadzenie do problemu (2019), Wydawnictwo Adam Marszałek, Toruń.

Bachelard G. (2002), Kształtowanie umystu nankowego, tłum. D. Leszczyński, Wydawnictwo Słowo/Obraz/Terytoria, Gdańsk.

Barbier J.-M. (2016), Leksykon analiz aktywności. Konceptualizacje zwyczajowych pojęć, tłum. E. Marynowicz-Hetka, Wydawnictwo Uniwersytetu Łódzkiego, Łódź.

Braudel F. (1999), Historia i trwanie, thum B. Geremek, Czytelnik, Warszawa. Dziedzictwo idei i pęknięcia międzypokoleniowe w pedagogice polskiej. Wprowadzenie do problemu (2019), L. Witkowski (red.), Wydawnictwo Adam Marszałek, Toruń.

Kaliszewska M. (2019), Wyzyskiwanie w praktyce akademickiej impulsów „przetomu dwoistości”. Glos w dyskusji, [w:] L. Witkowski (red.), Dziedzictwo idei, Wydawnictwo Adam Marszałek, Toruń. 
Kruszelnicki M., Kruszelnicki W. (2019), Afirmacja versus Reakcja Marginesu (nowe uwagi do Lecha Witkowskiego), [w:] L. Witkowski (red.), Dziedzictwo idei, Wydawnictwo Adam Marszałek, Toruń.

Kuźma E. (2002), Od linearnej do cyrkularnej komunikacji literackiej, a stąd do milczenia (O sytuacji we wspótczesnych doktrynach literackich), „Przestrzenie Teorii”, nr 1, Poznań, Wydawnictwo Uniwersytetu im. Adama Mickiewicza, s. 47-64, https://repozytorium.amu.edu.pl/bitstream/10593/9233/1/03 Erazm_ku\%C5\%BAma_Od_linearnej_do_cyrkularnej_47_64.pdf (dostęp: 3.12.2019).

Kwieciński Z. (2019), Grzęzawisko. Eseje z pedagogiki spotecznej i krytycznej socjologii edukacji, Wydawnictwo Stary Toruń, Studio „Kropka”, Toruń.

Kwieciński Z. (2019a), Przywrócona ciagtość. Nieodrobiona lekcja. Dwa przypadki. Komunikat, [w:] L. Witkowski (red.), Dziedzictwo idei, Wydawnictwo Adam Marszałek, Toruń.

Lepalczyk I. (2003), Wśród ludzi i książek, Wydawnictwo WiNG, Łódź.

Maliszewski K. (2019), Pedagogika jako filozofia stosowana. Glos w sprawie rewitalizacji formuty Sergiusza Hessena, [w:] L. Witkowski (red.), Dziedzictwo idei, Wydawnictwo Adam Marszałek.

Markowski M.P. (2019), Wojny nowoczesnych plemion. Spór o rzeczywistość w epoce populizmu, Wydawnictwo Karakter, Kraków.

Marynowicz-Hetka E. (2019), Pedagogika społeczna. Pojmowanie aktywności w polu praktyki, Wydawnictwo Uniwersytetu Łódzkiego, Łódź.

Marynowicz-Hetka E. (2019a), Helena Radlińska i jej pokolenie historyczne: uwspólnianie doświadczeń i wzajemność oddziatywań, [w:] L. Witkowski (red.), Dziedzictwo idei, Wydawnictwo Adam Marszałek, Toruń.

Michalski Ł. (2019), Odprawa kohort, czyli granice stosowania pojęcia „pokolenie" (w kontekście analiz dziejów polskiej myśli pedagogicznej i projektu jej archiwum), [w:] L. Witkowski (red.), Dziedzictwo idei, Wydawnictwo Adam Marszałek, Toruń.

Nawroczyński B. (2019), Oddech myśli. Archiwalia gtówne: Polska myśl pedagogiczna. Pamiętnik starego pedagoga. „Ojciec chrzestny” pedagogiki polskiej, wybór, opracowanie i wstęp L. Witkowski, Oficyna Wydawnicza Impuls, Kraków.

Pedagogika spoleczna. Wstępy i kontynuacje (2015), E. Marynowicz-Hetka, E. Skoczylas-Namielska (red.), Wydawnictwo Uniwersytetu Łódzkiego, Łódź.

Ricoeur P. (2000), La Mémoire, l'histoire, l'oubli, Points, Paris.

Ricouer P. (2003), Krytyka i przekonanie. Rozmowy z François Azouvim i Markiem de Launay, tłum. M. Drwięga, Wydawnictwo KR, Warszawa.

Ricoeur P. (2006), Mémoire, Histoire, Oubli, „Esprit”, marzec-kwiecień, https://esprit.presse.fr/article/paul-ricoeur/memoire-histoire-oubli-13290 (dostęp: 03.12.2019).

Ricoeur P. (2012), Pamięć, historia, zapomnienie, tłum. J. Margański, wyd. II, Universitas, Kraków.

Ricoeur P. (2019), Politique, économie et société: Ecrits et conférence, wybór Pierre-Olivier Monteil, Le Seuil, Paris.

Suchodolski B. (1918), Dzieje kultury polskiej, wyd. II zmienione i rozszerzone, Wydawnictwo Interpress, Warszawa. 
Witkowski L. (2009), O pamięć teoretyczna myśli pedagogicznej, [w:] L. Witkowski, Ku integralności edukacji i humanistyki II. Postulaty. Postacie. Pojęcia. Próby, Wydawnictwo Adam Marszałek, Toruń.

Witkowski L. (2013), Przetom dwoistości w pedagogice polskiej. Historia, teoria, krytyka, Oficyna Wydawnicza Impuls, Kraków.

Witkowski L. (2019) (red.), Dziedzictwo idei i pęknięcia międzypokoleniowe $w$ pedagogice polskiej. Wprowadzenie do problemu, Wydawnictwo Adam Marszałek, Toruń.

Witkowski L. (2019a), Relacje międzypokoleniowe jako wyzwanie poznawcze dla historii myśli pedagogicznej $w$ Polsce (zarys problematyki), [w:] L. Witkowski (red.), Dziedzictwo idei, Wydawnictwo Adam Marszałek, Torun. 


\title{
Myśl pedagogiczna i edukacja wobec anomii, bierności obywatelskiej, dysfunkcjonalności władzy i demokracji proceduralnej
}

\author{
Abstract \\ Pedagogy and education in the face of anomie, civic passivity, \\ dysfunction of power and procedural democracy
}

The article critically analyses political power in Poland. Two charges are formulated against the authorities: 1. lack of rational economic policy, 2. deliberate sparking of hostility and division in the society. These deliberately destructive divisions are accompanied by manipulation of facts, hypocrisy over the past and incitement of hostility on the basis of political, moral and other differences. A bizarre example of the aberration of the country's political authorities is establishing "LGBT-free zones". The article presents threats resulting from the introduction of a failed reform of the educational system. This includes the reduction of protective, medical and social functions of the school, and the commercialization of extracurricular activities, thereby increasing educational inequalities. The article sheds a critical light on employment policy, employee protection and working conditions. The scandalous neglect in this respect has led to the highest economic emigration in recent decades, including that of young people.

A separate area of criticism is the scandalous neglect of ecology, lack of concern for renewable energy sources, growing exclusion of communication and growing income inequalities, which puts Poland in the group of countries with the highest social stratification rates.

Keywords: pathology of political power, hate speech, intolerance, education anti-reform, marginalization and exclusion, social policy, ecological threat

Słowa kluczowe: patologia władzy politycznej, mowa nienawiści, nietolerancja, antyreforma oświaty, marginalizacja i wykluczenie, polityka socjalna, zagrożenie ekologiczne 


\section{Wszechmoc władzy \\ a pedagogika milczenia}

Nie można dać w krótkim referacie nawet zarysu diagnozy polskiej rzeczywistości w 30-lecie odzyskania przez społeczeństwo pełnej suwerenności w 1989 r. Wśród wielu wskaźników stanu ducha polskiego społeczeństwa może najbardziej bulwersujący jest brak zgody w kwestii wspólnego, narodowego świętowania tego historycznego zdarzenia na terenie miasta-symbolu, Gdańska, w dniu 4 czerwca. Nawet jeśli pominąć zamach szaleńca na życie prezydenta Gdańska Pawła Adamowicza, manifestowany przez zabójcę jako akt „politycznej wrogości wobec znienawidzonego 'przeciwnika'", zostaje kilka innych okoliczności, które czynią $\mathrm{z}$ nas plemię opanowane jakimś tajemnym zaślepieniem, amokiem wzajemnej wrogości, dla którego porozumienie jest synonimem zdrady, „zaprzaństwa”, odstąpieniem od ideałów i jedynie słusznych wartości. Dramat polega na tym, że wprawdzie władza jest inicjatorem owych stanów obcości plemiennej i wrogości wśród swoich, ale za tą władzą idą miliony po jednej i drugiej stronie. I tego nie można zrozumieć w kraju, w którym narodziła się „Solidarność”, która zmieniła oblicze świata.

Oto związek zawodowy „Solidarność”, a raczej żałosna resztówka byłego, światowego fenomenu, jakim był NSZZ Solidarność, ogłasza z poparciem wojewody, czyli rządu, wyłączność na dysponowanie placem - uświęconym miejscem pamięci narodowej. Nie przemawia za tym nic, żadna racja, poza pychą autorytarnej władzy, pogarda dla wszystkich, którzy nie klęczą przed nią i nie skandują chwały jedynie słusznej partii i jej lidera. Wcześniej podobny gest czyni rząd wobec równie sakralnego miejsca w Warszawie - pl. Zwycięstwa, po to, aby bez protestów społecznych postawić pomniki, których prawomocności nie zweryfikował czas i powszechna aprobata.

W pokojowych warunkach władza odwołuje się do schematów działania charakterystycznych dla stanu wyjątkowego. Miarą rozbieżności poglądów rządzącej partii i społeczeństwa Warszawy jest okoliczność pilnowania ustawicznego owych pomników przez patrole policyjne. Czy to jest sposób na budowanie wspólnoty i jedności społecznej wokół wartości?

Jak to możliwe, że po tysiącu lat wspólnej historii, wspólnego losu w doli i niedoli Polska stała się polem walki nienawidzących się plemion. Nienawidzących się z inspiracji zorganizowanych sił 
politycznych mających postać partii autorytarnych i wodzowskich. Co szczególnie osobliwe - przyczyny i źródła owych animozji i wrogości są wręcz groteskowe. Jak to się stało, że dramatyczne doświadczenia historyczne z XVIII i XIX w., które nota bene sami na siebie sprowadziliśmy, straszliwa tragedia II wojny światowej, nie uleczyła duszy polskiej, nie wyzwoliła z nieufności, zawiści, wrogości, nietolerancji? Jak to się stało, że doświadczenie niewoli zaborców, którzy podzielili naród, i zagrożenie egzystencji tegoż narodu przez agresję faszyzmu czy ponure czasy reżimu komunistycznego nie wykształciły w polskim narodzie naturalnych odruchów więzi wspólnotowych, solidaryzmu plemiennego, postaw i aktywności obywatelskiej. Wręcz odwrotnie; jedyną inicjatywę jednoczącą naród, którą była NSZZ Solidarność, szybko sprowadzono do niejasnej genezy, agenturalnych manipulacji, publikowania list agenturalnej hańby, rzekomych nieprawości; aż została z niej żałosna wydmuszka na usługach partyjnych interesów. Rozsławiona w świecie Wielka Orkiestra Świątecznej Pomocy, która jednoczy naród w bezprecedensowej solidarności dla potrzebujących, przez państwową propagandę jest na wszelkie sposoby odsądzana od czci i wiary, we wspólnocie z władzami kościoła katolickiego - czego już nie sposób zrozumieć!

Nie sposób w tym miejscu nie zapytać nas - pedagogów, dlaczego jesteśmy wobec takich aktów obojętni? Dlaczego milczymy, kiedy w wyniku zdarzeń historycznych dostajemy szansę stworzenia czegoś wielkiego i trwałego, co w niepomiernej skali wzbogaciłoby ducha narodu i społeczną moralność. Dlaczego nie wspieramy czynności i działań człowieka, który z pozoru może wydawać się ekscentryczny, ale który dowiódł czynem, że jest naprawdę wielkim człowiekiem służby. To dzieci, które wychowujemy, masowo, tysiącami, biorą udział w zbiórce środków na najbardziej szlachetny cel: pomagania bliźnim. Czy takie stanowisko nie jest integralną częścią naszego pedagogicznego etosu? Powinnością wobec naszych wychowanków, wobec społeczeństwa? Więcej: czy nie jest naszą powinnością bronić pamięci największego w historii zjednoczenia narodu w organizacji związkowej, która w pokojowy sposób odmieniła oblicze świata i przeciwstawić się skandalicznej, skompromitowanej przez historię prawdzie wygłaszanej przez prezydenta kraju, że to odrodzenie narodowe nie może mieć rangi trwałości, bo nie zostało przypieczętowane daniną krwi?! Czy nie jest powinnością myśli pedagogicznej przeciwdziałać nieodpowiedzialnej, rządowej 
propagandzie niszczącej na wszelkie sposoby jeden z najszlachetniejszych zrywów narodowej solidarności z potrzebującymi, jakim jest WOŚP. Jak ten akt miłosierdzia narodowego - podstawowa idea ewangeliczna, może być tak nieprzyjaźnie traktowany przez Kościół katolicki, a my wobec tej niepojętej zdrowym rozsądkiem postawy Kościoła pozostajemy obojętni?

My, pedagogowie, powinniśmy się zastanowić, czy wymienione zjawiska mają związek z misją edukacji jako procesu wychowania narodowego. Jest naszą powinnością naukową wyjaśnienie historycznych uwarunkowań podziałów klasowych, grupowych, regionalnych. Ustawicznego istnienia klimatu wzajemnej wrogości, uczuć zawiści, tworzenia się spontanicznego ruchów i organizmów, które kultywują najdziwniejsze przekonania o nieusuwalności walki, dążenia do dominacji, przekonań o wyższości jednych nad drugimi. Czy takie wyjaśnienia możemy przełożyć na zadania wychowawcze szkoły? Czy można wyobrazić sobie bardziej praktyczną metodę wychowania obywatelskiego niż masowy udział dzieci i młodzieży w zbiórce datków na Wielką Orkiestrę Świątecznej Pomocy? I czy nie jest to właściwy trop wyjaśnienia wielu naszych narodowych tajemnic i droga do budowania nowej osobowości Polaka - obywatela? Jest oczywistą prawdą, że nie ma dziedziny życia zbiorowego, która nie wymagałaby zainteresowania badawczego i analitycznego pedagogiki jako nauki. I nie ma takich zjawisk publicznych, które nie powinny być inspiracją do akcji wychowawczej wobec dzieci i młodzieży.

Podnoszę kwestię powinności i odpowiedzialności pedagogiki i wychowania za kondycję treściową badań naukowych i procesów wychowawczych, bo spotykamy się z wielce zdeterminowaną akcją oficjalnej polityki, aby na wzorach Orwella budować rzeczywistość, w której podyktowane zostają decyzje co jest słuszne, co jest prawdziwe, a co niegodne pamięci. Stworzono specjalny organ, nazwany Instytutem Pamięci Narodowej, który spełnia wszystkie niemal atrybuty orwellowskiego ministerstwa prawdy. To on orzeka jakie treści i zdarzenia z przeszłości zasługują na pamięć, jakie są zdradą, a jakie noszą znamiona sakralne. Właśnie jeden z prominentnych kierowników owego instytutu orzekł, że ks. Józef Tischner był agentem komunistycznych służb specjalnych. Natomiast do rangi zjawisk sakralnych podniesiono tzw. „żołnierzy wyklętych”. Zjawisko w swych historycznych uwarunkowaniach tragiczne, obciążone zarówno heroizmem oporu wobec obcej przemocy, jak i autentycznymi zbrodniami popełnianymi wobec 
bezbronnych kobiet i dzieci, co znam z osobistych doświadczeń. Wcześniej takie prawdy - jak w tym wypadku dyrektora Cenckiewicza - tyle, że na masową skalę - ogłaszał redaktor Wildstein. Zapewne taka działalność Instytutu Pamięci Narodowej i jego akolitów spełnia oczekiwania rządzących sił politycznych, skoro w bieżącym roku otrzymał na swoją działalność większą dotację niż wszystkie wydziały Polskiej Akademii Nauk. Nie było słychać głośnych protestów środowiska naukowego wobec takiej polityki naukowej rządu. Podobnie zresztą jak nie było głośnych protestów, poza pojedynczymi wystąpieniami, wobec nowych regulacji w systemie nauki, których jedyną pewną cechą jest niejasność skutków. To są objawy pośmiertnego zwycięstwa ideologii i praktyk komunistycznych, kiedy ontologiczny kształt świata budowany jest wyobraźnią partii i jej liderów, a świat aksjologii rozkłada się według dualistycznego schematu struktury społecznej $w$ rzeczywistości komunistycznej: „my” i „oni”.

I ten chaos informacyjno-ideowy transponowany jest przez anonimowych autorów do programów szkolnych, aby dzieci nasiąkały od najmłodszych lat dwoistą postacią prawdy: oficjalnej, przekazywanej w szkole, i odmiennej, poznawanej w warunkach nieoficjalnego przekazu rodzinnego, lub przez opozycyjne wydawnictwa. Praktyka całkowicie analogiczna do stosowanej w czasach rządów komunistycznych, której byłem już jako uczeń biernym podmiotem. Tylko wówczas protest był wykluczony, dzisiaj jego brak jest tylko oportunizmem.

Janusz Czapiński na początku 2006 r. opublikował w „Polityce” artykuł pt: Polska - państwo bez spoleczeństwa. Wyrażał w nim ubolewanie, że Polska nie stworzyła społeczeństwa obywatelskiego, zaangażowanego. Ja uważam, że ten tytuł należy rozszerzyć w następujący sposób: „Polska - państwo bez odpowiedzialności i bez społeczeństwa”. Mam na myśli odpowiedzialność polityki i polityków za jakiekolwiek deficyty w procesach rozwoju społecznego. Wszelkie decyzje zapadają bez konsultacji społecznych lub są przesiąknięte propagandą. Najbardziej kontrowersyjne decyzje dotyczące kształtu życia, jego warunków, rozwiązań systemowych, strategicznych podejmowane są w gremiach politycznych - ostatnio nawet z pominięciem obowiązkowych konsultacji społecznych, jako tzw. projekty poselskie, które zwolnione są od obowiązku jakiegokolwiek konsultowania. Nikt nigdy za taką aspołeczną politykę nie poniósł odpowiedzialności. Najbardziej 
spektakularna w bieżącym roku porażka w zakresie reformy edukacji, o której uprzedzały nieliczne organy i instytucje społeczne została „ukarana” mandatem poselskim do parlamentu europejskiego dla jej autorki - minister edukacji, Pani Anny Zalewskiej. Nowy minister edukacji, Pan Dariusz Piontkowski, z przekonaniem ogłasza, że reforma jest wielkim sukcesem oświatowym, a wszelkie trudności pochodzą z nieudolności samorządów, natomiast krytyka wypływa z wrogich intencji opozycyjnych ośrodków. Tego, że w ciągu ostatniego stulecia nikt na świecie nie skrócił powszechnego obowiązkowego kształcenia z 9 do 8 lat, oraz nie cofnął wieku rozpoczynania nauki z 6. na 7. rok życia - ani politycy, ani opinia publiczna zdają się nie zauważać. Bezradne okazują się wobec absurdów politycznych: szkoła, społeczeństwo, organizacje publiczne, bo politycy rekrutowani są przez partie polityczne na zasadzie doboru wsobnego, a w przypadku nawet wielkich błędów „karani” są awansem na placówki zagraniczne, przesunięciem na inne pole aktywności... itp. Są to praktyki dobrze znane z czasów PRL. Wszelka działalność lub krytyka niezgodna $\mathrm{z}$ koncepcjami lub oczekiwaniami partii władzy jest nazywana przez lidera partii „ofensywą zła”. Towarzyszy temu rozniecanie waśni, wrogości, enigmatyczne identyfikowanie przeciwników i odbieranie im godności. Przykładem jest ruch LGBT, który jest w opinii PiS i Kościoła uniwersalizowanym symbolem zła i zagrożenia. Kreowanie uniwersalnego wroga jest starą praktyką systemów totalitarnych, jako mechanizm jednoczenia zwolenników, rozniecania wrogości, usprawiedliwiania własnych błędów i nieudolności. Nikt się nie troszczy o to, by choćby w przybliżeniu objaśnić istotę tego humanistycznego ruchu.

Tworzymy wspólnotę rodzinną, sąsiedzką, towarzyską uważa Czapiński, lecz nie tworzymy wspólnoty społecznej. Nie ufamy nikomu, przypisujemy innym złe intencje, nie chcemy i nie potrafimy współpracować. Polacy mają najniższy wskaźnik przynależności do organizacyjnych form życia społecznego i najniższy wskaźnik zaufania do instytucji państwa, także do polityków. Polski patriotyzm jest bardzo romantyczny, ale Polak jest najmniej pragmatyczny (Czapiński).

Czy to nie są powody do najwyższej troski nauk pedagogicznych i procesów wychowawczych? Wszak wszystkie te cechy są wdrukowywane w świadomość społeczną w procesie nauczania, a następnie utwierdzane praktyką życia i obserwacjami mechanizmów społecznych. 
Polacy są niezwykle podatni na rozbudzanie wzajemnych zawiści, animozji. Nie potrzeba do tego realnych powodów lub zagrożeń. Wystarczą propagandowe insynuacje, głupawe bon-moty typu: „my stoimy tu gdzie staliśmy kiedyś, a ,oni’ stoją tam, gdzie kiedyś stało ZOMO”. Ci „oni” są nieokreśleni; to jest insynuacja $z$ okazjonalnym adresem, nader często używana przez polityczną propagandę. Generalnie chodzi o tych „onych”, którzy nie są z nami, którzy „nam” nie są oddani. Bo władzy autorytarnej nie wystarcza obywatelska poprawność. Ta władza oczekuje oddania, "miłości”. I to też rys charakterystyczny dla władzy z czasów komunizmu.

Dramatyczną egzemplifikacją takiej właśnie bezrozumnej, pozbawionej racjonalnych przesłanek agresji, i próbą pogromu, były „wypadki” w Białymstoku 19 lipca 2019 r. Nic ich nie usprawiedliwia i nie tłumaczy. Pokazują natomiast „strony konfliktu” i postawę władzy politycznej i kościelnej wobec niego. $Z$ jednej strony grupa osób podniesiona przez państwową propagandę do mitycznej, groźnej siły zagrażającej bezpieczeństwu i tożsamości (jakiej?, czego?) narodu - ideologia LGBT, z drugiej histeryczne oblicze władz państwowych i kościelnych, inspiratorów klimatu wrogości i nienawiści (marszałek Podlasia - Artur Kosicki, minister edukacji D. Piątkowski, metropolita białostocki - abp T. Wojda, lokalne duchowieństwo - „oczadziali”, jak mówią na Podlasiu zwykli obywatele...). A w środku wykonawcy programowanej przez kilka miesięcy bezwzględnej i nienawistnej propagandy państwowej zwykli bandyci, żądni rozboju i bezrefleksyjnej rozróby, dalecy od posiadania jakichkolwiek przekonań i refleksji aksjologicznej. Dwie reakcje godne są uwagi socjologicznej i pedagogicznej. Władza polityczna, widząc poziom agresji stadionowych bandytów, rozhuśtanej przez jej własną propagandę, nad którymi policja straciła kontrolę, ustami minister SWiA, E. Witek, oświadczyła: „Nie było i nie ma przyzwolenia na chuligańskie zachowania godzące w prawa innych...” Ale już minister edukacji, Pan Piontkowski radzi, aby nie dawać zezwoleń na marsze równości, skoro wywołują takie emocje! Natomiast duchowni z parafii św. Jadwigi Królowej oświadczyli publicznie swoje uznanie dla agresorów, nazwanych przez prezydenta Białegostoku T. Truskolaskiego bandytami: „Niech wam Bóg wynagrodzi i błogosławi wszelkie dalsze, dobre poczynania” - obiecując modły w ich intencji!

„Władzo, Kościele - obudźcie się!” - woła Kampania przeciwko Homofobii (2019) w swoim apelu. „Homofobiczny jad 
wylewający się od miesięcy z ust władzy, oraz przedstawicieli Kościoła doprowadził w Białymstoku do polowania na ludzi”. Warto tu wspomnieć, że pojęcie ,jady polskie” - to termin sformułowany przez Ludwika Petrażyckiego na oznaczenie specyficznych dyspozycji Polaków do kształtowania relacji interpersonalnych.

Ukształtowane zostały one $\mathrm{w}$ społecznej podświadomości przez kilka wieków nękających nas wojen, anarchii szlacheckiej, korupcji politycznej, gospodarki feudalnej z właściwym jej niewolnictwem chłopów, powiązane z rozbiorami, przegranymi powstaniami, wyniszczającymi wojnami XX wieku, z krótkim doświadczeniem spójności narodowej 1918-1926, a potem dyktaturą i kłótniami politycznymi w latach 1926-1939, okrucieństwami okupacji niemieckiej, przegranym powstaniem warszawskim, ze sprzedaniem nas w strefę wpływów Rosji sowieckiej (Kwieciński 2018: 29).

Przytaczam dlatego obszerne wyjaśnienie Zbigniewa Kwiecińskiego o genezie owego osobliwego pojęcia, bo daje ona szczególny ogląd zjawiska, w którym tkwimy od wielu lat i które charakteryzuje szczególny klimat rządów Prawa i Sprawiedliwości. I wydaje się, że jest nieusuwalną właściwością narodowego charakteru Polaków. To jedno z największych wyzwań edukacji narodowej!

Sporo nadziei wiązać można z narastającym protestem społeczeństwa polskiego na te tragiczne wydarzenia w Białymstoku. Przez kraj przetoczyła się fala protestów i manifestacji przeciw przemocy i agresji, a w domyśle - przeciw jej inspiratorom.

Wszystkie niemal partie polityczne we współczesnej Europie mają mniej lub bardziej jawny charakter wodzowski. A sprawowanie władzy dokonuje się przez zwycięską formację polityczną. Ten autorytaryzm ma raz postać Angeli Merkel czy Emanuela Macrona..., innym razem przybiera twarz i przejmuje praktyki Wiktora Orbana, Jarosława Kaczyńskiego czy Aleksandra Łukaszenki. Jedynym sposobem do zablokowania Orbanowi, Kaczyńskiemu, Łukaszence... drogi do samodzierżawia jest aktywne społeczeństwo obywatelskie, lub szczególne ustrojowe regulacje, które w krajach demokracji zachodnich nie pozwalają na przekroczenie linii oddzielającej charyzmatyczne pełnienie funkcji od autorytaryzmu. Tam gdzie tego brak, łamie się konstytucję, niszczy sądy, ustanawia dowolne organy władzy - np. w Polsce. Gdzie indziej bez skrępowania tworzy się praktyki i państwo 
mafijne - to przykład Węgier. A jeszcze gdzie indziej funkcjonuje jawne samowładztwo, ze spacyfikowaną opozycją i elementami opiekuńczości - zhumanizowany komunizm - to Białoruś. Nie bez znaczenia dla zrozumienia natury władzy autorytarnej jest fakt, że władcy typu Orbana i Putina należą do grupy najbogatszych ludzi świata.

\section{Spór o granice kompetencji}

Postaram się teraz dokonać niepełnej typologii zjawisk, które stanowią wielkie problemy naszego kraju, wokół których toczy się ustawiczny spór, w czyjej powinny leżeć kompetencji: polityków i rządu, religii i kościoła, specjalnych instytucji, czy też może w kompetencji społeczeństwa, którego dotyczą. Otóż wraz z narodzinami władzy instytucjonalnej nastąpiła wyraźna specyfika przynależności obszarów i zakresu władzy. To była zasada powszechna, że istnieją obszary spraw i zjawisk zawarowane do wyłącznej kompetencji władcy. W każdej epoce i kulturze obszary wyłączności ulegały zmianom, zawężaniu lub poszerzaniu wedle aktualnych okoliczności. Suweren dzielił władzę z lennikami, podobnie jak dziś władze centralne dzielą się zakresem kompetencji z samorządami.

Ale nadeszła współczesna demokracja, nominalnie rządy ludu. Wszelka władza trafiła w ręce ludu, który na zasadzie ustanowionych praw i reguł praktycznych delegował tę władzę w ręce swoich przedstawicieli. Formalnie więc władza należy dalej do suwerena, tylko suwerenem jest ogół obywateli. Ich przedstawiciele dostają tę władzę do wykonywania. Są - mówiąc w dużym uproszczeniu - „najemnikami” do sprawowania władzy. Nominalnie władza należy więc do owych „najemników” społeczeństwa, popularnie nazywanych politykami. Nie mogą żadną miarą kwestionować uprawnień suwerena, rzeczywistego dzierżyciela władzy, do posiadania prawa ingerowania w umowny, prawem przewidziany sposób we wszelkie formy działalności władczej.

To wszystko teoria. Tymczasem z uporem upowszechniana jest od dziesiątków lat, a już szczególnie dobitnie w systemie komunistycznym i w innych systemach autorytarnych, rzekoma prawda, przekonanie, że istnieje ścisłe rozgraniczenie kompetencji i sfer życia zbiorowego na sferę polityczną i inną, nazwijmy ją umownie - obywatelską. Ta pierwsza jest ściśle zawarowana do wyłącznej kompetencji organów politycznych i osób pełniących 
funkcje polityczne. Jakakolwiek ingerencja w obszar uważany za sferę spraw politycznych uznawana jest za bezprawną uzurpację i przekroczenie... Właśnie - czego? Prawa? Pisanych regulaminów? Dobrych obyczajów? Nie ma żadnego prawa, które zabrania obywatelom zainteresowania kwestiami politycznymi i wyrażania opinii na ich temat! Nie istnieją regulacje organizacyjne, zwyczajowe, konwencjonalne, które uznawałyby wyrażanie opinii w kwestiach podejmowanych decyzji politycznych przez nawet najwyższe organy, rząd, sejm, ministerstwa, za rzecz niedopuszczalną lub wręcz niewłaściwą.

Tymczasem większość z nas pamięta propagandę komunistyczną: „pisarze do piór, studenci do nauki, uczeni do książek”... To autentyczne zawołania komunistycznej propagandy, które zostały wdrukowane i zinternalizowane wyłącznie w środowisku naukowym. Studenci odwrócili się plecami do polityki, ${ }^{1}$ pisarze mają swój świat, w którym polityka jest nieobecna. Natomiast uczeni najmniejszą aluzję do rzeczywistości społecznej są skłonni traktować jako sprzeniewierzenie się statusowi kapłana nauki, obojętnego wobec brudnej polityki, nieuwikłanego w zależności polityczne. Proszę mi pokazać taką kwestię/decyzję polityczną, która nie rodzi skutków społecznych, socjalnych, wychowawczych, kulturowych. Czy Pani Pawłowicz, Pan Gliński, Pan Zybertowicz - że nie będę wymieniał dalej - przestali być uczonymi? Czy wygłaszając swoje opinie, robią to jako politycy a nie uczeni? Słyszałem kilkakrotnie prof. Glińskiego, kiedy formułował swoje sądy z powołaniem się na naukę. Nie „angażując się w politykę”.

Mam obywatelskie prawo a nawet powinność sprzeciwiać się głupim politycznym decyzjom! Jako obywatel mam prawo domagać się w polityce decyzji i rozstrzygnięć korzystnych dla społeczeństwa, dla niepełnosprawnego, ucznia, pacjenta służby zdrowia! To jest polityka? A jeśli jest, to ja, pedagog, nauczyciel, rada wydziału dowolnego uniwersytetu, szkoły wyższej nie może wyrazić swojej opinii, stanowiska? Czy reforma edukacji, uchwalona przez sejm - jest „nietykalna” dla uczonych i nauczycieli, bo jest aktem politycznym? To przecież absurd!

Dobitnym przykładem sporu o kompetencje pomiędzy sferą „publiczną” a władzą polityczną była procedura powołania Rzecznika Praw Dziecka. Jako przedstawiciele akademickiego środowiska

1 Szerzej na ten temat piszę $\mathrm{w}$ artykule Pokolenie odwróconych pleców. Po 35 latach opublikowanym w „Pedagogice Społecznej” (2016), nr 2, s. 13-25. 
pedagogicznego nie mieliśmy wątpliwości, że Pani prof. UŚ Ewa Jarosz jest znakomitą Kandydatką do tego urzędu. W głosowaniu wzięło udział 31 członków i specjalistów KNP PAN, którzy jednomyślnie wyrazili poparcie dla naszej kandydatki. Poparcia udzieliło jej ok. 70 organizacji i stowarzyszeń społecznych.

Dziekan Wydziału I Nauk Humanistycznych i Społecznych PAN prof. dr. hab. Stanisław Filipowicz - skierował do Komitetu Nauk Pedagogicznych PAN list, w którym wyraził opinię, że proces wyboru Rzecznika Praw Dziecka ma charakter aktu politycznego, a KNP PAN nie powinien angażować się $\mathrm{w}$ działalność polityczną. Chyba że np. do KNP PAN zwróci się Marszałek Sejmu czy Komisja Sejmowa opiniująca kandydatów na to stanowisko, wówczas moglibyśmy przedłożyć opinię osiągnięć naukowych kandydatki i jej dokonań zawodowych, gdyż ta - jak stwierdził Pan Dziekan

mieściłaby się w polu poczynań, które możemy traktować jako politycznie neutralne. Wypowiedzi ad meritum mogą mieć oczywiście polityczne skutki, ale nie mogą być traktowane jako zajmowanie politycznego stanowiska. Przedstawiając niezależną, ekspercką opinię Komitet nie angażuje się w żaden spór polityczny, zachowuje bezstronność. ${ }^{2}$

Na obecnym etapie zgłaszania kandydatów Komitet Nauk Pedagogicznych PAN nie powinien włączać się do tzw. komitetów poparcia któregokolwiek z kandydatów na Rzecznika Praw Dziecka, gdyż wszystkie podmioty PAN - w świetle jej Statutu nie mogą $\mathrm{w}$ swoich działaniach angażować się $\mathrm{w}$ działalność polityczną w państwie. Tym samym kieruję do Państwa sugestię, by w sytuacji gotowości udzielenia osobistego poparcia Pani Profesor, skierować na Jej adres osobistą deklarację.

Uzasadnienie zakazu poparcia dla kandydatury uznanej przez najbardziej kompetentne gremium pedagogiczne za najwłaściwszą to ekwilibrystyka logiką i argumentacją rzeczową. Jedyny konkret, to uwaga o tym, że statut PAN „zakazuje” wszelkim podmiotom tejże instytucji angażowanie się w działalność polityczną w państwie. Istnieje niezmiernie ciekawa czasowa geneza

2 Fragment urzędowego i niepublikowanego dotychczas listu Dziekana Wydziału 1. PAN prof. Stanisława Filipowicza, skierowanego do Komitetu Nauk Pedagogicznych PAN, w/s wyboru przez sejm Rzecznika Praw Dziecka. List znajduje się w zasobach archiwalnych KNP PAN. 
tego zakazu. Można iść o zakład, że sięga ona czasów komunistycznego reżimu, kiedy taki zakaz był całkowicie naturalny! Ale dzisiaj, w systemie demokratycznym, to oczywisty, niedemokratyczny anachronizm. A co oznacza "działalność polityczna” w tej i w podobnych sytuacjach? Czy także wyrażenie opinii, że reforma edukacji ma fatalne skutki?

Komitet Nauk Pedagogicznych PAN jest ciałem pochodzącym $\mathrm{z}$ wyborów powszechnych $\mathrm{w}$ swoim środowisku. Oznacza to merytoryczną i prawną niezawisłość w działalności naukowej, oraz wszelkiej aktywności mieszczącej się w autonomii szeroko rozumianego funkcjonowania, wyrażania opinii, sądów, zajmowania stanowiska, podejmowania ekspertyz... oprócz opinii i czynów naruszających przepisy prawa. Pan Dziekan ma prawo domagać się przykładowo od Przewodniczącego każdego komitetu rzetelnego rozliczenia się $\mathrm{z}$ dotacji lub innych formalnych powinności stanowionych przez przepisy, ale nie ma żadnego prawa do ograniczania wyrażania opinii przez Przewodniczącego NP, lub dowolnego członka KNP PAN, np. surowej oceny społecznych skutków reformy edukacji, dokonanej przez polityków, $\mathrm{w}$ akcie politycznym, przez nawet najwyższy organ polityczny. Dochodzimy do absurdu - próbując wyznaczyć granicę między merytorycznym, słusznym racjonalnie i moralnie koniecznym protestowaniem przeciw złemu funkcjonowaniu szkoły i systemu wychowania a krytykowaniem organu i procedur związanych z jego wprowadzaniem, bo to już zaangażowanie polityczne. Ja, obywatel, mam prawo (a nawet obowiązek) wybrać mojego reprezentanta na posła do Sejmu RP, ale, ja profesor uczelni nie mam prawa krytykować posła, który uchwalił szkodliwe prawo, bo to już będzie czynność polityczna!!! Tym bardziej absurdalne jest ograniczanie prawa do wyrażania opinii i krytycznych sądów wszelkim organom Polskiej Akademii Nauk - ciału z natury swej skupiającemu elitę intelektualną i kompetencyjną (w każdym obszarze) naszego kraju. Posłowie i senatorowie... (nie będę wymieniał ich nazwisk, respektując zasadę: nomina sunt odiosa) mają wszelkie prawo uchwalać złe, czasem kuriozalne prawo, a ja, my, ich wyborcy, nie mamy prawa ich skorygować i naszych nominatów przywołać do rozsądku?

$\mathrm{Z}$ takim rozdzielczym rozumieniem rzeczywistości na polityczną i umownie nazwijmy tę drugą „merytoryczną" wiąże się kwestia odpowiedzialności. Bo jeśli nikt poza politykami nie ma prawa wnikać w skutki decyzji politycznych, to wszelka ich 
odpowiedzialność jest iluzoryczna. Co więcej, w rzeczywistości politycy nie ponoszą $\mathrm{w}$ takiej sytuacji żadnych konsekwencji nawet za najbardziej absurdalne, szkodliwe decyzje w dziedzinie finansów, organizacji życia zbiorowego, zdrowia publicznego, oświaty, obronności itp., itd. Skala nieodpowiedzialności polityków, naszych „najemników” do rządzenia, za złe, szkodliwe, kosztowne decyzje jest niepoliczalna, jej opisowi można by poświęcić opasłe tomy. I dopóki nie uczynimy z odpowiedzialności fundamentalnego prawa dla oceny i osądzania prawidłowości, nieszkodliwości działalności politycznej - dopóty władza będzie miejscem narodzin nieprawości i patologii, tak jak to się dzieje od wieków, od zawsze, z małymi wyjątkami. To bardzo ważna kwestia dla refleksji i decyzji środowiska pedagogicznego. Ono bowiem, jak żadne inne, bliskie jest wszelkim problemom społecznym, oświatowym, zdrowotnym. Długa historia pokazuje jak fatalne są rezultaty „samodzielności” i niezależności posłów, polityków od społecznego wsparcia i kontroli!

\section{Bolesne problemy rzeczywistości}

Niechże incydent Komitetu Nauk Pedagogicznych PAN z wyborem kandydata na Rzecznika Praw Dziecka będzie impulsem do refleksji dla całego środowiska pedagogicznego o naszych prawach i powinnościach. Tym bardziej, że rejestr problemów, które stają na drodze rozwoju naszego kraju i są uciążliwościami i zagrożeniami dla ładu społecznego, prawnego i moralnego oraz wymagają zjednoczonych, zdecydowanych działań naprawczych społeczeństwa obywatelskiego jest ogromny i ciągle narasta.

Pierwszym obszarem dla nas najważniejszym jest edukacja. Przemawia za jej czołową rangą jej fundamentalna rola w budowaniu przyszłości i pomyślności całego narodu i państwa. Mimo oczywistości i powszechności opinii Jana Zamojskiego - „takimi będą Rzeczypospolite - jakie ich młodzieży chowanie” - trzeba ją powtórzyć, aby szczególnie politycy mieli świadomość, że nie sejm, rząd, prezydent są najważniejszymi instytucjami państwa, lecz szkoła! Tymczasem szkoła i jej funkcje są zaniedbywane i poddawane nieodpowiedzialnym manipulacjom polityków. Mamy tego rzeczowy dowód w postaci ostatniej „reformy” oświatowej.

Równość szans, główny warunek dobrego funkcjonowania szkoły i udziału w jej oddziaływaniu dzieci jest fikcją. Młodzież ze środowisk defaworyzowanych uczestniczy w studiach w znikomej 
ilości. Mówię od razu o studiach wyższych, bo te zaczynają się w przedszkolu. To twierdzenie ma głęboki sens. Studia są drogie, stypendia uwarunkowane. Miejsc w domach studenckich nie przybywa, lecz ubywa. Niezwykły skok w liczebności studentów po roku 1990 dokonał się za pieniądze obywateli. Państwo do rozwoju „pojemności” uczelni dołożyło się w ilości ok. 10\% nakładów. Oczywiście część tego nowego nurtu studiów wyższych stała się „biznesem”. Wiejskie regiony kraju, o znacznym rozproszeniu osadniczym, np. lubuskie czy Warmia i Mazury nie stwarzają szans dzieciom na powszechne wychowanie przedszkolne. I to nie wina systemu czy samorządów. Na jedno wiejskie przedszkole na Warmii i Mazurach przypada od 8 do 14 jednostek osadniczych. Odległych w niektórych przypadkach od przedszkola nawet o kilkanaście kilometrów. Z moich badań wynika, że w niektórych badanych gminach do przedszkola uczęszczało zaledwie co drugie dziecko. Brak dostępu do przedszkola to jedna z przyczyn wykluczenia oświatowego. MEN takie sprawy nie spędzają snu z powiek. W reformie tej kwestii nie poświęcono żadnej uwagi. Nie pomyślano o systemie wyrównywania szans poprzez organizację powszechnego wychowania przedszkolnego.

Do szkół podstawowych i do niedawna do gimnazjów dojeżdżało ok. pół miliona dzieci i młodzieży. Wyjeżdżały z domu ok. godziny 7 rano i wracały do domu ok. 15, 16 po południu. Można to racjonalnie wytłumaczyć. Ale nie można ze spokojem przyjąć, że tylko ok. 12\% - 15\% tych dzieci jadło w szkole obiady. To jest niebywały skandal i pogwałcenie wszelkich zasad odżywiania dziecka w tym wieku. Wśród przyczyn znajduje się często brak stołówek szkolnych, ale także ubóstwo. Równocześnie od roku 2010 samorządy zabrały się za likwidację szkolnych stołówek, zastępując je cateringiem. Nie wdając się w szczegóły, praktyka pokazuje, że catering redukuje ilość dzieci korzystających z posiłków o ok. 10\% (wyższa cena). Nie słyszałem o jakimkolwiek zainteresowaniu MEN sprawami odżywiania dzieci. Znam natomiast argumenty samorządów, które likwidację stołówek szkolnych oceniają w kategoriach grubych oszczędności. Czy taka strategia troski o rozwój dzieci przez ministerstwo kwalifikuje się do nagradzania ministra awansem, czy może skierowania sprawy do trybunału stanu? Świadczy o czymś fakt deficytów rozwojowych polskich dzieci. Specjaliści mogą się wypowiadać o przyczynach. Tylko że specjalistów od medycyny szkolnej nie ma. Od lat 80., a nawet wcześniej, ze szkół wyprowadzono opiekę medyczną. 
Zlikwidowano gabinety lekarskie, dentystyczne. Zdziesiątkowano obecność opieki pielęgniarskiej. Efekty są znane: pierwsze miejsce wśród krajów OECD polskich uczniów w dziedzinie próchnicy zębów oraz prymat w wadach postawy i wadach rozwojowych. Nie wspominam tu o zbawiennej roli profilaktyki zdrowotnej, która w wielu wypadkach jest bezcenna dla całego rozwoju dziecka. Ale za to jakie oszczędności uzyskano! W samej Warszawie udało się zaoszczędzić kilkadziesiąt milionów złotych - i to po odliczeniu strat za zdekapitalizowane wyposażenie medycznych gabinetów.

Dodać trzeba jeszcze jeden obszar polityki oszczędnościowej likwidację burs i internatów. Od lat 90. ubyło ok. 120 tysięcy miejsc $\mathrm{w}$ bursach $\mathrm{i}$ internatach. W tym roku $\mathrm{z}$ racji „podwójnego rocznika" ilość chętnych do zamieszkania w internatach przekroczy dziesięciokrotnie ilość wolnych miejsc. Czy można racjonalnie wytłumaczyć redukcję burs i internatów w takiej skali? Oczywiście! Internaty generują wyłącznie koszty. Przeznaczenie ich na inne funkcje może przysporzyć dochodów.

Uprzedzając próby wytłumaczenia tego stanu rzeczy należy stanowczo zaznaczyć, że za kondycję systemu oświaty - wszelkich jego elementów - odpowiada władza państwowa, czyli rząd, a nie starosta, samorząd lub inna instytucja, także w odniesieniu do szkolnictwa prywatnego. Uchylanie się rządu od odpowiedzialności za edukację młodego pokolenia jest hipokryzją i skrajną formą nieodpowiedzialności politycznej. Podobnie jak opóźnienie o rok rozpoczęcia przez dzieci edukacji szkolnej oraz skrócenie czasu obowiązkowej nauki - również o rok. Z racji akceleracji współczesnych dzieci oraz relatywnego wydłużania nauki obowiązkowej w krajach rozwiniętych obie decyzje mają charakter manifestacyjnej głupoty. To jakby celowe przygotowywanie polskich dzieci do pełnienia usługowych, podrzędnych funkcji w zjednoczonej Europie.

$\mathrm{Na}$ koniec tego telegraficznego rejestru niedomogów naszego systemu oświatowego ostatnich lat należy wymienić bezprecedensową komercjalizację zajęć rozwojowych dzieci i młodzieży oraz powszechną komercjalizację oświaty dorosłych, co doprowadziło niemal do całkowitej atrofii klasycznych form „edukacji przez całe życie”. Zajęcia pozalekcyjne i wszelkie inne formy wspomagania rozwoju dzieci i młodzieży dostępne są tylko w większych ośrodkach i dla zamożnych. Całkowicie wykluczone są z nich dzieci wiejskie, a szczególnie dojeżdżające. Wydaje się, że rządząca klasa polityczna nie radzi sobie $\mathrm{z}$ rozumieniem swej roli kreatywnego prowadzenia edukacji narodowej. Oto poseł PiS, i nauczyciel (!), 
Zbigniew Dolata, wygłasza w sejmie opinię: „Nie można sprawy stawiać tak, że to państwo ma utrzymywać oświatę”. Skracając ten mętny wywód, można skutki takiej filozofii przewidzieć w narastających różnicach $\mathrm{w}$ położeniu społecznym, w ograniczeniach dostępu i udziału w formach nobilitującego życia, w dysproporcjach dostępu do dóbr powszechnie pożądanych - szczególnie dzieci z warstw defaworyzowanych i środowisk zaniedbanych!

Dlaczego milczymy w tej sprawie? Bo to polityka? Owszem są prowadzone badania i sporządzane ekspertyzy, ale należą one wyłącznie do dorobku naukowego środowiska akademickiego. Nie mają żadnego wpływu na decyzje polityków, bo są im nieznane lub zostają przez nich lekceważone.

Drugim wielkim obszarem zaniedbań i bezczynności władzy politycznej, a równocześnie naszego braku reakcji są zjawiska i problemy socjalne. Transparentną manifestacją stosunku do tych zjawisk była demonstracja rządu i parlamentu wobec protestujących rodzin $\mathrm{z}$ dziećmi niepełnosprawnymi na terenie sejmu. Jedyną reakcją władz politycznych RP na tę manifestację tragedii rodzin doświadczonych przez los było wzniesienie żelaznych zapór wokół sejmu i rozbudowanie sił porządkowych, które zachowywały się haniebnie wobec protestujących matek z dziećmi niepełnosprawnymi.

Nieudolność lub celowa polityka ministra pracy i polityki społecznej doprowadziła do ukształtowania się specyficznej formy zatrudnienia, która z kolei wywołała powstanie tzw. prekariatu, współczesnej odmiany marksowskiego „lumpenproletariatu” - grup ludzi pozbawionych uprawnień pracowniczych, bądź mogących korzystać z nich jedynie w bardzo ograniczonej formie, i większości praw socjalnych. Znowu w tym zakresie dzierżymy palmę pierwszeństwa w Europie. Mimo jawnej, gorszącej niesprawiedliwości tego stanu rzeczy - rząd nie kiwnął palcem, aby ograniczyć wyzysk niegodny XXI w. i pracę z epoki akumulacji pierwotnej ucywilizować. Natomiast Polacy odpowiedzieli masową emigracją. Ok. 2 miliony, najczęściej młodych ludzi, często dobrze zawodowo wykształconych, wyjechało do krajów zachodnich, aby tam „realizować się na zmywaku”. Część z nich osiąga czasami poważny awans ekonomiczny i prestiżowy. Są wśród nich i tacy, którzy tu, w kraju, jako przedsiębiorcy zostali zniszczeni przez samowolę fiskusa. Czy stać nasz kraj na taką politykę, która wypycha przygotowanych zawodowo młodych ludzi na obce rynki pracy, bo na naszym nie mają szans na godne życie? 
Wielkim wstydem Polski jest istnienie i trwałość enklaw biedy i wykluczenia. Ich archetypem był skandaliczny i, nie waham się użyć tego określenia, przestępczy akt likwidacji Państwowych Gospodarstw Rolnych. Ponad pół miliona rodzin nieodpowiedzialnym aktem politycznym zostało wyzutych z pracy, elementarnego poczucia bezpieczeństwa, wrzuconych w czarną dziurę bezradności i beznadziei. Dzisiaj w dawnych osiedlach popegeerowskich dorasta trzecie pokolenie wykluczonych, które poprzez mechanizmy dziedziczenia skazani są na status „ludzi bez szans”. Nikt nigdy im ręki pomocnej nie podał. W osiedlach tych straszą ruiny dawniej działających przedszkoli i świetlic dla dzieci. Niektórzy pracują „u Pana z Warszawy”, na ziemi - dawniej pegeerowskiej, a dziś sprzedanej za grosze „panu z Warszawy”. Pan z Warszawy jest dobrym panem, bo zadowala się tylko dopłatami unijnym, a płody z ziemi oddaje swoim wyrobnikom (Pilch 2017). Według moich szacunków w takich osiedlach „wykluczenia” zamieszkuje minimum 150 tys. dzieci.

Inną formą wykluczenia są zakładane i ciągle rozbudowywane „osiedla socjalne”, dla ludzi o poplątanych życiorysach, rozbitków życiowych, byłych skazanych, posiadających już status odziedziczonej nieporadności. $Z$ założenia te osiedla są przedmiotem pracy i zainteresowania służb socjalnych. W rzeczywistości to enklawy ubóstwa, nieporadności, miejsca działalności przestępczej i trwałego wykluczenia. Według wyników badań prowadzonych pod moim kierunkiem los mieszkających tam dzieci jest przesądzony. Odziedziczą położenie swoich rodziców, kształcenie zakończą na szkole podstawowej, niekiedy nawet jej nie kończąc. Są potencjalnymi podopiecznymi systemu resocjalizacyjnego. Zjawiskiem gorszącym jest brak jakiegokolwiek programu skutecznej pomocy dla rodzin i tolerowanie bezradności służb państwowych, m.in. Policji, dla działających tam dystrybutorów narkotyków, melin alkoholowych. Tolerowanie pracy mieszkańców, z reguły na czarno, co jest okolicznością o różnorodnych negatywnych konsekwencjach życiowych (zaopatrzenie emerytalne, kredyt mieszkaniowy...). Obserwacje moje dowodzą, że to idealne i klasyczne warunki dla dziedziczenia wykluczenia i powielania losu rodziców przez wychowujące się tam dzieci i młodzież. Sami mieszkańcy są najczęściej także dziedzicami losu swoich rodziców. Zjawisko jest znane, wielokrotnie opisywane i nie zakłóca samopoczucia klasy rządzącej. 
Ale dlaczego polska pedagogika o tym milczy? Dlaczego nie zakłócamy politykom dobrego samopoczucia przez uświadamianie im ich powinności i odpowiedzialności za los bezradnych, a szczególnie za los dotkniętych dramatami życia dzieci i młodzieży?

Szczególnie godna zasygnalizowania, spośród setek problemów socjalnych, jest ponadto nieudolność organów państwowych w realizacji polityki alimentacyjnej. Tolerowanie zatrudnienia dłużników alimentacyjnych na czarno. Proceder tak łatwy do ukrócenia, od lat nie jest przedmiotem zainteresowania władz państwa, a fundusz alimentacyjny tę patologię jeszcze pogłębia. Wiążę się z tym pośrednio „bezdomność” dzieci i ich matek. Liczebnie problem niewielki, psychologicznie i socjalnie dla dziecka wielka tragedia.

Wielkim problemem dla młodzieży dojeżdżającej do szkół staje się narastające wykluczenie komunikacyjne. Rozdęte do patologicznych wymiarów kadry kierownicze kolei państwowych pracują nad racjonalizacją komunikacji kolejowej, co na ogół skutkuje likwidacją kolejnych połączeń. Ofiarami tej racjonalizacji jest młodzież dojeżdżająca, której już przed wielu laty zamknięto wszystkie świetlice kolejowe dla młodzieży, stworzone za czasów realnego socjalizmu. Ostatnio władze PKP „na złość” Owsiakowi zlikwidowały połączenia kolejowe w okolicach Kostrzynia, miejsca festiwalu młodzieży. Nawet nie pomyślały, że ta likwidacja najboleśniej dotknie młodzież dojeżdżającą do szkól. Za ten pomysł, jak to z władzą bywa, nikt nie odpowie. Ale bezmiar bezmyślności polityków poraża.

Cała niemal polityka socjalna ma swoje konsekwencje wychowawcze, pedagogiczne dla dzieci i młodzieży. Odbija się na ich kondycji materialnej, zdrowotnej, możliwościach rozwojowych, aspiracjach edukacyjnych. Polityka rządzącej partii wyrażana rozdawnictwem środków pieniężnych, zasługiwałaby na aprobatę, gdyby jej celem był trwały awans upośledzonych, a nie manipulacja opinią publiczną i kupowanie elektoratu wyborczego. Tymczasem mamy chaos rozdawnictwa i brak nadzoru służb socjalnych nad formami spożytkowania owej politycznej dobroczynności. Warto zwrócić uwagę rządzącym, że dobroczynność jako cnota ewangeliczna była szczególnie popularna w średniowieczu. Dzisiaj dobroczynność ma postać racjonalnej pracy socjalnej.

Czy my, pedagogika polska, ma prawo być wobec tych zjawisk obojętna? Czy nie powinna nie tylko interweniować, ale głośno protestować i nie ulegać sugestiom, że polityka socjalna - to polityka! 
I wara uczonym od polityki! Politycy dawno dowiedli, a przytoczone przykłady dowodzą, że ich kwalifikacje nie dorastają do wielkości zagrożeń, jakie niesie za sobą nieudolna polityka socjalna.

Trzecim wielkim, polskim problemem jest zjawisko, które umownie tu nazwę tolerancją. W pojęciu tym zawiera się zarówno klasyczna kategoria tolerancji, czyli respektowania odmienności i prawa do bycia innym, posiadania cech odrębności i nie doznawania z tego tytułu jakiegokolwiek dyskomfortu. Równocześnie $\mathrm{w}$ pojęciu tolerancji umieszczam specyficzny klimat stworzony przez klasy polityczne, różnych orientacji, styl rządzenia państwem i społeczeństwem poprzez mechanizmy dzielenia, przeciwstawiania jednych grup innym ze względu na enigmatycznie określane cechy. Geneza tej polityki dzielenia narodu, społeczeństwa ma stare tradycje. Nie będę jednak odnosił się do niesławnej tradycji Rzeczypospolitej szlacheckiej, która podziały społeczne wywodziła ze specyficznego rasizmu klasowego, wedle którego chłop był arystotelesowskim mówiącym narzędziem pracy. To naturalistyczne rozumienie klas społecznych znalazło swój wyraz u samych narodzin odzyskanej niepodległości, kiedy hr Tarnowski w sejmie zgłosił konieczność powołania dwu torów kształcenia powszechnego: dla „wyższych klas” i dla „prostego ludu”, dla którego treści nauki „będą niemożebne do pojęcia”. Istniejący od kilku wieków w naszym kraju podział na warstwy wyższe - czyli arystokrację i szlachtę, oraz warstwy niższe - mieszczaństwo i lud, był tak utrwalony, że znalazł kontynuację w poglądach potomków „panów” polskich jeszcze w niemal 130 lat po rewolucji francuskiej. Hr Tarnowski musiał ustąpić przed siłą ruchu ludowego w odrodzonym sejmie, bez którego odzyskanie niepodległości narodowej było niemożliwe. Ale tradycje i echa kształcenia dla bogatych i biednych w zmodyfikowanych formach rozwijane są w naszym kraju w najlepsze. Schodzą już nawet na poziom przedszkoli. Nierówne szkolnictwo, tworzenie elitarnych ciągów kształcenia za duże pieniądze - to nowa forma stratyfikacji współczesnego społeczeństwa.

Tylko polityka nie uległa przymusowi kreowania elitarności w doborze kadr i wciąga w swoją praktyczną działalność każdego, kto posiada określone cechy charakteru i gotowość podporządkowania się hierarchicznej strukturze władzy partyjnej, i gwarantuje wierność naczelnikom partyjnym.

Drugim „umownym” aktem założycielskim odrodzonej Rzeczypospolitej w zakresie budowania klimatu tolerancji i deprawowania 
duszy narodowej był haniebny pogrom lwowski. Opanowany przez wojsko polskie Lwów stał się areną okrutnych ekscesów antyżydowskich, z rabunkami i mordami, przy udziale wojska, dowodzonego przez komendanta obrony Lwowa Czesława Mączyńskiego. Stosunek ówczesnej Polski do lwowskich antysemickich rozruchów ilustruje kariera owego Mączyńskiego, odznaczonego orderami Virtuti Militari i Polonia Restituta, Krzyżem Walecznych, który... został posłem i niemal bohaterem narodowym. Ten tragiczny incydent, skrzętnie latami zatajany przed opinią publiczną, dobrze oddaje klimat rządów Polski międzywojennej wobec mniejszości narodowych. Andrzej Strug, ówczesny pisarz, ostrzegał, „że nacjonalizm będzie zgubą Polski”. To jakby komentarz do aktualnej polskiej polityki i jej losów w zjednoczonej Europie.

Rychło pojawiają się inne akty polskiego nacjonalizmu; niesławne getto ławkowe - haniebny rys na rodzącym się szkolnictwie wyższym. Dziś mamy tylko liczne akty przemocy i inne barbarzyńskie zachowania „prawdziwych Polaków” wobec odmiennych rasowo studentów, ale także wobec ukraińskich studentów, którzy studiują w Polsce za opłatą.

Okres międzywojenny to dla byłej Rzeczpospolitej Obojga Narodów czas obfitujący w zdarzenia i procesy nie tworzące ani jedności narodowej, ani chluby dla polityki wobec mniejszości narodowych, religijnych i względem własnych upośledzonych grup społecznych - rolników i robotników - m.in. w Krakowie i w Małopolsce.

Po wojnie rozpoczął się szczególny czas indoktrynowania świadomości narodowej. Obok pustosłowia o niezwykłych tradycjach polskiej tolerancji, stosowana jest totalna nietolerancja wobec wszystkich i wszystkiego, co nie mieści się w ciasnych kategoriach komunistycznej doktryny. Ten typ nietolerancji jest elementem doktryny zarządzania życiem społecznym, w tym naukowym, artystycznym i pozostawia trwałe ślady w mentalności społecznej jako naturalny mechanizm zarządzania życiem zbiorowym. Ubocznym owocem tych praktyk rygoryzmu ideologicznego jest utwierdzenie zrodzonego już wcześniej podziału świata społecznego i politycznego wedle kategorii: „my” i „oni”.

Jesteśmy aktualnie świadkami powtórnych narodzin schematu rozumowania i praktyki, kiedy to partia rządząca - niegdyś komunistyczna, dziś konserwatywna - tworzy dualistyczną postać świata. Na użytek wewnętrzny partia rządząca tworzy fikcyjny system wartości, w który wprzęga wszelkie patriotyczne, religijne, 
historyczne i wszelakie inne humanitarne wartości, których mieni się strażnikiem, nosicielem i obrońcą. Czyni z nich instrument zarządzania państwem i społeczeństwem. Ubogaca go manipulacyjną polityką społeczną obliczoną na doraźne korzyści wyborcze. Unika, bardzo łatwo, bo nikogo to nie interesuje, refleksji o skutkach gospodarczych i społecznych takiej polityki transakcyjnej dla najbliższego pokolenia. A drugą stronę - „onych” ubiera w szaty wcielonego zła, antypolskości, sprzedawczyków narodowych, świętych wartości, którzy dzielą, chcą zniszczyć, zaprzedać... Jest oczywistością, że podstawowym mechanizmem stosunków i zachowań w takiej formule polityki wewnętrznej jest nietolerancja! W jej najostrzejszej postaci - której emanacją jest m.in. mord na prezydencie Gdańska czy wypadki białostockie.

$\mathrm{Na}$ użytek zewnętrzny klasa polityczna, ciągle nazywająca siebie: „my”, kreuje się na obrońcę narodowych interesów i wartości. Świat zewnętrzny przedstawia jako perfidny spisek, którego celem jest pozbawienie ojczyzny jej wyjątkowego charakteru, wartości, a nawet niezawisłego istnienia. Głosi prawo i konieczność rechrystianizacji Europy, która stacza się w odmęty odrażających ideologii i praktyk. Wszelkie wewnętrzne poczynania, które budzą zdumienie świata zdrowego rozsądku, np. manipulacje wokół wymiaru sprawiedliwości, przedstawia jako heroiczne wysiłki obrony uniwersalnych wartości przed napierającą z Zachodu zgnilizną moralną. I oczywiście, wśród mechanizmów „naprawy” zdemoralizowanego i wrogiego świata Zachodu na czoło wysuwa się - nietolerancja wobec wszystkiego co kłóci się z głoszoną przez klasę rządzącą doktryną zarządzania rzeczywistością. Równocześnie władza usilnie pracuje nad tym, aby nie powstało społeczeństwo obywatelskie. Do rangi jedynie słusznej wizji obywatelstwa urastają woluntarystycznie uznane przez władzę ruchy, grupy oraz organizacje związane z partią rządzącą i popierające ją.

Powyższy opis zawiera elementy groteski, żałosnych zachowań w skali międzynarodowej, drastycznych kłamstw w interpretacji sytuacji wewnętrznych i dramatycznych skutków dla pozycji Polski. Skutki dla naszego kraju są dramatyczne. Z podziwianego za transformację ustrojową lat 80 . kraju spadliśmy do roli osamotnionego i żałosnego organizmu politycznego, wobec którego toczy się najwięcej procesów przed międzynarodowymi trybunałami o łamanie prawa. Kraju, którego przedstawiciele przegrywają wszelkie głosowania na stanowiska kierownicze w organach 
unijnych, kraju zyskującego sławę inicjatora aktów wrogości i nietolerancji wobec innych podmiotów prawa międzynarodowego.

Śledząc przez ostatnie dwa lata doniesienia polskiej prasy odnotowałem kilkaset opisywanych przypadków manifestacyjnych zachowań nietolerancji polskiego społeczeństwa; od groteskowego zasłaniania własną piersią przez „prawdziwego Polaka” wejścia do katolickiego kościoła polskiemu dziecku o czarnym kolorze skóry w Gdańsku, poprzez podpalenie mieszkania zajmowanego przez małżeństwo Polki i Hindusa w Białymstoku, i wielu podobnych ataków na cudzoziemcach, do samobójstwa nastolatków prześladowanych przez rówieśników za odmienną orientację seksualną. Nie można pominąć rozpętanej w ostatnim czasie histerii nietolerancyjnej wobec zjawiska tzw. LGBT, uznanego przez episkopat, a w ślad za nim partię PiS, stowarzyszenie Ordo Iuris i inne równie "racjonalne” byty - za zagrożenie odwiecznego ładu moralnego we współczesnym świecie. Homofobia stała się wręcz oficjalnym stanowiskiem rządu, wspieranego stanowczo w tym zakresie przez władze kościelne, a jeden z publicystów politykę informacyjną rządowych środków przekazu oraz sztukę oratorską przedstawicieli rządu w odniesieniu do jakichkolwiek odmienności obyczajowych nazwał - szczuciem.

I tak można w nieskończoność ukazywać - w kraju, który chce chrystianizować Europę (plan premiera Morawieckiego) codzienne ekscesy pogańskiej wrogości, agresji i nietolerancji. Polska prasa w ciągu roku donosi i dokumentuje ok. 800 do 1 tys. przypadków aktów nietolerancji, zachowań nienawistnych, wrogich.

To wszystko dzieje się w wyniku braku informacji, jawnego kłamstwa, przestępczych zachowań m.in. ludycznych bandytów (kiboli), którzy swoją strategię nienawiści uświęcają w sanktuarium jasnogórskim. Inspiratorami i uczestnikami tych wszystkich zachowań i przekonań są ludzie wychowani w polskim systemie szkolnym! Czy my, polscy pedagogowie, patrząc na ekscesy ludycznych bandytów w Białymstoku, możemy się czuć bez winy i nie powiązani przyczynowo z tymi ekscesami? Czy my, nauczyciele nauczycieli możemy nie widzieć związku sprawczego między naszą pracą a formacją polityków, którzy infekcję nienawiści do odmienności traktują jako cenę za udział w elitach władzy? Czy nie odpowiadamy za władze polityczne, które za główny mechanizm tej władzy uznają obecność wyimaginowanego wroga, najlepiej obcego rasą, wyznaniem, narodowością, ale 
także bliźniego, którego jako wroga wskaże rządząca wyobraźnią publiczną siła polityczna?

Nie mogę w tym zakresie oceniać szkoły. Ale nie są znane przypadki, aby środowisko akademickie zaangażowało się czynnie lub choćby deklaratywnie po stronie ofiar nietolerancji. Tymczasem prawda jest taka, że polskie społeczeństwo jest zarażone chorobą nietolerancji przez politykę i polityków, która dziś dopisuje haniebne karty do historycznych win naszej przeszłości. I dobitnie chcę zaznaczyć, że nietolerancja, to nie antysemityzm, co często jest utożsamiane. To wieki stosunków szlachty do chłopów, inteligencji do robotników, miasta do wsi, wierzących do niewierzących... Kiedy to tragiczne dziedzictwo naszego narodu stanie się przedmiotem troski akademickiej pedagogiki?

Wymieniłem tylko kilka wybranych zjawisk, aby ukazać ważną okoliczność; wszelkie zjawiska, które polityka uznaje za swoje wyłączne pole kompetencji, mają swoje źródła w procesie wychowania i nauczania, i wpływają na działalność szkoły. Wszystko to dzieje się w kręgu naszej zawodowej aktywności oraz naszego zawodowego obowiązku. Przed trzema laty w Białymstoku obradował IX. Ogólnopolski Zjazd Pedagogiki. Akurat reforma wchodziła w życie. Wśród jej regulacji były elementy organizacyjne i programowe. Skutki reformy organizacyjnej widać dzisiaj w nieszczęsnym zderzeniu podwójnego rocznika absolwentów gimnazjum i szkoły podstawowej. Inne skutki organizacyjnych ekscesów władzy, m.in. skrócenie powszechnego kształcenia polskich dzieci oraz opóźnionego startu szkolnego - poznamy w losach pokoleniowych. Podobnie jak skutki reformy programowej przygotowanej przez anonimowych autorów. Znając jednak ideologię klasy rządzącej trudno o optymizm w tym zakresie. Najliczniejsze gremium pedagogiki akademickiej przyjęło projekt reformy tradycyjnym milczeniem.

Mimo to jestem programowym optymistą. Jest ku temu kilka co najmniej przesłanek. Wychowanie i szkoła są odwiecznym procesem i odwieczną instytucją rozwoju człowieka. Mijały epoki, zmieniała się cywilizacja, upadały systemy politycznego istnienia społeczeństw, ale szkoła i jej misja trwały we wszystkich epokach i formach życia zbiorowego. Ludzkość po prostu nie jest w stanie trwać i rozwijać się bez owego, można rzec, biologicznego przymusu kształcenia nowych pokoleń, i w uproszczeniu mówiąc budowania przyszłości przez wychowanie. Oczywiście historyczne formy dydaktyki i wychowania przybierały niepoliczalne postacie. 
Zawsze to jednak była relacja uczeń - nauczyciel, wychowawca wychowanek. Otwartość, empatia społeczna, tolerancja dla słabości to cechy współczesnego wychowania zweryfikowane przez ostatnie wieki zapisanej historii człowieka. Chwilowe zaburzenia tych cech i celów wychowawczych przez ideologię i złą politykę mają także spore tradycje, ale były właśnie chwilowe, w sensie dziejowym, i odchodziły do lamusa historii wraz ze swymi twórcami i strażnikami. I dlatego taką wielką mądrością jest myśl Czesława Czapowa, że „ideologia oślepia, a wiedza oświeca”. Powinniśmy się starać, aby w szkole było jak najmniej ideologii, a jak najwięcej wiedzy i mądrego wychowania. Wiedzy pozwalającej ratować nasz zagrożony świat i przygotowania młodych pokoleń do nieuchronnych zmian, do nieodłącznego od kondycji człowieka współdziałania z drugim człowiekiem i służby potrzebującym. Miejmy nadzieję, że Zjazd pobudzi akademickie środowisko do zabrania głosu w sprawie całości polityki oświatowej państwa - fundamentu, na którym powstaje przyszłość społeczeństwa i kraju.

\section{Bibliografia}

Kwieciński Z. (2018), Utrata złudzeń edukacji publicznej. Fatalne dziedzictwo, eskapizm elit, iskry nadziei, „Studia Edukacyjne”, nr 49, s. 25-39.

Kwieciński Z. (2019), Grzęawisko. Eseje z pedagogiki spolecznej i krytycznej socjologii edukacji, Wydawnictwo Stary Toruń, Toruń.

O krok od pogromu - podpisz apel do wladzy i Kościola (2019), Kampania przeciw homofonii, https://kph.org.pl/o-krok-od-pogromu-podpisz-apeldo-wladzy-i-kosciola/.

Pilch T. (2016), Pokolenie odwróconych pleców. Po 35 latach, „Pedagogika Społeczna", nr 2, s. 13-25.

Pilch T. (2017), Dzieci na drogach Warmii i Mazur, T. Pilch (red.), WSIiZ TWP, Olsztyn. 


\title{
Pedagogiczno-społeczne konteksty bierności obywatelskiej w III RP
}

\author{
Abstract \\ Pedagogical and social contexts of civic passiveness \\ in the Third Republic of Poland
}

The paper presents transformations that have taken place in the Polish educational policy in the context of systemic changes within the past thirty years. The key phenomena that have been analysed include process of education socialisation, crisis in social participation and civic passiveness. The first part of the paper refers to opportunities and options that have become available in the Polish educational system as a result of systemic changes. The second part covers the crisis in social participation and civic passiveness as categories characteristic for the contemporary Polish society. The conclusion presents possible reasons for reluctance in terms of undertaking grassroots actions and involvement in education-related matters as well as actions proposed to stimulate activity and cooperation to contribute to development of democracy in the educational policy.

Keywords: educational policy, education socialisation system, civic passiveness, social participation

Słowa kluczowe: polityka oświatowa, uspołecznienie systemu oświaty, bierność obywatelska, partycypacja społeczna

\section{Wprowadzenie}

Zapoczątkowany w 1989 r. okres transformacji ustrojowej w Polsce postawił przed całym społeczeństwem nowe wyzwania. Pierwsze częściowo wolne wybory parlamentarne były poprzedzone wielomiesięcznym dialogiem prowadzonym przez przedstawicieli władzy i stronę solidarnościowo-opozycyjną. Przełomowy moment stanowiły obrady Okrągłego Stołu, w wyniku których została wypracowana i przyjęta koncepcja zmiany ustroju politycznego i gospodarczego Polski. Proces transformacji 
polityczno-gospodarczo-społecznej miał także ważny wymiar w sferze oświaty, której sytuacja była wyjątkowo trudna. Wśród zjawisk świadczących o kryzysie zinstytucjonalizowanego systemu kształcenia należy wymienić złe warunki lokalowe placówek oświatowych, niski poziom wyników nauczania i wychowania oraz silną ideologizację w zakresie dydaktyczno-wychowawczym. Do tego dochodziła skomplikowana sytuacja kadrowa przejawiająca się brakiem kwalifikacji pedagogicznych u około 120000 nauczycieli (Kupisiewicz 1994: 34). Biorąc pod uwagę powyższe przesłanki u progu lat 90. XX w. oświata polska potrzebowała całościowej reformy programowej i strukturalnej. W trakcie rozmów prowadzonych $\mathrm{w}$ ramach podzespołu do spraw oświaty, szkolnictwa wyższego, nauki i postępu technicznego Okrągłego Stołu zwrócono uwagę na konieczność zwiększenia środków finansowych na edukację, podjęto decyzję o oparciu pracy wychowawczej szkół na zasadach Konstytucji RP i Powszechnej Deklaracji Praw Człowieka, ponadto pojawiły się postulaty uspołecznienia szkoły, zwiększenia autonomii nauczycieli i kompetencji rad pedagogicznych, a także uwolnienia oświaty od ideologii i polityki (Kupisiewicz 1994: 35-36). Kierunki proponowanych zmian miały prowadzić do gruntownych przeobrażeń systemu edukacji i nadania mu demokratycznego oblicza.

\section{Przeobrażenia systemu oświaty w III RP}

Przełom lat 80. i 90. XX w. był w Polsce okresem dynamicznych zmian. Spuścizna po poprzednim systemie politycznym wymagała podjęcia zdecydowanych działań naprawczych także na gruncie oświaty, która potrzebowała dostosowania zarówno jakości, jak i form kształcenia do zmieniającej się rzeczywistości gospodarczej i rynku pracy. Niezbędnym stało się opracowanie nowych założeń polityki edukacyjnej oraz jej koncepcji programowo-organizacyjnych. Prace rozpoczęto od tworzenia nowego prawa szkolnego i projektu reformy systemu edukacji. Przeobrażenia wskazujące na rodzącą się demokrację wprowadziła ustawa o systemie oświaty z dnia 7 września 1991 r. (Dz.U. z 1996 r., nr 67, poz. 329). Zawarte w niej zapisy gwarantowały m.in. wzrost autonomii szkół, możliwość zakładania placówek niepublicznych przez osoby prawne i fizyczne, rozszerzenie kompetencji społecznych organów szkól, wybór dyrektorów poprzez 
konkursy. Reformę ustroju szkolnego wdrożyła ustawa Przepisy wprowadzające reformę ustroju szkolnego z dnia 8 stycznia 1999 r. (Dz.U. z 1999 r., nr 14, poz. 124-134). Tym samym zmodyfikowano strukturę organizacyjną szkolnictwa, programy nauczania, zarządzanie i nadzorowanie oświatą, sposób oceniania i egzaminowania uczniów, system kształcenia i doskonalenia nauczycieli oraz ich awansowania i wynagradzania. Reforma została powiązana z reformą administracyjną, w ramach której powołano dodatkowe szczeble samorządu terytorialnego kraju. Wśród jej podstawowych celów wymieniano zmniejszanie nierówności edukacyjnych, podwyższenie jakości nauczania i racjonalizację wydatków (Zahorska 2009: 122-123).

Kolejne zmiany strukturalne w oświacie wdrożone zostały na podstawie ustawy z dnia 14 grudnia 2016 r. Prawo oświatowe (Dz.U. z 2017 r., poz. 59) oraz ustawy Przepisy wprowadzające ustawę - Prawo oświatowe (Dz.U. z 2017 r., poz. 60) z tego samego dnia. Po raz kolejny zmieniono strukturę systemu oświaty, wprowadzono obowiązek rocznego przygotowania przedszkolnego dla sześciolatków, postulowano wzmocnienie kształcenia ogólnego i zawodowego w szkołach średnich poprzez wydłużenie o rok cyklu kształcenia, wprowadzono trzyletnie kształcenie branżowe z możliwością przygotowania do matury w dwuletniej szkole branżowej II-go stopnia. Wdrażane od 2017 r. modyfikacje spotkały się z licznymi głosami krytyki ze strony przedstawicieli władz samorządowych, ekspertów zajmujących się sprawami edukacji oraz osób, których zmiany te miały dotknąć bezpośrednio uczniów, rodziców i nauczycieli. Odniósł się do nich również rzecznik praw obywatelskich, który przestrzegał, że pospieszne przekształcenie ustroju szkolnego, niepoparte rzetelną analizą, może doprowadzić do pogorszenia się jakości nauczania i naruszania praw uczniów (Reforma edukacji. Działania Rzecznika Praw Obywatelskich w sprawie likwidacji gimnazjów 2019: 4).

Jednym z kluczowych założeń transformacji społeczno-ustrojowej oraz reform systemu edukacji miał być proces decentralizacji i uspołecznienia oświaty polegający na przekazaniu części kompetencji decyzyjnych społeczności lokalnej (w tym rodzicom). Ważnymi elementami zmian miało być wprowadzenie czynnika społecznego do zarządzania szkołą oraz umożliwienie wpływu otoczenia szkoły (tzw. interesariuszy) na model kształcenia i wychowania uczniów. Mimo wielu przekształceń w strukturze i funkcjonowaniu oświaty ani decentralizacja, ani uspołecznienie nie nastąpiły. 
Wprowadzane pomysły jedynie pozornie demokratyzowały system szkolnictwa. Teoretycznie już od lat 90. proces decentralizacji i zwiększenia swobody władz lokalnych w realizacji polityki oświatowej oraz uspołecznienia szkół mógł być realizowany poprzez organizowanie rad rodziców, rad szkół czy rad oświatowych. Niestety w praktyce wciąż było widoczne silne uzależnienie systemu szkolnictwa i kształtu sieci szkół od decyzji organów nadzoru, które uniemożliwiały racjonalne kreowanie i realizowanie polityki oświatowej. To z kolei, z uwagi na wysokie koszty, przyczyniało się do paraliżu działań w obrębie innych polityk publicznych. Sytuacja taka trwa nieprzerwanie do dziś (Kołomycew 2017: 192).

Na przyczyny braku rzeczywistego uspołecznienia oświaty po transformacji ustrojowej zwraca uwagę Bogusław Śliwerski, który wśród powodów opisanego stanu wymienia następujące czynniki: utrzymanie dualistycznej administracji publicznej z podziałem na rządową i samorząd terytorialny, częściową decentralizację zadań i kompetencji samorządu terytorialnego oraz przywrócenie polityki etatyzmu (Śliwerski 2014: 14). Słabości systemu edukacji autor upatruje w nieudolności władz oświatowych, przypadkowości działań i biurokratyzacji. Wszystkie powyższe elementy powodują, że decyzje oświatowe na wyższych szczeblach mają konsekwencje dla lokalnych środowisk szkolnych. Według Śliwerskiego bez radykalnych zmian prowadzących do decentralizacji i uspołecznienia oświaty „nie wyjdziemy z głęboko zakorzenionych w edukacji pozostałości ‘homosowietyzmu’” (Śliwerski 2014: 13).

\section{Kryzys partycypacji społecznej i źródła bierności obywatelskiej}

Możliwość uczestnictwa w życiu społeczno-politycznym, a także konstytucyjnie gwarantowany wpływ obywateli na działania organów władzy państwowej należą do podstawowych zasad demokracji. Lech Szczegóła uważa, że „demokracja (zarówno jako idea oraz jako fakt - empirycznie istniejący porządek polityczny) implikuje normę aktywności obywateli, ich współudziału w polityce" (Szczegóła 2013: 10), natomiast jej istotą jest działanie, które daje możliwość realizacji celów. Maria Mendel i Tomasz Szkudlarek zwracają uwagę, że „demokracja jako proces powstaje w określonych warunkach kulturowych, realizowana jest w określonych praktykach społecznych, m.in. w świadomym korzystaniu 
z praw i wypełnianiu obywatelskich obowiązków” (Mendel, Szkudlarek 2012: 213).

Prezentowane podejścia ujmują demokrację jako proces. Z kolei Małgorzata Karwowska-Struczyk podkreśla znaczenie relacji i konieczność partycypacji społecznej w jej budowaniu. „Demokracja, jako akceptowany ustrój polityczny, tworzy podstawy demokracji społecznej, oddolnej, bez niej jest pusta, pozorna, staje się tylko sloganem bez pokrycia. A zatem musi wyrażać się w specyficznych, charakterystycznych dla siebie, sposobach relacji z innymi” (Karwowska-Struczyk 2012: 134).

Przywołane definicje wskazują na proces, w którym ważne są relacje oparte na aktywności, zaangażowaniu, współdziałaniu. W związku z tym można przyjąć, że największym wrogiem w budowaniu demokracji, w tym również na gruncie edukacji, jest bierność i przekonanie, że pewne wartości, takie jak na przykład wolność czy współstanowienie, są dane raz na zawsze. Sytuacji tej może zapobiec starannie zaplanowana i rzetelnie realizowana edukacja obywatelska przygotowująca do racjonalnego i odpowiedzialnego korzystania z praw społecznych i obowiązków. Kazimierz Przyszczypkowski utożsamia ją z edukacją $w$ i $k u$ demokracji będącą próbą odpowiedzi na potrzebę wychowania społeczeństwa otwartego, gotowego na dynamiczne zmiany i jednocześnie ciekawego tych zmian (Przyszczypkowski 1999: 75-85). Zdaniem autora głównym terenem różnych inicjatyw prowadzących do wzmacniania społeczeństwa obywatelskiego powinna być szkoła, która poprzez swoje działania będzie czynnie wspierała rozwój wspólnoty i państwa demokratycznego. W związku z powyższym najważniejszym wyzwaniem stojącym przed edukacją obywatelską jest kształtowanie prospołecznych dyspozycji i kompetencji obywatelskich uczniów, których wskaźnikami są aktywność, zaangażowanie i partycypacja $\mathrm{w}$ życiu publicznym. O stopniu ich rozwoju decyduja „wszystkie zorganizowane, systematyczne działania edukacyjne mające na celu wyposażenie młodzieży i dorosłych w wiedzę oraz umiejętności niezbędne do uczestnictwa w życiu społecznym i politycznym" (Raabe, Womela 2008: 9-10).

Marta Pietrusińska opisuje kształtowanie kompetencji obywatelskich i społecznych jako jeden z obszarów kompetencji kluczowych. Autorka zgodnie z wytycznymi Parlamentu Europejskiego wiąże kompetencje obywatelskie z „umiejętnościami umożliwiającymi aktywne zaangażowanie w działania społeczne i polityczne na różnych poziomach” (Pietrusińska 2018: 141). 
Kolejnym ważnym czynnikiem przeciwdziałającym kryzysowi partycypacji i bierności obywatelskiej jest proces budowania kapitału społecznego:

Kapitał społeczny pełni szczególną rolę edukacyjną, rozwijając określone wzory zachowań i instytucje społeczne adekwatne do demokratycznej organizacji społecznej. Jest więc niezbędnym czynnikiem, który powoduje że charakterystyczne dla demokracji uprawnienia osób i grup oraz formy organizacyjne tworzą demokratyczny ład społeczny (Theiss 2009: 95).

W relacjach społecznych istotnym elementem budującym kapitał społeczny i wzmacniającym więzi jest zaufanie, które pozwala oczekiwać, że ludzie wywiążą się z podjętych zadań. Piotr Sztompka pisze o tym następująco: „Podstawą skutecznego współdziałania jest wzajemne zaufanie członków grupy. Zaufanie to oczekiwanie, które rodzi się w zbiorowości na temat regularnego, uczciwego kooperującego zachowania innych członków wspólnoty, w oparciu o wspólnie uznane normy" (Sztompka 2007: 70).

Członkowie społeczności nie muszą zgadzać się ze sobą we wszystkich kwestiach, ważne jest by czuli więź opartą na wspólnocie celów i wartości, co ułatwia współdziałanie. Czynnikiem warunkującym pomyślną współpracę jest również wiarygodność, która jest kategorią silnie powiązaną z pojęciem zaufania. W teorii dotyczącej budowania bardziej złożonych relacji Sztompka wskazuje na sześć fundamentów, którymi oprócz zaufania są lojalność, wzajemność, solidarność, szacunek i sprawiedliwość. „Te sześć relacji elementarnych to swoisty budulec relacji bardziej złożonych. Powód, dla którego nie dołączam do tej listy takich, intuicyjnie równie ważnych relacji, jak współpraca czy przyjaźń, jest właśnie taki: to są relacje złożone z różnych kombinacji tych sześciu relacji podstawowych" (Sztompka 2019: 12).

W praktyce pomiędzy wymienionymi terminami zachodzi silna korelacja i są one ściśle powiązane z budowaniem kapitału społecznego, który „obejmuje przydatne sieci społeczne, poczucie wzajemnego zobowiązania i wiarygodności, znajomość norm kierujących skutecznym postępowaniem i - szerzej rzecz ujmując - inne zasoby społeczne, dzięki którym jednostki skutecznie działają" (Giddens 2012: 818).

W dzisiejszym świecie zacieśnianie więzi społecznych opartych m.in. na zaufaniu, lojalności czy wiarygodności oraz budowanie kapitału społecznego są głównymi czynnikami warunkującymi 
rozwój. W obliczu wielu słabości i niedoskonałości współczesnego systemu oświaty należy zadbać o wspomniany kapitał społeczny, podejmować dyskusje, rozmowy i działania prowadzące do zmian. Wagi tych procesów nie dostrzegają niestety władze, które nie są zainteresowane uczestnictwem podmiotów edukacji w procesach decyzyjnych dotyczących kształtowania polityki oświatowej, i które w żaden sposób nie zachęcają do dialogu i partycypacji społecznej. Śliwerski zwraca uwagę, że w polityce oświatowej wciąż dominuje typ pseudodialogu, w którym nie chodzi o porozumienie władzy ze społeczeństwem, a jedynie o osiągnięcie określonego celu (Śliwerski 2016: 314).

Bez wątpienia przyczyn obecnej sytuacji związanej z biernością obywatelską można doszukiwać się w okresie przed transformacją ustrojową i w uwarunkowaniach społeczno-politycznych czterdziestu lat destrukcyjnego upaństwawiania społeczeństwa, kiedy władza brała odpowiedzialność za wszelkie przejawy życia publicznego i nadawała kierunek procesom społecznym. O konsekwencjach komunizmu dla aktywności obywatelskiej pisał Józef Tischner (1993), który jako jeden z pierwszych przywołał koncepcję homo sovieticus (człowieka cechującego się m.in. biernością i postawą roszczeniową). W sposobach sprawowania rządów realnego socjalizmu odrzucano istnienie pluralistycznych interesów grupowych, środowiskowych czy jednostkowych. Paradoksalnie przez trzydzieści lat wolności sytuacja niewiele się zmieniła „nadal żyjemy w państwie scentralizowanym, w którym dają o sobie znać pozostałości po minionym ustroju, a wywodzące się z przeszłości wzorce centralizmu zostały zastąpione skrywanym przez władze etatyzmem" (Śliwerski 2014: 12).

Aktualnie, pomimo możliwości wdrażania oddolnych zmian, w wielu obszarach życia widoczna jest tendencja do wycofywania się z oferowanych przez system szans partycypacji społecznej. Brak zaangażowania i bierność obywatelską można zaobserwować również w kontekście szeroko rozumianej edukacji. Decyzje w kwestiach programowych i finansowych placówek oświatowych zapadają odgórnie chociaż powinny i mogłyby zapadać w porozumieniu z przedstawicielami organów społecznych o charakterze konsultacyjnym i opiniodawczo-doradczym. Prawa obywateli do społecznego udziału w sprawowaniu władzy, kontroli i stymulowaniu procesów rozwojowych w szkolnictwie gwarantuje możliwość tworzenia rad oświatowych (przy organach samorządowych) oraz powołania krajowej rady oświatowej (która na przestrzeni 
trzydziestu lat nigdy nie powstała). We współczesnej szkole wpływ na proces jej uspołecznienia miały mieć takie instancje, jak: rada szkoły, rada rodziców, rada pedagogiczna oraz samorząd uczniowski. Pomimo różnych możliwości podjęcia społecznej aktywności wciąż jej brak, a jeśli występuje, często są to działania wymuszone i pozorowane. Taki stan może świadczyć o niskim poziomie zaufania społecznego, potrzebie odbudowania etosu służby publicznej, konieczności podejmowania prób prowadzenia dialogu, budowania kapitału społecznego, a także zadbania o odpowiedni poziom edukacji obywatelskiej.

\section{Zakończenie}

Przyczyn bierności obywatelskiej Polaków można doszukiwać się w specyficznych doświadczeniach autorytarnych, postkomunistycznej mentalności, braku poczucia sprawstwa czy wyuczonej bezradności. W opinii Szczegóły „rozmiary bierności politycznej społeczeństwa pozostają w związku z niską jakością funkcjonowania polskiej demokracji” (Szczegóła 2013: 15). Pomimo upływu trzydziestu lat od transformacji ustrojowej należy zaznaczyć, że metrykalnie jest to krótki czas wdrażania zmian, co pozwala stwierdzić, że w porównaniu z krajami zachodnimi polska demokracja jest jeszcze niedojrzała. Do tego stanu przyczyniło się m.in. szybkie tempo dezintegracji systemu autorytarnego i przejście do nowego ładu społeczno-politycznego. Szczegóła opisuje sytuację Polski okresu transformacji, porównując ją do zjawiska określanego mianem hiszpańskiego terminu „desencanto” (Szczegóła 2013: 131). Jest to proces, który odzwierciedla charakterystyczną dla ewolucji postaw politycznych społeczeństwa dynamikę wyczerpywania się entuzjazmu zauważalnego zazwyczaj w pierwszej fazie tranzycji do demokracji. W polskiej polityce oświatowej zjawisko to można było zaobserwować w okresie przemian przypadających na lata 1980-1992. Była to pierwsza faza

dojrzewającego buntu i oporu, przygotowująca dzięki racjonalności hermeneutyczno-emancypacyjnej polskie elity oświatowe i pedagogiczne do transformacji ustrojowej. Ten okres pierwszych lat po Okrągłym Stole i wolnych wyborach, po zmianie ustroju politycznego państwa, który cechowała fala euforii wolnością związana z rodzącą się demokracją, pluralizmem i otwartością; jest to faza nasycona racjonalnością emancypacyjną w polityce oświatowej (Śliwerski 2015: 162). 
Niestety po krótkim okresie dynamicznych przemian w polityce oświatowej nastąpił powrót do centralizacji i etatyzmu. Potwierdzają to wieloletnie badania Śliwerskiego pokazujące centralistyczny układ nadzoru i zarządzania szkolnictwem, lekceważenie społecznych organów doradczo-kontrolnych, w tym opinii rodziców bądź prawnych opiekunów dzieci, deprecjonowanie wyników badań naukowych i bagatelizowanie przebiegu procesów glokalnych (Śliwerski 2013, 2016: 316). Ponadto wciąż widoczna jest postawa bierności i niechęci do podejmowania działań i partycypacji społecznej ze strony społeczności lokalnych. Wydawało się, że czynnikiem, który przyczyni się do zmiany tej sytuacji i spowoduje wzrost zaangażowania obywatelskiego będzie nadanie uprawnień i określonego zakresu kompetencji w sprawach oświaty jednostkom samorządu terytorialnego. Fakt ten powinien być bodźcem do podejmowania aktywności społecznej i działań sprzyjających rozwiązywaniu problemów lokalnych placówek edukacyjnych. Jest to szczególnie ważne ponieważ ze względu na odmienne uwarunkowania gospodarcze, społeczne, kulturowe, organizacyjne jednostek proces edukacji może różnie przebiegać. Działania będące w kompetencjach terenowych rad oświatowych desygnowanych przy organach samorządowych, rad szkoły, rad rodziców czy innych oddolnie powoływanych organizacji, mogłyby przyczynić się do poprawy funkcjonowania oświaty. To z kolei prowadziłoby do wzrostu uspołecznienia i poprawy efektywności działań edukacyjnych i wychowawczych realizowanych przez szkoły. Większa swoboda decyzyjna przyznana placówkom oświatowym, a w konsekwencji ich wewnętrznym podmiotom, może sprzyjać wzrostowi efektywności kształcenia poprzez zwiększenie motywacji, samodzielności i niezależności uczniów, nauczycieli i rodziców.

Proces uspołecznienia oświaty, rozumiany jako faktyczny udział społeczności lokalnych w świadczeniu usług publicznych, poza zaangażowaniem wymaga aktywnej postawy, wiedzy i umiejętności organizacyjnych. Do tego powinien przygotować system edukacji uwzględniający m.in. trening zachowań obywatelskich wyłaniający osoby predystynowane do roli przyszłych liderów. Niestety obecny system kształcenia zaniedbał wychowanie obywatelskie, które jest niezbędnym elementem wdrażającym do funkcjonowania $\mathrm{w}$ demokratycznym społeczeństwie. W celu zapobiegania bierności obywatelskiej warto przyjrzeć się treściom zawartym w programach nauczania z zakresu edukacji obywatelskiej i zwrócić 
baczną uwagę na proces budowania kompetencji i kształtowania postaw obywatelskich młodych ludzi. Współcześnie ani szkoła, ani rodzina nie uczy „obywatelskości”, przez co rośnie pokolenie aspołecznych młodych ludzi, u których dominuje przewaga postaw indywidualistycznych nad zachowaniami prospołecznymi. Konsekwencją takiego stanu jest niska aktywność obywateli angażujących się w działalność wspólnot i realizację zadań na własnym terenie.

W obliczu kryzysu partycypacji społecznej i utrzymującego się zjawiska bierności obywatelskiej należy zastanowić się, jak włączyć lokalne społeczności w nurt kształtowania się społeczeństwa upodmiotowionego, aktywnego w życiu społecznym i publicznym. W celu przeciwdziałania opisanej sytuacji warto rozważyć takie działania, jak:

1. prowadzenie rzetelnej edukacji obywatelskiej, której celem będzie upowszechnianie wiedzy i kształtowanie umiejętności pozwalających na aktywne uczestnictwo w życiu społeczno-politycznym, w którym obywatele będą zdolni do współpracy i działania na rzecz wspólnego dobra;

2. podjęcie dialogu obywatelskiego i budowanie rzeczywistych, a nie fasadowych relacji opartych na dialogu społecznym;

3. aktywizowanie społeczności lokalnych poprzez budowanie lokalnej wspólnoty, w tym budowanie relacji między ludźmi, wzajemnego zaufania i zaangażowania we wspólne sprawy dotyczące edukacji;

4. aktywizowanie społeczeństwa w sprawach publicznych polegające na wspieraniu oraz promowaniu zaangażowania i zainteresowania sprawami lokalnej polityki oświatowej, w tym organizowanie debat publicznych dotyczących edukacji (przykładem może być ogólnopolska akcja Narad Obywatelskich o Edukacji zorganizowana $\mathrm{w}$ związku ze strajkiem podjętym przez nauczycieli w 2019 r.);

5. partycypacja obywatelska i współudział w rządzeniu, a także kontrola zadań powierzonych administracji publicznej.

Dzięki podjęciu powyższych kroków społeczeństwo polskie ma szansę na budowanie swojej drogi ku rzeczywistej demokracji. Aktualnie, po trzydziestu latach wolności, poziom aktywności obywatelskiej i kapitału społecznego w Polsce jest jednym z najniższych w Unii Europejskiej, co świadczy o tym, że wciąż nie jesteśmy społeczeństwem obywatelskim, a proces uspołecznienia w różnych obszarach życia nadal jest pozorny. W kontekście polityki 
oświatowej potwierdza to Śliwerski, pisząc: „W okresie transformacji 1989-2016 edukacja polska nie stała się źródłem zachodzących w kraju przemian. Wyłaniane w wyniku wyborów kolejne formacje władzy w resorcie edukacji zamiast decentralizować i decentrować ustrój szkolny, prowadziły do kreowania rzekomo nowych modeli szkoły w gorsecie centralizmu” (Śliwerski 2016: 313).

\section{Bibliografia}

Giddens A. (2012), Socjologia, PWN, Warszawa.

Karwowska-Struczyk M. (2012), Edukacja przedszkolna. W poszukiwaniu innych rozwiazań, Wydawnictwo Uniwersytetu Warszawskiego, Warszawa.

Kołomycew A. (2017), Uspolecznienie procesu realizacji zadań oświatowych jako forma racjonalizacji polityki publicznej gmin, "Środkowoeuropejskie Studia Polityczne", nr 3, s. 191-213.

Kupisiewicz C. (1994), Propozycje $i$ kierunki reform szkolnych w USA, Anglii $i$ Polsce na przełomie lat osiemdziesiątych $i$ dziewięćdziesiątych, Wydawnictwo „Żak”, Warszawa.

Mendel M., Szkudlarek T. (2012), Demokratyczna izolacja. Krytyczna partycypacja obywatelska, „Zoon Politikon”, nr 3, s. 207-222.

Pietrusińska M.J. (2018), Wspótczesne wyzwania edukacji obywatelskiej dorostych $w$ Polsce, [w:] M. Gromadzka (red.), Przestrzenie i miejsca edukacji dorostych $w$ Polsce, Wydawnictwo FRSE, Warszawa.

Przyszczypkowski K. (1999), Edukacja dla demokracji. Strategie zmian a kompetencje obywatelskie, Wydawnictwo Edytor, Toruń-Poznań.

Raabe S., Womela P. (2008), Stowo wstępne, [w:] K. Siellawa-Kolbowska (red.), Edukacja obywatelska $w$ Niemczech $i$ Polsce. Raport z badań, Instytut Spraw Publicznych, Warszawa.

Reforma edukacji. Dziatania Rzecznika Praw Obywatelskich w sprawie likwidacji gimnazjów, (2019), s. 3-4, https://www.rpo.gov.pl/sites/default/ files/Raport\%20-\%20RPO\%20ws\%20reformy\%20edukacji.pdf (dostęp: 28.10.2019).

Szczegóła L. (2013), Bierność obywateli. Apatia polityczna w teorii demokratycznej partycypacji, Dom Wydawniczy Elipsa, Warszawa.

Sztompka P. (2007), Zaufanie. Fundament spoleczeństwa, Wydawnictwo Znak, Kraków.

Sztompka P. (2019), Sześć fundamentów wspólnoty, „Rzeczpospolita” 226, 27.09.2019.

Śliwerski B. (2013), Diagnoza uspolecznienia publicznego szkolnictwa III RP $w$ gorsecie centralizmu, Oficyna Wydawnicza Impuls, Kraków.

Śliwerski B. (2014), Pedagogika (w) demokracji, „Rocznik Pedagogiczny”, nr 37, s. 9-36.

Śliwerski B. (2015), Racjonalność pedagogiczna polskiej polityki oświatowej w latach 1989-2014, [w:] R. Nowakowska-Siuta, B. Śliwerski, Racjonalność procesu kształcenia. Studium z polityki oświatowej i pedagogiki porównawczej, Oficyna Wydawnicza Impuls, Kraków. 
Śliwerski B. (2016), Kryzys oświatowej demokracji w świetle makropolitycznych badan pedagogicznych, „Przegląd Pedagogiczny”, nr 2, s. 313-322.

Theiss M. (2009), Krewni - znajomi - obywatele. Kapitat spoteczny a lokalna polityka spoleczna, Wydawnictwo Adam Marszałek, Toruń.

Tischner J. (1993), Nieszczęsny dar wolności, Wydawnictwo Znak, Kraków.

Ustawa z dnia 7 września 1991 r. o systemie oświaty (Dz.U. z 1996 r. nr 67, poz. 329).

Ustawa z 8 stycznia 1999 r. Przepisy wprowadzające reformę ustroju szkolnego (Dz.U. z 1999 r. nr 14, poz. 124-134).

Ustawa z dnia 14 grudnia 2016 r. - Prawo oświatowe (Dz.U. z 2017 r., poz. 59)

Ustawa z dnia 14 grudnia 2016 r. Przepisy wprowadzające ustawę - Prawo oświatowe (Dz.U. z 2017 r., poz. 60).

Zahorska M. (2009), Sukcesy i porażki reformy edukacji, „Przegląd Socjologiczny", t. 58, nr 3, s. 119-142. 


\title{
Odwaga dialogu, wspólnotowości i sceptycyzmu. Uniwersytet w obronie rudymentarnych wartości stanowiących o jego (prze)trwaniu
}

\author{
Abstract \\ The courage of dialogue, community \\ building and scepticism. University in defense \\ of the values rudimentary to its survival
}

University - both in the Middle Ages and today - has been a part of the society and was prone to processes similar to the societal ones, which determined its functioning. Last decades rapidly accelerated the discussions about contemporary higher education institutions. The aim of the article is to indicate the expectancies towards the university expressed by individuals and social groups, as well as by the state. A contemporary state does not need engaged citizens, it needs competent users of an institution, which radically changes the expectancies towards university. It is often acknowledged that the university should equip students not with general knowledge, but specific skills enabling them to function in social life. It is contrary to the idea of general education, in which not only knowledge, but also specific cultural dispositions: openness to otherness, negotiation skills and respect towards other worldviews are crucial. The article calls to traditional university values and describes how their perception has changed in the contemporary university.

Keywords: university, values, rationality of education, contemporary university models

Słowa kluczowe: uniwersytet, wartości, racjonalność kształcenia, modele uniwersytetu współczesnego 


\section{Wprowadzenie}

Współczesne Uniwersytety stanowią integralną część nie tylko systemu edukacyjnego, ale także szerzej - systemu funkcjonowania społeczeństwa, i podlegają przemianom podobnie jak ów system. Intensywny namysł nad zachowaniem lub zniesieniem dotychczasowych zadań Uniwersytetu nie jest specyficzny dla czasów, w których żyjemy. Także wieki minione obfitowały w rozliczne spory dotyczące edukacji i Uniwersytetu jako jej integralnej części. Często spory te przybierały postaci gwałtownych rewolucji, w wyniku których podejmowano radykalne reformy nie tylko krytykowanych instytucji, ale czasem także i całościowych form życia społecznego. Mam tu na myśli chociażby ruch reformacyjny w Europie zapoczątkowany wystąpieniem Marcina Lutra (1517) i występujące w wielu krajach Europy dyskusje na temat odnowy życia kościelnego, czy też gruntowne zmiany modeli życia społecznego, ekonomicznego, religijnego i naukowego w epoce wiktoriańskiej w Anglii (1837-1901), za przyczyną których stała się ona demokracją liberalną gwarantującą wiele praw obywatelskich.

Ostatnie dekady cechowało bezprecedensowe przekraczanie granic. Tradycyjne wyobrażenia o porządku społecznym i politycznym zostały zakwestionowane przez gospodarczą i kulturalną globalizację, pojawienie się i rozpowszechnienie nowych technologii, które wpływają na postrzeganie rzeczywistości, a zatem i myślenie, oraz zasadniczy i naznaczony kryzysami przełom w stosunkach międzynarodowych. Nowe formy życia społecznego, wcześniej nieznana mobilność i przekształcanie stosunków pracy, przyniosły poszerzenie wolności i pól działania - nie zawsze o charakterze pozytywnym. Zmiana wspólnej kultury nie wynika jedynie z zewnętrznej presji na adaptację, ale bierze się również z dystansu lub obojętności wobec własnych tradycji. W tym samym stopniu dotyczy to regionalnych zwyczajów i religijności, jak i kultury akademickiej, będącej niezbywalną częścią społecznych struktur.

\section{Zachować wartości pomimo ich deprecjacji - czyli Uniwersytet w świecie współczesnym}

Dążenia do dostosowania Uniwersytetu do wymagań współczesnego świata sprawiają, że Uniwersytet - miejsce odkrywania prawdy, wspólnotowości, stawiania wolnych pytań, dialogu 
i debaty, bezinteresowności i racjonalności - zaczyna podlegać przede wszystkim argumentacji rynkowej i partykularnym interesom rozmaitych grup społecznych.

W efekcie tego znika z pola widzenia m.in. znaczenie szerokich podstaw wiedzy i kreatywności na rzecz dostosowania procesu kształcenia do ram kwalifikacji zawodowych, a krytyczne myślenie i bogactwo języka ustępują umiejętnościom prezentowania szablonowych wiadomości. W dążeniu do dostosowania Uniwersytetu do nowego, zmiennego i chaotycznego sposobu funkcjonowania społeczeństw mogą ulec zatraceniu jego cechy, które przez stulecia decydowały o jego przemożnym wpływie na świat.

Nie ulega wątpliwości, iz horyzontem poznania humanistycznego i hermeneutycznego jest prawda wykuwana $\mathrm{w}$ drodze racjonalnej debaty. To dzięki debacie (dialogiczności i spotkaniu) uwiarygodnieniu lub zakwestionowaniu podlega poznanie. Chcę się zatem zastanowić po pierwsze nad ujmowaniem zadań Uniwersytetu w perspektywie procesu dziejowego oraz nad kilkoma ważnymi aspektami jego dzisiejszego funkcjonowania w tym odpowiedzialności za sprawności jednostkowe i wspólnotowe umożliwiające dialog kulturowy.

Biorąc pod uwagę zadanie pierwsze, zasadnicze staje się pytanie, jak moglibyśmy w rozumny sposób uczynić zrozumiałym chaos zdarzeń, losów i poczynań, które jawią się naszym oczom.

Niemiecki historyk Johann Gustav Droysen mówił, iż nie ulega wątpliwości, że w pełni rozumiemy to, co jest, gdy rozpoznajemy, jak ono powstało (Leyh 1977). Według niego „rozpoznawanie” (Erkennen) występuje jako wariant „rozumienia” (Verstehen). Istotne jest to, że hermeneutyczna tradycja jest skłonna utożsamiać ze sobą rozumienie, „co" i „skąd”, istoty rzeczy i jej stawania się. Anselm von Feuerbach przedstawiał to zagadnienie następująco: „Historia wyjaśnia w jaki sposób Coś stopniowo powstawało; o tym, jak i czym to Coś jest, historia nie poucza. To co należy do historii obumarło dla życia" (Hattenhauer von 2002: 153). Friedrich Carl von Savigny odpowiada zaś:

Ten pogląd na historię jest bardzo dziwny. Czyż można bowiem pojmować teraźniejszość stanu inaczej niż w powiązaniu z jego przeszłością, tzn. inaczej niż w sposób genetyczny? $\mathrm{Z}$ tego co niegdyśs uznawano za prawo wynikło prawo obecnie obowiązujące, i jest ono tym, czym i jak jest. [...] tylko bezduszny tłum gapiąc się stoi przed tym, co jest, niczego więcej nie dostrzegając, i nie chce widzieć nic, prócz tego, że coś jest: ale pytania ,jak?' lub ,dlaczego?' zastrzega dla siebie każdy umysł wyższego rodzaju (cyt. za Hattenhauer von 2002: 154). 
W sensie metodologicznym jedyną zatem stosowną formą przedstawienia procesu dziejowego i zachodzących w nim zmian jest nie statyczny opis „jak było i jest” lecz dynamiczny narratywizm „skąd i dlaczego się wzięło to co było i to co jest” (rozumienie, czyli uchwycenie znaczeń). Opowieści różnią się od kronikarskiego porządkowania danych tym, że organizują je w jakiejś strukturze czasu i z perspektywy znaczenia tego, co było wcześniej, dla tego, co stało się później (zauważmy jak wiele odnajdujemy np. w rzeczywistości współczesnej polskiej debaty politycznej, także tej, która niestety pojawia się i na Uniwersytetach, analogii do lat 20. i 30. XX w. - brutalizacja języka, obrażanie innych ze względu na ich odmienność (różnorodną), kuszenie populistycznymi obietnicami, uwielbienie dla tzw. wartości tradycyjnych, które obnażone okazują się często fundamentalistycznym przekonaniem o wyższości jednych nad drugimi, konfrontacja i permanentny konflikt zamiast dialogu i partycypacji.

Czy w świecie niepokoju i chaosu jest możliwe nadawanie wydarzeniom partykularnego i arbitralnego znaczenia - a jeśli tak, to w jaki sposób - oraz ocalenie rudymentarnych dla Uniwersytetu wartości i będących ich emanacją postaw:

1. szacunku dla wolności i różnorodności myślenia (Freiheit; liberty), rozumianej nie jako dowolność wyboru każdego rozwiązania lecz jako szacunek dla swobody poszukiwań/dociekań prawdy;

2. respektu dla wątpienia (Zweifel; skepticism) o prawdziwości stwierdzeń - będącego podstawą postępu naukowego, i wreszcie;

3. krzewienia racjonalności (Vernunft; rationality) sądów o świecie, będącego przeciwwagą dla wszelkiego rodzaju ułudy, pozoru i mistyfikacji w świecie, który dopuszcza prawomocność każdego sądu (por. Nowakowska-Siuta 2018).

Klamrą spinającą te trzy kategorie definiujące Uniwersytet jako wspólnotę był i jest dialog. Akademickie dialogi (dysputy, debaty) od średniowiecza stanowiły podstawę dociekań. Argumentacja opierać się musiała na logice, retoryce, dialektyce, miała swój kanon, własne zasady etyczne, przy czym dążenie to wymagało od uczonego przede wszystkim pokory i unikania pokusy, zwanej ambitio dignitatis.

Średniowieczne dochodzenie do prawdy miało oczywiście reguły wyznaczane przez scholastyczne przekonanie, iż obowiązkiem uczonego jest uznawanie wiedzy już pozyskanej i dowiedzionej. Pojęcie wolności naukowych dociekań stało się dopiero zdobyczą humboldtowskiej XIX-wiecznej reformy Uniwersytetu. 
Chęć odkrywania prawd naukowych, racjonalizm, innowacyjność, oryginalność i dialogiczność to zjawiska stojące niejako w kontraście do średniowiecznej powściągliwości, choć wiele cech Uniwersytetu z tradycji średniowiecznej zachowało się w kolejnych wiekach - przecież w neohumanistycznym ujęciu uniwersyteckich wartości dziedzictwo przeszłości jest wartością, którą należy pomnażać i ubogacać. Jedynie szacunek dla tego dziedzictwa zapewnia racjonalność i sensowność każdej innowacji.

W wieku XIX, a także następnych, reformy stały się permanentnym składnikiem życia akademickiego. Na dawnych fundamentach budowano pojęcie wolności akademickiej, choć czasami miało (i ma) ono wydźwięk sentymentalny, zwłaszcza w złożonych stosunkach między państwem i Uniwersytetem, ale także w sensie jednostkowym - wierzę, że można w drodze wymiany myśli dojść do porozumienia. Autonomia nauki i wolność nauczania sprawiała, iż poszczególni uczeni mogli swobodnie decydować o kierunkach podejmowanych badań, wyborze metod badawczych. Mogli swobodnie wypowiadać się na tematy społeczne i polityczne, a gwarantem niezależności była zasada stałego zatrudnienia i nieusuwalności ze stanowiska. Stały związek uczonych z własną dyscypliną naukową pozwalał na poszerzanie zakresu kompetencji naukowych i budowanie autorytetu. Ale też wolność myśli i ich wyrażania opierała się na obowiązujących i respektowanych normach, jak:

- uniwersalizm,

- wspólnotowość,

- dialogiczność,

- bezinteresowność,

- sceptycyzm,

- oryginalność.

Dodatkowo jedną z istotniejszych kwestii dotyczących nauki w XIX w., wymienianych przez Leibniza i kontynuowanych przez Wilhelma von Humboldta, była więź pomiędzy nauką i nauczaniem. Oznaczała ona profesjonalizację i personalizację jednocześnie. Profesjonalizację - bo nauka to warsztat w działaniu, a nauczanie to wdrażanie tego warsztatu do działania. Personalizację - bo związek nauki i nauczania realizuje się przez więź osobistą nauczyciela i ucznia, uczonego i adepta. Jedyną realną drogą urzeczywistniania tego związku wydawała się być indywidualizacja nauczania i dróg naukowych, co ujawniało się w idei humboldtowskiej i do dziś budzi tyleż samo pozytywnych, co krytycznych uwag i rozważań. 


\section{Wielość idei Uniwersytetu a potrzeba stabilności i stawiania granic nieracjonalnościom $\mathrm{w}$ myśleniu}

Współcześnie trudno mówić o dominacji jakiejś jednej idei, która mogłaby sterować funkcjonowaniem współczesnego Uniwersytetu. Jego organizacja jest wypadkową wielu czynników, nie zawsze uświadamianych. Zdarza się, iż na tym samym terenie, prawie obok siebie, w granicach tego samego państwa, wspólistnieją Uniwersytety oparte na zupełnie różnych ideach - czego przykładem mogą być Stany Zjednoczone. Nakładają się na siebie dzisiaj jednocześnie odmienne (aktualne i spodziewane) kierunki zmian $\mathrm{w}$ różnych systemach narodowych oraz (aktualne i spodziewane) kierunki zmian na poziomie europejskim. Przedsięwzięcie akademickie w Europie staje się zatem coraz bardziej skomplikowane. Być może mamy obecnie do czynienia z kolejną, jak to nazwał Allan Bloom (1996) w swojej książce Umyst zamknięty, zmianą układu pomiędzy filozofem a społeczeństwem obywatelskim. O ile zmiana oświeceniowa przyniosła nieznany wcześniej aksjomat, zgodnie z którym postęp wiedzy i postęp polityczny wzajemnie się warunkują, o tyle dzisiejsze wyczerpywanie się projektu nowoczesności prowadzić może do zerwania wprowadzonych w oświeceniu trwałych związków wiedzy i władzy. Dzięki obietnicom filozofów oświecenia, pisze Bloom, „rozum był nie tylko akceptowalny dla społeczeństwa obywatelskiego, ale również zyskał w nim sobie naczelne miejsce. Społeczeństwo oparte na rozumie potrzebuje tych, którzy najlepiej rozumują” (Bloom 1996: 27). I dalej: „Oświecenie było śmiałym przedsięwzięciem. Stawiało sobie za cel tak przebudować życie polityczne i umysłowe, aby znalazło się w całości pod nadzorem filozofii i nauki” (tamże). Bloom idzie jeszcze dalej, stwierdzając, że uniwersytety są „osnową liberalnej demokracji, jej fundamentem, rezerwuarem zasad, które je ożywiają, oraz nie wysychającym źródłem wychowania i wiedzy napędzającej maszynerię ustroju” (tamże: 32). Wolny uniwersytet istnieje zatem tylko w ustroju wolnościowym.

Dzisiejsza rosnąca złożoność podejść do roli i funkcji instytucji Uniwersytetu spowodowana jest tym, że systemy szkolnictwa wyższego znajdują się pod permanentną presją reform. W coraz większym stopniu dzisiejsze fale reform wprowadzanych w życie we wszystkich systemach europejskich prowadzą do ich kolejnych 
fal. Reformy wywołują kolejne reformy. Być może kres pewnej idei uniwersytetu jest kresem pewnej jego filozoficznej idei. Ale czy może być inna? Czy może istnieć uniwersytet pozbawiony stojącej za nim i dającej mu rację bytu filozofii? Co z niego zostaje, gdy odbierzemy mu obowiązujące od XIX w. kanony, dla kogo i na jak długo? Jakie są koszty tej bolesnej operacji na kulturze? Czy jest ona nieunikniona? Czy nadchodzą czasy, w których uniwersytet będzie wymagać szczególnych mów obrończych czy też apologii w tradycyjnym sensie? Kto miałby mówić „w imieniu” uniwersytetu? Kto miałby go bronić w obliczu zagrożeń, jakie niesie ze sobą globalizacja? Wydawałoby się, że najbardziej do tego predestynowani są sami uczestnicy uniwersyteckiego dyskursu, widzący poza różnorodnymi fragmentami szerszy obraz; wydawałoby się, że pomysłodawcy instytucji uniwersytetu, którzy obdarzyli ją nowoczesną ideą i tchnęli w nią na dwieście lat nowe życie - czyli naukowcy. Czemu zatem większość reform uniwersytetu projektują politycy?

Czy naprawdę jesteśmy zmuszeni w naszym kręgu kulturowym do inkorporacji alochtonicznych (inwazyjnych) wzorców uniwersytetu?

Jeżeli założyć prawdziwość sądu, że uniwersytet stanowi bodaj jedyną instytucję średniowiecznego świata, którą przejęła epoka nowożytna, to należy równocześnie przyjąć, iż przejęcie to było możliwe tylko pod warunkiem pełnego przystosowania się tej instytucji do odmiennych realiów społecznej i kulturalnej nowoczesności. Tak więc znów wykształcenie i oświecenie okazują się dziś tym, co najważniejsze i najbardziej cenne.

Dla uniwersytetów i wspólnot akademickich oznacza to oczywiście nowe wyzwania - i to zarówno na Wschodzie, jak i na Zachodzie Europy. Upadek komunizmu wyzwolił bowiem również groźne moce społecznej nieprzejrzystości i irracjonalności, które dają o sobie znać w obydwu częściach kontynentu. Jasno już zarysowuje się bodaj najbardziej niebezpieczne zjawisko, alternatywne wobec europejskiej modernizacji i integracji, jakim są coraz gwałtowniejsze wybuchy plemiennego nacjonalizmu (wzmagające się szczególnie w obliczu różnorodności kulturowej napływającej wraz z kolejnymi falami migracji), populistycznej demagogii, etnicznej i religijnej nietolerancji, agresji, nienawiści. To właśnie instytucje szkolnictwa wyższego, w tym przede wszystkim uniwersytety, powinny tworzyć instancję, która da odpór irracjonalizacji/mistyfikacji/krzywym zwierciadłom życia 
społecznego. Dzisiejsze uniwersytety raz jeszcze muszą skupić wszystkie siły, by zachować ogólnoeuropejską universalitas. Nie chodzi przy tym o to, by tworzyć utopijne wizje republiki uczonych, ale by poczynić starania o intelektualne i pragmatyczne rozwiązania trudnych problemów życia społecznego.

Moda na wprowadzanie do systemów szkolnictwa wyższego korporacyjnych zasad, a tym samym pomniejszanie znaczenia modelu neohumanistycznego, jest widoczna w wielu współczesnych państwach, w tym również w Polsce. Jednocześnie nawet w samych Stanach Zjednoczonych Ameryki Północnej uznaje się, że wprowadzanie na uniwersytet kultury korporacyjnej to trend należący do przeszłości. Wśród uczelni, które w rankingach mieszczą się w pierwszej dwudziestce na świecie, widać wyraźnie korektę tej tendencji i powrót do tradycji, do kultury wspólnotowej, tak zwanej starej idei uniwersytetu badawczego. American Academy of Arts and Sciences, prestiżowa reprezentacja amerykańskiej nauki, powołała kilkudziesięcioosobową komisję złożoną z uczonych, polityków i czołowych dziennikarzy. Obszerny raport Komisji opublikowany został w 2013 r. Ostra krytyka dotyka w raporcie kilku zjawisk, jako przejawów szkodliwej kultury korporacyjnej:

- dominacji ekonomicznego i fiskalnego myślenia w uniwersytetach;

- przerostu znaczenia jednostronnych ocen bibliometrycznych i naukometrycznych;

- wąskiego, zawodowego profilu kształcenia;

- marginalizacji dyscyplin o małej bezpośredniej użyteczności (historii, filozofii, archeologii, literaturoznawstwa);

- fetyszyzacji techniki.

Autorzy raportu piszą o tych tendencjach jako poważnym zagrożeniu nie tylko dla uniwersytetów, ale co ważniejsze dla siły, innowacyjności i konkurencyjności całego społeczeństwa. Krytyka ta prowadzi do takiej m.in. konkluzji: zdolność do adaptowania się i sukcesu w zmieniającym się szybko świecie opiera się nie tylko na wyuczeniu konkretnych zawodów dnia dzisiejszego, ale na ukształtowaniu profesjonalnej elastyczności i zawsze aktualnych cnót umysłu: ciekawości, spostrzegawczości, zdolności używania odziedziczonej wiedzy i umiejętności w nowy sposób oraz zdolności do tworzenia nowych idei w dialogu/ polilogu z innymi, szacunku dla różnorodnych wizji i sposobów kształtowania osobistych wyborów i kreowania własnego życia. 
Całe wieki wartości, które posiadały społeczeństwa, tylko $\mathrm{w}$ nieznacznym stopniu zmieniały się z pokolenia na pokolenie. Wiek XX bardzo zmienił zasady gry. W obecnym świecie wartości nie odgrywają już głównej roli w procesach zakorzeniania i poczucia identyfikacji. Można je więc przyjmować i porzucać do woli. Uniwersytet jako przekaziciel wartości jest często pozostawiony sam sobie, a wolność mylona jest z dowolnością i dopuszczalnością sądów nieracjonalnych czy wręcz głupich. Uprawniona głupota pokrywa korozją fundamenty uniwersyteckiej chwały i niszczy poczucie instytucjonalnej przynależności.

$\mathrm{Z}$ jednej strony uczelnia wyższa znajduje się pod naciskiem społecznym (trzeba przekazywać te, a nie inne wartości); z drugiej zaś strony ta sama opinia publiczna, a zwłaszcza politycy i przedstawiciele gospodarki, obwinia uniwersytety za deficyty, za które odpowiedzialność ponosi całe społeczeństwo. Wszystko to dzieje się w sytuacji, kiedy sami jej aktorzy, a mianowicie nauczyciele akademiccy, czują, że zadanie przekazywania wartości jest często ponad ich siły. Odbiorcy wytworów akademickich szkół wyższych postrzegają wprawdzie tę słabość jako deficyt wychowawczy, w praktyce próbują jednak przeciwdziałać jego powstawaniu, wysuwając olbrzymie roszczenia co do racjonalności procesu kształcenia - i to w jego formie zorientowanej wyłącznie na potrzeby gospodarki. W efekcie racjonalność procesu kształcenia jest postrzegana jako zaspokojenie potrzeb intelektualnych jednostki, zupełnie pomija się zaś kształtowanie osobowości. Nauczyciele akademiccy, którzy za istotne zadanie uznają w swej pracy przekazywanie wiedzy i wspieranie osiągnięć studentów, łatwo narażają się wobec takiej argumentacji na podejrzenie, że wywierają nacisk na osiągnięcia, a do tego jeszcze sprowadzają społeczne cele kształcenia i wychowania do wszczepiania takich cnót jak gotowość do pracy, mobilność i elastyczność, zaniedbując czy wręcz negując konieczność przekazywania wartości podstawowych - prawdy, dobra, piękna.

\section{Ostoja mądrości czy pole gry o nią?}

W swoim wykładzie Pochwała madrości Tadeusz Gadacz (2013) stwierdza „słowo ,mądrość’ zniknęło z naszego języka, wyparowało jak wiele innych słów, jak duch, honor czy cnota. Wstydliwą rzeczą jest obecnie mówić o mądrości. Słowo to brzmi jakoś anachronicznie. Kojarzy się z siedmioma greckimi mędrcami, 
z mądrością stoików czy Spinozy. Obecnie zostało zastąpione pojęciem wiedzy". Mądrość, kontynuuje Gadacz, sytuuje się zawsze pośrodku między głupcami i bogami. Możemy zatem mówić jedynie o dążeniu do mądrości, a nie jej posiadaniu. Kto by stwierdził, że posiada mądrość, musiałby być bogiem, a okazałoby się, że jest głupcem. Pierwszą cechą mądrości wynikającą z tego pośredniego położenia jest niepewność. Drugą cechą mądrości jest skromność.

Mądrość określić można również przez negację głupoty. Przez głupotę rozumiemy brak bystrości, szybkości myślenia i skojarzeń, brak łatwości w stosowaniu prawa przyczynowości, czyli niezdolność do bezpośredniego uchwytywania związków między przyczyną i skutkiem, motywem i działaniem, a także tępotę. Ten ostatni rodzaj głupoty opisał wiele wieków temu grecki filozof, uczeń Arystotelesa - Teofrast: „Tępotę określić można jako ociężałość duszy w słowach i w działaniu. A tępak to ktoś taki, kto np. kiedy rachuje przy pomocy liczmanów i już ułożył sumę, pyta siedzącego obok: 'Ileż to jest razem?’” (Teofrast 1963: 33).

Jednak najczęstszym objawem głupoty, można wręcz powiedzieć jej współczesnym przejawem, jest przeciętność. Mądrość ma odwagę sprzeciwić się przeciętności i banalności. Jej diagnostą był hiszpański filozof i pisarz José Ortega y Gasset:

Być może mylę się, ale wydaje mi się, że obecnie pisarz, kiedy bierze do ręki pióro, by napisać coś na znany mu gruntownie temat, powinien pamiętać o tym, że przeciętny czytelnik, dotąd tym problemem nie zainteresowany, nie będzie czytał dla poszerzenia własnej wiedzy, lecz odwrotnie - po to, by wydać na autora wyrok skazujący, jeśli treść jego dzieła nie będzie zbieżna z banalną przeciętnością umysłu owego czytelnika (Ortega y Gasset 2008: 32).

Czyż nie znajdujemy tu prostej analogii do współczesnej sytuacji akademickiej?

Wymagania oficjalne wobec studentów zawarte w Ramach Kwalifikacji są współcześnie repetycją taksonomii Blooma z lat 50. zawierającą określenia opisujące efekty kształcenia, podzielone na trzy dziedziny: poznawczą, psychoruchową oraz emocjonalną. W sensie codziennej praktyki dotyczą jednak przede wszystkim wiedzy rozumianej jako pakiet wiadomości, w mniejszym stopniu mądrości, prawie w ogóle nie odnoszą się do zawartej w emocjonalnych obszarach efektów kształcenia skromności/pokory. Dzisiaj wypada raczej być prowokacyjnym, narzucającym, rywalizującym, 
do granic śmieszności śmiałym, dążącym do osobistego sukcesu i urzeczywistniania szybkiej ścieżki sławy.

$\mathrm{Z}$ drugiej strony proces kształcenia w podstawowym zakresie i zaawansowanych procedurach odnosi się do modelowania zachowań. Postawy eksponowane w idei uniwersytetu kształcącego osobowość były zawsze odzwierciedleniem wartości. Dzisiaj często postawy są odzwierciedleniem braku wartości lub ich nadmiaru i rozproszenia, co de facto równa się nihilistycznemu podejściu. Pozbawieni naturalnych autorytetów lub nie zauważający ich $\mathrm{w}$ swoim otoczeniu studenci nie mają szans ukształtowania w sobie dyspozycji mądrości. Teoretycznie zresztą być może nie powinni, ale niekoniecznie $\mathrm{w}$ wersji, która zamyka się $\mathrm{w}$ wyobrażeniu umysłu jako „czystej karty”, biorącym początek od Arystotelesa, a szczególnie lansowanym przez Locke'a. Genetyczne uposażenie człowieka całkowitej tajemnicy nie stanowi już od dawna, ale nauczycielskie role bywają tak pojmowane, jakby świat zaczynał się od kontaktu z danym nauczycielem albo od danego etapu edukacji ${ }^{1}$, a uczniowie czy studenci w tym momencie stanowili „czyste karty”. Jeśli zresztą nawet nie „czyste karty”, to i tak oświeceni wiedzą częstokroć lepiej, czego trzeba oświecanym i co dla oświecanych jest dobre. Oświecanym pozostaje w takiej relacji ćwiczyć w sobie poczucie wdzięczności. Jeśli dodamy do tego wiarę, że istnieje wiedza pewna, niefalsyfikowalna, do czego w swoim czasie przekonywał pozytywizm, trudno się dziwić, że na szkoły, a następnie uczelnie wyższe, całkowicie i bez oporów nakładana jest rola strażniczek i przekaźników tradycji.

Nie rozróżnia się przy tym na ogół znaczenia i funkcji przekazu kulturowego, bez którego bylibyśmy niewiele warci, od wyobrażeń, które zakładają, że istnieje przysłowiowy „lejek norymberski”. Lejek ów przykłada się komuś do głowy i przelewa komuś innemu co trzeba. Przekaz kulturowy i przekaz szkolny/ uniwersytecki to dwie całkiem inne sfery. Przekaz kulturowy jest procesem antropologicznym. Przekaz uniwersytecki wiąże

${ }^{1}$ Dość powszechne są opowieści o nauczycielach najmłodszych dzieci, którzy denerwują się, stwierdzając, że umieją one już to, czym właśnie miały się zajmować w szkole. Na przykład potrafią już czytać. Jak dalece typowa i uniwersalna jest taka reakcja, świadczyć mogą fragmenty z Zabić drozda Harper Lee. Nauczycielka mówi do małej bohaterki, która biegle czyta gazetowe, sążniste artykuły: „I naprawdę powiedz ojcu, żeby cię już nie uczył. Najlepiej zaczynać czytanie z całkiem świeżym umysłem. Powiedz, że odtąd przejmę jego dzieło i spróbuję naprawić szkody" (Lee 2014: 28-30). 
się z reguły z oczekiwaniami repetycji ustaleń znawców, bez dochodzenia sensu tych ustaleń.

Masowość kształcenia oznacza potrzebę przygotowania dużej liczby specjalistów. Z tą masowością, ale i z całym procesem masowego kształcenia, wiąże się coś, co można by określić jako bezwładność prezentowanych teorii pedagogicznych i metodycznych chwytów. Prezentuje się je choćby siłą rozpędu, choć od dawna wiadomo, że są niestosowne, bo nie odpowiadają na przykład nowej sytuacji cywilizacyjno-kulturowej. Podobnie rzecz dotyczy języka. Leszek Kołakowski (1993) mówił, iż język ma swoją bezwładność i używany jest również wtedy, kiedy już dawno nie przystaje do świata, który ma opisywać. Charakter języka niełatwo daje się zmieniać, on przechodzi niejako z pokolenia na pokolenie.

W dyskusjach na temat uniwersytetu słyszymy stale, i to od „zupełnych” koryfeuszy edukacyjnej nowoczesności, o sposobach nauczania, procesie nauczania czy systemie nauczania, choć pojęcie nauczania sygnuje bierność adepta owego nauczania. Rekordy popularności bije wspominane już pojęcie przekazywania/transmisji. W najnowszych raportach o stanie oświaty w propozycjach modelowych rozwiązań w kształceniu nauczycieli np. nieustannie używa się tych właśnie określeń, a przecież one także sygnują bierność podmiotu edukacji, a zatem sytuację, gdy podmiot traktowany jest jak przedmiot. Światli pedagodzy okładają w związku z tym anatemą pojęcie transmisji, ale bez eksponowanego wyżej rozróżnienia na transmisję kulturową i uniwersytecką. Rezultaty ukazuje na przykład raport ogłoszony 6 września 2012 r. przez „Unijną Grupę Ekspertów Wysokiego Szczebla ds. Umiejętności Czytania i Pisania”. Małe pocieszenie, że nie odnosi się on wyłącznie do Polski, lecz m.in. do Polski. Zaraz na wstępie stwierdza się, że wręcz zaskakująco duża liczba Europejczyków nie posiada wystarczającej umiejętności czytania i pisania. Raport dowodzi, że mniej więcej jedna na pięć dorosłych osób i co piąty piętnastolatek nie posiadają umiejętności czytania na poziomie niezbędnym do w pełni sprawnego funkcjonowania w nowoczesnym społeczeństwie. Mówiąc wprost, oznacza to, że co piąty mieszkaniec Unii Europejskiej, również Polski, jest rzeczywistym analfabetą. Przy czym z badań wynika, że statystyk nie podnoszą tu ludzie z marginesu społecznego czy imigranci, a większość dorosłych z tej grupy jest gdzieś zatrudniona. W związku z tym pozostaje pytanie o charakter oraz jakość wykonywanych przez nich prac. 
Dalsze partie raportu wskazują, że w żadnym razie nie chodzi tylko o techniczną sprawność czytania i pisania, lecz o znacznie więcej. Chodzi o twórczą postawę obywateli poszczególnych krajów wobec świata, który poznają oni za pomocą słowa pisanego, i do którego muszą się odnosić na ogół - a nawet coraz częściej, mimo wizualności współczesnej kultury - również za pomocą czytania i pisania. Inaczej mówiąc, chodzi o twórczą postawę wobec wszelkich ludzkich działań, ponieważ wpływają one na miejsce i rolę ich kraju w relacji do innych, wyzwalają innowacyjność, pozwalają proponować nowości i na tym polu mierzyć się z konkurencją - zaznaczając swoją wartość w wymiarze indywidualnym i wspólnotowym. Ta twórcza postawa wobec świata zależy bezsprzecznie od umiejętności krytycznego czytania, które nie odpowiada standardom osławionego już u nas czytania ze zrozumieniem, i badaniom $\mathrm{w}$ ramach PISA.

Niestety źródłem złych nastrojów, niepokoju i niepewności współczesnych społeczeństw europejskich jest również postępująca erozja tradycyjnej idei uniwersytetu, akademickiej kultury wspólnotowej i coraz mocniejsze ingerowanie w życie uniwersyteckie całkowicie obcej (wręcz inwazyjnej) wobec tej tradycji kultury korporacyjnej.

Jest jednak jeszcze inne zagrożenie dla neohumanistycznej idei uniwersytetu, aniżeli polityczne makro-uwarunkowania. Otóż współczesne rozumienie „wspólnotowości i dialogiczności”, a także innych wymienianych wcześniej kategorii, uległo - a proces ten niestety nadal postępuje - deprecjonowaniu przez „rzeczywistość” online (jest to swoisty paradoks, bowiem media społecznościowe powstały właśnie w celu „łączenia”, budowania globalnej społeczności). Kiedy jednak Mark Zuckerberg stwierdza, że Facebook ciągle ulepsza swoje narzędzia tak, by ludzie mogli dzielić się swoim doświadczeniem (Zuckerberg 2017), wraz z innymi zastanawiam się, czy owi ludzie poszukujący i często narzucający innym własny tok myślenia, posiadają narzędzia do nawiązania kontaktu z własnymi indywidualnymi doświadczeniami. Podam przykład: jeśli dzieje się coś ekscytującego, pierwotne instynkty użytkowników Facebooka każą najpierw wyciągnąć smartfon, zrobić zdjęcie, wrzucić do sieci i czekać na „lajki”. W trakcie tych działań nie zauważają często, co sami czują. Co więcej to, co czują, w coraz większym stopniu określają reakcje świata online. Mam takie odczucia, jakich oczekują moi obserwatorzy na Instagramie, FB, Twitterze, Tik-Toku, blogu, vlogu itd. 
Ludzie, którzy żyją odseparowani od własnego ciała, zmysłów i materialnego otoczenia, prawdopodobnie coraz bardziej czuć się będą wyobcowani i zdezorientowani. Eksperci często winą za tego rodzaju poczucie wyobcowania obciążają osłabienie więzi wspólnotowych: religijnych i narodowych. Ale czy nie ważniejszym powodem jest właśnie utrata kontaktu z osobistym rozumieniem świata? $\mathrm{Z}$ własnym ciałem, emocjami, myśleniem? Brak samorozumienia i samoakceptacji?

Jaka jest rola uniwersytetu w świecie, w którym być może już jesteśmy skazani na nieustanne bycie online? Przecież nowe reformy wymuszają coraz większą widoczność nas samych i naszej twórczości (akademia.edu czy researchgate sprawiają, że inni nas widzą i cytują, a google scholar liczy nasze cytowania i wylicza ich indeksy). Samo łączenie ludzi i konfrontowanie z innymi opiniami nie zasypie społecznych przepaści, pokazanie innym artykułu pisanego z innej perspektywy tak naprawdę tylko pogłębia polaryzację, ukazując inne perspektywy jako nie-moje, czyli obce. Być może najlepsze rozwiązania, które mogą poprawić poziom debaty, wspomóc budowanie wspólnotowości i dialogiczności, pochodzą z naszego wzajemnego całościowego poznawania się jako osób, a nie tylko poznawania naszych opinii. Takie całościowe poznawanie się jest jednak niezwykle trudne. Zajmuje mnóstwo czasu i wymaga bezpośrednich relacji. Czy w świecie nieustannego pośpiechu mamy czas na bezpośrednie relacje? I to jest pierwsze z pytań o odpowiedzialność Uniwersytetu za autentyczność dialogu. To wspólnota Uniwersytetu musi znaleźć czas i stworzyć warunki do poznania wzajemnego osób, a nie tylko uczestników procesu kształcenia, ale również znaleźć warunki i czas (w świecie dominacji mediów, przekonującym codziennie, że każdy sąd jest uprawniony, i że należy się tym „każdym mniemaniem” jak najszybciej dzielić z innymi) do wspierania racjonalizmu, sceptycyzmu oraz odwagi myślenia naukowego często niepopularnego.

Wraz z procesami przeobrażającymi życie społeczne zmianie uległy oczekiwania państwa wobec uniwersytetu. I tak, jeśli idzie o funkcjonowanie państwa, najistotniejszą zmianą wydaje się być przejście od rządzenia opartego na idei reprezentacji politycznej do zarządzania publicznego, opartego na systemie ogólnych regulacji i realizowanego przez zewnętrzne instytucje. W efekcie współczesne państwo nie potrzebuje już zaangażowanych obywateli. Potrzebuje natomiast kompetentnych użytkowników instytucji, 
co zmienia diametralnie oczekiwania wobec uniwersytetu, który zdaniem państwowych gremiów powinien wyposażać studentów nie tyle w ogólną wiedzę, ile w specyficzne umiejętności ułatwiające ich funkcjonowanie $\mathrm{w}$ instytucjach. Kłóci się to $\mathrm{z}$ ideą ogólnego wykształcenia, za którym stoi nie tylko wiedza, ale też szczególne dyspozycje kulturowe: otwartość na odmienność, możliwości negocjacyjne i szacunek dla nie-moich, odmiennych sposobów postrzegania świata.

\section{Kultura akademicka w odmętach permanentnych zmian}

Można powiedzieć, że u podstaw rozwoju kultury akademickiej odnajdujemy układ wzajemnych zależności łączących czterech aktorów: 1) państwo narodowe potrzebujące światłych obywateli i urzędników zapewniających racjonalne działanie administracji; 2) rozwijający się przemysł potrzebujący wykształconych kadr zarządczych; 3) ambitnych młodych ludzi z rosnącej w siłę klasy średniej, dla których wyższe wykształcenie stawało się drogą do awansu społecznego, oraz 4) kadrę akademicką, dla której praca na uniwersytecie była nie tylko sposobem na realizację własnych zainteresowań poznawczych, ale również źródłem prestiżu społecznego. I to właśnie w procesach, które całkowicie przeorganizowały ów wyjściowy układ zależności, należałoby, jak twierdzi Piotr Sztompka, doszukiwać się przyczyn tego, co określamy dziś mianem kryzysu uniwersytetu (por. Sztompka 2014).

We współczesnym społeczeństwie znaczącemu ograniczeniu uległa również pozycja racjonalizmu naukowego jako specyficznej postawy określającej stosunek do rzeczywistości. Z jednej strony staje się on tylko jednym z wielu równoprawnych sposobów poznania, dzieląc tę pozycję z emocjonalnością, gromadzeniem prywatnych doznań, z wewnętrznym przekonaniem, chęcią pokazania swoich przeżyć innym, często bez wglądu we własne emocje. $Z$ drugiej strony został on prawie całkowicie wyparty przez zasadę racjonalizmu ekonomicznego ze swej funkcji kulturowego kryterium decydującego o sensowności podejmowanych działań, czy to jednostkowych, czy społecznych. Jak wspomniałam powyżej, w obliczu rozwoju życia społecznego - a w szczególności przejścia od rządzenia wspartego na idei reprezentacji politycznej do zarządzania publicznego opartego na systemie 
ogólnych regulacji i realizowanego przez zewnętrzne instytucje zmianom podlegają także oczekiwania względem uniwersytetu. Współczesne państwo bardziej niż zaangażowanych obywateli potrzebuje kompetentnych użytkowników instytucji. Sytuacji tej podporządkowana zostaje także rola uniwersytetu, który powinien zadbać przede wszystkim o wyposażenie studentów w umiejętności umożliwiające sprawne użytkowanie instytucji. Od uniwersytetu pracodawcy oczekują wykształcenia u przyszłych pracowników tzw. miękkich umiejętności, tzn. sprawnej autoprezentacji, znajomości języków i umiejętności formułowania myśli na piśmie, komunikatywności i zaangażowania w prace zespołowe. Ceniona jest przedsiębiorczość, „elastyczność” oraz wiedza wynikająca z nagromadzonych doświadczeń zawodowych, a nie wiedza akademicka, często traktowana jako zbędny balast. W przypadku ambitnych młodych ludzi można zauważyć, że już na wstępie natykają się oni na podstawową przeszkodę, jaką jest narastająca rozbieżność między ukształtowanym przez akademicką tradycję myśleniem naukowym, a myśleniem potocznym kształtowanym głównie przez media.

\section{Konkluzja}

Uniwersytet - zarówno w swej wersji średniowiecznej, jak i nowożytnej - zawsze był częścią społeczeństwa, tym samym podlegał tym samym procesom, które wyznaczały jego funkcjonowanie. Jednocześnie kształtował ewolucję społeczeństwa, dostarczając mu nowych idei kwestionujących dotychczasowe sposoby postrzegania rzeczywistości i ludzkich działań. To od dopływu takich idei zależał i nadal zależy zarówno rozwój technologiczny, jak i rozwój społeczny, a w konsekwencji także rozwój uniwersytetu jako instytucji skupionej na rozszerzaniu granic ludzkiego poznania. We wszystkich cytowanych wyżej wypowiedziach jednoznacznie rysuje się przekonanie, iż uniwersytet neohumanistyczny w sposób wyraźny odcisnął swoje piętno na rozumieniu jego zadań nie tylko na sobie współczesnych, ale także oddziałuje na obecne sposoby postrzegania roli nauki jako kreatorki racjonalnych rozwiązań sine ira et studio - bez gniewu i upodobania, czyli bezstronnie, obiektywnie i neutralnie. Autorytety naukowe, jak ukazują biografie wielkich „ojców” neohumanistycznego uniwersytetu: Georga Wilhelma Leibniza, Wilhelma i Aleksandra von Humboldtów, Hansa-Georga Fichtego, 
Friedricha Schleiermachera, by wymienić jedynie kilku, wynikają nie tylko z dorobku naukowego, ale też ze sposobu życia, kreowanej drogi rozwoju naukowego i osobistego. Stanowiska naukowe pozostają zawsze istotną częścią biografii, natomiast biografia ukazuje drogę, jaką pokonać musi uczony, by wyodrębnić i zinternalizować prezentowane stanowisko. Nawet najbardziej przekonujący model Uniwersytetu jest jedynie szablonem, w który dopiero ludzkie biografie wpisują autentyzm, prawdę, racjonalizm, sądy asertoryczne, od zawsze pozostające ostoją naukowości i swoistym antidotum na dogmatyzmy, fanatyzmy, nieuzasadniony mistycyzm, pychę i pogardę dla osób o odmiennych poglądach, słowem - antidotum na współczesne intelektualne barbarzyństwo.

Czy mamy pewność, przyglądając się historycznym meandrom myślenia o roli nauki w świecie, że nie nastąpi odwrót od radykalnych konstrukcji systemowych, które w naszych realiach społecznych i ideowych mogą się okazać niesprawne, natomiast chaos struktur i funkcjonalności nie wyłoni tęsknoty za trwałymi rozwiązaniami aksjologicznymi i myśleniem o uniwersytecie racjonalnego dialogu i wzajemnego szacunku? Wszak jedyną stałą rzeczą w naszym pełnym rozedrgania i niejasności świecie jest zmiana.

\section{Bibliografia}

Bloom A. (1996), Umyst zamknięty. O tym, jak amerykańskie szkolnictwo wyższe zawiodto demokrację i zubożyto dusze dzisiejszych studentów, tłum. T. Bieroń, Zysk i Ska, Poznań.

Droysen J.G. (1977), Historik, Textausgabe von Peter Leyh, Frommann-Holzboog, Stuttgart-Bad Cannstatt.

Droysen J.G., Leyh P. (1977), Historik, Frommann-Holzboog, Stuttgart-Bad Cannstatt.

Gadacz T. (2013), Pochwata mądrości, http://www.iumw.pl/o-madrosci/articles/ wyklad-prof.gadacz.html (dostęp: 02.02.2020).

Hattenhauer H. von (red.) (2002), Thibaut und Savigny. Ihre programmatische Schriften, Vahlen, München.

Kołakowski L. (1993), Gdzie jest miejsce dzieci w filozofii liberalnej, tłum. J. Turowicz, „Znak”, nr 10, s. 11-21.

Lee H. (2014), Zabić drozda, tłum. M. Szymański, Dom Wydawniczy Rebis, Poznań.

Melosik Z. (2009), Uniwersytet i spoleczeństwo. Dyskursy wolności, wie$d z y$ i wladzy, wyd. II poprawione, Oficyna Wydawnicza Impuls, Kraków. 
Nowakowska-Siuta R. (2018), Romantyczny i pragmatyczny. Idea niemieckiego uniwersytetu neohumanistycznego i jej spoleczne rekonstrukcje, Wydawnictwo Naukowe ChAT, Warszawa.

Ortega y Gasset J. (2008), Bunt mas, tłum. P. Niklewicz, Muza, Warszawa.

Sztompka P. (2014), Uniwersytet wspótczesny: zderzenie dwóch kultur, „Nauka”, nr 1 , s. 7-18.

Teofrast (1963), Charaktery, [w:] Teofrast, Pisma, t. 1, tłum. I. Dąmbska, PWN, Warszawa.

Zuckerberg M. (2017), Building Global Community, www.facebook.com/ notes/mark-zuckerberg/building-global-community/10154544292806634/ (dostęp: 20.08.2018). 


\title{
Prognozowanie rozwoju systemu edukacji w kontekście wyzwań natury globalnej ${ }^{1}$
}

\author{
Abstract \\ The prognosis of the development of the education system \\ in the context of global challenges
}

The article reviews the reports on the directions of socio-economic development included in global categories. Against this background, the author presents prognosis regarding perspectives in the field of education, including professions (professional areas) of the future. An original classification of future competences is also proposed and referred to the current core curriculum of general education for general and technical secondary schools.

Keywords: forecasting, socio-economic development, future professions, competences of the future, sustainable development

Słowa kluczowe: prognozowanie, rozwój społeczno-gospodarczy, zawody przyszłości, kompetencje przyszłości, zrównoważony rozwój

\section{Wprowadzenie}

System edukacji z całą swoją złożonością i różnorodnością jest zaledwie elementem otaczającego nas świata. Można powiedzieć, że jest podsystemem systemu społecznego. Wraz z innymi podsystemami (np. ochrony zdrowia, bezpieczeństwa, komunikacji, transportu, prawa) tworzy lub, ujmując rzecz w kategoriach postulatywnych, powinien tworzyć spójny system natury społecznej. Aby ten ostatni zasługiwał rzeczywiście na miano systemu

1 Jest to rozszerzona wersja tekstu pt. Prognozy globalnego rozwoju społeczno-gospodarczego i ich edukacyjne implikacje, [w:] K. Wrońska (red.), Dobra edukacji $i$ ich pedagogiczna eksploracja, Wydawnictwo Uniwersytetu Jagiellońskiego, Kraków 2019. 
musi stanowić sieć powiązanych ze sobą podsystemów, w której zmiany w jednym z podsystemów wpływają na rozwój pozostałych. Zgodnie z tym założeniem podsystem edukacji powinien być wyczulony na przemiany, które zachodzą może nie we wszystkich podsystemach, ale w tych, które bezpośrednio wpływają na jego funkcjonowanie. Trudność w zidentyfikowaniu podsystemów wplywu, a następnie w scharakteryzowaniu na czym ten wpływ polega, kieruje nas ku wyzwaniom globalnym, które stają przed współczesnym światem. Z nich, utożsamianych z wyzwaniami w skali "makro", można bowiem wyprowadzić czekające nas wyzwania regionalne i lokalne - wyzwania w skali "mikro”.

Myślenie o przyszłości zarówno w skali makro, jak i mikro przebiega różnie w zależności od podsystemu, który poddajemy analizie. W przypadku podsystemu edukacji jest to myślenie perspektywiczne wyznaczane czasem trwania procesu kształcenia. Jest on w praktyce dłuższy - można do niego zaliczyć również czas przygotowywania zmiany (analizy sytuacji zewnętrznej, projektowania celów strategicznych i tworzenia warunków do ich realizacji). Sytuację dodatkowo komplikuje potrzeba i oczekiwanie społeczne, że podsystem edukacji będzie nie tylko możliwie szybko (z minimalną stata czasowa) reagował na zmiany w otaczających go podsystemach, ale też inicjował i kreował owe zmiany. Oczekiwanie, że to właśnie edukacja będzie wyznaczała drogi rozwoju społeczno-gospodarczego, wymaga zdecydowanie innego niż dotychczas podejścia do przyszłości.

Wypada w tym miejscu zauważyć, że ludzie od zarania dziejów interesowali się przyszłością - własną i planety, na której przyszło im żyć. Stąd niesłabnąca popularność wróżek i różnego rodzaju wizjonerów przepowiadających przyszłość ${ }^{2}$. Potrzeba wizji przyszłości indywidualnej (przyszłości w wąskim sensie) jest zatem wpisana w egzystencję człowieka. Chcemy znać swoje przyszłe losy, planujemy własne cele i wytyczamy drogi do nich prowadzące. Rozmawiamy o swoich planach w gronie rodziny i najbliższych przyjaciół. Mamy przy tym (na ogół) świadomość, że nasza

2 Wystarczy odwołać się do wyroczni w Delfach, Nostradamusa (Michela de Nostredame), czy bliższego nam Stanisława Ossowieckiego; do współczesnych wizjonerów można zaliczyć autorów książek i filmów science-fiction, takich jak: pisarze - Stanisław Lem (Solaris) i Philip K. Dick (Czy androidy śniq o elektrycznych owcach?), i reżyserzy - Stanley Kubrick (2001: Odyseja kosmiczna), Ridley Scott (Łowca androidów - scenariusz tego filmu został oparty na motywach wspomnianej powieści Philipa K. Dicka) czy George Lucas (Gwiezdne wojny). 
indywidualna przyszłość zależy nie tylko od nas samych - jest wypadkową wielu zmiennych i jedynie na niektóre $\mathrm{z}$ nich, $\mathrm{i}$ to w ograniczonym zakresie, mamy wpływ. Często powtarzamy, że podejmujemy jakieś działanie z myślą o przyszłości - własnej i, co naturalne, swojego potomstwa. Na ogół w codziennym zabieganiu nie rozpatrujemy swojej indywidualnej przyszłości w kontekście przyszłości świata, w którym funkcjonujemy. Owa przyszłość, którą możemy określić mianem przyszłości w szerokim sensie, jest bardzo enigmatyczna i ma swoje złożone oraz wieloaspektowe uwarunkowania społeczno-gospodarcze i środowiskowe, ale też polityczne i militarne.

Przyszłość indywidualna jest w sposób istotny zależna od czasu, w jakim żyjemy, od epoki, a nawet - w nieco krótszej perspektywie czasowej - od kilkunastu lub kilkudziesięciu lat, które mamy przed sobą. Należy również pamiętać, że czas historyczny nie jest dla jednostki linearny. Tempo jego upływania jest ściśle związane z bieżącymi wydarzeniami, w których uczestniczy. W pewnych sytuacjach, subiektywnie rzecz ujmując, czas niepostrzeżenie przemija, w innych niemiłosiernie się dłuży.

Ze społecznego punktu widzenia przyszłość indywidualna każdej jednostki jest pochodną kapitału społecznego, który zdobywamy w domu rodzinnym, w szkole i uczelni oraz w środowisku lokalnym - w różnorodnych kontaktach z innymi ludźmi. Co ciekawe, ale nie zawsze uświadamiane, przyszłość indywidualna jest komponentem określającym przyszłość świata. Z taką sytuacją w sposób wyrazisty mamy do czynienia w przypadku edukacji. Od jej poziomu zależy z pewnością przyszłość indywidualna, ale też przyszłość świata, który dzięki edukacji ma szanse zmieniać się $\mathrm{w}$ pożądanym kierunku.

Znaczenie hipotez odnoszących się do przyszłości świata jest ważnym elementem planowania przyszłości indywidualnej. Dzięki różnym prognozom dotyczącym najbardziej prawdopodobnych scenariuszy rozwoju społecznego i gospodarczego można bowiem planować własne, indywidualne działania w sferze edukacji $\mathrm{z}$ nadzieją na znalezienie satysfakcjonującej pracy $\mathrm{w}$ odpowiadającym nam środowisku zawodowo-społecznym.

Z tej perspektywy interesujące mogą okazać się rozważania na temat przyszłości świata rozpatrywanej w świetle międzynarodowych raportów prognostycznych oraz wynikających z nich zadań stojących przed edukacją - zarówno w wymiarze indywidualnym, jak i zbiorowym. 


\section{Prognozy społeczno-gospodarcze. Globalne kierunki rozwoju w świetle międzynarodowych raportów}

Współczesne wyobrażenia o przyszłości świata oparte są na wątłych podstawach wynikających z różnego rodzaju prognoz i projekcji. Są one formułowane z uwzględnieniem doświadczeń z przeszłości i analiz teraźniejszości - zakładają przy tym przede wszystkim liniowy rozwój wszystkich istotnych dziedzin życia społecznego i gospodarczego. Takie podejście nie bierze pod uwagę realnej możliwości rozwoju skokowego, którego w wielu obszarach należy się spodziewać, oraz nieprzewidywanych, bo nie występujących wcześniej, zagrożeń. W praktyce prognozowania opracowywane są równolegle dwie prognozy (Karpiński 2001: 17-18):

- prognoza długookresowa (z reguły liniowa);

- prognoza ostrzegawcza (przed ewentualnymi zagrożeniami ze zwróceniem uwagi na zmiany skokowe i sytuacje trudne do przewidzenia z dzisiejszej perspektywy).

Mimo wskazanych ograniczeń prace nad prognozowaniem przyszłości mają głęboki sens. Uświadamiają one konieczność myślenia o przyszłości świata w kategoriach holistycznych, a także potrzebę rozpatrywania relacji (na ogół zwrotnych), które z dużym prawdopodobieństwem wystąpią między rozwojem rozpatrywanym w skali globu a poszczególnymi dziedzinami życia ${ }^{3}$.

W syntetycznym ujęciu studia nad przyszłością mają trzy główne cele:

- wskazanie na znaczenie rozważań dotyczących kluczowych elementów mających decydującą wagę dla rozwoju cywilizacyjnego;

- opracowanie metod, technik i narzędzi niezbędnych do przygotowywania, elastycznie i wariantowo rozumianych, założeń na temat przyszłości;

- zidentyfikowanie rodzajów problemów, od których rozwiązania zależeć będzie przyszłość (Coates 2002: 10).

Odwołując się do wyróżnionych wyżej celów prognozowania skupimy uwagę na zidentyfikowaniu problemów, które z dzisiejszej perspektywy wydają się najbardziej istotne dla przyszłości.

3 W dalszej części tekstu będziemy rozpatrywać tego typu relacje z perspektywy edukacji. 
Będzie to więc opis zakładający przede wszystkim rozwój liniowy, ewentualnie z elementami rozwoju skokowego.

Pod koniec ubiegłego wieku prognozy rozwoju społecznego i gospodarczego koncentrowały uwagę na rozwoju technologii informacyjnych (znalazło to wyraz w Raporcie dla Klubu Rzymskiego z lat 80.). Doszukiwano się wówczas analogii występujących między rewolucją przemysłową $\mathrm{z}$ lat 1760-1830 a dynamicznymi zmianami z końca XX w., które były określane mianem rewolucji naukowo-technicznej. Wśród interesujących nas szczególnie skutków tej rewolucji wymieniano:

- bezrobocie technologiczne jako efekt szerokiego wykorzystania najnowszych rozwiązań technicznych opartych na zastosowaniach mikroelektroniki;

- trudności w znalezieniu pracy przez osoby w starszym wieku ze względu na konieczność opanowania nowych umiejętności zawodowych;

- wydłużenie czasu nauki w związku z potrzebą zdobywania wyższych kwalifikacji;

- skrócenie okresu pracy z powodu późniejszego jej podejmowania i rysującej się tendencji do wcześniejszego przechodzenia na emeryturę;

- wydłużanie okresu życia po zakończeniu pracy zawodowej;

- przesunięcia w obrębie struktury zatrudnienia w kierunku sektora usług (Secomski 1987: XXIV-XXV).

Co ciekawe prognozowano także zmiany zatrudnienia w mającym się rozwijać sektorze usług. Do obszarów z malejącym zatrudnieniem zaliczono:

- transport kolejowy i morski (perspektywiczna przegrana w konkurencji z transportem samochodowym i lotniczym);

- dystrybucję (w wyniku automatyzacji przetwarzania danych);

- banki i towarzystwa ubezpieczeniowe (dzięki wprowadzaniu terminali komputerowych pracujących w sieci);

- administrację publiczną (efekt automatyzacji przetwarzania dokumentów).

W grupie obszarów, w których prognozowano wzrost zatrudnienia znalazły się:

- edukacja (jako czynnik decydujący o innowacyjności gospodarki);

- działalność badawczo-rozwojowa (potrzeba opracowywania nowych rozwiązań natury technologicznej); 
- opieka społeczna (opieka zdrowotna, poradnictwo, rehabilitacja, resocjalizacja);

- hotelarstwo i gastronomia (w związku ze wzrostem poziomu życia);

- transport samochodowy i lotniczy (rezultat postępującej globalizacji, wymiany handlowej i mobilności społeczeństw) (Friedrichs 1987: 300-301).

Biorąc pod uwagę te prognozy możemy po blisko czterdziestu latach pokusić się o skonfrontowanie ich z rzeczywistością. Ogólnie rzecz ujmując, można stwierdzić, że w zasadzie wszystkie się potwierdziły. Jest to więc argument za podejmowaniem badań prognostycznych - zarówno o charakterze globalnym, jak i lokalnym, ograniczonym do konkretnego regionu i kraju.

Bezpośrednio do prognozowanych wyzwań cywilizacyjnych odnosi się raport UNESCO zredagowany przez Federico Mayora. Znajdujemy w nim prognozy dotyczące:

- demografii (tempo przyrostu ludności, poziom dzietności w kontekście wykształcenia kobiet, długość życia, gęstość zaludnienia, międzynarodowe migracje);

- bezpieczeństwa żywnościowego (produkcja żywności, poziom niedożywienia w skali globalnej i regionalnej);

- środowiska naturalnego (wytwarzanie i zużycie energii elektrycznej, alternatywne źródła energii, eksploatacja surowców naturalnych, emisja gazów - efekt cieplarniany);

- urbanizacji (migracje ze wsi do miast, zaopatrzenie miast w wodę, transport miejski, oczyszczalnie ścieków i zagospodarowanie śmieci);

- warunków życia na wsi (uprzemysłowienie produkcji rolnej, oferta edukacyjna i kulturalna);

- rozwoju naukowo-technicznego (nowe technologie - biotechnologie, nanotechnologie, technologie informacyjne);

- modeli życia i konsumpcji (równowaga między pracą zawodową a życiem rodzinnym, rozmiary konsumpcji dóbr przemysłowych i usług);

- ubóstwa i wykluczenia (stopień ubóstwa i poziom wykluczenia) (Mayor [red.] 2001: 43-334).

$\mathrm{Na}$ nieco inne aspekty prognozy przyszłości świata zwraca uwagę najnowszy Raport Klubu Rzymskiego. Jego kilkudziesięcioosobowy zespół autorski przygotował opracowanie zwracające uwagę na: 
- różnego rodzaju potencjalne kryzysy (społeczne, polityczne, kulturowe i moralne oraz demokracji, ideologii i systemu kapitalistycznego);

- postępujące rozwarstwienie ekonomiczne (8 najbogatszych ludzi na świecie posiada - według danych upowszechnionych podczas Światowego Forum Gospodarczego w 2017 r. - bogactwo równe bogactwu połowy światowej populacji);

- niedobór zasobów (wyniki analiz granic wzrostu gospodarczego);

- wyzwania klimatyczne (ograniczenie wzrostu temperatury);

- dynamikę populacji (zrównoważona polityka demograficzna, prognozy demograficzne uwarunkowane poziomem wykształcenia ludności);

- globalną urbanizację (w ciągu 100 lat populacje miejskie mogą wzrosnąć dziesięciokrotnie, co będzie stanowiło 70\% globalnej populacji);

- cyfryzację (relacje między cyfrowymi „tubylcami” a cyfrowymi „imigrantami”);

- prawdopodobieństwo redukcji miejsc pracy (w związku $\mathrm{z}$ innowacjami cyfrowymi),

- konsekwencje myślenia wolnorynkowego (przestroga przed chciwością, niecierpliwością i krótkowzrocznością);

- błękitną gospodarkę (w kierunku gospodarki obiegu zamkniętego i inwestycji „zaangażowanych społecznie”) (von Weizsäcker, Wijkman [red.] (2018): 21-177).

Również te prognozy już w chwili obecnej częściowo się sprawdzają. Warto zatem w sposób systemowy traktować prognozy, a szczególnie prognozy ostrzegawcze, które pozwalają na eliminowanie lub łagodzenie skutków ubocznych wprowadzanych zmian. Jeżeli proces prognozowania potraktujemy jako konstytutywny komponent długookresowego planowania społeczno-gospodarczego, to w każdej chwili będzie można wprowadzać odpowiednie korekty wynikające z bieżącej sytuacji i dających się przewidzieć z dużym prawdopodobieństwem krótkookresowych efektów polityki społeczno-gospodarczej.

\section{Prognozy edukacyjne - nowe zawody i kompetencje przyszłości}

We wszystkich przytoczonych wyżej prognozach rozwoju społeczno-gospodarczego można wyróżnić elementy wspólne. 
W syntetycznym ujęciu dotyczą one:

- globalizacji i jej skutków;

- kierunków rozwoju gospodarki światowej (z uwzględnieniem czwartej już rewolucji przemysłowej - za jej początek przyjmuje się umownie rok 2010);

- zmian demograficznych (starzejące się społeczeństwa);

- zmian struktury społecznej związanych z poziomem wykształcenia i nasilającym się rozwarstwieniem natury ekonomicznej;

- koncepcji polityki imigracyjnej (między zamykaniem a otwieraniem granic);

- podnoszącej się jakości życia (nastawienie na spożywanie zdrowej żywności, dbałość o zdrowie i wizerunek, uprawianie sportu i docenianie znaczenia rekreacji).

Spójrzmy na konsekwencje tych prognoz z punktu widzenia nowych zawodów - zawodów przyszłości, które powinny zainspirować system edukacji, a ściślej mówiąc gremia odpowiedzialne za przyszły kształt edukacji - za strukturę organizacyjną oraz plany i programy kształcenia (kierunki kształcenia w szkołach różnych typów i poziomów), a także, o czym później, za kształtowanie kompetencji przyszłości.

Globalizacja skłania do zwrócenia uwagi na zawody wymagające:

- biegłej znajomości języków obcych;

- wiedzy o innych kulturach i ich wpływie na skuteczne funkcjonowanie zespołów wielokulturowych.

Analiza kierunków rozwoju gospodarki światowej wskazuje, że pojawią się nowe zawody związane z:

- poszukiwaniem i eksploatacją alternatywnych źródeł energii;

- wykorzystywaniem metod i technik informatycznych (sztuczna inteligencja - automatyzacja i robotyzacja produkcji i usług).

Zmiany demograficzne, wynikające przede wszystkim z postępów medycyny i będącego ich wynikiem sukcesywnego wydłużania się życia, generują popyt na zawody opiekuńcze obejmujące:

- kompleksową opiekę domową nad osobami starszymi;

- opiekę, domową i w specjalistycznych ośrodkach, nad osobami z różnego rodzaju niepełnosprawnościami;

- rehabilitację osób starszych i osób z niepełnosprawnościami.

Zmiany struktury spotecznej wynikające ze wzrostu poziomu wykształcenia spowodują w pierwszej kolejności zwiększone zainteresowanie pracownikami o najwyższych kompetencjach 
specjalistycznych, niezależnie od wykonywanego zawodu. Trzeba się liczyć z tym, że szczególnie poszukiwane będą kompetencje zintegrowane, takie jak:

- łączące wiedzę i umiejętności techniczne (rozumiane ogólnie) z umiejętnościami informatycznymi;

- łączące wiedzę i umiejętności medyczne, biologiczne, czy też ekonomiczne $\mathrm{z}$ umiejętnościami tworzenia i zastosowania $\mathrm{w}$ tych obszarach odpowiedniego oprogramowania informatycznego.

Od koncepcji polityki imigracyjnej zależeć będzie przyszłość zawodów, w których zadania dotyczą:

- asymilacji obcokrajowców i umożliwienia im rozwoju zawodowego (sprawy bytowe, pomoc w adaptacji środowiskowej, kursy językowe, szkolenia zawodowe),

- wspierania rodzin obcokrajowców w ich codziennej egzystencji (edukacja dzieci, zajęcia edukacyjne i zawodowe dla współmałżonków, przygotowywanie oferty i prowadzenie działań integracyjnych).

Podnoszaca się jakość życia już obecnie owocuje powstawaniem nowych zawodów oferujących usługi w sferze:

- dietetyki,

- kosmetologii,

- medycyny estetycznej,

- różnego rodzaju doradztwa,

- organizacji czasu wolnego (Kwiatkowski 2018: 24-25).

Bez ryzyka popełnienia większego błędu można prognozować, że zawody (obszary zawodowe) tego rodzaju będą się w najbliższej przyszłości dynamicznie rozwijać. Trzeba dodać, że są to tylko wybrane przykłady zawodów, a precyzyjniej mówiąc obszarów zawodowych, z których będą się wyodrębniały zawody przyszłości.

Biorąc pod uwagę prognozy dotyczące najszybciej rozwijających się obszarów zawodowych, można już pokusić się o sformułowanie prognoz opisujących kompetencje przyszłości, czyli układy wiedzy, umiejętności i kompetencji społecznych niezbędne do realizacji zadań zawodowych przypisywanych zawodom przyszłości. Z oczywistych względów najtrudniej jest o prognozy odnoszące się do wiedzy i umiejętności. Nieco łatwiej jest przewidywać zapotrzebowanie na kompetencje społeczne, które nie są uwarunkowane tak silnie jak wiedza i umiejętności tempem rozwoju techniki i technologii. Przy tych zastrzeżeniach, patrząc z dzisiejszej perspektywy, do kompetencji przyszłości proponuję zaliczyć: 
- „kompetencje ogólne zdobywane w systemie edukacji formalnej (możliwie najwyższy poziom kompetencji językowych, matematycznych, informatycznych oraz społecznych);

- kompetencje ogólnozawodowe (specyficzne dla edukacji formalnej), wspólne dla grup zawodów (projektowanie, opracowywanie procedur realizacji projektów, szerokie wykorzystanie narzędzi informatycznych, praca w zespole, tworzenie zespołów i kierowanie nimi);

- kompetencje zawodowe wynikające $\mathrm{z}$ potrzeby realizacji zadań zawodowych (początkowo domena edukacji formalnej, a w późniejszym okresie edukacji pozaformalnej i nieformalnej), mające charakter obszarowy (branżowy);

- specyficzne kompetencje zawodowe związane $\mathrm{z}$ :

- możliwością transformacji umiejętności zawodowych (wraz ze zmianami technologicznymi);

- integracją wiedzy i umiejętności zawodowych z różnych obszarów (branż) - mechanika i elektronika, informatyka i medycyna, informatyka i ochrona środowiska, chemia i medycyna, biologia i nauki techniczne itd.;

- ogólne kompetencje spoleczne nabywane w toku interakcji $\mathrm{z}$ innymi uczestnikami życia społecznego i zawodowego, w ramach edukacji nieformalnej (komunikowanie - formułowanie, przekazywanie/odbiór komunikatów werbalnych i niewerbalnych, autoprezentacja, rozwiązywanie konfliktów, wywieranie wpływu społecznego, negocjowanie, współpraca w grupie - również wielokulturowej, organizacja pracy własnej, występowanie w różnych rolach społecznych);

- specyficzne kompetencje spoleczne (osobiste) będące wynikiem zarówno edukacji formalnej, jak i pozaformalnej i nieformalnej, pożądane w niektórych zawodach i specjalnościach, takie jak:

- empatia,

- rozwiązywanie problemów,

- kreatywność,

- elastyczność myślenia,

- inteligencja emocjonalna,

- dojrzałość moralna, etyczność,

- odwaga,

- otwartość na zmiany,

- zarządzanie czasem,

- umiejętność uczenia się,

- przewodzenie" (Kwiatkowski 2018: 26-27; por. także: Weissberg, Durlak, Domitrovich, Gullotta 2017: 6-7). 
Zaproponowany układ: kompetencje ogólne, ogólnozawodowe, zawodowe (w tym specyficzne) i społeczne (ogólne i specyficzne) można z powodzeniem uszczegóławiać, tworzyć nowe kategorie i rozbudowywać ich strukturę. Można również dokonywać ich racjonalnych syntez. W przedstawionej postaci jest to rodzaj propozycji do dyskusji. Rozpoczynając ją, warto zauważyć, że jeżeli przyjmiemy, że znakiem firmowym przyszłości jest zmiana, to podstawową - perspektywiczną kompetencją jest niewątpliwie zdolność do efektywnego reagowania na pojawiające się nowe elementy rzeczywistości - ich krytyczna analiza ze zwróceniem uwagi na potencjalne zagrożenia. Wymaga to rozwoju swoistego rodzaju kompetencji nadrzędnych, które charakteryzuje nie tylko gotowość na zmiany i wspomniane wyżej efektywne reagowanie na nie, lecz także aktywny udział $\mathrm{w}$ ich kreowaniu, a następnie w rozwiązywaniu problemów (napięć) pojawiających się nieuchronnie na styku starego i nowego porządku społecznego oraz gospodarczego.

Poza tym istotny jest namysł nad relacjami występującymi między edukacją formalną, pozaformalną i nieformalną. Jak już wspomniano, przy opisie kompetencji przyszłości, wyróżnione wyżej formy edukacji wzajemnie przenikają się i uzupełniają, ale dla idei uczenia sie przez cate życie kluczowe znaczenie ma edukacja formalna, która pozwala na zdobycie solidnego wykształcenia i jest podstawą do ciągłego uczenia się - już na drodze edukacji pozaformalnej i nieformalnej.

Na koniec odwołajmy się do obowiązującej podstawy programowej kształcenia ogólnego dla liceum ogólnokształcącego i technikum ${ }^{4}-\mathrm{w}$ poszukiwaniu zapisów umożliwiających właściwe kształtowanie zaproponowanych (autorskich) kompetencji przyszłości. Otóż na podstawie analizy celów kształcenia trzeba stwierdzić, że na poziomie ogólnych zapisów cele te sprzyjają rozwijaniu wyróżnionych wyżej kompetencji przyszłości. Na poparcie tej tezy wystarczy odwołać się do takich celów, jak:

- „traktowanie uporządkowanej, systematycznej wiedzy jako podstawy kształtowania umiejętności [...];

- rozwijanie osobistych zainteresowań ucznia i integrowanie wiedzy przedmiotowej z różnych dyscyplin [...];

4 Rozporządzenie Ministra Edukacji Narodowej z dnia 30 stycznia 2018 r., Dz.U. z dnia 2 marca 2018 r., poz. 467. 
- łączenie zdolności krytycznego i logicznego myślenia z umiejętnościami wyobrażeniowo-twórczymi [...];

- rozwijanie u uczniów szacunku dla wiedzy, wyrabianie pasji do poznawania świata i zachęcanie do praktycznego zastosowania zdobytych wiadomości” (tamże).

Również pozostałe cele zapisane w podstawie programowej, a odnoszące się do „doskonalenia umiejętności myślowo-językowych”, „zdobywania umiejętności formułowania samodzielnych przemyśleń i sądów” czy „rozwijania wrażliwości społecznej, moralnej i estetycznej", należy uznać za pomocne w procesie opanowywania kompetencji przyszłości.

W podstawie programowej, o której mowa, znajdujemy także wykaz umiejętności, które uczeń powinien zdobyć w toku nauki w szkole średniej (liceum ogólnokształcącym lub w technikum). Zaliczono do nich ważne z punktu widzenia kompetencji przyszłości:

- „myślenie [...] obejmujące [...] wnioskowanie, abstrahowanie, rozumowanie, wyobrażanie siebie, sądzenie, rozwiązywanie problemów, twórczość";

- „umiejętność komunikowania się w języku ojczystym i językach obcych";

- „kreatywne rozwiązywanie problemów z różnych dziedzin”;

- „umiejętność samodzielnego docierania do informacji, dokonywania ich selekcji, syntezy oraz wartościowania, rzetelnego korzystania ze źródeł";

- „nabywanie nawyków systematycznego uczenia się”;

- „umiejętność współpracy w grupie i podejmowania działań indywidualnych".

Wykaz ten uzupełniają zupełnie elementarne umiejętności czytania i sprawnego posługiwania się nowoczesnymi technologiami informacyjno-komunikacyjnymi. Wprawdzie nie znajdujemy nazwanej wprost umiejętności samodzielnego uczenia się, ale $\mathrm{w}$ kilku miejscach są odwołania do strategii uczenia się przez całe życie, której realizacja wymaga bazowania na właśnie takiej umiejętności. O tego typu umiejętności, warunkującej sprawne radzenie sobie w sytuacji wszechobecnej zmiany, wspominał już w latach 80. XX w. Alvin Toffler (1984: 414), który odnosząc się do tego, czym będzie analfabetyzm w XXI w., zaakcentował kluczowe znaczenie umiejętności niezbędnych do skutecznego i samodzielnego uczenia się, oduczania się tego, czego nauczono się już wcześniej oraz uczenia się na nowo. 
Lektura całej podstawy programowej, wraz z opisami odnoszącymi się do poszczególnych przedmiotów, pozwala na konstatację, że zbiory wiadomości, a także umiejętności są przedstawione w konwencji efektów uczenia się - co odpowiada wymaganiom Polskiej Ramy Kwalifikacji ${ }^{5}$. Jest to o tyle istotne, że umożliwia odniesienie pewnych umiejętności ogólnych do wymagań rynku pracy. Patrząc z nadzieją na sformułowania przyjęte w podstawie programowej należy pamiętać, że ich właściwa realizacja będzie zależała od przygotowania nauczycieli i ich motywacji, a także od infrastruktury dydaktycznej polskich szkół.

Patrząc z szerszej perspektywy na kompetencje przyszłości należy uwzględnić podstawowy cel edukacji, jakim staje się kształcenie dla zrównoważonego rozwoju. To pojęcie pojawiło się w refleksji nad przyszłością świata na przełomie lat 60. i 70. ubiegłego wieku, ale w początkowym okresie było traktowane jako utopijne hasło, które nieprędko znajdzie swoją konkretyzację. Utożsamiano je wówczas głównie ze sprawami związanymi ze środowiskiem naturalnym, takimi jak „dziura ozonowa” czy „efekt cieplarniany”. Stopniowo jednak do świadomości społecznej zaczęła przenikać koncepcja zrównoważonego rozwoju (sustainable development) kładąca nacisk na równowagę między rozwojem społeczno-gospodarczym a ekosystemami niezbędnymi do funkcjonowania człowieka. Szerszy rezonans pojęcie zrównoważonego rozwoju zyskało jako pokłosie Konferencji ONZ „Środowisko i Rozwój” (znanej również jako „Szczyt Ziemi”), która odbyła się w 1992 r. w Rio de Janeiro. Dwadzieścia kilka lat później - w roku 2015 - podczas szczytu ONZ w Nowym Jorku przyjęto Agendę 2030 zwierającą światowy program zrównoważonego rozwoju. Podpisali ten dokument przedstawiciele 193 państw - członków ONZ.

W syntetycznym ujęciu rozwój możemy określić mianem zrównoważonego, jeżeli ludzkość realizuje swoje potrzeby z myślą o aspiracjach rozwojowych kolejnych pokoleń (w imię sprawiedliwości międzypokoleniowej).

Z punktu widzenia rozwoju systemu (podsystemu) edukacji istotne jest rozpatrywanie analizowanego pojęcia w kontekście wzajemnych relacji między środowiskiem (przyrodą), społeczeństwem i gospodarką (Rokicka, Woźniak 2016: 10). Takie ujęcie

5 Ustawa z dnia 22 grudnia 2015 r. o Zintegrowanym Systemie Kwalifikacji. Dz.U. z dnia 14 stycznia 2016 r., poz. 64. 
umożliwia interdyscyplinarne podejście do poszukiwania metod przeciwdziałania istniejącym współcześnie zagrożeniom gospodarczym (np. spowalnianiu wzrostu) bez szkody dla środowiska i bez perturbacji natury społecznej.

Konsekwencje edukacyjne myślenia o rozwoju w sposób zintegrowany są wielowymiarowe. W pierwszej kolejności należy odwołać się do wyróżnionych wyżej - w strukturze kompetencji przyszłości - kompetencji ogólnych. To od nich zależy bowiem poziom wiedzy na temat związków między środowiskiem, społeczeństwem i gospodarką. Położenie nacisku na wiedzę o aktualnych zależnościach między tymi trzema obszarami zrównoważonego rozwoju, a także, co szczególnie istotne, o relacjach o charakterze prognostycznym, daje podstawę do racjonalnej analizy zagrożeń, które niesie ze sobą brak myślenia i działania zmierzającego do osiągnięcia w przyszłości stanu zrównoważonego rozwoju.

Rzetelna wiedza na temat stanu wyjściowego w zakresie wzajemnych zależności i uwarunkowań rozwoju środowiskowego, społecznego i gospodarczego pozwala na przygotowanie scenariuszy przyblizających efekty zrównoważonych działań w rozpatrywanych obszarach i tworzących je podobszarach. W obszarze środowiskowym efekty mogą być rozpatrywane z uwzględnieniem zrównoważonego rolnictwa (np. zdrowa żywność, zachowanie bioróżnorodności, obniżenie emisji gazów cieplarnianych, ochrona wód gruntowych). Z obszarem społecznym związane są efekty zrównoważonej produkcji i konsumpcji (np. racjonalne korzystanie z zasobów naturalnych, ograniczanie skali ubóstwa, efektywne zużycie energii, redukcja odpadów). Dla obszaru gospodarczego istotne są z kolei efekty dotyczące zrównoważonej energii (np. dostęp do „czystej” energii, bezpieczeństwo energetyczne, zmniejszanie energochłonności produkcji, poprawa jakości powietrza) (Na ścieżce zrównoważonego rozwoju, 2016: 19-23).

Jak już wspomniano, wiedza, o której mowa, ma cechy interdyscyplinarne wymagające integracji treści kształcenia wokół wyróżnionych wyżej problemów i procedur projektowania najbardziej efektywnych rozwiązań. Wprowadzanie ich do praktyki łączy się nierozerwalnie z zastosowaniami wiedzy w realnych sytuacjach, czyli z kompetencjami, które określiliśmy mianem ogólnozawodowych i zawodowych. Ich uzupełnieniem są kompetencje społeczne, które umożliwiają współpracę w grupie, rozwiązywanie konfliktów czy też wywieranie wpływu społecznego. Nie bez znaczenia są również takie kompetencje 
społeczne, jak: otwartość na zmiany, umiejętność uczenia się oraz dojrzałość moralna.

Jak łatwo zauważyć, aby osiągnąć w przyszłości satysfakcjonujące efekty zrównoważonego rozwoju trzeba odwoływać się selektywnie do wybranych kompetencji przyszłości. Swiadczy to niewątpliwie o ich uniwersalności, a zarazem o potrzebie wyeksponowania ich wśród perspektywicznych celów edukacji.

\section{Zakończenie}

Przedstawiona koncepcja analiz prowadzących od prognoz dotyczących przyszłości $\mathrm{w}$ rozumieniu globalnym do kompetencji przyszłości, które wydają się niezbędne do funkcjonowania w zmieniającym się świecie, może być wstępem do pogłębionej refleksji nad edukacją. Podstawowy problem w tym obszarze nie dotyczy reakcji (szybszej lub wolniejszej) systemu edukacji na zachodzące obiektywnie przeobrażenia społeczno-gospodarcze, ale możliwości realnego wpływu na kierunki i tempo owych przeobrażeń. Innymi słowy trzeba odpowiedzieć na pytanie czy rolą edukacji, utożsamianej z poziomem wykształcenia społeczeństw, jest jedynie rozumna reakcja (wynikająca z wiedzy i towarzyszącej jej świadomości nieuchronności pewnych zjawisk i ich skutków zagrożeń) na konkretne propozycje rozwojowe, czy też może ona efektywnie wpływać na przyszłość świata i jego zrównoważony rozwój, wskazując na potencjalne niebezpieczeństwa wynikające z myślenia i działania w krótkim horyzoncie czasowym (maksymalizacja zysków pozbawiona troski o pozostawienie środowiska naturalnego w stanie umożliwiającym życie następnym pokoleniom) i oferować alternatywne, eliminujące przynajmniej podstawowe zagrożenia, rozwiązania - drogi rozwoju? Oczywiście chcielibyśmy, żeby wpływ edukacji na losy świata był realny i widoczny możliwie szybko, ale trzeba pamiętać, że przejście od świadomości potrzeby a wręcz niezbędności pewnych działań, do ich realizacji, wymaga czasu - podobnie jak przejście od działań do dających się zaobserwować ich skutków. Pozostaje jednak nadzieja, że jeżeli będziemy traktowali świat jako system złożony ze współpracujących ze sobą elementów, to nawet najmniejsze zmiany $\mathrm{w}$ jednym $\mathrm{z}$ nich (np. w edukacji) spowoduja, oczywiście z pewnym opóźnieniem, modyfikację funkcjonowania całego systemu. 


\section{Bibliografia}

Coates J.F. (2002), O studiach nad przysztościa na świecie i w Polsce, „Polska 2000 Plus" 1 (5), s. 9-22.

Friedrichs G. (1987), Mikroelektronika i makroekonomia, [w:] G. Friedrichs, A. Schaff (red.), Mikroelektronika i spoleczeństwo. Na dobre czy na zte? Raport dla Klubu Rzymskiego, Książka i Wiedza, Warszawa.

Karpiński A. (2001), Studia nad przysztościa na świecie $i w$ Polsce (doświadczenia i wnioski), „Polska 2000 Plus” 2 (4), s. 9-23.

Kwiatkowski S.M. (2018), Kompetencje przyszłości, [w:] S.M. Kwiatkowski (red.), Kompetencje przysztości, Fundacja Rozwoju Systemu Edukacji, Warszawa.

Mayor F. (red.) (2001), Przyszłość świata, Fundacja Studiów i Badań Edukacyjnych, Warszawa.

Na ścieżce zrównoważonego rozwoju (2016), GUS, Warszawa.

Rokicka E., Woźniak W. (2016), W kierunku zrównoważonego rozwoju. Koncepcje, interpretacje, konteksty, Wydawnictwo Uniwersytetu Łódzkiego, Łódź.

Rozporządzenie Ministra Edukacji Narodowej z dnia 30 stycznia 2018 r. w sprawie podstawy programowej kształcenia ogólnego dla liceum ogólnokształcącego, technikum oraz branżowej szkoły II stopnia. Dz.U. z dnia 2 marca 2018 r., poz. 467.

Secomski K. (1987), Przedmowa, [w:] G. Friedrichs, A. Schaff (red.), Mikroelektronika i spoleczeństwo. Na dobre czy na zle?, Raport dla Klubu Rzymskiego, Książka i Wiedza, Warszawa.

Toffler A. (1984), Future Shock, Random House, New York.

Ustawa z dnia 22 grudnia 2015 r. o Zintegrowanym Systemie Kwalifikacji. Dz.U. z dnia 14 stycznia 2016 r., poz. 64.

von Weizsäcker E.U., Wijkman A. (red.) (2018), Ejże! Kapitalizm, krótkowzroczność i zniszczenie planety, Instytut Badań Stosowanych Politechniki Warszawskiej, Warszawa.

Weissberg R.P., Durlak J.A., Domitrovich C.E., Gullotta T.P. (2017), Social and Emotional Learning. Past, Present and Future, [w:] J.A. Durlak, C.E. Domitrovich, R.P. Weissberg, T.P. Gullotta (red.), Handbook of Social and Emotional Learning. Research and Practice, The Guilford Press, New York-London. 
Anna Sajdak-Burska

ORCID 0000-0002-0156-3986

Instytut Pedagogiki, Uniwersytet Jagielloński

\title{
Budowanie kultury zaufania i wspólnotowości w dydaktyce akademickiej
}

\author{
Abstract \\ Building a culture of trust within teaching \\ and learning in university didactics
}

What kind of culture dominates the domain of university teaching and learning - a culture of trust or culture of distrust? Higher education praxis of teaching and learning may be governed by one of the two paradigms: a "teaching paradigm" or a "learning paradigm". The first one requires less trust between a teacher and a learner. The second one needs more trust especially the learner's trust in teacher's competence. Maria Dudzik and her research team argue that in the praxis of Polish university didactics, we can find more distinct features of the "teaching paradigm" than of the "learning paradigm". That means that in the teaching-paradigm-dominated university education, there is no room for trust-based social-patterns-learning, participation, collaboration, and community building processes. The article presents an example of an original approach drawing on multiple social models and experiential learning in the Kolb's cycle fostering trust-based social competences development in the course of university education.

Keywords: university didactics, social constructivism, experiential learning, trust, feeling of community

Słowa kluczowe: dydaktyka akademicka, konstruktywizm społeczny, uczenie się przez doświadczenie, zaufanie, wspólnotowość

\section{Wstęp}

Organizatorzy X Zjazdu Polskiego Towarzystwa Pedagogicznego (Warszawa, 18-20 września 2019) zaprosili społeczność akademicką do dyskusji nad wyzwaniami, jakie stoją przed pedagogiką w dynamicznie zmieniającym się krajobrazie współczesności, 
w którym wyraźnie zaznaczają się pęknięcia związane z kryzysem zaufania, wspólnotowości i autonomii podmiotów szerokiej sceny edukacyjnej. Nurtujące mnie pytanie brzmi, czy istotnie mamy do czynienia z erozją zaufania i kulturą nieufności w obszarze najbardziej mi bliskim - w akademickim kształceniu? Wszak niemal każdy statut uniwersytetu zakłada, iż wszyscy nauczyciele akademiccy, studenci, doktoranci oraz pracownicy niebędący nauczycielami akademickimi stanowią wspólnotę uczelni. A bycie wspólnotą zakłada istnienie więzi nie tylko na poziomie formalnym. Kultura europejska immanentnie związana była i jest z rozwojem uniwersytetów, rozumianych właśnie jako wspólnota studentów i profesorów. W swych początkach uniwersytety zakładane były albo przez studentów (jak np. Uniwersytet w Bolonii), chcących pobierać nauki, zatrudniających w tym celu odpowiednich nauczycieli oraz ustalających reguły nauczania albo przez samych nauczycieli (jak np. Uniwersytet w Paryżu i Oxfordzie), kreujących program i formułę nauczania. Największy rozwój uniwersytetów przyniosła epoka renesansu oraz oświeceniowa debata nad ich kondycją. Funkcjonowanie uniwersytetów jako instytucji korporacyjnych zakończyło się kryzysem, związanym ze zmianą koncepcji człowieka oraz przejściem do świata nowoczesnego (Hejnicka-Bezwińska 2010: 31). Po nim nastąpił okres reformy. Różnorodne cele, dla których uniwersytety były powoływane, ukonstytuowały trzy główne modele, typy uniwersytetów - model francuski, niemiecki i angielski, które oczywiście różniły się od siebie znacząco przede wszystkim wagą, jaką przywiązywano do prowadzenia badań naukowych oraz kształcenia studentów. Model angielski, zachowujący średniowieczną strukturę collegów, zreformowany przez Johna Henry'ego Newmana, pomijał nawet obowiązek prowadzenia badań naukowych w uniwersytecie. Jak głosił Newman w jednym ze swych słynnych wykładów dublińskich, uniwersytet „to miejsce nauczania uniwersalnej wiedzy. Oznacza to, z jednej strony, cel intelektualny, a nie moralny tej instytucji; z drugiej zaś, raczej komunikowanie się i szerzenie wiedzy niż jej postęp. Gdyby celem były odkrycia naukowe i filozoficzne, nie widzę, dlaczego uniwersytet miałby przyjmować studentów" (Newman 1990: 79).

Kształcenie studentów, zdaniem Newmana, jest jedną z zasadniczych powinności uniwersytetu. Uniwersytet jest dla studentów, bez nich straciłby sens. Oczywiście potrzebni są także naukowcy nauczyciele akademiccy (chociaż, jak pisze Newman w innej części 
swych wykładów - nie jest to warunek niezbywalny), którzy wespół ze studentami tworzą społeczność akademicką. To właśnie bycie wspólnotą jest tradycyjnym filarem konstytuującym rację kształcenia w uniwersytecie. I to wspólnotą specyficzną, przepojoną atmosferą współdziałania. Wszak już w wydanej w 1899 r. pracy Idea uniwersytetu Newman pisat:

Mamy do czynienia ze zgromadzeniem uczonych, gorliwie zabiegających o rozwój swoich nauk i rywalizujących ze sobą, a ich obcowanie i zżycie ze sobą prowadzi ich, dla utrzymania intelektualnego pokoju, do wspólnego uzgadniania twierdzeń i relacji ich odnośnych dziedzin badań. Uczą się szanować wzajemnie, konsultować i wspomagać. Powstaje w ten sposób czysta i jasna atmosfera myślowa, którą oddycha również student (Newman 1990: 182).

A zatem u źródeł konstytuowania się obrazu współczesnych uniwersytetów leży przekonanie, iż ważnym - jeśli nie zasadniczym - filarem uniwersytetu jest współdziałająca wspólnota. Co współcześnie zrobiliśmy z powierzonym dziedzictwem? Obraz, jaki wyłania się z badań prowadzonych w Uniwersytecie im. Adama Mickiewicza w Poznaniu przez zespół badawczy pod kierownictwem Marii Dudzikowej (Dudzikowa, Wawrzyniak-Beszterda, Jaskulska, Marciniak, Bochno E., Bochno I., Knasiecka-Falbierska 2013), niestety nie jest optymistyczny. Autorzy prowadzili szeroko zakrojone badania wzdłużne, diagnostyczno-zależnościowe nad zasobami kapitału społecznego uniwersytetu w aspekcie jednostkowym oraz zbiorowym. Pośród wielu interesujących zmiennych badano także ofertę dydaktyczną uczelni, koncentrując się m.in. nad sposobem prowadzenia zajęć, treściami nauczania, warunkami aktywności poznawczej studentów, stosunkiem nauczycieli do studentów, jakością pracy nauczycieli akademickich oraz zaufaniem studentów wobec prowadzących zajęcia. Zespół badał także relacje w grupie studenckiej, ukierunkowując swe zaangażowanie na diagnozowanie poczucia wsparcia, akceptacji, zaufania w grupie, poczucia spójności grupy, gotowości do spontanicznej aktywności w grupie, atmosfery grupy oraz etosu grupy. Nie sposób przytaczać szczegółowe analizy uzyskanych wyników, nie jest to ani możliwe, ani celowe, warto jednak zwrócić uwagę na parę zasadniczych kwestii z punktu widzenia budowania kultury zaufania i wspólnotowości na zajęciach ze studentami. Z badań konsekwentnie wyłania się obraz dydaktyki akademickiej zanurzonej w tradycyjnym modelu kształcenia, 
nazywanym przez Autorów wręcz herbartowskim, w którym „dominuje przekaz gotowej, uporządkowanej wiedzy [...] Towarzyszy temu stosunkowo niewielkie zaangażowanie studentów $\mathrm{w}$ proces uczenia się oraz relatywnie małe zainteresowanie jego treściami” (Wawrzyniak-Beszterda 2013: 41). Nauczyciele i studenci nie tworzą wspólnoty uczących się, nie wspierają się $\mathrm{w}$ trudnym procesie zdobywania wiedzy poprzez indywidualne i społeczne konstruowanie znaczeń. Studenci rzadko mają okazję do samodzielnego działania, zadawania pytań, aktywnego poszukiwania odpowiedzi i twórczej pracy. Aktywność studenta na zajęciach jest dobrem deficytowym. Studentom towarzyszy brak poczucia sensu, iż to, co robią na zajęciach, jest pożyteczne. Pasywna postawa studentów jest odpowiedzią na preferowany przez nauczycieli model dydaktyki akademickiej, zakładającej przede wszystkim transfer wiedzy. Kategoria „zaufania” też nie wygląda imponująco. Badania pokazują, iż mimo tego, że studenci mają na ogół dobre relacje z nauczycielami akademickimi, to jednak „towarzyszy temu relatywnie małe zaufanie studentów do nich” (Wawrzyniak-Beszterda 2013: 41). Budowanie i doświadczanie wspólnotowości przez studentów podczas zajęć dydaktycznych też nie wypada najlepiej, co wynika m.in. z faktu, iż nauczyciele akademiccy rzadko wykorzystują model pracy w grupie.

Obraz edukacji akademickiej, jaki wyłania się z cząstkowych badań prowadzonych w Uniwersytecie im. Adama Mickiewicza w Poznaniu przez zespół Dudzikowej, a także prowadzonych w Uniwersytecie Gdańskim przez Teresę Bauman (Bauman 2001, Bauman 2011) pokazuje, iż dominujący jest bardzo tradycyjny, oparty na przekazie treści, mocno transmisyjny sposób myślenia o niej. Próżno szukać w tych badaniach śladów potwierdzenia, iż uniwersytety stanowią prawdziwą społeczność akademicką współdziałających nauczycieli i studentów, społeczność opartą na autonomii, zaufaniu i poczuciu wspólnotowości. W myśleniu o edukacji akademickiej kategorie autonomii studenta, zaufania i wspólnotowości zeszły na daleki plan wobec pierwszoplanowych zadań, jakimi stały się „skuteczność” i „efektywność” kształcenia. Mam jednak głębokie przekonanie, że ich dominacja przeminie, a stanie się to wraz z przemianą uniwersyteckiego kształcenia, która powoli dokonuje się wraz z implementacją nowoczesnych modeli kształcenia opartych m.in. na wzorach społecznego uczenia się. W artykule postaram się przedstawić moje odpowiedzi na pytania: o jaką edukację akademicką winniśmy zabiegać oraz skąd czerpać 
inspirację dla implementowania nowoczesnych propozycji akademickiego kształcenia, które z założenia mają sprzyjać budowaniu poczucia autonomii, współpracy i zaufania nauczycieli i studentów?

\section{Edukacja akademicka, ale jaka?}

Niektórzy badacze zwracają uwagę na pewne widoczne w ostatnich dekadach znieruchomienie polskiej dydaktyki, swego rodzaju inercję, okopanie się na pozycji nauki instrumentalistycznej, dostarczającej technologicznych wskazówek do skutecznego działania dydaktycznego, legitymizowanego przez argumentacje pozytywistyczne i behawioralne (Klus-Stańska 2011). Wydaje się jednak, że ten swego rodzaju kryzys przełamuje się i powoli pęka monolit tradycyjnego myślenia o procesach kształcenia. Prace polskich dydaktyków coraz częściej, kreśląc swego rodzaju mapy paradygmatyczne, ukazują teoretyczne zróżnicowanie dydaktyki ogólnej, które to bezpośrednio uprawomocnia zupełnie odmienne podejścia do praktyki procesu kształcenia (Klus-Stańska 2018). Dydaktyka akademicka, która ze względu na większą interdyscyplinarność pola teoretycznego i badawczego jest swego rodzaju subdyscypliną pedagogiczną zbliżoną do dydaktyki ogólnej i dydaktyk przedmiotowych, także nie pozostała w miejscu (Sajdak 2013, Sajdak-Burska 2018). Mamy jednak w stosunku do osiągnięć wielu krajów Europy Zachodniej czy USA wyraźne zapóźnienia. Już w latach 90. w krajach anglojęzycznych zapoczątkowano ożywioną dyskusję nad koniecznością zmiany i poprawy jakości akademickiego kształcenia, której to szansy upatrywano w zmianie dominującego paradygmatu dydaktycznego. Wskazywano głównie na konieczność zbudowania innego podejścia do procesu nauczania - uczenia się w szkolnictwie wyższym. Praca Georga Browna i Madeleine Atkins (1988) upomniała się o niedoceniane dotąd zagadnienia w refleksji nad akademickim kształceniem - problematykę efektywności pracy studentów w małych grupach, temat roli superwizji w kształceniu, postawy facylitacyjnej nauczyciela akademickiego oraz udzielania pomocy i wsparcia studentowi w procesie uczenia się. Nakreślone zostały zupełnie nowe obszary badań nad kształceniem na poziomie wyższym, które w żaden sposób nie wpisywały się w tradycyjny nurt myślenia o edukacji. W nurt refleksji promującej potrzebę odejścia od pasywnego nauczania na rzecz budowy aktywnego środowiska edukacyjnego włączyli się także Robert B. Barr i John Tagg, którzy w swych 
artykułach zaczęli posługiwać się metaforycznym, specyficznym zwrotem - the shift from teaching to learning - używanym jako określenie postulowanego, paradygmatycznego przesunięcia, związanego z odejściem od paradygmatu skoncentrowanego na dyrektywnym, kierowanym nauczaniu i zwróceniem się $\mathrm{w}$ stronę paradygmatu skoncentrowanego na osobie studenta i procesie jego uczenia się. Zaznaczyć należy wyraźnie, iż autorzy ci postulowali zmianę - zastąpienie starego paradygmatu nowym. Postulowana zmiana odnosiła się do szeregu ważnych z punktu widzenia procesu nauczania - uczenia się kwestii: formułowania celów kształcenia, podejścia do treści kształcenia, budowania programu nauczania, sposobu współdziałania nauczyciela i studenta w procesie kształcenia, metod kształcenia czy działań związanych z kontrolą i oceną. W paradygmacie określanym przez autorów jako „learning” zasadniczym celem kształcenia jest doprowadzenie studentów do osiągnięcia przez nich sukcesów w procesie uczenia się, związanych z realizacją zaplanowanych rezultatów owego uczenia. Dlatego też już w latach 90. ubiegłego wieku pojawił się postulat, iż należy określać efekty kształcenia jako rezultaty studiowania, a nie cele kształcenia rozumiane jako opis działań nauczyciela. Na marginesie nie sposób nie zauważyć, iż w Polsce ten zapis celów akademickiego kształcenia, wyrażanych językiem efektów kształcenia, pojawił się dopiero wraz z wprowadzeniem Krajowych Ram Kwalifikacji dla szkolnictwa wyższego, czyli około roku 2012. Tymczasem w piśmiennictwie amerykańskim już 20 lat wcześniej postulowano, by punkt ciężkości w myśleniu o akademickim kształceniu przenieść na osobę studenta, efekty jego uczenia się oraz możliwości tworzenia studentom jak najlepszych edukacyjnych warunków do aktywnego uczenia się zarówno poprzez kreowanie pełnego edukacyjnej mocy środowiska edukacyjnego, jak i otoczenie ich dydaktyczną opieką ze strony nauczycieli akademickich. Podkreślano, iż praca nauczycieli akademickich nie może, nie powinna polegać jedynie na przekazywaniu wiedzy i kierowaniu procesem nauczania, lecz winna stymulować studentów do podjęcia przez nich wysiłku aktywnego odkrywania i konstruowania wiedzy. Musi zatem być skoncentrowana na wspieraniu jakości procesu uczenia się studentów. Zdaniem autorów należy odejść od stawiania decydującego akcentu w procesie kształcenia na programie kształcenia oraz jego treściach. Wiedza nie powinna być pojmowana jedynie jako byt obiektywny, funkcjonujący niezależnie od osoby uczącej 
się, byt który staje się przedmiotem transferu od nauczyciela do studenta $\mathrm{w}$ procesie nauczania. Wiedza jest bowiem także konstruktem, powstaje w wyniku aktywnego uczenia się indywidualnego i społecznego, zależy od doświadczeń osoby studiującej oraz kontekstu społeczno-kulturowego, w którym funkcjonuje. Dlatego też student i jego ścieżki myślenia, kontekst uczenia się, doświadczenie stają się jądrem procesu kształcenia. Proces ów jest bowiem złożony i zróżnicowany, dlatego należy go traktować holistycznie, koncentrując się na kreowaniu edukacyjnego, aktywnie stymulującego środowiska, dostarczaniu osobom uczącym się okazji do wchodzenia w interakcje, nabywania doświadczeń i samodzielnego konstruowania wiedzy. Proces uczenia się opiera się nie tylko na indywidualnej aktywności uczącego się podmiotu, ale także na udzielaniu mu wsparcia ze strony wykładowców i innych studentów oraz na uczeniu się we współdziałaniu i na pracy grupowej.

Kolejną ważną kwestią, ilustrującą różnice pomiędzy opisywanymi przez Barra i Tagga paradygmatami, jest zagadnienie kontroli i oceny w akademickim kształceniu. W nauczaniu dyrektywnym, kierowanym, ocenie podlega rezultat procesu nauczania $\mathrm{w}$ postaci odzwierciedlenia materiału nauczania w zasobach pamięci studenta. Dlatego też ocena ma charakter ewaluacji końcowej, szacującej wyniki procesu nauczania - uczenia się, dokonywanej przez nauczyciela po zakończeniu przedstawienia materiału w ramach danego kursu. Ocena ma charakter oceny „prywatnej”, dokonywanej przez nauczyciela na podstawie wymagań sformułowanych programem nauczania. Student, realizując poszczególne kursy, kumuluje punkty, a po osiągnięciu określonego ich poziomu zdobywa odpowiednie dyplomy. Nowy paradygmat kształcenia studentów odmiennie podchodzi do zagadnienia kontroli i oceny. Ta służyć ma przede wszystkim procesowi uczenia się studenta i poprawie jego jakości. Kontrola nie może być zatem dokonywana jedynie na zakończenie kursu. Największe znaczenie dla wzmacniania procesu uczenia się oraz wspierania motywacji studentów do jego podejmowania i kontynuacji ma ewaluacja formatywna, bieżąca, która powinna być oparta na udzielaniu informacji o osiągnięciach oraz wskazywaniu obszarów do korekty. Zdaniem autorów należy odejść od sprawdzania tylko, lub głównie, poziomu przyswojenia treści podawanych przez nauczyciela akademickiego w toku nauczania, bowiem przedmiotem ewaluacji winny być specyficzne rezultaty uczenia - zdobyte w procesie uczenia się kompetencje oparte na wiedzy i umiejętnościach. 
Syntetyczną charakterystykę obu podejść do procesu akademickiego kształcenia przedstawia poniższa tabela.

\section{Tabela 1. Charakterystyka paradygmatu from teaching to learning}

\begin{tabular}{|c|c|}
\hline $\begin{array}{c}\text { TEACHING } \\
\text { podejście skoncentrowane } \\
\text { na treściach i osobie nauczyciela }\end{array}$ & $\begin{array}{c}\text { LEARNING } \\
\text { podejście skoncentrowane na } \\
\text { studencie i jego procesie uczenia się }\end{array}$ \\
\hline \multicolumn{2}{|c|}{ WIEDZA } \\
\hline $\begin{array}{l}\text { - Wiedza naukowa jest obiektywna, } \\
\text { sprawdzalna, powtarzalna, może być } \\
\text { treściowo dzielona } \\
\text { - Treści narzucone są standardem/ } \\
\text { programem } \\
\text { - Oferta obowiązkowych programów } \\
\text { i kursów, mały margines wolności } \\
\text { wyboru kursów, treści } \\
\text { - Uczenie się jest linearne, } \\
\text { kumulatywne } \\
\text { - Transfer wiedzy od nauczyciela } \\
\text { do studenta }\end{array}$ & $\begin{array}{l}\text { - Wiedza jest konstruowana indywi- } \\
\text { dualnie i społecznie, jest umysłową } \\
\text { reprezentacją świata, zależną od tego, } \\
\text { kto jest jej architektem } \\
\text { - Program podlega wyborowi, negocja- } \\
\text { cji, program to wspólny projekt } \\
\text { - Uczenie się ma charakter strukturalny, } \\
\text { jest oparte na budowaniu interaktywnej } \\
\text { konstrukcji } \\
\text { - Zadaniem akademickiego kształcenia } \\
\text { jest stymulowanie odkrywania wiedzy }\end{array}$ \\
\hline
\end{tabular}

\section{CELE KSZTALCENIA}

- Cele opisują działania nauczyciela

- Cele opisywane są przez standardy zewnętrzne, w większości zorientowane są na wiedzę

- Transmisja kulturowa - przekazanie dorobku i zasobów nauki następnym pokoleniom

- Cele jednolite dla wszystkich, formułowane a priori bez rozeznania w rzeczywistych potrzebach i możliwościach uczących się

- Konieczność ich dokładnego i precyzyjnego formułowania
- Cele opisują efekty uczenia się studenta: wiedzę, umiejętności, kompetencje społeczne; w większości zorientowane są na kompetencje i działanie

- Wyznacza się pewien poziom osiąganych kompetencji - narastający progres

- Droga do osiągnięcia efektów uczenia się może być zróżnicowana także poza formalnymi strukturami akademickimi

\section{PROCES NAUCZANIA - UCZENIA SIĘ}

- Nauczanie jest transmisją wiedzy, uczenie się jest przyswajaniem wiedzy

- Dominacja metod asymilacji wiedzy, metod podających: wykład, praca $\mathrm{z}$ tekstem

- Forma pracy: indywidualna i zbiorowa

- Czynności nauczyciela są pierwsze, konieczność udziału w zajęciach
- Uczenie się jest aktywną zmianą we wzorcach myślenia, jest siłownią umysłową

- Nauczanie to organizowanie sytuacji uczenia się, stawianie zadań wywołujących konflikt poznawczy, wymagających myślenia

- Duże zróżnicowanie metod, ważność metod problemowych, aktywizujących: PBL, TBL, Case study, debata oksfordzka, metoda projektów i inne 
- Uczenie się jest oparte zawsze na pracy z gotowymi materiałami, treściami, nawet gdy są samodzielnie wyszukiwane

- Kształtowanie umiejętności algorytmicznych
- Dialog z ekspertami

i przedstawicielami wiedzy, konfrontacja poglądów i stanowisk

- Forma pracy: indywidualna lub grupowa

- Dowolny czas, miejsce, środowisko uczenia się

\section{KONTROLA - OCENA}

- Kontrola i ocena zewnętrzna dokonywana przez nauczyciela na zakończenie kursu

- Wiedza i umiejętności mierzone są przez „obiektywne narzędzia pomiaru osiągnięć”

- Ocena jest „obiektywna”, ale arbitralna

- Kontrola i ocena służy procesom selekcyjnym i prognozowaniu sukcesu zawodowego

- Błąd jest niepożądany
- Kontrola służy rozwojowi, jest oparta na informacji zwrotnej, ważna jest także kontrola formatywna

- Przestrzeń na mylenie się, stawianie hipotez, tworzenie koncepcji (także błędnych)

- Pobudzanie do stawiania pytań

- Spory, różnice, bunt, błędy

- Błąd - przepracowany - służy rozwojowi

\section{NAUCZYCIEL AKADEMICKI}

- Kadra naukowa, każdy ekspert merytoryczny może nauczać

- Kadra naukowa i studenci działają w izolacji

- Nauczyciele oceniają, segregują studentów

- Uprzywilejowana pozycja nauczyciela, uprawniony dystans pomiędzy nauczycielem a studentem

- Uprawniona postawa dyrektywna, ingerencyjna

- Celem komunikacji jest transfer wiedzy i kontrola jej przyswojenia
- Kadra naukowa to projektanci środowiska studiowania

- Kadra naukowa i studenci pracują wspólnie

- Nauczyciel jest moderatorem, facylitatorem procesu uczenia się

- Nauczyciele rozwijają kompetencje i talenty studentów

- Cenione są kompetencje dydaktyczne i społeczne nauczyciela akademickiego

- Podmiotowy styl interakcji

- Celem komunikacji jest wspieranie aktywnego uczenia się studentów indywidualnego i w grupie

STUDENT

- Osoba podporządkowana, poznajacca, przyswajająca wiedzę, realizująca narzucony, gotowy program kształcenia, poddająca się procesowi kontroli i oceny zewnętrznej

- Odpowiedzialność za proces kształcenia po stronie instytucji kształcącej
- Osoba - uczący się dorosły, partnerstwo relacji

- Istota działająca, współprojektująca cele, program, strategie, metody, formy itp.

- Samokontrola i autoewaluacja formatywna przy współudziale nauczyciela poprzedza ewaluację zewnętrzną

- Współodpowiedzialność za proces kształcenia

Źródło: Opracowanie własne. 
Zapoczątkowana w latach 90. w krajach anglojęzycznych dyskusja nad koniecznością wprowadzenia w procesie kształcenia studentów paradygmatycznej zmiany the shift from teaching to learning zaowocowała szerokim ruchem na rzecz reformy szkolnictwa wyższego także w innych krajach. Nie sposób nie odnieść wrażenia, że dyskusja nad jakością amerykańskiego kształcenia na poziomie wyższym zaowocowała także uruchomieniem przemian w szkolnictwie europejskim m.in. na poziomie określania celów i efektów kształcenia. Budowane ramy kwalifikacji dla szkolnictwa wyższego stanowią szczególną metodę opisu kształcenia właśnie za pomocą języka efektów kształcenia (wiedzy, umiejętności oraz kompetencji społecznych). Położenie akcentu na osiągnięcie przez studenta określonych rezultatów uczenia się - efektów kształcenia/uczenia się jest wszak jednym z zasadniczych kierunków promowanej paradygmatycznej zmiany. Zmiana w zapisach dokumentacji procesu kształcenia na poziomie wyższym nie świadczy jednak o tym, że zmieniła się praktyka kształcenia. Obserwacja akademickiej rzeczywistości dydaktycznej pokazuje, jak duża jest inercja i bezwładność trwania tradycyjnych wzorców. Opisanie dwóch paradygmatów, a właściwie wskazanie przejścia/przesunięcia paradygmatycznego w obszarze akademickiego kształcenia znanego jako idea from teaching to learning może rodzić poczucie, iż w wyniku rozwoju linearnego nauki i zaistnienia pewnego „przewrotu” dokonało się pewne paradygmatyczne następstwo. Nic bardziej błędnego. To proces, który trwa. Myśląc jednak o budowaniu kultury zaufania i wspólnotowości w procesie kształcenia studentów, warto z pewnością poszukać tropów teoretycznych i rozwiązań praktycznych lokujących się właśnie w paradygmacie „learning” jako tym, który w centrum zainteresowania stawia osobę studenta.

\section{Drogi wyjścia - trop pierwszy: w stronę konstruktywizmu społecznego}

W jednym ze swych esejów Maria Dudzikowa, przedstawiając wyniki badań nad zasobami kapitału społecznego w szkole zanurzonej w kulturze nieufności oraz kreśląc niepokojący obraz ich erozji także na poziomie szkolnictwa wyższego, postawiła dramatyczne pytanie o to, co zatem należy robić, by szkoła stała się 
miejscem wspólnoty uczących się, budowania poczucia sprawstwa i podejmowania zaangażowanej w rozwiązywanie problemów refleksji (2008: 257-262). Inspiracji do budowania rozwiązań tego problemu można, zdaniem Autorki, szukać w pracy Jerome S. Brunera Kultura edukacji (2006), stanowiącej jeden z ważnych filarów podejścia konstruktywistycznego w myśleniu o procesie kształcenia. Konstruktywizm jest wielowątkowym i bardzo zróżnicowanym teoretycznie podejściem obejmującym z jednej strony uzasadnienia neurobiologiczne ludzkiego myślenia, z drugiej zaś sięgającym do wątków interpretacyjnych, społeczno-kulturowych. Oblicze współczesnego konstruktywizmu wyznaczają niewątpliwie prace Brunera. W twórczości i poglądach Autora można wyróżnić dwa okresy: pierwszy związany z udziałem w rozwoju psychologii poznawczej (inspirowanej pracami Jeana Piageta), drugi - z udziałem w rozwoju podejścia kulturowego (inspirowanego pracami Lwa Semionowicza Wygotskiego). Rozwój poglądów Brunera stanowi odwzorowanie zmiany punktu ciężkości w rozwoju i percepcji konstruktywizmu. Nurt psychologiczno-konstruktywistyczny stanowi uzasadnienie dla badań ukierunkowanych na rozpoznanie indywidualnych wzorów, stylów uczenia się. W tej perspektywie nauczyciel może być aktywnym trenerem aranżującym „edukacyjne okazje” do podejmowania aktywności uczenia się poprzez rozwiązywanie problemów. Nurt konstruktywistyczno-społeczny podkreśla rolę środowiska społecznego uczenia się osób. W tej perspektywie nauczyciel jest „elementem” owego środowiska, partnerem społecznego negocjowania znaczeń. Bruner w swych pracach podkreśla także wyraźnie, iż uczenie się, rozumiane jako proces zdobywania i konstruowania wiedzy, jest wzajemne, stąd wartość form i metod promujących wspólnotę nauczających i uczących się. Autor obrazował ową wspólnotowość następująco:

kultura z natury rzeczy jest zespołem wartości, umiejętności i obyczajów wytworzonych bynajmniej nie przez pojedynczego członka społeczności. Wiedzę można w tym sensie porównać z powrozem sporządzonym z włókien, których długość, każdego z osobna nie przekracza kilkunastu centymetrów, a wszystkie razem mocno skręcone stanowią solidną całość (Bruner 1974: 176).

Autor posługuje się pojęciem „kultura wzajemnego uczenia się” rozumianym jako „wzajemne dzielenie się wiedzą i pomysłami, wzajemna pomoc w przyswajaniu materiału, podział pracy 
i zamian ról, możliwość dokonywania refleksji nad działaniami grupy" (Bruner 2006: 9), podkreślając, iż jest to wersja kultury w najlepszym wydaniu. Poglądy Brunera budowane są na konstruktywizmie Wygotskiego, który - jak zauważa Dorota Klus-Stańska - szczególnie mocno podkreślał znaczenie udziału osoby bardziej kompetentnej w konstruowaniu znaczeń przez osobę uczącą się. Zdaniem Autorki kluczowe pojęcia, jakie mogą pojawić się $\mathrm{w}$ dydaktyce $\mathrm{z}$ inspiracji socjokulturowej teorii uczenia się, to „kontekst kulturowy, współpraca, negocjacje (zwłaszcza z osobą bardziej kompetentną, jako mogącą udzielić wsparcia), społeczności uczące się" (Klus-Stańska 2010: 283). Tropy teoretyczne wywodzące się z konstruktywizmu w odmianie społecznej, socjokulturowej bardzo mocno korespondują z praktyką kształcenia wykorzystującą wzory społecznego uczenia się. Warto w tym miejscu przywołać jeszcze jedną pracę, która, posiadając niezwykły walor praktyczny dla osób zainteresowanych poszerzaniem swego warsztatu dydaktycznego, może stanowić ważną propozycję dla kreślenia mapy współczesnych paradygmatów dydaktyki ogólnej - książkę Bruce'a Joyce’a, Emily Calhoun i Davida Hopkinsa (1999) oraz korzystającą z niej jako inspiracji - propozycję Bogusławy Doroty Gołębniak (2007). Stosując kryterium rodzaju myślenia, jaki wywołuje stosowanie danej strategii czy metody, oraz miejsca, jakie zajmuje $\mathrm{w}$ modelu uczeń, autorzy podzielili wszystkie im znane modele kształcenia na cztery grupy ${ }^{1}$ : modele przetwarzania informacji (typ procesualno-poznawczy), modele społeczne (których zadaniem jest tworzenie wspólnoty uczących się), modele rozwoju osobowości oraz modele behawioralne. Gołębniak w swej pracy rezygnuje z pojęcia "modelu” jako wywodzącego się z behawioralnego typu myślenia o edukacji, a w zamian przyjmuje pojęcie „strategii” jako szerszego niż tylko „metoda”. Autorka, przedstawiając typologię strategii nauczania, głównym kryterium doboru czyni rozpoznane i opisane we współczesnej psychologii kształcenia następujące wzory uczenia się (Gołębniak 2007: 172-173): uczenie się określonych zachowań pod wpływem wzmocnień zewnętrznych i skłonności do modelowania; uczenie się polegające na aktywnym

1 Autorzy nie stosują ostrego rozróżnienia pomiędzy pojęciami: strategia, model, metoda kształcenia. Model nauczania - uczenia się, strategia czy procedura kształcenia jest ich zdaniem pewnego rodzaju konstrukcją regulującą postępowanie nauczyciela, opartą na schemacie pewnego typu uczenia się. 
przetwarzaniu informacji; uczenie się społeczne (we współpracy) oraz uczenie się całościowe (osobowościowe). W kontekście szukania pomysłów na budowanie kultury zaufania i wspólnotowości podczas prowadzenia zajęć ze studentami wart uwagi jest trop wiodący ku możliwościom wykorzystywania modeli społecznych w procesie kształcenia lub - używając propozycji Gołębniak metod wykorzystujących społeczne wzory uczenia się. Wspólną ich cechą jest tworzenie wspólnoty uczących się, wspólnoty szczególnej, bowiem wytwarzającej kolektywną energię zwaną synergią, która, nie będąc prostą kumulacją energii członków wspólnoty lecz jej zwielokrotnieniem, ułatwia proces uczenia się. Wszelkie pomysły różnorodnych form pracy grupowej opierają się na pedagogicznie dowiedzionych korzyściach, wynikających z uczenia się wespół z innymi. Modele społeczne z jednej strony mogą służyć osiąganiu zamierzonych rezultatów natury czysto poznawczej (wspieraniu określonych rodzajów myślenia, wspólnego rozwiązywania problemów poznawczych, konfrontowania się z odmienną - indywidualną i grupową - perspektywą patrzenia na dane zagadnienie), z drugiej zaś mogą sprzyjać interakcjom społecznym, budowaniu norm grupowych, kontraktów umożliwiającym przede wszystkim dobrą współpracę. Modele te sprzyjają tworzeniu postaw prospołecznych, gotowości do udzielania sobie nawzajem wsparcia oraz kształtowaniu procedur demokratycznego podejmowania decyzji. Joyce, Calhoun i Hopkins opisali siedem modeli społecznych: model badań grupowych, badań społecznych, badań prawniczych, model laboratoryjny, odgrywania ról, pozytywnej współzależności oraz model ustrukturyzowanych badań społecznych. Gołębniak, nie wchodząc w poszczególne modele opisane przez Joyce'a i innych, wskazuje strategię uczenia się w małych grupach jako możliwość zainicjowania uczenia się we współpracy, umożliwiającej uczniom czy studentom kształtowanie umiejętności dyskutowania, słuchania siebie nawzajem, kierowania pracą własną i innych, przyjmowania zadań wynikających z decyzji grupy, a nade wszystko uczenia się od siebie nawzajem. Uczenie się we współpracy ma także walor uruchamiania społecznego negocjowania i wypracowywania znaczeń nadawanych rzeczywistości. Uczący się w małych grupach studenci mają szansę skonfrontować własną perspektywę poznawczą z cudzą, zwielokrotnić ją, wypracować umiejętność zmiany perspektywy, a przez to poszerzać własne horyzonty poznawcze. Korzystanie w dydaktyce akademickiej z modeli dydaktycznych bazujących 
na społecznych wzorcach uczenia się jest z pewnością ważnym budulcem poczucia sprawstwa, wspólnotowości i zaufania do grupy. Trop ten nie jest jednak jedyny.

\section{Trop drugi: inspiracje płynące z koncepcji uczenia się przez doświadczenie}

Poszukiwania przykładów innowacyjnych rozwiązań dydaktycznych, wychodzących poza ramy tradycyjnego podejścia do procesu nauczania - uczenia się, a jednocześnie możliwych do zaimplementowania w pracy ze studentami, zawiodły Gołębniak ku redefinicjom kształcenia w szkole wyższej wywodzącym się z kluczowego postulatu przesunięcia: od nauczania do uczenia się (opisanego uprzednio w tekście jako zmiana paradygmatyczna the shift from teaching to learning). Autorka wskazuje pewną relewantność studiów w zakresie edukacji dorosłych z badaniami dotyczącymi procesu kształcenia na poziomie wyższym (Gołębniak 2010: 260). Rozważa zatem możliwość aplikacji najbardziej „awangardowych z andragogicznych - jeśli chodzi o proweniencję - takich koncepcji, jak na przykład: koncepcja refleksyjności i/czy ,eksperymentującego uczenia się' w wydaniu Schöna (1983; 1987), Kolba (1984), czy Bouda, Keogha i Walkera (red. 1985)" (Gołębniak 2010: 260). Obserwacja rzeczywistości dydaktycznej pozwala na wysunięcie twierdzenia, iż jedną z najbardziej ożywczych i płodnych inspiracji jest koncepcja uczenia się przez doświadczenie Davida A. Kolba (Kolb 1974, 1987), która wywarła największy wpływ na kształt i projektowanie szkoleń dla dorosłych. Opisywany w wielu podręcznikach do prowadzenia szkoleń tzw. cykl Kolba tylko pozornie ukierunkowany jest na budowanie umiejętności praktycznych. W kształceniu akademickim może doskonale służyć na wyższych latach studiów do integracji wiedzy teoretycznej i jej aplikacji praktycznej. Analizując źródła koncepcji, Mariola Łaguna (2004: 38-39) wskazuje na odcinanie się przez Autora zarówno od podejścia behawiorystycznego, traktującego uczenie się jako nabywanie trwałych nawyków poddających się procedurom sterowania poprzez wzmacnianie i wygaszanie, jak i empirycznej filozofii Johna Locke'a, sprowadzającej uczenie się do powiększania zasobów magazynu faktów, wzorców, nawyków itp. Autorka podkreśla, iż Kolb, odwołując się raczej do koncepcji Johna Deweya, 
rozumie uczenie się jako proces „ciągłej modyfikacji uprzedniego doświadczenia przez doświadczenie następujące po nim”, a także jako „proces, w którym doświadczenie przekształcane jest w wiedzę" (Kolb 1984: 38). Zatem zdaniem Autora każde doświadczenie można potraktować jako jednocześnie źródłowe dla kolejnego i jako „ponastępujące” - wynikające z poprzedniego. Uczenie się jest zatem ciągłym procesem modyfikacji doświadczenia, tzn. przeformułowywaniem idei i sądów pod wpływem doświadczenia kolejnego. Zdaniem Knuda Illerisa (2006: 44-45) Kolb udoskonalił teorię Piageta, zestawił ją z pracami Deweya i Lewina i w rezultacie doszedł do wniosku, iż proces uczenia się jest czterofazowy i układa się w cykl biegnący od konkretnego doświadczenia poprzez refleksyjną obserwację i abstrakcyjną konceptualizację do aktywnego eksperymentowania w toku kolejnego doświadczenia. Model uczenia się przez doświadczenie może być i jest $\mathrm{z}$ powodzeniem wykorzystywany $\mathrm{w}$ dydaktyce akademickiej na przykład na zajęciach z symulacji medycznych, a także na różnorodnych warsztatach ukierunkowanych na rozwój umiejętności praktycznych, niealgorytmicznych czy też kształtowanie kompetencji społecznych. Z powodzeniem jest też wykorzystywany na studiach pedagogicznych oraz w innych formach szkoleń, przygotowujących do wykonywania zawodu nauczyciela. Modele takie, oparte właśnie na pracy z doświadczeniem, wykorzystujące cykl Kolba, mogą być różnicowane ze względu na zwiększający się stopień otwartości cyklu uczenia się. Christopher Day (2004: 252-255), podając przykłady zastosowania cyklu Kolba w doskonaleniu zawodowym nauczycieli, przyjmuje za M. Hubermanem (1995: 193-221) podział omawianej formy na:

- Zamknięty cykl indywidualny, który polega na uczeniu się samego nauczyciela - refleksyjnego praktyka, na samodzielnej pracy ze swoim doświadczeniem „tu i teraz” w procesie nauczania studentów. Ten rodzaj jest najbliższy prowadzeniu refleksji nad działaniem w działaniu.

- Otwarty cykl indywidualny, polegający na szukaniu wsparcia $\mathrm{u}$ innych nauczycieli, ale z tego samego środowiska. Tu pomocna staje się grupa nieformalna, w której prowadzone są np. hospitacje wspierające czy co-teaching.

- Zamknięty cykl zbiorowy, polegający na tworzeniu grupy nauczycieli, wspólnoty uczących się i badających własną praktykę. Ten rodzaj bliski jest grupie wsparcia superwizyjnego, która 
umożliwia osobie przepracowanie doświadczenia oraz praktykowanie refleksyjnego i krytycznego podejścia do własnej praktyki.

- Otwarty cykl zbiorowy, najbardziej zbliżony do uczenia się „w sieci”, polegający na partnerstwie uczestnictwa w różnorodnych otwartych formach praktyki innych nauczycieli, w prezentacjach eksperckich, treningach, działaniach podejmowanych przez osoby posiadające różnorodną wiedzę „komplementarną” do praktyki nauczania.

Warto - szczególnie na studiach pedagogicznych, a także studiach przygotowujących do wykonywania zawodu nauczyciela - spróbować przepraktykować różnorodne formy uczenia się opartego na doświadczeniu z wykorzystaniem cyklu Kolba. Zamknięty cykl zbiorowy może być z powodzeniem wykorzystywany na warsztatach organizowanych dla czynnych nauczycieli ukierunkowanych na pracę z doświadczeniem oraz na dzielenie się doświadczeniami zawodowymi. Wprawdzie - jak pisze Day „cykl ten jest zamknięty w tym sensie, że niewielkie jest w nim zapotrzebowanie na wiedzę fachową pochodzącą z zewnątrz" (Day 2008: 252), ale wsparcie w rozumieniu własnego doświadczenia, jego znaczenia oraz konstruowania możliwych alternatyw może płynąć nie tylko z grupy samych uczestników spotkania, ale także od „nauczyciela nauczycieli” występującego w roli niedyrektywnego coacha. Ciekawą formą kształcenia i rozwoju pedagogów i nauczycieli jest także otwarty cykl zbiorowy, który nie ogranicza się w swym zastosowaniu do homogenicznej grupy treningowej czy grupy wsparcia nauczycieli, ale umożliwia udział ludzi „z zewnątrz”. Uczenie się w tej formule jest najbardziej elastyczne, ale i najbardziej wymagające. Zdaniem Michaela Hubermana (1995) niezbędne jest stałe podtrzymywanie interakcyjności między uczestnikami, wsparcie infrastrukturalne, długotrwałość, wzajemne powiązanie ze sobą projektów oraz silne niedyrektywne przywództwo wspierające i koordynujące proces wzajemnego uczenia się. Zastosowanie uczenia się przez doświadczenie w cyklu Kolba ma dla kształcenia pedagogów i wspierania rozwoju nauczycieli dodatkowy atut - lepsze i głębsze odniesienie osobistego doświadczenia do teorii pedagogicznych. W tradycyjnych szkoleniach najpierw uczestnikom przedstawiana jest teoria, a następnie jej aplikacje praktyczne i ćwiczenia. W szkoleniach opartych na cyklu Kolba to doświadczenia uczestników i ich wiedza osobista są podstawą do wejścia w koncepcje teoretyczne, które mają służyć zrozumieniu przeżytego doświadczenia oraz 
projektowaniu następnego. Tak budowana wiedza teoretyczna pozostaje $\mathrm{w}$ ścisłym związku z praktyką działania i osobistym doświadczeniem osoby uczącej się.

\section{Budowanie zaufania i wspólnotowości na zajęciach - przykład}

W myśl postulowanego przez Klus-Stańską hasła - myśleć teorią o praktyce - zawartego w tytule książki opisującej paradygmaty dydaktyczne (Klus-Stańska 2018), prowadzone powyżej rozważania teoretyczne są ważnym tłem dla proponowanych rozwiązań praktycznych. Przykład, który chcę opisać, dotyczy prowadzonych przeze mnie od paru lat zajęć „Dydaktyka upowszechniania wiedzy pedagogicznej”, kursu proponowanego dla studentów kierunku pedagogika szkolna z terapią pedagogiczną. Warto w tym miejscu dodać, iż kurs umieszczony jest w planie studiów na II roku studiów II stopnia, a zatem po pierwsze, jest kolejnym kursem związanym z budowaniem kompetencji dydaktycznych studentów, którzy już osiągnęli efekty związane z trzema kursami (Podstawy dydaktyki ogólnej, Metodyka pracy dydaktycznej, Projektowanie pracy dydaktycznej); po drugie, jego głównym celem jest integracja wiedzy dydaktycznej zdobytej w toku studiów i umiejętność jej zastosowania w praktyce. Zajęcia prowadzone są metodą warsztatową w cyklu Kolba w formule zamkniętego cyklu zbiorowego. Nie jest celowe w tym miejscu omawianie różnorodnych aspektów kursu, jego programu i przebiegu, warto jednak podkreślić pewne elementy, które niewątpliwie przyczyniają się do budowania w studentach poczucia wspólnotowości, sprawstwa i zaufania. Na początku zajęć najważniejsze jest wypracowanie i zawarcie ze studentami kontraktu. Jeśli zajęcia mają odbywać się $\mathrm{w}$ atmosferze otwartości, wzajemnego zaangażowania i zaufania, to należy zadbać o stworzenie podstaw emocjonalnego bezpieczeństwa. Tu dość ważnym elementem jest jasne określenie celu zajęć i sposobu uzyskania zaliczenia czy oceny. Jeśli celem zajęć ma być rozwój (tak jak pisali o nim L. Kohlberg i R. Mayer w ważnym eseju Rozwój jako cel wychowania - Kohlberg, Mayer 2000), to jego miarą musi być progres mierzony w tym wypadku nie serią zaawansowanych testów, a całkowicie subiektywnym wglądem w siebie, zakończonym samooceną, którą nauczyciel akademicki zobowiązany jest uszanować. Oczywiście studentów należy do 
tego doświadczenia przygotować, nie wolno ich pozostawiać samych sobie. Tu wsparciem mogą być narzędzia ankiet autoewaluacyjnych, inspirowanych na przykład pracami A. Brzezińskiej (2004). Do zagadnienia tego jeszcze powrócę. Kolejnym ważnym elementem kontaktu jest sposób doświadczania i podchodzenia do błędów czynionych przez studentów. W paradygmatach tradycyjnych, normatywnych, behawioralnych błąd jest czymś, czego osoba ucząca się stanowczo unika. Błąd oznacza porażkę i obniżenie oceny. Studenci przychodzący w mury uniwersytetu mają za sobą szereg niekorzystnych doświadczeń szkolnych, które każą im ukrywać swoją niewiedzę czasem nawet za cenę zachowań nieetycznych. Tymczasem zgodnie z opisanymi nurtami konstruktywistycznymi stanowiącymi podstawę paradygmatu „learning”, błąd jest czymś naturalnym w procesie uczenia się, co więcej przepracowany błąd ma moc rozwojową. Gdzie zatem student ma możliwość popełniania i przepracowywania ewentualnych błędów, jeśli nie w trakcie zajęć warsztatowych, w bezpiecznej przestrzeni tworzonej przez małą wspólnotę akademicką? Każdy kolejny rok prowadzenia zajęć zgodnie z tą regułą uświadamia mi, jak trudno studentom na początku zajęć przestawić się na tak określone podejście do błędu. Jeśli jednak uwierzą i przepracują pierwsze zajęcia, to ze spotkania na spotkanie widzę, jak zaczynają się otwierać się i szczerze rozmawiać o doświadczanych trudnościach. Refleksja nad doświadczeniem jest bowiem kluczem rozwoju. Prowadzone zajęcia - zgodnie z cyklem Kolba - przebiegają według określonych faz:

- Faza I - konkretne doświadczenie tu i teraz. W tej fazie zwykle dwójka studentów (w formule co-teachingu) współprowadzi dla pozostałej grupy zajęcia, które uprzednio przygotowała. Zajęcia te ukierunkowane są na upowszechnianie wiedzy pedagogicznej, a ich przebieg ma być zgodny z wybranym przez studenta modelem kształcenia spośród całej ich puli opisanych przez Joyce, Calhoun i Hopkinsa. Warto w tym miejscu dodać, że na kolejnych zajęciach następne dwie osoby prowadzą swoje warsztaty, tak aby cykl Kolba nie był tylko uruchomiony dla jednego spotkania, ale także dla całej grupy w wymiarze wszystkich spotkań.

- Faza II - refleksyjna obserwacja, polegająca na czynnej obserwacji zajęć przez jej uczestników, prowadzącego zajęcia i prowadzącego warsztaty. Celem obserwacji jest analizowanie doświadczenia, które jest udziałem tym razem wszystkich (choć 
każdego w innej roli i pozycji), oraz zbieranie tychże doświadczeń traktowane jako kumulowanie danych. $\mathrm{Na}$ tym etapie nauczyciel akademicki stwarza możliwość dyskusji wszystkim członkom grupy warsztatowej, analizując minuta po minucie to, co zdarzyło się na zajęciach. Umożliwia to przepracowywanie doświadczenia $\mathrm{z}$ wielu perspektyw. Ważne jest, by nauczyciel akademicki potrafił uważnie słuchać, analizować, wykazywać ogromne zainteresowanie, tak, by każdy mógł wielokrotnie się wypowiedzieć. Faza refleksyjna obserwacji często przeplata się $\mathrm{z}$ fazą generalizacji.

- Faza III - generalizacja, abstrakcyjna konceptualizacja. To faza, która z założenia ma prowadzić do integracji wiedzy pedagogicznej, psychologicznej, socjologicznej, a także filozoficznej z praktyką działania. Każde bowiem zdarzenie można rozpatrywać $\mathrm{z}$ wielu punktów widzenia, odpowiadając na pytania: dlaczego tak się stało? Dlaczego takie a nie inne rozwiązania praktyczne? Dlaczego taka reakcja grupy? Dlaczego taka reakcja prowadzącego? Dlaczego reakcji nie było? Jakie okazje edukacyjne się pojawiły? Co zostało wykorzystane, a co niedostrzeżone? Jakie są alternatywy? Skąd one wynikają? Prowadzona z uczestnikami w kręgu dyskusja ma prowadzić studentów do aktywnego, refleksyjnego myślenia teorią o doświadczonej praktyce. Zadaniem tej fazy jest nie tylko przyjrzenie się doświadczeniu z różnych perspektyw, nie tylko otrzymanie informacji zwrotnych od grupy i prowadzącego, ale przede wszystkim uruchomienie procesów uogólniania i tworzenia własnych konstrukcji wiedzy pedagogicznej.

- Faza IV - aktywne eksperymentowanie. Faza ta w zamyśle Kolba ma polegać na zmianie działania, zmianie zachowania uczestników warsztatu. W omawianych zajęciach dyskusja ma prowadzić do pewnego rodzaju podsumowania, sformułowania ważnych wniosków na bazie przepracowanego wspólnie doświadczenia. Zasadą pracy jest, iż prowadzący kolejne zajęcia próbowali zastosować owe wskazówki podczas realizacji następnego scenariusza. Mają jednak pełne prawo do odczuwania trudności, do popełniania własnych błędów, które to po przepracowaniu staną się kołem zamachowym dla czynienia progresu w rozwoju ich umiejętności i pogłębiania wiedzy.

Zgodnie z kontraktem zawartym na począ̧tku zajęć, studenci dokonują samooceny, opartej na wglądzie we własny rozwój. Przygotowany na bazie propozycji Anny Brzezińskiej arkusz ankiety autoewaluacyjnej (Brzezińska 2004: 198) zawiera nie tylko 
proponowaną ocenę, ale także zaprasza do udzielania odpowiedzi na pytania o to, co utrudniało studentowi efektywną pracę na zajęciach, co mu ułatwiało dobrą pracę na zajęciach oraz o to, czego się dowiedział, nauczył, odkrył, zrozumiał, a co musi jeszcze przemyśleć. Analiza ankiet $\mathrm{z}$ wielu lat stanowi bogaty materiał badawczy. Myśląc jednak tylko i wyłącznie o możliwości zastosowania w dydaktyce akademickiej zajęć wykorzystujących modele społeczne jako propozycji budowania poczucia sprawstwa, wspólnotowości i zaufania studentów, warto przytoczyć mały wycinek wypowiedzi²:

- „zrozumiałam, że ważna jest praca nad samym sobą, samopoznaniem, usłyszenie stanowiska, odczuć i porad innych osób, ponieważ to pomaga w doskonaleniu siebie";

- „odkryłam w sobie pokłady energii do poznawania nowych rzeczy, ale zrozumiałam równiez, jak duże wsparcie mam w grupie”;

- „ostatecznie przedmiot ten kończę z pozytywnym nastawieniem do mojej przyszłości”;

- „na tych zajęciach stałam się bardziej pewna swoich możliwości”;

- „odkryłam, że współpraca jest bardzo ważna, niezbędna do stworzenia czegoś niepowtarzalnego";

- „pracę ułatwiło mi wsparcie osób, z którymi przygotowywałam scenariusz";

- "zaangażowanie grupy motywowało mnie do pracy, wywoływało chęć współpracy i zaangażowanie wszystkich osób”;

- „grupa była bardzo zgrana, pomocna, wspierająca”;

- „atmosferę na zajęciach cechowały: aktywne słuchanie, aktywność, odpowiadanie na pytania, życzliwość, wyrozumiałość”;

- „na każdych zajęciach miałyśmy możliwość czynnego w nich udziału, uczenia się przez własne doświadczenie”.

\section{Refleksja na zakończenie}

Dość często w przestrzeni debat publicznych pada postulat nowoczesnego kształcenia, który niestety bywa rozumiany bardzo jednostronnie. Jeśli nowoczesność dydaktyki akademickiej

2 Zanonimizowane wypowiedzi studentów zajęć „Dydaktyka upowszechniania wiedzy pedagogicznej” prowadzonych przez Annę Sajdak-Burską dla II roku studiów II stopnia kierunku pedagogika szkolna z terapią pedagogiczną, realizowanych w cyklu 2018/2019. 
będziemy rozumieli jako umiejętność wykorzystywania w procesie kształcenia najnowszych osiągnięć technologii informacyjnych i komunikacyjnych, to łatwo możemy wpaść w pułapkę tradycyjnego, transmisyjnego, niemal herbartowskiego modelu edukacji, w którym XIX-wieczna tablica i kreda zostaną zastąpione przez platformy zdalnego nauczania. I tak zamiast e-learningu będziemy mieli e-teaching, znakomicie wpisujący się w paradygmat dyrektywnego, kierowanego nauczania, w którym centralną osią będą zamieszczone na platformie treści kształcenia. Nowoczesność dydaktyki akademickiej oznacza raczej paradygmatyczne przejście w kierunku szeroko rozumianego paradygmatu „learning”, który tworzy przestrzeń zarówno dla aktywności indywidualnej, jak i grupowej studentów. Jestem przekonana, że nowoczesna dydaktyka promująca konstruktywistyczne i humanistyczne modele kształcenia jest wyzwaniem, które ciągle czeka na urzeczywistnienie $\mathrm{w}$ akademickim kształceniu. Wykorzystywanie $\mathrm{w}$ procesie kształcenia różnorodnych modeli bazujących na społecznych wzorach uczenia się jest niezwykle ważne dla osiągania szeregu kompetencji społecznych, niemożliwych do budowania w inny sposób, niż tylko w i poprzez doświadczenie pracy w grupie. Badania pokazują, że nieco zapomnieliśmy o tej możliwości. Idea tradycyjnie rozumianego uniwersytetu jako miejsca, w którym przede wszystkim prowadzi się - na światowym poziomie oczywiście - badania naukowe, w którym nauka jest esencją i podstawą istnienia tej instytucji, a kształcenie studentów schodzi zdecydowanie na drugi plan, czasem nawet traktowane jest jako uciążliwy dodatek do podstawowej aktywności badawczej, $\mathrm{w}$ moim przekonaniu opiera się na mylnie rozumianych fundamentach akademii. Kształcenie studentów nie powinno polegać tylko na upowszechnianiu wyników badań w danej dyscyplinie, na przekazywaniu dorobku wiedzy ludzkości. Kształcenie wymaga tworzenia studentom warunków do aktywnego zdobywania i uprawiania wiedzy, kształtowania umiejętności mentalnych i praktycznych oraz przede wszystkim uzyskiwania wysokich kompetencji społecznych. I wcale nauczyciel akademicki, naukowiec, profesor nie musi być najważniejszy. U schyłku XIX w. Newman pisał:

Oświadczam Panom, że gdybym musiał wybierać pomiędzy jakimś tak zwanym uniwersytetem, który by nie wymagał obowiązku przebywania w jego murach ani opieki indywidualnej nad studentem, udzielając swych stopni każdemu, kto zdał pomyślnie egzamin w zakresie wielu przedmiotów, a uniwersytetem, który by w ogóle nie miał 
profesorów, ani egzaminów, a jedynie gromadził pewną liczbę młodych ludzi na okres trzech czy czterech lat, a potem ich wypuszczał, tak jak Uniwersytet Oksfordzki czynił podobno jakieś sześćdziesiąt lat temu, i gdyby mnie pytano, która z tych dwóch metod stanowi lepszą dyscyplinę dla intelektu [...] jeżeli muszę zdecydować, który $\mathrm{z}$ tych dwóch rodzajów postępowania będzie z większym powodzeniem ćwiczył, formował, rozszerzał umysł, wysyłał ludzi lepiej przygotowanych do działalności świeckiej, [...], to nie waham się przedkładać uniwersytetu, który by nic nie robił, nad uniwersytet, który by wymagał od swoich członków zapoznania się z wszelką wiedzą pod słońcem (Newman 1990: 220-221).

Z pewną dozą ostrożności można zaryzykować tezę, iż pod koniec XIX w. Newman opowiedział się za kształtem uniwersytetu, który nie stawia w centrum osoby naukowca, eksperta, nauczyciela akademickiego, ani zgromadzonej dorobkiem ludzkości wiedzy. Odchodzi zatem od powszechnego w tradycyjnym akademickim kształceniu paradygmatu opisanego wcześniej jako „teaching”. Właściwie uniwersytet może - zdaniem wspomnianego autora - nawet obejść się bez profesorów i bez egzaminów. Istotą bowiem studiowania są sami studenci, którzy, gromadząc się w murach uczelni, zdolni są do kształtowania własnych umysłów. Newman tłumaczy to w ten sposób:

Przypuszczam, że tak oto: kiedy masa młodych ludzi, pełnych zapału, o otwartych oczach i sercach, przyjaznym stosunku do otoczenia, jak to bywa regułą u młodych, zejdzie się w jednym miejscu i swobodnie ze sobą obcuje, można być pewnym, że będą się uczyć jedni od drugich, nawet jeżeli nie byłoby nikogo, kto ma ich nauczać; rozmowa wszystkich jest serią wykładów dla każdego z osobna, zdobywają sobie nowe idee i poglądy, świeży materiał do przemyśleń i określone zasady wypowiadania sądów i działania, dzień po dniu (Newman 1990: 221-222).

Te rewolucyjne poglądy Newmana wpisują się w niedoceniany nurt dydaktyki wykorzystującej w procesie kształcenia społeczne wzorce uczenia się. Newman pokazuje mocne filary budowania wspólnoty akademickiej jako wspólnoty studiujących młodych ludzi, którzy działając wspólnie, osiągają lepsze rezultaty, niż starannie przygotowane profesorskie wykłady. Uniwersytet bez nauczycieli akademickich to być może dziwaczna skrajność, tak jak i skrajnością jest uniwersytet bez studentów. Warto moim zdaniem czynić wszystko, by jednak w codziennej praxis akademickiego kształcenia podejmować wysiłek budowania wspólnoty ze studentami, tu i teraz. 


\section{Bibliografia}

Barr R.B., Tagg J. (2000), From Teaching to Learning. A New Paradigm for Undergraduate Education, [w:] D. DeZure (ed). Learning from Change. Landmarks in Teaching and Learning in Higher Education from Change Magazine, 1969-1999, American Association For Higher Education, Kogan Page, London.

Bauman T. (2001), Uniwersytet wobec zmian spoleczno-kulturowych. Casus Uniwersytetu Gdańskiego, Wydawnictwo Uniwersytetu Gdańskiego, Gdańsk.

Bauman T. (2011), Proces ksztatcenia $w$ uniwersytecie $w$ perspektywie potrzeb nauczycieli akademickich i oczekiwań studentów. Raport z badań, Zakład Poligrafii Fundacji Rozwoju Uniwersytetu Gdańskiego, Gdańsk.

Brown G., Atkins M. (1988), Effective Teaching in Higher Eduaction, Methuen \& Co.Ltd., New York.

Bruner J. (2006), Kultura edukacji, tłum. T. Brzostowska-Tereszkiewicz, Universitas, Kraków.

Bruner J.S. (1974), W poszukiwaniu teorii nauczania, tłum. E. Krasińska, Państwowy Instytut Wydawniczy, Warszawa.

Brzezińska A. (2004), Ewaluacja w procesie ksztatcenia, [w:] A. Brzezińska, J. Brzeziński, A. Eliasz (red.), Ewaluacja a jakość ksztatcenia w szkole wyższej, Academica Wydawnictwo SWPS, Warszawa.

Brzezińska A., Brzeziński J., Eliasz A. (red.) (2004), Ewaluacja a jakość ksztatcenia $w$ szkole wyższej, Academica. Wydawnictwo SWPS, Warszawa.

Day Ch. (2004), Od teorii do praktyki. Rozwój zawodowy nauczyciela, tłum. J. Michalak, Gdańskie Wydawnictwo Psychologiczne, Gdańsk.

Dudzikowa M. (2008), Erozja kapitatu spolecznego w szkole w kulturze nieufności, [w:] M. Dudzikowa, M. Czerepaniak-Walczak (red.), Wychowanie. Pojęcia. Procesy. Konteksty, t. 4, Gdańskie Wydawnictwa Psychologiczne, Gdańsk.

Dudzikowa M., Wawrzyniak-Beszterda R., Jaskulska S., Marciniak M., Bochno E., Bochno I., Knasiecka-Falbierska K. (red.) (2013), Oblicza kapitatu spotecznego uniwersytetu. Diagnoza - interpretacje - konteksty, Oficyna Wydawnicza Impuls, Kraków.

Gołębniak B.D. (2007), Nauczanie i uczenie się w klasie, [w:] B. Śliwerski, Z. Kwieciński (red.), Pedagogika. Podręcznik akademicki, t. 2, PWN, Warszawa.

Gołębniak B.D. (2010), Poszukiwanie - refleksyjność - dialektyczne uczenie się. Nowe praktyki edukacyjne w szkole wyższej, [w:] J. Piekarski, D. Urbaniak-Zając (red.), Innowacje w edukacji akademickiej. Szkolnictwo wyższe $w$ procesie zmiany, Wydawnictwo Uniwersytetu Łódzkiego, Łódź.

Hejnicka-Bezwińska T. (2010), Szanse i ograniczenia związane z integracja różnych rodzajów wiedzy, [w:] J. Piekarski, D. Urbaniak-Zając (red.), Innowacje $w$ edukacji akademickiej. Szkolnictwo wyższe $w$ procesie zmian, Wydawnictwo Uniwersytetu Łódzkiego, Łódź.

Huberman M. (1995), Networks that alter teaching, "Teachers and Teaching: Theory and Practice", nr 1 (2), s. 193-212.

Illeris K. (2006), Trzy wymiary uczenia się, tłum. A. Jurgiel, Wydawnictwo Naukowe Dolnośląskiej Szkoły Wyższej Edukacji TWP we Wrocławiu, Wrocław. 
Joyce B., Calhoun E., Hopkins D. (1999), Przyktady modeli uczenia się i nauczania, tłum. K. Kruszewski, Wydawnictwa Szkolne i Pedagogiczne, Warszawa.

Klus-Stańska D. (2010), Dydaktyka wobec chaosu pojęć i zdarzeń, Wydawnictwo Akademickie Żak, Warszawa.

Klus-Stańska D. (2011), Oderwanie dydaktyki od pedagogiki ogólnej jako źródto jej kryzysu i znieruchomienia, [w:] T. Hejnicka-Bezwińska (red.), Pedagogika ogólna. Dyskursy o statucie naukowym i dydaktycznym, Wydawnictwo Uniwersytetu Kazimierza Wielkiego, Bydgoszcz.

Klus-Stańska D. (2018), Paradygmaty dydaktyki. Myśleć teoriq o praktyce, PWN, Warszawa.

Knowles M.S., Holton III E.F., Swanson R.A. (2009), Edukacja dorostych. Podrecznik akademicki, tłum. M. Hubura, PWN, Warszawa.

Kohlberg L., Mayer R. (2000), Rozwój jako cel wychowania, [w:] Z. Kwieciński (red.), Alternatywy myślenia o/dla edukacji, tłum. P. Kwieciński, A. Nalaskowski, Instytut Badań Edukacyjnych, Warszawa.

Kolb D. (1984), Experiental Learning: Experience as the Source of Learning and Development, Prentice Hall, New Jersey.

Kolb D. (1997), The Processes of Experiental Learning, [w:] M. Thorpe, R. Edwards, A. Hanson (red.), Culture and Process of Adult Learning, Routledge, London.

Łaguna M. (2004), Szkolenia. Jak je prowadzić, by..., Gdańskie Wydawnictwo Psychologiczne, Gdańsk.

Malewski M. (2010), Od nauczania do uczenia się. O paradygmatycznej zmianie $w$ andragogice, Wydawnictwo Naukowe Dolnośląskiej Szkoły Wyższej, Wrocław.

Newman J.H. (1990), Idea uniwersytetu, tłum. P. Mroczkowski, PWN, Warszawa.

Newman J.H. (2000), Kazania uniwersyteckie, tłum. P. Kostyło, Wydawnictwo Znak, Kraków.

Sajdak A. (2013), Paradygmaty ksztatcenia studentów i wspierania rozwoju nauczycieli akademickich. Teoretyczne podstawy dydaktyki akademickiej, Oficyna Wydawnicza Impuls, Kraków.

Sajdak-Burska A. (2018), Paradygmaty dydaktyki akademickiej. Analiza wybranych podejść. „Roczniki Pedagogiczne”, t. 10 (46), nr 2, s. 9-29.

Schön D. (1983), The Reflective Practitioner: How Professional Think in Action, Basic Books, New York.

Schön D. (1987), Educating the Reflective Practitioner, Jossey Bass, London.

Wawrzyniak-Beszterda R. (2013), Oferta dydaktyczna uczelni, [w:] M. Dudzikowa, R. Wawrzyniak-Beszterda, S. Jaskulska, M. Marciniak, E. Bochno, I. Bochno, K. Knasiecka-Falbierska (red.), Oblicza kapitatu spolecznego uniwersytetu. Diagnoza - interpretacje - konteksty, Oficyna Wydawnicza Impuls, Kraków. 


\section{CZĘŚĆ DRUGA}

\section{PODMIOTY EDUKACJI JAKO PRZEDMIOT BADAŃ I REFLEKSJI PEDAGOGICZNEJ}



Piotr Kostyło

ORCID 0000-0002-7484-9766

Uniwersytet Kazimierza Wielkiego w Bydgoszczy

\title{
Leszka Kołakowskiego pojęcie charyzmatycznego nauczyciela
}

\author{
Abstract \\ The notion of charismatic teacher by Leszek Kołakowski
}

A Polish philosopher Leszek Kołakowski, the author of essays pertaining to philosophy of education, emphasised the charismatic dimension of the teacher's work as paramount in this area. The following article analyses three selected essays by Kołakowski, in which the philosopher deals with the theme of the teacher's charisma. Bringing together the overlaying concepts and insights from each of these three essays, in the first instance, the article elaborates a comprehensive image of a charismatic teacher. Then, it argues that Kołakowski's notion of a charismatic teacher is more negative than positive. Namely, the philosopher devotes a great deal of attention to the detrimental attitudes that inhibit charisma in teachers, rather than those which would guarantee their success as charismatic educators. Kołakowski suggests, then, the article concludes, that teacher's charisma is absolutely unique and cannot be defined, unless it fully develops within an individual.

Keywords: charismatic teacher, ethics without a code, educating to hate, giving hope and confidence

Słowa kluczowe: charyzmatyczny nauczyciel, etyka bez kodeksu, wychowanie do nienawiści, dawanie nadziei i zaufania

\section{Wprowadzenie}

W niniejszym artykule zajmuję się konstrukcją pojęcia charyzmatycznego nauczyciela, którą opieram na trzech tekstach polskiego filozofa Leszka Kołakowskiego: Etyka bez kodeksu (1962), Wychowanie do nienawiści, wychowanie do godności (1977) oraz Charyzmatyczny przywódca, charyzmatyczny nauczyciel (2006)1.

${ }^{1}$ Nie są to jedyne teksty Kołakowskiego, w których można znaleźć wątki dotyczące pojęcia charyzmatycznego nauczyciela, ograniczam się tu do nich ze względu na przejrzystość i zwięzłość argumentacji. 
Teksty te są dobrze znane, były wielokrotnie komentowane i cytowane (por. Kaniowski 1994, Flis 1994, Bauman 1995, Witkowski 2009). Jeżeli sięgam po nie, to nie w celu ich ponownego omówienia, ale w celu wyzyskania ich potencjału dla konstrukcji tytułowego pojęcia. Niniejszy artykuł wpisuje się w dociekania filozofii edukacji, którą rozumiem, za Harveyem Siegelem, jako zorientowaną z jednej strony na rzetelne analizy filozoficzne, z drugiej zaś strony na pytania o praktykę edukacyjną (por. Siegel 2017: 19-20) ${ }^{2}$. Jest on również głosem w dyskusji nad etyką zawodową nauczycieli (por. Kostyło 2008, Michalak 2010, Zając 2019).

Punktem wyjścia dla moich rozważań jest tematyka X Ogólnopolskiego Zjazdu Pedagogicznego, a zwłaszcza uwypuklony w niej wątek kryzysu zaufania, wspólnotowości i autonomii. Kryzys ten ma charakter etyczny, gdyż dotyka postaw, które są konstytutywne dla nawiązywania relacji moralnych między ludźmi. W przytoczonych tekstach Kołakowski również zajmuje się tymi zagadnieniami. W pierwszym zastanawia się nad warunkami możliwości osobistego doświadczenia etycznego, w szczególności doświadczenia wartości i powinności. W drugim, wspominając o możliwej przyczynie dezintegracji solidarności między ludźmi, zwraca uwagę na fatalne skutki wdrażania pewnego modelu wychowawczego, który nazywa wychowaniem do nienawiści. Wreszcie w trzecim mówi wprost o potrzebie wzmacniania zaufania między ludźmi, a także o szczególnej roli, jaką ma do odegrania w tym przedsięwzięciu charyzmatyczny nauczyciel.

Teza, jaką stawiam, sprowadza się do stwierdzenia, że koncepcja charyzmatycznego nauczyciela, wyłaniająca się z tekstów polskiego myśliciela, stanowi spójną intelektualnie i wartą rozważenia od strony praktyki edukacyjnej propozycję rozumienia tego pojęcia. Koncepcja ta zawiera się w trzech wezwaniach kierowanych przez Kołakowskiego do nauczycieli: Nie liczcie na kodeksy! Nie uczcie nienawiści! Nie osłabiajcie zaufania do świata! Przejęcie się tymi wezwaniami nie zagwarantuje jeszcze, że ktoś stanie się charyzmatycznym nauczycielem. Ale zlekceważenie ich z pewnością uniemożliwi osiągnięcie takiej rangi.

2 Takie podejście do zagadnienia charyzmatycznego nauczyciela nie bierze pod uwagę prób operacjonalizacji tego pojęcia, choć próby takie same w sobie są filozoficznie i edukacyjnie interesujące (por. Huang, Lin 2014). 


\section{Nihilizm, konserwatyzm \\ i zaangażowanie pozorne}

W odróżnieniu od wielu etyk maksymalistycznych, które kładą akcent na to, co ludzie powinni robić, aby osiągnąć doskonałość moralną, Kołakowski w eseju Etyka bez kodeksu stawia pytanie o to, czego ludzie nie powinni robić, jeśli chcą w sposób odpowiedzialny i twórczy wieść życie moralne, to znaczy osobiście doświadczyć wartości i powinności. Myśliciel sugeruje, że ludzie powinni przede wszystkim unikać postaw nihilistycznych, konserwatywnych oraz takich, które nazywa zaangażowaniem pozornym. Spośród tych trzech szczególnie dużo miejsca poświęca Kołakowski krytyce konserwatyzmu.

Wprowadzeniem do krytyki tych postaw jest pytanie o akceptację świata - Kołakowski zastanawia się, czy można świat akceptować tylko częściowo. Odpowiada, że nie, gdyż jest to możliwe albo w całości, albo w ogóle. Jeżeli żyjemy w świecie, to znaczy, że akceptujemy go w całości, że jesteśmy za niego odpowiedzialni, i że odpowiedzialność tę podjęliśmy dobrowolnie. „W chwili, gdy posiedliśmy wiedzę o możliwości śmierci dobrowolnej, a żyjemy nadal, bierzemy niejako na siebie zadłużenie świata jako zadłużenie własne" (Kołakowski 2000: 141).

Kołakowski nie zgadza się ze stwierdzeniem, że nasza akceptacja świata jest zdeterminowana biologicznie, niejako wbrew nam samym. Nawet jeśli życiu zależy na utrzymywaniu w nas postawy przychylnej dla świata, to ostatecznie to od nas zależy, czy na to przystaniemy. Kołakowski pisze: „Żyć po prostu - nie może to uchodzić za inercję sytuacji, w jaką wtrącili nas nasi rodzice; żyjąc, akceptujemy tę sytuację dobrowolnie, podpisujemy się, by tak rzec, pod owym fiat, mocą którego ukształtował się świat w takiej postaci, w jakiej go właśnie widzimy" (Kołakowski 2000: 141-142).

Dalej Kołakowski przechodzi do krytyki wspomnianych trzech postaw. Pierwszą postawą jest nihilizm, odrzucany przez Kołakowskiego w sposób zdecydowany. Dla filozofa postawa nihilisty żyjącego w świecie i uskarżającego się na niego jest wewnętrznie sprzeczna. Kołakowski podkreśla, że „nihilizm nigdy nie może być autentyczny, póki wyraża się w życiu, dno samolubstwa i strachu prześwituje przez jego deklarację" (Kołakowski 2000: 144). Jeżeli ktoś uważa, że życie jest bez sensu i stara się o tym ciągle przekonywać innych, to jego twierdzenia nie mają żadnej 
wiarygodności. To, a także krytyka ściśle związanego z nihilizmem narcyzmu, każe Kołakowskiemu odrzucić taką postawę.

O wiele bardziej złożona jest zaproponowana przez Kołakowskiego krytyka konserwatyzmu. Najogólniej, chodzi o to, że konserwatyzm stoi na stanowisku, iż ze światem niczego już nie da się zrobić - albo dlatego, że jest doskonały, albo dlatego, że jest niepodatny na udoskonalenia. Wieloaspektowe rozważania o tym, czym jest konserwatyzm i jaki jest jego cel, kończy Kołakowski stwierdzeniem, że, podobnie jak nihilizm, także konserwatyzm unika wzięcia odpowiedzialności za świat. Konserwatyzm nie odrzuca jednak wartości en bloc, natomiast „pozwala uchylić się od odpowiedzialności przez tworzenie sobie trwałych i bezwzględnych hierarchii wartości, to znaczy przez tworzenie kodeksów etycznych" (Kołakowski 2000: 149). Konserwatyzm potrzebuje kodeksów etycznych jako zwieńczenia i zarazem usprawiedliwienia swojego poglądu na świat, a zwłaszcza przekonania, że niczego w świecie nie można zmienić. Kołakowski pisze: „Pragnienie posiadania kodeksu moralnego, jak powiedzieliśmy, jest składnikiem owej dążności do bezpieczeństwa, owej ucieczki od decyzji; jest pragnieniem życia w świecie, gdzie wszystkie decyzje zostały już raz na zawsze powzięte” (Kołakowski 2000: 156).

Kodeksy etyczne są więc, w ocenie polskiego filozofa, narzędziami utrzymywania ludzi w inercji i poczuciu bezsilności. Ich atrakcyjność polega jednak na tym, że dają również poczucie bezpieczeństwa, które w tym kontekście oznacza głębokie przekonanie, że jak długo trzymamy się ich rozstrzygnięć, tak długo niczego nie można nam zarzucić. Uspakajają one nasze sumienia i zdejmują z barków ciężar odpowiedzialności za świat. Kołakowski twierdzi jednak, że przypisywanie kodeksom tych dwóch ostatnich funkcji wynika z pewnej iluzji co do możliwości tego rodzaju rozstrzygnięć. Iluzja ta dotyczy ich kompletności i niesprzeczności. Założenie kompletności sprowadza się do przekonania, że każda sytuacja podjęcia lub zaniechania działań przez człowieka, która podpada pod ocenę etyczną, może być podciągnięta pod konkretny przepis kodeksu; natomiast założenie niesprzeczności każe ufać, że nigdy nie staniemy wobec takiej sytuacji, co do której nie będziemy wiedzieli, jaki z dwóch lub większej liczby przepisów kodeksowych zastosować. O tym, że mamy tu do czynienia z iluzjami, świadczą, zdaniem Kołakowskiego, trzy nieuwzględniane przez kodeksy zjawiska kluczowe dla moralnego doświadczenia ludzi: asymetria powinności i roszczeń, niejednorodność wartości oraz asymetria powinności i wartości. 
Zaangażowanie pozorne jest trzecią postawą etyczną, przed którą przestrzega Kołakowski. Sprowadza się ona do afirmacji zaangażowania jako samego zaangażowania, bez względu na wartości, na które jest ono zorientowane. O ile nihilizm i konserwatyzm mają długą tradycję i są rozpoznawalne intuicyjnie, o tyle zaangażowanie pozorne jest trudniejsze do zrozumienia. Kołakowski pisząc o nim, odnosi się do filozofii egzystencjalistycznej, zwłaszcza do heideggerowskiego pojęcia Entschlossenheit. Powiadając, że „Entschlossenheit jest warunkiem egzystencji autentycznej, Heidegger stwarza sytuację, która pozwala go oskarżyć o nieodpowiedzialność; sugeruje bowiem, że autentyzm, czyli samoregulacja bytu ludzkiego, dochodzi równie dobrze do skutku w zaangażowaniu jakimkolwiek, w dowolnie obranych, a ze względu na tę filozofię w równouprawnionych obszarach życia społecznego" (Kołakowski 2000: 149).

Tym, z czym Kołakowski się nie zgadza, jest twierdzenie Heideggera, że w poszukiwaniu własnej tożsamości człowiek musi przede wszystkim się angażować, natomiast nie jest istotne, na rzecz jakich wartości to czyni. Kołakowski wychodzi z założenia, że dla ludzi istotne jest nie tyle to, czy w ogóle się angażują, ile to, czy angażują się po stronie dobra czy zła ${ }^{3}$.

W Etyce bez kodeksu nie ma bezpośrednich odniesień do filozofii edukacji, niemniej wyraźnie wyłania się z tego tekstu implikatywny postulat dotyczący etycznej postawy nauczycieli ${ }^{4}$. Krytyka, jaką Kołakowski kieruje wobec nihilizmu, konserwatyzmu oraz zaangażowania pozornego, nie pozostawia wątpliwości, jaki rodzaj edukacji, zdaniem filozofa, byłby szkodliwy dla młodego pokolenia. Trudno nie zgodzić się z Kołakowskim co do zasadniczej krytyki nihilizmu i zaangażowania pozornego jako niepożądanych rezultatów edukacji. Większe problemy nastręcza konserwatyzm. Czy edukacja konserwatywna, zgodnie

${ }^{3} \mathrm{~W}$ artykule Gdzie jest miejsce dla dzieci w filozofii liberalizmu? (1993) Kołakowski stwierdza, że wyraźne pokazanie różnicy między dobrem a złem jest obowiązkiem każdego państwa, które bierze na siebie obowiązek kształcenia i wychowywania dzieci. Państwo nie może w tym punkcie pozostawać neutralne (por. Kołakowski 1993: 16).

${ }^{4}$ Zwrócił na to uwagę Lech Witkowski w słowach: „Warto by poważnie podyskutować nad hasłem Leszka Kołakowskiego postulującego ,etykę bez kodeksu', uczulającego na pułapki porządkowania przestrzeni aksjologicznej strategią kodeksową, gdzie na szwank narażone jest poczucie i zdolność do ponoszenia odpowiedzialności za decyzje i gdzie odkrywamy konieczność respektowania ,asymetrii powinności i wartości’” (Witkowski 2007: 31). 
z Kołakowskiego rozumieniem konserwatyzmu i jego społecznych funkcji, byłaby również czymś niepożądanym? Czy konserwatywni nauczyciele przynosiliby więcej szkody niż pożytku w swojej pracy $\mathrm{z}$ dziećmi i młodzieżą?

Odpowiedzi na te pytania wymagałyby głębszych analiz, które zepchnęłyby nas z drogi naszych zasadniczych rozważań. W tym miejscu powiedzmy, że Kołakowski, odnosząc się implikatywnie do kwestii edukacji, wyklucza możliwość wychowania dzieci i młodzieży do dobrowolnej odpowiedzialności za świat przez konserwatywnych nauczycieli. Nauczyciele tacy byliby w stanie wlać w serca swoich wychowanków wewnętrzny pokój, a nawet wzbudzić w nich poczucie bezpieczeństwa, ale nie potrafiliby przygotować ich do podejmowania trudu zmiany świata na lepszy. Tymczasem taki jest właśnie, zdaniem Kołakowskiego, cel ludzkiego wzrostu, rozwoju i edukacji. Aby móc ten cel zrealizować, należy w pierwszej kolejności uwolnić się od iluzji, że świat został już raz na zawsze uporządkowany. To zaś oznacza zdystansowanie się wobec etyki kodeksowej i oparcie się na etyce osobistej.

\section{Nienawiść i godność jako cele wychowania}

Drugim ważnym w kontekście niniejszych dociekań tekstem Kołakowskiego jest jego przemówienie wygłoszone w 1977 r. we Frankfurcie nad Menem w związku z przyznaniem mu nagrody pokojowej niemieckiego księgarstwa. Przemówienie nosi tytuł Wychowanie do nienawiści, wychowanie do godności.

Skąd w ogóle pomysł, by mówić o wychowaniu do nienawiści? Czy jakikolwiek system pedagogiczny lub, szerzej, jakakolwiek kultura może zachęcać, czy wręcz wymagać wychowania do nienawiści? Kołakowski odpowiada, że tak. Nie dzieje się to jednak wprost, nienawiści nigdy nie afirmuje się jako celu samego w sobie. Raczej dopuszcza się ją lub zachęca do niej, rozumiejąc ją jako narzędzie $\mathrm{w}$ dochodzeniu do jakiegoś dobra. Jak to się dzieje, że chcąc osiągnąć dobro, powinniśmy nienawidzić? Kołakowski tłumaczy, że nienawiść, o której tu mowa, kieruje się przeciwko jednostkom lub grupom, które w przekonaniu rządzących stają na drodze osiągnięcia pożądanego dobra. Innymi słowy, rządzący mówią społeczeństwu, że gdyby nie ta jednostka lub ta grupa, bylibyśmy szczęśliwsi, lepsi, bardziej rozwinięci. Wystarczy więc pozbyć się tych „zawalidróg”, byśmy mogli zrealizować nasze szczytne zamierzenia. W zależności od miejsca i czasu tymi 
„Zawalidrogami” mogli być heretycy, kapitaliści, Żydzi lub jeszcze inni ludzie. Kołakowski zwraca uwagę, że wychowanie do nienawiści zawsze dokonuje się w kontekście walki o „większe dobro”. Właśnie to dobro, dodajmy, jako szczytny cel zdaje się usprawiedliwiać nienawiść jako środek służący jego urzeczywistnieniu. W tym właśnie należałoby upatrywać bagatelizowanie wychowania do nienawiści lub niedostrzeganie go.

Swój sprzeciw wobec wychowania do nienawiści wyraża Kołakowski w następujących tezach:

- nie istnieje prawo do nienawiści, bez względu na okoliczności;

- nonsensem jest powiedzenie, że ktoś zasługuje na nienawiść;

- w naszej mocy jest żyć bez nienawiści;

- wyrzec się nienawiści, nie znaczy wyrzec się walki;

- żadne przysługujące człowiekowi prawo nie może być potwierdzane za pomocą nienawiści (por. Kołakowski 1990: 90).

Kołakowski wskazuje, że wychowanie do nienawiści jest charakterystyczne głównie dla państw totalitarnych ${ }^{5}$. Powód jest prosty - pozwala ono kontrolować całe społeczeństwo. Kontrola ta polega na tym, że gdy przekona się społeczeństwo, iż należy odnosić się z nienawiścią do innych ludzi, staje się ono całkowicie zależne od rządzących. Następuje w wyniku tego głęboka degradacja ludzi, którzy - odarci z poczucia własnej godności są gotowi do zaakceptowania oczywistej niesprawiedliwości, a nawet do brania udziału w jej czynieniu. Kołakowski słusznie zauważa, że prawdziwą ofiarą nienawiści nie jest ten, przeciwko komu nienawiść jest kierowana, ale ten, kto nienawiść w sobie nosi, podtrzymuje oraz na jej podstawie działa. Autor pisze „zapotrzebowanie na nienawiść wyjaśnia się tym, że niszczy

${ }^{5}$ Nie znaczy to, że nie możemy się z nim spotkać w państwach liberalno-demokratycznych. Niemniej w tym kontekście natychmiast zostaje ono dostrzeżone, nazwane i poddane krytyce. O tym, że Kołakowski miał rację, łącząc wychowanie do nienawiści przede wszystkim z państwem totalitarnym, świadczy choćby treść przemówienia Pierwszego Sekretarza Komitetu Centralnego PZPR Edwarda Gierka z 26 czerwca 1976 r., w dwa dni po rozpoczęciu protestów i strajków robotniczych w Radomiu. Gierek zwrócił się wówczas do wojewódzkich sekretarzy PZPR w następujących słowach: „[...] trzeba załodze tych czterdziestu paru zakładów powiedzieć, jak my ich nienawidzimy, jacy to są łajdacy, jak oni swoim postępowaniem szkodzą krajowi. Uważam, że im więcej będzie słów bluźnierstwa pod ich adresem, a nawet jeśli zażądacie wyrzucenia z zakładów pracy elementów nieodpowiedzialnych - tym lepiej dla sprawy" (cyt. za Mazur 2003: 46). 
ona wewnętrznie tych, co nienawidzą, że czyni ich bezbronnymi wobec państwa, że równa się duchowemu samobójstwu, samozniszczeniu, a przez to wydziera korzenie solidarności również między tymi, co nienawidzą" (Kołakowski 1990: 94).

Wątek ten jest szczególnie interesujący, gdyż, jak mówi Kołakowski, na nienawiści nie można zbudować prawdziwej solidarności. Jeżeli najtrwalszym spoiwem, które łączy mnie z innymi ludźmi, jest nienawiść kierowana na wspólnego wroga, to nigdy nie będziemy mieli tu do czynienia z solidarnością. Nienawiść niszczy solidarność między ludźmi, nawet jeśli mogłoby się wydawać, że ci, którzy nienawidzą tej samej osoby, idei czy instytucji, są w jakiś sposób ze sobą zbratani. Nie jest to jednak braterstwo, ale współuczestnictwo w czynieniu zła, a tym samym w procesie samodegradacji.

Wątek nienawiści inicjowanej i wzmacnianej w życiu społecznym przez rządzących zasługiwałby na głębsze analizy. Szczególnie ważne byłoby dostrzeżenie i uwypuklenie związku pomiędzy rozbudzaniem nienawiści w życiu publicznym przez władze totalitarne a rolą, jaką w promowaniu nienawiści mieli odgrywać nauczyciele. Dla Kołakowskiego wychowanie do nienawiści oznacza największą krzywdę, jaką nauczyciel może wyrządzić uczniowi, a zarazem jest najcięższym zarzutem, jaki można postawić nauczycielowi. Wychowanie do nienawiści jest skrajnie destrukcyjne dla ucznia, gdyż ostatecznie niszczy w nim szacunek do samego siebie oraz pozbawia go poczucia własnej godności. Kołakowski jest przekonany, że młodzi ludzie nauczeni nienawiści nie potrafią nawiązywać między sobą relacji zaufania i solidarności, w zamian za to żywią się podejrzliwością i żądzą dominacji. Tacy uczniowie stają się ostatecznie całkowicie zależni od władzy politycznej, która wskazuje kolejne grupy lub pojedyncze osoby jako obiekty nienawiści. Jeżeli można sobie wyobrazić najbardziej wynaturzoną i przerażającą formę socjalizacji, to byłoby to właśnie wychowanie do nienawiści.

Przeciwieństwem takiego wychowania jest dla Kołakowskiego wychowanie do godności ${ }^{6}$. W odróżnieniu od rozważań o nienawiści, w omawianym przemówieniu niewiele jest odniesień wprost do godności. Czym jest owa godność, do której powinniśmy wychowywać? Na dwie rzeczy Kołakowski zwraca uwagę w tym kontekście. Po pierwsze, na związek wychowania do godności

6 Warto zwrócić uwagę, że Kołakowski nie pisze tu o wychowaniu do miłości, nie oczekując tym samym wdrażania w życie przez nauczycieli maksymalistycznej etyki miłości bliźniego. 
z wychowaniem do demokracji, oraz po drugie na związek samej godności z przekonaniem, że w naturze ludzkiej zawsze znajduje się coś dobrego, to znaczy, że nie ma człowieka na wskroś złego, który zasługiwałby wyłącznie na naszą nienawiść. Wychowanie do godności zawiera w sobie dwa komponenty: gotowość do walki bez nienawiści oraz ducha pojednawczego, któremu jednak towarzyszy przekonanie, że co do istoty sprawy nie można ustępować.

Koncepcja wychowania do godności wydaje się lepiej zrozumiała w kontekście prawa, a zwłaszcza praw człowieka. Godność jest wartością, która przysługuje każdemu człowiekowi z tej racji, że jest człowiekiem. Godność ta jest przyrodzona i niezbywalna, towarzyszy nam od chwili narodzin i nigdy jej nie tracimy, niezależnie od tego, co zrobimy lub czego nie zrobimy. Wychowanie do godności to z jednej strony ukazanie wychowankom rzeczy, których nie mogą robić, o ile chcą zachować szacunek do samych siebie, natomiast z drugiej - uświadomienie im, że ich przeciwnikom, z którymi w przyszłości będą toczyli spory w społeczeństwie demokratycznym, także przysługuje godność. Godność jest zatem nierozerwalnie związana zarówno z gotowością do walki bez nienawiści, jak i z podtrzymywaniem w sobie ducha pojednawczego.

Kołakowski zachęca do angażowania się w sprawy tego świata i oczekuje, że również nauczyciele będą do tego zachęcali swoich wychowanków. Zaangażowanie to musi być przede wszystkim wolne od nienawiści. Niezależnie od tego, jak ważna dla nas byłaby wartość, na rzecz której chcielibyśmy się zaangażować, a także jak bardzo bylibyśmy skłaniani, czy to przez własne sumienie, czy przez innych, do użycia nienawiści jako narzędzia ochrony tej wartości, Kołakowski poucza, że dla naszego własnego dobra nie powinniśmy tego robić. Wyzbycie się nienawiści nie oznacza jednak wyzbycia się gotowości do walki, natomiast walka bez nienawiści zakłada poszanowanie godności własnej i godności przeciwnika.

\section{Nauczyciel jako źródło zaufania}

Trzeci z omawianych tekstów Kołakowskiego to zapis wykładu pt. Charyzmatyczny przywódca, charyzmatyczny nauczyciel, wygłoszonego w 2006 r. na Uniwersytecie Warszawskim?

7 Do pojęcia charyzmatycznego nauczyciela dochodził Kołakowski stopniowo. Przez długi czas interesowało go przede wszystkim pojęcie intelektualisty. 
Kołakowski wychodzi od zwięzłej prezentacji dwóch koncepcji charyzmatów, religijnej i świeckiej. Pierwsza wywodzi się z greckiej mitologii, została następnie przejęta przez pierwotne chrześcijaństwo, które ją zrekonstruowało zgodnie ze swoją doktryną. Oznacza ono wyjątkowy dar duchowy przekazany osobie przez bóstwo lub Boga, łaskę, której dostąpiła lub przywilej, z którego korzysta. Tak rozumiany charyzmat jest czymś jednoznacznie pozytywnym, optymistycznym, a nawet radosnym, a ten, kto go otrzymuje, ma obowiązek dzielenia się nim ze wspólnotą, do której należy. Pojęcie charyzmatu w ujęciu świeckim pojawiło się znacznie później i jest zazwyczaj łączone z przełomowym dziełem Maxa Webera pt. Gospodarka $i$ spoteczeństwo, w którym socjolog pisze o autorytecie charyzmatycznym jako pierwszej chronologicznie formie sprawowania władzy, charakterystycznej dla wspólnot, które nie wykształciły jeszcze stabilnych form organizacji państwowej. Taką wspólnotą było na przykład społeczeństwo żydowskie sprzed okresu królewskiego, rządzone przez przywódców religijnych, zwanych sędziami, którzy w przekonaniu wspólnoty byli powoływani bezpośrednio przez Boga do wypełnienia konkretnych zadań. Najbardziej znanym przywódcą tego rodzaju był Samson. Weber twierdził, że wraz z rozwojem instytucji państwa autorytet charyzmatyczny ustąpił miejsca autorytetowi tradycyjnemu, którego wyrazem stały się dynastie władców. Te natomiast zostały zastąpione, przynajmniej w zakresie realnie sprawowanej władzy, przez autorytety racjonalno-legalne, charakterystyczne dla współczesnych państw liberalno-demokratycznych.

Kołakowski wyklucza, by osoby charyzmatyczne mogły dziś, poprzez odwoływanie się wyłącznie do swego charyzmatu, przewodzić państwom liberalno-demokratycznym. Uważa, że zgodnie z podziałem autorytetu władzy wprowadzonym przez Webera, w państwach liberalno-demokratycznych można rządzić jedynie za pomocą procedur racjonalno-legalnych, czyli takich, które z jednej strony zostały wypracowane przez racjonalną dyskusję między obywatelami, z drugiej legitymizowane przez obowiązujące prawo.

Zbyszek Dymarski zauważa: „By lepiej przybliżyć to, kim on jest, filozof konfrontuje go z innymi postaciami. Intelektualista nie jest więc kapłanem (bo ten sprawuje pieczę nad rytuałem i jest głosicielem prawd religijnych od poprzedników otrzymanych), nie jest też nauczycielem (bo ten tylko zgromadzoną już wiedzę i technikę myślową ma przekazywać młodym), ani uczonym (o ile ten bada materiały już istniejące, jak archeolog, lingwista, historyk)” (Dymarski 2012: 272). 
W dzisiejszych rozwiniętych państwach (zgodnie z obowiązującą w nich koncepcją rozwoju) rządzi się nie na podstawie charyzmy, ale wyboru, powołania lub mianowania, będących zwieńczeniem sformalizowanych procedur. Także zgodnie z tymi procedurami władzę się oddaje lub traci. W tym obszarze ryzyko poddania całych narodów i społeczeństw wpływom takich jednostek jest zbyt duże. W Europie mogliśmy się o tym przekonać w XX w., obserwując przede wszystkim rządy Adolfa Hitlera w nazistowskich Niemczech oraz Józefa Stalina w komunistycznym Związku Radzieckim. W państwach liberalno-demokratycznych nie można zatem nikomu powierzać władzy tylko na tej podstawie, że jest osobą charyzmatyczną .

Kołakowski wychodzi od zarysowania tego, co uznaje za istotę relacji z charyzmatyczną osobowością:

Autorytet, którym promieniuje osoba charyzmatyczna, jest innego rodzaju. Taki człowiek nie może być zastąpiony przez innego, ja zaś nie mogę ani nauczyć się, ani skutecznie naśladować jego sprawności, jakkolwiek bym się wysilał. Poddaję się jego autorytetowi nie dlatego, bym był racjonalnie przekonany, że ma on słuszność, ale z racji szczególnej mocy jego osobowości (Kołakowski 2009: 181-182).

Kontynuując ten wątek, podkreśla irracjonalny charakter relacji z taką osobowością. „W jakimś sensie wierzę, że jest on nieomylny, chociaż niekoniecznie $w$ takich słowach swoje wierzenie wypowiadam. Nim coś powie, wierzę z góry w prawdę tego, co chce oznajmić. W tym znaczeniu autorytet osobowości charyzmatycznej jest quasi-sakralny i nie ma racjonalnego umocowania” (Kołakowski 2009: 182).

Taka konstrukcja osoby charyzmatycznej uświadamia nam ogromny wpływ, jaki wywiera ona na tych, którzy pozostają w kręgu jej oddziaływania. W przypadku przywódców politycznych wpływ ten jest szczególnie potężny. Mając w pamięci tragiczne doświadczenia Europy i świata, sprowadzone na ludzkość w XX w. przez charyzmatycznych przywódców politycznych, Kołakowski jasno deklaruje, że w dzisiejszych czasach nie ma

${ }^{8}$ Nie wyklucza to sytuacji, w których charyzmatyczny kandydat w rezultacie długiego i sformalizowanego procesu rekrutacyjnego, lub innego, zajął stanowisko dające mu dostęp do władzy. Niemniej wzajemna kontrola i równoważenie się władz w państwie liberalno-demokratycznym jest skuteczną ochroną przed możliwymi nadużyciami władzy z jego strony. 
miejsca na rządy charyzmatycznych i niekontrolowanych przez inne instytucje państwa polityków.

Wykluczając udział charyzmatycznych osobowości w sprawowaniu władzy politycznej, Kołakowski nie wyklucza obecności takich osobowości w sferze publicznej. Pisze, że obszarem, w którym są one szczególnie potrzebne, jest edukacja. Kołakowski analizuje, czym charyzmatyczny nauczyciel różni się od innych nauczycieli. Mówi, że w jego pracy nie chodzi o powiadamianie uczniów o faktach lub przekazywanie im określonych umiejętności. Chodzi raczej o budzenie lub wzmacnianie w nich pewnych postaw wobec świata i innych ludzi. Na przykład, że „powinniśmy wspierać naszych bliźnich w potrzebie, rozsiewać przyjaźń i miłość, a wyrzekać się zawiści i nienawiści" (Kołakowski 2009: 185). Im bardziej życie takiego nauczyciela wpisuje się w treść jego nauczania, tym większe zaufanie mamy do niego. Potrzebujemy takiego zaufania, gdyż, jak zauważa Kołakowski, nasza dusza zawsze pozostaje częściowo niedojrzała, skłonna do zrzucania z siebie odpowiedzialności i poszukiwania wsparcia w podejmowaniu decyzji. „Tęsknimy zatem za mistrzem, a jeśli go nie ma, czujemy się wystraszeni i bezsilni” (Kołakowski 2009: 186).

\section{W stronę pojęcia charyzmatycznego nauczyciela}

Jakie pojęcie charyzmatycznego nauczyciela wyłania się z przeanalizowanych tekstów Kołakowskiego? Nie jest to pojęcie do końca jasne ani precyzyjne, a definicja, jaką można dla niego skonstruować, jest raczej negatywna niż pozytywna - wskazuje głównie to, co nie może się w nim mieścić, nie zaś to, co je konstytuuje. Nie jest to zbyt wiele, ale już coś. Przypomnijmy zatem raz jeszcze, co mówi Kołakowski do nauczycieli, którzy chcą wzmacniać swój charyzmat: Nie liczcie na kodeksy! Nie uczcie nienawiści! Nie osłabiajcie zaufania do świata! Punktem wyjścia jest tu orientacja etyczna dystansująca się wobec konserwatyzmu (o dystansowaniu się wobec nihilizmu i zaangażowania pozornego nie piszę, gdyż są to sprawy oczywiste). Dla Kołakowskiego jest to jednoznaczne z dystansowaniem się wobec kodeksów etycznych. Co znaczy jednak, by nie liczyć na kodeksy? Trzeba tu odróżnić dwie postawy. Pierwsza polega na przekonaniu, że w życiu moralnym i rodzących się w nim dylematach w ogóle 
nie mogę odnosić się do kodeksów etycznych i w związku z tym wszystkie dylematy muszę rozstrzygać na gruncie etyki osobistej. Druga akcentuje pogląd, że w życiu moralnym pojawiają się takie dylematy, których nie rozstrzygnie żaden kodeks i dlatego muszę być zawsze gotowy, by oprzeć się na etyce osobistej. Kołakowski na pewno nie opowiada się za pierwszą postawą, nie oczekuje od nauczyciela, że ten usytuuje się poza kulturowo ugruntowanymi dobrem i złem, i w nietzscheański sposób będzie każdorazowo konstruował swoje własne wartości i powinności. Nie o taką etykę bez kodeksu tu chodzi. Kołakowski chce natomiast uświadomić ludziom, że w wielu sytuacjach moralnych kodeksy etyczne okazują się niekompletne lub niespójne, i po prostu nie można na nich polegać. Problemem konserwatysty jest to, że tego nie widzi.

Charyzmatyczny nauczyciel musi to dostrzegać. W pracy pedagogicznej ujawnia się wiele takich sytuacji, które są nieoczekiwane, niepowtarzalne, niepokojące. Często mają one postać paradoksalną. Kołakowski wskazuje tu na asymetrię powinności i roszczeń (wiem, że powinienem coś zrobić dla ucznia, choć ani on sam, ani nikt inny nie ma prawa tego ode mnie wymagać), niehomogeniczność (niejednorodność) wartości (ten sam stan rzeczy będzie inaczej wartościowany przez różne osoby, na przykład nauczycieli, uczniów i rodziców, natomiast identyczne pod względem cech konstytutywnych stany rzeczy będą różnie wartościowane przez tę samą osobę w zależności od przypadkowych okoliczności), oraz asymetrię powinności i wartości (wiem, że powinienem coś zrobić, choć jest to złe, lub nie powinienem czegoś robić, choć jest to dobre). W takich sytuacjach charyzmatyczny nauczyciel dostrzega, że zastosowanie przepisu kodeksowego byłoby wielkim błędem? Jeżeli jednak nie przepis, to co? Skąd charyzmatyczny nauczyciel ma wiedzieć, jak rozstrzygnąć konkretny dylemat etyczny? Kołakowski nie odpowiada na to pytanie, gdyż takiej odpowiedzi nie ma. Właśnie na tym polega charyzmat nauczyciela, że w takiej sytuacji potrafi on podjąć dobrą decyzję. Jeżeli można by w tej materii udzielić nauczycielom jakiejś rady, to brzmiałaby ona: przyznanie się do własnej niewiedzy i powstrzymanie się z podejmowaniem decyzji jest nieporównanie lepsze niż decydowanie na podstawie przekonań, co do których samemu ma się wątpliwości.

9 W kulturze prawnej starożytnego Rzymu stosowano tu sentencję summum ius, summa iniuria, która wskazywała, że kurczowe trzymanie się litery prawa prowadzi do niesprawiedliwości. 
Etyka osobista, której Kołakowski oczekuje od charyzmatycznych nauczycieli, jest nazywana także etyką mglistą. Nauczyciel, który buduje w sobie taką etykę, musi wyrzec się konserwatyzmu. Jak przedstawia się jednak jego stosunek do poszczególnych etyk normatywnych? Czy któraś z tych etyk bardziej niż inne byłaby pomocna w konstruowaniu etyki osobistej? W filozofii edukacji i etyce pedagogicznej toczy się od wielu dekad dyskusja na temat przydatności etyki cnoty oraz etyki powinności w pracy nauczyciela. Autorem wielu interesujących tekstów na ten temat jest David Carr (por. Carr 1999), w polskiej pedagogice wątek ten rozwijali Joanna Madalińska-Michalak (zob. Michalak 2010), Dariusz Zając (2019) i autor tego artykułu (Kostyło 2018). W socjologii edukacji konsekwentnie podkreśla się znaczenie etyki umowy społecznej, zwłaszcza w kontekście sprawiedliwości i bezstronności, oczekiwanych od nauczyciela. O taką etykę upomina się m.in. Zbigniew Kwieciński (por. Kwieciński 2007, 2019). Wreszcie, pedagodzy usytuowani w nurcie chrześcijańskiego personalizmu akcentują znaczenie normy miłości bliźniego jako podstawy oceniania nauczycielskich zachowań pod kątem etycznym. Takie podejście znajdujemy przykładowo w tekstach Mariana Nowaka (por. Nowak 2015). Widać zatem, że różne etyki normatywne mogą służyć nauczycielowi jako punkty odniesienia w budowaniu własnego charyzmatu. Będą one jednak tym mniej przydatne, im bardziej będą formalizowały i upodabniały do kodeksów.

Nieco więcej na temat faktycznego oddziaływania etyki bez kodeksu w relacjach między nauczycielem i uczniem mógłby nam powiedzieć tekst Henriego Bergsona O grzeczności (por. Bergson 2017). Kołakowski dobrze znał filozofię Bergsona, napisał książkę o tym myślicielu, wydaną w 1985 r. w oksfordzkiej serii Past Masters, a następnie przetłumaczoną na język polski. Czy zgodziłby się natomiast $\mathrm{w}$ pełni z bergsonowskim opisem wyjątkowej relacji nauczyciela z uczniem, nazwanej przez Bergsona grzecznością serca trudno rozstrzygnąć. W każdym razie bergsonowski opis grzeczności serca sytuuje się całkowicie poza logiką kodeksów etycznych:

Czyż w tym punkcie nie tkwiłaby, młodzi uczniowie, najwyższa grzeczność, grzeczność serca, to, co nazwaliśmy cnotą? Jest to życzliwość objawiająca się w obszarze miłości własnych, tu gdzie niekiedy jest równie trudno rozpoznać zło, jak i chcieć je uleczyć. Jej głębią jest wielka naturalna dobroć; ale dobroć ta pozostawałaby może nieskuteczna, gdyby przenikliwość ducha nie dołączyła do niej delikatności i dogłębnej znajomości ludzkiego serca (Bergson 2017: 98-99). 
Trudno powiedzieć, czy ta wyjątkowa umiejętność rozumienia najgłębszych tęsknot szczególnie wrażliwych uczniów przesądza o tym, że mamy do czynienia z charyzmatycznym nauczycielem. Jeżeli jednak nauczyciel, odwołując się do swojej osobistej etyki, nie potrafi nawiązać takiej lub podobnej relacji z uczniem, to z pewnością, zdaniem Kołakowskiego, nie sposób go będzie nazwać charyzmatycznym.

Kwestia wychowania do nienawiści i wychowania do godności jest rozwijana przez Kołakowskiego w kontekście angażowania się na rzecz udoskonalania świata w kulturze demokratycznej. Przekonanie, że świat można i należy udoskonalać, jest charakterystyczne dla charyzmatycznych nauczycieli, świadcząc o ich anty-konserwatywnym nastawieniu. Nauczyciele ci są świadomi, że angażując się na rzecz dobrych celów, nie można odwoływać się do nienawiści i trzeba być gotowym na kompromis, nie wyrzekając się istoty swojego stanowiska. Kołakowski zdaje jednak sobie sprawę, że w zapale zmieniania świata na lepszy rządzący mogą zatracić umiar, zachęcając uczniów (często za pośrednictwem nauczycieli) do nienawiści ze względu na szybsze i pewniejsze osiągnięcie zakładanych celów. Dokonuje się to w procesie zwanym indoktrynacją, dobrze rozpoznanym i opisanym przez filozofię edukacji (por. Siegel 1991). Tak działo się w państwach totalitarnych, które wzbudzały nienawiść do różnego rodzaju „wrogów” i oczekiwały od nauczycieli i uczniów stosownych deklaracji i zachowań ${ }^{10}$.

Wychowanie do godności jest trudniejsze niż wychowanie do nienawiści, gdyż, nie rezygnując $\mathrm{z}$ apelu o zaangażowanie na rzecz udoskonalania świata, zwraca ono jednocześnie uwagę, że wokół nas znajdują się inni ludzie, którzy mogą mieć i faktycznie mają inne wizje społecznej aktywności. Ludziom tym przysługuje taka sama godność jak nam i jeśli nie zgadzamy się ze sobą, to musimy szukać dróg porozumienia, komunikacji, jakiegoś minimalnego konsensusu odnośnie do podstawowych wartości i powinności. Wychowanie do godności może w związku z tym wzbudzać obawy niektórych osób ze względu na rzekome hamowanie entuzjazmu i ofiarności uczniów. Charyzmatyczny nauczyciel

${ }_{10}$ Witold Chmielewski pisze o tym w kontekście kształcenia polskich nauczycieli w latach 1944-1956: „W ramach wychowania w duchu humanizmu socjalistycznego propagowano wyrabianie solidarności z proletariatem. W praktyce było to budzenie niechęci do wszystkich potencjalnych przeciwników socjalizmu i Polski Ludowej, np. do burżuazji, USA, RFN, czy też konkretnych przywódców zachodnich" (Chmielewski 2006: 173). 
nie podziela tych obaw, ponieważ, troszcząc się o przyszłość uczniów, wie, że równie ważna jak osiągnięcie celu jest droga, która do niego prowadzi. Trwałe udoskonalenie społeczeństwa jest możliwe tylko pod tym warunkiem, że godność wszystkich zainteresowanych tym przedsięwzięciem jednostek i grup będzie $\mathrm{w}$ równym stopniu chroniona.

Dochodzimy wreszcie do punktu, w którym Kołakowski wprost pisze, kim jest według niego charyzmatyczny nauczyciel:

Istnieją jednak ludzie obdarzeni autorytetem charyzmatycznym, których naprawdę potrzebujemy. Nie są oni przywódcami politycznymi, lecz - by tak rzec - strażnikami, przewodnikami czy pomocnikami. Mogą być nauczycielami, ale nauczycielami szczególnego rodzaju: mistrzami raczej niż nauczycielami w sensie zwyczajnym. Nie dostarczają nam po prostu informacji, których potrzebujemy czy które mieć chcemy, ale niejako wpisują się sami jako osoby w treść swojego nauczania, zwłaszcza - ale nie tylko - jeśli jest to nauczanie moralne albo religijne (Kołakowski 2009: 185).

Filozoficznie opis ten może być śmiało nazwany bergsonowskim. Również francuski filozof zajmował się tym zagadnieniem i w podobny sposób opisał oddziaływanie wybitnych osobowości moralnych, które nazywał niekiedy duszami uprzywilejowanymi. Proces wychowawczy realizowany przez te osobowości zasługiwał zdaniem Bergsona na miano mistycznego (por. Bergson 1993). Jak widzieliśmy, Kołakowski bardzo dobrze znał prace Bergsona i odnosił się do jego myśli z sympatią. Nie będziemy pogłębiali rozważań na temat tej afiliacji, skupimy się natomiast na funkcji, którą, według Kołakowskiego, wypełnia charyzmatyczny nauczyciel. Najogólniej jest on gwarantem sensu i źródłem zaufania dla młodego pokolenia, które, wystawione na pokusę nihilizmu, łatwo może stracić energię potrzebną do angażowania się na rzecz zmiany świata na lepszy. Charyzmatyczny nauczyciel świadczy przed uczniami, że świat i toczące się w nim wydarzenia zmierzają do jakiegoś celu, że nie są bezsensowne i przypadkowe; że to wszystko, co nas otacza i co na co dzień przeżywamy, ma jakieś głębsze znaczenie, nie jest tylko zbiorem przypadkowych doświadczeń. Poświadczając to własnym życiem, charyzmatyczny nauczyciel utwierdza młode pokolenie w przekonaniu, że warto żyć.

Interesujące jest, że Kołakowski często porusza kwestię niedoli ludzkiego losu, naszych cierpień, błędów i lęków. Dotykają one wszystkich ludzi, także tych najmłodszych. Charyzmatyczny 
nauczyciel nie zdejmuje z ludzi tych ciężarów, ale pozwala im patrzeć z nadzieją w przyszłość pomimo nich. Zaufanie, jakie wzmacnia w młodym pokoleniu, przywołuje na myśl pierwotne znaczenie autorytetu jako instytucji prawnej, gwarantującej ludziom skuteczną ochronę przed niesprawiedliwością ${ }^{11}$. W kontekście autorytetu, nieco inaczej pojmowanego, pisze o pojęciu charyzmatycznego nauczyciela również Lech Witkowski (por. Witkowski 2009: 32-35).

Nie liczcie na kodeksy! Nie uczcie nienawiści! Nie osłabiajcie zaufania do świata! Pedagogiczno-etyczny projekt Kołakowskiego oferuje dzisiejszym nauczycielom jasne wskazówki, co należy robić, aby budować i wzmacniać własną charyzmę. Projekt ten w pierwszej kolejności wymaga od nauczycieli oduczenia się fatalnych postaw, które uniemożliwiają ujawnienie się i rozwój ich charyzmatów. Filozof znany z ostrożności i unikania skrajnych poglądów nie obiecuje nauczycielom magicznego zaklęcia, które uczyni z nich charyzmatyczne osoby. Wskazuje natomiast, jakie zachowania z pewnością nie pozwolą im uzyskać tej rangi.

\section{Bibliografia}

Bauman Z. (1995), A jeśli etyki zabraknie, „Kultura Współczesna”, nr 1-2 (5-6), s. $145-159$.

Bergson H. (1993), Dwa źródta moralności i religii, tłum. P. Kostyło, K. Skorulski, Znak, Kraków.

Bergson H. (2017), O grzeczności, tłum. P. Kostyło, D. Rybicka, [w:] H. Bergson, Teksty pedagogiczne, Wydawnictwo Uniwersytetu Kazimierza Wielkiego, Bydgoszcz.

Carr D. (1999), Professionalism and Ethics in Teaching, Routledge, Abington.

Chmielewski W. (2006), Ksztatcenie nauczycieli w okresie ideologizacji szkolnictwa 1944-1956, Wydawnictwo Neriton, Warszawa.

Dymarski Z. (2013), Ktopot z madrościa. Leszka Kolakowskiego próba opisania nowoczesnego mędrca, "Zeszyty Naukowe Centrum Badań im. Edyty Stein - Fenomen Mądrości”, nr 10, s. 263-277.

Flis M. (1994), Leszek Kolakowski - teoretyk kultury europejskiej, Universitas, Kraków.

Huang Y.-C., Lin S.-H. (2014), Assessment of Charisma as a Factor in Effective Teaching, "Educational Technology \& Society", nr 17 (2), s. 284-295.

${ }_{11}$ Mowa tu o specjalnym powództwie, które mogło być kierowane przeciwko nieuczciwemu sprzedawcy, tzw. actio auctoritatis. 
Kaniowski M.A. (1994), Zapomniany wymiar moralności - kilka uwag o wspótczesnych dyskusjach etycznych, [w:] Honoris causa. Ksiega pamiatkowa dla uczczenia aktu nadania profesorowi Leszkowi Kolakowskiemu honorowego doktoratu Uniwersytetu Łódzkiego, Wydawnictwo Uniwersytetu Łódzkiego, Łódź.

Kołakowski L. (1990), Wychowanie do nienawiści, wychowanie do godności, [w:] L. Kołakowski, Cywilizacja na tawie oskarżonych, ResPublica, Warszawa.

Kołakowski L. (1993), Gdzie jest miejsce dla dzieci w filozofii liberalizmu?, tłum. J. Turowicz, „Znak”, nr 461 (10), s. 11-21.

Kołakowski L. (2000), Etyka bez kodeksu, [w:] L. Kołakowski, Kultura i fetysze, PWN, Warszawa.

Kołakowski L. (2008), Bergson, Znak, Kraków.

Kołakowski L. (2009), Charyzmatyczny przywódca, charyzmatyczny nauczyciel, [w:] L. Kołakowski, Czy Pan Bóg może być szcześliwy i inne pytania, Znak, Kraków.

Kostyło P. (2008), Wykluczanie jako problem filozofii edukacji. Komentarz do badań empirycznych, Oficyna Wydawnicza Impuls, Kraków.

Kwieciński Z. (2007), Sprawiedliwa nierówność czy niesprawiedliwa równość? Implikacje edukacyjne, „Nauka”, nr 4, s. 35-42.

Kwieciński Z. (2019), O różnym rozumieniu równych szans edukacyjnych, [w:] P. Kostyło (red.), Szkoła równych szans. Namyst teoretyczny i rozwiqzania praktyczne, Wydawnictwo Uniwersytetu Kazimierza Wielkiego, Bydgoszcz.

Michalak J.M. (2010), Profesjonalizm w zawodzie nauczyciela, [w:] J.M. Michalak (red.), Etyka i profesjonalizm w zawodzie nauczyciela, Wydawnictwo Uniwersytetu Łódzkiego, Łódź.

Mazur M. (2003), Propagandowy obraz świata. Kampanie prasowe w PRL 1956-1980, Wydawnictwo TRIO, Warszawa.

Nowak M. (2005), Pedagogika personalistyczna, [w:] Z. Kwieciński, B. Śliwerski (red.), Pedagogika, PWN, Warszawa.

Siegel H. (1991), Indoctrination and Education, [w:] B. Spiecker, R. Straughan, Freedom and Indoctrination in Education: International Perspectives, Cassell, London.

Siegel H. (2017), Philosophy of Education and the Tyranny of Practice, [w:] M. Spieker, K. Stojanov (red.), Bildungsphilosophie. Disziplin - Gegenstandsbereich - Politische Bedeutung, Zakład Wydawniczy „Nomos”, Tutzing.

Weber M. (2002), Gospodarka i społeczeństwo, tłum. D. Lachowska, PWN, Warszawa.

Witkowski L. (2007), O nowych polach i wymiarach odpowiedzialności etycznej w pedagogice, [w:] W. Sawczuk, Po co etyka pedagogom?, Wydawnictwo Adam Marszałek, Toruń.

Witkowski L. (2009), Wyzwania autorytetu w praktyce spolecznej i kulturze symbolicznej, Oficyna Wydawnicza Impuls, Kraków 2009.

Zając D. (2019), Etyczność pracy zawodowej nauczycieli, Wydawnictwo Uniwersytetu Kazimierza Wielkiego, Bydgoszcz. 


\section{Czy praca nauczycieli jest ceniona? ${ }^{1}$}

\section{Abstract \\ Is the teacher's work valued?}

This text primarily draws from current Polish and international data and is divided into two main parts. Firstly, when we consider the question whether the work of a person, group of people or professions is valued, we have several options for expressing this assessment. We can use the opinions of people (more or less objective and authoritative), i.e. what people think about a given job or profession. These can be opinion surveys regarding the hierarchy of professions according to social respect, prestige, honesty, reliability and trust. Finally, in the opinion-based assessment group - the beliefs of the representatives of the teacher profession are an important aspect of the assessment. In some cases it shows great diversification between these two groups (society and teachers). The second, more measurable group of indicators that are the basis for formulating the assessment of the profession are earnings. They are compared to the earnings in other professions, the salaries of people with similar education and in comparison to earnings in a given profession in many countries. The presented data and analysis concern mainly teachers as a whole professional group. In the text, the author focuses on the issues identified at the beginning, concerning the two groups and related not only to Polish teachers.

Keywords: teachers, teachers' profession assessment, teachers' salaries

Słowa kluczowe: nauczyciele, ocena zawodu nauczycielskiego, zarobki nauczycieli

${ }^{1}$ Jest to częściowo zmieniony i zaktualizowany tekst artykułu: R. Piwowarski (2018), Prestiz $i$ zarobki polskich nauczycieli, „Ruch Pedagogiczny”, nr 2, s. $39-53$. 


\section{Wprowadzenie}

Gdy rozważamy kwestię, czy praca jakiejś osoby, grupy osób czy zawód są cenione przez społeczeństwo, mamy kilka możliwości wyrażenia tej oceny. Możemy posłużyć się opiniami konkretnych osób (mniej lub bardziej obiektywnymi i miarodajnymi) o danej pracy czy zawodzie. Mogą to być badania opinii dotyczące hierarchii zawodów według kryteriów: poważania społecznego/prestiżu, uczciwości, rzetelności i zaufania. Wreszcie, w grupie ocen opartych na opiniach ważnym aspektem są przekonania przedstawicieli ocenianego zawodu na temat tego, jak postrzega ich społeczeństwo. Drugą, bardziej wymierną grupą wskaźników będących podstawą do formułowania oceny zawodu są zarobki - w porównaniu do zarobków w innych zawodach, do pensji osób posiadających podobne wykształcenie oraz zestawienie zarobków w danym zawodzie w ujęciu międzynarodowym. Poniżej przedstawione zostaną dane i analiza dotyczące przede wszystkim nauczycieli jako całej grupy zawodowej. W prezentowanym wywodzie autor koncentruje się na wyróżnionych na początku dwóch grupach zagadnień, odnoszących się nie tylko do polskich nauczycieli.

\section{Opinie o zawodzie nauczyciela}

Istnieją badania i opracowania dotyczące m.in. prestiżu oraz wynagrodzeń osób wykonujących różne zawody. Na ogół są to publikacje socjologiczne i ekonomiczne. W literaturze tematu prestiż nazywany bywa „poważaniem, szacunkiem, estymą, respektem, honorem, wreszcie statusem społecznym" (Domański 2012: 9) - i prawdopodobnie można by dodać jeszcze inne określenia. Henryk Domański przypomina, że „Max Weber zaliczył prestiż do jednej z trzech podstawowych płaszczyzn nierówności - oprócz zakresu władzy i podziałów klasowych utożsamianych z ekonomicznym statusem” (Domański 2012: 9), stwierdzenie to znajdzie częściowo potwierdzenie w dalszej części tekstu w świetle danych statystycznych. Warto także odnotować, że pedagodzy rzadko używają określenia „prestiż” w odniesieniu do nauczyciela - znacznie częściej pojawia się słowo autorytet (nauczyciela) (Piwowarski 2013).

Często zwraca się uwagę na fakt niejednakowego postrzegania zawodu nauczycielskiego przez tzw. opinię publiczną 
z jednej strony - i przez samych nauczycieli z drugiej. Poczucie niskiej pozycji wykonywanego zawodu, w przekonaniu prawie 2200 badanych w 1995 r. nauczycieli, wynikało przede wszystkim z niskich zarobków i błędnej polityki rządu wobec nauki i szkolnictwa (Lepiech 1997). Według nauczycieli spadek prestiżu zawodu nauczycielskiego był skutkiem:

- braku dobrego systemu premiowania najlepszych nauczycieli;

- nieprawidłowych kryteriów doboru do pracy w szkolnictwie;

- nieprawidłowości w systemie kształcenia (tamże).

Te stwierdzenia nadal zasługują na uwagę. Do innych wniosków dochodzą autorki badania opartego na indywidualnych wywiadach pogłębionych (81 nauczycieli +23 przedstawicieli dyrektorów szkół, pracodawców i pracowników samorządowych):

przyczyn niewielu oznak szacunku społecznego nauczyciele upatrują również w postawach rodziców. Nauczyciele winili rodziców za brak zainteresowania dziećmi i stosowanie pobłaźliwych metod wychowawczych. Część nauczycieli wskazuje na brak wystarczającej opieki rodziców nad dziećmi. W związku z tym nie ma jasności czy dla dobra dziecka powinni w pierwszej kolejności wypełniać te deficyty troski, opieki i wychowania, czy stawiać na przekazywanie wiedzy. Ważne, że w narracjach nauczycieli rzadko pojawia się refleksja na temat własnych niedoskonałości oraz zachodzących zmian społecznych, rzutujących na społeczny odbiór ich profesji. Analiza materiału badawczego pozwoliła zaobserwować mechanizm polegający na zdejmowaniu odpowiedzialności za brak prestiżu zawodu z osób go wykonywujących, a przenoszeniu jej na czynniki zewnętrzne, zwłaszcza makrospołeczne (Smak, Walczak 2015: 62).

Smak i Walczak stwierdzają ponadto, że „obniżający się prestiż zawodu nauczyciela pedagodzy relatywnie rzadko tłumaczą własnym brakiem profesjonalizmu, niską jakością pracy, czy złymi relacjami z uczniami i ich rodzicami” (Smak, Walczak 2015: 62).

Porównanie przytoczonych wyników z badaniami hierarchii zawodów z lat 80. i późniejszych wskazuje jednak, że zawód nauczyciela plasował się na dość wysokich pozycjach, i nie spotykał się z tak krytyczną oceną, jak w przypadku zacytowanych autorek. Badając wizerunek zawodu nauczyciela na tle innych profesji warto sięgnąć do źródła moim zdaniem chyba najbardziej miarodajnego, jakim są komunikaty z badań Centrum Badania Opinii Społecznej dotyczących prestizu zawodów. Jest to społeczna „wycena” poszczególnych zawodów, w tym - zawodu nauczyciela. W latach 1975-1999 zawód nauczyciela zajmował 
w klasyfikacji czwarte, a niekiedy nawet trzecie miejsce (w 1995 i 1999 r.). W roku 2008 pozycja nauczyciela była niższa - 6-7 miejsce (w zależności od tego, czy ocenie przypisano wartość na skali od 0 do 100, czy na tej samej skali zsumowano „poważanie” duże i średnie). Przez wiele lat w badaniach CBOS na pierwszym miejscu plasował się profesor uniwersytetu, natomiast na ostatnich - działacz partii politycznej i poseł (wśród 33 zawodów i funkcji). W ostatnim badaniu z 2013 r., wśród 30 zawodów nauczyciel nadal był na 7 miejscu i wyprzedzał lekarza, profesora wyprzedził strażak, a na ostatnim miejscu niezmiennie znalazł się działacz partii politycznej, na przedostatnim - poseł na Sejm (CBOS Prestiż zawodów 2013: 3). Trudno mówić w świetle tych danych o spadku prestiżu zawodowego nauczyciela, należałoby raczej mówić o jego stabilizacji.

W dużym stopniu z powyższymi danymi koresponduje badanie innej „sondażowni”, poświęcone zaufaniu, jakim cieszą się w Polsce przedstawiciele poszczególnych grup zawodowych. Podobnie jak w badaniu CBOS'u na pierwszym miejscu są strażacy. Na drugim jest wojsko, na trzecim naukowcy a nauczyciele na miejscu czwartym (nie jest to zła pozycja). Najmniej zaufania niezmiennie społeczeństwo ma do polityków. Warto dodać, że w tym badaniu uwzględniono tylko 11 grup zawodowych, uzupełniając je o kategorię „żadne z wymienionych” („Które grupy zawodowe w Polsce cieszą się Twoim największym zaufaniem”: ogólnopolski panel badawczy Ariadna, 21-24 czerwca 2019).

W badaniu CBOS'u z 2016 r. zbadano opinie respondentów dotyczące uczciwości i rzetelności 24 zawodów. Według opinii społecznej, na pierwszym miejscu pod tym względem znajdowali się naukowcy, na drugim pielęgniarki, na trzecim informatycy, a na czwartym, wysokim miejscu - nauczyciele (politycy i posłowie - na miejscach ostatnich) (CBOS 2016, komunikat nr 34: 2).

Czy rozdźwięk między odczuciami nauczycieli a prestiżem, oceną ich zawodu (bądź stosunkiem do zawodu nauczycielskiego) dokonaną przez opinię publiczną, jest faktem? Aby odpowiedzieć na to pytanie, analizie poddane zostaną jeszcze dwa inne materiały źródłowe: komunikat CBOS Wizerunek nauczycieli z 2012 r. oraz Diagnoza Spoleczna 2015.

Diagnoza Spoleczna dotyczy przede wszystkim samooceny jakości i zadowolenia z życia. Cykliczne badania koncentrują się na gospodarstwach domowych i ich członkach (kilkanaście tysięcy gospodarstw, kilkadziesiąt tys. osób). Wyłaniane są także 
(\%)

Strażak
Profesor uniwersytetu

Robotnik wykwalifikowany, np. tokarz, murarz

Górnik

Inżynier pracujący w fabryce

Pielęgniarka

Nauczyciel

Lekarz

Rolnik indywidualny na średnim gospodarstwie

Oficer zawodowy w randze kapitana

Księgowy

Adwokat

Przedsiębiorca, właściciel dużej firmy

Informatyk, analityk komputerowy

Sędzia

Właściciel małego sklepu

Dyrektor dużego przedsiębiorstwa

Sprzątaczka

Policjant

Sprzedawca w sklepie

Dziennikarz

Robotnik budowlany niewykwalifikowany

Burmistrz

Referent w biurze, urzędnik

Ksiądz

Minister

Makler giełdowy

Radny gminny

Poseł na Sejm

Działacz partii politycznej
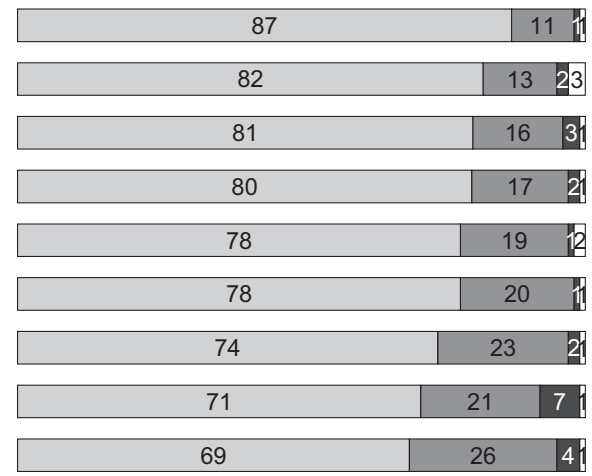

\begin{tabular}{|l|l|l|}
\hline 63 & 29 & 35 \\
\hline
\end{tabular}

\begin{tabular}{|l|ll|}
\hline 63 & 31 & 24 \\
\hline
\end{tabular}

\begin{tabular}{|l|l|l|}
\hline 63 & 27 & 73 \\
\hline
\end{tabular}

\begin{tabular}{l|l|l|}
61 & 31 & 62 \\
\hline
\end{tabular}

\begin{tabular}{|l|l|l|}
61 & 31 & 35 \\
\hline
\end{tabular}

\begin{tabular}{|l|l|l|l|}
60 & 26 & 11 & 3 \\
\hline
\end{tabular}

\begin{tabular}{|l|ll|}
\hline 58 & 36 & 32 \\
\hline
\end{tabular}

\begin{tabular}{|l|l|l|}
\hline 58 & 33 & 63 \\
\hline
\end{tabular}

\begin{tabular}{|c|c|c|}
\hline 57 & 33 & 9 \\
\hline 53 & 36 & 10 \\
\hline
\end{tabular}

\begin{tabular}{|l|l|l|}
\hline 53 & 40 & 70 \\
\hline
\end{tabular}

\begin{tabular}{|l|l|l|}
\hline 50 & 40 & 82 \\
\hline
\end{tabular}

\begin{tabular}{|l|l|l|}
\hline 49 & 35 & 15 \\
\hline
\end{tabular}

\begin{tabular}{|l|l|l|l|}
\hline 46 & 38 & 12 & 4 \\
\hline
\end{tabular}

\begin{tabular}{|l|l|l|}
\hline 44 & 43 & $10 \quad 3$ \\
\hline
\end{tabular}

\begin{tabular}{|l|l|l|l|}
\hline 41 & 35 & 21 & 3 \\
\hline 37 & 41 & 18 & 4 \\
\hline
\end{tabular}

\begin{tabular}{|l|l|l|l|}
\hline 36 & 38 & 15 & 11 \\
\hline
\end{tabular}

\begin{tabular}{|l|l|l|l|}
\hline 33 & 45 & 18 & 4 \\
\hline 32 & 39 & 24 & 5 \\
\hline
\end{tabular}

20 32

Poważanie:

$\square$ duże $\square$ średnie $\quad \square$ małe $\quad \square$ Trudno powiedzieć

Wykres 1. Hierarchia zawodów (2013)

Źródło: CBOS (listopad 2013). Prestiż zawodów, s. 3. 
grupy zawodowe, a wśród nich nauczyciele szkół podstawowych i ponadpodstawowych. Informacje z Diagnozy pozwalają pokazać, jak siebie postrzegają nauczyciele - na tle podobnej charakterystyki innych grup zawodowych.

Stosunek nauczycieli do wielu szczegółowych zagadnień (m.in. zadowolenia z pracy i płacy) pozwolił ustalić pozycje nauczycieli pod względem różnego rodzaju dobrostanu, dobrobytu, poziomu materialnego i ogólnego wskaźnika jakości życia. Przykładowo, pod względem dobrobytu materialnego nauczyciele szkół podstawowych zajmowali 14 pozycję a szkół ponadpodstawowych - 15 (1 miejsce władze, 55 - ostatnie miejsce - robotnicy pomocniczy w górnictwie i budownictwie) (Czapiński, Panek [red.] 2015: 540).

Pod względem samooceny dobrostanu społecznego nauczycieli, który koresponduje z prestiżem ich zawodu - w 2011 r. nauczyciele szkół podstawowych uplasowali się na 16 pozycji, natomiast ponadpodstawowych na 22. Według Diagnozy 2015 samoocena nauczycieli pod tym względem uległa pogorszeniu - nauczyciele szkół podstawowych i ponadpodstawowych zajęli odpowiednio miejsca 20 i 46 (wśród 55 grup zawodowych) (Diagnoza Społeczna 2015: 539). Warto tu dodać, że nauczyciele akademiccy znaleźli się w tym rankingu na 3 miejscu, lekarze na 4, prawnicy na 29. Najważniejszym jednak wskaźnikiem charakteryzującym samopoczucie przedstawicieli nauczycieli i innych zawodów jest ogólny wskaźnik jakości życia. Można stwierdzić, iż pod tym względem nauczyciele zajmują nienajgorsze pozycje - nauczyciele szkół podstawowych 10-tą, a szkół ponadpodstawowych 9-tą pozycję. Najwyższe poczucie jakości życia mają lekarze (pozycja 1) i nauczyciele akademiccy (pozycja 2), natomiast najniższą (55) - robotnicy zatrudniani przy pracach prostych (Czapiński, Panek [red.] 2015: 425).

Jaki jest w takim razie obraz nauczycieli w oczach Polaków, poza przytoczonymi wcześniej danymi dotyczącymi prestiżu zawodów? Znacznie wzbogacają ten obraz dane pochodzące z sondażu CBOS, z listopada 2012 r. (Wizerunek nauczycieli 2012). Zbadano stosunek dorosłych mieszkańców Polski - do warunków zatrudnienia nauczycieli i do cech pracy nauczyciela, a także określono, jaki jest społeczny odbiór zawodu nauczyciela.

Część odpowiedzi na pytania dotyczące pracy nauczycieli może świadczyć o tym, że jest ona przez dorosłych Polaków nadal ceniona. $74 \%$ respondentów uważało, że nauczyciele wykonują 
trudną, ciężką pracę - jeszcze bardziej zdecydowanie ocenili tę pracę pracownicy instytucji publicznych, średni personel i technicy a także osoby biorące udział w praktykach religijnych kilka razy w tygodniu (85-86\% odpowiedzi potwierdzających tę opinię). Ponad $80 \%$ badanych uważało, że nauczyciele są narażeni w pracy na duży stres (86\%) i wykonują szczególnie odpowiedzialną pracę (83\%). 68\% badanych uważało, że nauczyciele mają wysokie kwalifikacje i są gotowi je zwiększyć. 55\% stwierdziło, że nauczyciele wykonują pracę, która daje dużo satysfakcji, ale już tylko 43\%, że mają oni poczucie misji.

Analiza odpowiedzi na pozostałe pytania w znacznie mniejszym stopniu świadczy o docenianiu zawodu nauczyciela. 36\% badanych uważało, że nauczyciele cieszą się dużym szacunkiem, ale taki sam odsetek respondentów jest przeciwnego zdania. Najwyższym szacunkiem (52\%) nauczyciele byli darzeni przez ludzi posiadających wykształcenie podstawowe, najmniejszym (22-23\% odpowiedzi pozytywnych) - pracownicy usług, mieszkańcy miast liczących co najmniej 500 tys. mieszkańców. Podzielone są też opinie dotyczące wynagrodzeń nauczycieli: tylko 30\% ogółu badanych uważało, że zarobki nauczycieli są zbyt niskie (34\%, że nie są zbyt niskie) Dość znaczne są tu także rozpiętości ocen w zależności od pełnionych funkcji i wykształcenia: 50\% respondentów zaliczanych do kadr kierowniczych i specjalistów posiadających wyższe wykształcenie uważa, że nauczyciele zarabiają za mało, natomiast 54\% osób pracujących w prywatnych gospodarstwach rolnych uważa że zarobki nauczycieli nie są za niskie.

W jeszcze bardziej zdecydowany sposób badani ocenili długość urlopów nauczycielskich. Prawie połowa (49\%) była zdania, że nauczyciele mają za długie urlopy, a tylko 31\% osób badanych było przeciwnego zdania. Podobnie wypowiadano się odnośnie wymiaru godzin pracy w tygodniu - 49\% uważało, że nauczyciele pracują niewiele godzin tygodniowo, a 24\% było przeciwnego zdania. Tu także mamy do czynienia ze znacznym rozrzutem odpowiedzi w zależności od grupy społeczno-zawodowej: prawie $70 \%$ robotników niewykwalifikowanych uważało, że nauczyciele mają zbyt dużo „wolnego”, i co interesujące - tak uważało tylko $27 \%$ uczniów i studentów, co by świadczyło o tym, że bezpośredni odbiorcy „usług” edukacyjnych doceniają pracę swoich nauczycieli.

Sporo wnosi do oceny pracy nauczyciela analiza odpowiedzi na następujące pytanie: „Niezależnie od tego, czy ma pan(i) dzieci, czy też nie, proszę powiedzieć, czy chciał(a)by pan(i), żeby któreś 
z nich pracowało w przyszłości jako nauczyciel w szkole?” (Wizerunek nauczycieli 2012: 7). 54\% biorących udział w tym badaniu odpowiedziało, że „nie” - „tak” tylko 34\%. Nawet większość nauczycieli nie chciałaby, aby ich dzieci wykonywały ten zawód (48\% odpowiedzi „nie”, 46\% „tak”). Interesujące, że z najwyższą aprobatą zawodu nauczyciela dla swoich dzieci wypowiedziały się osoby deklarujące udział w praktykach religijnych kilka razy $\mathrm{w}$ tygodniu (51\%), natomiast $\mathrm{z}$ najmniejszą - osoby z dużych miast (19\%), a także z najwyższymi dochodami na jedna osobę, pracujący na własny rachunek oraz studenci i uczniowie (po 27\% odpowiedzi „tak”).

Wyniki badania CBOS-u w dużym stopniu podtrzymują dość pozytywny wizerunek nauczycieli w odbiorze społecznym, pokazują jednak także, że obraz ten nie jest wyłącznie optymistyczny, jak wynikałoby to z niektórych komentarzy („praca nauczyciela jest przez Polaków ceniona” - „Głos Nauczycielski” nr 1 z 2013 r.), („nauczyciele cieszą się w Polsce wysokim i stabilnym poważaniem" - Wizerunek, 2012) (za: Piwowarski 2013). W przypadku opinii przedstawicieli większości grup społeczno-zawodowych mamy więc na ogół pozytywne oceny zawodu nauczyciela. Dostrzega się, że jest to praca trudna i odpowiedzialna. I może właśnie z tego powodu tak wiele osób uważa, że nie jest to „zawód dla ich dzieci”.

Najbardziej miarodajne w zakresie postrzegania zawodu nauczyciela przez samych nauczycieli wydają się wyniki badania TALIS 2013. Szczególnie interesujące jest tu przede wszystkim zestawienie opinii 105,5 tys. badanych nauczycieli z 34 krajów i regionów (w tym przeszło 3,8 tys. nauczycieli z Polski), ze szkół będących odpowiednikiem polskiego gimnazjum, odnośnie stwierdzenia: „myślę, że zawód nauczyciela jest ceniony przez społeczeństwo".

Warto zwrócić uwagę, iż nauczyciele z krajów płd.-wsch. Azji byli najbardziej przekonani, że są doceniani przez społeczeństwo. Z Europy najwyżej uplasowała się Finlandia. Prawie 60\% badanych nauczycieli z tego kraju uważało, że ich zawód jest ceniony przez społeczeństwo. Może nie jest to jedynie przypadek, że uczniowie z tych krajów zajmują najwyższe pozycje w badaniach osiągnięć szkolnych. Zaledwie 18\% polskich nauczycieli gimnazjum uważało, że są doceniani przez społeczeństwo, ale są też kraje (głównie europejskie), w których odsetki tak myślących nauczycieli były jeszcze niższe. 


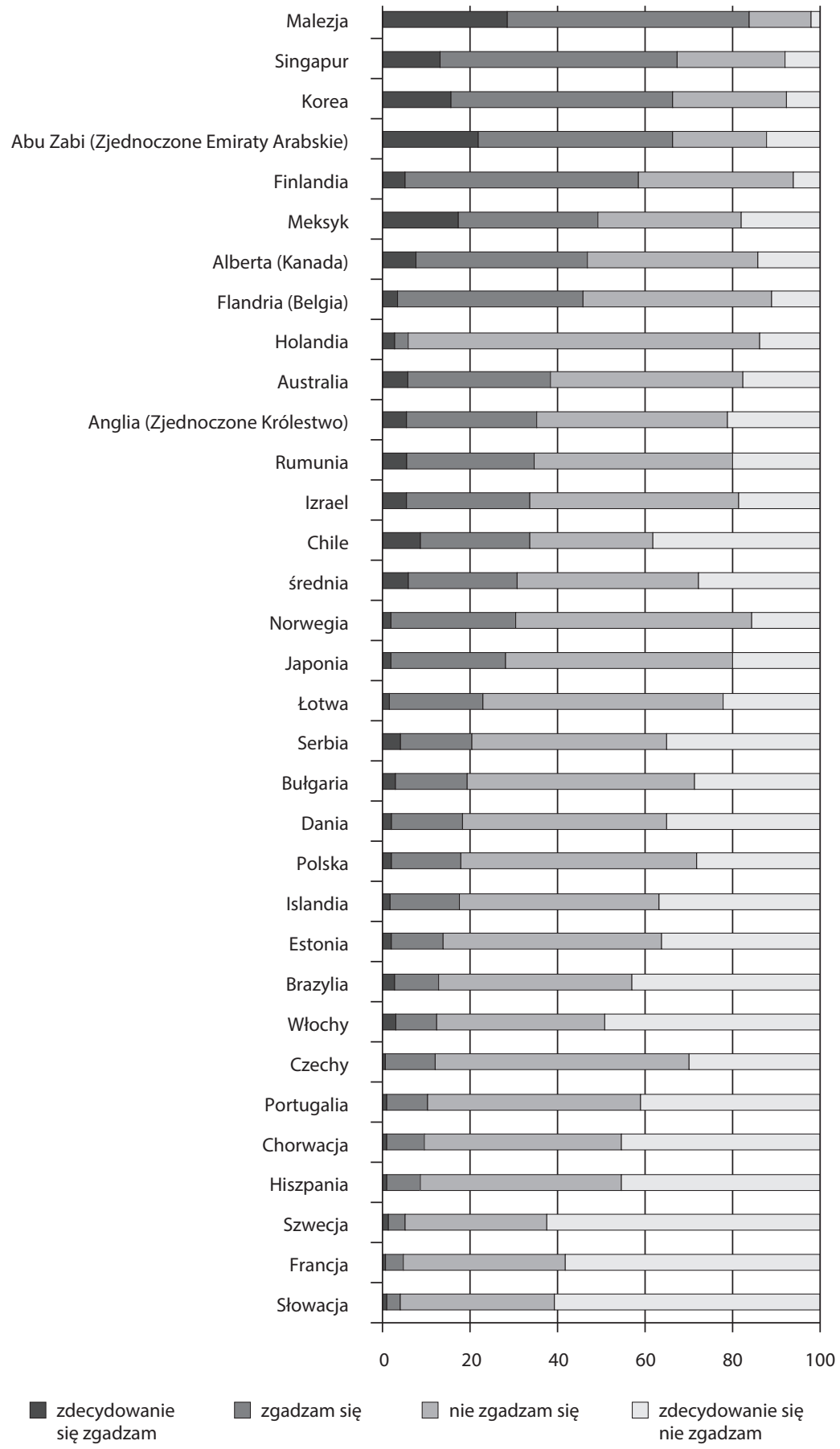

Wykres 2. Opinie nauczycieli (gimnazjów) dotyczące stwierdzenia: „Myślę, że zawód nauczyciela jest ceniony przez społeczeństwo” (w \%) Źródło: OECD (2014). TALIS 2013 Results, s. 187, 408. 


\section{Zarobki nauczycieli}

W wielu opracowaniach podkreśla się, że wynagrodzenie jest ważnym czynnikiem satysfakcji zawodowej, czynnikiem wpływającym na prestiż i atrakcyjność zawodu (m.in. Raport o Systemie Edukacji 2010: 188). Stwierdzenie to odnosi się także do zawodu nauczyciela. Główny Urząd Statystyczny od wielu lat publikuje dane dotyczące m.in. przeciętnego wynagrodzenia (miesięcznego) brutto w Polsce według tzw. „wielkich” grup zawodów. Do pierwszej grupy zaliczani są przedstawiciele władz, wyżsi urzędnicy, kierownicy, do drugiej - specjaliści, do trzeciej - technicy i inny tzw. średni personel, do czwartej - pracownicy biurowi, do piątej - pracownicy usług i sprzedawcy, do szóstej - rolnicy, ogrodnicy, leśnicy, rybacy, do siódmej - robotnicy przemysłowi i rzemieślnicy, do ósmej - operatorzy i monterzy maszyn, a do dziewiątej grupy zaliczani są tzw. pracownicy przy pracach prostych.

Porównanie wynagrodzenia dziewięciu „wielkich” grup zawodów (według klasyfikacji GUS-owskiej) prowadzi do wniosku, iż nadal utrzymują się te same tendencje, które występowały w poprzednich latach. Zwłaszcza jeśli tę analizę ograniczymy do wynagrodzeń „specjalistów”. Wyróżnionych jest w tej grupie 31 zawodów, podzielonych na 6 podgrup (najliczniejsza to specjaliści ds. zdrowia, obejmująca 9 zawodów). Specjaliści to najliczniejsza grupa zawodowa: 25,5\% ogółu zatrudnionych (wśród 8208 tys. badanych), ze średnim miesięcznym wynagrodzeniem brutto 5342,99 zł (Struktura wynagrodzeń według zawodów 2018: 64, 73).

Również większość nauczycieli jest zaliczana do tej najliczebniejszej grupy zawodowej (do specjalistów zaliczani są m.in.: większość inżynierów, lekarze, pielęgniarki, położne, nauczyciele akademiccy, specjaliści do spraw ekonomicznych i zarządzania, prawnicy, dziennikarze, twórcy i artyści oraz wiele innych zawodów). Część z nich, jak np. nauczyciele praktycznej nauki zawodu i instruktorzy, zaliczana jest jednak do techników i średniego personelu, a zarobki tej grupy są niższe niż specjalistów (w dalszym toku rozważań przekonamy się, że nie chodzi tu tylko o wynagrodzenia tych grup nauczycieli).

Podobnie jak w przypadku większości zawodów płace są zróżnicowane m.in. przez staż pracy i płeć. Jeśli jednak porównamy wynagrodzenie brutto nauczycieli wszystkich etapów kształcenia (z wyjątkiem nauczycieli akademickich, których wynagrodzenia 
są wyższe od wynagrodzeń nauczycieli nieakademickich) z wynagrodzeniem średnim całej grupy „specjalistów”, to niezależnie od tego, czy będzie to nauczyciel początkujący czy też w wieku przedemerytalnym, przegrywają oni pod względem zarobków z tzw. statystycznym specjalistą (porównanie z poszczególnymi zawodami na ogół są jeszcze mniej korzystne dla nauczycieli). Szczególnie zarobki nauczycieli najstarszych są zdecydowanie niższe od zarobków specjalistów (ogółem), co prawdopodobnie związane jest z wcześniejszym przechodzeniem na emeryturę przez nauczycieli i pracą w niepełnym wymiarze godzin. Przykładowo - wynagrodzenie specjalistów ogółem w wieku 60-64 lat i 65 lat oraz powyżej wynosiło odpowiednio 6029,75 zł i 7290,10 zł, w tych samych przedziałach wiekowych nauczycieli szkól gimnazjalnych i ponadgimnazjalnych - 4604,89 i 4409,45, nauczycieli kształcenia zawodowego - 4218,05 i 3976,81, nauczycieli szkół podstawowych - 4394,89 i 4275,53 zł (GUS Struktura wynagrodzeń 2018: 120). Wynagrodzenie nauczycieli akademickich w porównaniu do specjalistów ogółem są niższe w grupie pracowników do 34 roku życia - zarobki starszych nauczycieli akademickich są wyższe.

W przypadku nauczycieli nieakademickich działa inny mechanizm niż w większości zawodów, a mianowicie kobiety nauczycielki zarabiają na ogół więcej niż nauczyciele mężczyźni (wyłamują się z tego nauczyciele akademiccy, wśród których wynagrodzenia mężczyzn są wyższe). Można przypuszczać, że w oświacie spowodowane jest to przede wszystkim wyższymi kwalifikacjami, a tym samym wyższym stopniem awansu zawodowego nauczycielek. Nawet wśród nauczycieli kształcenia zawodowego kobiety zarabiają więcej (jednak wg Diagnozy Społecznej 2011 - nauczyciele mężczyźni zarabiali więcej).

Porównując dane GUS-owskie dotyczące 31 zawodów zaliczanych do „specjalistów” można stwierdzić, że tylko pielęgniarki, położne, specjaliści ratownictwa medycznego oraz „inni specjaliści ochrony zdrowia" zarabiają mniej niż nauczyciele; bibliotekoznawcy, archiwiści i muzealnicy mają wynagrodzenia zbliżone do wynagrodzeń nauczycielskich. Uwzględnienie nadgodzin dydaktycznych realizowanych przez niektórych nauczycieli, tylko w niewielkim stopniu zmieniłoby przedstawiony obraz wynagrodzeń.

Czy w takim razie stereotypowy obraz pracy nauczyciela, tłumaczący niższe zarobki przeszło 600-tysięcznej grupy zawodowej (509 tys. w przeliczeniu na pełne etaty) - znacznie większą 


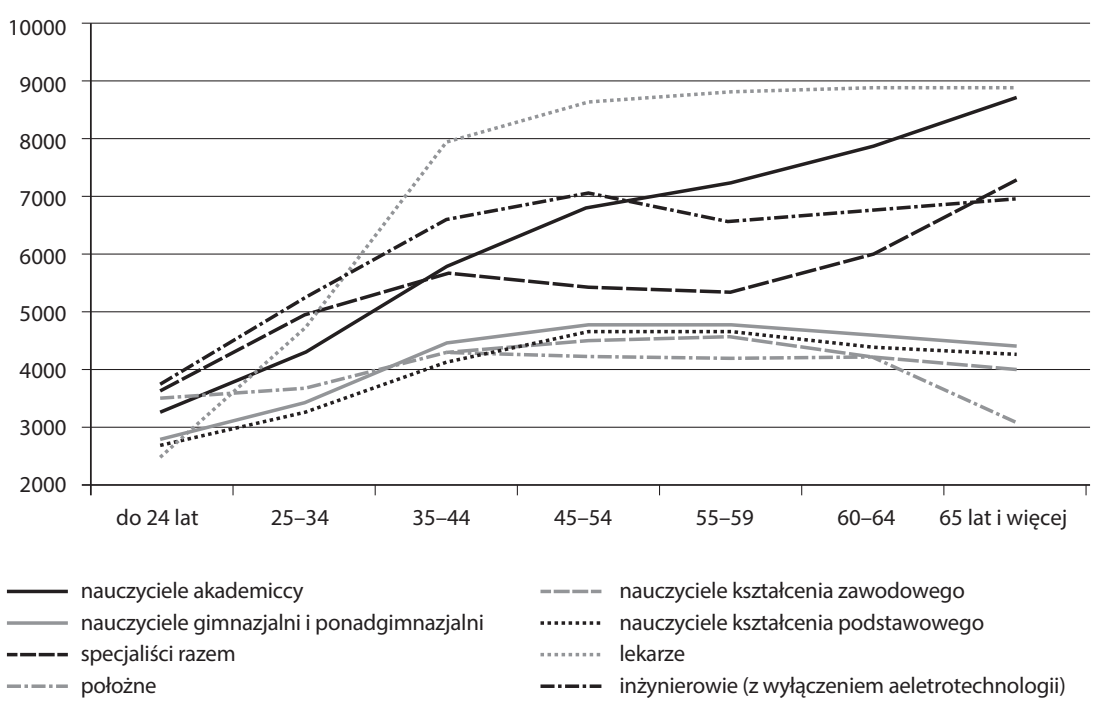

Wykres 3. Przeciętne miesięczne wynagrodzenia brutto nauczycieli i przedstawicieli wybranych zawodów w Polsce, w zł według wieku (październik 2016 r.)

Źródło: Opracowanie własne na podstawie: GUS Struktura wynagrodzeń wg zawodów w październiku 2016 r., GUS 2018, Warszawa, s. 118-120.

liczbą dni, w czasie których nauczyciel jest poza miejscem pracy (szkołą) i traktowanych przez niektórych jako dni wolnych od wszelkich obowiązków - jest wytłumaczeniem wystarczającym? Czy formułując dosadniej - ceną niższych zarobków jest dużo większa liczba dni „wolnych”? Wiadomo, że w wielu przypadkach te tzw. wolne dni służą doskonaleniu zawodowemu, przygotowaniu lekcji itp.

Kwestię wynagrodzeń nauczycieli mogą znacznie wzbogacić porównania międzynarodowe. Pewnych informacji dostarczają opracowania OECD (np. Education at a Glance), ale w niewielkim stopniu ukazują one pozycję zarobków nauczycielskich na tle wynagrodzeń w innych zawodach. Dość miarodajnym jest porównanie rocznego wynagrodzenia nauczyciela do dochodu per capita (produkt krajowy brutto podzielony przez liczbę mieszkańców danego kraju).

Takie wskaźniki uwzględniają możliwości i strategię rozwoju gospodarki danego kraju, ale może także w jeszcze większym stopniu politykę danego państwa wobec zarobków nauczycieli. Informacje ukazane na wykresie 4 dotyczą krajów członkowskich 


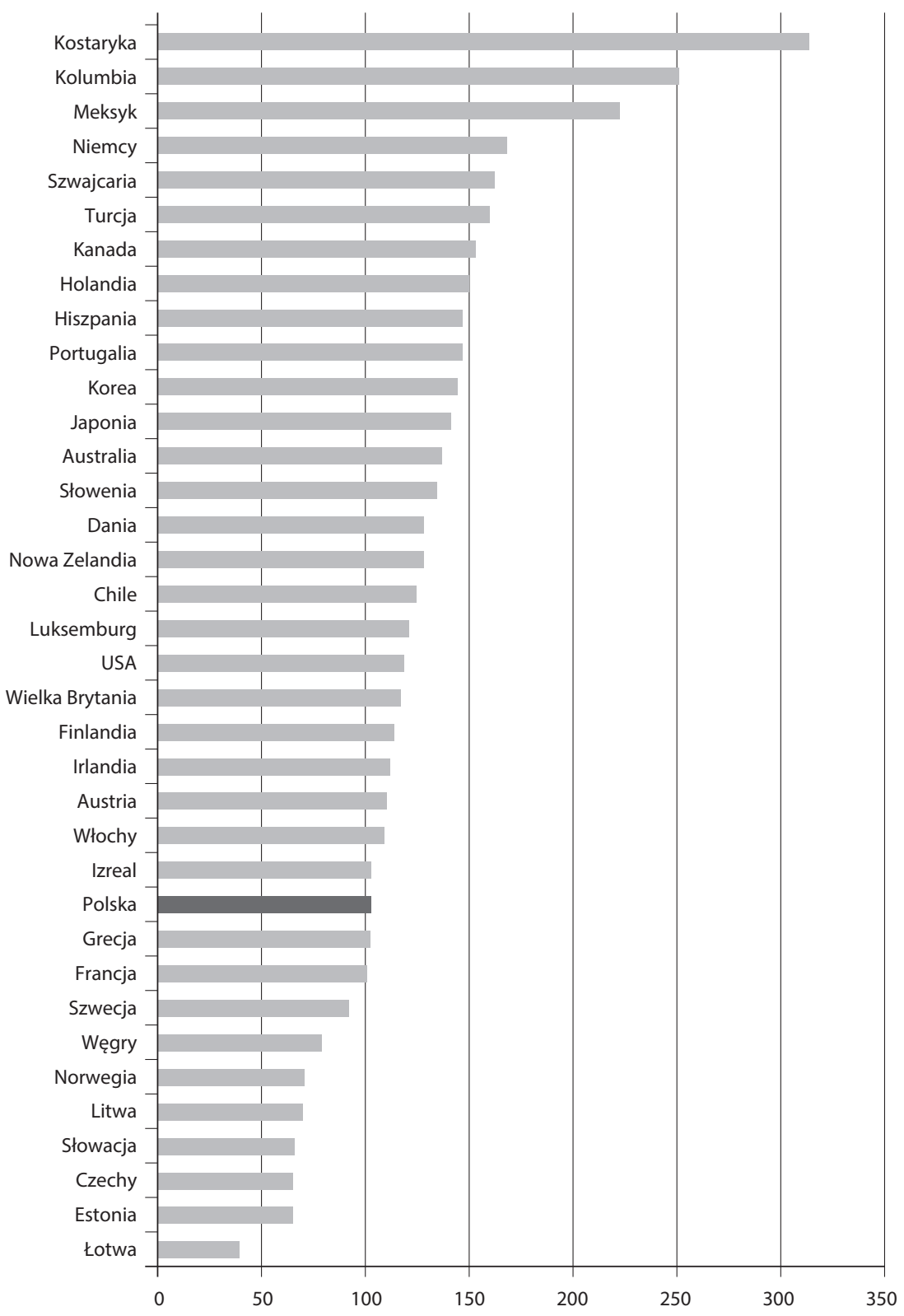

Wykres 4. Roczna pensja nauczyciela niższej szkoły średniej z co najmniej 15-letnim stażem w stosunku do produktu krajowego brutto na 1 mieszkańca (GDP per capita), w \%, 2015 r. (kraje członkowskie i partnerskie OECD)

Źródło: Opracowanie własne na podstawie: Education at a Glance. OECD Indicators 2017, OECD, s. 374 i Human Development Report 2017, s. 234-235. 
i partnerskich OECD. Nie są one reprezentacją świata, czy któregoś kontynentu, ale ilustracją prezentowanego zagadnienia przede wszystkim w najbardziej rozwiniętych (i aspirujących do tej grupy) krajach świata. Analiza wykresu pozwala wydzielić cztery grupy państw. Pierwsza, to kraje, w których zarobki nauczyciela są niższe niż produkt krajowy per capita - są to trzy kraje Europy Środkowej (kraje tzw. byłego bloku wschodniego, zależnego od ZSRR), trzy republiki „nadbałtyckie” (byłe republiki ZSRR) oraz Szwecja i Norwegia. Pojawienie się krajów skandynawskich wśród tej grupy państw może wzbudzać zdziwienie, ale być może ich zasobność nie zmusza do nadmiernego wysiłku w wynagradzaniu za pracę nauczycieli. Druga grupa to państwa, w których średnia roczna pensja nauczyciela jest zbliżona do dochodu per capita. Do nich zalicza się Polska oraz przeważnie inne kraje europejskie i USA. Trzecia - to kraje, w których wynagrodzenie nauczyciela jest wyższe od dochodu per capita o ok. 25-70\%. W tej grupie znalazły się m.in. najbogatsze kraje europejskie, azjatyckie, Kanada, Australia, ale także Turcja. Czołówkę w tym rankingu stanowią trzy kraje z półkuli zachodniej (Meksyk, Kolumbia i Kostaryka), w których pensja nauczyciela przekracza dwu-, a nawet trzykrotnie dochód krajowy brutto przypadający na jednego mieszkańca, co może świadczyć o tym, jak duże znaczenie rządy tych krajów przywiązują do wynagradzania nauczycieli za ich pracę. Można także domniemywać, że prestiż zawodu nauczycielskiego jest tam bardzo wysoki.

Porównanie zarobków nauczycieli w szkołach będących odpowiednikiem gimnazjum (klasy VII-IX) z zarobkami pracowników posiadających wykształcenie powyżej średniego (tertiary education) w 31 krajach (oraz średnich: 23 krajów Unii Europejskiej oraz państw należących do OECD) - pozwoliło wypracować wskaźniki, które przynajmniej częściowo dają wgląd w usytuowanie się zarobków nauczycieli w porównaniu do grupy zawodów, których wykonywanie wymaga podobnego poziomu wykształcenia, jakim legitymują się nauczyciele.

Spośród analizowanych zarobków w 31 państwach i regionach, tylko w trzech (Kostaryka, Portugalia, Łotwa) nauczyciele szkół z klasami 7-9 zarabiali lepiej o ok. 40\% niż ww. pracownicy. W Niemczech zarobki obu porównywanych grup zawodowych były jednakowe - w pozostałych krajach OECD, dla których dokonano tych obliczeń, nauczyciele zarabiają mniej niż pracownicy z wykształceniem zaliczanym do trzeciego poziomu. Średnia 


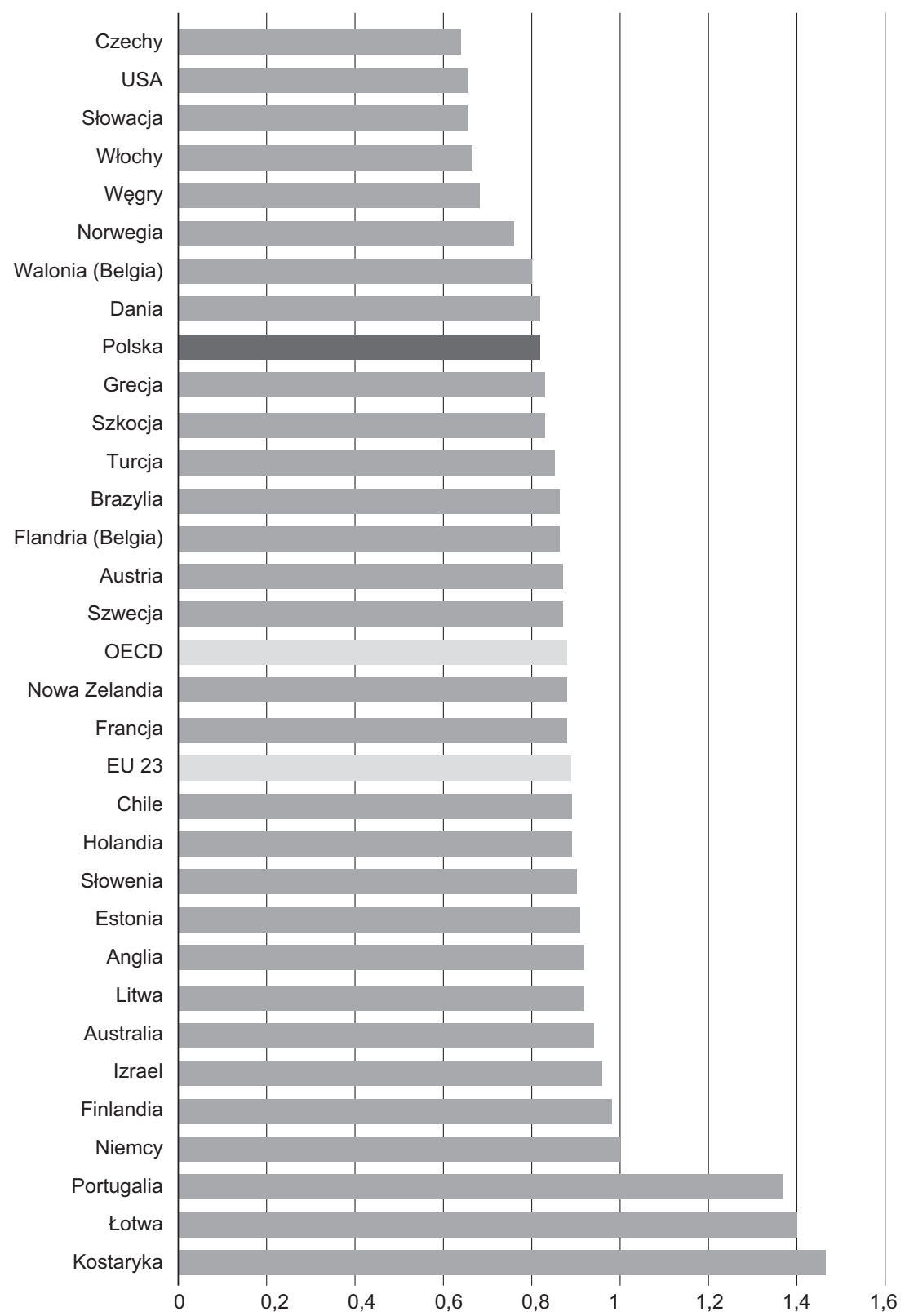

Wykres 5. Stosunek rocznych pensji nauczycieli niższych szkół średnich (publicznych) do rocznych pensji pracowników z wykształceniem odpowiadającym III poziomowi (w 2018 r.)

Źródło: Opracowanie własne na podstawie: Education at a Glance. OECD Indicators 2019, OECD, s. 393 oraz wykres D3.1. 
państw OECD była następująca: zarobki nauczycieli stanowiły 88\% zarobków pracowników z wykształceniem powyżej średniego (jest duża różnorodność tej kategorii wykształcenia - nie zawsze oznacza ono „wyższe”) i była ona podobna w porównaniu do danych z roku 2010 (86\%) i 2016 (88\%).

Według tych danych (OECD) w 2018 r. pensja polskich nauczycieli gimnazjów stanowiła ok. $82 \%$ zarobków porównywanej, bardzo szerokiej grupy pracowników (w 2010 r. - 77\%, w 2016 - 85\%). Jeszcze mniej korzystne niż w Polsce wskaźniki można zaobserwować m.in. w Czechach, USA, Słowacji, Węgrzech, Włoszech, gdzie pensje nauczycieli stanowiły $64-68 \%$ pensji pracownika z porównywanej grupy (wykres 5).

Dane przedstawione na wykresie 5 wskazują, że jest to zgodne $\mathrm{z}$ informacjami i wcześniejszą analizą zarobków polskich nauczycieli w porównaniu do innych zawodów zaliczanych do grupy „specjalistów”. Ponadto należy podkreślić, że w wielu krajach sytuacja płacowa nauczycieli (w tym przypadku: nauczycieli szkół średnich pierwszego poziomu) jest gorsza niż ogólu pracowników z wykształceniem powyżej średniego.

Uzupełniając wątek dotyczący zarobków nauczycieli (także na podstawie danych OECD 2019), można stwierdzić, iż są one w większym stopniu porównywalne z zamożnością danego kraju niż ze wskaźnikiem dochodu per capita. Analiza rocznych zarobków nauczycieli publicznych niższych szkół średnich w 28 krajach świadczy, iż są one bardzo zróżnicowane - podobnie jak poziom dostatku materialnego w tych krajach (a w porównaniu tym nie występują kraje biedne). Średnia roczna dla państw należących do OECD to 42,5 tys. USD w przeliczeniu na siłę nabywczą tej waluty w danym kraju (podobne jest średnie roczne wynagrodzenie w 22 krajach Unii Europejskiej: 44 tys.). Zdecydowanie najlepiej zarabiali nauczyciele w Holandii i Austrii. Oceniono, że w Polsce wzmiankowani wcześniej nauczyciele zarobili 32,7 tys. USD (w 2015 r. średnio ok. 25,3 tys. USD - dla porównania dochód per capita w Polsce szacowany był w 2015 na ok. 24,8 tys. USD) (Human Development Report 2016: 234). Publikowane co roku tego typu dane wskazują na pewne przesunięcia w rankingu, $\mathrm{z}$ tego względu nie należy przywiązywać nadmiernej wagi do tego, że polscy nauczyciele zarabiali więcej niż czescy, greccy czy łotewscy. Należy także pamiętać, że są to porównania oparte na przeliczeniowych wskaźnikach „dolarowych” (w uproszczeniu - ile można zakupić dóbr, usług za pensję wyrażoną w walucie danego kraju). 


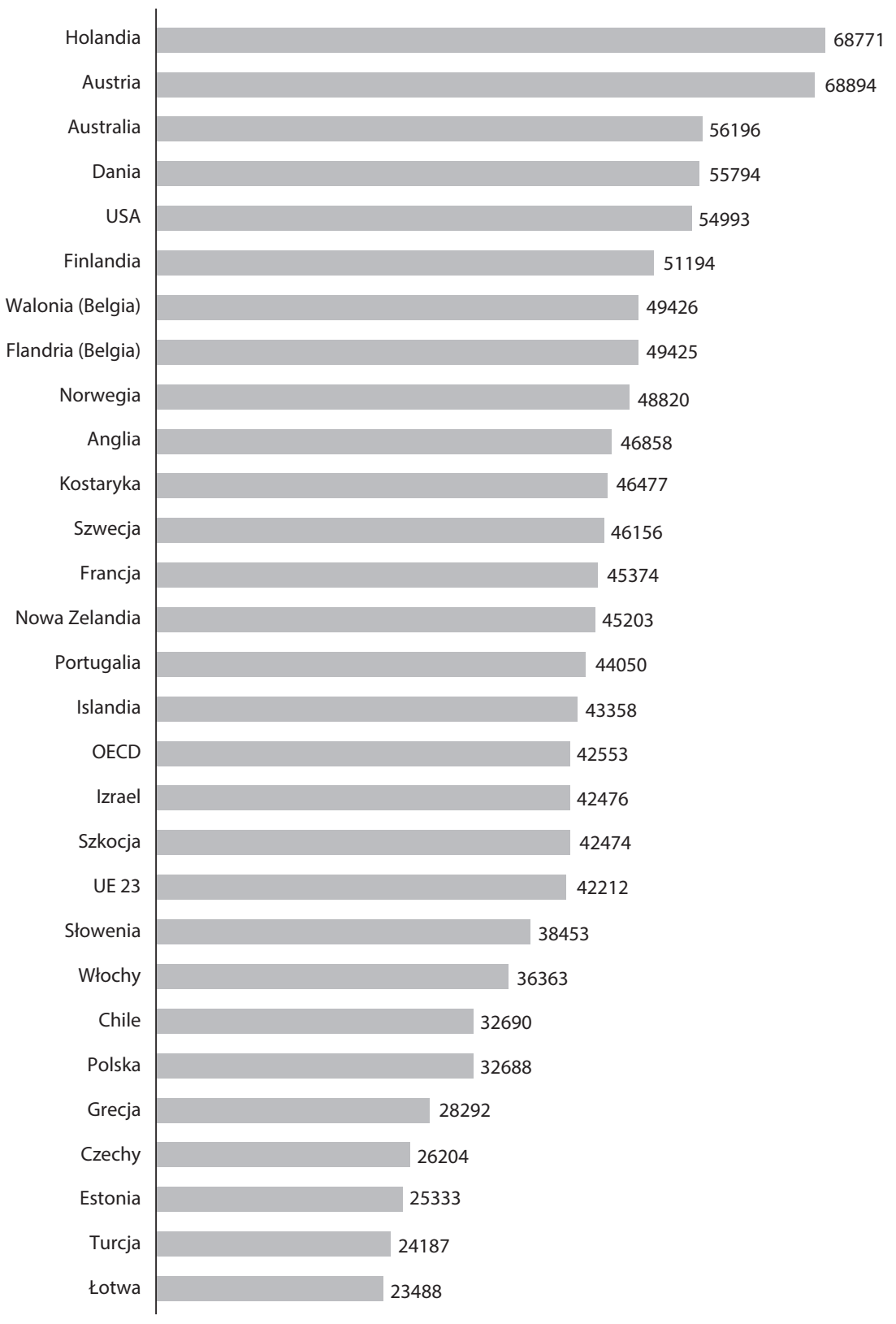

Wykres 6. Roczne pensje nauczycieli niższych publicznych szkół średnich w 2017 r., w USD według parytetu siły nabywczej

Źródło: Opracowanie własne na podstawie: Education at a Glance. OECD Indicators 2019, OECD, s. 400 oraz wykres D3.5. 
Tak więc nauczyciele polskich gimnazjów w porównaniu do nauczycieli $\mathrm{w}$ analizowanych krajach zarabiali na ogół znacznie mniej. Natomiast prawie identyczne były relacje między pensją początkową i pensją nauczyciela z najwyższymi kwalifikacjami. Płaca początkowa nauczyciela gimnazjum w Polsce w 2015 r. stanowiła 58\% zarobków, jakie mieli nauczyciele z najwyższymi kwalifikacjami (w tych szkołach). Był to wskaźnik identyczny, jak dla krajów OECD (58\%) i 22 krajów Unii Europejskiej (59\%) (OECD 2017: 376).

Pomimo znacznego zróżnicowania wynagrodzeń nauczycieli w poszczególnych krajach - będącego rezultatem wielu uwarunkowań - polityka wynagradzania nauczycieli za ich pracę jest podobna (na ogół zarabiają gorzej niż pracownicy posiadający podobne wykształcenie). Natomiast zróżnicowanie płac nauczycieli zaczynających pracę w zawodzie nauczyciela i płac nauczycieli z najwyższymi kwalifikacjami nie jest już uwarunkowane sytuacją gospodarczą, poziomem „bogactwa” poszczególnych państw. Przykładowo: wynagrodzenia początkujących nauczycieli w Czechach, Danii, Turcji w szkołach z klasami VII-IX stanowiły w 2015 r. ponad 80\% wynagrodzeń najwyższych, natomiast w Izraelu i Korei Płd. - poniżej 40\%. Wydaje się także, iż na podstawie porównań polskich płac różnych zawodów można stwierdzić, że nie zarobki nauczycieli (w Polsce) decydują o prestiżu tego zawodu.

Dodatkiem i uzupełnieniem do przytoczonych danych mogą być wyniki badania opinii społeczeństwa polskiego, zawierające m.in. odpowiedź na pytanie dotyczące oczekiwań finansowych nauczycieli wobec rządu. Badanie to zostało przeprowadzone jeszcze w trakcie negocjacji związków nauczycielskich z rządem, a częściowo już podczas strajku (co mogło mieć wpływ na wyniki). $47 \%$ badanych osób uważało, że oczekiwania nauczycieli są zbyt duże, $40 \%$ że odpowiednie, a tylko $3 \%$, że zbyt małe (10\% nie miało zdania) (CBOS 2019, komunikat nr 54: 3).

\section{Uwagi podsumowujące}

Do informacji i ich analiz zawartych w powyższym tekście, celowe wydaje się przytoczenie jeszcze raz Domańskiego, który stwierdza, iż socjologów interesuje też kwestia związana z hierarchią wysokości zarobków, a mianowicie wizja sprawiedliwych zarobków. Na podstawie badań z początku lat 90. obejmujących 
15 kategorii zawodowych podaje on, że „jest stosunkowo niska korelacja średnich prestizu i zarobków uznanych za sprawiedliwe $(\mathrm{r}=0,49)$. Jeszcze niższa jest korelacja prestiżu z opiniami o faktycznych zarobkach - wynosi ona 0,41" (Domański 2012: 31-32). Potwierdzają to, przynajmniej częściowo, przedstawione wybrane zagadnienia dotyczące opinii o zawodzie nauczyciela i zarobków polskich nauczycieli na tle porównawczym - z pewnością nie są one jednoznaczne. Podkreślane są - dość wysoka ranga zawodu nauczycielskiego w społeczeństwie i odbiegające od tego odczucia samych nauczycieli. Wydaje się, że na ten proces oddziałuje wiele czynników, wśród których należałoby wymienić bardzo szybko powiększającą się grupę osób posiadających wyższe wykształcenie, które kiedyś automatycznie dawało przepustkę do wąskiego grona elit, inteligencji. Dzisiaj dyplomy się zdewaluowały, spowszedniały, często podważana jest ich jakość. Pojawiają się stale szybkie, nowe, ale też powierzchowne źródła wiedzy, które konkurują z wiedzą przekazywaną przez nauczycieli.

Czy rozbieżności w postrzeganiu prestiżu nauczycieli tkwią w nauczycielu, czy może w systemie? Czy nauczyciele są za słabo przygotowani i zmotywowani do pracy zawodowej i cechuje ich zbyt niska odpowiedzialność i skuteczność zawodowa? W jakim stopniu ich frustracja wynika z braku odpowiedniej wiedzy i umiejętności, a w jakim ze stosunkowo niskich zarobków? Pewną szansę na zmiany stwarza obecna i przyszła sytuacja demograficzna Polski: mniejsza liczba uczniów, a tym samym mniejsze zapotrzebowanie na nauczycieli powinny wymusić ostrzejsze niż obecnie mechanizmy selekcyjne kandydatów do zawodu nauczycielskiego (a także rekrutacji na studia pedagogiczne), ale przy jednoczesnym podnoszeniu wynagrodzeń nauczycieli przynajmniej do poziomu średnich zarobków specjalistów.

\section{Bibliografia}

CBOS (2013), Prestiz zawodów, CBOS - BS/164/2013, Warszawa oraz cbos. pl/SPISKOM.POL/K_164_13.PDF (dostęp: 27.09.2019).

CBOS (2012), Wizerunek nauczycieli, CBOS - BS/173/2012, Warszawa oraz cbos.pl/SPISKOM.POL/K_173_12.PDF (dostęp: 27.09.2019).

CBOS (2019), Spoleczne poparcie dla protestu nauczycieli, CBOS - BS/54/2019, Warszawa oraz cbos.pl/SPSKOM.POL/2019/K_054_19.PDF (dostęp: 03.11.2019).

Czapiński J., Panek T. (red.) (2015), Diagnoza społeczna 2015, Rada Monitoringu Społecznego, Warszawa. 
Domański H. (2012), Prestiż, Wydawnictwo Naukowe Uniwersytetu Mikołaja Kopernika, Toruń.

GUS (2016), Struktura wynagrodzeń wedtug zawodów w październiku 2014, GUS, Warszawa.

GUS (2018), Struktura wynagrodzeń wedtug zawodów w październiku 2016, GUS, Warszawa.

Lepiech M. (1997), Prestiż zawodu nauczyciela $w$ świetle badań Instytutu Gospodarstwa Spolecznego, Wydawnictwo SGH, Warszawa.

OECD (2019), Education at a Glance. OECD Indicators 2019, OECD Publishing, Paris.

OECD (2017), Education at a Glance. OECD Indicators 2017, OECD Publishing, Paris.

OECD (2014), TALIS 2013 Results: An International Perspective on Teaching and Learning, OECD Publishing, Paris.

Piwowarski R. (2013), Życie i praca polskiego nauczyciela oraz czynniki budujace i niszczace jego autorytet, "Ruch Pedagogiczny”, nr 2, s. 19-35.

Piwowarski R. (2018), Prestiz $i$ zarobki polskich nauczycieli, „Ruch Pedagogiczny", nr 2, s. 39-53.

Raport o systemie edukacji (2010), IBE, Warszawa.

Smak M., Walczak D. (2015), Pozycja spoleczno-zawodowa nauczycieli. Raport $z$ badań jakościowych, IBE, Warszawa.

UNDP (2017), Human Development Report 2016: Human Development for Everyone, hdr.undp.org/sites/default/files/2016_human_develpoment_report. pdf (dostęp: 18.08.2018). 
Izabella Kust

ORCID 0000-0003-2153-2404

Wyższa Szkoła Menedżerska w Warszawie

\title{
Misja nauczyciela szkoły zawodowej
}

\author{
Abstract \\ The mission of vocational school teachers
}

The article attempts to answer the question: what is the mission of practical vocational training teachers? The following thesis has been assumed: The mission of a technical teacher is dual professionalism consisting in applying both specialist and pedagogical knowledge to prepare students for their future careers. Teachers who are passionate about their profession shape the culture of their schools and contribute to the enhanced quality of education. The following questions are asked in the article: 1 . What is the mission of vocational school teachers and how should it be understood? 2. How is mastery expressed? How does mastery relate to mission? How does mentorship relate to mission? 3. How is the mission accomplished? The above questions are discussed in the context of the work of a vocational school teacher.

Keywords: mission, master, authority, master-apprentice relationship, professional mastery, vocational school teacher, dual professionalism, passion

Słowa kluczowe: misja, Mistrz, autorytet, relacje Mistrz - uczeń, mistrzostwo w zawodzie, nauczyciel szkoły zawodowej, dwuprofesjonalizm, pasja

Trudno mówić o misji nauczyciela, o kontekstach jej realizacji w szkołach zawodowych, kiedy brakuje podstawowej specjalistycznej kadry czy też odpowiedniej bazy. Zatrudnionym specjalistom często brakuje przygotowania pedagogicznego. Zdecydowana większość to kadra, która ma bardzo duże doświadczenie zawodowe i trudności z metodycznym, specjalistycznym doskonaleniem zawodowym. Fachowcy w szkołach w zdecydowanej większości podnoszą swoją wiedzę w ramach samodoskonalenia. Dokonując wyboru zawodu nauczyciela podejmujemy jednak decyzje, które wymagają odpowiedzialnej realizacji. Podejmowane decyzje mają swoje konsekwencje. Wybrany zawód należy szanować i konsekwentnie 
doskonalić się dla własnej samorealizacji i spełnienia w swojej profesji. Zawód nauczyciela jest wyjątkowym i pomimo trudności wymaga zaangażowania i właśnie realizacji misji.

Podejmując rozważania na temat misji zawodu nauczyciela szkoły zawodowej przyjmuję definicję za Uniwersalnym słownikiem języka polskiego: „Misja łac. missio, posłanie, wysłanie [...] 2. Obowiązek podjęty $\mathrm{w}$ przeświadczeniu, że się jest do tego powołanym" (2003: 676).

\section{Czym jest misja nauczyciela szkoły zawodowej i jak ją rozumieć?}

Misję nauczyciela szkoły zawodowej rozumiem w szczególności jako profesjonalne przygotowanie ucznia do wykonywania zawodu. Każdy z nas oczekuje dobrego fachowca w zawodzie. Od jego wiedzy oraz profesjonalizmu zależy jakość wykonanej pracy i zadowolenie odbiorcy, klienta, pacjenta, rodzica. Wiedza, zaangażowanie w każdym zawodzie zależy w dużej mierze od osoby, od jej profesjonalizmu, wiedzy, umiejętności i kompetencji. Nauczyciel jest przewodnikiem dla ucznia w osiąganiu tego celu. Nauczyciel jest ekspertem w swojej dziedzinie. Kierunkowe przygotowanie nauczyciela przedmiotów zawodowych to podstawa profesjonalnego działania. Ponadto, nauczyciela zawodu obowiązuje wymóg przygotowania pedagogicznego, który jest równocześnie wymogiem formalnym. Zatem, jak określiła Pani Profesor Maria Czerepaniak-Walczak, nauczyciel przedmiotów zawodowych jest „dwuprofesjonalistą"

Z punktu widzenia uczniów szkół zawodowych ważny jest poziom, jaki prezentują profesjonalni i merytoryczni nauczyciele zawodu. Nauczyciel staje się autorytetem dla ucznia, gdy ten otrzymuje fachową, aktualną wiedzę. Istotne są innowacje, osiągnięcia i ciekawostki w danej dziedzinie, międzynarodowe rozwiązania, zastosowanie nowoczesnych technologii i praktycznych rozwiązań. Taki właśnie potencjał wnoszą do szkół zawodowych absolwenci, w szczególności uczelni technicznych. Przekazując aktualną wiedzę, stają się niejednokrotnie niewiele starszymi „kolegami”, których warto słuchać.

${ }^{1}$ Określenie Pani Profesor Marii Czerepaniak-Walczak, Spotkanie z Mistrzem na XXXIII Letniej Szkole Młodych Pedagogów, Łańsk 9 września 2019 r. 
Młoda kadra jest oczekiwana w szkołach zawodowych nie tylko dlatego, że szczególnie brakuje nauczycieli przedmiotów zawodowych. Młodzi nauczyciele stymulują i kreują wiele nowych rozwiązań. Młoda kadra w szkołach daje nowy impuls do działań. Absolwenci w szczególności technicznych wyższych uczelni są oczekiwaną, wartościową i cenioną młodą kadrą w szkołach zawodowych. Młody nauczyciel jako absolwent uczelni mimowolnie staje się autorytetem. Niejednokrotnie intuicyjnie rozwiązuje z sukcesem trudne sytuacje i problemy wychowawcze.

Nie tylko absolwentów technicznych wyższych uczelni brakuje w szkołach zawodowych, ale generalnie kadry specjalistów. Analizując statystyki można zaobserwować tendencje zwiększania średniego wieku nauczycieli przygotowujących uczniów do pracy zawodowej oraz wyraźny spadek w zatrudnianiu specjalistów.

Rynek pracy proponuje absolwentom uczelni różnorodne atrakcyjne oferty pracy, stwarzając możliwość rozwoju zawodowego. Zawód nauczyciela wymaga dodatkowych kwalifikacji pedagogicznych i zaangażowania czasu. Jest zawodem przynoszącym więcej satysfakcji niż profitów finansowych. Dla absolwenta „dyplom uczelni stanowi przepustkę do realizacji własnych aspiracji zawodowych, kreowania kariery zawodowej, a także dążenia do uzyskania pozycji w zawodzie" (Michalak - Dawidziuk 2017: 136).

Wybór zatrudnienia między szkołą a sektorem gospodarczym dla absolwentów Politechniki, Szkoły Głównej Handlowej czy Akademii Górniczo-Hutniczej, Wojskowej Akademii Technicznej, Akademii Morskiej i innych tego typu uczelni jest oczywisty i jednoznaczny. Decyzje w przypadku inżynierów, ekonomistów, geologów i innych specjalistów są bezdyskusyjne. Każdy z nich pójdzie własną ścieżką dalszego rozwoju zawodowego. Adepci uczelni dla samorealizacji zawodowej dokonają wyboru zgodnie z własnymi aspiracjami, marzeniami i możliwościami rozwoju zawodowego. Młodzi ludzie dążą do autentycznego rozwoju, spełnienia w zawodzie, do awansu i kariery zawodowej. Realizując swoje plany i zamierzenia absolwenci uczestniczą w aktualnych zmianach gospodarczych i społecznych. To oni w przyszłości stają się liderami - a tylko liderzy zmieniają świat. Retoryczne zatem wydają się pytania o wybór przez absolwentów specjalistycznych uczelni zatrudnienia między gospodarką a szkołą zawodową/branżową. Warunki i perspektywy rozwoju zawodowego, samorealizacji i spełnienia w zawodzie 
są nieporównywalne. Wyraża się to w płacach, możliwościach realizacji i spełniania zawodowych marzeń.

Absolwenci uczelni, chcąc realizować się w zawodzie, nie są zainteresowani pracą w szkole zawodowej/branżowej. Mając specjalistyczną, aktualną wiedzę wykorzystają szansę, szukając ciekawej oferty pracy lub zakładając własne firmy. Dodatkowym utrudnieniem dla podjęcia decyzji o rozpoczęciu pracy jako nauczyciel zawodu jest brak przygotowania pedagogicznego do pracy w szkole.

Gruntowne wykształcenie studentów w zakresie wiedzy, umiejętności i kompetencji społecznych, jakie otrzymują na uczelni, stanowi podstawę podejmowanych przez nich w przyszłości działań. W przypadku nauczycieli przedmiotów zawodowych i praktycznej nauki zawodu, czyli dwuprofesjonalistów zatrudnionych $\mathrm{w}$ szkołach zawodowych, wymagane są poza przygotowaniem specjalistycznym kompetencje pedagogiczne. Z uwagi na brak kadry specjalistycznej dopuszcza się możliwość zatrudniania osób bez kwalifikacji pedagogicznych ${ }^{2}$, ale w przyszłości osoby te uzupełniają przygotowanie pedagogiczne. Kwalifikacje pedagogiczne są podstawą awansu zawodowego oraz warunkiem sine qua non w przypadku ubiegania się o stanowisko dyrektora szkoły. Mając wybór i zupełnie inne możliwości rozwoju zawodowego, w tym gratyfikacji finansowej, młodzi absolwenci wyższych uczelni podejmują jednoznaczną decyzję, zatrudniając się w sektorze gospodarki. Konieczne jest, aby praca w szkole była atrakcyjna i porównywalna z zatrudnieniem w gospodarce. Istotnym atutem wyboru zatrudnienia jest wynagrodzenie, które jest niewspółmierne do wynagrodzenia w szkole.

Porównywalność warunków pracy i płacy zarówno w sektorze gospodarczym, jak i w szkole to podstawa rozwiązania problemów zatrudniania młodej kadry nauczycielskiej. Idealną sytuacją byłaby

2 Ustawa z dnia 26 stycznia 1982 r. Karta Nauczyciela (Dz.U. z 2019 r., poz. 2215 ) - art. 9 ust. 1, art. 10 ust. 5 pkt 3 i 4, art. 10 ust. 2-3, ust. 7 i 9; Ustawa z 14 grudnia 2016 r. Prawo Oświatowe (Dz.U. z 2019 r., 1148 z późn. zm.) art. 13 ust. 6 pkt 2, art. 14 ust. 3 pkt 6, art. 15 ust. 1-2, ust. 6, art. 32 ust. 8-9, art. 34); Rozporządzenie Ministra Edukacji Narodowej z dnia 1 sierpnia 2017 r. w sprawie szczegółowych kwalifikacji wymaganych od nauczycieli (Dz.U. z 2017 r., poz. 1575 z późn. zm.); Rozporządzenie Ministra Edukacji Narodowej z dnia 11 sierpnia 2017 r. w sprawie wymagań, jakim powinna odpowiadać osoba zajmująca stanowisko dyrektora oraz inne stanowisko kierownicze w publicznym przedszkolu, publicznej szkole podstawowej, publicznej szkole ponadpodstawowej oraz publicznej placówce (Dz.U. z 2017 r., poz. 1597 z późn. zm.). 
oczywiście możliwość płynności zmiany pracy między szkołą a sektorem gospodarczym bez perturbacji finansowych z zachowaniem porównywalności warunków pracy. Motywacja finansowa jest tu niezbędna.

Zachętą do pracy w szkole jest zapewnienie warunków pracy nauczycielowi przedmiotów zawodowych. Wyposażenie pracowni, laboratoriów na miarę porównywalności z gospodarką jest warunkiem koniecznym. Obecnie jest to mało realny plan, który może powieść się jedynie w odległej przyszłości.

Aktualnym pytaniem i problemem jednocześnie jest to, $c z y-$ $i$ na ile - pracodawcy wtaczaja sie $w$ proces obowiazkowego szkolenia nauczycieli? Już proces realizacji praktyk dla uczniów był i jest tematem trudnym, ponieważ wciąż brakuje do współpracy ze szkołami zainteresowanych pracodawców. Obecna sytuacja w dwójnasób obarcza dyrektorów szkół poszukiwaniem pracodawców nie tylko dla uczniów - aby zrealizowali praktyki, ale również dla nauczycieli - aby sprostać wymaganiom prawnym w zakresie realizacji szkoleń ${ }^{3}$. Nie ma umów międzyresortowych, aby rozwiązać ustawiczne problemy kształcenia zawodowego. Poza deklaracjami rozwiązań systemowych wciąż brak. Pracodawcy nie są zainteresowani partycypowaniem $\mathrm{w}$ generowaniu kolejnych kosztów dla własnych firm. Za proces wdrażania i realizacji odpowiedzialny jest funkcyjny nauczyciel, czyli dyrektor szkoły. W tym przypadku misję zawodu należy rozumieć w kontekście radzenia sobie z trudnościami rzeczywistości kształcenia zawodowego.

Misja nauczyciela szkoły zawodowej to poziom przygotowania merytorycznego i metodycznego do wykonywania zawodu oraz powinność pedagogiczna. Waldemar Furmanek pisze o nich, jak następuje:

3 Ustawa Karta Nauczyciela, art. 70c, wprowadza obowiązkowe szkolenia branżowe nauczycieli. Zgodnie z ust. 1 tej regulacji nauczyciele teoretycznych przedmiotów zawodowych oraz nauczyciele praktycznej nauki zawodu, zatrudnieni w szkołach prowadzących kształcenie zawodowe w rozumieniu art. 4 pkt 28a lit. a ustawy Prawo oświatowe, oraz placówkach i centrach, o których mowa w art. 2 pkt 4 tej ustawy (placówki kształcenia ustawicznego oraz centra kształcenia zawodowego, umożliwiające uzyskanie i uzupełnienie wiedzy, umiejętności i kwalifikacji zawodowych), są zobowiązani doskonalić umiejętności i kwalifikacje zawodowe potrzebne do wykonywania pracy poprzez uczestniczenie w szkoleniach branżowych realizowanych w trzyletnich cyklach, w łącznym wymiarze 40 godzin w cyklu. 
Obecnie należy dodać problematykę związaną z opracowaniem i weryfikacją nowego systemu kształcenia, dokształcania i doskonalenia nauczycieli dla potrzeb edukacji zawodowej. Analizować ją należy w kontekście kwalifikacji nauczycieli i dróg ich pozyskiwania. Nie możemy pomijać całej problematyki dotyczącej motywacji do ciągłego uczenia się nauczycieli, podnoszenia ich kompetencji, wprowadzania rozwiązań innowacyjnych do środowiska dydaktycznego (Furmanek 2013: 105).

W kształceniu i przygotowaniu do wykonywania zawodu nauczyciela ważna jest rola zachowania wzajemnych relacji między teorią i praktyką pedagogiczną. „Filozofia studiów nauczycielskich opierać się powinna na paradygmacie wzajemnych powiązań i niezbędnej równowagi między teorią a praktyką, między realizmem a empirią, czyli myśleniem opartym na rozumie, doświadczeniu oraz przeżyciach" (Dereń 2014: 260).

Realizacji tego celu służy opanowanie wiedzy z zakresu przedmiotów pedagogiczno-psychologicznych. Integralną częścią kształcenia zawodowego kandydatów na nauczycieli są praktyki pedagogiczne. Kształcenie praktyczne potrzebne jest do zdobycia umiejętności zastosowania wiedzy w codzienności pracy nauczycielskiej, w szkole i środowisku lokalnym.

$\mathrm{Z}$ uwagi na to, że rozpatrywane zagadnienie dotyczy szkoły zawodowej, realizację misji nauczyciela należy rozumieć również w kontekście współpracy z pracodawcami. Pracodawcy oprócz braku kadry w szkołach zawodowych oraz sposobu finansowania szkół zawodowych sygnalizują, co moim zdaniem jest priorytetem i koniecznością, zadbanie o pozytywny wizerunek szkolnictwa zawodowego.

Zdaniem przedsiębiorców wyzwaniem pozostaje brak kadry nauczycielskiej odpowiedzialnej za kształcenie zawodowe i szkół oferujących naukę w zawodach technicznych oraz długi czas oczekiwania na decyzje administracyjne związane z edukacją. [...] Konieczne jest szybkie przedefiniowanie roli państwa, przedsiębiorców oraz ich wzajemnej relacji w procesie edukacji ogólnej i zawodowej na wszystkich jej szczeblach. Na nowo powinny zostać określone zasady finansowania kształcenia zawodowego. Bardzo ważną kwestią jest to, jak kształcenie zawodowe jest postrzegane przez społeczeństwo. Należy pracować nad jego pozytywnym wizerunkiem wśród młodzieży i ich rodziców, by wybór nauki zawodu był postrzegany jako decyzja pozytywnego wyboru (Eada [red.] 2017: 4-5).

Warunkiem realizacji misji zawodu nauczyciela szkoły zawodowej jest baza szkoły, zatem warunki realizacji planów i programów 
kształcenia. Często szkoły nie są wyposażone w nowoczesny sprzęt sprzyjający realizacji nowoczesnych lub nawet funkcjonujących rozwiązań gospodarczych. Stanisław Szelewa wskazuje na zmiany $\mathrm{w}$ szkolnictwie zawodowym $\mathrm{w}$ aspekcie dofinansowania kształcenia zawodowego i zwrotu kosztów pracodawcom. Autor wyraża jednocześnie troskę o to, że nie planuje się przeglądu w zakresie wyposażenia i stanu kadry nauczycielskiej w zawodach, w których szkoła uczy od kilkudziesięciu lat. „Przecież tam dość często nie ma ani sprzętu, ani dobrze wykwalifikowanych nauczycieli" (Szelewa 2018).

Misja to również konieczność permanentnego uczenia się i doskonalenia. Komitet Ekspertów wskazywał w Raporcie m.in. na pilną potrzebę przebudowy sytemu kształcenia i doskonalenia kadr pedagogicznych. Stwierdzono: „to, że szkoła nauczycielem stoi, wiedziano już od dawna, ale nigdy jeszcze hasło to nie było tak aktualne i bezdyskusyjne jak w połowie XX wieku” (Kupisiewicz 2006: 16). W XXI w., mimo upływu lat, przesłanie to nie straciło nic ze swej aktualności, a wręcz przeciwnie - stało się jeszcze bardziej istotne. Postulat dotyczył kształcenia w uczelniach wyższych nauczycieli dla wszystkich typów szkół i poziomów edukacji, od przedszkola do maturalnych szkół średnich. Kształcenie to, nazwane później wstępnym, należało traktować jako tzw. doskonalenie przywarsztatowe. Postulowano zatem wprowadzenie obowiązku ciągłego doskonalenia zawodowego kadr pedagogicznych.

Zawód [...] nauczyciela wymaga ustawicznego aktualizowania posiadanej wiedzy oraz pogłębiania umiejętności dysponowania nią w pracy dydaktyczno-wychowawczej, a równocześnie śledzenia i przyswajania sobie zdobyczy nowoczesnej nauki, techniki, technologii i kultury. Zawód ten wymaga również, [...] opanowania podstaw poradnictwa szkolnego i zawodowego; głównych założeń oraz metod profilaktyki, diagnozy i terapii pedagogicznej, niezbędnych do wykrywania i zwalczania niepowodzeń szkolnych; a oprócz tego umiejętności ,nauczenia uczniów tego, aby sami mogli się uczyć efektywnie i ustawicznie' (Kupisiewicz 2007: 16).

W dużej mierze jednak, szczególnie w odniesieniu do nauczycieli specjalistycznych przedmiotów zawodowych, aktualizacja wiedzy i doskonalenie własnego warsztatu pracy wymaga osobistego zaangażowania i samodoskonalenia. 
Odpowiadając na pytanie: Czym jest misja nauczyciela szkoty zawodowej i jak ja rozumieć?, należy podkreślić złożoność odpowiedzi na to zagadnienie. Przede wszystkim, aby wypełniać misję trzeba mieć miejsce pracy i warunki do jej realizacji. Stabilność i merytoryczna troska o rzetelność przekazywanej wiedzy są czynnikami podstawowymi. Istotne jest, aby nie działać pod presją. Człowiek, który działa z pasją, postępuje w dużej mierze intuicyjnie, bezinteresownie z poświęceniem własnego czasu, bez obawy czy wręcz frustracji o przeżycie następnego dnia. Wspierająca rodzina i dobra atmosfera domowa są czynnikami wspierającymi, stymulującymi i sprzyjającymi realizacji misji zawodu. Nauczyciel wówczas może spełniać swoją rolę, realizować misję, i ma poczucie dobrze wykonywanej pracy, jak również realizacji i spełnienia w zawodzie.

Próbując wznieść się ponad przemijalność, zmienność, szukając tego, co wieczne, niepowtarzalne, niezależne od subiektywnych odczuć i zwodniczych zmysłów starożytni filozofowie szukali odpowiedzi na pytanie o prawdę, dobro, piękno. Podobnie współcześnie, próbując wznieść się ponad podziały, przeciętność i kolejne zmiany, w tym kolejne reformy oświatowe, konieczne jest odniesienie do wartości, czyniąc i postępując zgodnie z misją i powołaniem Mistrza-Nauczyciela. „Człowiek w swoim poszukiwaniu sensu życia poszukuje nieustannie prawdy, dobra, piękna, sprawiedliwości, szczęścia. To poszukiwanie staje się tym bardziej dojrzałe, im większe szanse na poznanie przez jednostkę wymienianych wartości mają wpływ środowisko życia i otoczenie społeczne" (Kieszkowska 2015: 131).

Reasumując, w postępowaniu pedagogicznym, w poszukiwaniu odpowiedzi na pytanie o to, czym jest misja nauczyciela szkoly zawodowej i jak ja rozumieć, ważne jest, aby wpisać się we wdzięczną pamięć uczniów - „żyć pięknie to wpisać w ludzką codzienność określone normy postępowania przyczyniające się do czynienia dobra dla innych, zgodnie z jasno określonymi celami życiowymi, w prawdzie na drodze do ludzkiej wolności” (Kieszkowska 2015: 142).

Misja to rzetelne wykształcenie i powołanie do zawodu, to wiedza, umiejętności i kompetencje nauczyciela. To chęć do pracy z uczniami i gotowość do aktualizacji wiedzy w dużej mierze z własnej inicjatywy. Misja to zaangażowanie, to kreatywność, innowacyjność działań i przezwyciężanie trudności. „Zatem nie chodzi o nauczanie szkół o kreatywności i innowacyjności, ale o przeprowadzenie 
z nimi procesu uczenia się na podstawie tego, co produkują. Ale aby było to możliwe, konkluduje Rui Canário, konieczne jest stworzenie warunków, aby przekazać słowo szkołom i nauczyć się ich słuchać"'.

\section{W czym wyraża się mistrzostwo? Jaka jest relacja mistrzostwa i misji? Mentorstwa i misji?}

Tadeusz Wacław Nowacki definiuje mistrzostwo w zawodzie jako „etap rozwoju zawodowego, który charakteryzuje się perfekcją pracy pracownika. Wykonuje on nie tylko zadania, ale również stawia sobie do rozwiązania problemy powstałe w wyniku trudności pojawiających się w pracy" (Nowacki 2004: 135).

Mistrzem jest „człowiek posiadający najwyższe kwalifikacje” (Nowacki 2004: 135). W Encyklopedii pedagogicznej XXI w. „mistrz” (łac. magister) to osoba wyróżniającą się „kwalifikacjami, sprawnościami, umiejętnościami, cechami charakteru; [...] Obecnie częściej używa się terminu - autorytet. W pedagogice Mistrz, mentor to tyle co przewodnik dla tych, którzy chcą zdobywać określone umiejętności, sprawności, cechy charakteru, dążyć ku ideałowi" (Encyklopedia pedagogiczna XXI w. 2004: 320).

Uważam, że Mistrzem jest osoba, która może zaświadczać swoją wiedzą, umiejętnościami, kompetencjami, swoją pasją i osobowością o wartości wykonywania zawodu. Mistrz to wzór do naśladowania. Mistrzem jest osoba, która wierzy w sens ksztalcenia zawodowego.

Do istotnych cech Mistrza w szkolnictwie zawodowym, moim zdaniem, należy dodać doświadczenie osobiste w danej dziedzinie zawodowej. Doświadczenie w dużej mierze jest wynikiem naszych starań, naszego zaangażowania w pozyskanie praktyki w danej dziedzinie. Wyraża również nasze zainteresowanie wykonywanym zawodem i pozyskiwanie nowych uprawnień. Nabywamy je $\mathrm{w}$ toku realizacji rzetelnych praktyk studenckich, staży studenckich, w tym wymiany międzynarodowej, jak również pracy w przemyśle, gospodarce, turystyce itp. Nauczyciel z doświadczeniem zawodowym przybliża młodzieży praktyczne aspekty

${ }^{4}$ F.I. Ferreira, Reformas educativas, formação e subjectividades dos professores, „Revista Brasileira de Educação” 2008, t. 13, nr 38 (maj-sierpień), s. 244. 
realizacji zawodu. Zajęcia stają się ciekawsze i w naturalny sposób zblizają zawodowo i mentalnie nauczyciela i ucznia. Doświadczenia oraz dorobek zawodowy nauczyciela mają duży wpływ na rozwój ucznia i zachęcają go do zainteresowania zawodem. Tworzenie dobrych relacji z uczniem jest tym samym budowaniem własnego autorytetu.

Mistrzostwo wyraża się w autorytecie, a „podstawowymi wyznacznikami atrakcyjności i autorytetu nauczyciela a tym samym jego mocy poznawczej i wychowawczej, są wyrazistość i niepowtarzalność jego osobowości” (Dereń 2014: 234). Wzorzec ten należy modyfikować dostosowując do głównych trendów i tendencji społeczno-kulturowych i oświatowych przemian w kraju i na świecie oraz umiejętności przewidywania uwarunkowań procesów edukacyjnych.

Naturalnym autorytetem wśród uczniów cieszy się nauczyciel, który zaprasza, a nie narzuca do tworzenia własnych interpretacji istniejącej rzeczywistości szkolnej i pozaszkolnej. Taki nauczyciel „jest przez nich traktowany jako partner, a nie jako opresor. Działania oporowe nabierają tu dużego potencjału rozwojowego, ponieważ wynikają z krytycznego namysłu nad rzeczywistością, która także podlega kontestacji przez moralny autorytet nauczyciela" (Babicka-Wirkus 2019: 282). Zatem autorytet nauczyciela to umiejętność tworzenia podmiotowości w relacjach z uczniem.

W procesie zmierzającym do mistrzostwa istotną rolę odgrywają doskonalenia zawodowe. „Nie chodzi w nich o poszerzenie zakresu kompetencji, lecz uzyskanie wyższego poziomu wprawy w realizacji kompetencji już posiadanych" (Furmanek 2013: 429). Celem ustawicznego doskonalenia i samokształcenia jest m.in. udoskonalanie wiedzy zarówno merytorycznej, jak metodycznej. Doskonalenie stosowanych metod dydaktycznych zajmuje szczególne miejsce wśród dydaktyków dla podnoszenia atrakcyjności prowadzonych zajęć i zwiększania innowacyjności pedagogicznej. Czynniki te wpływają również na przeobrażenie całokształtu osobowości i wzbogacają sferę intelektualną. Zatem Mistrz to talent pedagogiczny „polegający na intuicyjnym doborze właściwych w określonej sytuacji środków pedagogicznych” (Dereń 2011).

Mistrz zapewnia troskę o dbałość i rozwój intelektualny ucznia oraz pielęgnowanie jego zamiłowań - dzięki czemu rozwijamy pasję. Jarosław Kordziński uważa, że rozbudzanie wewnętrznej ciekawości i dążenie do poznania i rozbudzania zainteresowania wiedzą procentuje tym, że „nie odczujemy nawet, kiedy się uczymy, 
gdy bowiem coś nas pasjonuje, intryguje, poświęcamy temu uwagę, nie czując wysiłku, a zarazem przyswajamy znalezioną wiedzę błyskawicznie, mimochodem, bez potrzeby powtórek i utrwalania wiadomości” (Kordziński 2018: 102). Ciekawość poznania świata zainspirowana i rozbudzona przez nauczycieli jest wstępem do całożyciowego rozwoju. Zasób wiedzy wpływa na umiejętności planowania ścieżki kariery zawodowej i planowania własnego rozwoju, określania priorytetów w życiu. Szczególną umiejętnością jest znajomość języków obcych, dzięki którym możemy komunikować się ze światem i pozyskiwać dalszą wiedzę. Mistrzostwo wyraża się w stymulowaniu do przekraczania granic ludzkiego poznania, własnych słabości i własnej niewiedzy, do transgresji. „Pokonywanie własnej niewiedzy, słabości i braku umiejętności pozwoliło człowiekowi na przestrzeni wieków dokonać transgresji zarówno w sferze otaczającego świata (odkrywanie nowych lądów, planet, Internetu, tworzenie nowych systemów politycznych), jak i nauki, kultury, sztuki (kreowanie nowych idei czy poglądów) (Michalak-Dawidziuk 2014: 213).

Mistrzostwo to budowanie relacji Mistrz - uczeń. Relacje te są ważne dla ucznia (na każdym etapie rozwoju), gdyż inspirują go i motywują do działań. Mistrz, doceniając zdolności i potencjał tkwiący w uczniu, staje się mentorem jego poczynań. Mentor

to ktoś więcej aniżeli osoba dostarczająca wyznaczone porcje wiedzy, to osoba, która wyciąga do innych swoją pomocną dłoń, pomaga im znaleźć właściwe rozwiązanie i w razie potrzeby udziela odpowiednich porad. Mentor to ktoś, kto sprawia, że jego podopieczni podążają w procesie swojego rozwoju właściwym kursem. Wie, że sukces jego ucznia jest jednocześnie jego sukcesem. Cieszy się nim, nie ocenia, a przede wszystkim nie zazdrości, że jego uczeń staje się mądrzejszy i lepszy. Wręcz przeciwnie - po to właśnie jest. Po to, żeby tak się działo (Kordziński 2018: 135).

Autor ceni regularne rozmowy z Mistrzem, ponieważ uczeń zdobywa nową wiedzę, poznaje siebie, rozwija zawodową samoświadomość i dąży samodzielnie do samorealizacji. „Mentoring zakłada bowiem budowanie relacji między Mistrzem a uczniem, zorientowanej na odkrywanie i rozwijanie potencjału ucznia" (Kordziński 2018: 135).

Relacji Mistrz - uczeń należy uczyć już na etapie kształcenia nauczycieli ponieważ są to nowi adepci sztuki pedagogicznej. „Jednym z celów edukacji nauczycielskiej na pierwszym etapie jest 
ukazanie wzorca postępowania nauczyciela w relacji dobrze przygotowanej Mistrz i uczeń, z której wypływać będą wnioski dla odkrywania własnej indywidualności, w przygotowaniu do zawodu nauczycielskiego, a następnie w jego doskonaleniu” (Dereń 2014: 234).

Relacji Mistrz - uczeń wzorcowo uczyli Profesorowie Szkoły Lwowsko-Warszawskiej, m.in. Tadeusz Kotarbiński i Kazimierz Twardowski. Dorobek Profesorów tejże szkoły jest dla współczesnych przesłaniem, inspiracją i wyzwaniem do kolejnych działań. Mistrzostwo wyraża się w budowaniu relacji Mistrz - uczeń. Relacje takie jak w Szkole Lwowsko-Warszawskiej to mistrzostwo i misja, mentorstwo i misja. To ciągłe źródło poszukiwań, kuźnia wiedzy i inspiracji do pracy. W codziennej pracy pedagogicznej należy starać się, aby być Mistrzem.

\section{Jak realizować misję?}

Realizacja misji zawodu nauczyciela zdaniem Wincentego Okonia wyraża się w postępowaniu nauczyciela, który powinien być dla uczniów wzorem do naśladowania. Aby to osiągnąć, powinien on ustawicznie pracować nad własnym rozwojem, kierując się przy tym ideami prawdy, dobra i piękna. Bardzo cenną wartością jest podmiotowe traktowanie i partnerskie relacje nauczyciel - uczeń. Należy przede wszystkim lubić uczniów. Powodzenie realizacji misji Okoń sprowadza do rozumienia przez nauczyciela celów wychowania i kształcenia. Stosując odpowiednio dobrane środki i metody oraz zapewniając warunki realizacji celów nauczyciel inspiruje aktywność: poznawczą, emocjonalną i praktyczną ucznia. Wzajemne zaufanie to zachęta do budowania dobrych relacji. „Obydwa czynniki pozostają we wzajemnej zależności. Pierwszy, zbyt mało doceniany dotąd w zakładach kształcenia nauczycieli, polega na kształtowaniu u kandydatów na nauczycieli świadomości własnej roli, na samopoznaniu nauczyciela, drugi na kształtowaniu kompetencji nauczycielskich tej roli podporządkowanych" (Okoń 1992: 135).

Odpowiadając na pytanie Jak realizować misję przez nauczyciela szkoły zawodowej warto przytoczyć definicję nauczyciela szkoły zawodowej w rozumieniu Tadeusza Wacława Nowackiego, w której zawarł on odpowiedź na to pytanie. Poza kwalifikacjami merytorycznymi i formalno-prawnymi nauczyciel, w ujęciu Nowackiego, to osoba reprezentująca społeczeństwo, powołana do realizacji zarówno indywidualnych, jak i społecznych celów 
wychowania. W swej definicji Nowacki zawarł tak posłannictwo, jak i misyjność zawodu nauczyciela. Te dwa warunki to odpowiedź na pytanie, jak realizować misję. Zawód nauczyciela to posłannictwo i misja.

N. w szkole zawodowej swoją działalnością ma się przyczyniać do uzyskiwania przez uczniów odpowiednich kwalifikacji zarówno ściśle zawodowych, jak i zdrowotnych i społeczno-moralnych. N. jest przedstawicielem społeczeństwa, które powołało go do pełnienia funkcji i jest odpowiedzialny za realizację społecznych celów wychowania, za możliwie pełny rozwój indywidualności ucznia i wprowadzenie go w świat wartości, w tym opartych na pracy (Nowacki 2004: 144).

Misję zawodu może realizować tylko dobrze wykształcony nauczyciel. Zadanie to należy do szkolnictwa wyższego,

w tym głównie uniwersytetów. Chcąc je właściwie wykonać, muszą one dysponować niezbędnymi do tego planami i programami studiów nauczycielskich, zapewnić odpowiednie warunki infrastrukturalne dla ich realizacji, w tym stały kontakt ze szkołami ćwiczeń, a ponadto brać pod uwagę aktualne tendencje rozwojowe edukacji na świecie, a przynajmniej w krajach uprzemysłowionych (Kupisiewicz 2005: 156).

W kształceniu zawodowym ważne jest wykształcenie specjalistyczne nauczyciela przedmiotów zawodowych ${ }^{5}$. Uczeń postrzega nauczyciela zawodu jako fachowca dysponującego aktualną profesjonalną wiedzą. W tym celu, jak pisałam powyżej, wprowadzono zgodnie z reformą z 2017 r. czterdziestogodzinne szkolenia dla nauczycieli oraz swobodę doboru metod. Założenie jest szczytne, ale praktyka i rzeczywistość w pozyskiwaniu pracodawców do tego celu są trudne do zrealizowania.

Zawód wykonywany z powołania przynosi satysfakcję, możliwość samorealizacji, nadaje życiu sens, ponieważ „sukcesy nauczycieli jakkolwiek są ich sukcesami, to jednocześnie stają się sukcesami życiowymi ich uczniów”. Inspiracji do pracy w zawodzie nauczyciela można doszukać się, jak podkreśla Joanna Madalińska-Michalak, w silnej identyfikacji z zawodem i dobrze wykonanej pracy. To właśnie praca „może nadawać sens ich życiu, stawać

${ }^{5}$ Cztery kategorie „n.s.z.: nauczycieli przedmiotów teoretycznych niezawodowych, nauczycieli przedmiotów teoretycznych zawodowych, nauczycieli działalności opiekuńczo-wychowawczej i nauczycieli zajęć praktycznych, wśród nich nauczycieli zawodu i instruktorów" (Nowacki 2004: 144). 
się źródłem osobistej satysfakcji, być wartością samą w sobie, wyborem określonej postawy życiowej i mieć duże znaczenie dla rozwoju osobistego nauczycieli” (Madalińska-Michalak 2012: 263).

Nauczyciel to profesjonalista i ekspert prezentujący postawę moralno-etyczną wymagającą "przyjęcia odpowiedzialności za drugiego człowieka poprzez wyposażenie go w wiedzę i umiejętności przydatne w życiu dorosłym (pedagogika tradycyjna), tworzenie warunków do rozwoju (pedagogika humanistyczna) czy kreowanie okazji sprzyjających emancypacji (pedagogika emancypacyjna)" (Gołębniak 2001: 170).

W realizację misji zawodu nauczyciela, w tym również nauczyciela szkoły zawodowej, wpisuje się jakość i efektywność nauczania i wychowania. Czesław Kupisiewicz wymienia siedem zadań. Wśród nich jest prowadzenie w szkole systematycznej orientacji szkolnej i poradnictwa zawodowego (por. Kupisiewicz 2005: 155), co w przypadku szkół zawodowych jest kluczowe. Zadanie to jest obecnie realizowane $\mathrm{w}$ reformowanym systemie kształcenia i jest to pozytywna zmiana. Wsparcie doradcy zawodowego i poradnictwo zawodowe jest potrzebne na każdym etapie edukacyjnym nawet w szkole zawodowej - już sprofilowanej zawodowo. Uczniowie dzięki profesjonalnemu doradcy mogą zmienić zawód i kreować własną ścieżkę rozwoju zawodowego zgodnie ze swoimi zainteresowaniami. Zmniejszają się wówczas społeczne koszty nietrafionych wyborów zawodowych młodzieży.

Jakość i efektywność nauczania to systemowe wsparcie merytoryczne. Nauczyciele zawodu nie mają pomocy i konkretnego, fachowego wsparcia. Brak instytucji, którą kiedyś pełnił np. Instytut Kształcenia Zawodowego czy Instytut Badań Edukacyjnych - instytucje, które analizowały m.in. treści, formy i metody kształcenia, jak również podręczniki. Obecnie brak jest systemowych rozwiązań w tym zakresie.

Spełnieniem misji zawodu nauczyciela jest zapewnienie jakości kształcenia poprzez ustawiczne doskonalenie i podnoszenie kwalifikacji. Uzasadnione jest w przypadku doskonalenia nauczycieli zatrudnianie w ośrodkach doskonalenia fachowców o najwyższych kwalifikacjach teoretycznych i praktyce edukacyjnej, która daje możliwość sprostania potrzebom i wymaganiom XXI w. (por. Kupisiewicz 2005: 156).

Uważam, że miernikiem jakości kształcenia jest pasja do wykonywanego zawodu. „Daje ona podstawę do kształtowania postaw, które stwarzają młodym ludziom możliwość realizacji swoich 
marzeń, pasji, rozwijania talentów i zainteresowań. Dzięki temu osoba może w przyszłości realizować się i spełniać w zawodzie" (Kust 2015: 187).

Realizacja misji to budowanie wśród młodzieży i ich rodziców, w społeczeństwie, wśród polityków i samorządowców, pozytywnego wizerunku szkoły zawodowej/branżowej jako decyzji pozytywnego wyboru. Jest to społeczne wyzwanie i konieczność. „Bardzo ważną kwestią jest to, jak kształcenie zawodowe jest postrzegane przez społeczeństwo. Należy pracować nad jego pozytywnym wizerunkiem wśród młodzieży i ich rodziców, by wybór nauki zawodu był postrzegany jako decyzja pozytywnego wyboru" (Łada [red.] 2017: 5). Dotyczy to również pozytywnego wizerunku i rangi zawodu nauczyciela szkoły zawodowej/branżowej. W tym aspekcie istotną rolę odegrają nauczyciele zarówno przedmiotów ogólnokształcących, jak i teoretycznych przedmiotów zawodowych oraz praktycznej nauki zawodu. Uzasadnione i ważne jest zatem prowadzenie rozważań w kontekście nauczyciela szkoły zawodowej.

Realizacja misji nauczyciela szkoły zawodowej to przygotowanie ucznia do egzaminów potwierdzających kwalifikacje zawodowe. Wymaga to sprawdzenia wiedzy, umiejętności i kompetencji społecznych. O ile wiedzę sprawdzają egzaminy to jednak trudno sprawdzić umiejętności i kompetencje społeczne na jednym zewnętrznym egzaminie. $Z$ uwagi na to, że forma egzaminu zewnętrznego ewaluuje, warto rozważyć możliwość oceny tych elementów egzaminu $\mathrm{w}$ toku/na zakończenie nauki.

Trudno jest mówić o powołaniu czy też stawiać pytanie natury zasadniczej jak postrzegać misję zawodu nauczyciela szkoly zawodowej a tym bardziej jak realizować misję, skoro brakuje specjalistycznie wykwalifikowanej kadry. Zapewne jest to następstwo deprecjonowania i likwidacji szkolnictwa zawodowego. W sposób oczywisty tracili pracę nauczyciele przedmiotów zawodowych, brak było motywacji do rozwoju zawodowego. Absolwenci uczelni wyższych jako specjaliści przedmiotów zawodowych nie mieli motywacji do zatrudniania w szkołach zawodowych. Wdrażane reformy i prowadzona wobec szkolnictwa zawodowego polityka oświatowa państwa w latach 2001-2010 spowodowała zmniejszenie o ponad połowę liczby szkół zawodowych. Oczywistym i naturalnym efektem wprowadzanych zmian było obniżenie rekrutacji i tym samym zmniejszenie liczby uczniów w szkolnictwie zawodowym (o 48\%). Na tle innych dobrze 
rozwiniętych gospodarczo europejskich krajów, t.j. Niemiec, Belgii, Holandii, Austrii czy Szwajcarii, udział młodzieży w kształceniu zawodowym na poziomie średnim był w Polsce niższy w stosunku do ww. krajów o ok. 20\% (72\% do 52\%). Polska znalazła się wśród czterech krajów UE o najniższym udziale kształcenia zawodowego w średnim kształceniu młodzieży (por. Kabaj 2010: 73).

Obniżono, jak pisze Mieczysław Kabaj, prestiż szkół zawodowych. Nie zdołano przywrócić rangi i jakości kształcenia zawodowego, nie rozwinięto na szerszą skalę współpracy szkół zawodowych z pracodawcami. Działania te nie sprzyjały budowaniu misji zawodu nauczyciela i na pewno nie budowały autorytetu nie tylko szkół zawodowych, ale również zatrudnionych w nich nauczycieli przedmiotów zawodowych.

Realizacja misji to nie narzucanie, ale rozbudzanie zainteresowań zawodem, zamiłowania do wykonywania zawodu, szacunek dla zawodu. W przypadku szkół zawodowych istotne jest uczenie krytycyzmu wobec otaczającej rzeczywistości. Anna Babicka-Wirkus wskazuje na umiejętność wyzwolenia wśród uczniów potencjału i przeciwstawiania się rzeczywistości.

Działalność opozycyjna dorosłych uczestników kultury szkoły: nauczycieli i rodziców ma szczególne znaczenie, ponieważ jest zaproszeniem uczniów do kontestowania świata, w którym żyją. Dorośli pokazują przez to, że obywatele mogą godzić się i legitymizować ustanowiony porządek społeczny, lecz równocześnie mogą mu się przeciwstawić, gdy władza zaczyna postępować niemoralnie lub w sposób dla nich krzywdzący (Babicka-Wirkus 2019: 282).

Postaw aktywizujących, obywatelskich, uczestniczących w życiu społeczności szkolnej, aktywności i samoorganizacji uczą nauczyciele w szkole. Te relacje i postawy nabierają szczególnego znaczenia w relacjach z profesjonalnymi nauczycielami, którzy swoją postawą wychowują i wskazują uczniom jak działać. Maria Assunção Flores na podstawie badań przeprowadzonych wśród nauczycieli podkreśla rolę profesjonalizmu i koncentrowania się na uczniach i klasie: „To profesjonalizm sprawia, że robisz to, co robisz [...] nikt nie jest $\mathrm{w}$ stanie radzić sobie $\mathrm{z}$ tak dużą ilością pracy"6. W związku z tym potrzebne jest pełne zrozumienie pro-

${ }^{6}$ Fragment wykładu Pani Profesor Marii Assunção Flores pt. "The Teaching Profession at the Crossroads: Contexts, Challenges and Possible Directions”, University of Minho, Portugal. Wykład wygłoszony na Wydziale Pedagogicznym 
fesjonalizmu nauczycieli w celu uznania i zbadania kontekstów i czynników, które mogą utrudniać lub promować jego rozwój.

Poprzez umiejętność znalezienia się w konkretnej sytuacji szkolnej, zawodowej, życiowej uczymy zaangażowania i uczestnictwa w tym, co społecznie i indywidualnie istotne. Uczniowie zdobywają doświadczenie, które przydatne jest do kreowania własnej ścieżki zawodowej i innowacyjnych działań. O aktywności i samoorganizacji pisze Anna Wiłkomirska

Społeczeństwo obywatelskie może funkcjonować dzięki postawie obywatelskości swoich członków, czyli uczestnictwu w zbiorowości (czasem ograniczającej indywidualność) w celu działania dla wspólnego dobra określonego terytorium i grupy je zamieszkującej. Społeczeństwo obywatelskie w liberalnej demokracji wynika z wartości pluralizmu, ograniczanego i porządkowanego przez reguły normatywne (Wiłkomirska 2013: 27).

Wychowanie w duchu demokratycznej odpowiedzialności i funkcjonowania w społeczeństwie obywatelskim jest powinnością profesji nauczycielskiej. Jak pisze Bogusława D. Gołębniak: „wzrasta w stosunku do nauczycieli społeczne oczekiwanie odpowiedzialnego kreowania, w ramach uzgodnionego w demokratycznych procedurach programu czy modelu szkoły, rzeczywistości edukacyjnej” (Gołębniak 2001: 167). W kierunkach pracy wychowawczej na przyszłość warto pamiętać o jakości świadomej i celowej pracy wychowawczej: „Nie jest to co prawda teza nowa w dziejach teorii i praktyki wychowania, ale warto ją przypominać" (Kupisiewicz 2012: 300).

Kreowanie współczesnego modelu szkoły staje się wyzwaniem i wpisuje się w misję realizowanego zawodu nauczyciela, w tym nauczyciela szkoły zawodowej. Jak realizować misję? Misję zawodu nauczyciela szkoły zawodowej (i nie tylko) należy traktować jako posłannictwo i pasję.

\section{Zakończenie}

Misją zawodu nauczyciela szkoły zawodowej jest dwuprofesjonalizm polegający na posługiwaniu się wiedzą zarówno

Uniwersytetu Warszawskiego w dniu 12 grudnia 2019 r. Zacytowany fragment jest przytoczoną przez Panią Profesor wypowiedzią nauczyciela szkoły podstawowej z 33-letnim stażem. 
specjalistyczną, jak i pedagogiczną celem przygotowania fachowca do wykonywania zawodu. Ten szczytny cel może zostać osiągnięty tylko dzięki zaangażowanym nauczycielom, którzy wykonują zawód z przekonaniem, z pasją. Codzienna rzeczywistość jest jednak odmienna. Młodzi adepci wyższych uczelni nie są zainteresowani pracą w szkole. Do podjęcia zatrudnienia nie zachęcają ich ani zarobki, ani perspektywy rozwoju zawodowego. Podjęcie zatrudnienia w szkole może oznaczać stagnację i przeczekanie na lepszą ofertę pracy. Zmiany i ustawiczne reformowanie oświaty również nie sprzyjają realizacji misji zawodu nauczyciela. Strajki w kwietniu 2019 r. znacznie obniżyły prestiż zawodu oraz spowodowały dodatkowe wakaty w oświacie. Praca bez zaangażowania nie ma sensu i szybko prowadzi do wypalenia zawodowego.

Mimo trudnej zawodowej rzeczywistości oświatowej to właśnie dla młodzieży i z młodzieżą warto pracować. Zachęcać ich do zainteresowania zawodem. Należy wyróżnić nauczycieli dwuprofesjonalistów w szkołach zawodowych, którzy mimo przeciwności angażują się w pracę z młodzieżą. Podejmując trud pracy pedagogicznej w szkołach zawodowych nauczyciele ci stanowią grupę pasjonatów. Innowacyjna i twórcza praca nauczyciela z uczniami szkoły zawodowej jest inspiracją do działań wśród i dla młodzieży. Wyzwala w uczniach, wielokrotnie już pełnoletnich, potencjał twórczej aktywności, rozbudza zainteresowania i entuzjazm. Emocje, zainteresowania i pasja są czynnikami motywującymi dla młodzieży. „Twórczy nauczyciel wspiera uczniów w rozwoju, nie pracuje szablonowo, wykorzystuje spontaniczną aktywność swoich wychowanków, bezpośrednie doświadczanie, przeżycia i emocje, stwarza sytuacje do podejmowania różnych działań” (Kust 2010: 228). Dobre autorskie programy tworzone przez nauczycieli sprzyjają realizacji odpowiednio dobranych treści, uwzględniając konkretną grupę uczniów. Odpowiednia konstrukcja programów nauczania służy refleksji młodzieży i projektowaniu własnej zawodowej rzeczywistości.

Współczesny system edukacji wymaga od nauczyciela samodzielności, otwartości dystansu intelektualnego, zdolności do autorefleksji, umiejętności budowania przestrzeni edukacyjnej, w której dziecko i młodzież będzie poznawać siebie jako wartość, a nauczyciela dostrzegać jako kogoś, kto stanie się wsparciem, doradcą i ważnym punktem odniesienia. Należy więc kształcić nauczycieli o wysokim poczuciu autonomiczności i aspiracji twórczych (Dereń 2014: 236). 
Misja zawodu nauczyciela wyraża się w ponadczasowym charakterze koncepcji Tadeusza Kotarbińskiego pojęcia opiekuna spolegliwego: „człowiek dobry, rzetelnie odnoszący się do swoich obowiązków, godny szacunku, uczciwy, gotowy pomóc innym, bezinteresowny wychowawca, dla którego Dobro byłoby jednocześnie punktem wyjścia i celem” (Kotarbińska, Kiejzik, Huńczak 1991: 48). Motto samo w sobie oddaje pointę i sens misji zawodu nauczyciela. Być dobrym człowiekiem to punkt wyjścia i cel jednocześnie - taka jest misja zawodu nauczyciela, w tym nauczyciela szkoły zawodowej. Być dobrym nauczycielem, jak pisał Tadeusz Kotarbiński, to być opiekunem spolegliwym.

Kazimierz Twardowski, „nauczyciel nauczycieli”, przedstawiciel Szkoły Lwowsko-Warszawskiej, zyskał uznanie uczniów, którzy w dowód wdzięczności w 1930 r. ofiarowali swemu Mistrzowi specjalny medal pamiątkowy. Maksymie Discipulorum Amor et Pietas - Mitość i przywiązanie uczniów przedstawiciele Szkoły Lwowsko-Warszawskiej pozostali wierni w swej naukowej drodze. Swoistym „testamentem duchowym” Kazimierza Twardowskiego, posługując się określeniem Jana Woleńskiego, były słowa:

Nauczyciel uniwersytecki jest przede wszystkim sługą prawdy obiektywnej, przedstawicielem jej i głosicielem wśród młodzieży i społeczeństwa. Służba to szczytna i niezmiernie zaszczytna, ale zarazem wymagająca nie tylko odpowiednich kwalifikacji intelektualnych i stosownej wiedzy fachowej, lecz także wielkiego hartu ducha i silnego charakteru (Woleński 1985: 16).

Współcześnie w proces przemian aktywnie angażują się pedagodzy. Realizowane są badania empiryczne, międzynarodowe projekty badawcze, obserwacje dynamicznie zmieniającej się rzeczywistości. Pedagodzy włączają się w dyskurs o przeobrażeniach w oświacie, kulturze, uczestniczą w zmianach społecznych wynikających z procesu globalizacji. Anna Wiłkomirska podkreśla: "Zmiany stały się trwałym elementem diagnozy pedagogicznej" (Wiłkomirska 2010: 23).

Nauczyciele profesjonaliści wykonujący zawód z pasją tworzą kulturę szkoły i podnoszą jakość kształcenia. Autorytet nauczyciela budowany jest poziomem wykształcenia, postawą jaką prezentuje wobec uczniów, społeczności szkolnej, rzetelnym zaangażowaniem w pracę. Dążenie nauczyciela do osiągnięcia mistrzostwa 
w zawodzie, do samorealizacji, do spełnienia się w profesji, która nadaje życiu sens, przynosi satysfakcję - jest wyzwaniem wobec codzienności pedagogicznej.

\section{Bibliografia}

Babicka-Wirkus A. (2019), Kultura oporu w szkole. Dziatania - motywacje przestrzeń, Wolters Kluwer, Warszawa.

Ferreira F.I. Reformas educativas, formação e subjectividades dos professores, „Revista Brasileira de Educação” 2008, t. 13, nr 38 (maj-sierpień), s. 244.

Flores M.A. "The Teaching Profession at the Crossroads: Contexts, Challenges and Possible Directions", University of Minho, Portugal. Wykład wygłoszony na Wydziale Pedagogicznym Uniwersytetu Warszawskiego w dniu 12 grudnia 2019 r.

Furmanek W. (2013), Humanistyczna pedagogika pracy. Charakterystyka dyscypliny naukowej, Wydawnictwo Uniwersytetu Rzeszowskiego, Rzeszów.

Dereń E. (2014), Nowy paradygmat $w$ ksztatceniu $i$ doskonaleniu nauczycieli, Forum Inicjatyw Edukacyjnych i Obywatelskich, Wałbrzych.

Dereń E. (2011), Nauczyciel - zawód czy misja i powolanie? Przyczynki do nowej koncepcji ksztatcenia nauczycieli, [w:] Ksztatcenie nauczycieli w Polsce, https://sites.google.com/site/ksztalcenienauczycieli/nauczyciel---zawód-czy-misja-i-powołanie (dostęp: 26.08.2019).

Różycka E. (red. prowadzący Encyklopedii) (2004), Encyklopedia pedagogiczna XXI, vol. III, Wydawnictwo Akademickie „Żak”, Warszawa.

Gołębniak B.D. (2001), Etyczny wymiar edukacji nauczycieli, [w:] U. Ostrowska (red.), Edukacja przełomu wieków wobec kwestii aksjologicznych, Wydawnictwo Uniwersytetu Warmińsko-Mazurskiego, Olsztyn.

Kabaj M. (2010), System ksztatcenia zawodowego i kierunki jego doskonalenia $w$ warunkach integracji $i$ wzrostu konkurencyjności. Diagnoza i elementy programu szerszego wdrożenia dualnego systemu ksztatcenia w Polsce, Związek Rzemiosła Polskiego, Warszawa, https://docplayer.pl/4560253-Prof-dr-hab-mieczyslaw-kabaj.html, s. 73 (dostęp: 08.01.2020).

Kieszkowska A. (2015), Prawda, dobro, piękno w rozważaniach naukowych Profesora, [w:] A. Kieszkowska (red. nauk.), Prawda, dobro, piękno: wymiar filozoficzno-prawny $i$ socjopedagogiczny, Difin, Warszawa.

Kordziński J. (2018), Szkoła uczenia się, Wolters Kluwer Polska, Warszawa.

Kotarbiński T., oprac. Kotarbińska J., Kiejzik L., Huńczak T. (1991), Myśli i stowa, Wyższa Szkoła Pedagogiczna im. Tadeusza Kotarbińskiego, Zielona Góra.

Kotarbiński T., wybór Duralska-Macheta T. (1989), Żyć zacnie, Instytut Wydawniczy Nasza Księgarnia, Warszawa.

Kupisiewicz Cz. (2005), Podstawy dydaktyki, WSiP S.A., Warszawa.

Kupisiewicz Cz. (2007), Projekty reform edukacyjnych w Polsce, Instytut Badań Edukacyjnych, PWN, Warszawa.

Kupisiewicz Cz. (2012), Z dziejów teorii i praktyki wychowania, Oficyna Wydawnicza Impuls, Kraków. 
Kust I. (2010), Znaczenie wychowania estetycznego w rozwoju czlowieka, [w:] K. Pankowska (red.), Sztuka i wychowanie. Wspótczesne problemy edukacji estetycznej, Wydawnictwo Akademickie Żak, Warszawa.

Kust I. (2015), Jak szkola może pomóc uczniowi w odkrywaniu pasji? Analiza przypadku, [w:] D. Bis, K. Braun, M. Jeziorański (red.), Opowiem wam o swojej pasji: stowem, obrazem, dźwiękiem..., KUL Jana Pawła II, Instytut Pedagogiki, Lublin.

Łada A. (red.) (2017), Rynek pracy wyzwaniem, ksztatcenie zawodowe szansa, Polsko-Niemiecka Izba Przemysłowo-Handlowa (AHK Polska), Warszawa, https://ahk.pl/pl/hr-i-szkolenia/rynek-pracy-wyzwaniem-ksztalceniezawodowe-szansa / (dostęp: 30.07.2019).

Madalińska-Michalak J. (2012), Dylematy etyczne w pracy nauczyciela, „Studia Pedagogiczne", vol. LXV/2012, s. 263-281.

Michalak J.M. (2007), Uwarunkowania sukcesów zawodowych nauczycieli. Studium przypadków, Wydawnictwo Uniwersytetu Łódzkiego, Łódź.

Michalak-Dawidziuk J. (2014), Lifelong learning - potrzeba wspótczesnego rynku pracy czy catożyciowa autokreacja czlowieka?, [w:] I. Paszenda, R. Włodarczyk (red.), Transgresje w edukacji, Oficyna Wydawnicza Impuls, Kraków.

Michalak-Dawidziuk J. (2017), Studia a sytuacja zawodowa studentów studiów niestacjonarnych pierwszego stopnia w świetle badań, „Edukacja Ustawiczna Dorosłych", t. 2 (97), s. 129-136.

Nowacki T.W. (2004), Leksykon Pedagogiki Pracy, Instytut Technologii i Eksploatacji, Radom.

Okoń W. (1992), Stownik Pedagogiczny, PWN, Warszawa.

Szczepański J. (1965), Czynniki ksztattujace zawód i strukture zawodu, [w:] A. Sarapata (red.), Socjologia zawodów, Książka i Wiedza, Warszawa.

Szelewa S. (2018), Zmiany w szkolnictwie zawodowym - pomysty dobre, ale diabet tkwi w szczególach, https://www.prawo.pl/oswiata/zmiany-w-szkolnictwie-zawodowym-w-2018-r,294714.html (dostęp: 08.01.2020).

Sztumski J. (1999), Socjologia pracy, Górnośląska Wyższa Szkoła Handlowa, Katowice.

Uniwersalny stownik języka polskiego, PWN, Warszawa 2003, vol. 2, s. 676.

Wiatrowski Z. (2005), Zawody szkolnictwa zawodowego, MEN, Warszawa.

Wiłkomirska A. (2010), Zmiana - trauma i szansa, próba pedagogicznej refleksji, [w:] A. Przecławska, A. Wiłkomirska (red.), Między nieuchronnościq a możliwościq - wychowanie w warunkach zmiany, Wydawnictwa Uniwersytetu Warszawskiego, Warszawa.

Wiłkomirska A. (2013), Wiedzieć i rozumieć, aby być obywatelem. Studium empiryczne, Wydawnictwa Uniwersytetu Warszawskiego, Warszawa.

Woleński J. (1985), Filozoficzna szkoła lwowsko-warszawska, PWN, Warszawa. 


\title{
Młody nauczyciel w szkole. Problemy związane z rozwojem kompetencji i autonomii
}

\author{
Abstract \\ Problems of development of competences \\ and autonomy of novice teachers at school
}

Many authors have long been involved in research concerning the development of teachers' personal and professional competences. According to them, teacher professional development is stadial and should lead to the critical use of knowledge, development of their own ways of working, revising the patterns of professional role and, consequently, to independence from external pressure and the creation of a teacher's "autonomous identity".

The goal of this paper, based on several empirical studies, is the identification of some systemic and mental obstacles hindering the development of teachers' competence and autonomy. The requirements related to the professional promotion system allow us to develop only some of the teachers' competences that are the basis for building their autonomy, e.g. teaching and development of the teacher's workshop. In the construction of the professional promotion system, communication skills, skills to motivate students, supporting them in solving problems, building their authority in relations with students were neglected. At the school level, a lack of trust among teachers, a lack of culture of cooperation and shared responsibility, a conflict between teacher generations, lack of respect and openness to others can hinder or even prevent the development of the autonomy of young teachers.

Keywords: teachers' competences, professional development in the workplace, teachers' autonomy, systemic and mental obstacles to the development of autonomy

Słowa kluczowe: kompetencje nauczyciela, rozwój zawodowy w miejscu pracy, autonomia nauczycieli, systemowe i mentalne przeszkody w rozwoju autonomii 
Nauczycielom ze względu na szczególny charakter tego zawodu zawsze stawiano wysokie wymagania, domagano się nawet od nich „doskonałości” (por. Okoń 1962). Charakter pracy nauczyciela związany z koniecznością poruszania się w sytuacjach zmiennych, niepowtarzalnych, wymagających porozumienia i współdziałania w czasach, w których musimy zmierzyć się z „kryzysem zaufania, wspólnotowości i autonomii" stanowi i dla nauczycieli, i dla tych, którzy powinni wspierać ich rozwój i wkraczanie w rolę zawodową, szczególne wyzwanie. Stawanie się nauczycielem jest wszędzie trudne. Dokonuje się bowiem w rzeczywistości ponowoczesnej, którą charakteryzuje zmienność, nietrwałość, rozproszenie zasad i wartości, współzależność będąca konsekwencją relacyjności struktur społecznych oraz „refleksyjność jako zasada metodologicznego wątpienia zarówno w wiedzę uogólnioną, jak i we własne zasoby poznawcze" (Dróżka 2017: 8). Z tej charakterystyki naszego świata społecznego wynika potrzeba kształtowania nauczyciela, który zmierzy się z tymi wyzwaniami. Odpowiedzią na zmienność i nietrwałość powinny być: elastyczność, kreatywność, mobilność, odpowiedzią na współzależność: współpraca, dialog, partycypacja, współodpowiedzialność, natomiast zasada refleksyjności wymaga namysłu, ciągłego uczenia się, doskonalenia (por. Dróżka 2017: 8).

W naszym społeczeństwie te wyzwania są wzmocnione, a trudności pogłębiane przez kontekst społeczno-polityczny, w jakim przyszło działać polskim nauczycielom. Nieprzygotowana, naprędce przeprowadzona zmiana systemowa w szkolnictwie, lekceważenie problemów nauczycieli i brak chęci do dialogu z nimi powoduje u wielu $\mathrm{z}$ nich zniechęcenie, bierność, a nawet odchodzenie $\mathrm{z}$ zawodu. Wszędzie nauczyciel jest oceniany nie tylko przez władze oświatowe i dyrektora szkoły, lecz również przez uczniów i ich rodziców, ale w naszym kraju napięcie pojawiające się w relacji między nauczycielami i rodzicami było podsycane, co utrudnia dodatkowo niełatwą w dzisiejszych czasach współpracę nauczycieli z rodzicami uczniów.

Należałoby więc postawić pytanie o to, jakie kompetencje nauczycieli są dzisiaj szczególnie ważne i jak należy je wspierać i rozwijać. Drugim ważnym pytaniem, od odpowiedzi na które zależy charakter szkoły, którą chcemy tworzyć, jest pytanie o istotę i zakres autonomii nauczyciela. Te dwie kwestie są podstawowe dla wypracowania koncepcji rozwoju zawodowego nauczyciela. Koncepcje i modele rozwoju zawodowego od lat są przedmiotem 
refleksji w wielu krajach. Do klasycznych opracowań tej tematyki należy koncepcja faz rozwoju zawodowego wskazana przez Frances E. Fuller (1969). Autorka wskazała trzy fazy rozwoju zawodowego nauczyciela: nastawienie na przetrwanie, nastawienie na sytuację dydaktyczną oraz nastawienie na zmianę i rozwój. Donald E. Super i Jean Pierre Jordan (1973) wyodrębnili aż pięć faz w życiu zawodowym nauczyciela, a mianowicie fazy rozwoju, poszukiwania, utrwalania, kontynuacji i spadku. Rozwojem kompetencji nauczyciela zajmowało się wielu autorów już w latach 80. i 90. - m.in. Hugh O. Jenkins i David Fontana.

Termin „kompetencje” nie ma precyzyjnie określonego pola znaczeniowego, jest pojemny, niedookreślony, używany jest także w języku potocznym, w publicystyce, w polityce. Można wyodrębnić dwa odmienne podejścia do kompetencji. Są one traktowane albo jako ogólne cechy osobowości, zdolności, transferowalne umiejętności, albo jako wiedza i doświadczenie właściwe dla danej struktury organizacyjnej. W Polsce kompetencje były przedmiotem badań i refleksji wielu autorów. W szerokim zakresie podjęli tę problematykę: Maria Dudzikowa (1994), Stanisław Dylak (1995), Anna Wiłkomirska (2002), Robert Kwaśnica (2004), Wacław Strychowski, Justyna Strychowska i Józef Pielachowski (2007), Henryka Kwiatkowska (2008), Joanna Madalińska-Michalak, Renata Góralska (2012), Joanna Madalińska-Michalak (2019). Szeroką, a jednocześnie precyzyjną definicję kompetencji zaproponowała Maria Czerepaniak-Walczak (1997: 89): „Kompetencja podmiotu jest to jego szczególna właściwość, wyrażająca się w demonstrowaniu na wyznaczonym przez społeczne standardy poziomie, umiejętności adekwatnego zachowania się, w świadomości potrzeby i konsekwencji takiego właśnie zachowania oraz w przyjmowaniu na siebie odpowiedzialności za nie".

Ciekawe podejście do rozwoju kompetencji nauczycielskich przedstawił Robert Kwaśnica (2004). Wszystkie kompetencje potrzebne nauczycielowi możemy, według tego autora, przyporządkować do jednej z dwóch kategorii: kompetencji praktyczno-moralnych lub technicznych. Ze względu na szczególny charakter pracy nauczyciela nadrzędną rolę $\mathrm{w}$ tym zawodzie pełnią kompetencje praktyczno-moralne, do których Kwaśnica zaliczył kompetencje interpretacyjne (zdolność rozumiejącego odnoszenia się do świata), moralne (zdolność autorefleksji nad swoim postępowaniem i relacją z innymi ludźmi), komunikacyjne (zdolność do bycia w dialogu z sobą lub innymi). Kompetencje 
techniczne to: kompetencje postulacyjne (normatywne), które sprowadzają się do umiejętności opowiadania się za instrumentalnie pojętymi celami, kompetencje metodyczne, stanowiące „umiejętność działania według reguł określających optymalny porządek czynności” (Kwaśnica 2004: 301) i kompetencje realizacyjne, oznaczające umiejętność doboru środków i warunków do osiągania celu. Według Roberta Kwaśnicy kompetencje techniczne można nauczycielowi przekazać, w prosty sposób, przygotowując go do zawodu. „Kompetencje praktyczno-moralne [...], które mają charakter osobisty i niepowtarzalny, wymagają przekazu dialogowego i włączenia w proces wspomagania rozwoju nauczyciela pedagogiki krytyczno-hermeneutycznej” (Kwaśnica 2004: 305).

Kwaśnica traktuje rozwój zawodowy nauczycieli jako równoległą i powiązaną ze sobą ewolucję kompetencji praktyczno-moralnych i technicznych. Logika ich rozwoju (kierunek i stadia) jest taka sama i kieruje nią „tendencja do wzrastającej niezależności człowieka od presji zewnętrznego otoczenia” (Kwaśnica 2004: 306), czyli rozszerzenie jego autonomii. Kwaśnica podkreśla, że takie podejście do rozwoju człowieka jest widoczne we wszystkich współczesnych teoriach rozwoju, można je zauważyć u Jeana Piageta, Lawrenca Kohlberga, Erica Eriksona i Jürgena Habermasa. Kwaśnica uważa, że możemy rozwój kompetencji tworzących zawód nauczyciela przedstawić na linii rozwojowej prowadzącej od przedkonwencjonalnego stadium, przez konwencjonalne do postkonwencjonalnego. Według tej typologii stadium przedkonwencjonalne - to stadium wchodzenia w rolę zawodową. W tej fazie nauczycielskiego rozwoju kopiuje on wzory działania otoczenia, naśladuje innych, w sposób bezrefleksyjny „odtwarza konwencję”. Następne stadium - konwencjonalne to faza pełnej adaptacji do roli zawodowej. Nauczyciel dąży do sprostania w pełni uświadomionej konwencji, stara się wypełniać rolę w sposób utrwalony w zastanej wiedzy i zwyczajach, sprawnie posługuje się wiedzą i umiejętnościami w sposób odtwórczy. Może także wykazywać pewien rodzaj nonkonformizmu, odrzucać te wymagania, sposoby postępowania, które uważa za sprzeczne $\mathrm{z}$,instytucjonalnie zdefiniowaną rolą zawodową" (Kwaśnica 2004: 307). Stadium postkonwencjonalne - to stadium twórczego przekraczania roli zawodowej. Charakterystyczne dla tego stadium jest krytyczne posługiwanie się wiedzą, opracowanie własnych sposobów działania, rewidowanie schematu roli zawodowej. Nauczyciel poszukuje własnych uzasadnień, modyfikuje związane z rolą zarówno 
standardy praktyczno-moralne (np. sposoby rozumienia sytuacji edukacyjnej), jak i techniczne, dotyczące metod i wykorzystywanych narzędzi. Kwaśnica twierdzi, że tylko dla tego stadium źródłem uzasadniającym działanie nauczyciela jest wskazywana przez Eriksona i Habermasa „tożsamość autonomiczna”, którą rozumie jako wyprowadzanie sensu powinności zawodowych z rozumienia własnej osoby jako integralnej całości. „Na poziomie tożsamości autonomicznej dokonuje się zrównanie powinności zawodowych z moralnymi, które kształtują się dzięki identyfikacji z uniwersalnymi wartościami” (Kwaśnica 2004: 308). W postkonwencjonalnym stadium rozwoju nauczyciel jest w stanie podjąć próby przełożenia wartości uniwersalnych na „zobowiązania i przełożenia moralne, jakie nauczyciel ma wobec ucznia i w stosunku do siebie" (Kwaśnica 2004: 308). Z koncepcji rozwoju zawodowego, rozwoju kompetencji nauczyciela zaproponowanego przez Kwaśnicę, wynika, że tylko w stosunku do nauczyciela, który w rozwoju przebiegającym na linii stadium przedkonwencjonalne - postkonwencjonalne osiągnie to ostatnie, można mówić o autonomii myślenia i działania. Tylko takiego nauczyciela może charakteryzować „tożsamość autonomiczna”, czyli przy takim rozumieniu autonomii nauczycielskiej jest ona niedostępna dla młodego nauczyciela.

Koncepcja rozwoju Kwaśnicy prowadzi do analizy zagadnienia autonomii nauczycielskiej. Termin „autonomia” ma jeszcze bardziej rozmyte pole znaczeniowe niż termin „kompetencja”. Występuje w języku prawniczym, politologicznym, spotykamy to pojęcie $\mathrm{w}$ psychologii, socjologii, kulturoznawstwie. W klasycznym już dziele dotyczącym autonomii Gerald Dworkin (1988) podkreśla, że pojęcie autonomii nabiera coraz większego znaczenia we współczesnej filozofii moralnej i politycznej. Filozofowie tacy jak John Rawls, Thomas Scanlon, Robert P. Wolff i Ronald Dworkin wykorzystali tę koncepcję do zdefiniowania i wyjaśnienia takich kwestii, jak charakterystyka zasad sprawiedliwości, granic wolności słowa i natury państwa liberalnego.

Zagadnienie autonomii stało się również bardzo ważne dla pedagogiki i pedeutologii. Podjęto próby wskazania cech konstytuujących autonomię nauczycieli. Wielu autorów traktuje autonomię w inny sposób niż wynikający z przedstawionej przez Roberta Kwaśnicę koncepcji stadialnego rozwoju zawodowego nauczycieli, który może, lecz nie musi prowadzić do wykształcenia się „tożsamości autonomicznej”. Przez niektórych autorów autonomia jest 
traktowana jako nierozłącznie związana z zawodem nauczyciela i rozumiana, w najszerzej akceptowanym sensie tego słowa, jako wolność od kontroli sprawowanej przez innych. Tak rozumiana autonomia nauczycieli jest uznawana za podstawową cechę ich profesjonalizmu, a ciągłe napięcie między autonomią nauczycieli a zadaniami wyznaczonymi przez państwo postrzegane jest jako czynnik przyczyniający się do deprofesjonalizacji tego zawodu i obniżenia jego rangi (Andersen 1987). Możliwość samodzielnego organizowania swojej pracy, wolność od ingerowania innych osób $\mathrm{w}$ działania lub rozwój zawodowy nauczyciela jest jednym ze sposobów rozumienia autonomii nauczyciela (Smith 2000). Autonomia jest także wiązana z kompetencjami nauczyciela i traktowana jako zdolność do samodzielnego działania zawodowego. Nauczyciel jest autonomiczny, jeśli posiada silne poczucie osobistej odpowiedzialności za nauczanie, jest zdolny do ciągłej refleksji i analizy oraz afektywnej i poznawczej kontroli procesu nauczania (Little 1995). Autonomia nauczyciela jest także traktowana jako zdolność do samodzielnego planowania swojego rozwoju zawodowego (Tort-Molney 1997). Biorąc pod uwagę częste zmiany systemu edukacji w Polsce, w tym zmiany o charakterze koncepcyjnym, strukturalnym i prawnym, wielu badaczy zwróciło uwagę na szczególną potrzebę przygotowania nauczycieli autonomicznych, według definicji autonomii nauczycielskiej bliskiej stanowisku Tort-Molney i Little (Radziewicz 1992; Kwiatkowska 1994; Dróżka 2017).

System edukacji w Polsce począwszy od czasu przełomu politycznego, społecznego i ekonomicznego, który został zapoczątkowany w 1989 r., aż do roku 2016 miał, w założeniach twórców reform, prowadzić do większej autonomii szkół i nauczycieli. W pierwszej połowie lat 90. zwrócono uwagę na podział kompetencji między organem prowadzącym szkoły, a organem sprawującym nad nim nadzór. Kontrola miała zmienić się w kierunku badań i ocen efektów działalności szkół i placówek oświatowych zamiast ścisłego nadzoru. („Główne kierunki doskonalenia systemu edukacji w Polsce”, 1994). Te zamiany powinny prowadzić do wzrostu autonomii nauczycieli rozumianej jako ograniczenie kontroli zewnętrznej nad ich działaniami (por. Smith 2000). Kompleksowa reforma systemu oświaty rozpoczęta na przełomie lat 1999/2000 wymagała przygotowania nauczycieli, którzy będą w stanie zmierzyć się z jej wymaganiami, będą nie tylko specjalistami w zakresie nauczanych przedmiotów i dobrymi dydaktykami, ale będą w stanie podjąć 
wyzwania zmieniającego się społeczeństwa, otworzyć się na zróżnicowane potrzeby dzieci i rodziców, obciążonych różnymi problemami. Podniesienie kompetencji nauczycieli i ich zdolności do lepszego radzenia sobie w rzeczywistości szkolnej stało się ważnym wyzwaniem reformy. Wprowadzono nowy system awansu zawodowego nauczycieli, który miał ich zachęcić do podnoszenia kompetencji. Przyjęte w aktach prawnych, Ustawie o Systemie Oświaty i Rozporządzeniu wykonawczym rozwiązania miały sprzyjać rozwijaniu samodzielności i niezależności nauczyciela w planowaniu swojej pracy i rozwoju zawodowego. Nauczyciel bardziej doświadczony (mianowany) samodzielnie, a mniej doświadczony (stażysta, nauczyciel kontraktowy) we współpracy z opiekunem stażu miał przygotować swój plan rozwoju zawodowego. Uzyskanie stopnia nauczyciela mianowanego wiązało się z wykazaniem się umiejętnością doskonalenia swojego warsztatu pracy, przeprowadzania jego ewaluacji i dokonywania korekt. Kandydat na stopień nauczyciela dyplomowego powinien być zdolny do opracowania i wdrożenia programu działań edukacyjnych, uzyskać pozytywne efekty w pracy dydaktycznej, wychowawczej, opiekuńczej przez wdrożenie działań służących zarówno doskonaleniu pracy własnej, jak i podnoszeniu jakości pracy szkoły. ${ }^{1}$ Te z kolei zmiany prawne powinny przyczynić się do wzrostu autonomii rozumianej jako zdolności do samodzielnego działania zawodowego (por. Little 1995) i planowania rozwoju zawodowego (por. Tort-Molney 1997). Oprócz kontekstu systemowego, rozpatrując możliwość rozwoju autonomii nauczycielskiej, trzeba uwzględniać przede wszystkim warunki, jakie stwarza bezpośrednie otoczenie nauczyciela, np. klimat szkoły, w której pracuje, relacje z innymi nauczycielami, motywujące i wspierające działanie dyrektora, organizacja pracy i inne, często nie formułowane wprost, oczekiwania związane z pełnieniem roli nauczyciela.

\section{Rozwój kompetencji i autonomii nauczycieli - wyniki badań}

Celem tej części jest próba udzielenia odpowiedzi na pytanie, na podstawie wyników kilku prowadzonych w ostatnich latach badań, w jakim stopniu rozwój kompetencji i autonomii

1 Rozporządzenie Ministra Edukacji Narodowej i Sportu z dnia 1 grudnia 2004 r. w sprawie uzyskiwania stopni awansu przez nauczycieli. 
nauczycieli, w szczególności młodych nauczycieli, wspierany jest przez system organizacyjno-prawny, w tym wymagania związane $\mathrm{z}$ awansem zawodowym nauczycieli, oraz jak wspomagany jest on na poziomie szkolnym. Wykorzystuję dane z trzech badań naukowych, w których stosowano zarówno metodologię ilościową, jak i jakościową. Analizując wybrane wyniki badań, w których pojawił się problem oceny kompetencji nauczycieli i autonomii nauczycielskiej, spróbuję odpowiedzieć na pytania: Czy system oceniania i promowania nauczycieli służy rozwojowi ich kompetencji? Czy zwiększa ich możliwości samodzielnego działania, wzmacnia ich autonomię? Jak nauczyciele rozumieją autonomię? Czy uważają, że posiadają ją w wystarczającym stopniu? Czy oczekiwania wobec młodego nauczyciela w środowisku szkolnym pomagają mu rozwijać kompetencje i osiągnąć zawodową autonomię?

Badania, których wybrane wyniki zaprezentuję poniżej, były prowadzone w latach 2010-2019. W jednym z nich, prowadzonym na próbie ogólnopolskiej, korzystano zarówno z metodologii ilościowej, jak i jakościowej (ograniczę się w tym opracowaniu do przedstawienia kilku wyników badania ilościowego) ${ }^{2}$, w dwóch pozostałych stosowano wyłącznie metodologię jakościową.

Analizując ocenę przez nauczycieli i dyrektorów realizacji systemu awansu zawodowego w praktyce szkolnej, a szczególnie zadań, które nauczyciele podejmują w związku z awansem, można spróbować odpowiedzieć na pytania: Czy system oceniania i promowania nauczycieli służy rozwojowi ich kompetencji? Czy zwiększa ich możliwości samodzielnego działania? Wzmacnia ich autonomię?

Punktem wyjścia do tych rozważań powinna być ocena kompetencji zawodowych młodych nauczycieli. Badani dyrektorzy szkół dość wysoko oceniają umiejętności młodych nauczycieli $\mathrm{w}$ zakresie radzenia sobie $\mathrm{z}$ problemami wychowawczymi (co może wydawać się zaskakujące), natomiast najsłabiej oceniają umiejętności dydaktyczne nauczycieli i umiejętność zastosowania zdobytej podczas studiów wiedzy w praktyce. Niewielu młodych nauczycieli dobrze radzi sobie $\mathrm{z}$ organizowaniem i ewaluacją własnej pracy, a także ze stresem związanym z pracą w szkole.

${ }^{2}$ Dokładny opis badania i przyjętej metodologii [w:] A. Wiłkomirska, A. Zielińska (2013), Ocena systemu awansu zawodowego nauczycieli w Polsce. Studium Empiryczne, Wydawnictwa Uniwersytetu Warszawskiego, Warszawa. 
Tabela 1. Informacja o badaniach wykorzystywanych w publikacji

\begin{tabular}{l|l|l}
\hline Badanie 1 & $\begin{array}{l}\text { Poziom } \\
\text { ogólnokrajowy } \\
\text { Próba } \\
\text { reprezentatywna } \\
\text { Nauczyciele - } \\
\mathrm{N}=499 \\
\text { Szkoły }-\mathrm{N}=93\end{array}$ & $\begin{array}{l}\text { Ocena efektywności systemu awansu } \\
\text { zawodowego nauczycieli a jakość pracy } \\
\text { szkoły (2010-2013); } \\
\text { Wiłkomirka A. (kierownik projektu), } \\
\text { Zielińska A. } \\
\text { Badanie ilościowe (próba ogólnopolska), } \\
\text { badani nauczyciele i dyrektorzy szkól. }\end{array}$ \\
\hline Badanie 2 & $\begin{array}{l}\text { Poziom szkoły } \\
\text { N=61 }\end{array}$ & $\begin{array}{l}\text { Rozwój kompetencji zawodowych młodego } \\
\text { nauczyciela (2015, 2017) } \\
\text { Zielińska A. } \\
\text { Badanie jakościowe, badani czynni } \\
\text { nauczyciele. Wywiady zbiorowe } \\
\text { zogniskowane prowadzone były } \\
\text { w 6 grupach słuchaczy studiów } \\
\text { podyplomowych. }\end{array}$ \\
\hline Badanie 3 & $\begin{array}{l}\text { Poziom szkoły } \\
\text { Not2 }\end{array}$ & $\begin{array}{l}\text { Rozwój autonomii i samodzielności zawodowej } \\
\text { nauczycieli w miejscu pracy (2019) } \\
\text { Brzosko-Barratt K., Zielińska A. } \\
\text { Badanie jakościowe, badani nauczyciele. } \\
\text { Wywiady zbiorowe zogniskowane, prowadzone } \\
\text { w dwóch grupach słuchaczy studiów pody- } \\
\text { plomowych i grupie uczestników sympozjum } \\
\text { dotyczącego zmian wprowadzanych w edukacji. }\end{array}$ \\
\hline
\end{tabular}

Źródło: Opracowanie własne.

Brak dobrze rozwiniętych umiejętności dydaktycznych, związanych z samodzielnym tworzeniem, ocenianiem i modyfikowaniem swojego warsztatu jest poważnym utrudnieniem w budowaniu autonomii traktowanej zarówno jako zdolność do samodzielnego działania, jak i planowania swojego rozwoju.

Czy system awansu zawodowego, jego wymagania, procedury i zasady, pomaga w rozwijaniu u nauczycieli kompetencji, które będą sprzyjały kształtowaniu się ich „autonomicznej tożsamości”? Badani dyrektorzy szkół mieli ocenić (na skali: w bardzo dużym stopniu, raczej dużym, raczej małym, bardzo małym, wcale), czy wymagania awansu rozwijają różne kompetencje nauczycieli. Kategoriom odpowiedzi przypisano wartości liczbowe, obliczono średnie i odchylenia standardowe.

Wymagania awansu pozwalają rozwijać kompetencje nauczycieli w zakresie dydaktyki, tworzenia materiałów i dokumentów w tym obszarze. Najsłabiej wspierają kompetencje miękkie nauczyciela: komunikacyjne, umiejętności motywowania uczniów, 
Tabela 2. Ocena wiedzy i umiejętności początkujących nauczycieli. Opinie dyrektorów

\begin{tabular}{l|c|c}
\hline \multicolumn{1}{c|}{ Wiedza i umiejętności } & $\begin{array}{c}\text { zdecydowanie } \\
\text { tak } \%\end{array}$ & $\begin{array}{c}\text { raczej } \\
\text { tak } \%\end{array}$ \\
\hline $\begin{array}{l}\text { Radzenie sobie z problemami } \\
\text { wychowawczymi }\end{array}$ & 62,4 & 28,0 \\
\hline $\begin{array}{l}\text { Znajomość prawa oświatowego, } \\
\text { obowiązków administracyjnych }\end{array}$ & 36,7 & 44,1 \\
\hline Współpraca z rodzicami & 26,9 & 50,5 \\
\hline Organizacja własnej pracy & 19,4 & 48,4 \\
\hline Ewaluacja własnej pracy & 18,3 & 57 \\
\hline Radzenie sobie ze stresem & 16,1 & 48,4 \\
\hline $\begin{array}{l}\text { Znajomość dydaktyki przedmiotowej } \\
\text { (metod nauczania) }\end{array}$ & 6,5 & 26,9 \\
\hline Stosowanie wiedzy w praktyce & 3,2 & 35,5 \\
\hline
\end{tabular}

Źródło: Opracowanie własne na podstawie: Wiłkomirska, Zielińska (2013), s. 76.

wspomaganie ich w rozwiązywaniu problemów i budowaniu własnego autorytetu w relacji z nimi. Rozwój umiejętności dydaktycznych oraz budowanie warsztatu swojej pracy, może wzmocnić autonomię nauczyciela. Jednak trudno budować ją w sytuacji bezradności wobec uczniów i ich problemów, nie radząc sobie z emocjami i stresem. W takich sytuacjach nauczyciel raczej szuka oparcia i autorytetu instytucjonalnego niż jest gotów rozwijać swoją autonomię. System awansu zawodowego pozwala rozwijać tylko niektóre kompetencje nauczyciela stanowiące podstawę budowania jego autonomii, inne zaś zaniedbuje.

W drugim badaniu celem było poznanie opinii doświadczonych nauczycieli na temat kompetencji, posiadanych przez ich młodszych, startujących w zawodzie kolegów i znalezienie odpowiedzi na pytanie, czy preferowana przez doświadczonych nauczycieli koncepcja rozwoju kompetencji w miejscu pracy pozwala młodym kolegom osiągać wyższe stadia rozwoju oraz zbliżyć się do „tożsamości autonomicznej”.

Badanie fokusowe przeprowadzono w 2015 r. w 4 grupach doświadczonych nauczycieli, słuchaczy Studiów Podyplomowych Organizacji i Zarządzania oświatą przygotowujących przyszłych dyrektorów szkół (2 grupy fokusowe) i Studiów Podyplomowych dla Nauczycieli, chcących zdobyć dodatkowe kwalifikacje w zakresie 
Tabela 3. Ocena wymagań awansu w zakresie budowania umiejętności radzenia sobie z ważnymi w szkole zadaniami i problemami. Ocena dyrektorów szkół

\begin{tabular}{l|c|c}
\hline \multicolumn{1}{c|}{ Zadania i problemy } & Średnie & $\begin{array}{c}\text { Odchylenie } \\
\text { standardowe }\end{array}$ \\
\hline $\begin{array}{l}\text { Samodzielne przygotowywanie materiałów } \\
\text { dydaktycznych }\end{array}$ & 3,83 & 0,8 \\
\hline $\begin{array}{l}\text { Współpraca z innymi nauczycielami } \\
\text { Stosowanie metod aktywizujących w procesie } \\
\text { nauczania - uczenia się }\end{array}$ & 3,74 & 0,8 \\
\hline $\begin{array}{l}\text { Tworzenie dokumentów szkolnych } \\
\text { (np. program wychowawczy, wewnętrzny } \\
\text { system oceniania) }\end{array}$ & 3,50 & 0,7 \\
\hline $\begin{array}{l}\text { Tworzenie programów kształcenia w zakresie } \\
\text { swojego przedmiotu }\end{array}$ & 3,49 & 0,8 \\
\hline Budowanie kultury szkoły & 3,40 & 0,7 \\
\hline Aktywizowanie rodziców & 3,0 & 0,8 \\
\hline Niechęć uczniów do uczenia się & 2,89 & 0,9 \\
\hline Pokonywanie stresu w miejscu pracy & 2,86 & 0,9 \\
\hline Problemy emocjonalne uczniów & 2,83 & 0,8 \\
\hline Przemoc uczniów wobec siebie & 2,71 & 0,9 \\
\hline Arogancja uczniów w stosunku do nauczyciela & 2,64 & 0,9 \\
\hline
\end{tabular}

Źródło: Wiłkomirska, Zielińska, 2012: 105-106.

Edukacji Wczesnoszkolnej i Terapii Pedagogicznej (2 grupy fokusowe). W 2017 r. wywiady zogniskowane przeprowadzono w kolejnych dwóch grupach słuchaczy studiów podyplomowych.

Badani nauczyciele na ogół wysoko oceniali wiedzę przedmiotową swoich młodszych kolegów i ich umiejętność posługiwania się nowymi technologiami. Uważali także, że ci ostatni posiadają wiedzę psychologiczno-pedagogiczną, choć nie zawsze potrafią zastosować ją w praktyce. Oto przykład takiej wypowiedzi: „Dużo wiedzą o rozwoju dziecka, ale brakuje im kompetencji wychowawczych i tej przewidywalności, co dzieci mogą zrobić”.

Znacznie częściej wskazywano na kompetencje, których młodzi nauczyciele rzekomo nie posiadają, albo które posiadają w niewielkim stopniu. Wymieniono m.in. brak kompetencji:

- komunikacyjnych (w relacjach z uczniami, rodzicami, innymi nauczycielami); 
- kierowania klasą, „panowania nad uczniami”;

- planowania pracy na lekcji (np. z braku czasu zadawanie prac domowych na przerwie, brak refleksji, podsumowania lekcji);

- dokonywania ewaluacji (rozumienia celu i sensu ewaluacji, znajomości metod ewaluacji);

- „asertywności wobec postaw roszczeniowych” (strach przed rodzicami, nieumiejętność stawiania granic);

- radzenia sobie ze stresem, umiejętności pracy w stresie;

- stosowania metod i form nauczania dostosowanych do potrzeb uczniów (indywidualizacji pracy, stosowania metod aktywizujących).

Doświadczeni nauczyciele widzieli potrzebę nabywania i rozwijania kompetencji, które według nich byłyby odpowiedzią na zmiany zachodzące $\mathrm{w}$ szkole i otoczeniu. Uważali, że są one potrzebne wszystkim nauczycielom, nie tylko młodym. Wskazano potrzebę ciągłego rozwoju kompetencji komunikacyjnych, językowych i kulturowych związanych z migracjami, kompetencji informatyczno-medialnych, wychowawczych (praca ze „zmieniającymi się”, „coraz trudniejszymi” uczniami), radzenia sobie ze stresem i przeciwdziałania wypaleniu zawodowemu. Na pytanie, jakie kompetencje będą potrzebne nauczycielowi, padały także i takie odpowiedzi: „Trudno określić, jakie kompetencje będą potrzebne, nauczyciel powinien być otwarty i gotowy na zmiany".

Charakterystyczne i niepokojące jest, że nauczyciele nie wymienili szeregu kompetencji, które są przez pedeutologów uważane za podstawę do budowania nauczycielskiej samodzielności i autonomii. Nie wymieniono potrzeby rozwijania umiejętności współpracy w zespołach nauczycielskich, wspólnego rozwiązywania problemów, budowy wzajemnego zaufania. W żadnej z grup nie wskazano potrzeby rozwoju kompetencji $\mathrm{w}$ zakresie rozpoznawania potrzeb środowiska, konkretnych uczniów konkretnej szkoły. W bardzo specyficznym kontekście pojawił się problem współpracy z rodzicami. Nie podkreślano potrzeby rozwijania umiejętności komunikowania się z rodzicami, szczególnie ze środowisk wykluczonych, otwarcia na ich potrzeby. Podkreślano potrzebę umiejętności komunikowania z rodzicami, ale po to, żeby rodzice nie skrzywdzili nauczyciela, nie zdominowali, żeby umiał „określić granicę w kontaktach z rodzicami”. Badani nie widzieli ponadto potrzeby żadnej współpracy międzypokoleniowej, wzajemnego uczenia się od siebie młodych i starszych nauczycieli. Wprost przeciwnie, na podstawie wypowiedzi nauczycieli 
można wnioskować, że w tej grupie zawodowej występuje dość silny konflikt pokoleniowy, często duża niechęć „starych” wobec „młodych”. Oto kilka charakterystycznych wypowiedzi:

- Niewiele umieja, a nie potrafia zwrócić się o pomoc.

- Myśmy mieli praktyki, pisali konspekty, a oni sobie w ogóle nie radza.

- Ja akurat pracuje z koleżanką, z która różni nas granica wiekowa dwudziestu kilku lat. Jej metoda nauczania i moja metodyka nauczania to jedna wielka przepaść. Ona dostata taki warsztat praktyczny, ale tak naprawde porównanie mojej i jej praktyki to jest... W ogóle nie ma o czym mówić.

- Kompetencje mtodego nauczyciela opieraja się na tym, jak zrealizować narzucony program, a starego nauczyciela - jak nauczyć.

Do mniejszości należały, i pojawiły się tylko w "grupach dyrektorskich”, wypowiedzi wskazujące na potrzebę współpracy między nauczycielskimi pokoleniami, wyrażające otwartość i szacunek oraz wskazujące korzyści, które z takiej współpracy mogą czerpać obie strony. Chociaż i w nich widać dość stereotypowe podejście do współpracy różnych nauczycielskich pokoleń. Ilustruje to następująca wypowiedź: Najlepiej to by byto, gdyby oni mogli obserwować swoja prace nawzajem, czyli starszy nauczyciel zyskatby więcej wiedzy na temat wspótczesnych metod pracy, form pracy, niestandardowych uktadów tawek itd. Natomiast co by zyskat młody nauczyciel? Wydaje mi sie wtaśnie, że to doświadczenie, spokój, pomyst na to, jak radzić sobie w sytuacjach trudnych $z$ uczniami, dyscypline, bo myśle, że tego też brakuje mtodym nauczycielom, którzy bardzo często reaguja żywiołowo i na tyle, na ile im wlasne doświadczenie życiowe pozwala, ale nie sa jednak dostatecznie przygotowani.

Zdarzały się także pojedyncze wypowiedzi wyrażające sympatię, szacunek, a nieraz nawet podziw dla młodych nauczycieli i uznanie dla ich kompetencji, na przykład: Ja jestem wtaśnie po obserwacji lekcji dziewczyny, która jest świeżo po studiach przeprowadzata te zajęcia $w$ bardzo ciekawy sposób, a do tego $w$ momencie jak wychodzity jakieś takie sytuacje wychowawcze ona natychmiast reagowata - czyli przerywata lekcje i wyjaśniata. I myśle, że z jednej strony tego brakuje nauczycielom. Szukajac potrzeby wykazania sie na koniec roku, zeby zostat zrealizowany program, zapominaja o tych stricte spotecznych wartościach, czyli wychowywania tych dzieci, uczenia ich jak należy postępować wobec kolegi, koleżanki, którzy pochodzq z innego kraju, a coraz 
więcej jest takich klas $w$ naszym kraju. Jak radzić sobie $z$ dziećmi, które sa $z$ nizin spolecznych $i z$ marginalizowanych rodzin.

Doświadczeni nauczyciele wskazywali także, że młodzi potrzebują wsparcia w miejscu pracy. Najczęściej uważali, że powinno ono polegać na opiece mentora (poza awansem zawodowym), obowiązku odbywania szkoleń w ramach WDN, a także powinien być udoskonalony system wspierania nauczycieli przez ośrodki doskonalenia zawodowego i przez Poradnie Psychologiczno-Pedagogiczne i specjalistyczne (np. w diagnozowaniu i opracowaniu programów naprawczych, mediacjach). Nauczyciele (wszyscy, nie tylko młodzi) powinni także otrzymywać większe wsparcie psychologiczne i prawne w sytuacjach trudnych (takich jak: pomówienia, groźby, szantażowanie, wymuszanie ocen).

Czy szkoła - jej atmosfera, przekonania ludzi, którzy ją tworzą - sprzyja rozwojowi nauczycielskiej autonomii? Czy pozwala młodemu (i nie tylko młodemu) nauczycielowi osiągnąć postkonwencjonalne stadium rozwoju? Wydaje się, po analizie przedstawionych wyników, że można dostrzec wiele przeszkód w rozwoju nauczyciela w miejscu pracy. Doświadczeni nauczyciele nie są skłonni wspierać młodych kolegów w rozwoju kompetencji i uznać ich prawa do szukania własnej drogi. Jeśli widzą potrzebę ich wspierania, to uważają, że przy pomocy metodyków i opiekunów stażu powinni przejąć wzorce starszych. Wyraźny konflikt pokoleń, niechęć do współpracy, postawa obronna (a nie twórcza, otwarta na wyzwania) - „musimy być asertywni”, „musimy nie dać się rodzicom", a także brak świadomości potrzeby rozwoju nowych kompetencji odpowiadających „nowej szkole” (nauczyciele wskazywali, że potrzebne są im nowe kompetencje, ale techniczne, np. używanie nowych mediów w edukacji) może stanowić przeszkodę w rozwoju nauczycielskiej autonomii i na pewno stanowi wyzwanie dla wszystkich pracujących z przyszłymi i obecnymi nauczycielami.

Trzecie badanie dotyczyło bezpośrednio problemów rozwoju nauczycielskiej autonomii i zawodowej samodzielności. Przeprowadzono to badanie wśród czynnych nauczycieli, słuchaczy studiów podyplomowych oraz uczestników sympozjum poświęconego zmianom w edukacji, kończącego kolejną edycję studiów. Badania prowadzono w trzech grupach fokusowych. Nauczyciele różnie rozumieli pojęcie „autonomia nauczyciela”, a ich opinie odpowiadały wszystkim trzem, wcześniej przedstawionym próbom definiowania autonomii. 
Traktowanie autonomii jako wolności od kontroli zewnętrznej można dostrzec w następujących wypowiedziach nauczycieli:

- W tej szkole nie miatem autonomii. Wszystkie decyzje musiatem skonsultować $z$ dyrektorem;

- Jestem catkowicie niezależny w podejmowaniu decyzji dotyczacych mojego nauczania;

- Trudno być autonomicznym, ponieważ nauczyciel $w$ trudnych sytuacjach szkolnych czesto potrzebuje formalnej akceptacji swoich dziatań $i$ wsparcia od dyrektora.

Bardzo wielu nauczycieli traktowało autonomię jako zdolność do samodzielnego działania, organizowania swojej pracy:

- Podczas nauczania nauczyciel sam decyduje, co robić. Wszystko zależy od niego.

- Nauczanie to zawód, w którym nauczyciel tworzy swoje metody, sposoby, filozofie nauczania i dostosownje je do potrzeb swoich uczniów.

- Wrzeczywistości nauczyciel jest sam w swojej pracy i organizuje prace klasowa na swój wtasny sposób. Jest trochę artystą.

Stosunkowo rzadko pojawiały się wypowiedzi wskazujące, że autonomia wyraża się $\mathrm{w}$ samodzielnym planowaniu swojego rozwoju zawodowego:

- Mlodzi nauczyciele rzadko sq autonomiczni z powodu braku doświadczenia. Nie wiedzq co ich spotka, i czego sie jeszcze powinni nauczyć. Nie wiedzq, jak przewidzieć różne wydarzenia, $i$ jak się na nie przygotować. Często nie mogq wskazać, jakich umiejętności będa potrzebować.

Nauczyciele w zróżnicowany sposób oceniali możliwość rozwijania własnej autonomii w szkole. Ci z nich, którzy wiązali autonomię z wolnością, swobodą działania, brakiem zewnętrznej kontroli, wskazywali na dyrektora i jego styl kierowania szkołą jako czynniki decydujące o zakresie ich autonomii. Uważali, że bez znaczenia są tu uwarunkowania systemowe i prawne. Nauczyciele, którzy rozumieli autonomię jako zdolność do samodzielnego działania, planowania i organizowania swojej pracy, widzieli problemy $\mathrm{z}$ osiągnięciem autonomii raczej $\mathrm{w}$ organizacji pracy i przeciążeniu obowiązkami. Nauczyciel zmęczony, wypalony nie może być autonomiczny w swoich działaniach, raczej „popada w rutynę” i „powiela schematy”, bo jest to łatwiejsze. Braki w zakresie kompetencji komunikacyjnych, strach przed rodzicami i uczniami, brak pewności siebie, nie sprzyjają osiąganiu autonomii. Nauczyciele, którzy tak rozumieli autonomię, 
często raczej oczekiwali wsparcia dyrektora, niż obawiali się, że ograniczy on ich wolność.

Nauczycielom przedstawiono także koncepcję rozwoju i osiągania autonomii przez nauczyciela autorstwa Roberta Kwaśnicy i poproszono o ich opinię. Znaczna grupa zgodziła się z autorem, że osiągnięcie autonomii nauczycielskiej jest zwieńczeniem długiej drogi, na której najpierw uczymy się wymagań roli, powielamy wzorce wypracowane przez innych, a dopiero z czasem zyskujemy zdolność krytycznego posługiwania się wiedzą i „twórczego przekraczania roli zawodowej”. Wielu nauczycieli, zarówno młodych, jak i ze średnim stażem w zawodzie, uważało jednak, że decydują o tym czynniki indywidualne, zdolność do refleksji, twórczości, a także doświadczenie życiowe zdobyte poza zawodem nauczyciela, a w końcu talent pedagogiczny. Dość charakterystycznym jest, że takie opinie formułowali nauczyciele, którzy wybrali ten zawód jako drugi (nieraz trzeci), po długim poszukiwaniu drogi życiowej, często po powrocie zza granicy, gdzie wykonywali różne inne zawody.

\section{Podsumowanie}

Celem tego opracowania było zidentyfikowanie systemowych i mentalnych przeszkód utrudniających rozwój autonomii nauczycieli. Następnym krokiem powinno być zaproponowanie rozwiązań wzmacniających autonomię nauczycieli i ułatwiających nabywanie tych kompetencji, które prowadzą do rozwoju autonomii, zarówno w kształceniu nauczycieli, jak i w miejscu ich pracy, a także wskazanie kierunku dalszych badań tej problematyki. Rzetelne wykonanie tego zadania wykracza poza ramy tego opracowania, dlatego ograniczę się tylko do krótkiego podsumowania analizowanych zagadnień.

Doskonalenie, rozwijanie i poszerzanie zakresu nauczycielskich kompetencji w sytuacji pojawiania się nowych potrzeb uczniów i zmiany społecznej jest niezbędne dla budowania ich autonomii, rozumianej jako zdolność samodzielnego działania, oceniania tego działania oraz planowania rozwoju zawodowego. Do budowania autonomii rozumianej jako wolność od zewnętrznej presji potrzebny jest demokratyczny styl kierowania szkołą i rozwój kompetencji dyrektorów w zakresie zarządzania wspomagającego, szczególnie młodych nauczycieli. Autonomię nauczycieli trzeba także wspierać na poziomie makro - organizacyjno-prawnym, 
analizując i zmieniając wymagania dotyczące awansu zawodowego nauczycieli tak, aby w jak najszerszym zakresie wspierały rozwój kompetencji prowadzących do samodzielności myślenia i nauczycielskiej autonomii.

Niezwykle ważne dla rozwoju młodego nauczyciela są oczekiwania formułowane wobec niego w miejscu pracy i kultura szkoły, w której zaczyna podlegać procesowi stawania się nauczycielem. Brak zaufania wśród nauczycieli, brak kultury współpracy i współodpowiedzialności, silny konflikt pokoleń nauczycielskich, brak szacunku i otwartości na innych mogą utrudnić, a nawet uniemożliwić rozwój autonomii młodych nauczycieli. Wspierać nauczycielską autonomię powinni również „nauczyciele nauczycieli”. To od sposobu pracy kadry kierunków nauczycielskich, dialogu i otwartości w relacjach ze studentami, a także przekazania im rzetelnej wiedzy i kompetencji społecznych, które wzmocnią ich poczucie własnej wartości i pozwolą im się zmierzyć z problemami życia szkolnego, zależy samodzielność przyszłych nauczycieli i zdolność do rozwijania „autonomicznej tożsamości”.

\section{Bibliografia}

Andersen L.W. (1987), The Decline of Teacher Autonomy: Tears or Cheers?, "International Review of Education", nr 33, s. 357-373.

Czerepaniak-Walczak M. (1997), Aspekty i źródta profesjonalnej refleksji nauczyciela, Wydawnictwo Edytor, Toruń.

Dokument Ministra Edukacji Narodowej „Główne kierunki doskonalenia systemu edukacji w Polsce", 1994.

Dróżka W. (2017), Wartości i cele życiowe i zawodowe nanczycieli, Wydawnictwo Uniwersytetu Jana Kochanowskiego, Kielce.

Dudzikowa M. (1994), Kompetencje autokreacyjne - czy i jak możliwe do nabycia w toku studiów pedagogicznych, [w:] H. Kwiatkowska (red.), Ewolucja tożsamości pedagogiki, Instytut Historii, Nauki, Oświaty i Techniki, Warszawa.

Dworkin G. (1988), The Theory and Practice of Autonomy, Cambridge University Press, Cambridge.

Dylak S. (1995), Wizualizacja $w$ ksztatceniu nauczycieli, Wydawnictwo UAM, Poznań.

Fuller F.E. (1969), Concerns of Teacher: A Developmental Conceptualization, “American Educational Research Journal”, nr 6, s. 207-226.

Kwaśnica R. (2004), Wprowadzenie do myślenia o nauczycielu, [w:] Z. Kwieciński, B. Śliwerski (red.), Pedagogika. Podręcznik akademicki, t. 2, PWN, Warszawa.

Kwiatkowska H. (red.) (2004), Ewolucja tożsamości pedagogiki, Instytut Historii, Nauki, Oświaty i Techniki, Warszawa. 
Kwiatkowska H. (2008), Pedeutologia. Podręcznik akademicki, WAiP, Warszawa.

Little D. (1995), Learning as Dialogue. The Dependence of Learner Autonomy on Teacher Autonomy, "System", vol. 23, nr 2, s. 175-181.

Madalińska-Michalak J., Góralska R. (2012), Kompetencje emocjonalne nauczyciela, Wydawnictwo ABC Wolters Kluwer Business, Warszawa.

Madalińska-Michalak J. (2019), Kompetencje nauczyciela. Między dziataniem zgodnie z możliwościami a koniecznościq rozwoju zawodowego, [w:] I. Kopaczyńska, M. Magda-Adamowicz (red.), Dziecko w ksztatceniu instytucjonalnym. Idee - refleksje - badania, Wydawnictwo Uniwersytetu Zielonogórskiego, Zielona Góra.

Okoń W. (red.) (1962), Osobowość nauczyciela, Państwowe Zakłady Wydawnictw Szkolnych, Warszawa.

Radziewicz J. (1992), Edukacja Alternatywna, Wydawnictwa Szkolne i Pedagogiczne, Warszawa.

Rozporządzenie Ministra Edukacji Narodowej i Sportu z dnia 1 grudnia 2004 r. w sprawie uzyskiwania stopni awansu przez nauczycieli.

Smith R.C. (2000), Starting with Ourselves: Teacher-Learner Autonomy in Language Learning, [w:] B. Sinclair, I. McGrath, T. Lamb (red.), Learner Autonomy, Teacher Autonomy: Future Directions, Harlow, Logman.

Strychowski W., Strychowska J., Pielachowski J. (2007), Kompetencje nauczyciela szkoly wspótczesnej, Wydawnictwo EMPI2, Poznań.

Super D.E., Jordan J.P. (1973), Career Development Theory, "British Journal of Guidance \& Consulting”, nr 1, s. 3-16.

Tort-Moloney D. (1997), Teacher Autonomy: A Vygotskian Theoretical Framework, "CLCS Ocassional Paper", nr 48.

Wiłkomirska A. (2002), Zawodowe i spoleczno-polityczne orientacje młodzieży, Wydawnictwo Akademickie „Żak”, Warszawa.

Wiłkomirska A., Zielińska A. (2012), Is the Teachers' Advancement System a Chance for Professional Development and Better Schools? Case of Poland, Kwartalnik Pedagogiczny, nr 2 (223).

Wiłkomirska A., Zielińska A. (2013), Ocena systemu awansu zawodowego nauczycieli $w$ Polsce. Studium Empiryczne, Wydawnictwa Uniwersytetu Warszawskiego, Warszawa. 


\title{
Prawo dziecka do kontaktów z obojgiem rodziców a konflikt okołorozwodowy
}

\author{
Abstract \\ Children's right to the contact with both parents \\ and the divorce conflict
}

Family divorce is undoubtedly one of the most painful experiences in the lives of spouses and their children. However, the immaturity of younger family members, their dependence on parents, and the strong need for security and susceptibility to injury mean that the breakup of marriage is more strongly experienced by children than parents. Divorce is a kind of emotional shock for them, a critical and crisis period. As indicated by research reports and the analysis of court files, in many cases the right of minors to the contact with both parents is not respected, which is largely due to the behaviour of the parents themselves. It should be emphasized that all parents' activities, such as: rivalry between them for the child's feelings, engaging him or her in conflict with the former partner, striving to form a coalition with the child, as well as obtaining physical and mental exclusivity for the child by isolation from the other parent and devaluing him or her - should be considered as forms of emotional abuse of the youngest family members and manifestations of violation of one of the basic rights of children, which is the right to both parents.

Keywords: child, children's rights, conflict, divorce, parents, relations

Słowa kluczowe: dziecko, prawa dziecka, konflikt, rozwód, rodzice, kontakty

\section{Wprowadzenie}

W domu rodzinnym dziecko nawiązuje pierwsze kontakty z innymi ludźmi i zdobywa pierwsze doświadczenia z dziedziny współżycia społecznego. Stają się one podwaliną i zaczątkiem rozwoju społecznego małego człowieka, rzutując - nieraz w decydujący sposób - na całe jego przyszłe życie. Rodzina jest dla 
dziecka pierwszym i najważniejszym źródłem wiedzy o świecie; jest naturalnym środowiskiem, w którym człowiek rozwija się, uczy kontaktów interpersonalnych, zdobywa doświadczenia i kształtuje swoje umiejętności. W rodzinie funkcjonuje tzw. prawo pierwszych polączeń, polegające na szczególnym utrwalaniu prezentowanych w niej wzorców, które jako pierwsze poznane przez jednostkę traktowane są jako modelowe i przenoszone na inne sytuacje społeczne (Pospiszyl, Żabczyńska 1980).

Maria Przetacznik-Gierowska i Ziemowit Włodarski (1994) zwracają uwagę na ogromne znaczenie funkcji wychowawczych rodziny. Autorzy wskazują, że rodzina zaspokaja podstawowe biologiczne i psychologiczne potrzeby dziecka, takie jak: potrzebę bezpieczeństwa, zależności, miłości, a zarazem kształtuje nowe potrzeby poznawcze, emocjonalne i społeczne. Rodzina przekazuje dziecku dorobek kulturowy społeczeństwa, pośredniczy w nadawaniu przez dziecko znaczenia przedmiotom i zjawiskom z otoczenia, a także kształtuje określony system wartości i norm społecznych. Dom rodzinny stanowi teren socjalizacji dziecka uczy współdziałania w grupie i pełnienia ról społecznych.

Jak twierdzi Brunon Hołyst (1991: 85), zaburzona struktura rodziny w wyniku rozwodu, separacji lub śmierci może, ale nie musi doprowadzić do zaburzeń procesu uspołecznienia dziecka, bowiem osoba pozostająca $\mathrm{z}$ dzieckiem może stwarzać warunki wychowawcze kompensujące brak ojca lub matki. Najgorsza wychowawczo sytuacja występuje w tych rodzinach, w których rozbicie poprzedzane jest konfliktami na podłożu głębokich antagonizmów między rodzicami. Atmosfera wychowawcza w takiej rodzinie wpływa niekorzystnie na psychikę dziecka, może być przyczyną zaburzeń w zachowaniu (agresji, wagarów, ucieczek z domu itp.).

Rozstanie rodziców (rozbicie rodziny) według Alicji Czeredereckiej (2018: 30) pociąga za sobą naruszenie równowagi we wszystkich sferach funkcjonowania tworzących ją osób: psychicznej, społecznej, a nawet biologicznej. Zakłócenie to jest konsekwencją łańcucha przyczynowo-skutkowego, na początku którego znajduje się zerwanie więzi pomiędzy rodzicami, a kolejne ważne ogniwa stanowią zmiany w strukturze i funkcjach rodziny: poczynając od relacji interpersonalnych pomiędzy poszczególnymi jej członkami, występujących w niej zakłóceń w przepływie informacji lub ich całkowitego zerwania, przeformułowania funkcji pełnionych przez rodziców, dzieci, rodzeństwo. 
Problem nietrwałości związków małżeńskich implikuje wiele negatywnych konsekwencji, niosąc ze sobą wysokie koszty demograficzne, gospodarcze i moralne (Majkowski 1997). Wzrastająca liczba rozstań rodzicielskich (w świetle danych GUS liczba rozwodów w Polsce stanowi jedną trzecią spośród zawieranych małżeństw w danym okresie) powoduje konieczność poszukiwania rozwiązań w zakresie podziału opieki nad dziećmi. W wielu przypadkach tradycyjny model sprawowania opieki, w którym matka jest tak zwanym rodzicem wiodącym, spędzającym z dzieckiem większą ilość czasu, a ojciec jest tak zwanym rodzicem weekendowym, przestaje być satysfakcjonujący dla obojga rodziców, a co najistotniejsze - pojawiają się także opinie, że może nie być najkorzystniejszy dla rozwoju dziecka.

$\mathrm{Z}$ punktu widzenia współczesnej wiedzy psychologicznej kluczowym kosztem rozwodu dla dziecka wydaje się naruszenie istniejącego przywiązania z rodzicem. Zatem zachowanie więzi staje się priorytetem w planowaniu opieki po rozwodzie (Kujawa, Jezierski 2016). Teoria przywiązania dotyczyła początkowo głównie relacji dziecko - matka, co było zgodne z panującym w tamtym czasie tradycyjnym podziałem ról społecznych. Z czasem zaczęto doceniać rolę ojca w rozwoju dziecka. Co więcej, zauważono, że ojcowie mogą być główną figurą przywiązania - przykładowo odkryto, że ciepła relacja z ojcem jest predyktorem późniejszego pozytywnego rozwoju (Lucassen i in. 2011, za: Kujawa, Jezierski 2016).

\section{Prawne aspekty rozwodu}

Kwestie formalne związane z ustaniem związku małżeńskiego regulują przepisy ustawy z 25.02.1964 r. Kodeks rodzinny i opiekuńczy (Dz.U. 1964 nr 9, poz. 59). Zgodnie z art. 56 \$ 1 Kodeksu (k.r.o.) małżeństwo może być rozwiązane, jeżeli rozkład pożycia między małżonkami jest trwały i zupełny.

Obiektywne ujęcie rozkładu pożycia ułatwia z pewnością sądowi ustalenie jego istnienia na podstawie konkretnych faktów z życia małżonków. Całkowity charakter rozkładu pożycia polega na tym, że zanikły trzy zasadnicze więzi między małżonkami: więź psychiczna (uczuciowa), więź fizyczna oraz więź gospodarcza (Smyczyński 2001: 184). Gdy jednak przy zupełnym braku więzi duchowej i fizycznej pozostały pewne elementy więzi materialnej wywołane szczególnymi okolicznościami (np. wspólnym 
mieszkaniem) rozkład pożycia można mimo to uznać za zupełny (Winiarz, Gajda 2001: 124).

Drugą wymaganą cechą pożycia jest jego trwałość, tzn. przekonanie, że małżonkowie nie powrócą już do wspólnego pożycia. Przy ocenie trwałości rozkładu należy wziąć pod uwagę czas trwania małżeństwa i czas rozłączenia małżonków. Z doświadczenia życiowego wynika, że im dłużej trwa małżeństwo, tym większe istnieje prawdopodobieństwo przezwyciężenia konfliktu i powrotu do wspólnego pożycia (Smyczyński 2001: 185).

Istotną rolę w prawie rozwodowym odgrywa wzgląd na dobro wspólnych małoletnich dzieci małżonków oraz dążenie do przeciwdziałania zachowaniom, które w następstwie prowadzą do rozkładu pożycia, a także troska o to, by rozwód nie naruszał zasad współżycia społecznego. Mając na uwadze te okoliczności, Kodeks Rodzinny i Opiekuńczy nie zadowolił się uzależnieniem możliwości orzeczenia rozwodu jedynie od istnienia zupełnego i trwałego pożycia, lecz możliwość tę ograniczył dodatkowymi przesłankami. Mianowicie zakazem orzeczenia rozwodu, jeżeli wskutek niego miałoby ucierpieć dobro wspólnych małoletnich dzieci małżonków lub orzeczenie rozwodu naruszałoby zasady współżycia społecznego (art. 56 \ 2 k.r.o.), a także jeżeli rozwodu żąda małżonek wyłącznie winny rozkładu pożycia, a drugi małżonek nie wyraził zgody na rozwód, przy czym jego odmowa nie jest sprzeczna z zasadami współżycia społecznego. Przepis zabraniający udzielenia rozwodu w wypadku, gdyby wskutek niego miało ucierpieć dobro wspólnych małoletnich dzieci małżonków stawia interesy i dobro tych dzieci ponad interesy i dobro dzieci pozamałżeńskich jednego z małżonków (Winiarz, Gajda 2001: 125-126).

O dobru dziecka myśli również niejeden rodzic przed podjęciem decyzji o złożeniu pozwu rozwodowego. Bywa, że matki i ojcowie próbują wytrwać w związku tylko dlatego, że za wszelką cenę starają się funkcjonować w roli „pełnej rodziny”. Dochodzi wówczas do sytuacji, w której dwoje dorosłych próbuje zachować pozory szczęśliwego życia rodzinnego, w przekonaniu, że postępują właściwie przez wzgląd na dobro dzieci. Gdy w takich przypadkach dochodzi do rozwodu małżeństwa dotkniętego zupełnym i trwałym rozkładem pożycia, można przypuszczać, że nie wpłynie to ujemnie na dobro dziecka. Zatem skoro sami rodzice miewają dylematy co będzie lepsze dla ich dziecka - rozwód czy pozornie „pełna rodzina”, również sąd może mieć wątpliwości przed ogłoszeniem wyroku rozwodowego. 
Doświadczenie życiowe pokazuje, że atmosfera domowa wytworzona wskutek zupełnego i trwałego rozkładu pożycia zazwyczaj wywołuje w psychice dziecka i kształtowaniu jego charakteru większe szkody aniżeli orzeczenie rozwodu. Niemniej niepodobna kwestionować stanowiska judyktury, która przyjmuje, iż ustawa w przedmiocie dobra dziecka na tle sprawy rozwodowej nie stwarza żadnego domniemania. Trzeba więc problem ten wnikliwie analizować w odniesieniu do każdej rozpatrywanej sprawy (Winiarz, Gajda 2001: 127).

W wyroku rozwodowym sąd rozstrzyga o władzy rodzicielskiej nad wspólnym małoletnim dzieckiem obojga rodziców, a także o kontaktach dziecka z rodzicami. Ponadto ustala, w jakiej wysokości każdy z rodziców jest obowiązany do ponoszenia kosztów utrzymania i wychowania dziecka.

Zgodnie z art. 58 \$ 1 k.r.o. - „Sąd uwzględnia pisemne porozumienie małżonków o sposobie wykonywania władzy rodzicielskiej i utrzymywaniu kontaktów z dzieckiem po rozwodzie, jeżeli jest ono zgodne z dobrem dziecka”, a także z art. 107 \$ 1 k.r.o. „Sąd pozostawia władzę rodzicielską obojgu rodzicom, jeżeli przedstawili zgodne $\mathrm{z}$ dobrem dziecka pisemne porozumienie o sposobie wykonywania władzy rodzicielskiej i utrzymywaniu kontaktów z dzieckiem".

Porozumienie rodzicielskie można określić jako umowę między rodzicami wspólnego dziecka obejmującą swoją treścią kwestie dotyczące praw i obowiązków w relacji rodzic A - dziecko rodzic B. Umowa taka może dotyczyć zarówno praw i obowiązków pomiędzy poszczególnymi rodzicami a dzieckiem, jak i pomiędzy samymi rodzicami (Antoszek, Zajączkowska 2018). Porozumienie rodzicielskie obejmować może kwestie związane ze sposobem wykonywania władzy rodzicielskiej, utrzymywania kontaktów z dzieckiem, jak również inne obszary m.in. związane z kosztami utrzymania dziecka, jego miejscem zamieszkania czy inne istotne sprawy dotyczące małoletnich (np. wybór szkoły, formy opieki medycznej, metod wychowawczych czy utrzymywanie kontaktów z pozostałymi członkami rodziny).

Kształt porozumienia rodzicielskiego determinowany jest wzajemną relacją rodziców. Jeśli opiekunowie darzą się zaufaniem i faktycznie chcą dzielić się obowiązkami rodzicielskimi w zgodzie z dobrem dziecka, mogą pozwolić sobie na duży stopień swobody i ogólności. Jednak w sytuacji odczuwanej wrogości szczegółowe i wyczerpujące postanowienia porozumienia 
stanowią większą gwarancję zapobieżenia potencjalnym konfliktom (Antoszek, Zajączkowska 2018). Jak zauważa Alicja Czerederecka (2008), to właśnie brak uzgodnienia kwestii wychowawczych sprawia, że konflikty między rodzicami bywają bardzo nasilone i długotrwałe, utrzymując się niejednokrotnie wiele lat po rozstaniu, przy czym to dzieci stają się centralnym punktem relacji rodzinnej, a zarazem osią konfliktu.

\section{Psychologiczne konsekwencje rozwodu}

Konsekwencje rozwodu dotyczą wielu sfer życia: psychicznej, ekonomicznej, zdrowotnej, mieszkaniowej, rodzinnej, towarzyskiej i zawodowej. Rozwód jest stresującym doświadczeniem, często traktowanym jako sytuacja trudna. Według skali wskaźników zmian życiowych znajduje się na drugim miejscu - zaraz za śmiercią współmałżonka (Holmes, Rahe 1967; za: Grudziewska 2015: 39).

Rozpad małżeństwa jest wydarzeniem, które zmienia dotychczasowe funkcjonowanie wszystkich członków rodziny. Destruktywny jest najpierw konflikt przedrozwodowy, a następnie funkcjonowanie $\mathrm{w}$ rodzinie niepełnej. Każde $\mathrm{z}$ rozwodzących się małżonków w indywidualny sposób radzi sobie z tą sytuacją. Ludwika Wojciechowska (1984) zauważa, że stres, jaki przeżywają rozwodzący się małżonkowie, jest proporcjonalny do siły związku emocjonalnego, jaki istniał pomiędzy nimi.

Małżeństwa, które decydują się na rozwód mimo wcześniejszych prób ratowania swojego związku muszą przyznać, że istotny jest sposób, w jaki dochodzi do rozstania.

Anna Pohorecka (1994) do niekorzystnych sposobów rozstania dla samych małżonków, a w szczególności dla dzieci, zalicza:

- uciekanie z domu niepoprzedzone jasnym i otwartym załatwieniem spraw ze współmałżonkiem/partnerem;

- niepełne rozstanie się, tzw. życie na dwa domy;

- składanie pozwu rozwodowego, aby wymusić coś na małżonku/partnerze, bez zamiaru rozstania się;

- wspólne mieszkanie po rozwodzie;

- rozstawanie się $\mathrm{w}$ walce; wzajemne poniżanie się, ranienie i oskarżanie małżonków/partnerów.

Radzenie sobie z rozstaniem jest swoistym procesem, w którym można wyróżnić następujące po sobie etapy, w których towarzyszą rozwodzącym się małżonkom różne emocje. Pierwszy etap 
to rozwód emocjonalny, kiedy dochodzi do zanikania czułości, miłości, a nawet życzliwości w kontaktach pomiędzy małżonkami. Drugim etapem jest rozwód w świetle prawa. Oprócz przykrych emocji pojawiają się w tej fazie bardzo często urazowe przeżycia np. publiczne omawianie osobistych spraw. Jest to czas silnego napięcia dla obu stron konfliktu, nasila się lęk przed oceną innych ludzi oraz poczucie wstydu. $\mathrm{Na}$ tym etapie pojawia się konieczność podjęcia wielu ważnych decyzji podczas rozprawy rozwodowej i uporządkowania spraw codziennych. Ostatnia faza to rozwód psychiczny. Mimo że w świetle prawa małżonków nic już nie łączy, to towarzyszy im silny stres emocjonalny (około roku). Na tym etapie rodzina wypracowuje nowe sposoby funkcjonowania, np. dotyczące organizacji życia domowego. Zmianie ulegają także relacje towarzyskie, konieczna jest naturalna selekcja bliższych i dalszych znajomych, zanikają też często kontakty z rodziną byłego małżonka. Warto nadmienić, że dorośli na tym etapie powinni zwrócić uwagę na emocje towarzyszące dzieciom i w miarę możliwości pomóc im je odreagować (Jelonkiewicz 1994).

Rozwód w rodzinie jest niewątpliwie jednym z najbardziej bolesnych przeżyć w życiu małżonków oraz ich dzieci. Jednak niedojrzałość młodszych członków rodziny, ich zależność od rodziców oraz silna potrzeba bezpieczeństwa i podatność na zranienia sprawiają, że rozpad małżeństwa silniej przeżywają dzieci aniżeli rodzice. Rozwód jest dla nich swoistym wstrząsem emocjonalnym, okresem krytycznym i kryzysowym (Lewicka-Zelent, Wąsik 2015).

Relacja rozwodzących się lub rozwiedzionych rodziców staje się podstawą wykreowania obrazu świata i obrazu siebie jako osoby funkcjonującej w tym świecie (Beisert 2008). Na podstawie wyników badań empirycznych Maria Beisert (2008) wskazuje trzy czynniki wpływające w sposób istotny na efektywne radzenie sobie dziecka z rozwodem:

- rodzaj relacji łączącej rodziców;

- jakość kontaktów dziecka z rodzicami;

- sposób, w jaki rodzice radzą sobie z kryzysem rozwodu.

Konsekwencje rozwodu są niekorzystne dla dziecka na każdym etapie jego rozwoju. Zarówno niemowlęta, jak i dzieci w wieku starszym, a także osoby dorosłe przeżywają następstwa rozstania matki i ojca. Jednak według większości badaczy najbardziej „niekorzystnym czasem na rozwód rodziców” jest preadolescencja (11-13 lat), gdyż w tym wieku dziecko jest już doskonale 
zorientowane w sytuacji domowej, ale nie jest na tyle silne, aby poradzić sobie z ciężarem własnych emocji i przeżyć (Rusinkiewicz 2015). Nastolatki często oczekują od dorosłych wynagrodzenia za straty związane z rozwodem w formie materialnej. Niekiedy dzieci zawierają przymierze z jednym z rodziców, równocześnie odtrącając drugiego (Herbert 2005).

Opis funkcjonowania dzieci rozwiedzionych rodziców z podziałem na różne grupy wiekowe znajdziemy w publikacjach wielu autorów (por. Skalska 1991; Stojanowska 1997; Farnicka 2000; Kuśmierz 2000; Cudak 2004; Herbert 2005; Beisert 2008; Lewicka-Zelent, Korona 2015).

\section{Prawo dziecka do obojga rodziców}

Jak piszą Marek Michalak i Paweł J. Jaros (2014) nie ulega wątpliwości, że prawa dziecka są typem praw człowieka, natomiast podmiotowość dziecka opiera się głównie na uznaniu, że jest ono osobą, której ze względu na niedojrzałość pod względem psychicznym i fizycznym należy się szczególna troska i ochrona ze strony dorosłych.

Według Jolanty Szempruch (2009) istotą podmiotowości jest osobista sprawczość, czyli świadoma aktywność, w trakcie której człowiek dokonuje samodzielnych wyborów i podejmuje decyzje, stając się niejako twórcą zdarzeń i stanów, przez co wywiera wpływ na otoczenie, na swoje zachowanie i swój los, przejmując odpowiedzialność za swoje życie. Co istotne, jest to kategoria stopniowalna - można być (bywać) podmiotem i odczuwać własną podmiotowość w różnym stopniu i zakresie. Podmiotowość uważa się także za cechę, która nie jest wrodzona, lecz do której jednostka dojrzewa w procesie rozwoju (Majczyna 2000).

Podmiotowość przejawia się w szczególnym sposobie traktowania dziecka, który zdaniem Bożeny Gulli (2009: 64) polega na szacunku, przypisywaniu mu autorstwa własnych działań, pozostawianiu możliwości podejmowania decyzji, uznawaniu prawa do rozwoju w nienarzucanym kierunku, na akceptowaniu osoby, mimo braku akceptacji niektórych jej zachowań, w końcu na zaniechaniu działań związanych z poniżaniem, dewaluowaniem, ośmieszaniem i ignorowaniem w relacjach.

Lucjan Miś i Katarzyna Ornacka (2015) uważają, że dzieci w większości współczesnych krajów europejskich narażone są na traktowanie ich jako przedmiotów, pomimo politycznych 
i kulturowych uregulowań co do ich ważności i należnego im szacunku. Dzieci często służą dorosłym do zaspokojenia ich własnych potrzeb, na przykład potrzeby opieki, ochrony, a czasami odwrotnie - do zaniedbywania, molestowania czy maltretowania. $\mathrm{Na}$ podstawie przeprowadzonych wśród polskich dzieci badań Miś i Ornacka (2015) wskazują, że w relacji dziecko - dorosły dochodzi do naruszenia zasad kluczowych dla budowania podmiotowości, co równa się przedmiotowemu traktowaniu najmłodszych. Nie ma znaczenia, czy dziecko jest wychowankiem instytucji pomocowej czy członkiem sprawnie funkcjonującego systemu rodzinnego. Instrumentalne podejście dorosłych, pozbawione empatii oraz szacunku wobec drugiej osoby, prowadzi prędzej czy później do poważnych zakłóceń w komunikacji. Jak wynika z badań przeprowadzonych przez ww. autorów, dorośli zawłaszczają przestrzeń dziecka, przyznając sobie prawo do narzucania kierunku jego rozwoju. W rezultacie dzieciństwo przestaje być beztroskim okresem, w którym dziecko ma możliwość poznawania świata i otaczających go ludzi przez swobodną zabawę. Dziecko staje się projektem swoich rodziców bądź opiekunów, którzy nadają mu cechy pożądanego produktu, starając się je za wszelką cenę dostosować do wymogów współczesnego świata (Miś, Ornacka 2015: 73).

Manfred Liebel (2004) podkreśla, że dzieci mają swoje zasadnicze prawa i są zdolne do brania udziału we wszystkich decyzjach, które ich dotyczą, i do ostatecznego określenia swojego życia. Prawa te zostały zapisane przede wszystkim w deklaracjach różnych organizacji międzynarodowych i w ustawach państw narodowych (za: Miś, Ornacka 2015).

Potrzeba otoczenia dziecka szczególną troską została po raz pierwszy wyrażona w przyjętej w 1924 r. przez Zgromadzenie Ogólne Ligi Narodów Deklaracji Praw Dziecka, która zważywszy na niedawne doświadczenia wojenne wzywała do zapewnienia dzieciom opieki i pomocy, szczególnie w sytuacji zagrożenia. Następnie w Deklaracji Praw Dziecka przyjętej przez Zgromadzenie Ogólne Organizacji Narodów Zjednoczonych w 1959 r. uznano, że „dziecko z racji swej fizycznej i umysłowej niedojrzałości potrzebuje specjalnej ochrony i opieki, w tym odpowiedniej ochrony prawnej przed, jak i po urodzeniu" (Michalak, Jaros 2014).

Najobszerniejszy katalog praw dziecka znajduje się w Konwencji o prawach dziecka (Kpd) uchwalonej w 1989 r. przez Zgromadzenie 
Ogólne Organizacji Narodów Zjednoczonych i ratyfikowanej przez Polskę w 1991 r. W preambule Kpd uznano m.in., iż „dziecko dla pełnego i harmonijnego rozwoju swojej osobowości powinno wychowywać się w środowisku rodzinnym, w atmosferze szczęścia, miłości i zrozumienia”. Na podmiotowe traktowanie dziecka wskazują m.in. art. 7 i $8 \mathrm{Kpd}$, dotyczące obowiązku sporządzenia natychmiast po narodzinach aktu urodzenia dziecka, otrzymania nazwiska i nabycia obywatelstwa. W następnej kolejności należy wymienić prawo dziecka do rodziny, które wynika z art. 5, 9 i 18 konwencji (Smyczyński 1999).

$\mathrm{Na}$ gruncie systemu prawa polskiego należy odnieść się do treści art. 18 Konstytucji Rzeczpospolitej Polskiej. Artykuł ten przewiduje ochronę i opiekę państwa wobec małżeństwa, rodziny, macierzyństwa i rodzicielstwa. Michalak i Jaros (2013: 21) twierdzą, że mimo iż ww. artykuł literalnie nie wymienia ojcostwa, nie może budzić wątpliwości, że również ono znajduje się pod ochroną i opieką Rzeczpospolitej Polskiej. Tezę taką uzasadniają obejmowaniem przez termin rodzicielstwo również ojcostwa.

Zdaniem Michalaka i Jarosa (2013: 40) naturalne prawo dziecka do rodziców będzie oznaczało jego prawo do takich relacji z rodzicami, w których godność, podmiotowość i wolność dziecka będą szanowane, które stworzą najlepsze warunki dla jego rozwoju osobowego i materialnego z wzajemnością z jego strony wobec rodziców. Natomiast po stronie państwa będzie oznaczało istnienie obowiązku wobec każdego dziecka do zapewnienia warunków wykonywania tego prawa, a więc realizacji właśnie takich relacji dziecka z rodzicami, w ramach których urzeczywistniana jest odpowiedzialność rodzicielska. Michalak i Jaros w jednej ze swoich publikacji wymieniają obszerny katalog praw wchodzących w skład prawa dziecka do rodziców. Zdaniem autorów na zawartość materialną tego prawa będzie się składać:

- zasada, że to rodzice ponoszą wspólnie główną odpowiedzialność za wychowanie i rozwój dziecka oraz jak najlepsze zabezpieczenie interesów dziecka ma być przedmiotem ich największej troski (art. 18 ust. $1 \mathrm{Kpd}$ );

- prawo dziecka do niepozostawania oddzielonym od rodziców wbrew ich woli, chyba że oddzielenie takie jest konieczne ze względu na najlepiej pojęte interesy dziecka (art. 9 ust. $1 \mathrm{Kpd);}$

- prawo dziecka odseparowanego od jednego lub obojga rodziców do utrzymywania bezpośrednich kontaktów z obojgiem rodziców (art. 9. ust. $2 \mathrm{Kpd}$ ); 
- prawo dziecka do otrzymywania istotnych informacji o miejscu pobytu rodziców na wypadek działań podjętych przez państwo - zatrzymania, uwięzienia, wygnania, deportacji lub śmierci jednego lub obojga rodziców (art. 9 ust. $4 \mathrm{Kpd}$ );

- prawo dziecka do utrzymywania regularnych, osobistych stosunków i bezpośrednich kontaktów z rodzicami przebywającymi w różnych państwach z wyjątkiem okoliczności nadzwyczajnych (art. 10 ust. 2. Kpd);

- prawo dziecka do poznania swoich rodziców i pozostawania pod ich opieką (art. 7 ust. $1 \mathrm{Kpd}$ );

- prawo dziecka do zapewnienia mu możliwości ukierunkowywania go i udzielania mu rad przez rodziców przy korzystaniu przez nie z przysługujących mu praw oraz do poszanowania odpowiedzialności, praw i obowiązków rodziców w tym zakresie (art. $5 \mathrm{Kpd}$ );

- prawo dziecka do respektowania praw i obowiązków rodziców odnośnie do ukierunkowania go w korzystaniu z prawa do swobody myśli, sumienia i wyznania (art. $14 \mathrm{Kpd);}$

- prawo dziecka do zachowania tożsamości, w tym obywatelstwa, nazwiska i stosunków rodzinnych (art. $8 \mathrm{Kpd}$ );

- prawo dziecka do ochrony przed arbitralną lub bezprawną ingerencją $\mathrm{w}$ sferę jego życia prywatnego, rodzinnego lub domowego (art. $16 \mathrm{Kpd}$ );

- prawo dziecka pozbawionego czasowo lub na stałe środowiska rodzinnego do adopcji lub rodziny zastępczej (art. 20 $\mathrm{Kpd}$ );

- prawo dziecka uchodźcy do odnalezienia jego rodziców (art. 22 ust. $2 \mathrm{Kpd}$ );

- prawo dziecka do zapewnienia mu łożenia na jego utrzymanie ze strony rodziców (art. 27 ust. 4 Kpd);

- prawo dziecka do zapewnienia, by rodzice ponosili główną odpowiedzialność za zabezpieczenie mu, w ramach swych możliwości finansowych, warunków życia niezbędnych do rozwoju oraz do wspomagania rodziców w realizacji tego prawa (art. 27 ust. $2 \mathrm{Kpd}$ );

- prawo dziecka do korzystania z systemu zabezpieczenia społecznego, w tym ubezpieczeń socjalnych, z uwzględnieniem, tam gdzie to możliwe, zasobów i warunków życia dziecka oraz jego rodziców (art. $26 \mathrm{Kpd}$ );

- prawo dziecka do ukierunkowania nauki na rozwijanie w nim szacunku dla jego rodziców (art. 29 ust. 1 lit. c Kpd); 
- prawo do pomocy rodziców w postępowaniu karnym (art. 40 ust 2 lit. b Kpd) oraz do utrzymywania z nimi kontaktów w przypadku pozbawienia wolności (art. 37 lit. c Kpd) (za: Michalak, Jaros 2014: 39-40).

Pomimo istnienia zaprezentowanego powyżej katalogu praw dziecka dotyczących m.in. jego kontaktów z obojgiem rodziców, doświadczenia życiowe pokazują, że w wielu sytuacjach pojawiają się trudności ich egzekwowania, związane z różnorodnymi obszarami i etapami funkcjonowania rodziny. Począwszy od ustaleń dokonywanych przez sąd $\mathrm{w}$ trakcie procesu rozwodowego az po realizację tych praw poprzez działania podejmowane przez samych rodziców.

Ustalenie, jakie rozstrzygnięcie sądu będzie zgodne z dobrem dziecka, jest często bardzo trudne w sytuacji ostrego konfliktu między rodzicami, którzy niejednokrotnie nie potrafią lub nie chcą postawić na pierwszym miejscu potrzeb emocjonalnych dziecka i jego uczuć, także w stosunku do drugiego z rodziców. Ważniejsze są bowiem dla nich własne negatywne emocje wobec byłego partnera, wynikające $\mathrm{z}$ ich osobistych relacji, które nie są związane bezpośrednio z osobą dziecka (Wicherek 2018: 15-16). Często pomimo wyraźnych deklaracji, że najważniejsze jest dziecko i jego dobro, parom bardzo trudno jest na nim właśnie się skoncentrować. Jak zauważa Maria Kujawa (2018: 129) dziecko jest autonomicznym podmiotem (osobą niepowtarzalną) i nie można od niego wymagać, aby swoje uczucia dzieliło po połowie w stosunku do każdego z rodziców.

Dla lepszego społecznego zrozumienia praktycznego wymiaru kształtowania relacji rodzice - dziecko w kontekście rozstania rodziców, w 2013 r. ówczesny Rzecznik Praw Dziecka Marek Michalak przeprowadził kampanię społeczną pt. Jestem mamy $i$ taty. Celem przedsięwzięcia było zwrócenie uwagi na problem niewłaściwego angażowania dziecka w sprawy rozwodowe oraz wikłania go w konflikt lojalnościowy, bowiem z perspektywy dziecka największym problemem podczas rozwodu są towarzyszące mu destrukcyjne zachowania dorosłych. Ze spraw, które trafiają do Rzecznika Praw Dziecka z prośbą o interwencję, wynika, że skłóceni rodzice czy opiekunowie nie przebierają w środkach walki między sobą. Dziecko mimowolnie staje się uczestnikiem wielu sytuacji, które poważnie naruszają jego poczucie bezpieczeństwa. W rezultacie chaos spowodowany rozstaniem sprawia, że prawa dziecka schodzą na dalszy plan (Michalak, Jaros 2014: 46). 


\section{Sytuacja dziecka w sytuacji konfliktu okołorozwodowego}

Wraz z upływem czasu reakcje dzieci na rozwód i związany z nim stres zmieniają się. Joanna Rusinkiewicz (2015: 32-33) zwraca uwagę, że w pierwszej fazie następuje proces wypierania rozwodu. Dziecko unika tematu rozstania rodziców, izoluje się, może być hałaśliwe. Następnie wkracza w fazę złości - walczy o rodzinę, kierując swój żal i gniew w stronę rodziców, jak i innych osób (np. nauczycieli). Taka postawa dziecka może przerodzić się w zaburzenia wymagające intensywniejszej opieki nad nim, a choroba dziecka spaja rodziców, którzy w trosce o jego dobro podejmują wspólne decyzje. Kiedy natomiast następuje faza przygnębienia czy wręcz depresji, dziecko staje się apatyczne, bezradne i żałuje poprzednich zachowań.

Sytuacja konfliktowa między rodzicami skutkuje utratą lub zaburzeniem u dzieci poczucia bezpieczeństwa i stabilizacji, a także w wielu przypadkach zaniżeniem samooceny. Maria Przetacznik-Gierowska (1994) wśród skutków obserwowanych u dziecka angażowanego w konflikt między rodzicami przed, w trakcie oraz po rozwodzie wymienia: załamanie się dotychczasowego obrazu każdego z rodziców, rodziny jako nienaruszalnej całości, poczucie osamotnienia i bezradności, zagrożenie poczucia bezpieczeństwa i przynależności, którym często towarzyszą objawy nerwicowe.

Potencjalnie to dorośli mają wpływ na przebieg rozwodu, kontrolują sytuację, a przynajmniej do pewnego stopnia mogą przewidzieć, co się będzie działo. Dziecko natomiast czuje się bezsilne, ponieważ nie ma żadnego wpływu na rozstanie rodziców i związane z tym konsekwencje. Silny stres wywołany napiętą atmosferą w domu może przyczynić się do wystąpienia zaburzeń psychosomatycznych (Lewicka-Zelent, Wąsik 2015).

Doniesienia z badań wskazują, że łatwiej z rozwodem radzą sobie dzieci, które są pewne siebie i świadome swoich mocnych stron, samodzielne, znające różne strategie radzenia sobie ze stresem i potrafiące je stosować. Natomiast dużo gorzej radzą sobie z rozwodem te dzieci, które w trakcie rozstania rodziców obciążane są emocjami i zadaniami, które powinny dotyczyć osób dorosłych oraz doświadczają parentyfikacji (Śniegulska 2018).

Zjawisko „parentyfikacji” występuje w rodzinie, jeśli dziecko opiekuje się dorosłym (najczęściej rodzicem) w sposób nieadekwatny do swojego wieku i możliwości, przyjmując na siebie 
rolę dorosłego (Schier 2014). Parentyfikacja może mieć dwa oblicza - instrumentalne, gdy dziecko dba o byt rodzica, np. zdobywa jedzenie, gotuje, sprząta, karmi, oraz emocjonalne, które polega na tym, że dziecko wspiera psychicznie - pociesza, wysłuchuje, doradza, rozwiązuje problemy. Często rozwodzący się rodzice szukają w dziecku powiernika własnych trosk, zwierzają mu się, oczekują wsparcia i zrozumienia. Mały człowiek zostaje wówczas obarczony ładunkiem informacji, którego nie jest w stanie udźwignąć. Efektem parentyfikacji w dorosłym życiu są m.in. depresja, obniżona samoocena, zaburzony stosunek do własnego ciała, poczucie osamotnienia i niezrozumienia, choroby psychosomatyczne (Schier 2014).

Badania wskazują, że u dzieci, które przeżyły rozwód swoich rodziców, częściej występują problemy rozwojowe. Doświadczenie rozwodu w dzieciństwie zwiększa prawdopodobieństwo wykształcenia się przywiązania pozabezpiecznego w późniejszym wieku (Lewis, Feiring, Rosenthal 2000; za: Kujawa, Jezierski 2016). Wyniki badań Marii Beisert (2008) wskazują, że tendencje odwetowe matek wobec ojców sprzyjają wzrostowi agresji i niższym kompetencjom społecznym u dzieci. Ojcowie tymczasem wpływają na poziom przystosowania się dziecka do sytuacji rozwodu za pomocą własnej efektywności, jak i sposobu, w jaki wypełniają swoje role rodzicielskie przed rozstaniem.

Większość autorów podkreśla, że nie tyle sam rozwód, co kontynuowanie konfliktu pomiędzy rodzicami, a jeszcze bardziej angażowanie dziecka w konflikt, manipulowanie nim, indoktrynacja przeciw drugiemu opiekunowi i ograniczanie swobodnych kontaktów z drugoplanowym opiekunem powodują zaburzenia w rozwoju dzieci i utrudniają ich adaptację do sytuacji kryzysowej, w jakiej się znalazły (por. Pohorecka 1994; Stojanowska 1997; Czerederecka 2018).

Konsekwencje takiego postępowania dla dzieci zostały po raz pierwszy przedstawione w koncepcji amerykańskiego psychiatry Gardnera (1985) jako syndrom oddzielenia od opiekuna (parental alienation syndrome - PAS). Autor opisał to zjawisko jako pojawiające się niemal wyłącznie w kontekście sądowej walki o uregulowanie władzy rodzicielskiej, a za jego podstawowy przejaw uznał nieuzasadnioną „kampanię” oczerniania wybranego opiekuna, która jest wynikiem kombinacji programowania („prania mózgu”), indoktrynacji przez jednego opiekuna z jednej strony, z drugiej zaś własnego wkładu dziecka w szkalowanie drugiego 
opiekuna. Jednocześnie dodawał, że jeśli w rzeczywistości mają miejsce nadużycia lub zaniedbania ze strony drugiego opiekuna, niechęć dziecka może być uzasadniona i wówczas wyjaśnianie wrogości dziecka syndromem alienacji rodzicielskiej jest nieuzasadnione (Gardner 2000, za: Czerederecka 2008).

Przez kilkanaście lat obserwowano znaczne zainteresowanie zjawiskiem PAS, jednak na przełomie lat 90. i początku pierwszej dekady XXI w. pojawiły się głosy krytyczne, które szybko przerodziły się w oznaki zdecydowanego odrzucenia koncepcji. Podstawowy zarzut dotyczył braku wystarczającej literatury specjalistycznej, która potwierdzałaby wartość naukową tez przedstawianych przez Gardnera, nieprecyzyjność (nienaukowość) języka używanego przez niego do opisu zjawiska, nieuwzględnienie syndromu w klasyfikacji chorób DSM-IV (Diagnostic and Statistical Manual of Mental Disorders) (Czerederecka 2008). Obecnie amerykańscy psychologowie i psychiatrzy sądowi są skłonni doceniać wkład Gardnera w opis tego zjawiska, skłaniają się jednak ku określeniu parental alienation, pomijajac słowo syndrome, a więc odmawiając podstaw do uznania syndromu za jednostkę chorobową (Ackerman 2006; za: Czerederecka 2008).

Polskie badania prowadzone przez Alicję Czerederecką i Teresę Jaśkiewicz-Obydzińską (1996) potwierdzają występowanie zależności opisanej przez Gardnera (za: Czerederecka 2008). Autorki stwierdzają, że im bardziej rodzice rywalizujący o przejęcie opieki nad dzieckiem manipulowali nim i angażowali je w konflikt, im bardziej aktywne formy nacisku stosowali, tym poważniejsze zaburzenia obserwowano we wszystkich obszarach rozwoju psychicznego dziecka. Poważniejsze zaburzenia odnotowano ponadto u dzieci, których rodzice demonstrowali względem siebie postawy opozycyjne, angażowali szersze otoczenie w konflikt lub prezentowali nieadekwatne, patologiczne formy zachowania.

Jak wynika z wyżej przedstawionych rozważań, rozbicie rodziny zawsze jest dla dziecka sytuacją trudną i związaną z wieloma obciążeniami emocjonalnymi. Jednakże warto podkreślić, że to od rodziców w dużej mierze zależeć będzie, jak dziecko poradzi sobie z zaistniałymi zmianami w środowisku rodzinnym, i jak będzie funkcjonować $w$ relacji z każdym z nich. Celem wyboru określonej formy opieki po rozwodzie jest minimalizacja kosztów psychologicznych, które ponosi dziecko, szczególnie tych związanych z naruszeniem warunków sprzyjających rozwojowi przywiązania (Kujawa, Jezierski 2016). 
Powszechnie znany jest pogląd, że nie istnieje na świecie taka forma modelu sprawowania opieki przez rozwiedzionych rodziców, która byłaby idealna dla każdego dziecka. Ze względu na różnice indywidualne między dziećmi oraz między rodzinami każdy przypadek należałoby rozpatrywać osobno, a zadaniem specjalistów (w tym psychologów, pedagogów) jest wskazanie korzyści i kosztów, które poniesie dziecko w proponowanych rozwiązaniach (Kujawa, Jezierski 2016).

W kontekście podejmowanej tematyki związanej z umożliwieniem dziecku realizacji jego praw do obojga rodziców - zasadnym wydaje się poszukiwanie takiego rozwiązania, które umożliwi dziecku znajdującemu się w sytuacji okołorozwodowej zachowanie więzi z każdym z rodziców oraz zbliżony udział zarówno matki, jak i ojca w jego wychowaniu. Powyższa zasada odnosi się zarówno do kwestii opiekuńczych, wychowawczych, edukacyjnych, czy zdrowotnych, jak również związanych ze spędzaniem czasu wolnego. Model zbliżonego udziału w wychowaniu dziecka po rozwodzie bywa różnie nazywany. W polskim piśmiennictwie najczęściej mówi się o „opiece naprzemiennej” lub „pieczy naprzemiennej”.

Piecza naprzemienna to ustalona $\mathrm{w}$ drodze odpowiednich postępowań sądowych formuła sprawowania pieczy nad dzieckiem polegająca na tym, że dziecko - zgodnie ze z góry określonym harmonogramem - będzie na przemian przebywać w równych lub zbliżonych okresach u każdego z rodziców (Domański 2015), o ile przysługuje im pełna władza rodzicielska i - co najtrudniejsze do zweryfikowania, a jednocześnie stanowi kwestię kluczową - oboje deklarują zamiar wspólnego i spójnego wychowywania dziecka, a ich deklaracja jest dla sądu wiarygodna (Andrzejewski 2018).

Warto podkreślić, że następujące po sobie okresy przebywania dziecka u każdego z rodziców nie muszą być równe. $\mathrm{Z}$ wielu powodów może to być nawet niemożliwe lub niewskazane (np. ze względu na charakter pracy rodzica w zawodzie aktora, pilota czy policjanta). Dlatego o pieczy naprzemiennej mowa jest wtedy, gdy owe okresy są równe, jak i wówczas, gdy są zbliżone i wynoszą np. 60\% do 40\% (Smyth 2017; za: Andrzejewski 2018).

Jak zauważa Marek Andrzejewski (2018: 90):

specyficznym czynnikiem, jaki w Polsce bezpośrednio przyczynił się do postawienia postulatu orzekania pieczy naprzemiennej w sprawach o rozwód i miał decydujący wpływ na gorącą atmosferę społecznej debaty na ten temat, była kilkudziesięcioletnia nieudolność polskiego ustawodawcy, a także polskich sądów i organów egzekucyjnych 
w kwestii respektowania prawa dziecka do kontaktów z obojgiem rodziców w przypadku życia w odseparowaniu (art. 9 ust. 3 Konwencji o Prawach Dziecka).

W literaturze przedmiotu brak jest jednoznacznego stanowiska co do warunków uniemożliwiających sprawowanie opieki nad dzieckiem w modelu pieczy naprzemiennej. Kujawa i Jezierski (2016) wymieniają następujące aspekty, które warto wziąć pod uwagę przed podjęciem decyzji o takiej formie sprawowania opieki: właściwości środowiska rodzinnego (np. baza materialno-lokalowa, odległość między miejscami zamieszkania rodziców, rodzaj ich pracy zawodowej), oczekiwania i motywy rodzica dotyczące przyjętej formy opieki (np. czy dominują motywy egocentryczne czy te związane z realnymi potrzebami dziecka), właściwości rodzica (m.in. choroby, dysfunkcje, uzależnienia, tendencje do stosowania zachowań przemocowych), umiejętności komunikacyjne rodziców, a także właściwości dziecka (m.in. okres rozwojowy, przywiązanie między dzieckiem a rodzicami).

Rozpatrując możliwość orzeczenia wykonywania wspólnej władzy rodzicielskiej poprzez naprzemienną opiekę nad dzieckiem, wielu autorów i specjalistów podnosi wątek związany z istniejącym między rodzicami konfliktem. Linda Nielsen (2017) uważa, że poziom konfliktu pomiędzy rodzicami i jakość ich współpracy w opiece nad dziećmi nie są tak silnie związane z dobrostanem dziecka, jak jakość relacji rodzic - dziecko (za: Czerederecka 2018: 140). Argumentów przeciwko powoływaniu się na konflikt rodzicielski jako przeciwwskazanie do ustalenia opieki naprzemiennej dostarczają także wyniki badań, które wskazują na brak różnic w nasileniu nieporozumień pomiędzy rodzicami sprawującymi opiekę naprzemienną i realizującymi pieczę $\mathrm{w}$ innych trybach zarówno w momencie rozstawania się, jak i w okresie następującym po rozwodzie (Czerederecka 2018: 142).

\section{Podsumowanie}

Z uwagi na ograniczenia objętościowe niniejszego tekstu poruszane zagadnienia zostały przedstawione w sposób ogólny, w niektórych przypadkach jedynie zasygnalizowano kwestie wymagające pogłębionej analizy (m.in. problem alienacji rodzicielskiej czy pieczy naprzemiennej w sytuacji konfliktu między rodzicami). 
Jak wskazują doniesienia z badań oraz analizy akt sądowych, w wielu przypadkach prawo małoletnich do kontaktów z obojgiem rodziców nie jest respektowane, co wynika w znacznej mierze z postępowania samych rodziców. Skłóceni małżonkowie, skoncentrowani na udowodnieniu własnych racji oraz winy strony przeciwnej, prezentują poważne trudności w oddzieleniu spraw małżeńskich od rodzicielskich.

W związku z powyższym bardzo istotne są inicjatywy podejmowane przez Rzecznika Praw Dziecka (publikacje i kampanie społeczne dotyczące prawa dziecka do obojga rodziców), Komitet Ochrony Praw Dziecka (wydanie „Standardów pomocy dziecku w sytuacji rozstania rodziców" - poradnik dla rodziców i profesjonalistów) czy Stowarzyszenie Pelikan (wydanie poradnika dla rodziców - „Dziecko w rozwodzie”). Wszystkie ww. działania mają na celu ochronę dzieci oraz zwiększenie świadomości rodzicielskiej w zakresie potrzeb $\mathrm{i}$ interesów małoletnich znajdujących się w procesie rozpadu rodziny. Co ważne, podejmowane inicjatywy służą także profesjonalistom pracującym z dziećmi i rodzicami rozwodzącymi się.

Należy podkreślić, że wszystkie działania rodziców, takie jak: rywalizacja między nimi o uczucia dziecka, angażowanie go w konflikt z byłym partnerem, dążenie do stworzenia koalicji z nim, a także do uzyskania fizycznej i psychicznej wyłączności do dziecka poprzez izolowanie od drugiego z rodziców i dewaluowanie go (za: Czerederecka 2018) należy uznać za formy krzywdzenia emocjonalnego najmłodszych członków rodziny i przejawy łamania jednego z podstawowych praw dzieci, jakim jest prawo do obojga rodziców.

\section{Bibliografia}

Andrzejewski M. (2018), Piecza naprzemienna - między formalna dopuszczalnościa a merytoryczna zasadnościq jej orzekania, [w:] Rodzina w sytuacji okołorozwodowej. Współczesne dylematy psychologiczne i prawne, Wydawnictwo Instytutu Ekspertyz Sądowych, Kraków.

Antoszek T., Zajączkowska J. (2018), Porozumienie rodzicielskie jako rezultat mediacji, [w:] A. Czerederecka (red.), Rodzina w sytuacji okolorozwodowej. Wspótczesne dylematy psychologiczne i prawne, Wydawnictwo Instytutu Ekspertyz Sądowych, Kraków.

Beisert M. (2000), Rozwód. Proces radzenia sobie z kryzysem, Wydawnictwo Fundacji Humaniora, Poznań.

Beisert M. (2008), Strategie radzenia sobie z rozwodem rodziców podejmowane przez dzieci w wieku dorastania, [w:] „Dziecko krzywdzone. Teoria, badania, praktyka”, t. 7, nr 4. 
Czerederecka A. (red.) (2018), Rodzina w sytuacji okołorozwodowej. Wspólczesne dylematy psychologiczne i prawne, Wydawnictwo Instytutu Ekspertyz Sądowych, Kraków.

Czerederecka A. (2008), Manipulowanie dzieckiem przez rodziców rywalizujacych o udziat w opiece, [w:] „Dziecko krzywdzone. Teoria, badania, praktyka”, t. 7 , nr 4.

Cudak H. (2004), Funkcjonowanie dzieci z matżenstw rozwiedzionych, Wydawnictwo Adam Marszałek, Toruń.

Domański M. (2015), Orzekanie o pieczy naprzemiennej w wyrokach rozwodowych, Instytut Wymiaru Sprawiedliwości, Warszawa.

Farnicka M. (2000), Sposoby radzenia sobie z rozwodem przez dzieci, „Wychowanie na co dzień”, nr 3.

Grudziewska E. (2015), Rozwód w ujęciu prawnym i psychologicznym, [w:] A. Lewicka-Zelent, K. Korona (red.), Dziecko a rozwód. Bajki dla dzieci rozwodzacych sie rodziców, Difin, Warszawa.

Gulla B. (2009), Wolność a zależność dziecka, [w:] B. Gulla, M. Duda (red.), Dziecko a świat dorostych, Wydawnictwo św. Stanisława BM Archidiecezji Krakowskiej, Kraków.

Herbert M. (2005), Rozwód w rodzinie. Jak wesprzeć dzieci?, Wydawnictwo Psychologiczne, Gdańsk.

Hołyst B. (1991), Problemy mtodego pokolenia. Studium z zakresu profilaktyki spolecznej, Wydawnictwo Prawnicze, Warszawa.

Jelonkiewicz I. (1994), Rozstanie jest zawsze trudne, [w:] A. Pohorecka (red.), Rozwód? Czy się rozwodzić? Jak się rozwodzić? Co po rozwodzie?, Instytut Psychiatrii i Neurologii, Warszawa.

Kujawa M., Jezierski K. (2016), Wspólne rodzicielstwo po rozwodzie - psychologiczne aspekty opieki naprzemiennej, [w:] A. Czerederecka (red.), Standardy opiniowania psychologicznego w sprawach rodzinnych i opiekuńczych, Wydawnictwo Instytutu Ekspertyz Sądowych, Kraków.

Kujawa M. (2018), Opieka (piecza) naprzemienna-wielogtos, [w:] Rodzina w sytuacji okolorozwodowej. Wspólczesne dylematy psychologiczne i prawne, Wydawnictwo Instytutu Ekspertyz Sądowych, Kraków.

Kuśmierz W. (2000), Wplyw rodziny rozbitej na sytuacje szkolna dzieci, „Życie Szkoły”, nr 3, s. 137-140.

Majczyna M. (2000), Podmiotowość a tożsamość, [w:] A. Gałdowa (red.), Tożsamość człowieka, Wydawnictwo Uniwersytetu Jagiellońskiego, Kraków.

Majkowski W. (1997), Czynniki dezintegracji współczesnej rodziny polskiej. Studium socjologiczne, Wydawnictwo Księży Sercanów, Kraków.

Michalak M., Jaros P. (2014), Prawo dziecka do obojga rodziców, [w:] „Dziecko krzywdzone. Teoria, badania, praktyka”, t. 13, nr 3.

Miś L., Ornacka K. (2015), Podmiotowość dziecka w rodzinie i w sferze publicz$n e j$, [w:] Problemy Polityki Społecznej. Studia i Dyskusje (2015), nr 28(1), s. 63-82, www.problemypolitykispolecznej.pl (dostęp: 12.12.2019).

Lewicka-Zelent A., Korona K. (red.) (2015), Dziecko a rozwód. Bajki dla dzieci rozwodzacych się rodziców, Difin, Warszawa.

Lewicka-Zelent A., Wąsik M. (2015), Funkcjonowanie psychospołeczne dzieci rozwodzacych się rodziców, [w:] A. Lewicka-Zelent, K. Korona (red.) 
(2015), Dziecko a rozwód. Bajki dla dzieci rozwodzacych się rodziców, Difin, Warszawa.

Pohorecka A. (1994), Jak się rozstaja, [w:] A. Pohorecka (red.), Rozwód? Czy się rozwodzić? Jak się rozwodzić? Co po rozwodzie?, Instytut Psychiatrii i Neurologii, Warszawa.

Pospiszyl K., Żabczyńska E. (1980), Psychologia dziecka niedostosowanego spolecznie, PWN, Warszawa.

Przetacznik-Gierowska M., Włodarski Z. (1994), Psychologia wychowawcza, wyd. 6 rozszerzone i zmienione, t. 2, PWN, Warszawa.

Rusinkiewicz J. (2015), Rola rodziców w procesie rozwoju dziecka, [w:] A. Lewicka-Zelent, K. Korona (red.) (2015), Dziecko a rozwód. Bajki dla dzieci rozwodzacych sie rodziców, Difin, Warszawa.

Schier K. (2014), Doroste dzieci, Wydawnictwo Naukowe Scholar, Warszawa.

Skalska M. (1991), Sytuacja emocjonalna dziecka $w$ trakcie procesu rozwodowego rodziców, „Problemy Opiekuńczo-Wychowawcze”, nr 8.

Smyczyński T. (2001), Prawo rodzinne. Analiza i wyktadnia, C.H. Beck, Warszawa.

Smyczyński T. (1999), Prawo dziecka do wychowania w rodzinie, [w:] T. Smyczyński (red.), Konwencja o Prawach Dziecka: analiza i wyktadnia, Ars boni et aequi, Poznań.

Stojanowska W. (1997), Ochrona dziecka przed negatywnymi skutkami konfliktu między jego rodzicami, Wydawnictwo WSPS, Warszawa.

Stojanowska W. (1979), Rozwód a dobro dziecka, Wydawnictwo Prawnicze, Warszawa.

Szempruch J. (2009), W poszukiwaniu idei podmiotowości relacji edukacyjnych rodziny $i$ szkoly, Chowanna, tom jubileuszowy.

Śniegulska M. (2018), Dzieci i mlodzież doświadczajace rozstania rodziców - wywiady psychologiczne, [w:] Rodzina w sytuacji okolorozwodowej. Wspótczesne dylematy psychologiczne i prawne, Wydawnictwo Instytutu Ekspertyz Sądowych, Kraków.

Ustawa z 25.02.1964 roku Kodeks rodzinny i opiekuńczy (Dz.U. z 1964 r. nr 9, poz. 59).

Wicherek P. (2018), Problemy orzecznictwa w sprawach o uregulowanie sposobu wykonywania władzy rodzicielskiej i kontaktów $z$ dzieckiem $w$ sytuacji ostrego konfliktu między rodzicami - glos sędziego rodzinnego, [w:] Rodzina w sytuacji okolorozwodowej. Wspólczesne dylematy psychologiczne i prawne, Wydawnictwo Instytutu Ekspertyz Sądowych, Kraków.

Winiarz J., Gajda J. (2001), Prawo rodzinne, LexisNexis, Warszawa.

Wojciechowska L. (1984), Oddziatywania wychowawcze rozwiedzionych matek a przystosowanie spoleczne ich dzieci, [w:] L. Wołoszynowa (red.), Materiaty do nauczania psychologii, t. 11: Psychologia rozwojowa, wychowawcza i społeczna, PWN, Warszawa. 


\title{
Rodzice w kryzysie małżeńskim na warsztatach umiejętności wychowawczych - szanse i zagrożenia
}

\author{
Abstract \\ Parents in marital crisis attending workshops \\ on education skills - opportunities and risks
}

Many parents go through a marital crisis, including some who take part in workshops on education skills. For five years, the author has been leading workshops entitled "Bless Children". The programme of the workshop is similar to the programme of the well-known in Poland "School for Parents and Educators" (based on the book by A. Faber and E. Mazlish How to Talk so Kids Will Listen హ Listen so Kids will Talk), but it also includes Marhsall Rosenberg's Nonviolent Communication approach and some aspects of Christian spirituality. The author's goal was to examine opportunities and risks related to participation in the workshops on education skills of parents in a marital crisis.

The author used the individual case study method and the participant observation technique, in some cases supported by an analysis of e-mails. The goal of the study was achieved partially, which is why the conducted research should be considered a pilot project. the results allowed to draw practical conclusions, which could be useful for leaders of workshops on education skills.

Keywords: interpersonal communication, marital crisis, workshops on education skills, parents in education, psychopedagogy, Christian spirituality, nonviolent communication

Słowa kluczowe: komunikacja międzyludzka, kryzys małżeński, warsztaty kompetencji wychowawczych, rodzice w edukacji, psychopedagogika, duchowość chrześcijańska, Porozumienie Bez Przemocy

\footnotetext{
${ }^{1}$ Autorka jest również realizatorką Szkoły dla Rodziców i Wychowawców.
} 


\section{Wprowadzenie}

Polskie słowo „kryzys” oraz podobnie brzmiące słowa w wielu językach europejskich pochodzą od greckiego rzeczownika „krisis”, a ten z kolei od czasownika „krinein”, który ma wiele znaczeń, m.in. „rozróżniać” czy „rozstrzygać”. Podstawowe, ogólne znaczenie słowa „kryzys” to „moment rozstrzygający, punkt zwrotny, okres przełomu" (Sobol 2002: 617). W samym pojęciu kryzysu zawierają się więc i szanse, i zagrożenia: czas przełomu jest na ogół trudny i może przynosić zmiany - na korzyść lub na niekorzyść (Stefan 2012).

Psychologicznych definicji kryzysu sformułowano bardzo wiele. Richard K. James i Burl E. Gilliland, specjaliści od interwencji kryzysowej, zaproponowali definicję, zgodnie z którą kryzys jest „odczuwaniem lub doświadczaniem wydarzenia bądź sytuacji jako trudności nie do zniesienia, wyczerpującej zasoby wytrzymałości i naruszającej mechanizmy radzenia sobie z trudnościami” (2005: 33). Definicja ta obejmuje subiektywne doznania związane z teraźniejszością, ów trud czasu kryzysu, a zatem akcentuje bardziej zagrożenia niż szanse. Inaczej patrzy na kryzysy psychoterapeutka Verena Kast (2001). Zajmuje się ona zarówno trudną teraźniejszością kryzysów, jak i korzyściami, które kryzysy mogą przynieść, toteż akcentuje ich pozytywną stronę, widząc w nich przede wszystkim szansę na rozwój, twórcze rozwiązywanie problemów, odnalezienie nieznanych dotąd elementów własnej tożsamości.

Kryzys małżeński dotyka nie tylko dwie osoby, ale również a może przede wszystkim - ich związek:

Taki związek staje się nie tylko sumą dwu elementów, ale nową całością, w której oboje małżonkowie oddziałują na siebie, a oddziaływanie to ma charakter sprzężeń zwrotnych. Aby go opisać, nie wystarczy określić osobno męża, osobno żonę, ale trzeba też pokazać to, co się dzieje ,między’ nimi, a więc wzajemne oczekiwania, postawy, odniesienia emocjonalne i sposób porozumiewania się (Braun-Gałkowska 1992: 19).

Jest on więc specyficznym rodzajem kryzysu, dlatego przytoczona definicja wydaje się zbyt szeroka, by go dokładnie opisać. Ponieważ „odczuwanie lub doświadczanie wydarzenia bądź sytuacji jako trudności nie do zniesienia” można rozpatrywać też w kategoriach zaspokajania swoich potrzeb, proponuje 
doprecyzować tę definicję zgodnie z podejściem Marshalla B. Rosenberga (2018) i zdefiniować kryzys małżeński jako utrzymującą się sytuację, w której ważne potrzeby małżonków, zasadnicze dla ich związku, takie jak potrzeba więzi, szacunku, bliskości, nie są w tym związku zaspokajane.

Kryzysy małżeńskie znacznie wykraczają poza zwykłe, codzienne, jednorazowe konflikty spowodowane różnicami w preferowanych strategiach zaspokajania potrzeb - zwykle w kryzysach małżeńskich tego rodzaju drobne konflikty wciąż nawracają, albo jest jakiś jeden, duży, nierozwiązany problem. Wydaje mi się, że długość trwania tej sytuacji nie ma tak istotnego znaczenia, jak to, że utrzymuje się ona, mimo że małżonkowie podejmują próby poradzenia sobie z nią - co wskazuje, iż małżonkowie napotkali przeszkodę, której nie potrafią pokonać. Przezwyciężenie tak rozumianego kryzysu następuje wówczas, gdy nie zaspokajane dotąd potrzeby małżonków zaczynają być $\mathrm{w}$ ich związku zaspokajane. Może zdarzyć się też tak, że małżonkowie nauczą się zaspokajać te potrzeby poza związkiem małżeńskim zamiast w nim - co oznacza, że kryzys małżeński nie został przezwyciężony i trwa nadal, lub że skończył się, ponieważ związek małżeński przestał istnieć. Ta ostatnia sytuacja nie jest równoznaczna z rozwodem - zdarza się bowiem, że rozwód nie kończy związku małżeńskiego, bądź też związek małżeński przestaje istnieć, mimo że nie doszło do rozwodu. Przezwyciężenie kryzysu małżeńskiego jest więc alternatywą dla dwóch pozostałych, niekorzystnych dla związku wariantów: rozpadu związku lub utrzymywania się kryzysu.

Kryzysy małżeńskie mogą różnić się pod wieloma względami. Część z nich to kryzysy rozwojowe, wywołane np. przyjściem na świat kolejnego dziecka, inne to kryzysy, które określiłabym jako dysfunkcyjne ${ }^{2}$, czyli związane z jakąś dysfunkcją w związku. A.S. Reber i E.S. Reber definiują dysfunkcję jako „każde zaburzenie normalnego funkcjonowania" (2005: 174) - co oczywiście prowadzi do trudności z określeniem „normy”. Za dysfunkcję uznaję, zgodnie z własną definicją, zaburzenie funkcjonowania,

2 W literaturze przedmiotu spotkałam się z określeniem takich kryzysów, które ja nazwałam dysfunkcyjnymi, jako „kryzysy endogenne” (Nowak 2011: 46) - określenie to wydaje mi się jednak mylące, ponieważ mogłoby sugerować, że przeciwieństwem tego rodzaju kryzysów są kryzysy „egzogenne”, a nie o takie rozróżnienie tutaj chodzi. 
które jest w poważny sposób niekorzystne dla jakości życia osób tworzących związek oraz dla jakości ich związku (może to być np. zaburzona komunikacja, niewierność, uzależnienie, przemoc itp.). W dalszej części artykułu, pisząc „kryzys małżeński”, będę miała na myśli dysfunkcyjne kryzysy małżeńskie, gdyż kryzysy rozwojowe, o ile nie towarzyszy im jakaś dysfunkcja, są stosunkowo łatwe do przezwyciężenia i na ogół nie mają gwałtownego przebiegu, ani nie powodują poważnych konsekwencji (Nowak 2011: 43-44).

Kryzysy dysfunkcyjne mogą mieć różną dynamikę: jedne prowadzą do separacji lub rozwodu (niektóre z nich trwają jeszcze długo po rozstaniu małżonków), inne mają przebieg cykliczny, obejmujący wiele rozstań i powrotów, jeszcze inne cechują się stagnacją i nie prowadzą do żadnych zmian, a małżonkowie latami pozostają $\mathrm{w}$ dysfunkcjonalnym związku. W zależności od tej dynamiki niektóre kryzysy charakteryzuje stosunkowo krótkotrwała tzw. „ostra faza” (np. okołorozwodowa), pełna burzliwych, trudnych uczuć (Freeman 1991: 14), inne natomiast w ogóle nie mają „ostrej fazy” i są stanem przewlekłym. Różny może być też stopień świadomości małżonków co do kryzysu: niektórzy z nich o nim wiedzą, inni nie zdają sobie sprawy, że ich małżeństwo przechodzi kryzys, i żyją w złudzeniu, że ich potrzeby są w związku małżeńskim zaspokojone (czasem w takim złudzeniu żyje jedno z małżonków, czasem obydwoje).

Powszechność dysfunkcyjnych kryzysów małżeńskich, dająca się obserwować we współczesnej Polsce, przejawia się m.in. w liczbie rozwodów, która w ostatnich latach utrzymuje się na bardzo wysokim poziomie i stanowi ok. 1/3 liczby zawieranych małżeństw ${ }^{3}$. Wnioski z badań nad rozwodami w Polsce, jakie przeprowadziła w 2017 r. dr hab. Dominika Maison, prof. UW, na zlecenie Fundacji Mamy i Taty, są m.in. następujące:

Choć małżonkowie często mają świadomość, że nad związkiem trzeba pracować, to nie wiedzą, na czym polega ta praca, i brakuje im do tego odpowiednich umiejętności. Edukacja w zakresie komunikacji i rozwiązywania problemów natury osobistej czy relacji międzyludzkich

3 Według danych z Rocznika Demograficznego GUS 2018 w 2017 r. orzeczono w Polsce 65257 rozwodów; zawartych w tym samym czasie małżeństw było 192 576, https://stat.gov.pl/obszary-tematyczne/roczniki-statystyczne/roczniki-statystyczne/rocznik-demograficzny-2018,3,12.html (dostęp: 16.09.2019). Zob. także Nowak 2015, Zagrodzka 2017. 
jest niewystarczająca (zazwyczaj taka edukacja pojawia się w kontekście zawodowym: np. kursy negocjacji biznesowych lub komunikacji z klientem $)^{4}$.

Na podstawie własnych doświadczeń mogę dodać, że taka edukacja pojawia się również w kontekście rodzicielskim: wielu małżonków zaczyna szukać wiedzy i umiejętności w zakresie komunikacji i relacji międzyludzkich w związku z trudnościami z wychowaniem dziecka - można powiedzieć, że dzieci „przyprowadzają” rodziców do różnego rodzaju specjalistów. Dotyczy to również rodziców będących w kryzysie małżeńskim: niektórzy z nich zgłaszają się po pomoc nie dlatego, że ich małżeństwo jest w kryzysie, lecz dlatego, że niepokoi ich zachowanie dziecka lub ich własne zachowanie w relacji z dzieckiem. Część z tych rodziców, szukając rozwiązania swoich problemów wychowawczych, trafia na różnego rodzaju warsztaty dla rodziców, w tym również na warsztaty umiejętności wychowawczych.

Od pięciu lat prowadzę warsztaty umiejętności wychowawczych dla rodziców i nauczycieli „Błogosławmy Dzieciom”, według autorskiego programu ułożonego wspólnie z Joanną Lisotą ${ }^{6}$, którego podstawą jest program pierwszej części kursu psychoedukacyjnego „Szkoła dla Rodziców i Wychowawców” - dalej w skrócie będę nazywała pierwszą część tego kursu "Szkołą"7. Program „Szkoły” powstał na podstawie książki Adele Faber i Elaine Mazlish Jak mówić, żeby dzieci nas stuchaty, jak stuchać, żeby dzieci do nas mówity (Faber, Mazlish 2013) ${ }^{8}$. Autorką tego programu jest polska psycholog Joanna Sakowska (Sakowska 2010). Kurs adresowany jest do rodziców i nauczycieli:

${ }^{4}$ Strategia Odbudowy Rodziny, oprac. Fundacja Mamy i Taty, Warszawa, 5 czerwca 2017, http://centrumprasowe.pap.pl/cp/en/news/info/100192,,strategia-odbudowy-rodziny-zalozenia-cele-narzedzia-(centrum-prasowe), dostęp: 16.09.2019.

${ }_{5}^{5}$ https://www.facebook.com/blogoslawmydzieciom/ (dostęp: 16.09.2019).

${ }^{6}$ Joanna Lisota jest magistrem resocjalizacji i socjoterapeutką.

7 Pierwsza część „Szkoły dla Rodziców i Wychowawców” nosi nazwę „Relacja i dialog”, potocznie jednak często mówi się na tę część „Szkoła dla Rodziców i Wychowawców”, na zasadzie pars pro toto, dlatego i tutaj posługuję się tą nazwą w takim znaczeniu. Są jeszcze dwie kolejne części: część druga „Rodzeństwo” i część trzecia „Nastolatek” (dokładniejsze informacje na stronie: http://szkoladlarodzicow.eu/dla-realizatorow/, dostęp: 16.09.2019).

8 Ściśle rzecz biorąc, tylko pierwsza część ma za podstawę książkę Jak mówić do dzieci; podstawą dwóch kolejnych części są dwie inne publikacje tych samych autorek. 
W trakcie zajęć rodzice [a także nauczyciele - A.Z.] nabywają i doskonalą umiejętności:

- rozpoznawania i rozmawiania o uczuciach,

- stawiania jasnych granic i wymagań,

- zachęcania dzieci do współpracy,

- wspierania samodzielności dzieci,

- rozwiązywania problemów i konfliktów,

- uczenia dzieci samodyscypliny,

- uwalniania od grania ról i niekorzystnego etykietowania,

- wzmacniania ich poczucia własnej wartości ${ }^{9}$.

Na głębszym poziomie celem kursu jest kształtowanie postawy dialogu, opartej na szacunku i do dziecka, i do siebie samego, oraz wzmacnianie więzi między dorosłymi (rodzicami oraz nauczycielami) i dziećmi. Wyniki ewaluacji programu wskazują na zmianę deklarowanych postaw wychowawczych uczestników, przy czym zmiana ta dotyczy m.in. budowania bardziej podmiotowej relacji z dzieckiem (Sochocki 2009: 24). Ze względu na to, że program „Szkoły” służy wzmacnianiu więzi, która uważana jest za najsilniejszy czynnik chroniący przed wszelkimi zaburzeniami (m.in. uzależnieniami i zachowaniami ryzykownymi), i ze względu na skuteczność tego programu, bywa on określany jako najcenniejsze narzędzie profilaktyki uniwersalnej, jakim obecnie dysponujemy w Polsce (Wojcieszek 2009: 5).

Kursy nazywane „Szkołą dla Rodziców i Wychowawców” obejmują 10 cotygodniowych spotkań, trwających po ok. 3 godziny każde. Organizuje się je w różnych miejscach, takich jak poradnie psychologiczno-pedagogiczne, przedszkola, kluby i kawiarnie, wyższe szkoły pedagogiczne, parafie. Przeważnie uczestniczą w tych kursach rodzice oraz nauczyciele - przy czym nie zawsze obydwoje rodzice dziecka biorą udział w tym samym kursie: czasem $\mathrm{z}$ różnych powodów jedno z nich uczestniczy w innej edycji (np. ze względu na konieczność zapewnienia dziecku opieki), czasem jedno z rodziców nie chce lub nie może wziąć udziału w kursie. Zajęcia prowadzone są metodami warsztatowymi, a grupy liczą maksymalnie 15 osób (optymalna liczba osób w grupie: 11-13). Certyfikat do prowadzenia tych zajęć otrzymują wszyscy, którzy odbędą szkolenie dla realizatorów „Szkoły”. Na szkolenia te przyjmowane są osoby zajmujące się pracą z rodzicami - nauczyciele, wychowawcy oraz pedagodzy i psychologowie.

9 http://szkoladlarodzicow.eu/dla-rodzicow/ (dostęp: 16.09.2019). 
Po kilku latach prowadzenia warsztatów według programu „Szkoły” postanowiłyśmy z Joanną Lisotą wzbogacić go - i tak powstał program „Błogosławmy Dzieciom”10. Jest to program warsztatów psychoedukacyjnych z wybranymi elementami psychoterapii i rozwoju duchowego. Zawiera wszystkie treści i ćwiczenia „Szkoły dla Rodziców i Wychowawców”, ale wzbogacony został jeszcze o wiele innych, m.in. wybrane treści programu warsztatów rozwoju duchowego „Wreszcie żyć - 12 kroków ku pełni życia"11, niektóre elementy metody M.B. Rosenberga (2018) nazywanej „Porozumieniem Bez Przemocy” oraz treści pochodzące z Pisma Świętego i konferencji rekolekcyjnych ks. Zbigniewa Wądrzyka ${ }^{12}$. W związku z tym uczestnicy zdobywają również więcej konkretnych umiejętności, np. uczą się określać swoje potrzeby ${ }^{13}$ i odróżniać je od strategii ich zaspokojenia, odróżniać postawę błogosławienia i postawę przeklinania. Mają też okazję, by zintegrować swe rodzicielstwo (lub pracę nauczycielską) ze swoją duchowościąa ${ }^{14}$.

Cele, które sobie stawiamy, są także nieco szersze niż cele „Szkoły”: zależy nam na poprawie relacji uczestników nie tylko z dzieckiem, ale także z Bogiem, z samym sobą i z innymi członkami rodziny (np. ze współmałżonkiem) $)^{15}$. Przyczyny tego są

10 https://www.facebook.com/blogoslawmydzieciom/ (dostęp: 16.09.2019).

11 https://www.12krokow.com.pl/ (dostęp: 16.09.2019).

12 Ks. Zbigniew Wądrzyk interesuje się relacjami między ludźmi i głosi nauki rekolekcyjne na takie tematy, jak lęki, więzi, błogosławieństwo i przekleństwo, które stały się inspiracją do powstania i wzbogacenia różnych programów terapeutycznych.

13 Temat potrzeb jest niestety nieobecny w standardowym programie „Szkoły”, uwzględniono go natomiast w scenariuszu zajęć warsztatowych dla rodziców dzieci z niepełnosprawnością zainspirowanym „Szkołą” (Górecka, Hanusz, Kucharska-Zygmunt, Zygmunt 2008: 11-12). Jest to jak najbardziej uzasadnione, by właśnie tych rodziców szczególnie wspierać w odkrywaniu i zaspokajaniu swoich potrzeb, ponieważ w ich sytuacji zarówno rozpoznanie potrzeb, jak i zaspokojenie ich jest wyjątkowo trudne (Pisula 1998).

14 Proponujemy uczestnikom m.in. spojrzenie na budowanie więzi w wymiarze duchowym: według wiary chrześcijańskiej zbawienie prowadzi do Nieba; jeśli przyjmiemy, że Niebo to miłość i więzi, wówczas uczenie siebie samych i dzieci bycia w bliskich relacjach opartych na dialogu i szacunku, uczenie siebie i dzieci przyjmowania i dawania miłości, jest wychowaniem do zbawienia (zob. Zagrodzka, Wądrzyk 2019).

15 Program „Szkoły” również prowadzi do poprawy więzi z dzieckiem poprzez nawiązanie przez rodzica lepszego kontaktu z samym sobą, jednak mniej akcentuje relację z pozostałymi członkami rodziny i nie przewiduje zajmowania 
dwie. Po pierwsze, odwołujemy się do relacji z Bogiem jako źródła rodzicielskiej siły, mądrości i miłości, wewnętrznego pokoju i wolności - dlatego proponujemy uczestnikom nie tylko psychoedukację, ale także modlitwę i lekturę Pisma Świętego oraz zachęcamy ich do korzystania z sakramentów, adoracji i innych form życia duchowego. Po drugie, relacja rodzic - dziecko jest elementem systemu rodzinnego, a relacja rodzic - dziecko lub nauczyciel dziecko bardzo silnie uwarunkowana jest przez sposób, w jaki rodzic czy nauczyciel funkcjonuje $\mathrm{w}$ życiu i w relacjach $\mathrm{z}$ innymi. Można powiedzieć, że wychowanie dziecka jest „na końcu” - jest wypadkową tego, jaka jest historia życia rodzica czy nauczyciela, i jak on tę historię przepracował; dużo zależy także od tego, jakie są jego pozostałe relacje - dlatego zdobywanie i doskonalenie umiejętności wychowawczych bez podjęcia uprzednio lub równolegle głębszej pracy nad sobą jest bardzo trudne, a czasem wręcz niemożliwe. Byłoby najlepiej, gdyby osoby przychodzące na warsztaty umiejętności wychowawczych korzystały wcześniej z jakiejś innej formy pomocy, np. uczestniczyły w psychoterapii dla DDA, terapii uzależnień ${ }^{16}$ czy terapii małżeńskiej (jeśli mają jakieś poważniejsze problemy) lub uczestniczyły w warsztatach rozwoju osobistego (jeśli nie mają poważniejszych problemów,

się relacją z Bogiem. W praktyce jednak realizatorzy „Szkoły” prawdopodobnie elastycznie podchodzą do programu i - jeśli chcą i znajdą czas - w odpowiedzi na zapotrzebowanie uczestników poruszają czasem również i ten temat.

16 Z naszych doświadczeń wynika, że niejednokrotnie przemoc powiązana jest z uzależnieniem. Obecnie coraz więcej rodziców ma problem z pornografią, którą oglądają, chociaż woleliby tego nie robić - być może są od niej uzależnieni. Jest w nich dużo złości na samych siebie, którą przerzucają na otoczenie. Dlatego, jeśli zgłasza się do nas rodzic, który krzyczy na dzieci, czasem je bije, i mimo wielu starań nie może przestać tego robić - a nie jest uzależniony od substancji psychoaktywnych - pytamy go (poza grupą) o pornografię i przeważnie kierujemy do grupy Anonimowych Seksoholików (SA, https://www.sa.org.pl/, dostęp: 16.09.2019) lub do Wspólnoty Uzależnionych od Seksu i Miłości (SLAA, http:// www.slaa.pl/, dostęp: 16.09.2019) i na terapię uzależnień. Dopiero po podjęciu pracy nad sobą w tym obszarze rodzic jest gotowy do udziału w warsztatach umiejętności wychowawczych - odwrotna kolejność nie ma sensu, gdyż korzyść wyniesiona przez rodzica z warsztatów jest niewspółmierna do włożonego wysiłku, a czasem nie ma jej wcale i wtedy jedynym efektem jest jego zniechęcenie. Bardzo często jednak rodzic nie zdaje sobie sprawy ze swojego uzależnienia, dlatego najpierw trafia na warsztaty umiejętności wychowawczych, a nie na terapię lub do grupy samopomocowej dla osób uzależnionych - pomimo to dobrze, naszym zdaniem, że zgłasza się na warsztaty, bo dzięki temu ma szansę dostrzec swoje uzależnienie i zająć się nim. 
ale też nie mają skłonności do autorefleksji i, co za tym idzie, brakuje im samoświadomości). Często tak się jednak nie dzieje wielu osobom nie przychodzi nawet do głowy, żeby zająć się sobą w taki sposób. Duża część osób przychodzących na nasze warsztaty zaczyna „od końca” ${ }^{17}$. Z tego powodu uznałyśmy, że jeśli warsztaty mają przynieść pożądany skutek w postaci poprawy relacji rodziców i nauczycieli z dziećmi, należy podjąć wyzwanie i umożliwić uczestnikom również pogłębioną pracę nad innymi obszarami ich życia. Jeśli zaś napotykamy jakiś problem nie dający się rozwiązać na warsztatach (np. uzależnienie) - a często tak jest - wówczas proponujemy podjęcie pracy także poza warsztatami, spotykamy się z uczestnikiem indywidualnie i sugerujemy skorzystanie z konkretnych form pomocy. Niejednokrotnie skonfrontowanie się uczestnika z własnym głębszym problemem, który uniemożliwia mu efektywną pracę na warsztatach, oraz podjęcie decyzji o terapii są największymi korzyściami, jakie uczestnik ten wynosi z warsztatów.

Ze względu na szersze cele i zwiększenie zakresu materiału kurs „Błogosławmy Dzieciom” prowadzony jest w mniejszych grupach, maksymalnie 12-osobowych (optymalna liczba uczestników w grupie to 8-10 osób), i obejmuje więcej cotygodniowych spotkań niż „Szkoła”, bo aż 15 (każde spotkanie trwa 3,5 godziny). Kurs organizujemy w Warszawie w Pallotyńskim Centrum Pomocy Duchowej SITIS ${ }^{18}$, a od niedawna prowadzony jest także w Ostrowi Mazowieckiej przy tamtejszej parafii katolickiej ${ }^{19}$. Czasem odbywają się także wakacyjne kursy „Błogosławmy Dzieciom”, nieco skrócone: zajęcia wówczas są codziennie przez ok. 14 dni i trwają po 3 godziny 15 minut. Przeważnie uczestniczą

${ }^{17}$ Inne założenia przyjął zespół psychologów Stowarzyszenia OPTA, który jak wynika z opracowanego przez ten zespół poradnika dla profesjonalistów (Jakubowska, Markiewicz 2002) - proponuje nie zapraszać do grup psychoedukacyjnych dla rodziców osób „uzależnionych i nieleczących się, sprawców przemocy i wykorzystania” (s. 63). Podręcznik ukazał się kilkanaście lat temu - w obecnej sytuacji, kiedy coraz częściej występują uzależnienia behawioralne, nie tak łatwe do zdiagnozowania i mało jeszcze obecne w świadomości społecznej, przedstawione w nim zasady rekrutacji rodziców są mało realistyczne (zob. Niewiadomska 2015).

18 https://www.sitis.org.pl/ (dostęp: 16.09.2019).

19 Prowadzą go tam osoby, które przeszły szkolenie do prowadzenia „Szkoły” oraz nasze szkolenie do prowadzenia „Błogosławmy Dzieciom” i uzyskały obydwa certyfikaty: Anna Kotwica (psycholog) i Katarzyna Karpiej (pedagog specjalny). 
w tych kursach - zarówno stacjonarnych, jak i wakacyjnych rodzice oraz nauczyciele. Wszyscy dotychczasowi uczestnicy deklarowali się jako katolicy, chociaż przynależność do Kościoła Katolickiego nie jest warunkiem uczestnictwa - być może nazwa warsztatów, miejsce, w którym się odbywają, i zapowiedź, że będą poruszane tematy duchowe, zachęcają do udziału właśnie katolików. Zajęcia „Błogosławmy Dzieciom”, podobnie jak zajęcia „Szkoły”, prowadzone są metodami warsztatowymi, ale zaczynają i kończą się modlitwą.

Ze względu na szersze cele oraz pojawiające się na zajęciach elementy psychoterapii, warsztaty „Błogosławmy Dzieciom” są regularnie nadzorowane i konsultowane (superwizja) przez certyfikowanego psychoterapeutę ${ }^{20}$. Z tego samego względu opracowałyśmy także dość wymagające standardy szkolenia dla realizatorów warsztatów. Warunkiem przyjęcia na szkolenie jest posiadanie certyfikatu uprawniającego do prowadzenia „Szkoły”. Nasze szkolenie jest dwustopniowe: obejmuje udział w warsztatach „Błogosławmy Dzieciom” w charakterze uczestnika oraz współprowadzenie warsztatów „Błogosławmy Dzieciom” pod superwizją uczestniczącą. Oceniamy predyspozycje i umiejętności kandydatów według naszych kryteriów i zastrzegamy sobie możliwość nieprzyznania certyfikatu, mimo że kandydat odbył szkolenie ${ }^{21}$.

Uczestnikiem warsztatów przeważnie jest jedno z rodziców, rzadko w tej samej edycji warsztatów bierze udział oboje rodziców. Jeżeli małżeństwo nie jest w kryzysie, można przypuszczać, że żadne z tych rozwiązań nie wiąże się z jakimiś zagrożeniami, natomiast każde z nich przynosi nieco inne korzyści, a więc szanse. Udział w dwóch osobnych edycjach warsztatów wydłuża czas kontaktu rodziców z treściami warsztatowymi (rodzic uczestniczący w warsztatach „przynosi do domu” te treści), co sprzyja utrwalaniu się ich wiedzy i umiejętności. Z kolei udział obojga małżonków w tej samej edycji to wspólnie przeżyta przygoda,

${ }^{20}$ Superwizja pracy warsztatowej zalecana jest także realizatorom „Szkoły”, wymaga się od nich ponadto jakiegoś doświadczenia i wiedzy w pracy terapeutycznej - wynika to „z faktu, że choć z założenia warsztaty mają charakter psychoedukacyjny, to jednak często dochodzi do sytuacji, w których istnieje konieczność podejmowania działań typowo terapeutycznych” (Sakowska 2010: 13).

21 Zamieszczony w niniejszym artykule opis „Szkoły dla Rodziców i Wychowawców” oraz „Błogosławmy Dzieciom” został zaczerpnięty ze wstępu do książki A. Zagrodzka, J. Lisota, J. Sakowska, Szkoła miłości, Pelplin, Wydawnictwo Bernardinum (seria Niebo na ziemi, cz. 2), przygotowywanej obecnie do druku. 
wspólne doświadczenie, coś, co zbliża i łączy. Dość szybko jednak okazało się, że część rodziców uczestniczących w prowadzonych przez nas warsztatach przeżywa kryzys małżeński. Szanse i zagrożenia wynikające z obecności na warsztatach umiejętności wychowawczych rodziców będących w kryzysie małżeńskim zauważyła już Joanna Sakowska:

często padają pytania, czy lepiej jest, gdy przychodzi na spotkanie oboje rodziców i jak jest ze skutecznością nowych oddziaływań, gdy na zajęciach jest tylko jedno z nich. Odpowiedź nie jest jednoznaczna. 1. Jeśli przychodzą oboje rodzice i skoncentrowani są na poprawie relacji z dziećmi i między sobą, jest to oczywiście sytuacja optymalna - łatwiej i szybciej wprowadzą oni w swojej rodzinie pożądane zmiany. Czasem jednak zdarza się, że właśnie warsztat [...] wydobywa głęboko zepchnięte wzajemne urazy [...]. Jest to sytuacja wymagająca ogromnej uwagi i odpowiedzialności od prowadzących grupę. Nie można bowiem tych spraw pominąć, zostawić (bezpośrednio i znacząco wpływają one na funkcjonowanie całej rodziny), ale nie można też pozwolić, aby zdominowały zajęcia całej grupy i przysłoniły faktyczną treść zajęć. Rodzice tacy wymagają oddzielnej pomocy (poza zajęciami grupy). 2. Jeżeli w zajęciach uczestniczy tylko jedno z rodziców, należy pamiętać o tym, że [...] rodzina funkcjonuje jako system. Zmiana funkcjonowania jednego ogniwa tego systemu wpływa na funkcjonowanie pozostałych ${ }^{22}$ (choć może nie tak łatwo i szybko, jak byśmy oczekiwali) (Sakowska 2010: 12-13).

Zagadnienie uczestnictwa w warsztatach umiejętności wychowawczych rodziców będących w kryzysie małżeńskim nie było dotychczas przedmiotem badań.

\section{Metodologiczne aspekty badań}

Postawiłam sobie za cel sprawdzenie, jakie są szanse i zagrożenia uczestnictwa w warsztatach umiejętności wychowawczych rodziców będących w kryzysie małżeńskim: zarówno tych, którzy uczestniczą w tych warsztatach oboje w jednej grupie, jak i tych, którzy uczestniczą w nich pojedynczo (a drugi rodzic nie uczestniczy w nich wcale lub uczestniczy, ale w innej grupie).

22 Ostatnie stwierdzenie zgodne jest z doświadczeniem osób pracujących zgodnie z podejściem systemowym, które pokazuje, że „system rodzinny jest bardzo czuły na wszelkie zmiany, nawet bardzo drobne” (Karasowska, Szulirz 2015: 12). 
Sformułowałam trzy główne pytania badawcze. Pierwsze $\mathrm{z}$ nich to pytanie, jak przebiega na warsztatach praca rodziców w kryzysie. Drugie pytanie: co dzieje się ze związkiem małżeńskim tych rodziców - czy zachodzą w nim jakieś zmiany oraz jeśli zachodzą, to jakie. Trzecie pytanie dotyczyło grup, których uczestnikami było oboje małżonków przeżywających kryzys: chodziło o sprawdzenie, jak odbierali ich zachowanie pozostali uczestnicy i czy obecność takiej pary w grupie stanowi dla tej grupy zagrożenie czy szansę (założyłam, że tam, gdzie rodzice w kryzysie małżeńskim byli w grupie pojedynczo, nie wchodziło $\mathrm{w}$ grę zagrożenie dla pracy grupy). Pytanie pierwsze i drugie dotyczyło głównie czasu trwania warsztatów, choć jeśli tylko było to możliwe, gromadziłam dane również po ich zakończeniu. Pytanie trzecie dotyczyło wyłącznie czasu trwania warsztatów.

Do pierwszego pytania sformułowałam także pytania szczególowe: jak się zachowują rodzice, co mówią (jakie tematy poruszają i w jaki sposób), co czują, czy wynoszą jakieś korzyści, np. czy zwiększa się ich świadomość siebie (swoich uczuć, potrzeb, przekonań itp.) i czy zdobywaja jakieś nowe umiejętności (jeśli tak, to jakie).

Drugie pytanie badawcze wymaga dokładniejszego wyjaśnienia. Ponieważ związek jest to coś, co dzieje się pomiędzy dwiema osobami, zmiana w jednej z tych osób wpływa i na sam związek a zatem z definicji zachodzą zmiany w związkach małżeńskich rodziców będących w kryzysie małżeńskim, o ile zachodzą jakieś zmiany chociaż $\mathrm{w}$ jednym $\mathrm{z}$ nich. Nie jest jednak oczywiste, że te zmiany chociaż $\mathrm{w}$ jednym rodzicu $\mathrm{z}$ pary, uczestniczącym w warsztatach, zachodzą; chodzi również o zbadanie, na czym polegają zmiany w związku małżeńskim, o ile się pojawiają. Należałoby również określić, czy kierunek ewentualnych zmian jest dla tego związku korzystny - ma to zasadnicze znaczenie dla wniosków praktycznych: „Najważniejszy jest kierunek, w którym rodzina zmienia się. [...] Jeżeli [...] zmiany są pozytywne, interwencja terapeutyczna nie jest potrzebna" (Braun-Gałkowska 1992: 169-170).

Nie stawiałam żadnych hipotez, jeśli chodzi o pierwsze i trzecie pytanie badawcze. Jeśli chodzi o drugie pytanie, postawiłam hipotezę, że jeśli w związku małżeńskim rodziców uczestniczących $\mathrm{w}$ warsztatach zachodzą jakieś zmiany, to są to zmiany korzystne dla jakości tego związku - stanowią dla niego szansę, a nie zagrożenie. Podstawą tej hipotezy były moje wstępne 
obserwacje oraz dostępna mi wiedza pochodząca z literatury fachowej. W literaturze znalazłam przesłanki zarówno natury ogólnej, jak i bardziej specyficzne.

Oto przesłanki ogólne: 1) doświadczenie niektórych terapeutów małżeńskich, np. Valeria Albisettiego, twórcy psychoterapii personalistycznej, pokazuje, że im większa samoświadomość osób tworzących związek, tym lepsza jakość ich związku (Albisetti 2007); 2) podstawowe zasady dobrej komunikacji rodziców z dziećmi są takie same, jak ogólne zasady dobrego komunikowania się między ludźmi, a więc również w małżeństwie (McKay, Davis, Fanning 2019) - zatem opanowanie tych zasad i zdobycie umiejętności posługiwania się nimi w relacji z dzieckiem można wykorzystać tė̇ $\mathrm{w}$ relacji z małżonkiem; 3) częstą przyczyną trudności w małżeństwie są pozabezpieczne wzorce przywiązania ukształtowane w dzieciństwie (Tryjarska 2012, Kornaszewska-Polak 2016) i projektowanie na małżonka percypowanych postaw swoich rodziców (Mellody, Freundlich 2010) - na warsztatach umiejętności wychowawczych jest okazja, by poznać lepiej siebie i swoją historię, a także uświadomić sobie, że może być ona źródłem obecnych trudności w relacjach, również w związku małżeńskim; 4) niejednokrotnie problemy wychowawcze są pochodną problemów w małżeństwie (i odwrotnie: duża część konfliktów między małżonkami dotyczy wychowania dzieci, zob. Stefan 2012) - warsztaty umiejętności wychowawczych mogą być dobrą okazją, żeby zauważyć tę zależność i uświadomić sobie prawdziwe źródło problemów, a więc np. uświadomić sobie to, że jest się w kryzysie małżeńskim i z tego względu dzieci sprawiają większe trudności wychowawcze, natomiast świadomość kryzysu może być pierwszym krokiem do jego przezwyciężenia.

Przesłanki specyficzne do postawionej hipotezy to znalezione w literaturze wyniki badań ewaluacyjnych warsztatów zbliżonych do „Błogosławmy Dzieciom”. W wyniku ewaluacji ilościowej „Szkoły” przeprowadzonej rok po zakończeniu kursu stwierdzono, że

ponad połowa (59\%) spośród badanych małżonków i osób przebywających w związku z partnerką lub partnerem uznała, że zajęcia miały pływ na ich wzajemne relacje [...]. Niemal wszyscy $(99,7 \%)$ stwierdzili, ze zmiany te były pozytywne [...]. Dostrzegane zmiany dotyczyły komunikacji, wzajemnego porozumiewania się (96\%), rozwiązy wania konfliktów (94\%), rozumienia postaw i zachowań (92\%) oraz uczuć (85\%) (Sochocki 2009: 24). 
Nie podano informacji, ilu spośród tych rodziców uczestniczyło w warsztatach razem z drugim rodzicem, a ilu osobno; nie wiadomo też, czy któraś z tych par była w kryzysie. Mira Kępka prowadząca w Warszawie warsztaty umiejętności wychowawczych pod nazwą „Błogosławiąca komunikacja” opublikowała wyniki ankiet ewaluacyjnych swoich warsztatów (Kępka 2017). Wśród jej absolwentów było 6 par małżeńskich, przy czym byli to rodzice, którzy jednocześnie uczestniczyli w zajęciach. Zadała im pytanie, czy wspólne uczestnictwo w warsztatach przyniosło korzyści ich związkowi małżeńskiemu, i jeśli tak, to jakie - uzyskała 10 odpowiedzi pozytywnych na 11 i nieco konkretnych informacji o tym, jakie to były korzyści (nie wiadomo jednak, czy któraś z tych par przeżywała kryzys). Wyniki tych badań wskazują, że większość małżonków zauważa jakieś korzystne zmiany w swoich relacjach małżeńskich $\mathrm{w}$ związku z udziałem $\mathrm{w}$ warsztatach umiejętności wychowawczych.

Poszukując odpowiedzi na postawione pytania badawcze, zastosowałam metodę indywidualnych przypadków i posłużyłam się techniką obserwacji uczestniczącej, uzupełnioną w niektórych wypadkach również analizą e-maili. Prowadziłam obserwacje podczas 8 edycji stacjonarnych i 3 edycji wakacyjnych warsztatów „Błogosławmy Dzieciom”, na przestrzeni kilku lat (od września 2015 r. do czerwca 2019 r.): obserwowałam rodziców, którzy znajdowali się $\mathrm{w}$ kryzysie małżeńskim, oraz ( $\mathrm{w}$ tych grupach, gdzie rodzice ci byli przyjęci oboje do jednej grupy) pozostałych uczestników i zapisywałam niektóre ich wypowiedzi oraz własne spostrzeżenia i refleksje. Z niektórymi spośród tych małżonków spotykałam się również po zakończeniu warsztatów, ponieważ zdarzało się, że zgłaszali się do mnie na indywidualne konsultacje - wówczas także notowałam niektóre wypowiedzi, spostrzeżenia i refleksje. Czasami absolwenci kontaktowali się ze mną e-mailowo, co pozwalało mi uzyskać dodatkowe informacje. Analiza zgromadzonych danych polegała na uporządkowaniu ich, a następnie na wyciągnięciu wniosków.

\section{Wyniki badań}

Wyniki obserwacji podzieliłam na dwie grupy, w zależności od zmiennej, jaką jest udział w zajęciach obojga małżonków razem lub udział pojedynczych małżonków. 


\subsection{Rodzice w kryzysie małżeńskim, którzy wspólnie uczestniczyli w warsztatach w tej samej grupie}

Takich par było niewiele: w sumie 4 (na 5 par małżonków, którzy razem uczestniczyli w zajęciach jednej grupy) - warto przedstawić je wszystkie ${ }^{23}$.

Para A. Trafiła na warsztat w ostrej fazie trwającego od kilku lat kryzysu. Oboje oskarżali się nawzajem o przemoc psychiczną. On, jak twierdził, pochodził z rodziny, w której matka znęcała się w obecności dzieci nad ojcem; nosił w sobie ogromne pokłady niewyrażonego gniewu i miał trudność z mówieniem wprost, co czuje i czego potrzebuje; ona - nie umiała w ogóle zająć się sobą, próbowała mówić wciąż o mężu i krytykować jego zachowanie. Przychodzili na zajęcia osobno i siadali osobno, mimo to bardzo trudno było im obojgu w obecności współmałżonka pracować nad relacją z dziećmi. Podczas jednych zajęć doszło do kulminacji. On przyszedł wzburzony, jak się później okazało, po jakimś wcześniejszym konflikcie z żoną, i oświadczył: "Nie będę się otwierał, tak postanowiłem, jestem atakowany w domu”. Wyrażał swoje uczucia i emocje przez podniesiony ton, gwałtowne ruchy i mówienie o żonie „ona” w jej obecności, chociaż miał wcześniej sygnały od nas, prowadzących zajęcia, że nie zgadzamy się na taki sposób mówienia o żonie podczas zajęć. W pewnym momencie demonstracyjnie opuścił salę. Kilkoro pozostałych uczestników mówiło o trudnych uczuciach, które pojawiły się w związku z tą sytuacją: przeważnie był to lęk. Ostatecznie jedna $\mathrm{z}$ nas przeprowadziła mediację między małżonkami, zachęcając ich do nazywania swoich uczuć i potrzeb oraz do wysłuchania uczuć i potrzeb drugiej strony. On bardzo chętnie współpracował i szczerze mówił o sobie (m.in. o swoich trudnych uczuciach, takich jak złość, gniew, żal, samotność, oraz o niezaspokojonych potrzebach: szacunku, współpracy, bycia wziętym pod uwagę, bliskości), starał się też usłyszeć żonę. Ona nie współpracowała. Nie była w stanie ani mówić o sobie, ani usłyszeć, czego potrzebuje jej mąż. Wobec tego nie doszło do wypracowania jakichś wspólnych rozwiązań. Nie udało się też

${ }^{23}$ Szczegóły, które mogłyby umożliwić identyfikację osób, zostały pominięte. Wszystkie przykłady opisane są z konieczności skrótowo, więc nie ukazują całej złożoności sytuacji i przeżyć poszczególnych osób. 
zrealizować ćwiczeń zaplanowanych na ten dzień, a pozostali uczestnicy znów mówili o trudnych uczuciach, jakich doświadczali, patrząc na kłócących się małżonków: o lęku, bezsilności, smutku. I on, i ona pozostali w grupie do końca kursu: on od czasu mediacji był wyraźnie w lepszym kontakcie ze sobą i bardziej wprost wyrażał siebie; ona do końca kursu próbowała mówić o mężu, zamiast o sobie, mimo starań prowadzących, by przekierować jej uwagę na samą siebie - a kiedy mówiła o nim, wyrażała niezadowolenie, utrzymujące się, niezależnie od jego starań, na stałym poziomie, natomiast w nim narastała frustracja i gniew. Po jakimś czasie od zakończenia warsztatów dostałam od niego e-maila, z którego dowiedziałam się, że wyjechał za granicę na dłuższy kontrakt, a później dostałam e-maila także od niej, z którego wynikało, że doszło także do jakiegoś formalnego rozstania małżonków.

Para B. Przychodząc na warsztaty, oboje byli przekonani, że są idealnym małżeństwem - twierdzili, że się nawet nie kłócą. W trakcie warsztatów siedzieli obok siebie. On nieraz mówił jej komplementy i głaskał ją, bawił się jej włosami itp., a ona pozwalała na te pieszczoty, ale nie robiła wrażenia, żeby sprawiały jej przyjemność, ani ich nie odwzajemniała. Mówiła niewiele, robiła wrażenie napiętej, jej twarz nie wyrażała na ogół żadnych emocji. Zaczęłyśmy podejrzewać, że być może jest to małżeństwo w utajonym kryzysie. Poprosiłyśmy, żeby usiedli osobno. Od tego momentu ona zaczęła więcej mówić, również o problemach w ich relacjach rodzinnych, ożywiła się też jej mimika. W odgrywanych scenkach ujawniły się poważne trudności ich obojga: oboje bardzo silnie tłumili nieprzyjemne uczucia, zwłaszcza gniew i złość, przy czym ona zdała sobie z tego sprawę i z czasem miała z nimi coraz lepszy kontakt, natomiast on do końca kursu uśmiechał się $\mathrm{w}$ najtrudniejszych nawet sytuacjach i racjonalizował je (np. w jednej z odgrywanych scenek uzasadniał jakimś argumentem przemocowe zachowania „rodziców” wobec siebie jako „dziecka”), co było bardzo trudne w odbiorze dla kilku osób z grupy. Mówiły, że pojawił się u nich smutek i gniew. Ona zinterpretowała jedną ze scenek, w której uczestniczył jej mąż, grający „męża” i zarazem „ojca”, w taki sposób, że według niej „mąż” deprecjonuje „żonę” w obecności „córki” (takie samo wrażenie odniosłyśmy my, prowadzące) i odważyła się o tym powiedzieć. Bezpośrednio po zakończeniu jednych zajęć warsztatowych powiedziała mężowi z dużym wzburzeniem, że wcale nie 
jest zadowolona z ważnej decyzji dotyczącej ich obojga, którą on podjął bez porozumienia z nią - widać było, że ujawnienie problemu dużo ją kosztuje i jest w ich związku czymś niezwykłym. Po zakończeniu kursu byłyśmy przekonane, że jest to małżeństwo w poważnym kryzysie, o bardzo zaburzonej komunikacji i bardzo silnych mechanizmach obronnych, z czego ona zdaje sobie nieco sprawę, on natomiast jest tego zupełnie nieświadomy. Późniejsze konsultacje dla obojga potwierdziły te przypuszczenia: okazało się, że w ich związku brakuje szacunku, szczerości, bezpieczeństwa emocjonalnego, bliskości, i że on nie dopuszcza do świadomości tych problemów, a ona nie chce ich ujawniać ze względu na znakomitą opinię, jaką cieszy się jej mąż, i jaką oni oboje cieszą się jako małżeństwo w swoim otoczeniu. Po zakończeniu warsztatów relacja $\mathrm{w}$ tym małżeństwie wróciła prawdopodobnie do stanu zbliżonego do tego, jaki był przed warsztatami.

Para C. Oboje małżonkowie zgłosili się na warsztaty, mając świadomość, że są w kryzysie - bardzo jednak chcieli być w jednej grupie, i ze względów praktycznych, i ze względu na swój związek. On przyznał, że jest uzależniony od alkoholu, ona - że jest współuzależniona; byli już po jakichś terapiach. W trakcie warsztatów często siedzieli koło siebie, choć nie zawsze. Chętnie pracowali ze sobą w parze. Uważnie słuchali tego, co mówi współmałżonek, ale też wsłuchiwali się w siebie samych. Ona zajęła się głównie swoją relacją z Bogiem i z samą sobą, ale też z rodzicami, od których niezupełnie jeszcze się odseparowała, z mężem oraz z dziećmi. On koncentrował się głównie na relacji z dziećmi, ale czasem podejmował też tematy dotyczące ich obojga. Widać było, że coraz bardziej zbliżają się do siebie, co miało też zewnętrzny wyraz - zdarzyło się, że kiedy pracowali w parze, usiedli w taki sposób, że spletli się nogami, chyba nawet tego nie zauważając. Ona w podsumowaniu warsztatów stwierdziła, że teraz jeszcze lepiej dostrzega, czym było ich małżeństwo przed ujawnieniem się kryzysu: było „karzełkiem”. I że ona deprecjonowała męża, chcąc, żeby czuł i myślał to, co ona, a teraz chce go bardziej szanować. On powiedział, że od czasu przyjścia na warsztaty więcej przytula żonę, i że zaczął nosić dzieci „na barana” - przedtem bał się bliskości. Grupa bardzo życzliwie reagowała na ich wypowiedzi i przejawy czułości, zdarzało się, że dostawali oklaski. Niektórzy uczestnicy mówili o tej parze: „przyjemnie było na was patrzeć”, „chciałabym, tak jak wy...” - ich przykład dawał pozostałym nadzieję i wzór do naśladowania. 
Para D. Ona przyszła na warsztaty tylko po to, żeby zmobilizować do udziału męża, bo niepokoiły ją jego zachowania przemocowe wobec dzieci. On zdawał sobie sprawę z tego, że ma problem z takimi zachowaniami, i chciał nad nimi pracować, ale jednocześnie tak bardzo obawiał się krytyki, że nie był w stanie prawie nic powiedzieć ani zrobić. Siedzieli obok siebie, ale trudno było się zorientować, czy czują się ze sobą dobrze - oboje robili wrażenie bardzo napiętych. Z czasem on się ośmielił i zaczął mówić, a ona zorientowała się, że sama też niekiedy zachowuje się w sposób, który trudno jej zaakceptować, i że bardzo trudno jest jej wyrazić siebie, a czasami nawet nie wie, czego pragnie. Powoli odkrywała swoje uczucia i potrzeby. Po jakimś czasie zaczęli siadać daleko od siebie. W trakcie indywidualnych rozmów z nami, prowadzącymi, przyznawali, że ostatnio w domu więcej się kłócą. Zdali sobie też sprawę, że on ma problem z uzależnieniem, a ona - ze współuzależnieniem. Na ostatnim spotkaniu warsztatowym znów siedzieli bliżej siebie, ale byli bardziej ożywieni niż na początku, częściej na siebie spoglądali. Pozostali uczestnicy nie wypowiadali się na temat swoich uczuć, pojawiających się w związku z zachowaniem tej pary. Po zakończeniu warsztatów odbyłyśmy i z nim, i z nią rozmowy indywidualne. Oboje, niezależnie od siebie, podjęli decyzję o dalszej, bardziej pogłębionej pracy nad sobą.

\subsection{Rodzice $\mathrm{w}$ kryzysie małżeńskim, którzy uczestniczyli w warsztatach bez współmałżonka}

Spośród wszystkich 110 uczestników 11 edycji warsztatów pojedynczych małżonków łącznie we wszystkich grupach było 93 (spośród pozostałych 17 osób: 10 osób to małżonkowie, którzy uczestniczyli wspólnie, a 7 uczestników nie było w związku małżeńskim: 3 z nich było osobami samotnymi, nauczycielami, 2 osoby były w związku partnerskim, 1 uczestnik był księdzem, 1 uczestniczka była wdową) $)^{24}$. Wśród pojedynczych małżonków

${ }^{24}$ Niektórzy spośród tych 93 osób byli współmałżonkami, uczestniczącymi w warsztatach w osobnych grupach - takich osób było jednak niewiele, a ich sytuacja była zróżnicowana, ponieważ niektóre z nich uczestniczyły w warsztatach równolegle ze swoim współmałżonkiem, inne zaś nie - dlatego tej zmiennej w ogóle nie uwzględniałam w analizie. 
większość stanowiły kobiety: było ich 70, mężczyzn zaś 23 . Nie sposób z całą pewnością stwierdzić, ile spośród tych osób w trakcie kursu doświadczało kryzysu małżeńskiego, m.in. dlatego, że nie było możliwości zaobserwowania tych osób w relacji ze współmałżonkami, ale też i z tego powodu, że w ogóle trudno jest to ocenić. Trudno jest nawet ustalić kryteria takiej oceny. Kierując się sformułowaną przez mnie definicją kryzysu małżeńskiego, przyjęłam jako kryterium, że uznaję za małżonka w kryzysie takiego uczestnika, który w bezpośredni lub pośredni (bez użycia słowa „kryzys” ani „potrzeba”) sposób mówił o tym, że doświadcza w związku małżeńskim utrzymującej się deprywacji potrzeb, które na ogół są ważne dla tego związku (,jestem w trakcie rozwodu, żona mną pomiata”, ,jesteśmy w separacji, mąż ma kochankę”, „mieszkamy ze sobą, ale od lat w ogóle ze sobą nie rozmawiamy, łączy nas tylko dziecko i kredyt, nasze małżeństwo jest jakieś chore”, „mąż bierze dużo leków psychotropowych i całymi dniami śpi, ja się zajmuję wszystkim, co jest do zrobienia w domu"). Co charakterystyczne, również ci małżonkowie, którzy byli już wiele lat po rozstaniu ze współmałżonkiem, nadal mówili o nim jak o swoim mężu czy żonie, co miało swoje podłoże $\mathrm{w}$ ich przekonaniach religijnych i wierze w nierozerwalność sakramentu małżeństwa - dlatego ich również uznałam za osoby doświadczające kryzysu małżeńskiego.

Zgodnie z tymi kryteriami spośród pojedynczych małżonków uczestniczących w warsztatach w trakcie kursu doświadczało kryzysu małżeńskiego 66 osób, w tym 51 kobiet i 15 mężczyzn. Wynik ten jest zaskakujący z dwóch powodów: po pierwsze, to bardzo duża liczba; po drugie, zauważalna jest dysproporcja płci. Duża liczba uczestników doświadczających kryzysu małżeńskiego może mieć związek z tym, że warsztaty „Błogosławmy Dzieciom” są dobrze znane we Wspólnocie Trudnych Małżeństw SYCHAR ${ }^{25}$ oraz wśród uczestników i absolwentów warsztatów „Wreszcie żyć - 12 kroków ku pełni życia”. Wielu uczestników rekrutuje się z tych środowisk, a są to środowiska skupiające osoby z różnego rodzaju problemami osobistymi i problemami w związkach. Dysproporcja płci może być spowodowana różnymi czynnikami, np. większą powściągliwością mężczyzn w ujawnianiu kryzysu małżeńskiego lub tym, że faktycznie na warsztaty trafiło więcej kobiet będących w kryzysie małżeńskim niż mężczyzn. Należy

25 http://sychar.org/ (dostęp: 16.09.2019). 
jednak pamiętać, że dane te są wyłącznie szacunkowe. Bardzo trudno jest bowiem z całkowitą pewnością zorientować się, kto doświadcza kryzysu, a kto nie. Przypuszczam, że podane tu liczby są raczej niedoszacowane niż przeszacowane.

\subsubsection{Pierwsze pytanie badawcze: Jak przebiega na warsztatach praca rodziców żyjących w kryzysie? - Podsumowanie}

Nie sposób opisać, jak pracowało na warsztatach każde z rodziców, dlatego wyodrębniłam trzy typy ich funkcjonowania i opisałam każdy z nich.

\subsubsection{Uczestnik zajmujacy sie na warsztatach niemal wytacznie swoim związkiem matżeńskim}

Niektóre z osób doświadczały trudnych uczuć, charakterystycznych dla „ostrej fazy” kryzysu małżeńskiego - jak lęku, złości, rozpaczy, gniewu - w tak wysokim stopniu, że nie były w stanie przyswajać nowych treści dotyczących relacji z dzieckiem. Więcej nawet - nie bardzo zwracały na tę relację uwagę. W pewnym sensie traciły z oczu nie tylko własne dziecko, ale i sam fakt, że mają dziecko. Tak bardzo skupione były na relacji małżeńskiej i na swoim cierpieniu. Jedne z nich z pomocą osób prowadzących i pozostałych uczestników nazywały swoje uczucia i potrzeby, inne tylko przysłuchiwały się zajęciom i bardzo rzadko zabierały głos, odmawiały też udziału w scenkach, mówiąc, że jest im „za trudno”.

Przykład: Kasia ${ }^{26}$ przyszła na warsztaty świeżo po rozstaniu z mężem. W czasie rundek mało mówiła o dziecku, nie zgłaszała się do udziału w scenkach. Widać było, że zastanawia się, jak jej zachowanie wpłynęło na męża i jego decyzję o wyprowadzce. Próbowała zrozumieć też siebie samą i swoje reakcje. Mówiła, że myślenie o przeżyciach dziecka ją „przytłacza” i że potrzebuje teraz przede wszystkim spokoju, żeby zająć się sobą. Przypuszczałyśmy, że być może w kontakcie z dzieckiem jest emocjonalnie dla niego niedostępna. Uznałyśmy, że tym, co może jej najbardziej pomóc, będzie okazywanie jej empatii: towarzyszenie jej w jej trudnych uczuciach związanych ze stratą jedności małżeńskiej. Po około roku od zakończenia warsztatów Kasia ponownie wzięła w nich

26 Imiona uczestników zostały zmienione. 
udział (w innej edycji), żeby zająć się relacją z dzieckiem - przeszła już przez wszystkie etapy żałoby po stracie i była gotowa zwrócić się ku dziecku.

\subsubsection{Uczestnik zajmujący się na warsztatach niemal wytacznie swoja relacja $z$ dzieckiem, badź z samym soba, $z$ rodzicami lub z Bogiem}

Niektóre z osób w ogóle nie chciały myśleć ani mówić o małżonku - byli to przeważnie uczestnicy, którzy już dawno pogodzili się z rozstaniem albo z tym, że w ich małżeństwie źle się układa. W większości przypadków zauważali oni w czasie warsztatów, że jakość ich związku z małżonkiem ma duże znaczenie dla dzieci, ale pomimo tego nie chcieli zajmować się związkiem i tego nie czynili.

Przykład: Joanna zgłosiła się na warsztaty będąc w ciąży. Dużo mówiła o swoich starszych dzieciach i o swojej mamie, opowiadała też o własnych odkryciach duchowych. Twierdziła, że poznaje lepiej swoje uczucia i potrzeby. Przy tej okazji nieraz wspominała, że mąż nie bierze ich pod uwagę oraz że dzieci są tego świadkami, ale szybko ucinała temat. Osoby prowadzące przypuszczały, że w tym małżeństwie jest kryzys, ale - po konsultacji z superwizorką - nie zachęcały uczestniczki do dłuższego pozostania przy tym temacie ze względu na to, że była w ciąży. Po dwóch latach od zakończenia warsztatów Joanna zgłosiła się do jednej z prowadzących na konsultację, mówiąc, że ma kryzys w małżeństwie - okazało się, że mąż, prawdopodobnie uzależniony od seksu, od wielu lat ją zdradzał, i albo ją oszukiwał, albo obwiniał ją o swoje zdrady, a ona albo pozwalała mu się oszukiwać, albo brała winę na siebie. Twierdziła też, że wcześniej nie była gotowa dostrzec, jak naprawdę wygląda ich związek.

\subsubsection{Uczestnik nie miat zamiaru zajmować się na warsztatach swoim zwiazkiem matżeńskim, a jednak to robit}

Zauważyłam, że niektórzy uczestnicy, rozpoczynając warsztaty, jakby nie pamiętali o istnieniu swojego związku małżeńskiego i przypominali sobie o nim w trakcie warsztatów. Zdarzali się np. uczestnicy, którzy byli już dawno po rozstaniu z małżonkiem i nie zamierzali pracować na warsztacie nad swoją relacją z nim. Nie sądzili też, że ta relacja ma jakiekolwiek znaczenie dla ich dzieci. Jednak w trakcie warsztatów nieoczekiwanie dla siebie 
samych zaczynali znowu myśleć o małżonku i zastanawiać się nad własnym związkiem małżeńskim - albo ze względu na swoją relację z Bogiem, albo ze względu na dobro dzieci. Wydaje się, że uczestnicy „indukują się” pod tym względem wzajemnie: zauważyłam np. kilka razy, że uczestniczka z dużym zaangażowaniem notowała sobie wypowiedzi innych uczestników, kiedy ci opowiadali o swoim stosunku do współmałżonka. Sama jednak na temat swojej relacji małżeńskiej się nie wypowiadała, wspominała tylko, że „jest trudna”, czasem przy tym płakała i nie chciała powiedzieć, o co konkretnie chodzi. Potem jednak znów notowała właśnie te wypowiedzi, które dotyczyły spraw małżeńskich - a więc w jakiśs sposób pracowała nad swoim związkiem małżeńskim.

Przykład: Zuzanna była bardzo zaangażowana w pracę zawodową. Przez dużą część warsztatów mówiła głównie o swoich kłopotach w pracy, trochę też o dzieciach. W pewnym momencie powiedziała: „Wiecie co - przypomniałam sobie, że mam też męża!”. Mąż wprawdzie wyprowadził się od niej kilka lat wcześniej, ale przychodził do dzieci, które z nią mieszkały, a ona traktowała go wtedy obojętnie lub nawet wrogo. Jednocześnie deklarowała się jako katoliczka, która ze względu na złożoną przysięgę jest wierna mężowi. Zorientowała się, że jej postawa jest niespójna, i że aby dochować przysięgi, musiałaby kochać męża, a nie tylko nie wchodzić w kolejny związek. Ta świadomość była dla niej bardzo niewygodna, zwłaszcza że miejsce męża w jej życiu zajął jednak inny mężczyzna - nastoletni syn, z którym spędzała codziennie dużo czasu na wspólnych spacerach i wysłuchiwaniu jego zwierzeń. Córce natomiast nie poświęcała nawet kilku minut dziennie, chociaż dziewczyna ją o to niejednokrotnie prosiła - Zuzanna mówiła podczas zajęć, że nie rozumie, o co temu dziecku chodzi. Kiedy zauważyłyśmy tę nierównowagę oraz zachwianie ról w ich systemie rodzinnym i zaproponowałyśmy zmiany, zrezygnowała z udziału w kursie.

\subsubsection{Drugie pytanie badawcze: Co dzieje się} ze związkiem małżeńskim rodziców znajdujących się w kryzysie, czy zachodzą w nim jakieś zmiany, a jeśli tak, to jakie? - Podsumowanie

Obserwowanie rodziców znajdujących się w kryzysie małżeńskim i uczestniczących w warsztatach bez współmałżonka, 
pozwoliło mi odpowiedzieć częściowo również na drugie pytanie badawcze, czyli na pytanie o to, co dzieje się ze związkiem małżeńskim tych rodziców: czy zachodzą w nim jakieś zmiany, a jeśli tak, to jakie.

Uczestnicy ci czasem wprost mówili podczas warsztatów, że pod wpływem kursu dokonały się w nich korzystne zmiany, rzutujące na ich związek małżeński. Przeważnie zmiany te polegały na stawianiu granic sobie samym i bardziej stanowczym chronieniu swoich granic przed współmałżonkiem, na bardziej bezpośrednim komunikowaniu współmałżonkowi swoich uczuć oraz niezaspokojonych lub zaspokojonych potrzeb (komunikat JA) i - rzadziej - na docenianiu go, na okazywaniu mu empatii, szacunku i wdzięczności. Przynosiło to zmiany w związku: zaspokajali w nim potrzebę szczerości, autentyczności, bycia w zgodzie ze sobą, spójności, kontaktu, czasem również miłości i szacunku. Według tych uczestników, na ogół zmiany w ich zachowaniu po jakimś czasie pociągały za sobą jakieś zmiany także w zachowaniu ich współmałżonków, przy czym na ogół te zmiany były odbierane przez uczestników jako korzystne, ale nie zawsze. Byli też tacy uczestnicy, którzy mówili o swojej bezsilności i o niemożności wprowadzenia jakichkolwiek zmian: i we własnym zachowaniu, i w związku małżeńskim.

Obserwacja zachowania uczestników (w scenkach warsztatowych, w tzw. rundkach itp.) potwierdzała przeważnie ich deklaracje: ci, którzy opowiadali o dokonanych zmianach, zazwyczaj rzeczywiście zachowywali się inaczej niż na początku kursu; ci którzy opowiadali o swojej bezsilności i niemożności wprowadzenia zmian, często nie zmieniali swojego zachowania także w trakcie trwania kursu. Jest to jednak duże uproszczenie, a rzeczywistość była znacznie bardziej skomplikowana. Przykładowo niektóre ze zmian były delikatne i uczestnicy ich u siebie nie zauważali, natomiast zauważały je osoby prowadzące i pozostali uczestnicy. Innym razem zmiana u uczestnika była znacząca, ale polegała tylko na zwiększeniu samoświadomości i nowym nastawieniu, co nie przekładało się jeszcze na jego zachowanie.

Przykład: Jacek trafił na warsztaty w trakcie sprawy rozwodowej. Trudno mu było ustalić z żoną cokolwiek, co dotyczyło dzieci, a zwłaszcza bieżących kontaktów z nimi. Żona Jacka wyprowadziła się od niego z dziećmi, w sądzie oskarżała go o przemoc wobec nich, starała się ograniczyć jego kontakty z dziećmi i odebrać mu władzę rodzicielską. Mężczyzna nie rozumiał, o jaką 
przemoc chodzi żonie. Nie zdawał sobie sprawy z tego, że ją stosuje, chociaż nie tylko żona, ale też inne osoby z otoczenia dawały mu takie sygnały. Był chyba tak bezradny wobec swych intensywnych, gwałtownie przejawiających się uczuć, że wolał nie widzieć swoich przemocowych zachowań: krzyku, szarpania itp., do których dochodziło, kiedy nie radził sobie z uczuciami. $\mathrm{Na}$ warsztatach zafascynowała go metoda „Porozumienia Bez Przemocy" - prawdopodobnie dawała mu nadzieję, że uda mu się uniknąć zachowań przemocowych. Zapoznawszy się z tą metodą, odważył się dostrzec swoją skłonność do stosowania przemocy i to było chyba największą korzyścią, jaką wyniósł z warsztatów. Zauważył też u siebie ogromną, niezaspokojoną potrzebę empatii. Zrozumiał wtedy lepiej siebie samego, a także swoje dzieci i żonę. Mówił na warsztatach, że zaczął okazywać empatię: sobie, dzieciom i nawet żonie, mimo trwającej sprawy rozwodowej. Rozmowy małżonków dotyczące dzieci stały się dzięki temu nieco łatwiejsze, poprawiły się też relacje Jacka z dziećmi, dzięki czemu żona stała się bardziej elastyczna w kwestii ich kontaktów. Po zakończeniu warsztatów Jacek uczył się PBP dalej i skorzystał z warsztatów dla sprawców przemocy, a kiedy to okazało się niewystarczające, w końcu zdecydował się skorzystać z terapii długoterminowej na oddziale dziennym.

Przykład: Halina trafiła na warsztaty kilka lat po rozwodzie, chciała poprawić relację z młodszym synem (starszy był już samodzielny). Mąż Haliny, zanim od niej odszedł, przez wiele lat dopuszczał się przemocy wobec niej i dzieci (zwłaszcza starszego syna) - również fizycznej. Kiedy zaczęły się warsztaty mężczyzna nadal pojawiał się w jej domu bez zapowiedzi, nawet późnym wieczorem, chociaż ją to krępowało i próbowała protestować; dzwonił do niej, a ona odbierała telefon również wtedy, kiedy nie chciała z nim rozmawiać, i pozwalała mu krzyczeć na siebie przez telefon. W trakcie warsztatów Halina zrozumiała, że trudno jej będzie skłonić nastoletniego syna do tego, żeby ją szanował, jeśli ona sama nie będzie szanować siebie w relacji z mężem. Opowiadała, że zaczęła mówić mężowi stanowczo „nie”, a on, z początku zaskoczony, zaczął traktować ją z większym szacunkiem. Widać było też, że w trakcie trwania kursu zmieniła się jej postawa ciała i jej mimika: stały się bardziej naturalne, swobodne, uzewnętrzniały jej siłę.

Uczestnicy warsztatów mówili, że w czasie trwania kursu, w następstwie zmian, które się w nich dokonywały, zmieniały się 
także liczba i natężenie konfliktów między nimi a ich współmałżonkami o wychowanie dzieci: czasem te konflikty się zmniejszały, a czasem - wręcz przeciwnie. Niekiedy ich liczba i natężenie pozostawały bez zmian, ale inny niż dotąd był ich przebieg.

Przykład: Kasia - ta sama, która dwukrotnie wzięła udział w warsztatach - napisała mi w e-mailu około roku po zakończeniu swojej drugiej edycji warsztatów, że miała z mężem konflikt dotyczący odbioru syna w wieku wczesnoszkolnym z zajęć pozalekcyjnych. Mąż odebrał go koło godz. 19-tej. Chłopiec był poza domem od 8-mej rano i miał jeszcze do odrobienia pracę domową, a ojciec pojechał z nim po odebraniu z zajęć na zakupy, co opóźniło powrót dziecka do domu. Kasia napisała mi: „Zareagowałam dosyć mocno, ale z komunikatem ja, jedyny minus to taki, że miałam dosyć podniesiony głos - a jak się już wygadałam, to się po prostu uśmiechnęłam do męża, później była rozmowa, jak takie sytuacje w przyszłości rozwiązać i wszystko było ok”.

\section{Interpretacja wyników}

Interpretując uzyskane wyniki, będę formułować wnioski ostrożnie, tylko w odniesieniu do zbadanej grupy, choć bardzo możliwe, że mogłyby dotyczyć także innych osób.

\subsection{Rodzice w kryzysie małżeńskim, którzy wspólnie uczestniczyli w warsztatach w tej samej grupie}

Sposób, w jaki uczestniczyli w warsztatach umiejętności wychowawczych rodzice przeżywający kryzys małżeński, którzy znaleźli się $\mathrm{w}$ tej samej grupie, był $\mathrm{w}$ zasadniczy sposób związany $\mathrm{z}$ ich stosunkiem do współmałżonka, i w jakimś stopniu zależał także od jego zachowania. Można powiedzieć, że kryzys małżeński „przyszedł” razem z tymi rodzicami na warsztaty, i że również tam rozgrywał się jakiś jego etap. Jednak to, jaki był przebieg tego etapu, i w jakim stopniu rodzice ci angażowali się podczas warsztatów, a w konsekwencji co z nich wynieśli, zależało moim zdaniem od jednego decydującego czynnika: a mianowicie od tego, czy oboje byli gotowi na rozwój osobisty, czy tylko jedno z nich.

„Gotowość na rozwój osobisty” jest bardzo ogólną kategorią pojęciową, trudną do precyzyjnego zdefiniowania. Sądzę jednak, 
że bliską osobom udzielającym pomocy terapeutycznejej. Przez rozwój osobisty rozumiem pracę nad sobą prowadzącą do poznawania prawdy o sobie i do korzystnych zmian w funkcjonowaniu psychospołecznym; przez gotowość - stan, który pozwala na zmianę, przy czym „gotowość na rozwój osobisty” oznacza dla mnie gotowość na zmianę postaw lub choćby tylko przekonań, gdyż obserwuję, że właśnie od zmiany przekonań często zaczyna się zmiana postaw ${ }^{28}$. Oczywiście to, czy opisane tu osoby były gotowe na rozwój, czy nie, jest tylko moją subiektywną oceną, uzależnioną od interpretacji zaobserwowanych wypowiedzi i zachowań. Istnieje zatem ryzyko, że interpretacje te, podobnie jak i oceny, nie są trafne. Wydaje mi się jednak, że wobec braku jakichkolwiek badań w tym obszarze, warto sformułować wnioski nawet tak niepewne, choćby po to, by uzyskać tym sposobem kolejne hipotezy do weryfikacji i wyznaczyć kierunek dalszych badań.

Jeśli więc oboje małżonkowie gotowi byli według mojej oceny na rozwój (para $\mathrm{C}$ i para $\mathrm{D}$ ), to każde z nich pracowało w trakcie warsztatów nad sobą i wówczas każde z nich podczas zajęć się rozwijało. Oboje odnosiło wówczas z kursu widoczne korzyści. Polegały one przede wszystkim na zwiększeniu się ich świadomości własnych uczuć i potrzeb oraz chęci i umiejętności komunikowania ich współmałżonkowi; u niektórych osób (para C) zwiększyła się też wrażliwość na uczucia i potrzeby współmałżonka. Pojawienie się tych zmian u obojga małżonków miało pozytywne konsekwencje dla jakości ich związku: relacja między tymi małżonkami poprawiała się w widoczny sposób podczas trwania kursu - albo stopniowo i stale (para C), albo $\mathrm{z}$ okresem pogorszenia w środku, ale z lepszym stanem końcowym niż wyjściowym (para D). Ostatecznie ich związek stawał się bliższy, relacja bardziej autentyczna i szczera, a małżonkowie zaspokajali w tym związku więcej własnych potrzeb. Korzyści z obserwowania tych zmian czasem odnosili również pozostali uczestnicy (grupa z parą C): doświadczali przyjemnych uczuć,

27 Zob. też Gajdowie 2012.

${ }^{28}$ Ze względu na praktyczny w dużej mierze charakter artykułu nie będę już definiować poszczególnych składników tej roboczej definicji. Dodam tylko, że do uzyskania tego stanu gotowości konieczne jest według mnie „osobiste świadome zaangażowanie we własny rozwój” (Sujak 1992: 13). Niestety, decyzja o uczestnictwie w warsztatach nie musi iść w parze z taką postawą (może być np. podjęta z chęci zaangażowania współmałżonka). Może się ono pojawić w trakcie trwania warsztatów, ale nie musi. 
m.in. nadziei, co prawdopodobnie zwiększało ich motywację do pracy; mogli uczyć się korzystnych dla związku zachowań przez naśladowanie (para w niezamierzony sposób je modelowała).

Jeśli natomiast tylko jedno z małżonków było gotowe na rozwój (para A i para B), wówczas sytuacja stawała się trudna zarówno dla tej pary, jak i dla pozostałych uczestników, i dla nas prowadzących. Małżonkowie zachowywali się różnie: albo jedno z nich zajmowało się sobą a drugie współmałżonkiem, albo oboje zajmowali się samymi sobą, ale tylko jedno z nich robiło to w sposób dający szansę na rozwój, a drugie tkwiło w mechanizmach obronnych. Widoczne korzyści odnosiło wówczas tylko jedno z małżonków i polegały one (podobnie jak u małżonków, którzy oboje pracowali nad sobą) przede wszystkim na zwiększeniu świadomości własnych uczuć i potrzeb oraz chęci i umiejętności komunikowania ich małżonkowi, ale korzyści te były prawdopodobnie mniejsze, niż byłyby wówczas, gdyby osoba ta uczestniczyła w warsztatach bez współmałżonka, gdyż jego postawa wpływała na nią hamująco. Podczas trwania kursu między małżonkami nasilały się (para A) lub pojawiały się (para B) konflikty - trudno jednak ocenić, czy było to korzystne, czy nie dla jakości ich związku małżeńskiego, ani też, jakie były dalsze tego konsekwencje. W parze A zaognienie konfliktu w trakcie warsztatów mogło przyczynić się w jakimś stopniu do późniejszego rozstania małżonków, w parze B - skutkiem pojawienia się konfliktów było częściowe i być może przejściowe ujawnienie utajonego kryzysu. O ile rozstanie trudno zakwalifikować jako korzystne dla jakości związku (choć bywa i tak, że separacja bądź rozwód są tylko etapem, po którym małżonkowie znowu są razem i ich związek jest wówczas bliższy, zdrowszy, silniejszy niz przed rozstaniem), o tyle ujawnienie utajonego kryzysu uważam za korzystne - choć jeśli jest ono tylko częściowe i przejściowe, to korzyść wydaje się być niewielka. Trudno też ocenić, jakie mogły być długofalowe konsekwencje pojawienia się zmian u jednego z małżonków dla związku małżeńskiego. Nie wiadomo wreszcie, czy brak widocznych korzyści oznaczał rzeczywisty brak korzyści - skutek uczestnictwa w tego rodzaju warsztatach bywa odroczony w czasie.

Udział w zajęciach obojga małżonków, z których tylko jedno było gotowe na rozwój, stanowił zagrożenie dla pracy grupy: pozostali uczestnicy doświadczali trudnych uczuć, takich jak lęk, bezsilność, smutek, gniew, co prawdopodobnie odciągało 
ich uwagę od własnych spraw; czasem też tracili część zaplanowanych ćwiczeń.

Również my, prowadzące, w trakcie tych warsztatów doświadczałyśmy niejednokrotnie dużej bezradności - zapewne są to podobne doświadczenia do tych, jakie mają terapeuci małżeńscy, kiedy jedna ze stron zbuduje wokół siebie „mur oporu”29.

Jeśli chodzi o relacje $\mathrm{z}$ dziećmi, zostały one pominięte $\mathrm{w}$ tych krótkich opisach poszczególnych par, należy jednak zauważyć, że wszyscy ci małżonkowie, którzy odnieśli jakieś widoczne korzyści $\mathrm{z}$ warsztatów, chcieli wprowadzić również istotne zmiany w swojej relacji z dzieckiem (lub dziećmi). Jeśli sytuacja ta dotyczyła obojga rodziców (para C i para $\mathrm{D}$ ), wówczas zmiany były przez nich dyskutowane i uzgadniane w czasie spotkań warsztatowych, co prawdopodobnie zwiększało znacznie szansę na wprowadzenie tych zmian $\mathrm{w}$ życie. W tych parach, w których gotowe na rozwój było tylko jedno z małżonków, temat wychowania dzieci był jakby poboczny, marginalny - stanowił przede wszystkim jeden z obszarów konfliktu i poruszanie go prowadziło raczej do wzajemnych oskarżeń niż do szukania konstruktywnych rozwiązań (para A), albo był to jeden z wielu niewyjaśnionych do końca wątków, który, podobnie jak pozostałe, był w dużej mierze cenzurowany lub został nawet całkiem przemilczany (para B).

\subsection{Rodzice $\mathrm{w}$ kryzysie małżeńskim, którzy uczestniczyli w warsztatach bez współmałżonka}

Rodzice w kryzysie małżeńskim, którzy uczestniczyli w warsztatach bez współmałżonka, funkcjonowali bardzo różnie i podejmowali pracę nad odmiennymi obszarami swojego życia: jedni zajmowali się niemal wyłącznie swoim związkiem małżeńskim, inni relacją z dzieckiem bądź z samym sobą, z rodzicami lub z Bogiem, jeszcze inni nie planowali zajmować się na warsztatach swoim związkiem małżeńskim, a jednak z czasem to czynili. Można więc założyć, że związek małżeński stanowił dla nich bardzo ważny i trudny temat, dlatego, rozpoczynając warsztat, albo byli w ten temat mocno zaangażowani, albo starali się go pomijać. Niezależnie od tego, dla tych pojedynczych rodziców udział w warsztatach niewątpliwie był szansą na rozwój i nieraz następowały u nich korzystne zmiany. Natomiast nie udało się z całą

29 Szewczyk 2006: 107. 
pewnością ustalić, jakie zmiany w związku małżeńskim pociągnął za sobą ich rozwój - jeżeli się dokonywał - chociaż ich wypowiedzi zdają się przemawiać za tym, że były to zmiany korzystne.

\subsection{Podsumowanie i wnioski}

Cel badań - to jest sprawdzenie, jakie są szanse i zagrożenia uczestnictwa w warsztatach umiejętności wychowawczych rodziców będących w kryzysie małżeńskim: zarówno tych, którzy uczestniczą w tych warsztatach oboje w jednej grupie, jak i tych, którzy uczestniczą w nich pojedynczo (a drugi rodzic nie uczestniczy w nich wcale lub uczestniczy, ale w innej grupie). Cel ów został osiągnięty częściowo, przeprowadzone badania należy więc uznać za pilotażowe.

Udało się w dużej mierze znaleźć odpowiedź na pierwsze z głównych pytań badawczych, czyli ustalić, jak przebiegała praca tych rodziców na warsztatach. Przeprowadzone badania pozwoliły opisać, jak się oni zachowywali i co mówili (jakie tematy poruszali i w jaki sposób). Co czuli, czy wynieśli jakieś korzyści, np. czy zwiększyła się ich świadomość siebie i czy zdobyli jakieś nowe umiejętności (a jeśli tak, to jakie) - te aspekty udało się poznać częściowo. Zastanawiający jest zwłaszcza fakt, że jeśli w warsztatach uczestniczyli oboje małżonkowie i tylko jedno z nich było gotowe na rozwój osobisty, wówczas u drugiego z nich nie następowały żadne widoczne zmiany. Natomiast jeśli uczestniczyli pojedynczy małżonkowie i zachodziły w nich zmiany, wówczas często dostrzegali oni również zmiany u współmałżonków, którzy nie uczestniczyli w warsztacie $\mathrm{w}$ tej samej grupie (a przeważnie w ogóle nie uczestniczyli w warsztacie). Możliwe, że zmiany u „pojedynczych” uczestników były większe, ponieważ nie blokowała ich obecność współmałżonków, a zatem miały większą szansę wpłynąć na pojawienie się zmian także u współmałżonków; możliwe też, że „pojedynczy” małżonkowie życzeniowo dopatrywali się zmian u swoich współmałżonków. Zbadałam zbyt mało par biorących udział w warsztatach w jednej grupie, by uzyskać wynik, który pozwoliłby wnioskować o prawidłowościach. Warto byłoby powtórzyć badanie na większej próbie właśnie pod tym kątem. Dla uzyskania pełnego obrazu należałoby też przeprowadzić badania podłużne, gdyż, jak wspomniałam, efekty uczestnictwa w warsztatach bywają odroczone w czasie, czas też weryfikuje początkowe sukcesy. Dobrze byłoby zastosować również dodatkowe metody poza tymi, którymi się posłużyłam. 
Także na drugie z głównych pytań badawczych: co dzieje się ze związkiem małżeńskim rodziców znajdujących się w kryzysie - czy zachodzą w nim jakieś zmiany oraz jeśli zachodzą, to jakie - udało się dać częściową odpowiedź. Nie udało się potwierdzić hipotezy, że jeśli w związku małżeńskim rodziców będących w kryzysie małżeńskim uczestniczących w warsztatach zachodzą jakieś zmiany, to są to zmiany korzystne dla jakości tego związku, a więc stanowią one dla niego szansę, a nie zagrożenie. Aby ostatecznie zweryfikować tę hipotezę i zarazem w pełniejszy sposób odpowiedzieć na drugie pytanie badawcze, należałoby przeprowadzić badania podłużne, najlepiej w formie indywidualnych wywiadów. Wskazane byłoby przeprowadzenie takich wywiadów nie tylko z uczestnikami warsztatów, ale również z małżonkami „pojedynczych” uczestników (co niestety jest mało realne).

Trzecie pytanie dotyczyło tych grup, w których oboje małżonkowie przeżywający kryzys byli razem: chodziło o sprawdzenie, jak odbierali ich zachowanie pozostali uczestnicy i czy obecność takiej pary w grupie stanowi dla tej grupy zagrożenie czy szansę. Ponieważ pytanie to odnosiło się wyłącznie do czasu trwania warsztatów, udało się na nie odpowiedzieć w pełni. Zagrożenie stanowiła obecność pary, w której tylko jedno z małżonków było gotowe na rozwój osobisty. Obecność w grupie obojga małżonków gotowych na rozwój była dla grupy szansą, a w jednym przypadku przyniosła grupie widoczne korzyści.

Najciekawsze i najbardziej wyraziste okazały się być wyniki dotyczące tych małżonków w kryzysie, którzy uczestniczyli $\mathrm{w}$ warsztatach razem w jednej grupie - potwierdziły one przytoczony pogląd Joanny Sakowskiej (2010), iż przyjmowanie obojga małżonków do jednej grupy może stanowić zarówno szansę, jak i zagrożenie. U małżonków w kryzysie decydującym czynnikiem była ich gotowość na rozwój osobisty: gotowość obojga małżonków powodowała, że udział ich obojga był szansą, gdyż przynosił korzyści dla każdego z nich, dla ich związku i czasem również dla pozostałych uczestników, gotowość tylko jednego z małżonków powodowała, że ich udział był wątpliwą szansą dla małżonków i ich związku, a niewątpliwym zagrożeniem dla pozostałych uczestników.

Uzyskane wyniki, choć niepełne, upoważniają jednak do wyciągnięcia wniosków praktycznych, które mogą okazać się przydatne dla osób prowadzących warsztaty umiejętności wychowawczych: 
1) Przed przyjęciem obojga rodziców do jednej grupy warsztatowej dobrze jest, moim zdaniem, odbyć wstępną konsultację, która pozwoli być może zorientować się, czy dana para znajduje się w kryzysie małżeńskim, czy nie (co bywa trudne do ocenienia, ale na ogół jest jednak, w moim mniemaniu, możliwe), i czy obydwoje małżonkowie gotowi są na rozwój osobisty (co może być jeszcze trudniejsze do oceny, ale warto próbować) ${ }^{30}$, i na tej podstawie oszacować szanse oraz zagrożenia związane z udziałem pary w zajęciach jednej grupy, a następnie dopiero podejmować decyzję o przyjęciu bądź nieobojga małżonków.

2) Wskazane jest, aby pozwolić uczestnikowi na zajęcie się w trakcie warsztatów relacją, którą jest gotowy się zająć - niekoniecznie musi to być relacja z dzieckiem.

3) Dobrze jest zaoferować niektórym uczestnikom możliwość indywidualnych konsultacji w trakcie trwania warsztatów i po ich zakończeniu.

$\mathrm{Na}$ zakończenie chciałabym przedstawić propozycję, która może zainspiruje kogoś z realizatorów warsztatów umiejętności wychowawczych lub warsztatów dla par. Ponieważ małżonkowie uważają, że niemal wszystkie najważniejsze treści warsztatów „Szkoła dla Rodziców i Wychowawców” i „Błogosławmy Dzieciom" są przydatne nie tylko w relacji z dzieckiem, ale też $\mathrm{w}$ relacji małżeńskiej, można byłoby - w porozumieniu z autorkami książek i programów - adaptować te treści na potrzeby małżonków nie będących $\mathrm{w}$ poważnym kryzysie i dla narzeczonych. Tematy spotkań, jak się wydaje, mogłyby pozostać bez zmian, wystarczyłoby zmienić przykłady i nieco dostosować ćwiczenia: np. temat samodzielności można byłoby omówić w kontekście relacji z rodzinami, z których się pochodzi, i teściami. Warsztaty, które

$30 \mathrm{~W}$ trakcie konsultacji proponuję zaobserwować: Czy oboje małżonkowie mówią na zmianę, czy mówi tylko jedno, a drugie milczy, lub mówi głównie jedno, przerywając co chwilę drugiemu? Czy słuchają siebie nawzajem? Jak siedzą w stosunku do siebie? Czy spoglądają na siebie? Czy są uważni na samych siebie i na siebie nawzajem? Czy każde z nich dostrzega własne trudności, czy tylko trudności małżonka? W jaki sposób mówią o trudnościach małżonka: z oskarżeniem i pretensją, czy z życzliwością? Ile barier komunikacyjnych jest w ich wypowiedziach skierowanych do siebie nawzajem, a ile empatii, zrozumienia, życzliwości, współdziałania? Czy szanują nawzajem swoje granice (czas, miejsce, rzeczy, punkt widzenia itp.)? Jak bardzo starają się wypaść korzystnie, a ile w ich wypowiedziach jest szczerości, autentyczności? Czy przebywanie w obecności ich obojga wywołuje napięcie czy odprężenie? 
dają szanse na zwiększenie u małżonków świadomości własnych stanów emocjonalnych i potrzeb, ułatwiają komunikowanie ich otoczeniu, pomagają zachowywać zdrowe granice i uczą empatii wobec innych osób, prawdopodobnie mogłyby z powodzeniem pełnić rolę działań profilaktycznych zapobiegających poważnym kryzysom, a w niektórych wypadkach, tam, gdzie w małżeństwie pojawia się jakiś mniejszy kryzys, być może nawet z powodzeniem zastąpić niejednokrotnie kosztowną, przez wiele osób niechcianą i nie dla wszystkich dostępną terapię małżeńską.

\section{Bibliografia}

Albisetti V. (2007), O mitości. Jak przeżyć razem cate życie, przeł. A. Germeyan, Wydawnictwo JEDNOŚĆ, Kielce.

Braun-Gałkowska M. (1992), Psychologiczna analiza systemów rodzinnych osób zadowolonych $i$ niezadowolonych $z$ matzeństwa, Towarzystwo Naukowe KUL, Lublin.

Faber A., Mazlish E. (2013), Jak mówić, żeby dzieci nas stuchaty, jak stuchać, żeby dzieci do nas mówity, przeł. M. Więznowska, B. Horosiewicz, Media Rodzina, Poznań.

Freeman D.R. (1991), Kryzys matżeński i psychoterapia, przeł. J. Szymańska, J. Wójcik, PWN, Warszawa.

Gajdowie M. i M. (2012), Rozwój. Jak wspótpracować z laską?, Pro Homine, Szczecin.

Górecka M., Hanusz J., Kucharska-Zygmunt A., Zygmunt A. (2008), Wyjątkowe rodzicielstwo. Scenariusze zajęć warsztatowych dla rodziców dzieci niepetnosprawnych, Centrum Metodyczne Pomocy Psychologiczno-Pedagogicznej, Warszawa.

Jakubowska B., Markiewicz J. (2002), Rodzina w kryzysie. Podejście integrujace. Indywidualne i grupowe formy pomocy. Poradnik dla profesjonalistów, Stowarzyszenie OPTA, Warszawa.

James R.K., Gilliland B.E. (2005), Strategie interwencji kryzysowej, przeł. A. Bidziński, K. Mazurek, Wydawnictwo Edukacyjne PARPAMEDIA, Warszawa.

Karasowska A., Szulirz A. (2015), Ocalić więzi. Praca socjoterapeutyczna z rodzina zagrożona, ETOH Fundacja Rozwoju Profilaktyki, Edukacji i Terapii Problemów Alkoholowych, Warszawa.

Kast V. (2001), Kryzys jest szansq, czyli jak wykorzystać trudności, przeł. R. Zajączkowski, Wydawnictwo JEDNOŚĆ, Kielce.

Kornaszewska-Polak M. (2016), Poczucie przywiązania $i$ osamotnienia $w$ relacjach matzeńskich, „Roczniki Pedagogiczne” 8 (3), s. 23-38.

Matyjas B. (2008), Dzieciństwo w kryzysie. Etiologia zjawiska, Wydawnictwo Akademickie „Żak”, Warszawa.

Nowak B.M. (2015), Rodzina $w$ kryzysie. Studium resocjalizacyjne, PWN, Warszawa. 
Mellody P., Freundlich L.S. (2010), Droga do bliskości. Prawda, szacunek $i$ trwata miłość $w$ związk, przeł. A. Wolnicka, Wydawnictwo Czarna Owca, Warszawa.

McKay M., Davis M., Fanning P. (2019), Sztuka skutecznego porozumiewania się, przeł. A. Błaż, Gdańskie Wydawnictwo Psychologiczne, Sopot.

Niewiadomska I. (red.) (2015), Hazard i inne uzależnienia behawioralne. Doniesienia z badań, Polska Fundacja Pomocy Humanitarnej „Res Humanae”, Warszawa.

Nowak B.M. (2015), Rodzina w kryzysie. Studium resocjalizacyjne, PWN, Warszawa.

Pisula E. (1998), Psychologiczne problemy rodziców dzieci z zaburzeniami rozwoju, Wydawnictwa Uniwersytetu Warszawskiego, Warszawa.

Reber A.S., Reber E.S. (2005), Stownik psychologii, I. Kurcz, K. Skarżyńska (red.), przeł. zespół tłumaczy, Wydawnictwo Naukowe Scholar, Warszawa.

Rosenberg M.B. (2018), Porozumienie bez przemocy. O języku życia, przeł. M. Markocka-Pepol, M. Kłobukowski, Wydawnictwo Czarna Owca, Warszawa.

Sakowska J. (2010), Szkoła dla rodziców i wychowawców, cz. 1, Ośrodek Rozwoju Edukacji, Warszawa.

Sobol E. (red.) (2002), Stownik wyrazów obcych, PWN, Warszawa.

Sochocki M.J. (2009), Prezentacja rezultatów drugiego etapu badań ewaluacyjnych „Szkoly dla Rodziców i Wychowawców” (edycji wrzesień-grudzień 2007) oraz zogniskowanych wywiadów grupowych z absolwentami „Rodzeństwa bez rywalizacji”, Centrum Metodyczne Pomocy Psychologiczno-Pedagogicznej, Warszawa.

Stefan W. (2012), Jak radzić sobie z kryzysem $w$ matżeństwie i rodzinie?, Salwator, Kraków [audiobook].

Sujak E. (1992), Rozważania o ludzkim rozwoju, Wydawnictwo ZNAK, Kraków.

Szewczyk W. (2006), Dylematy w prowadzeniu terapii dla matżonków, „Studia nad Rodziną", nr 18/19, s. 105-117.

Tryjarska B. (red.) (2012), Bliskość w rodzinie. Więzi w dzieciństwie a zaburzenia $w$ dorostości, Wydawnictwo Naukowe Scholar, Warszawa.

Wojcieszek K.A. (2009), Wprowadzenie, [w:] M.J. Sochocki, Prezentacja rezultatów drugiego etapu badań ewaluacyjnych „, Szkoly dla Rodziców $i$ Wychowawców” (edycji wrzesień-grudzień 2007) oraz zogniskowanych wywiadów grupowych z absolwentami „Rodzeństwa bez rywalizacji”, Centrum Metodyczne Pomocy Psychologiczno-Pedagogicznej, Warszawa.

Zagrodzka A. (2017), Sytuacja dziecka w kryzysie matżeńskim rodziców fenomen Wspólnoty Trudnych Matzeństw SYCHAR, [w:] E.J. Kryńska, A. Suplicka, U. Wróblewska (red.), Dziecko w historii - w kręu kultury chrześcijańskiej, Wydawnictwo Uniwersytetu w Białymstoku, Białystok.

Zagrodzka A., Wądrzyk Z. (2019), Serce, błogostawieństwo i przekleństwo, Wydawnictwo Bernardinum, Pelplin (seria Niebo na ziemi, cz. 2). 


\section{Źródła internetowe}

Anonimowi Seksoholicy, https://www.sa.org.pl/ (dostęp: 16.09.2019).

Błogosławmy Dzieciom, https://www.facebook.com/blogoslawmydzieciom/ (dostęp: 16.09.2019).

Pallotyńskie Centrum Pomocy Duchowej SITIS, https://www.sitis.org.pl/ (dostęp: 16.09.2019).

Rocznik Demograficzny GUS 2018, https://stat.gov.pl/obszary-tematyczne/roczniki-statystyczne/roczniki-statystyczne/rocznik-demograficzny-2018,3,12. html (dostęp: 16.09.2019).

Strategia Odbudowy Rodziny, oprac. Fundacja Mamy i Taty, Warszawa, 5 czerwca 2017, http:/centrumprasowe.pap.pl/cp/en/news/info/100192,, strategia-odbudowy-rodziny-zalozenia-cele-narzedzia-(centrum-prasowe) (dostęp: 16.09.2019).

Stowarzyszenie Szkoła dla Rodziców i Wychowawców, http://szkoladlarodzicow.eu/dla-rodzicow/ (dostęp: 16.09.2019).

Stowarzyszenie Szkoła dla Rodziców i Wychowawców, Dla realizatorów, http:// szkoladlarodzicow.eu/dla-realizatorow/ (dostęp: 16.09.2019).

Wreszcie żyć-12 kroków ku petni życia. Warsztaty rozwoju duchowego, https:// www.12krokow.com.pl/ (dostęp: 16.09.2019).

Wspólnota Uzależnionych od Seksu i Miłości, http://www.slaa.pl/ (dostęp: 16.09.2019).

Wspólnota Trudnych Małżeństw SYCHAR, http://sychar.org/ (dostęp: 16.09.2019). 


\title{
Twórcze działania w pracy z dziećmi z cechami osobowości narcystycznej izolowanymi rówieśniczo jako sprawcami i ofiarami przemocy rówieśniczej
}

\author{
Abstract \\ Creative activities in working with peer isolated narcissist \\ children as victims and perpetrators of peer violence
}

The aim of the article is to discuss the phenomenon of peer rejection as a form of peer violence with particular emphasis on the process of art therapy as a form of support for rejected children. In the article, I tried to show the way in which plastic art therapy can help children who are rejected by their peers. Thanks to belonging to a group, the child satisfies important needs: affiliation, recognition, prestige and achievements. A special form of group interaction is peer rejection, which is treated as one of the main manifestations of social maladjustment. The etiology of rejection is multifactorial and includes personality traits that are negatively evaluated by peers. The peer group in school age becomes one of the pillars of building the child's identity and personality. A child who experiences rejection by peers - loses playing companions, is a victim of bullying - develops negative beliefs about himself. Rejected by a group, without friends, they may say that they are not worth the friendship. Negative emotions grow in the child - feelings of helplessness, loneliness, sadness, anger. A child not being able to deal with a difficult situation, unloads his/her anger and sense of helplessness by resorting to aggressive behavior. In the classroom, it can be considered a provocative perpetrator of bullying. The child then falls into the vicious circle of the victim-perpetrator, negatively affecting the peer group. This phenomenon has a negative impact on the child's further development and its functioning in the peer group. That is why therapeutic measures are very important to minimize the phenomenon of peer rejection. Art therapy can be an alternative form of working with peer-rejected children. It is a form of psychotherapeutic influence that can effectively supports work with children who experience difficulties in peer relationships.

Keywords: art therapy, peer violence, peer rejection

Słowa kluczowe: arteterapia, przemoc rówieśnicza, odrzucenie rówieśnicze 


\section{Wstęp}

Przynależność do grup jest warunkiem zaspokajania potrzeb życiowych i rozwojowych. Stąd też w życie człowieka wpisane jest wszechobecne dążenie do utworzenia i utrzymania przynajmniej minimalnej liczby trwałych i znaczących relacji interpersonalnych (Leary 2001).

Typy relacji interpersonalnych, które mają znaczenie dla tworzenia się konstruktu Ja dziecka, można ująć ogólnie w dwie kategorie: pionowe i poziome. Te pierwsze umożliwiają nawiązywanie relacji z kimś posiadającym większą wiedzę - w przypadku dziecka najczęściej z dorosłym opiekunem. Te drugie pozwalają dziecku zdobywać umiejętności, które możliwe są do nabycia jedynie w towarzystwie rówieśników (Hartup 1999: 44). Rówieśnicy pojawiają się w życiu dziecka bardzo wcześnie. Niektóre dzieci już pod koniec pierwszego roku życia podejmują interakcję z rówieśnikami (Carton 2006). Relacje z rówieśnikami nabierają większego znaczenia w miarę dorastania dziecka. W młodszym wieku szkolnym „zaspokojenie potrzeby kontaktu emocjonalnego $\mathrm{w}$ zespole rówiéśniczym ma dominujące znaczenie dla rozwoju osobowości” (Obuchowski 1983: 85). Zgodnie z poglądem Stefana Baleya (1959) potrzeba przynależności do grupy rówieśniczej osiąga swoje maksimum w ósmym roku życia. Nie zawsze jednak relacje jednostki z pozostałymi członkami grupy są prawidłowe. Nie da się bowiem uniknąć konfliktów, które są naturalną częścią życia społecznego. Dają one możliwość nauki wypracowywania kompromisu, szacunku dla opinii innych i obrony własnego stanowiska. Niekorzystną rozwojowo sytuację natomiast stanowi permanentne odsunięcie od grupy, izolowanie od wspólnych aktywności i zadań. Mowa wówczas o odrzuceniu rówieśniczym.

$\mathrm{Na}$ dziecięce „widzenie” siebie i innych oraz tworzenie relacji interpersonalnych sprzyjających „byciu wśród innych”, a nie „obok nich”, niezaprzeczalnie wpływają także doświadczenia dziecka w relacjach z dorosłymi i rówieśnikami, m.in. w przedszkolu i szkole, mające istotne znaczenie dla tworzenia się własnego wizerunku dziecka oraz jego kompetencji emocjonalno-społecznych, niezależnie od relacji z rodzicami. Klasyfikacja statusu dziecka w grupie rówieśniczej, opierająca się na kategoriach dziecka akceptowanego (lubianego, popularnego) i nieakceptowanego (lekceważonego, izolowanego, odrzuconego), sposób postrzegania go przez nauczycieli, ale też samoocena dziecka 
będąca wynikiem tego, jak wypada ono w sytuacji, gdy porównuje siebie (lub jest porównywane) z innymi, rzutuje na to, czy dziecko będzie miało poczucie, że jest „twórcą świata”. To poczucie jest niezmiernie znaczące, ponieważ - jak podkreśla Donald Winnicott - jednostka, która na początku swej drogi życiowej nie doświadczyła poczucia wszechmocy, ma niewielkie szanse na to, by poczuć się częścią zbiorowości i pracować $\mathrm{w}$ harmonii z innymi, wciąż musi bowiem „forsować swą wszechmoc i twórczość, i kontrolę, jakby usiłowała sprzedać niechciane udziały w fikcyjnej firmie" (Winnicott 2011: 50).

\section{Odrzucenie rówieśnicze wynikające ze specyficznych właściwości dziecięcego rozwoju. Mechanizmy zachodzące w grupie rówieśniczej prowadzące do odrzucenia}

Odrzucenie dziecka przez rówieśników w młodszym wieku szkolnym jest jedną z form okazywania dziecku braku akceptacji. Rówieśniczy brak akceptacji to sytuacja, w której koledzy i koleżanki tej samej grupy okazują dziecku w sposób mniej lub bardziej wyraźny, że nie życzą sobie kontaktu z nim (Deptuła 2013). Tacy badacze jak Andrews, Ladd, Herald (2006) twierdzą, że akceptacja albo odrzucenie rówieśnicze określane są przez to, w jakim stopniu jednostka jest lubiana bądź nielubiana przez członków grupy, w której się znajduje. Odrzucenie symbolizuje również negatywne nastawienie grupy do danej osoby oraz jest wskaźnikiem niekompetencji społecznej odrzuconej jednostki, podczas gdy w sytuacji przeciwnej akceptacja rówieśnicza, inaczej popularność socjometryczna, oznacza społeczną kompetencję (Ladd 2006). Jest to konsekwencja wzajemnej oceny członków grupy, która dokonuje się w momencie pierwszych spotkań. Na tym etapie grupa ma charakter formalny, a dopiero później wytwarza struktury nieformalne. Przykładowo - klasa szkolna, początkowo będąc grupą formalną, utworzoną w celu umożliwienia podjęcia edukacji jej członkom, stopniowo, w momencie nawiązywania bliższych relacji, i dzięki nim, przeradza się w jedną, bądź kilka, grup nieformalnych - koleżeńskich.

Odrzucane dzieci są też często wiktymizowane przez rówieśników: są atakowane, zastraszane i nękane, są przedmiotem plotek, są wykluczane ze społecznych aktywności. Porównanie wyników 
różnych grup badaczy uzyskujących podobne szacunki pozwala na stwierdzenie, że skala odrzucenia rówieśniczego pozostaje na przestrzeni lat na stale wysokim poziomie. Tak duże nasilenie zjawiska w grupach szkolnych jest o tyle istotne, że obrazuje rozmiar konsekwencji dla dalszego zdrowia psychicznego społeczności.

John Coie przedstawił teoretyczny model formowania się odrzucenia jednostki w grupie. W zaprezentowanym procesie można wyróżnić dwie fazy: fazę wstępną, w której interakcje z rówieśnikami prowadzą do początkowego odrzucenia, i fazę utrwalenia, kiedy odrzucenie staje się stabilne w czasie i pozostaje $\mathrm{w}$ związku z postrzeganiem sytuacji społecznych i trwałymi zachowaniami zarówno jednostki, jak i grupy. J. Coie w swoim modelu opisał cztery ścieżki, poprzez które dzieci w fazie wstępnej zostają „złapane w błędne koło” odrzucenia i pozostają na tej pozycji przez długi czas. Pierwsza ścieżka odnosi się do zachowań demonstrowanych w fazie początkowej dzieci niepopularnych. Są to przede wszystkim zachowania agresywne, które są słabo tolerowane przez grupy rówieśnicze. Uczniowie, którzy są agresywni w kontaktach z rówieśnikami, mogą być odrzucani przez grupę, a także ci, którzy doświadczyli braku akceptacji społecznej (z innych powodów niż agresja) mogą reagować agresywnie w różnych sytuacjach szkolnych. Zachowanie agresywne może być zatem przyczyną i skutkiem odrzucenia (Coie, Dodge 1990: 17).

Bronisława Urban stwierdza, że związki między agresją a odrzuceniem mają charakter przyczynowy i dwukierunkowy, to znaczy, że zarówno agresja wczesnodziecięca, jak i odrzucenie są predyktorami eksternalizacyjnych problemów przystosowawczych (Urban 2005: 82). Do zachowań eksternalizacyjnych, które skutkują odrzuceniem, należą impulsywność i zachowania o charakterze destrukcyjnym. Drugą klasę stanowią zachowania typu: nieśmiałość, brak pewności siebie, wycofanie (zachowania internalizacyjne), które pozostają w związku z odrzuceniem.

Druga ścieżka prowadząca do rozwoju procesu odrzucenia odnosi się do spostrzegania własnego statusu społecznego w grupie rówieśniczej. Dziecięca świadomość tego, jak jest się postrzeganym przez większość grupy, ma znaczenie dla przekonań, celów i zachowań w sferze społecznej. Jeśli odrzucane dziecko jest świadome, jaką pozycję zajmuje w strukturze klasy, to może podjąć wysiłki zmierzające do jej modyfikacji, a tym samym rozwinąć w sobie poczucie autonomii. Jeśli zaś dziecko wie, że jest odrzucane, ale 
czuje się bezsilne, nie podejmuje żadnych działań, wzmacniając tym samy swoją niską pozycję społeczną (Kulawska 2013: 198).

Trzecia ścieżka zawiera dziecięce przekonania o społecznym sukcesie lub porażce i wiąże się z umiejscowieniem kontroli. Działanie tego mechanizmu polega na tym, że pierwotne odrzucenie automatycznie prowadzi do odczuwania niechęci ze strony rówieśników (dziecko wie, że jest odrzucane) lub powiązania niskiego społecznego statusu z całkowitą kontrolą ze strony czynników zewnętrznych, nad którymi nie można zapanować.

W czwartym podejściu podkreśla się znaczącą rolę grupy rówieśniczej w podtrzymywaniu statusu społecznego. Normy grupowe i procesy stereotypizacji mają związek z różnicami kontekstu społecznego i decydują o tym, czy dziecko jest odrzucane czy akceptowane. Innymi słowy, zmiany norm społecznych w grupie prowadzą do zmian statusu ich członków.

Pozycja dziecka w grupie rówieśniczej jest determinowana również przez cechy jego osobowości odgrywające istotną rolę w nawiązywaniu relacji z innymi dziećmi. Kluczowym elementem tych interakcji jest prawidłowy rozwój struktur osobowości dziecka. W literaturze przedmiotu niewiele jednak możemy znaleźć informacji dotyczących świata intrapsychicznego dzieci odrzucanych rówieśniczo oraz rozwoju jego struktur osobowości. W dalszej części artykułu przybliżone zostanie zjawisko odrzucenia rówieśniczego w odniesieniu do rozwoju osobowości dziecka w ujęciu teorii relacji z obiektem Otto Kernberga. Rozwojowy model O. Kernberga jest pierwszą od czasów psychoseksualnego modelu Freuda koncepcją oferującą jednolitą integrację zarówno normalnych, jak i zaburzonych trajektorii rozwojowych, utrzymywaną w perspektywie intrapsychicznej (Grzegołowska-Klarkowska 2015). Opisując ostatnią fazę przedstawioną przez Kernberga fazę konsolidacji superego i integracji ego - autor podkreśla, że utrwaleniu tego procesu sprzyjają skuteczne interakcje z innymi (Kernberg 1976). Wyobrażenia obiektu, jeśli są wystarczająco dobrze zintegrowane, będą ułatwiać sprawne, bezproblemowe interakcje ze światem społecznym, które według Kernberga pomagają w przyszłej konsolidacji tych wewnętrznych reprezentacji. Produktem końcowym tego stadium jest stabilna i odporna tożsamość ego (Grzegołowska-Klarkowska 2015).

Poczucie tożsamości dziecka zależy od czynników zewnętrznych. Przykładowo wyobrażenie dziecka o tym, kim jest, w dużej mierze zależy od rodziny, szkoły i środowiska, w którym żyje. 
Jednocześnie większość dzieci rozwija autonomiczne, spójne i stałe poczucie tożsamości, czyli świadomość „ja jestem sobą, tą samą osobą, którą byłem wczoraj i którą najprawdopodobniej będę jutro". To poczucie tożsamości jest względnie niezależne od przejściowych uczuć dziecka, jego przynależności do rodziny lub grupy i jego własnych zmian rozwojowych. Wykonywanie zadań rozwojowych wydaje się być niemożliwe dla dzieci narcystycznych.

Narcystyczne zaburzenia osobowości opisane są w DSM-IV jako „trwały schemat wielkościowości (w fantazji lub w zachowaniu), potrzeba bycia adorowanym oraz brak empatii, rozpoczynający się w początkowym okresie życia dorosłego i obecny w różnych kontekstach". Pomimo iż w narcystycznych zaburzeniach osobowości centralnym elementem jest wielkościowe poczucie własnej ważności, współtowarzyszy mu łatwość naruszenia samooceny. Ta nadmierna wrażliwość sprawia, że pacjenci z narcystycznymi zaburzeniami osobowości są wyją̨tkowo wrażliwi na krytykę, na którą mogą reagować pogardą lub wściekłością. Ich poczucie uprzywilejowania wyraża się często $\mathrm{w}$ osłabionym funkcjonowaniu superego, braku zainteresowania innymi osobami, braku troski, przeżyć winy czy żalu z powodu złego traktowania innych ludzi (Kernberg, Weiner, Bardenstein 2000). Powstające pomyłki w samomonitorowaniu się mają cechy zachowań antyspołecznych, a osobiste porażki, przegrane lub nieodpowiedzialne zachowania, mogą być tłumaczone za pomocą racjonalizacji, lawirowania lub prostych kłamstw. Ponadto prymitywne, prześladowcze, niszczące introjekty, które składają się na sumienie, ale nie zostały dobrze zintegrowane z superego, zostają wyprojektowane na zewnątrz w innych jako paranoidalne lęki, lub wyrażone wewnętrznie jako objawy somatyczne albo hipochondryczne. W okresie dziecięcym możemy zauważyć wiele cech narcyzmu patologicznego (Grzegołowska-Klarkowska 2015). Ważne jest, aby zestawić patologiczne samouwielbianie u dzieci z narcystycznym zaburzeniem osobowości z tym, co jest uważane za normalny narcyzm dziecięcy. W normalnym narcyzmie potrzeba zależności i admiracji dziecka jest zaspokojona uwagą, jaką dziecko otrzymuje odpowiednio dla swojego wieku; dziecko jest w stanie doświadczyć opieki z wdzięcznością i wzajemnością. Dziecko z patologią narcystyczną zaprzecza swojej zależności i nie czuje wdzięczności za opiekę. W normalnym dziecięcym narcyzmie tendencja do przywłaszczania sobie niezwykłych osiągnięć i talentów zawiera się w zabawowych fantazjach o byciu kimś niezwykłym, na przykład dziecko bawi się, 
że jest Supermanem. W patologicznym przypadku narcystycznego zaburzenia osobowości wierzy ono, że osiągnęło już to, co zamierzało, i nie ma w tym doświadczeniu nic zabawowego. W patologicznym narcyzmie dziecko uważa, że nie potrzebuje kolegów, aby móc realizować powierzone mu zadania. Gardzi wszelkiego rodzaju wsparciem, traktując siebie z wyższością, nie potrafi nawiązywać prawidłowych, dostosowanych do etapu rozwojowego, relacji rówieśniczych. Takie formy zachowania powodują, że dzieci z narcystycznymi zaburzeniami osobowości nie potrafią przystosować się w grupie rówieśniczej. Dziecięce wielkościowe „ja” jest fuzją pozytywnych aspektów rzeczywistego „ja”, idealnego „ja” oraz idealnych modeli ról; wszystko, co ułomne, jest eliminowane, pozostaje znacząco rozdęty obraz siebie (Kernberg, Weiner, Bardenstein 2000). Nie ma miejsca dla nikogo innego, nie dopuszcza się myśli, że ktoś inny także mógłby być ważny. Wręcz przeciwnie - inni powinni być gorsi; dziecko odczuwa potrzebę kontrolowania własnego dokonania lub jego niszczenia, jak np. chłopiec, który podarł swoje świadectwo nagrody, gdy dowiedział się, że jego kolega też takie dostał. W odróżnieniu od normalnej, infantylnej rywalizacji u dziecka, które uczy się znosić przegrane $\mathrm{w}$ celu utrzymania relacji z rodzicem lub przyjacielem, dziecko z narcystycznym zaburzeniem osobowości walczy, aby wyeliminować rywala (Kernberg, Weiner, Bardenstein 2000).

U normalnego dziecka jego zależność od otoczenia i potrzeby korespondują z realistycznymi oczekiwaniami i mogą być spełnione. Dziecko z narcystycznym zaburzeniem osobowości ma oczekiwania nadmierne, wymuszone, uniemożliwiające jakiekolwiek poczucie gratyfikacji czy wdzięczności i budzące złość u opiekuna, który czuje się przymuszony do ich spełnienia. To, co dawane, nigdy nie wystarcza wielkościowemu self, tak więc niezależnie od tego, ile by się nie dało, dziecko czuje się niekochane. Ponadto dziecko doświadcza zawiści, ponieważ nie jest centrum tego, co dobre; są inni, którzy także mają to, co ono chce posiadać. Zawiść ta ogranicza jego zdolność do otrzymania opieki i doświadczenia sytości bez urazy (Kernberg, Weiner, Bardenstein 2000).

O ile normalne dzieci ujawniają prawdziwe przywiązanie i zainteresowanie innymi oraz mogą ufać ważnym osobom lub na nich polegać, to ludzie z narcyzmem patologicznym nie mogą ani nikomu ufać, ani na nikim polegać poza bezpośrednim kontekstem zaspakajania swoich potrzeb. Nawet dwuletnie dziecko może utrzymać pozytywne zainwestowanie w matkę podczas krótkich 
rozłąk, jednakże dziecko z narcystycznym zaburzeniem osobowości ma tylko niestabilne przywiązania, które załamują się w niemal każdej sytuacji, nawet niewielkiej frustracji (Kernberg 2004).

Osoby narcystyczne są szczególnie podatne na frustracje lub krytycyzm z powodu ich potrzeby bycia najlepszymi. Ciężar utrzymania specjalnej pozycji naraża ich na dodatkowe konfrontacje z bolesnymi, codziennymi frustracjami. Aby czuć się dobrze, potrzebują one nadmiernej i nieustającej admiracji, gdyż cierpią z powodu patologicznej formy regulacji samooceny. Normalny narcyzm z prawidłową regulacją samooceny prowadzi do rzeczywistego zaakceptowania siebie (tzn. zarówno pozytywnych, jak i negatywnych cech) (Kernberg, Weiner, Bardenstein 2000).

Osoba nie charakteryzująca się narcystycznym zaburzeniem osobowości otrzymuje gratyfikacje płynące z tytułu rzeczywistych osiągnięć oraz wysiłku zainwestowanego w osiąganie swoich celów. Ponieważ istnieje zdrowe napięcie pomiędzy rzeczywistym „ja”, idealnym „ja” oraz idealnymi modelami ról, sumienie takiej osoby pozwala jej czuć się wynagrodzoną, gdy coś osiąga. Może także uznać dokonania innych. Osoba $\mathrm{z}$ narcystycznym zaburzeniem osobowości, która już jest swoim ideałem, przeżywa zupełnie inne doświadczenie: musi się wyzbyć wszystkiego, co nie pasuje do jej wielkościowego poczucia self. Co oznacza, że musi postrzegać innych w zniekształcony sposób (Kernberg 2004).

$\mathrm{Z}$ powodu przesadzonego poczucia własnej wartości dziecko zaburzone narcystycznie nie jest w stanie doceniać innych i czuć wobec nich empatii; z powodu poczucia bycia nadmiernie uprzywilejowanym wykorzystuje ich i ma niski próg odporności na frustrację. Przejawia się to $\mathrm{w}$ manipulowaniu, kłamstwie, kradzieży lub innych zachowaniach antyspołecznych, które z kolei prowadzą do bycia odrzuconym przez rówieśników. Zawiść dziecka narcystycznego wobec radości i zabawy innych, a także jego reaktywna powściągliwość, jak i brak tolerancji dla odmienności sprawiają, że dzieci te odbierane są w grupie rówieśniczej jako odrzucające. Wzajemność, która jest zazwyczaj oczekiwana w latach szkolnych, praktycznie nie istnieje; $\mathrm{w}$ konsekwencji jego relacje z rówieśnikami są poważnie osłabione (Kernberg 2004). Osłabienie owych relacji bardzo często przyczynia się do wywołania zjawiska bullyingu. Dzieci, których struktura rozwija się w kierunku patologicznego narcyzmu, stają się poniekąd sprawcami przemocy rówieśniczej, będąc jednocześnie ofiarą, czyli tzw. sprawco-ofiarą (bully-victim), określaną także jako ofiara prowokująca czy ofiara agresywna 
(Juvonen, Graham 2014; Olweus 2007; Tłuściak-Deliowska 2017). Dla tych dzieci charakterystyczne jest współwystępowanie lęku i zachowań agresywnych, co stanowi dla nich niełatwą sytuację (chociażby pod względem psychoemocjonalnym).

\section{Odrzucenie rówieśnicze jako forma przemocy rówieśniczej}

Bullying jest specyficznym rodzajem przemocy rówieśniczej. Zjawisko to jest w swej istocie niezwykle złożone. Stanowi konfigurację trzech właściwości, do których powszechnie zalicza się: intencjonalność działań sprawcy, nierównowagę siły i powtarzalność zachowań w czasie, które mogą przybierać różne formy (Tłuściak-Deliowska 2017).

Dan Olweus w latach 80. XX w. prowadził w Skandynawii szeroko zakrojone badania kwestionariuszowe wśród dzieci, dotyczące przemocy rówieśniczej. Jako pierwszy sformułował on precyzyjną definicję bullyingu oraz wyznaczył granicę, od której kwalifikował uczniów jako ofiary przemocy. Za ofiarę bullyingu uznawał dzieci, które na pytanie o częstotliwość doświadczania przemocy wybierały odpowiedź mieszcząca się w przedziale od czasami przez raz $w$ tygodniu lub cześciej do kilka razy dziennie (1993). Według Olweusa (1993, 1998) ok. 9-10\% uczniów jest ofiarami bullyingu w szkole, a 3\% doświadcza dręczenia bardzo często - raz lub wiele razy w ciągu tygodnia. W badaniach Instytutu Badań Edukacyjnych (2015) pojawiło się także pytanie o doświadczanie powtarzających się aktów przemocy. Okazało się, że w okresie 4 tygodni poprzedzających badanie co dziesiąta (10\%) osoba doświadczyła bullyingu. Jego sprawcami, szczególnie w przypadku chłopców, częściej byli inni chłopcy niż dziewczynki. Dziewczynki były dręczone zarówno przez chłopców, jak i dziewczynki (Makaruk 2017). Teorię bullyingu opracowaną przez Dana Olweusa (1993) charakteryzują trzy zasadnicze wymiary, tj. powtarzalność (rozumianą jako wielokrotne atakowanie tej samej osoby), nierównowagę sił (rozumianą jako fizyczną lub psychologiczną przewagę sprawców) oraz intencjonalność (rozumianą jako celowe działanie sprawców nastawione na skrzywdzenie ofiary). Właśnie ta triada formalnych charakterystyk pozwala zidentyfikować te sytuacje bullyingu, które z perspektywy ich szkodliwości dla ofiary są najpoważniejsze. Forma wrogich działań 
realizowanych w ten sposób jest zróżnicowana. Zwykle badacze analitycznie wyróżniają następujące typy działań: bullying fizyczny - polegający na stosowaniu fizycznej przemocy wobec innej osoby lub jej własności; bullying werbalny - przejawiający się obraźliwym odnoszeniem się do drugiej osoby (przezywaniem, nadawaniem niechcianych przezwisk itp.) oraz tzw. bullying relacyjny - polegający na wykluczaniu z grupy, ignorowaniu, nastawianiu innych przeciwko osobie itp. W przypadku tego rodzaju przemocy możemy mówić o odrzuceniu rówieśniczym jako formie bullyingu relacyjnego (Pyżalski 2015). Bullying relacyjny (pośredni) jest mniej widoczny, ale zazwyczaj bardziej dotkliwy, gdyż dotyczy sfery psychicznej ofiary. Ma na celu wyrządzenie szkody osobie, ale nie przybiera formy bezpośredniego ataku na nią. Dzieje się to poprzez wykluczenie z grupy rówieśników, izolację społeczną (Tłuściak-Deliowska 2017). Czynnikiem ryzyka związanym z występowaniem bullyingu relacyjnego jest trudna sytuacja interpersonalna w klasie (Tłuściak-Deliowska 2017).

Reakcje ze strony rówieśników zamiast redukować deficyty rozwojowe zwiększają opóźnienia dziecka w rozwoju intelektualnym, emocjonalnym i społecznym (Urban 2005). Istotnym zadaniem jest podjęcie stosownych działań terapeutycznych mających na celu redukcję występowania owego zjawiska w grupie rówieśniczej. Analizując działania nastawione na przeciwdziałanie zjawisku odrzucenia rówieśniczego jako formy przemocy, możemy uwzględniać te uwarunkowania rozwiązań, które w swej formie przewidują zarówno prace z grupą rówieśniczą, jak i indywidualną pracę z osobami dotkniętymi odrzuceniem na tle grupy. Alternatywną formą wsparcia dzieci odrzuconych rówieśniczo jest arteterapia. W terapii przez sztukę wszelakie rodzaje działań, począwszy od swobodnej ekspresji poprzez ekspresję inspirowaną do tej ukierunkowanej, pełnią funkcję socjalizacyjną. Zatem możemy wnioskować, iż udział w owej działalności twórczej dzieci odrzuconych rówieśniczo będzie miał charakter wspomagający socjalizację i prawidłowe funkcjonowanie w grupie rówieśniczej.

\section{Arteterapia w pracy z dziećmi odrzuconymi rówieśniczo}

Wybór terapii przez twórczość plastyczną (stanowiącej alternatywę lub uzupełnienie innych rodzajów terapii) w procesie 
wspierania dzieci odrzuconych rówieśniczo jest moim zdaniem równoznaczny z próbą odpowiedzi na pytanie: W jaki sposób terapia przez twórczość plastyczną może prowadzić do zmiany związanej $\mathrm{z}$ radzeniem sobie $\mathrm{z}$ emocjami, myślenia dziecka o sobie samym, zachowania $\mathrm{w}$ relacjach $\mathrm{z}$ innymi, a co za tym idzie z minimalizacją zjawiska odrzucenia jako formy przemocy rówieśniczej?

Koncepcja leczenia sztuką ma swój rodowód w starożytności, gdzie można doszukiwać się początków łączenia medycyny ze sztuką (Szulc 2001). Słowo „arteterapia” złożone jest z dwóch członów: „arte” (z łac. ars, artis - sztuka) i „terapia” (z gr. therapeia przywracanie zdrowia chorym, leczenie, terapia). Arteterapia łączy w sobie kilka dziedzin wiedzy, do których należą: medycyna, pedagogika, psychologia, socjologia, sztuki piękne. W literaturze przedmiotowej można znaleźć wiele definicji terapii przez sztukę jak często określa się arteterapię. I tak np. Wita Szulc uważa, że arteterapia jest „działaniem skierowanym na człowieka i jego środowisko, podejmowanym w celu przywrócenia, utrzymania lub potęgowania zdrowia oraz zmierzającym do poprawy jakości życia i wykorzystującym do osiągnięcia tego celu określonych wytworów kultury, przede wszystkim sztuki” (Szulc 2009: 64). Zdaniem cytowanej autorki działania arteterapeutyczne nie tylko służą korekcji różnego typu zaburzeń, ale mogą być z powodzeniem stosowane w celach profilaktycznych, wspomagających proces socjalizacyjny. Tomasz Rudowski uważa, że im więcej jest działań stymulujących i poszerzających wykorzystanie w życiu w sposób naturalny artystycznych środków wyrazu, tym bardziej ich ranga i znaczenie przyczyniają się do lepszej socjalizacji jednostki, czego narzędziem staje się sztuka (Rudowski 2013: 56). Dzięki sztuce dochodzi do kształtowania się relacji społecznych o charakterze socjalizacyjnym.

Z terapeutycznymi właściwościami sztuki silnie wiąże się jej funkcja komunikacyjna: sztuka ułatwia komunikowanie się, czyni je pełniejszym i bardziej autentycznym. Te możliwości docenia I. Wojnar, zwracając uwagę, że sztuka to sposób życia, dzięki któremu jednostka może się wypowiedzieć w sposób pełny, lepiej kształtować oraz rozumieć swoje życie (Konopczyński 2006: 91-92). Maja Stańko-Kaczmarek zwraca uwagę na koncepcję mówiącą, iż twórcze działania dają poczucie sprawstwa i wewnątrzsterowności, które przenoszą się na zewnętrzną aktywność. Dzięki temu rośnie w człowieku poczucie własnej 
wartości. Twórcza aktywność w atmosferze zabawy i bezpieczeństwa wywołuje u uczestników pozytywne emocje, uruchamia ciało, za którym podąża psychika. Wspólna radość z procesu tworzenia wyzwala chęć i odwagę do dalszych działań. Przekłada się to na inne obszary życia, a co ważne także na pozytywne myślenie o sobie (Stańko-Kaczmarek 2013: 47). Sztuka działa przede wszystkim na sferę emocjonalną, powodując powstawanie silnych emocji, ułatwiając ich ekspresję. Jeśli dokonuje się to podczas zajęć szkolnych, mogą powstać głębokie, pozytywne relacje między jej uczestnikami, oparte na wspólnocie i podobieństwie przeżyć. Wspólne działania łamią bariery mentalne, pozwalają na prawdziwą, wieloaspektową integrację. Jak podaje L. Kossolapow informacje przekazywane podczas resocjalizacji sztuką są autentyczne, bardzo ekspresyjne, i jednocześnie oryginalne. Co więcej, podczas przedstawiania wytworów pacjenci uczą się interpretować autoprezentację, ponieważ „aby wejść w społecznie owocny dyskurs z otoczeniem, muszą do tego dojść własne wzory objaśniania i określania problemów” (Konopczyński 2013: 41-42).

Koncepcja uczenia się zachowań aprobowanych społecznie $\mathrm{w}$ arteterapii jednostek nieprzystosowanych społecznie Marka Konopczyńskiego zakłada, że przez działania oparte na sztuce rozwijać się będą w człowieku procesy wzmacniania (nagradzanie i utrwalanie zachowań pożądanych), a eliminowane będą zachowania naganne. Arteterapeutycznymi sposobami dochodzenia do zmian zachowania mogą tu być m.in. działania plastyczne, w których za pomocą środków wyrazu plastycznego prezentowane są sytuacje trudne, obniżające poziom samooceny. Treści i formy dotyczą okresu życia z czasu przeszłego, teraźniejszego i wyobrażonego przyszłego (prospekcji). W koncepcji zmiany zachowania przez warunkowanie klasyczne - w resocjalizacji osób nieprzystosowanych społecznie - istotą są działania twórcze pozwalające dokonywać zmian w zachowaniu jednostek agresywnych względem siebie lub/i otoczenia. Działania te mogą okazać się owocne, gdy odpowiednie wzmocnienia będą kierowane na zachowania aprobowane społecznie - przy braku zainteresowania wobec zachowań negatywnych. Gdy uczestnik zajęć z zachowań agresywnych (społecznie nagannych) czerpie określone przyjemności, winny być one ignorowane, natomiast wzmocnieniu mają podlegać jedynie te usprawiedliwione moralnie. Będą to przykładowo działania zawierające szeroko rozumiane artystyczno-estetyczne środki wyrazu, np. plastyczno-werbalne, które przypominają lub 
odzwierciedlają przebieg danego przykrego zdarzenia, w którym prezentowana jest osoba poszkodowana. Zdarzenie to pierwotnie u uczestnika zajęć wywoływało pozytywną reakcję emocjonalną, która pod wpływem wzmocnień negatywnych uległa właściwej weryfikacji. „Nieprzystosowawcze” zachowanie zostaje wyeliminowane, ponieważ zostaje skojarzone z nieprzyjemnymi konsekwencjami (Konopczyński 2009: 27).

M. Konopczyński postrzega przyczyny powstawania zjawiska niedostosowania społecznego jako procesu zablokowania rozwoju indywidualnego i społecznego w konsekwencji długotrwałego oddziaływania splotu niekorzystnych czynników biopsychicznych i socjokulturowych. Podstawą teoretyczną owego podejścia jest grupa koncepcji interakcyjnych. Odwołują się one do stosunków międzyludzkich (interakcji) ujmowanych jakościowo. Według teorii interakcyjnych człowiek jest przede wszystkim istotą społeczną i wszystkie jego zachowania i reakcje należy rozpatrywać w kategoriach pełnionych przez niego ról społecznych. Role te narzucają mu określone sposoby zachowań - od prospołecznych do aspołecznych czy antyspołecznych. Istotą twórczej resocjalizacji jest próba ukazania, że niepożądaną sytuację można zmienić w sposób odmienny od utartych schematów resocjalizacyjnych. Można podjąć próbę przemiany młodego człowieka, a właściwie wykreowania odmiennych od dotychczasowych parametrów jego tożsamości, które mają wpływ na jakość kontaktów z innymi ludźmi. Podstawowym celem praktycznych zabiegów twórczej resocjalizacji jest przemiana tożsamości indywidualnej i społecznej odrzuconej rówieśniczo młodzieży poprzez wychowawcze stymulowanie rozwoju jej struktur poznawczych i twórczych, jak również wyposażenie jej w nowe indywidualne i społeczne kompetencje (Konopczyński 2013: 15).

Warto dodać, że arteterapia wpływa na kształtowanie i rozwijanie się kompetencji emocjonalnych dzieci, wzmacnia również przekonanie, że można bez poczucia winy, lęku przed karą i wstydu przyznać się do przeżywania buntu, cierpienia oraz innych negatywnych emocji. Pomaga ona kształtować dziecku jego osobowość. Terapia przez sztukę pozwala ujawnić stłumione emocje i przejąć nad nimi kontrolę. Ma wpływ na samoocenę, poczucie własnej wartości, a także uwalnia od złych napięć (Olas 2006: 299). Sztuka może dopomóc w rozumieniu świata i budowaniu do niego pozytywnego stosunku. Może rozbudzić myślenie, emocje, ukazać obszary piękna, zachęcić do twórczej 
postawy, uczyć wartościowania i wskazać na potrzebę kontaktu z ludźmi. Sztuka jest „najwyższym przystosowaniem jednostki do świata zewnętrznego". Twórczość może pomóc spojrzeć w głąb siebie, może również stać się dla wielu osób jedynym środkiem ekspresji emocjonalnej. Poprzez symbol umożliwia komunikację różnych przekonań, konfliktów, urazów. Dialog z symbolicznymi obrazami pozwala na poznanie wypartych do nieświadomości treści. Może pomóc dostrzec, że spontaniczne wyrażanie siebie jest naprawdę możliwe, co więcej, możliwa jest nasza przemiana. Dzieciom, które na co dzień są odrzucone, działania twórcze za pomocą środków artystycznych pomagają zmierzyć się z problemem. Osoby odrzucone rówieśniczo poprzez wewnętrzny rozwój i wykreowanie nowej tożsamości stają się ludźmi akceptowanymi w szerszych kontekstach środowiskowych, gdyż stosują społecznie aprobowane sposoby rozwiązywania własnych sytuacji problemowych, zaspokajania potrzeb oraz prezentują akceptowane priorytety życiowe. Dzięki temu stwarzają sobie realną szansę pozytywnej readaptacji społecznej poprzez automatycznie uruchamiany proces destygmatyzacyjny.

\section{Podsumowanie}

Odrzucenie rówieśnicze prowadzi przede wszystkim do silnych negatywnych emocji, takich jak: smutek, samotność, poczucie krzywdy, poczucie winy, zazdrość oraz niepokój społeczny. Doświadczenie tych emocji skutkuje zmianą jakości życia, ale również obniżeniem samooceny i wycofaniem społecznym. Konsekwencje wynikające z doświadczenia odrzucenia rówieśniczego prowadzą głównie do zaburzeń w zachowaniu typu eksternalizacyjnego, w tym szczególnie do agresji. W przypadku dzieci, których relacje z rówieśnikami są poprawne, problemy przystosowawcze wieku przedszkolnego stopniowo zanikają (Urban 2000). Zjawisko to prowadzi do dwojakiego rodzaju negatywnych skutków: (1) dziecko odrzucone jest pozbawione optymalnych warunków i możliwości uczenia się społecznych sprawności i kompetencji, (2) czemu towarzyszyć może zepchnięcie do strefy oddziaływań dewiacyjnych grup subkulturowych i jednostek nieprzestrzegających zasad społecznych. Na tej podstawie można więc sądzić, za m.in. Bagwellem, Newcombem i Bukowskim (1989), że istotną rolę w prawidłowym przystosowaniu do życia społecznego odgrywają kontakty przyjacielskie, a ich brak lub zaburzenie stają się 
odpowiednim gruntem dla rozwoju psychopatologii w dorosłym życiu. Odrzucenie rówieśnicze nosi znamiona bullyingu relacyjnego. Tego rodzaju przemoc rówieśnicza stanowi znaczący problem w szkolnym funkcjonowaniu dziecka. Wpływa ona na wszystkie sfery jego funkcjonowania. Poprzez niewłaściwy rozwój intrapsychiczny dziecko to jest zarówno ofiarą, jak i sprawcą przemocy rówieśniczej, co stanowi proces sprzężony. W związku z wysoką szkodliwością odrzucenia rówieśniczego dla jednostki i ryzykiem wystąpienia sprzężonych destrukcyjnych skutków odrzucenia także dla społeczności, konieczne jest podejmowanie wszelkich działań profilaktycznych i naprawczych wobec tego zjawiska. Proponowana przeze mnie forma pracy terapeutycznej z wykorzystaniem sztuki stanowi alternatywę dla dzieci dotkniętych zjawiskiem odrzucenia rówieśniczego. Arteterapia służy nie tylko do zaspokajania potrzeb estetycznych i emocjonalnych, ale również spełnia ogromną rolę w socjalizacji. Proces arteterapeutyczny może więc stać się dla dziecka przestrzenią, w której Ja, ulegając zespoleniu z Ty i My, doświadcza poczucia niezależności, autonomii, ale i wspólnoty z innymi (Krauze-Sikorska 2016: 21).

Warto podkreślić, że nie zawsze przebieg procesu tworzenia jest bezkolizyjny i harmonijny. Zadaniem sztuki jest przecież, jak podkreślał Hary Read, nie tylko wyrażanie uczuć, ale także ułatwianie porozumienia. Przemiana, która może dokonać się w dziecku pod wpływem działań twórczych, pozwoli mu na bardziej trafne i adekwatne ujmowanie rzeczywistości zewnętrznej i siebie samego w tej rzeczywistości (Krauze-Sikorska 2016: 21). Dzięki arteterapii dziecko odrzucone rówieśniczo może na nowo odczytywać i „oswajać” świat. Może też uczyć się siebie i innych, poszukiwać, odkrywać i stopniowo budować prawidłową strukturę „ja”, a przekraczając granice osobistych problemów, przekształcać świat pojedynczych, zmiennych wrażeń w wibrującą całość.

\section{Bibliografia}

Boivin M. (2005), Origines des difficultés dans les relations entre pairs pendant la petite enfance et impacts sur l'adaptation psychosociale et le développement des jeunes enfants, [w:] Encyclopédie sur le développement des jeunes enfants, R.E. Tremblay, R.G. Barr, R. De V. Peters (red.), École de psychologie \& Université Laval.

Bukowski W.M., Hoza B. (1989), Popularity and Friendship; Issues in the Theory, Measurement, and Outcome, [w:] T.J. Berndt, G.W. Ladd (red.), Peer Relationships in Child Development, John Wiley and Sons, New York. 
Carton A. (2008), Développment des relations avec les pairs: contextes et fonctionnement des relations, [w:] Les relations sociales chez l'enfant. Genèse, développment, fonctions, A. Carton, F. Winnykamen (red.), Collection Cursus-Psychologie, Paris.

Coie J.D. (1982), Toward a Theory of Peer Rejection, [w:] S.R. Asher, J.D. Coie (red.), Peer Rejection in Childhood, Cambridge University Press, Cambridge.

Coie D., Ascher D., Kupersmidt J.B. (1990), Peer Group Behavior and Social Status, [w:] S.R. Asher, J.D. Coie, Peer Rejection in Childhood, Cambridge University Press.

Czerwińska A. (2003), Relacje rówieśnicze w klasach I-IV szkoly podstawowej, „Nauczyciel i Szkoła” 1-2 (18-19), s. 214-225.

Deptuła M. (2013), Odrzucenie rówieśnicze profilaktyka i terapia, PWN, Warszawa.

Ekiert-Grabowska D. (1982), Dzieci nieakceptowane w klasie szkolnej, WSiP, Warszawa.

Giza-Poleszczuk A., Komendant-Brodowska A., Baczko-Dombi A. (2011), Przemoc $w$ szkole. Raport z badań. Maj 2011, Instytut Socjologii UW, Warszawa.

Goodman K.L., Southam-Gerov M.A. (2010), The Regulating Role of Negative Emotions in Children's Coping with Peer Rejection, "Child Psychiatry Human Development”, vol. 41, nr 5, s. 515-534.

Guerin S., Hennessy E. (2004), Przemoc i prześladowanie w szkole, Gdańskie Wydawnictwo Psychologiczne, Gdańsk.

Gurycka A. (1990), Blad w wychowaniu, Wydawnictwa Szkolne i Pedagogiczne, Warszawa.

Grzegołowska-Klarkowska H.J. (2015), Psychoanalityczne teorie rozwoju, Wydawnictwo Akademia Pedagogiki Specjalnej, Warszawa.

Hartup W.W. (1999), Social Relationships and their Developmental Significance, “American Psychologist", vol. 44, nr 2, s. 120-126.

Idsoe T., Dyregrov A., Idsoe E.C. (2012), Bullying and PTSD symptoms, "Journal of Abnormal Child Psychology", vol. 40, nr 6, s. 901-911.

Jaskulska S. (2015), Wykluczenie rówieśnicze, Repozytorium UAM, Poznań.

Kernberg O.F. (1976), Object-Relations Theory and Clinical Psychoanalysis, Jason Aronson, New York.

Kernberg O.F. (2004), Aggressivity, Narcissism, and Self-Destructiveness in the Psychotherapeutic Relationship: New Developments in the Psychopathology and Psychotherapy of Severe Personality Disorders, Yale University Press, London.

Kernberg P.F., Weiner A.S., Bardenstein K.K. (2000), Personality Disorders in Children and Adolescents, Basic Books, New York, s. 215-218.

Konopczyński M. (2006), Twórcza resocjalizacja: wybrane metody pomocy dzieciom i mtodzieży, MEN, Editions Spotkania 2006, Warszawa, s. 91-92.

Konopczyński M. (2009), Metody twórczej resocjalizacji, Pedagogium, Warszawa.

Krauze-Sikorska H. (2016), Terapia przez twórczość plastycznq w procesie wspomagania i wspierania rozwoju dzieci z problemami internalizacyjnymi, czyli o tym jak można pomóc dziecku być „tym samym” ale „nie takim samym"?, EETP, t. 11, nr 3/41. 
Krupa B. (2011), Doświadczenia życiowe młodzieży z okresu wczesnego dzieciństwa i ich zwiazek z niedostosowaniem spolecznym, Wydawnictwo Wyższej Szkoły Edukacji Zdrowotnej i Nauk Społęcznych, Łódź.

Ladd G.W., Herald S.L., Andrews R.K. (2006), Young Children's Peer Relations and Social Competence, [w:] B. Spodek, O.N. Saracho (red.), Handbook of Research on the Education of Young Children, Lawrence Erlbaum Associates, Mahway.

Leary M.R. (2006), Interpersonal Rejection, Oxford University Press, New York. Łobocki M. (1985), Wychowanie w klasie szkolnej: z zagadnień dynamiki grupowej, WSiP, Warszawa.

Makaruk K. (2017), Przemoc rówieśnicza. Dzieci się liczą. Raport o zagrożeniach bezpieczeństwa i rozwoju dzieci w Polsce, Fundacja Dajemy Dzieciom Siłę, Warszawa.

Obuchowski K. (1983), Psychologia dq̨ień ludzkich, PWN, wyd. 3, Warszawa.

Olaś A. (2006), Arteterapia inspiracja dla pedagogiki, „Szkoła Specjalna”, nr 4, s. $298-306$.

Olweus D. (1993), Bullying at School: What We Know and What We Can Do, Blackwell, Oxford.

Olweus D. (2003), A Profile of Bullying at School, Educational Leadership, Blackwell, Oxford.

Pilch T. (1995), Grupa rówieśnicza jako środowisko wychowawcze, [w:] T. Pilch, I. Lepalczyk (red.), Pedagogika społeczna, Wydawnictwo „Żak”, Warszawa.

Pilkiewicz M. (1973), Socjometryczna skala akceptacji jako technika badania pozycji jednostki w nieformalnej strukturze grupy, [w:] L. Wołoszynowa (red.), Materiaty do nauczania psychologii. Metody badań psychologicznych, PWN, Warszawa.

Pytka L., Zacharuk T. (1995), Zaburzenia przystosowania dzieci i mlodzieży, WSRP, Siedlce.

Rigby K. (2008), Children and Bullying. How Parents and Educators Can Reduce Bullying at School, Blackwell Publishing.

Rudowski T. (2013), Edukacja i terapia przez sztukę. Arteterapia w świetle teorii doznań transakcyjnych, Warszawa.

Stańko-Kaczmarek M. (2013), Arteterapia i warsztaty edukacji twórczej, Warszawa.

Szulc W. (2009), Wspótczesne kierunki arteterapii. Arteterapia w programach terapeutycznych dla dzieci i mtodzieży, [w:] Sztuka dla dziecka jako forma komunikacji spolecznej, G. Leszczyński (red.), t. 1, Poznań 2009, s. 64.

Urban B. (2005), Zachowania dewiacyjne młodzieży w interakcjach rówieśni$c z y c h$, Wydawnictwo Uniwersytetu Jagiellońskiego, Kraków.

Urban B. (2000), Zaburzenia w zachowaniu i przestępczość mlodzieży, Oficyna Wydawnicza Impuls, Kraków.

Węgrzynowska J. (2016), Dzieci doświadczające przemocy rówieśniczej, „Dziecko krzywdzone. Teoria, badania, praktyka”, t. 15, nr 1.

Winnicott D.W. (2001), Dom jest punktem wyjścia. Eseje psychoanalityczne, Imago, Gdańsk. 
Jacek Pyżalski

ORCID 0000-0001-5817-276X

Agnieszka Cybal-Michalska

ORCID 0000-0001-7470-1473

Natalia Walter

ORCID 0000-0002-2347-9312

Mateusz Marciniak

ORCID 0000-0002-7131-626X

Sylwia Jaskulska

ORCID 0000-0002-3454-7894

Ewa Karmolińska-Jagodzik

ORCID 0000-0001-6076-8087

Wydział Studiów Edukacyjnych,

Uniwersytet im. A. Mickiewicza w Poznaniu

\title{
Picie alkoholu i zaburzenia związane z piciem alkoholu u polskich studentów - kilka ważnych wyników reprezentatywnych badań
}

\begin{abstract}
Alcohol consumption and problems related to alcohol drinking among Polish university students - a few important conclusions from a representative research
\end{abstract}

Alcohol drinking is often connected to serious long and short term health and social consequences. It is particularly true in the case of young people. One of the groups at risk are university students who are influenced by many psychosocial factors that may support risky alcohol consumption.

The article presents selected results of the research project exploring alcohol consumption and problems related to alcohol drinking among students of Polish universities. The representative sample of Polish university students 
(third year) $(\mathrm{N}=4503)$ took part in the survey covering alcohol drinking and factors such as depression, identity style, health behaviours, social engagement and selected socio-demographical variables.

The results confirm a serious prevalence of problems related to alcohol drinking. According to results of AUDIT-C test (measuring risky alcohol drinking) 9\% of the sample reach 8 points and more (that is twice the norm for males 4 points). Those results are confirmed by data obtained through RAPS- 4 test. It shows that one in ten student reaches 3 or 4 points (as indicator of risky alcohol drinking). Additionally, a substantial percentage of students experience short term consequences connected to alcohol drinking such as problems with police or being a victim of theft.

Keywords: university students, problems related to alcohol drinking, risk behaviours, health behaviours

Słowa kluczowe: studenci, problem związane z piciem alkoholu, zachowania ryzykowne, zachowania zdrowotne

\section{Wprowadzenie}

Studenci to grupa, o której, jeśli chodzi o kwestię zachowań zdrowotnych i ryzykownych, wiemy stosunkowo mało (w zestawieniu choćby z grupą adolescentów, którzy są regularnie pod tym względem diagnozowani - często w szeroko zakrojonych międzynarodowych badaniach populacyjnych) (Sierosławski 2018). Nie oznacza to jednak braku jakichkolwiek badań lecz częste projekty empiryczne na mniejszych, niereprezentatywnych próbach, zwykle ograniczonych do jednego kierunku studiów (np. Gersternkorn, Suwała 2003; Wojtowicz-Chomicz i in. 2008; Laszek i in. 2011). Informacje dotyczące zachowań zdrowotnych i ich uwarunkowań (zarówno w obszarze czynników chroniących, jak i czynników ryzyka) są niezbędne dla konstruowania adekwatnych programów z zakresu edukacji zdrowotnej i promocji zdrowia (Puchalski 1990; 2010). Szczególnie istotnym problem z punktu widzenia jego długofalowych i krótkoterminowych konsekwencji indywidualnych i społecznych są zaburzenia związane z piciem alkoholu (rozumiane w starszych klasyfikacjach jako picie szkodliwe i uzależnienie od alkoholu). Jak wskazują niektóre polskie i zagraniczne badania, picie alkoholu jest częstsze $\mathrm{w}$ grupie młodych ludzi, którzy studiują, w porównaniu z grupą młodzieży niestudiującej. Intensyfikację picia alkoholu w okresie studiów przypisuje się takim czynnikom jak presja rówieśników oraz oczekiwania akceptacji towarzyskiej (Meyer 2003; Sidor, Makara-Studzińska 2012). 
W DSM-5 wprowadzona jest kategoria diagnostyczna „zaburzenia spowodowane używaniem substancji”, która zawiera w sobie kategorie (występujące wcześniej osobno w DSM-IV): „nadużywanie alkoholu” i „uzależnienie od alkoholu”. Nie zmienia się definiowanie uzależnienia od alkoholu (nieobecnego z nazwy w obecnie obowiązujących typologiach) jako zbioru behawioralnych i somatycznych objawów występujących u osób spożywających duże ilości alkoholu, obejmujących alkoholowy zespół odstawienia, tolerancję i głód alkoholu (Samochowiec i in. 2015).

W klasyfikacji ICD-11 diagnoza „zaburzenia spowodowane używaniem alkoholu" obejmuje ostre zatrucie alkoholem, używanie szkodliwe, zespół uzależnienia, zespół abstynencyjny oraz spowodowane przez alkohol zaburzenia psychiczne i zaburzenia zachowania.

DSM V nie stosuje terminów „zależność” lub „uzależnienie”. W wypadku alkoholizmu w DSM-5 używa się określenia „zaburzenia związane z piciem alkoholu”. Obejmują one 11 kryteriów diagnostycznych, które muszą w liczbie przynajmniej dwóch utrzymywać się w przypadku określonej osoby przez 12 miesięcy, aby zdiagnozować problem.

O problemowym wzorze picia alkoholu można mówić, jeśli zachowanie danej osoby odpowiada co najmniej dwóm kryteriom z wymienionych ponizej i utrzymuje się przez 12 miesięcy:

1. Spożywanie alkoholu w większych ilościach lub przez dłuższy czas niż zamierzano;

2. Uporczywe pragnienie picia alkoholu albo towarzyszące temu nieudane próby ograniczenia lub kontrolowania picia;

3. Poświęcanie dużej ilości czasu na aktywności związane ze zdobywaniem alkoholu, piciem i likwidowaniem negatywnych skutków picia;

4. Głód alkoholu lub jego silne pragnienie, potrzeba picia;

5. Nawracające spożywanie alkoholu, powodujące zaniedbywanie głównych obowiązków w pracy, szkole czy w domu;

6. Spożywanie alkoholu pomimo ciągłych lub nawracających problemów społecznych i interpersonalnych spowodowanych lub pogłębianych przez działanie alkoholu;

7. Ograniczanie czy porzucanie z powodu alkoholu ważnych aktywności społecznych, zawodowych lub rekreacyjnych;

8. Powtarzające się spożywanie alkoholu w sytuacjach, w których jest to ryzykowne (np. prowadzenie samochodu lub obsługiwanie maszyn przez osobę znajdującą się pod wpływem alkoholu); 
9. Spożywanie alkoholu pomimo ciągłych, bądź nawracających, problemów fizycznych lub psychicznych, prawdopodobnie spowodowanych lub pogłębionych przez działanie alkoholu;

10. Ujawnienie się tolerancji na alkohol związanej z potrzebą spożycia istotnie większej ilości alkoholu, celem osiągnięcia pożądanego efektu lub z widocznym znacznym zmniejszeniem efektu używania tej samej ilości alkoholu;

11. Występowanie charakterystycznych objawów abstynencyjnych spowodowanych przerwaniem picia bądź zredukowaniem dawki alkoholu lub picie alkoholu/przyjmowanie substancji o podobnym działaniu (tj. benzodiazepiny) z zamiarem złagodzenia albo uniknięcia objawów abstynencyjnych (American Psychiatric Association 2013; Samochowiec i in. 2015).

Zaburzenie związane z piciem alkoholu dzieli się na trzy poziomy nasilenia $\mathrm{w}$ zależności od liczby objawów, przy czym umiarkowane (4-5) i ciężkie (6 lub więcej) są podobne do obrazu klinicznego pacjentów z „uzależnieniem” w tradycyjnym znaczeniu. Lekkie zaburzenie obejmuje występowanie 2-3 kryteriów (Möllers 2018).

W niniejszej analizie prezentujemy model badawczy naszego projektu oraz podstawowe wyniki dotyczące picia alkoholu i zaburzeń związanych z piciem alkoholu wśród polskich studentów. Powiązania picia alkoholu z innymi zmiennymi naszego modelu będziemy przedstawiać $\mathrm{w}$ dalszych publikacjach.

\section{Metodologia zrealizowanych badań}

Celem realizacji badań ${ }^{1}$ było rozpoznanie rozpowszechnienia zaburzeń związanych z piciem alkoholu w populacji studentów polskich uczelni publicznych i niepublicznych oraz czynników chroniących i ryzyka związanych z piciem alkoholu w tej grupie. Ponizej, na wykresie 1, przedstawiono schematycznie przyjęty model badawczy.

1 Tekst powstał w ramach przeprowadzania badania Studenci 2019 realizowanego przez UAM w ramach konkursu na realizację zadań z zakresu zdrowia publicznego określonych w Narodowym Programie Zdrowia na lata 2016-2020 w obszarze celu operacyjnego nr 2 Profilaktyka i rozwiązywanie problemów związanych z używaniem substancji psychoaktywnych, uzależnieniami behawioralnymi i innymi zachowaniami ryzykownymi, zadanie 40/3.4.2/19/DEA - Wspieranie badań naukowych w obszarze czynników ryzyka i czynników chroniących przed problemami wynikającymi z picia alkoholu. 

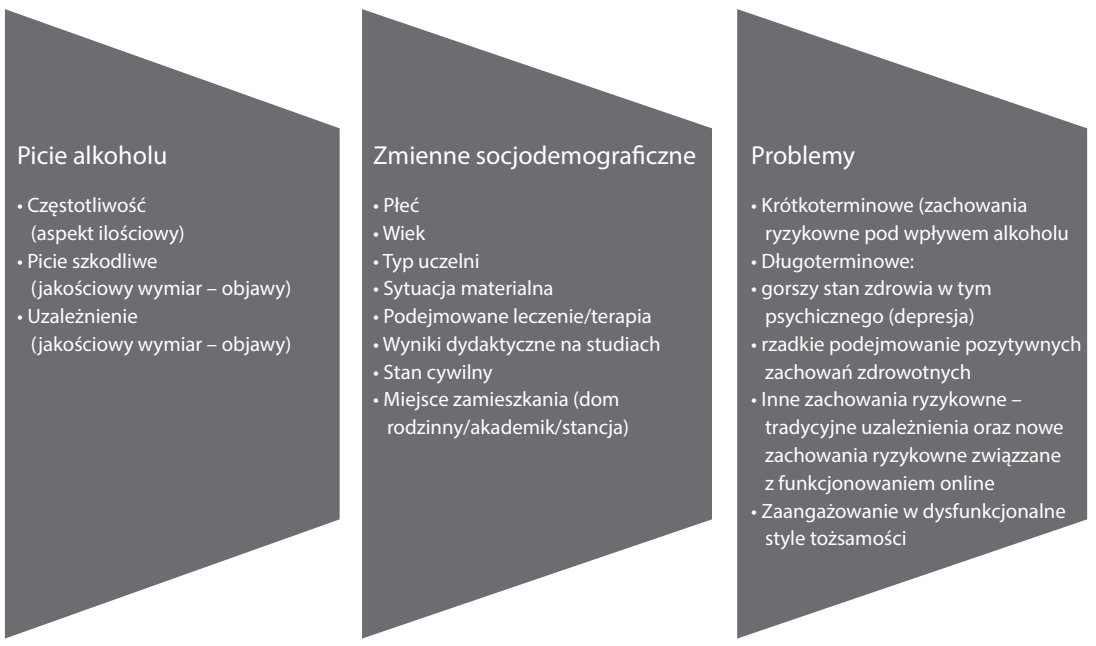

Wykres 1. Model badawczy przyjęty w badaniu (grupy zmiennych) Źródło: Opracowanie własne.

W niniejszym tekście przedstawiamy jedynie wybrane wyniki zrealizowanych badań odnoszące się do rozpowszechnienia zaburzeń związanych z piciem alkoholu i ich korelatów. W badaniach zastosowano baterię narzędzi, z których większość stanowiły sprawdzone w badaniach ilościowych skale o ustalonych właściwościach psychometrycznych. Część z nich specjalnie skonstruowano dla potrzeb badania. Poniżej, w tabeli 1, zaprezentowano jedynie te narzędzia, których wybrane wyniki przeanalizowano w niniejszym tekście.

W celu uzyskania reprezentatywnej próby osób studiujących na trzecim roku w polskich uczelniach zastosowano schemat losowania wielostopniowego. W pierwszym etapie doboru wylosowano wyższe uczelnie (z pełnego spisu uczelni). Dobór odbywał się przy pomocy proporcjonalnego schematu doboru w warstwach. Warstwy zostały zdefiniowane przez województwo, rodzaj uczelni oraz typ uczelni. Operatem losowania był aktualny wykaz uczelni znajdujący się w zintegrowanym systemie informacji o nauce i szkolnictwie wyższym POL-on oraz w Banku Danych Lokalnych GUS. W kolejnym kroku, w każdej z wylosowanych placówek, wylosowano grupy studentów III roku. Oprócz próby podstawowej wylosowana została, według tego samego schematu doboru, próba rezerwowa. Badania zrealizowano w 38 uczelniach $\mathrm{z}$ terenu całego kraju (w tym w 10 niepublicznych). 


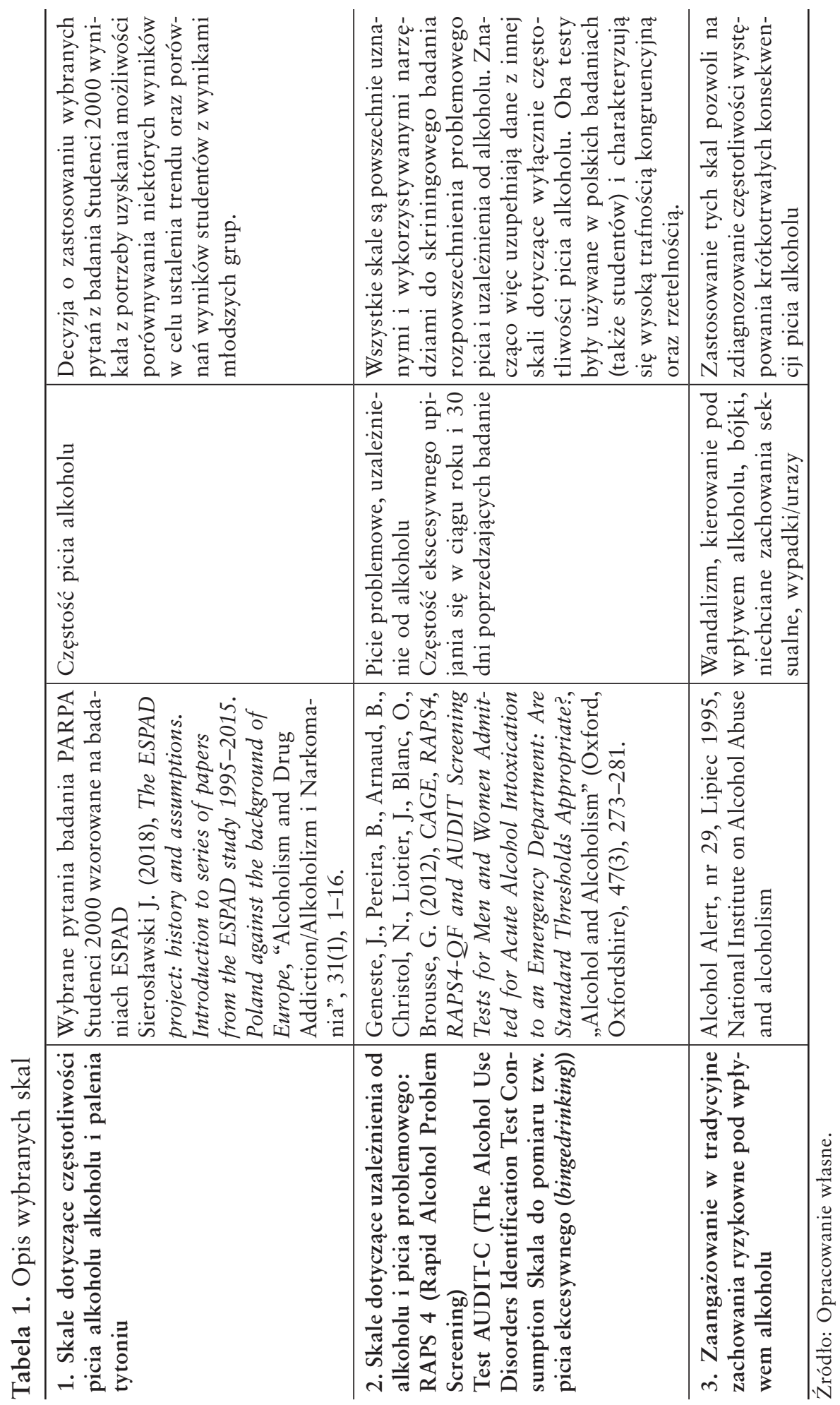


Zrealizowana próba nie jest równo podzielona w zakresie płci. Ma to związek $\mathrm{z}$ faktem, iż $\mathrm{w}$ populacji generalnej w podobnych proporcjach wśród osób kończących studia występuje przewaga kobiet. Z danych Głównego Urzędu Statystycznego wynika, że w roku akademickim 2018/19 kobiety stanowiły 58,0\% studiujących, a tendencja dysproporcji w tym zakresie rośnie. $\mathrm{Na}$ studiach stacjonarnych zarejestrowano 809,3 tys. osób, czyli $65,8 \%$ studiujących, natomiast na niestacjonarnych $-421,0$ tys. osób (GUS 2019). Można zatem przyjąć, że rozkład badanych jest zbieżny z rozkładem ogólnopolskim uczelni szkół wyższych. Podział taki należy zatem uznać za konieczny w celu zachowania reprezentatywności próby.

Wiek badanych obliczono na podstawie podanego roku urodzenia. Najwięcej było w próbie studentek i studentów w wieku od 21 do 25 lat, odpowiednio 21 l. (3,48\%), 221. (42,24\%), 23 1. (23, 8\%), 24 1. (9,35\%) i 25 1. (4, 89\%). Studenci w tym przedziale wiekowym stanowią najliczniejszą próbę jako ci, którzy w zwykłym trybie podjęli edukację uniwersytecką (lub z niewielkim opóźnieniem) i studiują obecnie na III roku (tab. 2).

Tabela 2. Rozkład wieku w próbie

\begin{tabular}{l|r|c|c}
\hline \multicolumn{1}{c|}{ Wiek (lata) } & n & n skumulowane & \% \\
\hline Do 20 & 105 & 105 & 2,44 \\
21-30 & 3877 & 3982 & 89,93 \\
31-40 & 215 & 4197 & 4,99 \\
41-50 & 94 & 4291 & 2,18 \\
Powyżej 51 & 20 & 4311 & 0,47 \\
Brak danych & 192 & 4503 & 4,45 \\
\hline
\end{tabular}

Źródło: Opracowanie własne.

Największa grupa respondentów zamieszkiwała w czasie badania w domu rodzinnym (ok. 44\%). Na drugim miejscu znajdowała się grupa, której miejscem zamieszkania było wynajęte mieszkanie (nieco mniej niż jedna czwarta badanych). Podobny odsetek badanych (ok. 11\%) zamieszkiwał w wynajętym pokoju lub we własnym mieszkaniu. Około 6\% badanych zamieszkiwało akademik. Pozostali badani (łącznie ok. 3\%) albo zamieszkiwali $\mathrm{w}$ innym miejscu, albo nie podali miejsca zamieszkania. 
Tabela 3. Miejsce zamieszkania badanych

\begin{tabular}{l|c|c}
\hline \multicolumn{1}{c|}{ Miejsce zamieszkania } & N & \% \\
\hline Dom rodzinny & 1987 & 44,13 \\
Własne mieszkanie & 539 & 11,97 \\
Akademik & 274 & 6,08 \\
Wynajęte mieszkanie & 1061 & 23,56 \\
Wynajęty pokój & 504 & 11,19 \\
Inne miejsce & 28 & 0,62 \\
Brak danych & 110 & 2,44 \\
\hline
\end{tabular}

Źródło: Opracowanie własne.

Tabela 4. Osoby, z którymi zamieszkują badani

\begin{tabular}{l|c|c}
\hline & $\mathbf{n}$ & $\%$ \\
\hline Sam & 352 & 7,82 \\
Z żoną/mężem lub partnerką/partnerem & 911 & 20,23 \\
Z rodzicami lub z kimś z rodziny & 1807 & 40,13 \\
Z innymi osobami (np. studentami) & 1233 & 27,38 \\
Z kimś innym & 76 & 1,69 \\
Brak danych & 124 & 2,75 \\
\hline
\end{tabular}

Źródło: Opracowanie własne.

Omawiając procedurę badawczą należy zaakcentować, iż badania terenowe przeprowadzono w terminie maj - czerwiec 2019. Badanie miało charakter audytoryjny i było prowadzone przez przeszkolonych ankieterów. Ankieterzy, za zgodą władz uczelni wyższych, po ich uprzednim pisemnym zawiadomieniu przez kierownika badań z UAM, realizowali badanie w wylosowanych grupach studentów III roku. Osoby przeprowadzające badanie wyjaśniały cel badania, wręczały respondentom ankietę, a po jej wypełnieniu zbierały ankiety do specjalnie przygotowanej urny. Ankieter przez cały czas badania był obecny w sali, tj. do momentu oddania wypełnionej ankiety przez wszystkich uczestników. Wykonawca terenowy przygotował procedurę losowania próby, przeszkolenie ankieterów według zaleceń zespołu badawczego, realizację badań terenowych, przygotowanie prawidłowej bazy danych do analizy. 
Zgodnie z przyjętymi przez realizatorów założeniami metodologicznymi, po zakończeniu każdego badania w wylosowanej placówce ankieter zobowiązany był do wypełnienia tzw. arkusza realizacji badania, w którym odnotowano wszystkie istotne dla przebiegu badania informacje - tj. data i godzina badania, adres placówki, liczba studentów uczestniczących w badaniu oraz własne uwagi z przebiegu badania. W około $30 \%$ przypadków korzystano z próby rezerwowej uczelni (wylosowanej równolegle z próbą główną).

W analizie statystycznej wyników badań uwzględniano w przypadku wszystkich analiz wyłącznie te rekordy, które w danym przypadku posiadały wszystkie uwzględniane dane (podając za każdym razem pełne liczebności). Uwzględniono testy nieparametryczne - głównie chi ${ }^{2}$ oraz testy t-Studenta, a także korelacje liniowe $r$ Persona, przyjęto powszechnie stosowany próg istotności statystycznej $\mathrm{p}<0,05$. Wskaźniki struktury zaokrąglono do jednego miejsca po przecinku.

\section{Problem picia alkoholu polskich studentów - wybrane wyniki badań}

Najbardziej zgeneralizowanym wskaźnikiem picia alkoholu przez studentów jest informacja o szacunkowej częstości picia alkoholu w określonych przedziałach czasu. Wyniki w tym zakresie przedstawiono w tabeli 5 .

Tabela 5. Częstość picia alkoholu w ciągu całego życia, 12 miesięcy, 30 dni poprzedzających badanie

\begin{tabular}{l|c|c|c}
\hline & $\begin{array}{c}\text { Kiedykolwiek } \\
\text { w życiu } \\
(\mathbf{N}=4317)\end{array}$ & $\begin{array}{c}\text { Ostatnie } \\
\mathbf{1 2} \text { miesięcy } \\
(\mathbf{N}=4285)\end{array}$ & $\begin{array}{c}\text { Ostatnie } \\
\mathbf{3 0} \mathbf{~ d n i} \\
(\mathbf{N}=4335)\end{array}$ \\
\hline Nie piłem & $\%$ & $\%$ & $\%$ \\
1-2 razy & 3,6 & 5,5 & 15,9 \\
\hline 3-5 razy & 2,3 & 6,7 & 27,8 \\
\hline 6-9 razy & 2,4 & 11,5 & 24,5 \\
\hline 10-19 razy & 3,4 & 13,9 & 15,3 \\
\hline 20-39 razy & 6,9 & 19,8 & 10,8 \\
40 razy i więcej & 71,0 & 15,4 & 2,7 \\
\hline
\end{tabular}

Źródło: Opracowanie własne. 
Zgodnie z oczekiwaniami najwięcej jest tych, którzy wcale nie pili alkoholu w najkrótszym uwzględnionym okresie, tj. 30 dni poprzedzających badanie. Znacznie mniej osób, bo tylko co dwudziesty badany, wcale nie pił alkoholu w ciągu roku poprzedzającego badanie. Wreszcie jedynie 3,6\% było takich, którzy nie pili alkoholu nigdy w życiu. Warto zwrócić uwagę, że wśród studentów całkiem sporo, bo około 20\%, to osoby, które piły alkohol jedynie 20 razy w życiu lub rzadziej.

Bliższa analiza powinna dotyczyć rozkładu częstotliwości picia alkoholu w ciągu 30 dni poprzedzających badanie. I tak picie do pięciu razy, czyli średnio co sześć dni, dotyczy aż 65\% badanych, z kolei picie bardzo częste, 20 razy i więcej, obejmuje 5,8\%. Należy zauważyć, że odsetek ten obejmuje osoby, które piją prawie codziennie oraz częściej (czyli nawet kilka razy dziennie). Warto zauważyć, że biorąc pod uwagę częstość picia alkoholu, jest to grupa wysokiego ryzyka problemów alkoholowych. Oczywiście dla takiej diagnozy niezbędne jest jeszcze przeanalizowanie występowania konsekwencji picia, a nie tylko jego częstotliwość. Posłużyły do tego testy przesiewowe wskazujące na rozpowszechnienie zaburzeń związanych $\mathrm{z}$ piciem alkoholu.

\section{Wyniki Badań w zakresie testu AUDIT-C}

Wyniki w zakresie testu Audit-C wskazują generalnie na wysokie zagrożenie zaburzeniami związanymi z piciem alkoholu wśród studentów. Warto zauważyć, że jedynie co dziesiąty student osiągnął 0 punktów. Znaczący jest odsetek badanych, którzy osiągnęli 8 punktów i więcej (przyjęto tu do analiz dwukrotność normy dla mężczyzn). Zważywszy, że wartości 4 punktów mężczyzn i 3 punkty u kobiet uznaje się za wysokie, fakt, że co 11 badany osiągnął 8 punktów i więcej należy uznać za niepokojący, gdyż wynik ten może być utożsamiany z pewną ostrożnością z ciężkimi zaburzeniami związanymi z piciem alkoholu (dawniej uzależnieniem).

Przyjmując normy Testu Audit-C należy uznać, że ponad $50 \%$ studentów ma doświadczenia z piciem alkoholu wskazujące, że są oni zagrożeni piciem ryzykownym lub uzależnieniem od alkoholu.

Takie zagrożenie istotnie częściej występuje wśród studentów (prawie 60\%) niż studentek (nieco mniej niż 50\%). 
Tabela 6. Rozkład odsetek badanych osiągających określoną liczbę punktów w teście Audit-C

\begin{tabular}{c|c|c|c}
\hline & $\mathbf{n}$ & \% ważnych & \\
\hline 0 & 445 & 10,1 & \\
\hline 2 & 485 & 11,0 & \\
\hline 3 & 622 & 14,1 & \\
4 & 683 & 15,5 & \\
\hline 5 & 714 & 16,2 & \\
6 & 461 & 10,4 & \\
\hline 7 & 368 & 8,3 & \\
8 & 243 & 5,5 & \\
9 & 176 & 4,0 & \\
10 & 125 & 2,8 & \\
\hline 11 & 51 & 1,2 & Eącznie 9\% \\
12 & 22 & 0,5 & \\
\hline
\end{tabular}

Źródło: Opracowanie własne.

Tabela 7. Zaburzenia związane z piciem alkoholu na podstawie norm testu Audit-C

\begin{tabular}{l|c|c}
\hline & $\mathbf{n}$ & $\%$ \\
\hline Problematyczne & 2265 & 50,30 \\
Norma & 2037 & 45,24 \\
Brak danych & 201 & 4,46 \\
\hline
\end{tabular}

Źródło: Opracowanie własne.

Tabela 8. Zaburzenia związane z piciem alkoholu według płci na podstawie norm testu Audit-C

\begin{tabular}{l|c|c}
\hline & $\begin{array}{c}\text { Zaburzenia związane } \\
\text { z piciem alkoholu }\end{array}$ & Norma \\
\hline Kobieta & 49,82 & 50,18 \\
Mężczyzna & 59,19 & 40,81 \\
\hline
\end{tabular}

$\mathrm{Chi}^{2}=32,1 ; \mathrm{p}<0,0001$. Źródło: Opracowanie własne. 


\section{Wyniki testu RAPS4}

Biorąc pod uwagę normy stosowane przy interpretacji wyników testu RAPS4 zagrożenie uzależnieniem od alkoholu występuje w przypadku 38,2\% próby. Zgodnie z normami tego testu wystarczy pojedyncza odpowiedź twierdząca na jedno z pytań tego testu, by osobę zaliczyć do grupy zagrożonych.

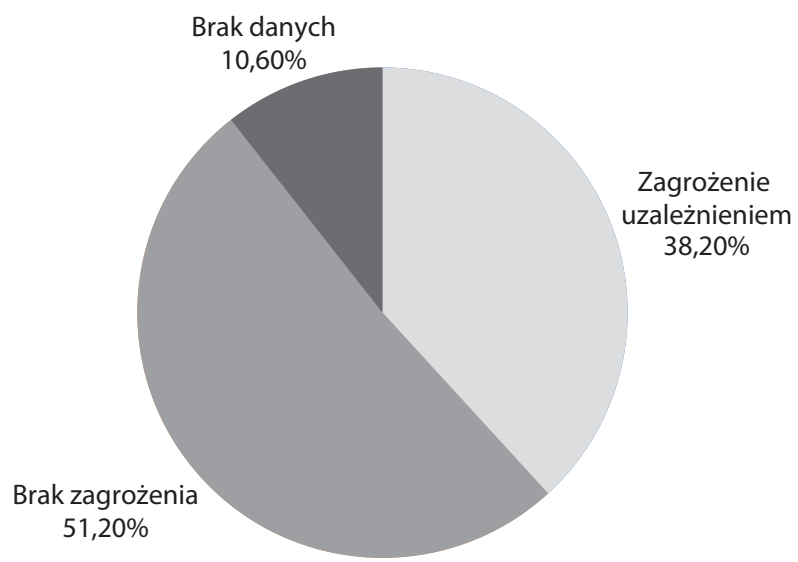

Wykres 2. Zagrożenie uzależnieniem od alkoholu na podstawie tekstu RAPS4 $(\mathrm{N}=4503)$

Źródło: Opracowanie własne.

W zagrożonej grupie, która osiągnęła przynajmniej jeden punkt, znalazło się 36,7\% kobiet oraz 55,8 mężczyzn $\left(\mathrm{chi}^{2}=125,9476\right.$, $\mathrm{p}<0,001)$. Rozkład ten jest podobny do przedstawionych wyżej wyników uzyskanych testem Audit-C. Jednak odsetek zarówno wszytkich zagrożonych, jak i uwzględniając podział na grupy ze względu na płeć, jest niższy od uzyskanego w drugim teście. Potwierdza to dość oczywistą konieczność pamiętania przy interpretacjach wyników o kluczowej roli sposobów operacjonalizacji zjawisk.

Dla dokładniejszych analiz w tabeli 8 przedstawiono odsetki badanych osiągających określoną liczbę punktów w tym teście. Wyniki zaprezentowano nie uwzględniając osób, których odpowiedzi zawierały braki danych. Warto zaznaczyć, że dosyć wysoki odsetek braków danych (ponad 10\%) może tu wynikać z drażliwości kwestii związanych $\mathrm{z}$ zaburzeniami $\mathrm{w}$ obszarze picia alkoholu. 
Tabela 9. Odsetki badanych osiągających określoną liczbę punktów w zakresie testu RAPS4 $(\mathrm{N}=4026)$

\begin{tabular}{c|r|c}
\hline Liczba punktów & $\mathbf{N}$ & $\%$ \\
\hline 0 & 2306 & 57,3 \\
1 & 759 & 18,9 \\
2 & 563 & 14,0 \\
3 & 296 & 7,4 \\
4 & 102 & 2,5 \\
\hline
\end{tabular}

Źródło: Opracowanie własne.

Należy zauważyć, że wyższe są odsetki tych, którzy uzyskali 1 lub 2 punkty (odpowiednio 18,9\% i 14\%). Stanowczo mniej jest osób, które uzyskały 3 i 4 punkty (7,4\% i 2,5\%). Warto ponadto zaznaczyć, że te ostatnie grupy z pewnością można zaliczyć do zagrożonych uzależnieniem od alkoholu. Dotyczy ono zatem jednoznacznie co dziesiątego studenta.

\section{Problemy związane z używaniem alkoholu}

Badani byli pytani o to, czy doświadczyli kiedykolwiek określonych problemów związanych z używaniem alkoholu.

Jak wskazuje tabela 10 najczęściej z powodu alkoholu badani doświadczali problemów mniej poważnych (jak kłótnia lub sprzeczka, czy zniszczenie prywatnego mienia, np. ubrania). Niestety - spory odsetek badanych doświadczał także problemów potencjalnie dużo poważniejszych:

- co dziesiąta osoba uczestniczyła w bójce lub sprzeczce;

- częściej niż co 11 miała problemy z rodzicami;

- 8,5\% utraciło pieniądze lub cenne przedmioty.

Dużo poważniejsze sprawy, jak przykładowo problemy z policją, dotyczą niższego, ale także znaczącego odsetka badanych:

- prawie co 20-ta osoba miała kłopoty z policją;

- 5\% kierowało pojazdami pod wpływem alkoholu;

- ponad 4\% miało niechciane doświadczenia seksualne.

Warto zauważyć, że odsetki takich doświadczeń związanych z używaniem narkotyków są w badanej populacji o wiele niższe.

Należy podkreślić, że konsekwencje wynikające z tego typu doświadczeń związanych z piciem alkoholu mogą całościowo wpłynąć na funkcjonowanie jednostki poprzez rażące pogorszenie 
stanu zdrowia (np. w wyniku wypadku czy zarażenia się chorobami przenoszonymi drogą płciową) lub konsekwencjami prawnymi (związanymi np. z popełnieniem przestępstwa).

Tabela 10. Doświadczane problemy związane z używaniem alkoholu

\begin{tabular}{l|c}
\hline & $\%$ \\
\hline Kłótnia lub sprzeczka & 15,7 \\
Zniszczenie rzeczy lub ubrania & 13,5 \\
\hline Przepychanka lub bójka & 9,9 \\
Problemy z rodzicami & 9,5 \\
\hline Utrata pieniędzy lub cennych przedmiotów & 8,5 \\
Problemy z przyjaciółmi & 6,7 \\
Wypadek lub uszkodzenie ciała & 6,6 \\
\hline Niszczenie własności publicznej & 5,5 \\
\hline Kłopoty z policją & 4,8 \\
Kierowanie pojazdami pod wpływem niedozwolonych substancji & 4,7 \\
Gorsze wyniki w nauce lub w pracy & 4,1 \\
Niechciane doświadczenia seksualne & 4,1 \\
\hline Interwencja pogotowia ratunkowego & 2,7 \\
\hline Stanie się ofiarą rabunku lub kradzieży & 2 \\
\hline Problemy z wykładowcami & 1,8 \\
\hline
\end{tabular}

Źródło: Opracowanie własne.

Chociaż większość badanych nie doświadczyła nieprzyjemnych sytuacji po użyciu alkoholu wcale lub doświadczyła tylko kilku rodzajów sytuacji, to jak wskazują dane przedstawione w tabeli 11, istotny jest odsetek tych, którzy doświadczyli bardzo wielu rodzajów takich sytuacji. Prawie 7\% respondentów wskazuje tutaj na 5 rodzajów i więcej. Należy zaznaczyć, iż wszystkich tych konsekwencji istotnie częściej doświadczyli studenci w porównaniu ze studentkami.

Warto zauważyć, że liczba doświadczanych rodzajów problemów wyraźnie koreluje z wynikami narzędzi mierzących ryzyko zaburzeń związanych z piciem alkoholu:

- w przypadku testu Audit-C r=0,34, p < 0,001;

- w przypadku testu RAPS4 $\mathrm{r}=0,46, \mathrm{p}<0.001$.

Takie wyniki potwierdzają trafność teoretyczną zastosowanych narzędzi oraz jakość zebranych w projekcie danych. 
Tabela 11. Odsetki osób doświadczających określonej liczby problemów związanych z piciem alkoholu $(\mathrm{N}=4466)$

\begin{tabular}{c|c|c}
\hline $\begin{array}{c}\text { Liczba doświadczanych } \\
\text { problemów }\end{array}$ & $\%$ & \\
\hline 0 & 64,1 & \\
\hline 1 & 14,3 & \\
\hline 2 & 7,7 & \\
\hline 3 & 4,0 & \\
\hline 4 & 3,1 & \\
\hline 5 & 2,2 & Łącznie \\
6 & 1,8 & $6,8 \%$ \\
7 & 1,1 & \\
8 & 0,6 & \\
\hline 9 & 0,4 & \\
\hline 10 i więcej & 0,7 & \\
\hline
\end{tabular}

Źródło: Opracowanie własne.

\section{Podsumowanie}

Uzyskane wyniki wyraźnie wskazują, że picie alkoholu i zaburzenia z nim związane są szeroko rozpowszechnionym problemem wśród polskich studentów. Zagrożenie zaburzeniami związanymi z używaniem alkoholu dotyczy przy konserwatywnych szacunkach 40\% studentów, a przy przyjęciu podwyższonych wskaźników dotyczy w sposób poważny co dziesiątego studenta. Studenci często doświadczają także różnych krótkoterminowych konsekwencji związanych z piciem alkoholu. W przypadku ok. 7\% studentów mamy do czynienia z syndromem takich konsekwencji.

\section{Bibliografia}

American Psychiatric Association (2013), Diagnostic and Statistical Manual of Mental Disorders, wyd. 5, Washington, DC.

Gerstenkorn A., Suwała M. (2003), Problem medyczno-spoleczny spożywania alkoholu w grupie przysztych lekarzy, „Wiadomości Lekarskie”, nr 56, s. 402-406.

Laszek M., Nowacka E., Szatko F. (2011), Negatywne wzorce zachowań studentów, cz. I: Konsumpcja alkoholu i stosowanie substancji psychoaktywnych, „Problemy Higieny i Epidemiologii”, nr 92, s. 114-119. 
Meyer R. (2003), SA-Student-alkoholik, [w:] R. Meyer (red.), Jeden przypadekwiele teorii, Gdańskie Wydawnictwo Psychologiczne, Sopot.

Möllers H.J. (2018), Możliwości i ograniczenia DSM-5 w polepszeniu klasyfikacji $i$ diagnozy zaburzeń psychicznych Psychiatria Polska 52.4.

Puchalski K. (1990), Zachowania zwiazane ze zdrowiem jako przedmiot nauk socjologicznych. Uwagi wokót pojęcia, [w:] A. Gniazdowski (red.), Zachowania zdrowotne. Zagadnienia teoretyczne, próba charakterystyki zachowań zdrowotnych spoleczeństwa polskiego, Wydawnictwo Instytutu Medycyny Pracy, Łódź.

Puchalski K. (2010), Uwarunkowania zachowań zdrowotnych i możliwości ich ksztaltowania, [w:] E. Korzeniowska, K. Puchalski (red.), Nisko wyksztatceni pracownicy a zdrowie - wyzwania dla edukacji zdrowotnej, Wydawnictwo Instytutu Medycyny Pracy w Łodzi, Łódź.

Samochowiec A., Chęć M., Kołodziej Ł., Samochowiec J. (2015), Zaburzenia używnia alkoholu: czy nowe kryteria diagnostyczne implikuja zmiane strategii terapeutycznych?, "Alkoholizm i Narkomania”, nr 28, s. 55-63.

Sidor K., Makara-Studzinska M. (2012), Profil studentów pijących ryzykownie w grupie studentów Uniwersytetu Medycznego w Lublinie, „Hygeia Public Health", nr 47, s. 85-88.

Sierosławski J. (2018), The ESPAD Project: History and Assumptions. Introduction to Series of Papers from the ESPAD Study 1995-2015. Poland Against the Background of Europe, "Alcoholism and Drug Addiction/Alkoholizm i Narkomania", vol. 31, nr 1, s. 1-16.

Wojtowicz-Chomicz K., Kowal M., Kowalska M., Nieradko-Iwanicka B., Borzecki A. (2008), Analiza uzależnienia od nikotyny, motywacji do zaprzestania palenia i narażenia na palenie bierne wśród studentów Akademii Medycznej w Lublinie, „Problemy Higieny Epidemiologii”, nr 89, s. 142-145. 
Małgorzata Orłowska

ORCID 0000-0003-1851-0335

Akademia WSB w Dąbrowie Górniczej

\title{
Czas wolny jako środowisko życia
}

\author{
Abstract \\ Free time \\ as a living environment
}

We usually associate free time only with rest and fun. Meanwhile, both the definitions and the functions performed place it in the mainstream of social life. And such view is the subject of the analysis in this text in reference to the fundamental paradigm of social pedagogy - the living environment.

Keywords: leisure time, living environment, social pedagogy

Słowa kluczowe: czas wolny, środowisko życia, pedagogika społeczna

\section{Wstęp}

Czas wolny zazwyczaj kojarzy się nam ze słodkim lenistwem. Tymczasem patrząc nań z perspektywy pedagoga społecznego widzimy w nim nie tylko instrument zmiany czy wskaźnik partycypacji społecznej, ale jedną z istotnych sfer życia człowieka. W tej sytuacji powstaje pytanie, czy może on być w rozumieniu pedagogiki społecznej środowiskiem życia - jednym z jej fundamentalnych paradygmatów.

\section{Czas wolny - pola dyskursu}

Czas wolny jest jednym z trzech (obok czasu pracy i czasu zaspakajania potrzeb fizjologicznych) znaczących sfer życia współczesnego człowieka. Według ostatnich badań GUS dorosłym współczesnym Polakom zajmuje on zazwyczaj około 1/4 ogółu posiadanego czasu w ciągu dnia (wykres 1 ). 


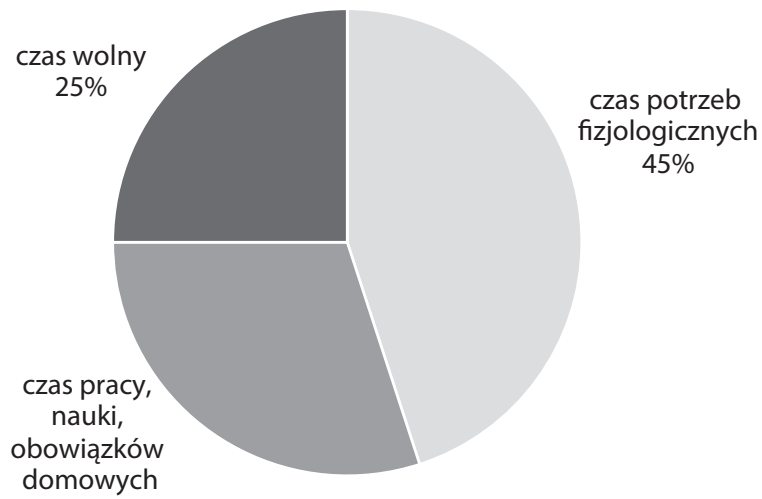

Wykres 1. Struktura dnia współczesnych dorosłych Polaków (w \%) według przeciętnego czasu trwania czynności

Źródło: Opracowanie własne za: Budżet czasu ludności 2013 (2016), cz. 2, GUS, Warszawa, s. 68.

Jednocześnie trzeba wyraźnie zaznaczyć, że wszystkie wyróżnione rodzaje czasów społecznych wchodzą między sobą we wzajemnego interakcje i stają się wypadkową pozostałych kategorii czasów. Dotyczy to też czasu wolnego. Jego ilość i sposoby spędzania są ściśle uwarunkowane ilością i rodzajem pracy zarobkowej (w tym płacy zań otrzymywanej) czy świadczonej nieodpłatnie na rzecz domu, czasem i formą zaspokajania potrzeb fizjologicznych (np. długość snu) i rodzajem dominującej formy odpoczynku - w tym sposobom narzucanym przez dominujący system gospodarczy - jak w przypadku ery prekariatu (szerzej Orłowska, Błeszyński 2016). Nie można zatem przejść obok niego obojętnie.

Sytuacja, kiedy czas społeczny dotyczy 1/4 ogółu czasu człowieka, musi nieść pewne konsekwencje. Musi być on zauważany i oceniany przez człowieka. Materiał badawczy zaprezentowany w tabeli 1 ujawnia hierarchię wartości różnych aspektów życia dla ogólnej oceny jego jakości. Jak wynika z zaprezentowanych danych wśród współczesnych Polaków najistotniejszym elementem życia, który odpowiada za jego jakość, jest rodzina. Jej ranga wobec innych jego składowych jest bardzo wysoka. Razem z miejscem zamieszkania i zdrowiem - niżej ocenianych, równie wysoko - stanowią swoistą triadę odpowiadającą za jego jakość. Jest to w dużej mierze potwierdzenie koncepcji fundamentalnych kręgów środowiskowych zaproponowanej swego czasu przez 
Tabela 1. Zadowolenie z poszczególnych aspektów życia a zadowolenie z życia

\begin{tabular}{|c|c|c|c|}
\hline $\begin{array}{c}\text { Czynnik zadowolenia } \\
\text { z poszczególnych warunków życia }\end{array}$ & $\begin{array}{c}\text { Liczba } \\
\text { stopni } \\
\text { swobody }\end{array}$ & $\begin{array}{c}\text { Statystyka } \\
\text { Walada }\end{array}$ & $\begin{array}{l}\text { Graniczny } \\
\text { poziom } \\
\text { istotności }\end{array}$ \\
\hline Obecna sytuacja zawodowa & 2 & & $<0,0001^{* * *}$ \\
\hline Szkoła, studia & 2 & & 0,1001 n.s. \\
\hline Wykształcenie & 2 & 34,8 & $<0,0001 * * *$ \\
\hline Sytuacja rodzinna & 2 & 689,5 & $<0,0001^{* * *}$ \\
\hline $\begin{array}{l}\text { Relacje z innymi ludźmi, } \\
\text { w tym znajomymi, przyjaciółmi }\end{array}$ & 2 & 89,6 & $<0,0001 * * *$ \\
\hline Sytuacja finansowa & 2 & 87,9 & $<0,0001 * * *$ \\
\hline Materialne warunki życia (poza dochodami) & 2 & 125,6 & $<0,0001 * * *$ \\
\hline ILOŚĆ CZASU WOLNEGO & 2 & 4,0 & 0,1373 n.s. \\
\hline SPOSÓB SPĘDZANIA CZASU WOLNEGO & 2 & 135,8 & $<0,0001 * * *$ \\
\hline Zdrowie & 2 & 314,7 & $<0,0001 * * *$ \\
\hline Typ miejscowości zamieszkania & 2 & 402,3 & $<0,0001 * * *$ \\
\hline \multicolumn{4}{|c|}{$\begin{array}{l}\text { Oznaczenia istotności statystycznej parametrów modelu i czynników: } \\
* * \text { istotny na poziomie } 0,1 \% \\
* \text { istotny na poziomie } 1 \% \\
\text { istotny na poziomie } 5 \% \\
\text { n.s. - nieistotny } 5 \% \\
\text { Źródło: Jakość życia w Polsce w } 2015 \text { r. Wyniki badań spójności spotecznej, GUS, War } \\
\text { szawa, s. } 198 \text {. }\end{array}$} \\
\hline
\end{tabular}

Aleksandra Kamińskiego (1961). Jednak pewne zaskoczenie budzi wysoka lokata czasu wolnego w rankingu, a w zasadzie sposobów jego spędzania. Nie ilość, ale jakość zagospodarowania czasu wolnego jest dla Polaków istotnym czynnikiem wpływającym na ich poczucie dobrostanu ${ }^{1}$.

Potwierdzeniem wysokiej lokaty sposobu spędzania czasu wolnego przez współczesnych Polaków w ich życiu osobistym są źródła czerpania przyjemności (tabela 2).

Jak wynika z przeprowadzonych badań, dla współczesnych Polaków czas wolny jest ważny. Często upatrują w nim drogi wyjścia z wykluczenia społecznego (szerzej w dalszej części tekstu - zob. też Orłowska 2010). Okazuje się, że niezależnie od tradycyjnie różnicujących populacje cech socjo-demograficznych

1 Zob. też szerzej Orłowska, Błeszyński 2018, s. 55 i 56. 
Tabela 2. Przyjemność czerpana z wykonywanych czynności dnia według płci i wieku (na poziomie podstawowych grup czynności) ${ }^{1}$ według GUS

\begin{tabular}{|c|c|c|c|c|c|c|c|}
\hline \multirow[b]{2}{*}{ Czynności } & \multirow[b]{2}{*}{$\frac{1}{0}$} & \multicolumn{2}{|c|}{ Płeć } & \multicolumn{4}{|c|}{ Wiek } \\
\hline & & 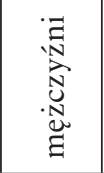 & $\begin{array}{l}\text { 离 } \\
\frac{0}{0} \\
0 \\
0\end{array}$ & 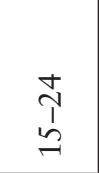 & $\begin{array}{l}\stackrel{1}{n} \\
i \\
i \\
n\end{array}$ & $\begin{array}{l}+ \\
b \\
1 \\
i n \\
n\end{array}$ & 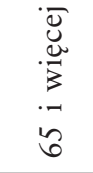 \\
\hline Potrzeby fizjologiczne & 0,885 & 0,880 & 0,889 & 0,894 & 0,900 & 0,881 & 0,850 \\
\hline Praca zawodowa ${ }^{2}$ & 0,274 & 0,254 & 0,309 & 0,212 & 0,274 & 0,300 & 0,364 \\
\hline Nauka $^{3}$ & 0,087 & 0,054 & 0,120 & 0,055 & 0,273 & 0,611 & 0,821 \\
\hline Zajęcia i prace domowe & 0,445 & 0,417 & 0,459 & 0,438 & 0,533 & 0,419 & 0,424 \\
\hline $\begin{array}{l}\text { Dobrowolna praca } \\
\text { w organizacjach, pomoc } \\
\text { innym, praktyki religijne }\end{array}$ & 0,727 & 0,644 & 0,777 & 0,559 & 0,632 & 0,747 & 0,837 \\
\hline $\begin{array}{l}\text { Życie towarzyskie } \\
\text { i rozrywki }\end{array}$ & 0,927 & 0,923 & 0,931 & 0,942 & 0,940 & 0,917 & 0,919 \\
\hline $\begin{array}{l}\text { Uczestnictwo w sporcie } \\
\text { i rekreacji }\end{array}$ & 0,939 & 0,933 & 0,945 & 0,950 & 0,947 & 0,930 & 0,928 \\
\hline Zamiłowania osobiste & 0,902 & 0,900 & 0,904 & 0,940 & 0,878 & 0,891 & 0,921 \\
\hline $\begin{array}{l}\text { Korzystanie ze środków } \\
\text { masowego przekazu }\end{array}$ & 0,916 & 0,910 & 0,922 & 0,934 & 0,930 & 0,907 & 0,900 \\
\hline Przemieszczanie się & 0,507 & 0,497 & 0,518 & 0,442 & 0,507 & 0,544 & 0,578 \\
\hline
\end{tabular}

Uwaga:

1. Na podstawie pytania: Czas poświęcony na czynność był w przeważającej mierze: przyjemny (+1); ani przyjemny, ani nieprzyjemny (0); nieprzyjemny (-1).

2. Dotyczy osób pracujących.

3. Dotyczy osób uczących się.

Źródło: Opracowanie własne na podstawie: Budżet czasu ludności 2013 (2016), cz. 2, GUS, Warszawa, s. 238.

(płeć i wiek) zachowania związane z czasem wolnym sprawiają współczesnym Polakom w równym stopniu satysfakcję i przyjemność niezależnie od istniejących między nimi różnic. Istniejące w tej sferze rozbieżności są symboliczne. Powstała hierarchia wartości na pierwszym miejscu stawia sferę czasu wolnego, następnie czynności dnia związane z biologiczną egzystencją, kolejno pomoc innym (czas na wpół wolny według nomenklatury A. Kamińskiego) i sferę religijnych wartości, a dopiero potem ze znacznym dystansem prace na rzecz domu oraz zdecydowanie oddaloną pracę zawodową oraz naukę (patrz tab. nr 2). 
Zastanawiające są różnice w ocenie nauki przez kobiety i mężczyzn oraz $\mathrm{w}$ znaczeniu przypisywanym jej z upływem czasu. Podobny proces daje się zauważyć $\mathrm{w}$ przypadku pracy zawodowej oraz pracy na rzecz innych wraz z praktykami religijnymi (tabela 2).

Wśród wyróżnionych przez GUS (tabela 2) grup rodzajów zachowań w czasie wolnym współcześni Polacy największą radość i przyjemność czerpali z uczestnictwa w sporcie i rekreacji, co jest sprzeczne $\mathrm{z}$ funkcjonującym stereotypem. Tym bardziej, iż żadna z wyróżnionych zmiennych socjo-demograficznych nie była w tym przypadku różnicująca. Kobiety, mężczyźni, ludzie starzy i młodzi w równym stopniu upatrywali w rekreacji i sporcie przyjemności. Pozostałe zachowania były równie egalitarne, choć można się było dopatrzeć drobnych różnic. Drugie w kolejności popularności było życie towarzyskie i rozrywka. W tym przypadku jedynie najstarsi mieli inne preferencje (zajmowanie się hobby). Podobnie było w przypadku trzeciego wyboru. Prawie wszyscy określali, że przyjemność sprawia im korzystanie z mass mediów. Inne zdanie mieli tylko najmłodsi i najstarsi respondenci. Ci pierwsi woleli zajmować się swoim hobby - korzystanie z internetu, drudzy przedkładali życie towarzyskie nad zamknięciem się w przysłowiowych czterech ścianach.

Mimo istniejących drobnych różnic preferencje Polaków są bardzo spójne. Można mówić zatem o określonych orientacjach. Choć trudno porównywać kategorie sposobów spędzania czasu, warto zauważyć, że obok czasu obowiązków i czasu regeneracji bio-psychicznej organizmu również czas wolny ma istotne znaczenie dla współczesnego człowieka.

Przytoczone wyniki badań pozostają w widocznym związku z określeniem definicyjnym czasu wolnego. Zacznijmy jednak od uświadomienia sobie, że definicja ta nie jest łatwa do zbudowania. Jedną z przyczyn jest uznaniowość w przyporządkowaniu określonych zachowań do sfery czasu wolnego. Ta sama czynność raz może być zaliczona do sfery czasu wolnego a innym razem nie. Dla zrozumienia problemu dobrym przykładem jest czytanie książki. Ta sama lektura w różnym kontekście może być zaliczana do różnych obszarów naszej aktywności. Jeśli czytamy książkę dla przyjemności to jest to obszar czasu wolnego, jeśli ta sama książka została nam np. zadana w szkole do przeczytania to jest to obszar obowiązków - nauki bądź pracy. W tej sytuacji w teoretycznych rozważaniach nad czasem wolnym pojawił się wątek tzw. cech konstytutywnych, tzn. takich, które 
pozwolą przyporządkować czynność do właściwej sfery. Od czasów Joffre'a Dumazediera w zasadzie sprowadza się je do trzech przesłanek: dobrowolności, satysfakcji i niekomercyjności. Takie podejście metodologiczne pozwala wybrnąć z sytuacji nie tylko na gruncie empirii, ale też teorii. Tym bardziej, że współcześnie możemy mówić o wręcz lawinowym przyroście definicji na ten temat, na co zwrócili uwagę i udokumentowali w swoich badaniach m.in. Gordon Walkner i Litwiller Fenton (2011). Tym niemniej istnieje potrzeba uporządkowania i klasyfikacji tak wielu definicji (szerzej: Orłowska 2007; Orłowska, Błeszyński 2018). Ciekawą propozycję klasyfikacyjną, o charakterze holistycznym, zaproponowała Maria Czerepaniak-Walczak (2007), sprowadzając je w konsekwencji do trzech rodzajów definicji: o charakterze strukturalnym, funkcjonalnym i atrybutywnym. ${ }^{2}$ I właśnie ten trzeci rodzaj - odwołujący się do atrybutów czasu wolnego wydaje się być najbardziej obiecującym dla niniejszego dyskursu.

Taką definicją o charakterze atrybutywnym, w sposób całościowy, wielopłaszczyznowy definiującą czas wolny, jest wspomniana definicja zaproponowana przez Marię Czerepaniak-Walczak, która określa go jako interwał

podmiotowego życia, w którym osoba doświadcza dobrostanu intelektualnego, emocjonalnego i fizycznego, w rezultacie możliwości samodzielnego, suwerennego przejawiania czynności posiadających znamiona dobrowolności i niekomercyjności oraz będących źródłem satysfakcji [...] brak któregoś z elementów [...] sprawia, że czas człowieka jest wypełniony obowiązkami, albo jest źródłem doświadczania przymusu, zniewolenia, deprywacji. [...] jest tkanką życia osobistego, potwierdzeniem siebie jako jednostki prywatnej, a jednocześnie daje szansę uczestniczenia w sferze publicznej (Czerepaniak-Walczak 2007: 236).

Fundamentem czasu wolnego, a właściwie partycypacji społecznej jednostki w pełnym wymiarze, jest jej podmiotowość oparta o niezbywalne cechy czasu wolnego. To one decydują o tym, czy możemy konkretną czynność przypisać do niego, czy nie. Jest to bardzo istotne w sytuacji odzierania współczesnego człowieka z jego czasu - czasu wolnego. $\mathrm{Na}$ to zjawisko - kiedy przykładowo pod pozorem zajęć wydawałoby się przypisanych do czasu wolnego ukrywa się pracę - zwraca uwagę w swoich

\footnotetext{
2 Szerzej: Orłowska 2007.
} 
publikacjach Guy Stending. Szczególnego znaczenia nabiera tu aspekt dobrowolności. Dobrowolności określonych czynności i zachowań. Jej brak - tak jak i pozostałych cech - pozbawia człowieka nie tylko dobrostanu, ale i podmiotowości. Więcej, jest wyrazem przymusu i zniewolenia. Rozszerzając myśl Marii Czerepaniak-Walczak, człowiek jest odzierany z podmiotowości, jest mu ona zabierana. Jaka jest tego konsekwencja? Z podmiotu staje się on przedmiotem oddziaływań. I chyba - na co zwraca uwagę Czerepaniak-Walczak - owa niezgoda na utratę podmiotowości jest fundamentem czasu wolnego, fundamentem dobrostanu intelektualnego, emocjonalnego i fizycznego, a drogą ku podmiotowości jest możliwość „samodzielnego, suwerennego przejawiania czynności posiadających znamiona dobrowolności i niekomercyjności oraz będących źródłem satysfakcji. Jest warunkiem partycypacji społecznej” (tamże).

\section{Środowisko - jedność w wielości stanowisk}

W pedagogice społeczne pojęcie środowiska jest „ważną kategorią pojęciową, postrzeganą najczęściej jako teoria i praktyka pracy społecznej, [gdzie oznacza - M.O.] ono przestrzeń, w obrębie której realizowane są cele wychowania za pomocą różnych form oddziaływań”. (Radziewicz-Winnicki 2008: 152). Jest ono odnoszone do „kręgów osób i wytworów kulturowych oddziałujących i wpływających na jednostkę" (tamże).

Koncepcja środowiska była na tyle znacząca w pedagogice społecznej, że stała się jednym z elementów składowych jej definiowania. Andrzej Radziewicz-Winnicki określa ją jako tę, „która zajmuje się badaniem środowiskowych uwarunkowań procesów edukacyjnych", albo jako tę, która analizuje środowisko życia wychowanka w celu postawienia określonej diagnozy, zdobycia wiedzy o ulepszeniu środowiska, tak by sprzyjało ono rozwojowi wychowanków" (Radziewicz-Winnicki 2008: 151). Stwierdza on wprost, że wszystkie określenia środowiska sprowadzają się do ujawnienia środowiskowych uwarunkowań procesów wychowawczych, analizy warunków sprzyjających zaspokajaniu potrzeb rozwoju człowieka (bądź grupy ludzi) w różnych fazach jego (ich) rozwoju i różnych sytuacjach życiowych - w pracy, podczas nauki czy zabawy, w czasie wolnym, w miejscu zamieszkania, w rodzinie, grupie rówieśniczej i towarzyskiej działalności kulturalnej, bądź w innych formach aktywności ludzkiej (Radziewicz-Winnicki 2008: 153). 
Wypada się z nim zgodzić, zwłaszcza po lekturze przemyśleń Heleny Radlińskiej zaprezentowanych w jej fundamentalnym dziele Pedagogika społeczna, gdzie ,środowisko życia [spostrzega ona jako - M.O.] zespół warunków, wśród których bytuje jednostka, czynników przekształcających jej osobowość, oddziaływujących stale lub przez dłuższy czas” (Radlińska 1961: 366).

Analiza koncepcji Radlińskiej dalej przewija się w rozważaniach kontynuatorów jej myśli. Ewa Marynowicz-Hetka stwierdza, że „obejmuje ono wszystkie możliwe konfiguracje elementów środowiska, w którym przebywa jednostka. Specyfiką tego pojęcia jest to, że w zależności od tego, jak jednostka sytuuje się w owym środowisku, tak przybiera ono różne atrybuty. Może ono być obiektywne, subiektywne, niewidzialne, materialne, szersze, bezpośrednie”. I dalej, że może „przyjmować postawę bierną, obronną i twórczą (czynną)" (Marynowicz-Hetka 2007: 54).

Inny ciekawy, choć zbliżony, punkt widzenia prezentuje Alicja Kargulowa (Kargulowa 1998 za: Winiarski 2001: 136). W swoich rozważaniach wyodrębnia ona trzy podejścia metodologiczne: orientację metodologiczno-naturalistyczną, orientację pozytywistyczną oraz orientację humanistyczną. Pierwsza z nich odwołuje się do kompleksu warunków sprzyjających naturalnemu wzrostowi, środowisko zaś to podłoże, z którego człowiek czerpie niezbędne dla rozwoju składniki. Drugie podejście upatruje w środowisku źródła bodźców stymulujących rozwój, natomiast w koncepcji zorientowanej humanistycznie widzi w nim układ społecznych interakcji świadomych podmiotów.

Anna Przecławska i Wiesław Theiss w rozważaniach zaprezentowanych w Pedagogika spoleczna - dyskusji ciagg dalszy określają środowisko jako „nie tylko to co się dzieje w bezpośrednim otoczeniu, ale też to co dociera dzięki przekazowi pośredniemu oraz pod postacią skutków politycznych i gospodarczych” (Przecławska, Theiss 1994: 13). Jak pisze Mikołaj Winiarski:

znaczącym novum w stanowisku A. Przecławskiej i W. Theissa dotyczącym rozumienia i specyfiki środowiska wychowawczego jest odchodzenie od orientacji formalno-instytucjonalnej, regulacji odgórnej uprzedmiatawiającej podmioty środowiskowe, a przywiązywanie szczególnej wagi do relacji międzyludzkich inwencji i twórczości ludzi rozwijającej się na podłożu dobrowolności, wolności, uznanych i preferowanych wartości. Podstawową formą (warunkiem) humanizacji środowiska wychowawczego staje się tutaj dialog i współdziałanie (Winiarski 2001: 137). 
Dziedzictwo intelektualne Radlińskiej wycisnęło niezbywalne piętno na podejściu do pedagogiki społecznej oraz jej fundamentalnych paradygmatów. Jednym z nich jest środowisko życia. Przytoczony (w ogromnym skrócie) przegląd istniejących stanowisk uzmysławia nam istotną rolę nie tylko wyróżnionych przez nią pojęć - w niniejszym dyskursie pojęcia środowiska, które było i pozostaje nadal fundamentalną kategorią analityczną pedagogiki społecznej - ale też ustanowione zręby definicyjne, czasami rozszerzane - jak w przypadku dywagacji A. Przecławskiej i W. Theissa, innym razem uszczegóławiane - jak u A. Kargulowej. Tym niemniej główne zręby idei Radlińskiej zostają.

Kończąc dyskurs określający pojęcie środowiska można powtórzyć za M. Winiarskim (2001: 139), że daje się zauważyć pewien dualizm interpretacyjny. Pierwszy odnosi się do interpretacji scjentycznej, drugi do humanistycznej.

Pierwsza kategoria definicji odnosić się będzie do „określonej i wyodrębniającej się przestrzeni wraz z czynnikami, elementami przyrodniczymi, społecznymi i kulturowymi, które są wzajemnie powiązane, stanowią swoistą funkcjonalną całość, którą określona grupa społeczna wykorzystuje do realizacji celów edukacyjnych" (tamże).

Drugie podejście interpretacyjne odnosi się do tych określeń środowiska, które postrzegają je jako „przestrzeń społeczno-kulturalną, z którą dana jednostka czy też grupa społeczna miała lub ma styczność bezpośrednią i pośrednią, w wyniku czego stała się ona (ta przestrzeń) źródłem doświadczenia indywidualnego lub zbiorowego oraz swoistym środkiem do zaspakajania potrzeb tej jednostki czy też grupy, zyskując przez to dlań szczególne znaczenie w wymiarze subiektywnym i obiektywnym" (Winiarski 2001: 139).

\section{Prekaryzacja życia}

Procesualność życia jest oczywistym faktem. Świat, w którym przyszło nam żyć, rządzi się innymi regułami niż dotychczas nam znane. Procesy gospodarcze nie tylko zmieniły reguły gry ekonomicznej, ale też stosunki społeczne. Guy Stending (2014) w swoich pracach zwraca uwagę na pojawiającą się nową, inną strukturę społeczną. W miejsce dotychczasowych grup i klas pojawiają się inne, w których przynależność jest spowodowana nową strukturą społeczną i przypisanymi człowiekowi cechami 
wynikającymi z owych zmian społecznych. Stąd możemy mówić o hierarchii klas, na szczycie której znajduje się plutokracja, niżej profesjonaliści i salariat. Natomiast podstawę piramidy społecznej stanowi proletariat, prekariat i lumpenproletariat. Użyta semantyka oddaje $\mathrm{w}$ pełni sens i znaczenie oraz miejsce w strukturze społecznej ludziom przypisanym do owych grup. Plutokracja - grupa najmniej liczna (około kilku tysięcy osób w skali świata) jest właścicielem większości dóbr świata. Dla ich obsługi zatrudniają oni średnio liczną, dobrze opłacaną grupę specjalistów - profesjonalistów i salariat. Pozostałe grupy są zepchnięte do roli wykonawców, użytecznych w danej chwili, nisko opłacanych pracowników o stale ograniczonych możliwościach zarobkowych i socjalnych. Mają oni ograniczone prawa obywatelskie. Wspomnieć należy przede wszystkim brak równości wobec prawa, nierówny dostępu do kultury, brak zabezpieczenia społecznego oraz równych praw do działalności zarobkowej. W tej sytuacji możemy mówić o braku kontroli nad czasem i stałym kurczeniu się zasobów czasu wolnego oraz bezpłatnej pracy na rzecz zatrudnienia (Standing 2014: 43-44).

Konsekwencje takiego stanu rzeczy dla czasu wolnego są poważne. Zmiany w strukturze pracy (jako kluczowe) powodują zmiany w sferze czasu wolnego. Następuje nie tylko zawłaszczanie czasu wolnego na rzecz pracy - a przynajmniej jego znacznych obszarów, ale i obniżenie jego jakości. Wiąże się to z wypoczynkowym ubóstwem i komercjalizacją sposobów jego spędzania. Możemy zatem mówić o dominacji czasu wolnego typu play a nie leisure ${ }^{3}$.

To praca stanowi o rodzaju czasu wolnego. Jeśli jest ona twórcza, to określa się ją zazwyczaj mianem work, jeśli zaś przynosi tylko środki na przeżycie, to możemy ją określić mianem labour. Pierwszy rodzaj pracy (twórczej i rozwijającej) tworzy i rozwija czas wolny związany z wolnością i twórczością - leisure. Jest to czas wolny „do”. Druga kategoria pracy (odtwórczej, przynoszącej tylko środki do zaspokojenia potrzeb egzystencji) - labour, kreuje czas typu play. Czas ukierunkowany na odreagowanie zmęczenia i trudów dnia. Gdzie nie ma miejsca na twórczość i kulturę wysoką nawet w najmniejszym stopniu (Stending 2014: 235; Orłowska, Błeszyński 2018: 18-19).

\footnotetext{
3 Szerzej: Orłowska, Błeszyński: 2016.
} 
W erze społeczeństwa prekariatu nie możemy zatem mówić o pełnej partycypacji w kulturze wysokiej, pozostaje jedynie powszechne zachowanie odwołujące się do prostej rozrywki (wypoczynkowe ubóstwo). Czas wolny dla większości społeczeństwa, a właściwie dla klas podporządkowanych (takich jak: proletariat, prekariat i lumpenproletariat ), zostaje sprowadzony do zachowań ukierunkowanych na wytchnienie „od” trudu i znoju dnia powszedniego czy nierzadko zawłaszczonego weekendu na rzecz pracy. To jest jedyna jego kategoria.

\section{Wnioski}

Przed laty Helena Radlińska (1961: 366) określała „środowisko życia [jako] zespół warunków, wśród których bytuje jednostka, czynników przekształcających jej osobowość, oddziaływujących stale lub przez dłuższy czas". Niewątpliwie w świetle niniejszego stwierdzenia czas wolny jest środowiskiem życia. Tym ważniejszym, że jak twierdzi Maria Czerepaniak-Walczak, jest on miejscem doświadczania wielorakiego dobrostanu i potwierdzeniem człowieczeństwa w sferze zarówno prywatnej jak i społecznej.

Jednak czas ery prekariatu powinien budzić niepokój dotyczący jego jakości i społecznej roli. Zostaje ona sprowadzona do prostej rozrywki odreagowującej zmęczenie dnia i pustkę intelektualną.

Można ironicznie stwierdzić, że historia zatoczyła koło. Badania społeczników okresu międzywojennego prowadzone w Instytucie Gospodarstwa Społecznego starały się uświadomić jego rolę i znaczenie dla grup społecznych, a zwłaszcza osób wykluczonych. To w tym czasie Korniłowicz odwoływał się do czasów antycznych i stwierdzał, że o stanie kulturalnym narodu świadczy sposób, w jaki jego przedstawiciele spędzają godziny „wczasów” - jak wtedy określano czas wolny.

W erze prekariatu mamy do czynienia z utratą jakości życia $\mathrm{w}$ wymiarze indywidualnym i społecznym. A przecież czas wolny był do tej pory jednym $\mathrm{z}$ istotnych wskaźników skal i narzędzi pomiaru owej jakości życia, jak chociażby HDI (Human Dewelopment Indeks), GDI (Gender Development Indeks), PDI (Poverty Development Indeks) czy ustawowa granica biedy, minimum socjalne, monitoring warunków życia GUS (przywołany w pierwszej części pracy). 


\section{Bibliografia}

Budzet czasu ludności 2013 (2016), cz. 2, GUS, Warszawa.

Czerepaniak-Walczak M. (2007), Od próżniaczenia do zniewolenia - w poszukiwaniu dyskursów czasu wolnego, [w:] E. Marynowicz-Hetka (red.), Pedagogika spoleczna, podręcznik akademicki, t. 2, PWN, Warszawa.

Jakość życia w Polsce w 2015 r. Wyniki badań spójności spolecznej (2017), GUS, Warszawa.

Kamiński A., (1961) Pedagogika spoteczna, PWN, Warszawa.

Kargulowa A. (1998), Kilka uwag na temat przesłanek metodologicznych pedagogiki spolecznej (relacja jednostka - środowisko), [w:] E. Marynowicz-Hetka, J. Piekarski, E. Cyrańska (red.), Pedagogika społeczna jako dyscyplina naukowa. Stan - perspektywy, Wydawnictwo Uniwersytetu Łódzkiego, Łódź.

Marynowicz-Hetka E. (2007), Pedagogika spoteczna, t. 1, PWN, Warszawa.

Orłowska M. (2007), Przymus bezczynności, studium pedagogiczno-spoleczne czasu wolnego bezrobotnych, PWN, Warszawa.

Orłowska M. (2010), Sytuacja dzieci w rodzinach objętych pomocq spolecznq $w$ wybranych dzielnicach m. st. Warszawy Praga Poludnie, Praga Pólnoc, Targówek. Raport z badań, Wydawnictwo Fundacja Wspólna Droga, Warszawa.

Orłowska M. (2016), Między leisure a play, [w:] „Historia-Kultura-Globalizacja”, nr 16, s. 111-116, http://www.khg.uni.wroc.pl/?type=archiwum\&nr=19 (dostęp: 01.02.2020).

Orłowska M., Błeszyński J.J. (2016), Czas wolny jako środowisko życia. Perspektywa pedagogiczna. Wybrane problemy, PWN, Warszawa.

Orłowska M., Błeszyński J.J. (2018), Czas wolny w stużbie niepetnosprawnych, PWN, Warszawa.

Przecławska A., Theiss W. (1994), Pedagogika spoleczna-dyskusji ciag dalszy, „Problemy Opiekuńczo-Wychowawcze” 4.

Radlińska H. (1961), Pedagogika spoleczna, Zakład Narodowy im. Ossolińskich - Wydawnictwo, Wrocław-Warszawa-Kraków.

Radziewicz-Winnicki A. (2008), Pedagogika spoleczna, WAiP, Warszawa.

Standing G. (2014), Prekariat: nowa niebezpieczna klasa, przeł. K. Czarnecki, P. Kaczmarski, M. Karolak, PWN, Warszawa.

Walker G., Fenton L. (2011), Institutional Concentration of Leisure Research: A Follow-up to and Extension of Jackson (2004), "Journal Of Leisure Research”, vol. 43, nr 4, http://js.sagamorepub.com/jlr/article/view/2410 (dostęp: 18.11.2019).

Winiarski M. (2001), Edukacja środowiskowa - istota, wymiary, aktualne problemy, [w:] S. Kawula (red.), Pedagogika spoleczna - dokonania - aktualności - perspektywy, Wydawnictwo Adam Marszałek, Toruń. 
Katarzyna Białożyt

ORCID 0000-0001-7047-5763

Uniwersytet Pedagogiczny im. Komisji Edukacji Narodowej w Krakowie

\title{
Edukacja kobiet w okresie późnej starości
}

\author{
Abstract \\ Womens education in the advanced old age
}

The article focuses on the education of women in advanced old age. An attempt was made to describe and indicate the most important elements of educational activity among the surveyed women. The research was conducted in a qualitative paradigm using focus interview. The study group consisted of 12 women aged 75-89. The main research problem was included in the question: What is the educational activity of women in advanced old age? The article aims to show the importance of education for women in advanced old age who participate in the classes of Universities of the Third Age.

Keywords: advanced old age, education, activity, quality of life, social change, lifelong education, education functions of the elderly

Słowa kluczowe: późna starość, edukacja, aktywność, jakość życia, zmiana społeczna, edukacja całożyciowa, funkcje edukacji osób starszych

\section{Wstęp}

Czasy współczesne naznaczone są licznymi przeobrażeniami i zmianami społecznymi, które generują przekształcenia w funkcjonowaniu indywidualnym, grupowym oraz społecznym. Paleta czynników, które wpływają na człowieka XXI w., powoduje sprężenie zarówno o charakterze pozytywnym, jak i negatywnym. Współczesny człowiek doświadcza naporu przeobrażeń technologicznych, kulturowych, społecznych, które implikują zachowania oraz postawy jednostek i grup.

W sytuacji licznych zmian zachodzących w systemie społecznym coraz częściej w opracowaniach podkreślana jest rola edukacji całożyciowej. Edukacja ta nabiera istotnego znaczenia w kontekście starzejących się społeczeństw i wydłużenia ludzkiego życia. 
Współcześnie obok długości życia ludzie dostrzegają potrzebę przeżywania go w sposób satysfakcjonujący, pozwalający zaspokoić potrzeby wyższego rzędu, a tym samym wpływający na jakość przeżytych lat. Poprzez aktywność edukacyjną człowiek może stymulować swój wielopłaszczyznowy rozwój, a tym samym implikować odczuwanie satysfakcji życiowej.

W prezentowanym artykule skoncentrowałam się na edukacji kobiet w okresie późnej starości, które uczestniczą w zajęciach Uniwersytetów Trzeciego Wieku. W artykule prezentuję wybrane wyniki przeprowadzonych przeze mnie badań w tym zakresie (zob. szerzej Białożyt 2020). Badania zostały przeprowadzone w paradygmacie jakościowym i podjęto w nich m.in. próbę odpowiedzi na pytanie o znaczenie aktywności edukacyjnej kobiet w wieku 75-89 lat w ich życiu.

\section{Edukacja osób starszych}

Edukacja stanowi jeden z podstawowych elementów warunkujących jakość życia człowieka. Jak zaznaczają Mirosław J. Szymański (2014: 19-34) oraz Agnieszka Gromkowska-Melosik (2014: 35-54) dostęp do edukacji oraz poziom wykształcenia wpływają na nierówności społeczne oraz pogłębiającą się marginalizację, zatem tylko poprzez aktywne uczestnictwo w różnych formach edukacji możliwym staje się wyrównywanie szans i pełne uczestnictwo w życiu społecznym.

Edukacja realizowana na różnych poziomach we wszystkich fazach życia człowieka pozwala na „bycie” w społeczeństwie i realizowanie zadań rozwojowych. Wielopłaszyznowe zmiany, które są cechą charakterystyczną współczesności, stawiają przed edukacją liczne wyzwania. Według Joanny Madalińskiej-Michalak (2017: 31) wśród tych wyzwań najistotniejsze wydaje się wychowanie ku wartościom i wartościowe życie. W kontekście zmiennej rzeczywistości wartościowe życie nabiera szczególnego znaczenia dla osób starszych, które zakończyły już okres aktywności zawodowej i w starości poszukują sensu dalszych działań.

Według Stefana M. Kwiatkowskiego (2018: 16) konieczność uczenia się przez całe życie wynika z przyśpieszenia cywilizacyjnego, które dotąd nie miało miejsca. Aktywność edukacyjna powinna być realizowana na różnych szczeblach poprzez kursy, warsztaty, ale także poprzez relacje i spotkania z innymi ludźmi. To całościowe postrzeganie edukacji w życiu człowieka jest 
osadzone w założeniach edukacji całożyciowej/permanentnej, która obejmuje wszystkie fazy ludzkiego życia, w tym także starość - często utożsamianą z okresem schyłku życia.

Całożyciowa edukacja pozwala na rozwój indywidualnych cech, które mają swoje odzwierciedlenie w życiu społecznym. Edukacja i wiedza zdobyte w szkole nie wystarczają już na całe życie. Człowiek współczesny musi aktualizować swoją wiedzę i rozwijać kompetencje w okresie całego życia, inaczej niemożliwe będzie jego pełne uczestniczenie w społeczeństwie (Półturzycki 2008: 69-81). Na potrzebę edukacji całożyciowej w czasach zmiany społecznej wskazuje Henryka Kwiatkowska, która pisze „Każda zasadnicza zmiana ludzkiego świata stawia bowiem pojedynczych ludzi i społeczeństwo przed koniecznością nabywania nowych sposobów zachowania i wartościowania, domaga się zasadniczych zmian mentalnych i świadomościowych, domaga się tym samym całożyciowej edukacji” (Kwiatkowska 1997: 9).

W kontekście starzejących się społeczeństw i wzrostu liczby osób najstarszych w strukturze społecznej zasadnym staje się skoncentrowanie na możliwościach, jakie daje seniorom aktywność edukacyjna $\mathrm{w}$ aspekcie ich codziennego funkcjonowania w rodzinie, grupie rówieśniczej, środowisku lokalnym czy globalnym. „Bez edukacji starość ma mniejsze szanse na ,wybrzmienie’ pełni ludzkiego człowieczeństwa. Bez edukacji starość może człowieka zniszczyć, zrujnować fizycznie i psychicznie, społecznie i duchowo" (Dubas 2008: 55).

Zofia Szarota podejmując problematykę edukacji ustawicznej osób starszych, wskazuje na otwarty charakter tego rodzaju edukacji, bowiem „nie preferuje żadnych instytucji, odnajduje natomiast sojuszników i realizatorów w różnych obszarach rzeczywistości, różnych instytucjach, różnych odmianach ludzkiej aktywności" (Szarota 2009: 88). Edukacja w starości powinna stanowić kontynuację aktywności ze wcześniejszych faz rozwojowych, pozwalać człowiekowi na zaspakajanie potrzeb wyższego rzędu, a także umożliwiać poszerzanie kontaktów interpersonalnych.

Aktywność edukacyjna seniorów może być realizowana na różnych płaszczyznach, które są adekwatne do możliwości, zainteresowań i ich predyspozycji. Zaangażowanie w działania o charakterze edukacyjnym stanowi podstawę samorealizacji i rozwoju, a jak podkreśla Maria Kuchcińska (2009: 174), żaden wiek nie stanowi bariery dla wywołania zmian rozwojowych, szczególnie tych, które wykorzystywane są w życiu społecznym. 
Aktywność edukacyjna w życiu osób w zależności od ich okresu rozwojowego ma za zadanie spełniać określone cele i funkcje. Celami edukacji podejmowanej w okresie starości są zrozumienie i interpretacja otaczającego seniora świata, wykorzystanie potencjału osób starszych poprzez samodzielność i odpowiedzialność za siebie samego, rozwiązywanie problemów życia codziennego (Skibińska 2008: 99), a także zmiana negatywnego obrazu starości i ludzi starych w społeczeństwie, doskonalenie osobowości jednostki, zdobywanie nowych umiejętności i kompetencji, propagowanie idei dialogu międzypokoleniowego, odkrywanie sensu życia w starości oraz podnoszenie jakości w starości (Halicki 2000: 143-147; Szatur-Jaworska, Błędowski, Dzięgielewska 2006: 168-169). Adam A. Zych (2009: 20) podkreśla natomiast, iż aktywność edukacyjna osób starszych powinna koncentrować się na pielęgnowaniu sprawności psychicznej i fizycznej, rehabilitacji sił życiowych, osiągnięciu w fazie starości większej satysfakcji, kontroli nad własnym życiem, zrozumieniu siebie i świata.

Obok celów edukacji w wieku senioralnym, znaczącym stają się także funkcje, jakie spełnia ta aktywność. Elżbieta Dubas (2008: 61) wymienia siedem podstawowych funkcji edukacji osób starszych:

- funkcje instrumentalne: poprzez edukację człowiek ma możliwość zrozumienia istoty pojawiających się problemów czy wręcz sytuacji kryzysowych. Funkcja tego rodzaju stanowi także środek zaradczy wobec zmian życiowych, w tym także starości;

- funkcje społeczne i kulturowo-cywilizacyjne: poprzez podejmowanie aktywności edukacyjnej człowiek określa swoją pozycję w społeczeństwie, podejmuje próbę nadążenia za dokonującymi się zmianami; edukacja warunkuje także styl życia, który wpływa na sposób przeżywania starości;

- funkcje auksologiczne: poprzez zaangażowanie w edukację dokonuje się wszechstronny rozwój, umożliwiający akceptację starości i starzenia się;

- funkcje emancypacyjne: aktywność edukacyjna stanowi podstawę samodzielności, pozwala na wyzwolenie się ze sztywnych ram myślowych. Człowiek uczący się ma możliwość poznania innego punktu widzenia na otaczającą go rzeczywistość. Edukacja pozwala na otwarcie się, akceptację i tolerancję;

- funkcje felictylogiczne: poprzez zaangażowanie w edukację człowiek może odczuwać poczucie przynależności, zadowolenie i satysfakcję. Podejmowanie działań edukacyjnych niweluje poczucie pustki i osamotnienia; 
- funkcje biograficzne: człowiek w toku podejmowanej edukacji ma możliwość uczenia się z własnych doświadczeń i przeżyć;

- funkcje egzystencjalne: poprzez edukację człowiek może zrozumieć sens starości, choroby, cierpienia. Edukacja pozwala na akceptację tego, co nieuniknione.

Obok typologii Dubas należy także wskazać na klasyfikację funkcji aktywności edukacyjnej seniorów autorstwa Artura Fabisia (2015: 180-184), który zaproponował trzy podstawowe funkcje w tym zakresie. Funkcja emancypacyjna ukierunkowana jest na samodzielność, rozwój jednostki na wielu obszarach, niwelowanie negatywnego obrazu osób starzejących się i starości, a także zrozumienie zachodzących zmian społecznych. Druga funkcja określana jest jako funkcja egotyczna i odnosi się do odczuwania zadowolenia oraz satysfakcji z własnego rozwoju. Funkcja ta związana jest z rozwojem duchowym, radzeniem sobie z problemami i ukierunkowana jest na samego siebie. Ostatnia funkcja, odnosząca się do działań altruistycznych i dobra drugiego człowieka, koncentruje się na poznaniu, zrozumieniu problemów i potrzeb innych ludzi. W przypadku jej realizacji człowiek poprzez zaangażowanie w edukację może otworzyć się na potrzebujących i przygotować do nowych ról np. opiekuna, wolontariusza.

Analizując złożenia edukacji osób starszych, można wnioskować, iż działalność ta bezpośrednio warunkuje jakość życia najstarszej generacji i pozwala na konstruktywne przeżywanie okresu starości. Skoncentrowanie się na możliwościach rozwojowych człowieka starzejącego się pozwala na waloryzację starości, co posiada istotne znaczenie w czasach kultu młodości i kultury instant.

\section{Metodologia badań własnych}

Celem przeprowadzonych badań jakościowych było opisanie i ukazanie znaczenia aktywności edukacyjnej wśród kobiet w wieku 75-89 lat, które uczestniczą w zajęciach na Uniwersytetach Trzeciego Wieku (UTW). W badaniach skoncentrowano się na aktywności edukacyjnej w percepcji badanych kobiet, znaczeniu edukacji w życiu badanych ze wskazaniem na zadania i funkcje, jakie są realizowane przez zaangażowanie w edukację. Problem główny przeprowadzonych badań zawarty był w pytaniu: Jak przedstawia się aktywność edukacyjna kobiet w okresie późnej starości? 
W badaniach wykorzystano wywiad jakościowy. Badania przeprowadzono w roku $2018 \mathrm{w}$ aglomeracjach województwa małopolskiego, mazowieckiego oraz śląskiego. W badaniach dokonano celowego doboru próby. Głównym kryterium doboru uczyniono wiek badanych, uczestnictwo w zajęciach Uniwersytetów Trzeciego Wieku, płeć (kobiety) oraz miejsce zamieszkania (aglomeracje miejskie). Dokonując wyboru grupy, kierowano się klasyfikacją wiekową zaprezentowaną przez Światową Organizację Zdrowia. Do badań zaproszono osoby w okresie późnej starości, tzn. od 75 do 89 roku życia.

Badaną grupę stanowiło 12 kobiet, zamieszkujących aglomeracje miejskie trzech wskazanych wyżej województw. W toku badań określiły one subiektywny stan swojego zdrowia, sytuację rodzinną oraz materialną. Wśród respondentek zdecydowaną większość stanowiły wdowy (10 kobiet), pozostałe były pannami. W badanej grupie nie pojawiły się osoby z wykształceniem zawodowym i podstawowym. Wszystkie respondentki posiadają wykształcenie wyższe lub średnie, a wznowioną aktywność edukacyjną podjęły w okresie późnej starości.

Szczegółową charakterystykę badanych przedstawia poniższy opis (imiona zostały zmienione):

Janina: 77 lat, Warszawa, panna, wykształcenie wyższe, swój stan zdrowia określa jako bardzo dobry, na zajęcia UTW uczęszcza od 1 roku, mieszka sama, z krewnymi utrzymuje regularny kontakt, swoją sytuację materialną określa jako dobrą;

Daniela: 79 lat, Warszawa, wdowa, wykształcenie wyższe, swój stan zdrowia określa jako bardzo dobry, na zajęcia UTW uczęszcza od 3 lat, mieszka sama, z krewnymi utrzymuje regularny kontakt, swoją sytuację materialną określa jako dobrą;

Zofia: 79 lat, Katowice, wdowa, wykształcenie wyższe, swój stan zdrowia określa jako dobry, na zajęcia UTW uczęszcza od 3 lat, mieszka sama, z krewnymi utrzymuje regularny kontakt, swoją sytuację materialną określa jako dobrą;

Magdalena: 79 lat, Kraków, wdowa, wykształcenie wyższe, swój stan zdrowia określa jako bardzo dobry, na zajęcia UTW uczęszcza od 3 lat, mieszka z córką i jej rodziną, z krewnymi utrzymuje regularny kontakt, swoją sytuację materialną określa jako bardzo dobrą;

Irena: 83 lata, Katowice, wdowa, wykształcenie średnie, swój stan zdrowa określa jako bardzo dobry, na zajęcia UTW uczęszcza od 4 lat, mieszka z córką i jej rodziną, z krewnymi utrzymuje regularny kontakt, swoją sytuację materialną określa jako dobrą; 
Barbara: 85 lat, Kraków, wdowa, wykształcenie wyższe, swój stan zdrowia określa jako dobry, na zajęcia UTW uczęszcza od 8 lat, mieszka sama, nie posiada krewnych ani bliskiej rodziny, z którą utrzymywałaby kontakty, swoją sytuację materialną określa jako dobrą;

Julia: 85 lat, Warszawa, wdowa, wykształcenie średnie, swój stan zdrowia określa jako bardzo dobry, na zajęcia UTW uczęszcza od 10 lat, mieszka sama, z krewnymi utrzymuje regularny kontakt, swoją sytuację materialną określa jako dobrą;

Krystyna: 85 lat, Warszawa, wdowa, wykształcenie wyższe, swój stan zdrowia określa jako bardzo dobry, na zajęcia UTW uczęszcza od 9 lat, mieszka z wnukiem i jego rodziną, z krewnymi utrzymuje regularny kontakt, swoją sytuację materialną określa jako dobrą;

Halina: 87 lat, Katowice, wdowa, wykształcenie średnie, swój stan zdrowia określa jako dobry, na zajęcia UTW uczęszcza od 10 lat (z „przerwami”), mieszka z synem i jego rodziną, z krewnymi utrzymuje regularny kontakt, swoją sytuację materialną określa jako dobrą;

Wiesława: 88 lat, Kraków, panna, wykształcenie wyższe, swój stan zdrowia określa jako bardzo dobry, na zajęcia UTW uczęszcza od 6 lat, mieszka sama, nie posiada krewnych, swoją sytuację materialną określa jako bardzo dobrą;

Franciszka: 88 lat, Kraków, wdowa, wykształcenie średnie, swój stan zdrowia określa jako dobry, na zajęcia UTW uczęszcza od 8 lat, mieszka sama, z krewnymi utrzymuje sporadyczne kontakty, swoją sytuację materialną określa jako dobrą;

Dorota: 88 lat, Warszawa, wdowa, wykształcenie średnie, swój stan zdrowia określa jako dobry, na zajęcia UTW uczęszcza od 12 lat, mieszka z córką i jej rodziną, z krewnymi utrzymuje regularne kontakty, swoją sytuację materialną określa jako dobrą.

\section{Edukacja kobiet w okresie późnej starości w świetle badań własnych}

Uczenie się przez całe życie wymaga od człowieka samodzielności, zaangażowania i aktywności. Tylko poprzez odczuwanie potrzeby podejmowania aktywności edukacyjnej jednostka może czerpać satysfakcję i zadowolenie z własnych działań. Zakres podejmowanych aktywności edukacyjnych w starości 


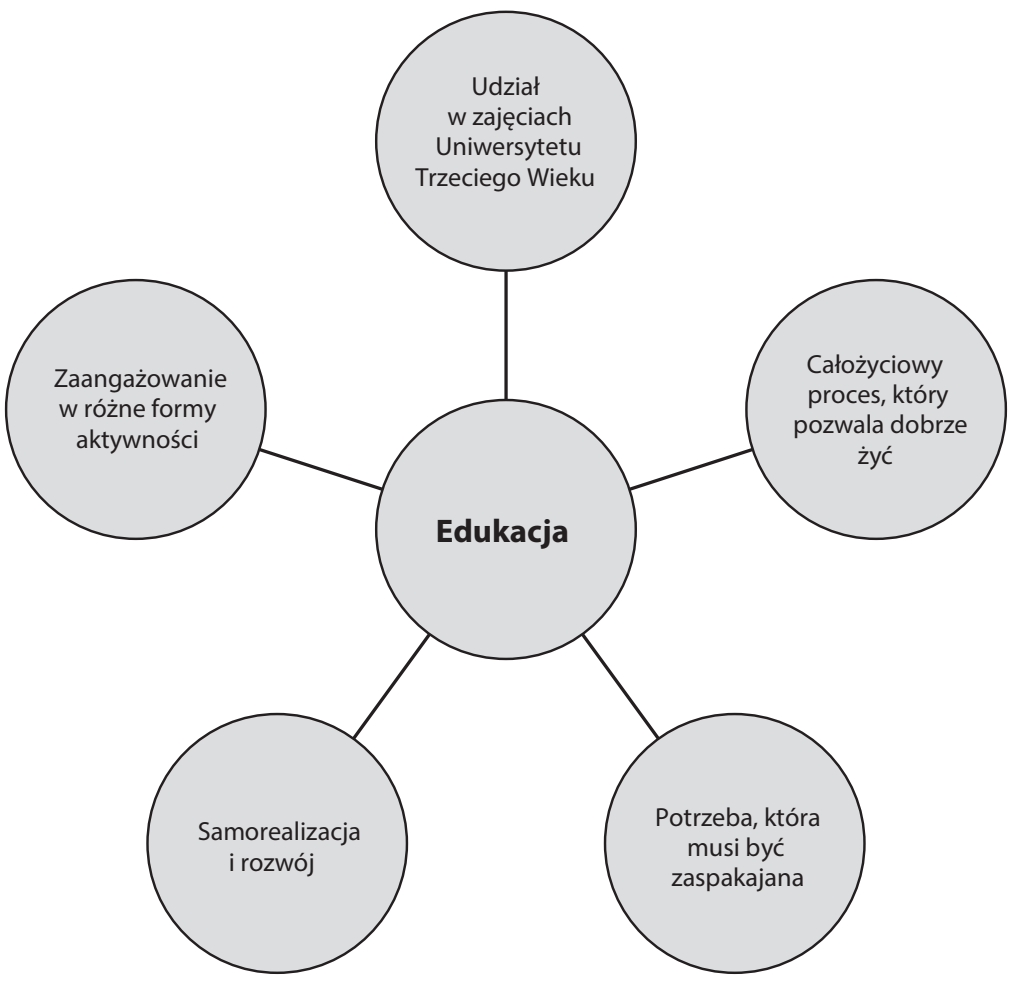

Wykres 1. Edukacja w percepcji kobiet w okresie późnej starości Źródło: Opracowanie własne.

warunkowany jest indywidualnym sposobem definiowania edukacji i postrzegania jej roli we własnym życiu. W diagramie 1 zaprezentowano rozumienie edukacji w percepcji badanych kobiet.

Powyższy diagram ukazuje najczęstsze kategorie odpowiedzi badanych kobiet. Utożsamiają one edukację w sposób wąski zarówno z zajęciami Uniwersytetów Trzeciego Wieku, jak i prezentują jej szersze aspekty.

Edukacja dla badanych kobiet to całożyciowy proces, który pozwala dobrze żyć, sprzyja rozwojowi, samorealizacji i jest realizowany poprzez wszelkie dostępne formy aktywności. Dla 9 badanych kobiet (Magdalena, Irena, Zofia, Krystyna, Halina, Franciszka, Dorota, Barbara, Julia) edukacja jest potrzebą, którą należy zaspakajać na różnych płaszczyznach, co w opinii respondentek warunkuje jakość życia.

Obok zbieżnych wypowiedzi badane kobiety wskazywały także na bardzo indywidualne pojmowanie edukacji $\mathrm{w}$ okresie 
starości. Wybrane wypowiedzi respondentek zostały zaprezentowanie poniżej:

Janina: „Edukacja to nieustana praca nad swoim nastawieniem do życia i otoczenia. Człowiek, który chodzi na Uniwersytet Trzeciego Wieku, otwiera się na świat";

Daniela: „Edukacja, według mnie, to mądrość życiowa i umiejętne korzystanie z tego co już człowiek przeżył, doświadczył. Jak człowiek jest stary, to wiedza z książek mu nie potrzebna, bardziej liczy się to, czego nauczyło go życie";

Zofia: „Człowiek uczy się całe życie, bo inaczej nie poradziłby sobie. Edukacja jest ze mną przez całe życie, nawet poprzez spotkanie z drugim człowiekiem można się czegoś nowego nauczyć";

Magdalena: „Edukacja to odskocznia od zmartwień i trosk”;

Krystyna: „Nie ma edukacji bez szkoły, dla nas starych Uniwersytet Trzeciego Wieku to szkoła, która pozwala się odmłodzić”;

Halina: „Edukacja to radość, dobre nastawienie i wiara, że w starości człowiek może być jeszcze aktywnym, gdyby nie Uniwersytet, to bym siedziała w domu przed telewizorem";

Wiesława: „Edukacja to dla mnie sposób na życie. Lubię zdobywać nową wiedzę, dowiadywać się interesujących rzeczy, spotykać ciekawych ludzi”;

Franciszka: „Edukacja to ludzkie zachowania, postawy, nastawienie do świata i ludzi. Ja realizuję edukację poprzez bycie otwartą na drugiego człowieka, stąd też chodzę na UTW, bo tam ludzie chcą się rozwijać, zmieniać swoje nastawienie do świata";

Dorota: „Edukacja to nauka z życia codziennego, czerpanie wiedzy i umiejętności od otoczenia, od bliskich osób".

Edukacja stanowi ważny element życia badanych kobiet. Istotnym jest, iż respondentki, pomimo iż w większości przypadków wskazują na UTW jako miejsce realizacji aktywności edukacyjnej, potrafią wskazać na głębsze rozumienie edukacji, z uwzględnieniem fazy życiowej, w której się znajdują.

Respondentki przypisują edukacji pozytywne cechy, dostrzegają jej wartościową rolę we własnym życiu. W aktywności edukacyjnej badane kobiety upatrują impuls do dalszej nauki związanej z mądrością życiową i wzbogacaniem własnej osoby poprzez otwarcie się na drugiego człowieka, co jest tożsame z założeniami edukacji permanentnej. „Człowiek, który czerpie wiedzę zarówno z podręczników, jak i otaczającej go rzeczywistości, kształtuje swoją przestrzeń życiową, potrafi uczyć się przez 
doświadczenie, jest otwarty, chętnie angażuje się w różne formy aktywności” (Pikuła, Białożyt 2017: 194).

Jak zostało wskazane powyżej, w rozważaniach teoretycznych edukacja całożyciowa we współczesności jest potrzebą poprzez zaspokojenie której człowiek - jak twierdzi Zygmunt Wiatrowski (2012: 40-42) - może aktywnie uczestniczyć w życiu społecznym. W wypowiedziach respondentek widoczne jest przekonanie, iz w czasach obecnych człowiek starszy musi być aktywny na różnych płaszczyznach, szczególnie na płaszczyźnie edukacyjnej, jeśli chce w pełni nadążać za zmieniającą się rzeczywistością: „Tylko poprzez zajęcia na Uniwersytecie Trzeciego Wieku dobrze funkcjonuję, zdobywam nową wiedzę, staram się zrozumieć pewne zmiany, które zachodzą w mojej rodzinie, choć nie zawsze je w pełni akceptuję” (Irena). „Dzięki temu, że uczęszczam na Uniwersytet Trzeciego Wieku mam o czym porozmawiać z wnukami. Staram się zrozumieć ich zachowania, bo wiem, że żyją w innych czasach niż ja. Teraz człowiek musi ciągle biegać z telefonem, komputerem, nie ma przywiązania do tradycji tak, jak za moich czasów" (Julia). „Póki człowiek chce być aktywnym, kształcić się, to trzeba mu to umożliwić. Ja dzięki edukacji potrafię samodzielnie korzystać z tableta, wszystko, co trzeba, sobie załatwię przez Internet. Gdybym nie poszła na Uniwersytet Trzeciego Wieku, nie potrafiłabym tego i byłabym zależna od dzieci i wnuków" (Dorota).

Jak wskazują wypowiedzi badanych aktywność edukacyjna pozwala im lepiej funkcjonować, daje szansę bycia samodzielnym i niezależnym, co według Norberta G. Pikuły (2016: 69) jest jednym z ważniejszych celów edukacji osób starszych.

Definiowanie i przypisywanie znaczenia edukacji podejmowanej w okresie starości jest bezpośrednio związane z funkcjami i zadaniami, jakie ten rodzaj aktywności spełnia w życiu badanych kobiet. W tabeli poniżej zostały zaprezentowane te wypowiedzi respondentek, które dotyczą znaczenia aktywności edukacyjnej w ich życiu.

Analizując wypowiedzi respondentek, można wnioskować, iż podejmowana przez nie aktywność edukacyjna warunkuje jakość ich życia oraz pełni wiele funkcji, które są zbieżne z klasyfikacją Dubas (2008). Badane kobiety poprzez zaangażowanie w omawiany rodzaj aktywności mają możliwość spotkania z nowymi ludźmi, wyjścia z domu, potrafią zrozumieć sens starości, są świadome swoich ograniczeń, podejmują próbę zrozumienia świata i zachodzących zmian, w sposób ciekawy i interesujący zagospodarowują 
Tabela 1. Znaczenie aktywności edukacyjnej w życiu respondentek

\begin{tabular}{|c|c|}
\hline $\begin{array}{l}\text { Osoba } \\
\text { badana }\end{array}$ & Aktywność edukacyjna... \\
\hline Janina & $\begin{array}{l}\text { stanowi szansę na poznanie nowych ludzi, motywuje do wyjścia } \\
\text { z domu, pozwala na ciekawe życie, inspiruje do dalszych działań, } \\
\text { daje akceptację swoich ograniczeń }\end{array}$ \\
\hline Daniela & $\begin{array}{l}\text { jest odskocznią od problemów i smutków, pozwala lepiej } \\
\text { funkcjonować po śmierci męża, daje radość, uwalnia człowieka } \\
\text { od złego nastawienia }\end{array}$ \\
\hline Zofia & $\begin{array}{l}\text { zaspakaja ciekawość świata, pozwala na poznanie nowych } \\
\text { ludzi, zachęca do otwartości, daje człowiekowi samodzielność, } \\
\text { zapełnia pustkę po stracie }\end{array}$ \\
\hline Magdalena & $\begin{array}{l}\text { zachęca do poznania tego, co nowe, pozwala na rozwój, daje } \\
\text { satysfakcję, umożliwia spotkania z nowymi ludźmi, pozwala } \\
\text { zaakceptować siebie }\end{array}$ \\
\hline Irena & $\begin{array}{l}\text { daje samodzielność i tolerancję wobec świata, umożliwia lepsze } \\
\text { życie, daje zadowolenie i satysfakcję, pozwala człowiekowi na } \\
\text { bycie wśród rówieśników, niweluje samotność }\end{array}$ \\
\hline Barbara & $\begin{array}{l}\text { daje nadzieję, że człowiek może poradzić sobie z problemami, } \\
\text { pozwala na bycie radosnym wśród rówieśników, daje szansę } \\
\text { na wyjście z domu }\end{array}$ \\
\hline Julia & $\begin{array}{l}\text { jest potrzebna, ponieważ pozwala na zrozumienie straty bliskich, } \\
\text { pozwala na bycie wśród ludzi, daje zadowolenie i uśmiech } \\
\text { w codzienności }\end{array}$ \\
\hline Krystyna & $\begin{array}{l}\text { daje samodzielność, akceptację siebie i swoich chorób, pozwala } \\
\text { na bycie wśród ludzi, pozwala ciekawie spędzić czas }\end{array}$ \\
\hline Halina & $\begin{array}{l}\text { pozwala cieszyć się każdym dniem, jest dobrowolna, daje } \\
\text { samodzielność i radośc, poszerza horyzonty, zapełnia czas, } \\
\text { pozwala na poznanie nowych ludzi }\end{array}$ \\
\hline Wiesława & $\begin{array}{l}\text { daje człowiekowi radość i zadowolenie, że na starość można } \\
\text { jeszcze zrobić coś ciekawego, pozwala zaspokoić potrzebę } \\
\text { kontaktu z rówieśnikami, pomaga człowiekowi starszemu na } \\
\text { zrozumienie i nauczenie się niektórych rzeczy, pobudza do } \\
\text { ciekawości i otwartości }\end{array}$ \\
\hline Franciszka & $\begin{array}{l}\text { pozwala na odczuwanie wewnętrznego spokoju, staje się szansą na } \\
\text { poznanie nowych ludzi i zyskanie przyjaciół w starości, pozwala } \\
\text { na samodzielne życie w zgodzie z własnymi przekonaniami }\end{array}$ \\
\hline Dorota & $\begin{array}{l}\text { pozwala na wyjście z domu, bycie wśród ludzi, stanowi oderwanie } \\
\text { od rzeczywistości, w sposób ciekawy zagospodarowuje wolny } \\
\text { czas, człowiek czuje się potrzebny }\end{array}$ \\
\hline
\end{tabular}

Źródło: Opracowanie własne. 
swój wolny czas, odczuwają poczucie przynależności do grupy rówieśniczej. Działania te mają odzwierciedlenie w celach i funkcjach edukacji osób starszych. Są one bezpośrednio związane z utrzymaniem samodzielności życiowej. W wypowiedziach kilku respondentek, które są wdowami (Daniela, Zofia, Barbara, Julia, Irena), mocno uwidacznia się funkcja instrumentalna, która w kontekście edukacji osób starszych pozwala na zrozumienie sytuacji kryzysowych, utraty bliskich oraz zrozumienia cierpienia. Wśród wszystkich badanych kobiet edukacja związana jest z odczuwaniem zadowolenia, radości, satysfakcji, co silnie odzwierciedla funkcję felictylogiczną omawianej aktywności. W badanej grupie widoczna jest także realizacja funkcji: społecznej, kulturowo-cywilizacyjnej, auksologicznej, emancypacyjnej i egzystencjalnej. W mniejszym stopniu uwidacznia się funkcja biograficzna.

Odwołując się do klasyfikacji funkcji edukacji osób starszych autorstwa Fabisia (2015: 180-184), można wnioskować, iż wśród badanych kobiet w okresie późnej starości dominuje funkcja emancypacyjna oraz egotyczna. Odczuwanie zadowolenia, satysfakcji i samodzielności życiowej są dla respondentek ważnymi elementami ich życia. W badanej grupie w mniejszym stopniu widoczna jest realizacja funkcji altruistycznej.

Analizując charakterystykę badanej grupy, zauważa się, iż większość badanych ocenia swój stan zdrowia jako dobry lub bardzo dobry. Taki stan może być spowodowany podejmowaniem aktywności edukacyjnej, która pozwala na kreowanie pozytywnego wizerunku własnej osoby. Jak wynika z przeprowadzonych badań, respondentki zaakceptowały swoje schorzenia zdrowotne i starają się z nimi samodzielnie funkcjonować: „Na starość człowieka wszystko boli, ale nie należy się tym martwić, bo najważniejsza jest rodzina i uśmiech na twarzy” (Halina), „Zdrowie raz jest, a raz go nie ma, ale trzeba się cieszyć z każdego dnia i nie wolno się zamartwiać, ani smucić” (Irena), „Gdyby człowiek na starość przejmował się wszystkimi chorobami, to by z domu nie wychodził, a przecież wśród ludzi jest najlepiej. Człowiek wtedy się pośmieje, porozmawia, kawę wypije w dobrym towarzystwie" (Halina).

Analizując otrzymane wyniki badań, można wnioskować, iż aktywność edukacyjna, badanych kobiet stanowi istotny element warunkujący jakość życia respondentek. Należy podkreślić, iż w wypowiedziach badanych pojawiają się wskazania świadczące o realizacji celów edukacji osób starszych wyszczególnionych przez Skibińską (2008), Jerzego Halickiego (2000), Barbarę 
Szatur-Jaworską, Piotra Błędowskiego i Małgorzatę Dzięgielewską (2006). Cele te, ukierunkowane na rozwój, utrzymanie samodzielności, zrozumienie świata, akceptację starości i starzenia się, podejmowanie różnych form aktywności, niwelowanie negatywnego obrazu finalnej fazy życia, zdobywanie umiejętności radzenia sobie w kryzysowych sytuacjach, bezpośrednio warunkują jakość życia kobiet w okresie późnej starości.

Działania podejmowane przez respondentki pozwalają im na realizację idei edukacji całożyciowej, co pomaga w wykonywaniu zadań przypisanych starości. Magdalena Pakuła, podejmując problematykę postaw osób starszych wobec edukacji, zauważa, iż „najogólniej ujęta wiedza - rezultat edukacji - sprawia, że ludzie sprawniej funkcjonują w codziennym życiu, efektywniej działają i zaspokajają potrzeby, radzą sobie z trudnościami” (Pakuła 2010: 62).

W grupie badanych kobiet nie ma zasadniczych różnic pomiędzy wskazaniami dotyczącymi znaczenia aktywności edukacyjnej w życiu respondentek. Definiowanie edukacji posiada natomiast wymiar indywidualny. Jest on zależny od przeżyć i doświadczeń danych osób. Pomimo, iż większość badanych utożsamia aktywność edukacyjną w okresie starości z Uniwersytetem Trzeciego Wieku, pojawiają się wypowiedzi świadczące o indywidualnym, subiektywnym pojmowaniu edukacji. Wśród badanych aktywność edukacyjna definiowana jest jako coś pozytywnego, pozwalającego na odczuwanie dobrostanu oraz podnoszenie jakości życia. Wskazania na znaczenie edukacji w życiu respondentek o charakterze pozytywnym pozwalają wnioskować, iż badane przypisują aktywności edukacyjnej nowe umiejętności, jak choćby radzenie sobie z sytuacjami trudnymi, adaptacja do zachodzących zmian zarówno na płaszczyźnie indywidualnej, jak i społecznej oraz ograniczanie wpływu fizycznych niedostatków na codzienne funkcjonowanie.

\section{Podsumowanie}

Edukacja w czasach szybkich zmian społecznych stanowi istotny element rozwoju zarówno młodych, jak i starszych pokoleń. Populacja osób po 75 roku życia, jak zaznacza Piotr Szukalski (2013: 18), często umyka zainteresowaniom badaczy, pomimo iż grupa ta sukcesywnie się powiększa, a co z tym związane wzrasta liczba osób w wieku późnej starości ukierunkowanych na aktywne życie w społeczności. 
Okres po 75 roku życia nie jest czasem bezpośrednio związanym z przejściem na emeryturę. Człowiek wchodzący w późną starość posiada już doświadczenia i przeżycia związane z funkcjonowaniem w społeczeństwie jako senior. Wzrastająca długość życia czy chęć odczuwania dobrostanu i satysfakcji motywują do zaangażowania w różne formy aktywności, szczególnie aktywności edukacyjnej. Edukacja w okresie późnej starości niejako stanowi wyzwanie dla jednostki, ale także pozwala na pogłębienie refleksji o starości i starzeniu się. Edukacja jest podstawą wszechstronnego rozwoju, który może dokonywać się na różnych płaszczyznach oraz $\mathrm{w}$ różnych wymiarach, $\mathrm{i}$ nie powinna być ograniczana przez wiek czy choroby.

W przeprowadzonych badaniach wszystkie respondentki rozpoczęły aktywność edukacyjną w okresie późnej starości, zatem można przypuszczać, iż wiek ten pozwala na podejmowanie działań aktywizujących, które pobudzają do samodzielności i samorealizacji.

Analiza wyników badań własnych wskazuje, iż edukacja kobiet w okresie późnej starości pozwala na podnoszenie jakości życia, co - jak zaznaczono powyżej - nabiera szczególnego znaczenia współcześnie, kiedy wydłużenie ludzkiego życia stało się faktem i rozpoczęła się „walka” o jak najlepszą jego jakość. Aktywność edukacyjna badanych kobiet stanowi szansę na ich pełną partycypację w życiu społecznym, adaptację do zmian kulturowych oraz poszukiwanie sensu życia i śmierci. Spełnia ona także szereg funkcji, które koncentrują się na odczuwaniu dobrostanu i satysfakcji życiowej kobiet w okresie późnej starości.

\section{Bibliografia}

Białożyt K. (2020), Aktywność edukacyjna kobiet w okresie późnej starości, Wydawnictwo Uniwersytetu Pedagogicznego im. Komisji Edukacji Narodowej, Kraków.

Dubas E. (2008), Edukacyjny paradygmat badawczy w geragogice, [w:] M. Kuchcińska (red.), Edukacja do i w starości, Wydawnictwo Kujawsko-Pomorskiej Szkoły Wyższej, Bydgoszcz.

Fabiś A., Wawrzyniak J.K., Chabior A. (2015), Ludzka starość. Wybrane zagadnienia gerontologii społecznej, Oficyna Wydawnicza Impuls, Kraków.

Gromkowska-Melosik A. (2014), Edukacja i nierówności spoleczne. Uwagi teoretyczne w kontekście problemu klasy spolecznej i ptci, [w:] A. Gromkowska-Melosik, M.J. Szymański, Edukacja i nierówności. Trajektoria sukcesu i marginalizacji, Wydawnictwo Naukowe UAM, Poznań. 
Halicki J. (2000), Edukacja seniorów w aspekcie teorii kompetencyjnej. Studium historycznoporównawcze, Trans Humana, Białystok.

Kuchcińska M. (2009), Edukacja przeciw marginalizacji seniorów, „Chowanna” 2(33), s. $173-186$.

Kwiatkowska H. (1997), Edukacja nauczycieli. Konteksty-kategorie-praktyki, Instytut Badań Edukacyjnych, Warszawa.

Kwiatkowski S.M. (2018), Kompetencje przyszłości, [w:] S.M. Kwiatkowski (red.), Kompetencje przyszłości, Wydawnictwo FRSE, Warszawa.

Madalińska-Michalak J. (2017), Pedagogika i życie wartościowe. Etos prawdy i odpowiedzialności, [w:] M. Czerepaniak-Walczak, J. Madalińska-Michalak, B. Śliwerski (red.), Ku życiu wartościowemu. Idee-Koncepcje-Praktyki, t. I: Idee-Koncepcje, Oficyna Wydawnicza Impuls, Kraków.

Pakuła M. (2010), Postawy osób starszych wobec edukacji. Studium teoretyczno-diagnostyczne, Wydawnictwo Uniwersytetu Marii Curie-Skłodowskiej, Lublin.

Pikuła N.G., Białożyt K. (2017), Edukacja całożyciowa - z perspektywy emerytowanych nauczycieli, [w:] J. Madalińska-Michalak, N.G. Pikuła, K. Białożyt (red.), Edukacja i praca nauczyciela: ciaglość - zmiana - konteksty, Scriptum, Kraków.

Pikuła N.G. (2016), Poczucie sensu życia osób starszych. Inspiracje do edukacji w starości, Oficyna Wydawnicza Impuls, Kraków.

Półturzycki J. (2008), Edukacja ustawiczna w ujęciu Roberta Kidda, Jacques'a Delorsa i Polskiej Strategii z 2003 roku, [w:] S.M. Kwiatkowski (red.), Edukacja ustawiczna. Wymiar teoretyczny i praktyczny, Wydawnictwo Instytutu Technologii Eksploatacji - PIB, Warszawa-Radom.

Skibińska E. (2008), Proces ksztatcenia seniorów, [w:] A. Fabiś (red.), Aktywność spoleczna, kulturalna i oświatowa seniorów, Wyższa Szkoła Administracji, Bielsko-Biała.

Szarota Z. (2009), Seniorzy w przestrzeni kulturalno-edukacyjnej spoleczeństwa wiedzy, „Chowanna”, t. 2 (33): Edukacja wobec starości. Tradycja i wspótczesność, nr 52(65), s. 77-96.

Szatur-Jaworska B., Błędowski P., Dzięgielewska M. (2006), Podstawy gerontologii spolecznej, Aspra, Warszawa.

Szukalski P. (2013), Ludzie wieku 75+ - nowa kategoria demograficzno-spoteczna?, [w:] K. Wieczorkowska-Tobis, D. Talarska (red.), Kwestionariusz Camberwell Assessment of Need for the Elderly (CANE) jako narzedzie do oceny zapotrzebowania na opieke przez osoby w wieku podesztym, Akademia Medyczna, Warszawa.

Szymański M.J. (2014), Nierówności edukacyjne w zmieniającym się spoleczeństwie, [w:] A. Gromkowska-Melosik, M.J. Szymański (red.), Edukacja i nierówności. Trajektoria sukcesu i marginalizacji, Wydawnictwo Naukowe UAM, Poznań.

Wiatrowski Z. (2012), Edukacja ustawiczna - nadal nieokreślona, „Edukacja ustawiczna dorosłych”, nr 1 (76), s. 47-52.

Zych A.A. (2009), Przekraczajac „smuge cienia”. Szkice z gerontologii i tanatologii, Wydawnictwo Śląsk, Katowice. 

CZĘŚĆ TRZECIA

\section{REFLEKSJE METODOLOGICZNE}





\title{
Trajektorie legitymizacji naukowej innowacyjnych metod pedagogicznych badań jakościowych: badanie w działaniu, badanie przez sztukę, autoetnografia
}

\author{
Abstract \\ Trajectories of scientific legitimization \\ of innovative methods of educational qualitative research: \\ Action research, arts-based research, autoethnography
}

The main goal of the paper is the explanation and empowerment of understanding methodology as an emergent, dynamic field of scientific knowledge about current research methods applied, constructed and re-constructed, following global socio-cultural changes. The author emphasises dialectic relations between normativity and descriptivity in methodological research, using the figure of scientific legitimization and proposing its three types: "finish", "ascend" and "departure". Various arguments are presented on the basis of nature, history and current practice of three research traditions: action research, arts-based research, and autoethnography.

Keywords: methodological emergence, scientific legitimization, action reseach, arts-based research, autoethnography

Słowa kluczowe: emergencja metodologiczna, naukowa legitymizacja, badania w działaniu, autoetnografia, badania artystyczne

\section{Cel opracowania}

Głównym celem niniejszego opracowania jest wzmocnienie przekonania, że humanistyczno-społeczne nauki stosowane, w tym pedagogika, aby ocalić i rozwinąć swoje cywilizacyjne znaczenie $\mathrm{w}$ adekwatnym poznawaniu, rozumieniu i interpretowaniu nowych procesów i zjawisk społecznych, muszą na bieżąco 
i intensywnie dostosowywać metody swoich badań do aktualnej sytuacji kulturowej oraz gwałtownej dynamiki jej przemian, rozpoznając i rozwiązując szczegółowe problemy badawcze, a przez to przyczyniając się do kreowania lepszego świata. Zwrócenie uwagi na nurt historyczno-porównawczy w badaniach metodologicznych przyczynia się bowiem do pogłębienia świadomości badaczy humanistycznych, społecznych, pedagogicznych etc. w zakresie możliwości i potrzeby wspierania tendencji do życiodajnej kreatywności i innowacyjności metodologicznej na miejsce reprodukowania nieaktualnych i przez to nieadekwatnych metod poznania naukowego.

Tekst zasadniczo skoncentrowany jest na wskazaniu empirycznych argumentów na rzecz zasadności i potrzeby pojmowania i traktowania metodologii badań pedagogicznych jako dynamicznej aktywności poznawczej, w rezultacie której konstruowana jest stale aktualizowana wiedza o stosowanych metodykach praktyk badawczych. Chodzi także o wykazanie konieczności (re)konstruowania norm poprawnościowych w nawiązaniu do tradycji, ale ze szczególnym nastawieniem na adekwatne ich korygowanie i emergentne dopasowywanie w trosce o jakość krytyki metodologicznej. Szczegółowo posłużyć ma temu zastosowana w niniejszym opracowaniu figura trajektorii jako uniwersalnego modelu reprezentacji dynamicznej zmienności, w tym wypadku trajektorii legitymizacji naukowej wraz z jej trzema rodzajami i egzemplifikującymi je trzema innowacyjnymi metodami jakościowych badań pedagogicznych.

\section{Spór o istotę metodologii i jej proponowana wykładnia}

Najogólniej rzecz ujmując, metodologia to nauka/wiedza o metodach. Słowo „metoda” pochodzi z języka greckiego, w którym termin „méthodos” oznacza sposób badania, poznawania. Dosłownie chodzi tu o sposób badania, poznawania, uwzględniający określoną drogę postępowania. Przenośnie odnosi się zaś do podążania właściwą drogą w celu adekwatnego poznania (Stownik grecko-polski 2001, t. 2: 36).

Pojęcia metoda używa się w kilku różnych znaczeniach, w tym m.in. jako sposobu postępowania, doboru rodzaju działania świadomie stosowanego z możliwością powtórzenia go we 
wszystkich przypadkach danego typu; doboru i kolejności czynności składowych działania złożonego; zespołu czynności i środków zastosowanych w określony sposób do osiągnięcia założonego celu; sposobu wykonania danego zadania praktycznego lub rozwiązania problemu teoretycznego; czy zespołu założeń ogólnych przyjmowanych jako ramy lub wytyczne badania. Metodologia jest analogicznie nauką/wiedzą o tak rozumianych metodach, z tym że metodologia ogólna zajmuje się badaniem metod wszelkiego celowego ludzkiego działania i ich teorią, a metodologia nauk charakterystyką i krytyką metod ogólnych pracy naukowej oraz metod swoistych różnych dyscyplin naukowych (Nowa encyklopedia powszechna PWN 1997, t. 4: 178).

Metodologia nauk, w tym także nauk humanistyczno-społecznych, uprawiana jest $\mathrm{w}$ dwóch powiązanych ze sobą wymiarach jako metodologia normatywna i opisowa. Metodologia normatywna koncentruje się zasadniczo na konstruowaniu wiedzy o normach poprawnościowych prowadzenia badań naukowych oraz zasadach i szczegółowych kryteriach ewaluacji projektów badawczych i szerzej krytyki metodologicznej w danej dyscyplinie naukowej. Metodologia opisowa zaś zajmuje się analizą i interpretacją historycznych i aktualnych praktyk badawczych, ze szczególnym uwzględnieniem badania relacji między przedmiotem badań a zastosowaną $\mathrm{w}$ danym projekcie badawczym metodyką postępowania poznawczego, a następnie wykorzystaniem metody porównawczej w celu identyfikacji zróżnicowania wykorzystywanych w danej dyscyplinie metod badawczych na tle transdyscyplinarnym (Nowak 2012: 23-24).

Za nieadekwatną i niekorzystną dla rozwoju nauki uważam tendencyjną separację metodologii normatywnej i opisowej, kiedy to metodologia normatywna przeradza się w zbiór ponadczasowych, niezmiennych, pozakontekstualnych, uniwersalnych, bezwzględnie obowiązujących, przeważnie abstrakcyjnych i przez to niemożliwych do spełnienia w praktyce badawczej norm i kryteriów, ogłaszanych co jakiś czas we wznawianych bądź nowych podręcznikach i innych publikacjach metodologicznych z odwołaniem do scjentystycznej wykładni naukowości. Metodologia opisowa w takiej sytuacji staje się studiowaniem raportów z przeprowadzonych badań pod kątem poszukiwania zgodności bądź odstępstw od metodologii normatywnej. Moim zdaniem nie ma to nic wspólnego z nauką jako adekwatnym poszukiwaniem prawdy i konstruowaniem aktualnej wiedzy. 
Paul Atkinson jednoznacznie uznał kreatywność za cechę konstytutywną uprawiania badań jakościowych w naukach społecznych, pisząc na początku XX w.: „Nie ma wątpliwości, że przeróżne warianty badań jakościowych rozkwitły na skalę globalną w ciągu ostatnich dwudziestu lat" (Atkinson 2005: 1). W związku z tak dynamicznym rozwojem metodologii badań jakościowych za zupełnie sprzeczne z podstawową funkcją nauki uważam publikowanie podręczników metodologicznych opartych na formule nieaktualizowanego (często autorytarnego) wykładu monolitycznej (często osadzonej w paradygmacie pozytywistycznym) wersji metodologii normatywnej (kilkanaście wydań na przestrzeni kilkudziesięciu lat bez zasadniczej aktualizacji), przeważnie przygotowanych przez pojedynczego autora. Przeciwieństwem takiego podejścia, w pełni uwzględniającym zasadę kreatywności metodologicznej i wymóg uzgadniania ustaleń metodologii normatywnej z wynikami najnowszych badań prowadzonych na gruncie metodologii opisowej, jest publikowanie podręczników metodologicznych opartych na formule stale aktualizowanego, emergentno-dyskursywnego, rewidowanego i doskonalonego wykładu w odmianach paradygmatycznych i wersjach autorskich (kilka wydań na przestrzeni kilkudziesięciu lat z programowym nastawieniem na gruntowną aktualizację), przeważnie w formie monografii zbiorowej. Przykładem takiego emergentnego podręcznika metodologicznego jest The Sage Handbook of Qualitative Research (Denzin, Lincoln [red.] 1994, 2000, 2005, 2011, 2018).

W odniesieniu do pedagogiki jako dyscypliny humanistyczno-społecznych nauk stosowanych zaproponowałem, aby

metodologia badań pedagogicznych pojmowana była i uprawiana jako nauka empiryczno-filozoficzna/filozoficzno-empiryczna nastawiona na emergentne konstruowanie stale aktualizowanej wiedzy o metodach badań pedagogicznych na podstawie rezultatów pedagogicznych badań metodologicznych (badań nad badaniami) w diachronicznych i dialektycznych relacjach między normatywnością a opisowością, co odzwierciedlać ma starania uczonych na rzecz poznawczego nadążania za bieżącymi przemianami społeczno-kulturowymi (Kubinowski 2019: 86).

Metodologia - w prezentowanej tu wykładni - to nauka empiryczna, stale aktualizowana i nastawiona na aktualizację. Takie pojmowanie i uprawianie metodologii odbiega zasadniczo od filozofii statycznej wykładni podręcznikowej o charakterze 
autorytatywnie normatywnym. Metodologia badań pedagogicznych nieustannie zmienia się jako rezultat sprzężenia zwrotnego jej normatywności i opisowości, to znaczy emergentnego rewidowania dotychczasowych ustaleń metodologii normatywnej w wyniku kreatywnego adaptowania wyników metodologii opisowej, czyli rezultatów badań metodologicznych nad praktykami badawczymi.

\section{Trajektorie legitymizacji naukowej wobec dogmatyczności scjentyzmu}

Na problem legitymizacji naukowej innowacyjnych metod badań jakościowych zwrócili w 1991 r. uwagę Brent Atkinson, Anthony Heath i Ronald Chenail, podkreślając potrzebę bieżącego rewidowania założeń paradygmatycznych oraz dystansowania się wobec konwencjonalnych sposobów uprawiania nauki. Ich zdaniem jest to niezbędne w realizacji wyzwania nadążania metodologii nauk za permanentnymi przemianami społecznymi, jednak bezpośrednio wymusza myślenie o adekwatnym rewidowaniu dotychczasowych wykładni naukowości (Atkinson, Heath, Chenail 1991: 175-180).

Problem legitymizacji naukowej innowacyjnych metod badawczych jest istotną barierą w poszukiwaniu i stosowaniu nowych, adekwatnych dróg poznania naukowego szczególnie w środowiskach akademickich funkcjonujących w warunkach konserwatywnej ortodoksji metodologicznej. Profesorowie socjalizowani naukowo w określonym paradygmacie nie akceptują, bądź akceptują niechętnie innowacje metodologiczne, wykraczające poza ramy tego paradygmatu i mogące w przyszłości go zakwestionować. Jednak zgodnie z zasadą paradygmatyczności na tym właśnie polega rozwój nauki i de facto istota badań naukowych, które bez innowacji, otwartości i kreatywności, wynikającej z nieuniknionych przemian badanej rzeczywistości, zaczynają przeradzać się w pozór naukowości. W szczególności ciągle przywoływane dogmaty scjentystycznie zorientowanych nauk społecznych osadzonych w paradygmacie pozytywistycznym stanowią uciążliwe balasty aktualnie realizowanych programów i projektów konstruowania wiedzy o człowieku/ludziach i jego/ich społecznym środowisku oraz kreowania wizji i wdrażania rozwiązań zmierzających do budowania lepszego świata. 
Trajektoria legitymizacji naukowej oznacza w tym kontekście dynamiczną zmienność stopnia uznawalności danej innowacyjnej metody badawczej za naukową. Towarzyszy temu założenie, że wykładnie naukowości obowiązujące albo proponowane w danym miejscu i czasie oscylują między paradygmatem pozytywistycznym z jego nastawieniem scjentystycznym a kolejnymi paradygmatami nauk humanistyczno-społecznych konstruowanymi i ugruntowywanymi w wieku XX i na początku XXI stulecia. Poszczególne - innowacyjne w swoim czasie - metody jakościowych badań pedagogicznych przechodzą w swej dłuższej bądź krótszej historii swoiste trajektorie legitymizacji ich naukowości, które modelowo lokują się na continuum od trajektorii „dokonanej” poprzez aktualnie „wznoszącą” do dopiero „wyjściowej”. Spróbujmy przyjrzeć się bliżej ich specyfice, odwołując się do losów trzech charakterystycznych tradycji badawczych, współokreślających także praktykę uprawiania badań pedagogicznych w naszym kraju, a mianowicie: badania w działaniu, badania przez sztukę i autoetnografii.

\section{Trajektoria „dokonana” - przykład: badanie w działaniu}

Typ trajektorii „dokonanej” oznacza w tym opracowaniu przebieg historii konstruowania, uprawiania, rozwijania danej innowacyjnej metody badawczej, począwszy od początkowej negacji jej naukowości, poprzez stopniowe łagodzenie tego stanowiska i jej kodyfikację metodyczną, aż do przekroczenia barier legitymizacji naukowej w pełnym zakresie.

Badanie w działaniu jako innowacyjną metodę jakościowych badań pedagogicznych można zdefiniować następująco:

Filozofia metody badawczej określanej w Polsce najczęściej mianem badań w działaniu (action research) opiera się zasadniczo na synergii rozumiejącego poznawania i konstruktywnego zmieniania. Jest zatem szczególnym wyrazem epistemologii, metodologii, teleologii i prakseologii - nauki społecznej zorientowanej praktycznie. Impulsem do jej wykorzystania staje się przeważnie zidentyfikowanie sytuacji kryzysowej w konkretnym organizmie społecznym (instytucji, środowisku, grupie etc.) oraz krytyczno-pedagogiczna intencja wsparcia jego pożądanej transformacji prohumanistycznej w wymiarze proosobowym, emancypacyjnym, modernizacyjnym, prodemokratycznym etc. Efektywność tak pomyślanych badań ocenia się przede wszystkim poprzez 
ewaluację praktycznej skuteczności zaprojektowanych i wdrażanych zmian, a korzyści poznawcze - istotne i niemożliwe do osiągnięcia za pomocą innych, konwencjonalnych metod - są tu wtórnym, ale przeważnie znaczącym dokonaniem naukowym (Kubinowski 2013: 171).

Powszechnie uważa się, że jako pierwszy terminu action research użył - w 1946 r. - psycholog Kurt Lewin. Stworzył on koncepcję badań nastawionych na rozwiązywanie konkretnych problemów społecznych $\mathrm{w}$ połączeniu z pracą socjalną (Lewin 1946). Okazuje się jednak, że już w latach 30. XX w. koncepcję połączenia badania i działania na gruncie pedagogiki społecznej wypracowała i zastosowała w Polsce Helena Radlińska - choć nie była ona traktowana równorzędnie $\mathrm{z}$ metodami naukowymi (zob. Smolińska-Theiss, Theiss 2013). W latach 70. XX w. z kolei we Francji Alain Touraine zaproponował analogiczną koncepcję badawczo-działaniową, którą nazwał „socjologiczną interwencją” (zob. Touraine 2010). Stopniowo idea action research zyskiwała zainteresowanie i coraz większe znaczenie na gruncie socjologii, antropologii, nauk o zarządzaniu, pedeutologii i pedagogiki w ogólności jako rodzaj badania zaangażowanego, łączonego synergicznie z filozofią teorii/pedagogii krytycznej i paradygmatu partycypacyjnego oraz wyraźnym nastawieniem emancypacyjnym (zob. Carr, Kemmis 1986; Červinkova, Gołębniak [red.] 2010, Červinkova, Gołębniak [red.] 2013). W Polsce momentem przełomowym uzyskania pełnej legitymizacji naukowej przez metodę badań w działaniu na gruncie pedagogiki były zakończone powodzeniem postępowania habilitacyjne, w których autorki posłużyły się nią w projektach badań naukowych (Červinkova [red.] 2008; Telka 2009). Tym samym badania w działaniu stały się w pierwszej dekadzie XXI w. ugruntowaną i pełnoprawną metodą poznania naukowego na gruncie polskiej pedagogiki.

Zestawienie nr 1 przedstawia wkład innowacyjności badań w działaniu w przełamywanie dogmatów scjentystycznie zorientowanych nauk społecznych i w konsekwencji wymuszenie głębokich przemian w obowiązującej od czasów pozytywizmu wykładni naukowości badań społecznych.

Stanisław Palka - znany metodolog pedagogiki i badań pedagogicznych - w 1990 r. nie uznawał naukowości metody badań w działaniu, pisząc: „Badania takie nie są metodą zdobywania wiedzy naukowej, nie dostarczają danych do tworzenia konstruktów teoretycznych, lecz dają podstawę do wprowadzenia zmian 
Tabela 1. Innowacyjność badań w działaniu wobec dogmatów scjentyzmu

\begin{tabular}{l|l}
\hline \multicolumn{1}{c|}{ Dogmat } & \multicolumn{1}{c}{ Innowacja } \\
\hline $\begin{array}{l}\text { Nauka i działalność praktyczna to } \\
\text { dwie różne sfery rzeczywistości }\end{array}$ & $\begin{array}{l}\text { Badanie i działanie mogą być efektyw- } \\
\text { nie łączone w naukach społecznych }\end{array}$ \\
\hline $\begin{array}{l}\text { Celem nauki nie jest zmienianie } \\
\text { rzeczywistości, a tylko jej neu- } \\
\text { tralne poznawanie }\end{array}$ & $\begin{array}{l}\text { Celem nauki jest wspieranie kreowa- } \\
\text { nia lepszego świata, zatem pozna- } \\
\text { wanie ma prowadzić do zmieniania }\end{array}$ \\
\hline - Nauka musi być wolna od war- \\
$\begin{array}{l}\text { tościowania } \\
\text { - Badacz nie może być jednocześnie } \\
\text { działaczem społecznym }\end{array}$ & $\begin{array}{l}\text { Wą w wartościowananie nauki uwikłane } \\
\text { sadacz zaangażowany społecznie jako } \\
\text { ideał nowoczesnego naukowca }\end{array}$ \\
\hline
\end{tabular}

Źródło: Opracowanie własne.

w określonym miejscu i czasie" (Palka 1990: 8). Szesnaście lat później jednak zmienił zdanie i stwierdził: „można uznać te badania za szczególnego rodzaju innowację pedagogiczną, poddaną rygorowi metody naukowej [...]. Uznanie badania w działaniu nie tylko za specyficzną metodę, lecz określoną strategię postępowania badawczego [...] pozwala analizować je przez pryzmat stosowania szczegółowych metod jakościowych" (Palka 2006: 57).

\section{Trajektoria „wznosząca” - przykład: badanie przez sztukę}

Typ trajektorii „wznoszącej” - na zasadzie analogii do trajektorii „dokonanej” - oznacza moment zainicjowania i dalej konstruowania metody w atmosferze odmowy legitymizacji naukowej, a następnie rozwijanie i kodyfikowanie jej metodyki w połączeniu z rosnaccym zainteresowaniem jej uprawnianiem $\mathrm{w}$ praktyce badawczej, jednak bez osiągnięcia - w danym momencie historycznym - statusu pełnej legitymizacji naukowej.

Badania przez sztukę (arts based research) jako innowacyjną metodę jakościowych badań pedagogicznych można zdefiniować następująco:

Idea badań przez sztukę opiera się na synergii poznania naukowego i artystycznego w ramach wszystkich etapów postępowania badawczego nastawionego na pogłębione rozumienie idiomatycznych zjawisk humanistycznych i społecznych. Jako metoda ,nowych' badań jakościowych w naukach społecznych zorientowanych humanistycznie polega na wykorzystaniu poznawczego potencjału różnych dziedzin sztuki 
i przejawów aktywności artystycznej w diagnozowaniu, rozumieniu $\mathrm{i}$ interpretowaniu aktualnych, istotnych problemów społecznych. Nie jest to jednak badanie sztuki i aktywności artystycznej jako takiej, ale posłużenie się nią jako medium poznania naukowego lub społecznego badania i działania (Kubinowski 2013: 207).

Już w starożytności doceniano synergię filozofii i sztuki jako istotne źródło wiedzy o człowieku. Analogiczne myślenie pojawiło się na gruncie pedagogicznym w koncepcjach edukacyjnych i badawczych Pestalozziego, Montessori i Deweya. Sztukę wykorzystywano już w XIX w. w terapii zaburzeń psychicznych, także w celach diagnostycznych. Mniej więcej w tym samym czasie zaczęto wykorzystywać diagnostycznie wykres w badaniach psychologiczno-pedagogicznych. Zalążki myślenia o koncepcji pedagogicznych badań przez sztukę pojawiły się w Polsce w latach 70 . $\mathrm{XX}$ w., a jako dobrze rozpoznawalny i innowacyjny - choć nie do końca akceptowany - kierunek badawczy w naukach społecznych, w tym edukacyjnych, rozwinęły się one w latach 80 . i szczególnie 90. XX w. (zob. Knowles, Cole [red.] 2008, Krasoń, Konieczna-Nowak 2016: 17-59). Za prekursora i czołowego reprezentanta zaawansowanych edukacyjnych badań przez sztukę uważa się Elliota W. Eisnera (1976, 1991). Początek XX w. to intensywny rozwój metod szczegółowych, łączących różne dziedziny sztuki $\mathrm{z}$ badaniem naukowym $\mathrm{w}$ różnych aspektach społecznych, oraz wykorzystanie filozofii sztuki w metodyce realizacji projektów badawczych na różnych ich etapach (Leavy 2018).

Zestawienie nr 2. ilustruje wybrane pola oddziaływania innowacji metodologicznych wprowadzanych do nauk społecznych za pośrednictwem badań przez sztukę oraz akcentuje kolejne aspekty krytyki i niwelowania dogmatów scjentystycznych.

Elliot W. Eisner i jego uczeń Tom Barone wskazali i uzasadnili szereg aksjomatów wykorzystywanych jako założenia epistemologiczne i metodologiczne w edukacyjnych badaniach przez sztukę. I tak, według nich, ludzie kreują różnorodne formy reprezentacji, aby opisać i rozumieć świat na możliwie wiele sposobów. Badania przez sztukę są w stanie uchwycić znaczenia w przeciwieństwie do pomiaru. Jako metodologia służąca prowadzeniu badań w naukach społecznych rozwijają one szeroki wachlarz możliwości odnalezienia form szczególnie dla nich predestynowanych. Aby wzmocnić badania przez sztukę, niezbędne jest różnicowanie rozwijania zdolności przyszłych badaczy w toku ich kształcenia. Celem badania przez sztukę nie jest zastępowanie tradycyjnych 
Tabela 2. Innowacyjność badań przez sztukę wobec dogmatów scjentyzmu

\begin{tabular}{|c|c|}
\hline Dogmat & Innowacja \\
\hline $\begin{array}{l}\text { - Nauka i sztuka to odrębne obszary } \\
\text { rzeczywistości }\end{array}$ & $\begin{array}{l}\text { - Nauka i sztuka stanowią pokrewne } \\
\text { przejawy ludzkiej kreatywności }\end{array}$ \\
\hline $\begin{array}{l}\text { - Nauka dostarcza wiedzy, sztuka - } \\
\text { przeżyć estetycznych }\end{array}$ & $\begin{array}{l}\text { - Sztuka tak samo jak nauka stanowi } \\
\text { istotne źródło wiedzy o człowieku }\end{array}$ \\
\hline $\begin{array}{l}\text { - Nauka i sztuka opierają się na innych } \\
\text { zasadach i ich cele są odmienne }\end{array}$ & $\begin{array}{l}\text { - Synergia nauki i sztuki wzmacnia } \\
\text { wydatnie poznanie humanistyczno- } \\
\text {-społeczne }\end{array}$ \\
\hline - Badacz społeczny to & - Badanie społeczne jako sztuka \\
\hline
\end{tabular}

Źródło: Opracowanie własne.

metod badawczych, jest nim wzbogacanie różnorodności potencjału metodyki badań humanistyczno-społecznych. Wykorzystywanie ekspresyjnych właściwości medium jest jednym z prymarnych sposobów, w jakich badania przez sztukę uczestniczą w rozumieniu człowieka (zob. szerzej Barone, Eisner 2012).

\section{Trajektoria „wyjściowa” - przykład: autoetnografia}

Typ trajektorii „wyjściowej” oznacza na zasadzie analogii do trajektorii „dokonanej” i „wznoszącej” wkroczenie na drogę inicjowania i konstruowania innowacyjnej metody badawczej z próbami jej rozwijania i kodyfikowania w atmosferze odmawiania statusu legitymizacji naukowej w danym miejscu i czasie, a mimo to podejmowania kolejnych prób jej stosowania w praktyce badawczej i poszerzania wachlarza metodycznego.

Autoetnografię jako innowacyjną metodę jakościowych badań pedagogicznych można zdefiniować następująco:

Autoetnografia jako metoda ,nowych' badań jakościowych w naukach społecznych zorientowanych humanistycznie polega - jak każda etnografia - na opisie określonej kultury poprzez bezpośrednie wykorzystanie w jej poznawaniu i pogłębionym rozumieniu przez badacza własnego doświadczenia źródłowego, które odnosi się do jego uczestnictwa w tejże kulturze - dawniej lub obecnie. Chcąc opisać dany świat społeczny z zastosowaniem tej metody, trzeba być jego współuczestnikiem. Idiomatyczne doświadczenie kulturowe badacza jest synergicznie łączone $\mathrm{z}$ analogicznym doświadczeniem innych 
osób, które badacz poddaje również badaniu. Tworzy integralną przestrzeń poznawczą i przyczynia się do wzmocnienia możliwości rozumienia zjawisk i procesów ukształtowanych w obrębie tej samej, badanej kultury (Kubinowski 2013: 209).

Pierwsze użycie pojęcia „autoetnografia” w kontekście prowadzenia badań naukowych miało miejsce w latach 70. XX w., jednak do przełomu XX i XXI w. pojmowano ją nie jako sposób badania, ale raczej jako ciekawostkę o znamionach nowatorstwa, bez większej wartości naukowej. Mimo że autoetnografia została na początku XXI w. z czasem uznana za innowacyjną i istotną poznawczo metodę badawczą w naukach społecznych w perspektywie międzynarodowej, w Polsce nadal czeka na legitymizację naukową - chociaż posiada istotny potencjał $\mathrm{w}$ badaniach nad wychowaniem/edukacją. Do grona jej prekursorów na świecie należą: Carolyn Ellis, Arthur P. Bochner, Norman K. Denzin. Pierwsza dekada XXI w. to okres zapoczątkowania kodyfikacji tej metody i intensyfikacji jej wykorzystania w praktyce badawczej w dwóch zasadniczych odmianach: autoetnografii analitycznej i ewokatywnej. Natomiast druga dekada XXI w. to czas rozwoju metody i wydatne poszerzenie kręgu jej zastosowań, a także pojawienie się nowej praktyki badawczej w postaci autoetnografii kolektywnej (Kacperczyk [red.] 2014, Ciechowska 2017). Pierwsze zaawansowane próby posłużenia się różnymi odmianami autoetnografii w badaniach pedagogicznych pojawiają się także ostatnio w Polsce (zob. Szwabowski 2019).

Zestawienie nr 3. porównuje wybrane dogmaty scjentystyczne nauk społecznych osadzonych w paradygmacie pozytywistycznym z odpowiadającymi im innowacjami metodologicznymi autoetnografii.

Anna Kacperczyk - metodolożka jakościowa rodzimych nauk społecznych, rozwijająca i wydatnie promująca autoetnografię jako innowacyjną metodę poznania naukowego czy wręcz nowy paradygmat badawczy - potwierdza jednoznacznie, że badania autoetnograficzne, mimo intensywnego rozwoju na świecie, czy nawet naturalnego wyczerpywania się znamion ich nowatorstwa wobec coraz szerszego zastosowania w badaniach społecznych, w Polsce nadal czekają na transdyscyplinarne odkrycie i szersze uznanie ich istotnych walorów poznawczych. Jak zaznacza Kacperczyk:

Pomimo bardzo bogatej literatury zagranicznej odwołującej się do tematyki autoetnografii, wciąż odczuwamy niedosyt wiedzy na temat 
Tabela 3. Innowacyjność autoetnografii wobec dogmatów scjentyzmu

\begin{tabular}{|c|c|}
\hline Dogmat & Innowacja \\
\hline $\begin{array}{l}\text { - Uprawianie nauki opiera się na za- } \\
\text { sadzie bezwzględnego obiektywi- } \\
\text { zmu }\end{array}$ & $\begin{array}{l}\text { - Nie jest możliwe spełnienie warunku } \\
\text { bezwzględnego obiektywizmu w po- } \\
\text { znaniu naukowym }\end{array}$ \\
\hline $\begin{array}{l}\text { - Subiektywizm jest zaprzeczeniem } \\
\text { istoty badań naukowych }\end{array}$ & $\begin{array}{l}\text { - Subiektywizm może być źródłem istot- } \\
\text { nych dokonań naukowych }\end{array}$ \\
\hline $\begin{array}{l}\text { - Badacz naukowy musi wyzbyć się } \\
\text { wszelkich uprzedzeń, przedzało- } \\
\text { żeń, osobistych nastawień aby za- } \\
\text { chować neutralność }\end{array}$ & $\begin{array}{l}\text { - Badacz pozostaje człowiekiem i posłu- } \\
\text { guje się uświadomionymi osobistymi } \\
\text { przedzałożeniami }\end{array}$ \\
\hline $\begin{array}{l}\text { - Emocjonalność musi być wyklu- } \\
\text { czona z uprawiania nauki }\end{array}$ & $\begin{array}{l}\text { - Emocjonalność może istotnie wzmac- } \\
\text { niać różne wymiary poznania nauko- } \\
\text { wego }\end{array}$ \\
\hline
\end{tabular}

Źródło: Opracowanie własne.

możliwości aplikacyjnych, zalet i ograniczeń tego podejścia w publikacjach polskojęzycznych. Na gruncie polskim autoetnografia jest dość rzadko stosowana. Wynikać to może z nowatorstwa samej metody, jak również i stąd, że jest to trudny i bardzo angażujący rodzaj metodologii badań jakościowych. Jednocześnie autoetnografia stanowi gatunek badania wciąż rozwijający się i podlegający intensywnym przemianom, co także utrudnia jej aplikację (Kacperczyk 2014: 11).

\section{Apel o „pomoc w tworzeniu” innowacyjnych metod badawczych}

Kazimierz Korniłowicz w latach 30. XX w. zaproponował na gruncie pedagogiki społecznej nowatorską - jak na owe czasy koncepcję pedagogiczną systemowego animowania, intensywnego rozwijania i intencjonalnego wspierania aktywności społeczno-kulturalnej i kreatywności w ogólności jako istotnych z punktu widzenia wzbogacania osobowości człowieka i funkcjonowania ludzkich społeczności (zob. Korniłowicz 1976).

W konkluzji niniejszego opracowania kieruję apel do badaczy i przede wszystkim metodologów o odstąpienie od ortodoksyjnej obrony i powielania scjentystycznej wykładni naukowości - rodem z okresu pozytywizmu, nieprzystającej do wyzwań współczesności. Apeluję o udzielenie wsparcia tym badaczom, którzy poszukują innowacyjnych rozwiązań metodycznych, starając się w ten sposób rozwiązywać nowe problemy badawcze, bowiem ich projekty 
wnoszą istotne korzyści poznawcze. Na trzech przykładach starałem się wykazać, jak kreatywność metodologiczna zmienia w konstruktywnym kierunku nauki humanistyczno-społeczne. Choć nadal nie wszyscy ich przedstawiciele to rozumieją, doceniają i akceptują.

\section{Bibliografia}

Atkinson B., Heath A., Chenail R. (1991), Qualitative Research and the Legitimization of Knowledge, "Journal of Marital and Family Therapy", vol. 17, nr 2, s. 161-166.

Atkinson P. (2005), Qualitative Research - Unity and Diversity, "Forum. Qualitative Social Research/Socialforschung”, vol. 6, nr 3, art. 36, s. 1-15.

Barone T., Eisner E.W. (2012), Arts Based Research, Sage Publications, Los Angeles-London-New Delhi-Singapore-Washington.

Carr W., Kemmis S. (1986), Becoming Critical. Education, Knowledge, and Action Research, The Falmer Press, Lewes.

Ciechowska M. (2017), Autoetnografia w badaniach pedagogicznych, [w:] M. Ciechowska, M. Szymańska, Wybrane metody jakościowe w badaniach pedagogicznych, cz. 1, Wydawnictwo WAM, Kraków.

Červinkova H. (red.) (2008), Animatorzy spoleczni na rzecz osób niepetnosprawnych. Animacja środowiska na pograniczu, Urząd Marszałkowski Województwa Dolnośląskiego, Wrocław.

Červinkova H., Gołębniak B.D. (red.) (2010), Badania w dziataniu. Pedagogika $i$ antropologia zaangażowane, Wydawnictwo Naukowe Dolnośląskiej Szkoły Wyższej, Wrocław.

Červinkova H., Gołębniak B.D. (red.) (2013), Edukacyjne badania w dziataniu, Wydawnictwo Naukowe Scholar, Warszawa.

Denzin N.K., Lincoln Y.S. (red.) (1994), The Handbook of Qualitative Research, Sage Publications, Thousand Oaks-London-New Delhi.

Denzin N.K., Lincoln Y.S. (red.) (2000), The Sage Handbook of Qualitative Research (second edition), Sage Publications, Thousand Oaks-LondonNew Delhi.

Denzin N.K., Lincoln Y.S. (red.) (2005), The Sage Handbook of Qualitative Research (third edition), Sage Publications, Thousand Oaks-London-New Delhi.

Denzin N.K., Lincoln Y.S. (red.) (2011), The Sage Handbook of Qualitative Research (fourth edition), Sage Publications, Los Angeles-London-New Delhi-Singapore-Washington.

Denzin N.K., Lincoln Y.S. (red.) (2018), The Sage Handbook of Qualitative Research (fifth edition), Sage Publications, Los Angeles-London-New Delhi-Singapore-Washington-Melbourne.

Eisner E.W. (1976), Educational Connoisseurship and Educational Criticism Their Forms and Functions in Educational Evaluation, "Journal of Aesthetic Education”, vol. 10, nr 3-4, s. 135-150.

Eisner E.W. (1991), The Enlightened Eye. Qualitative Inquiry and the Enhancement of Educational Practice, Merril-Printice Hall, Upper Saddle River-Columbus. 
Kacperczyk A. (2014), Autoetnografia - w stronę humanizacji nauki, „Przegląd Socjologii Jakościowej”, A. Kacperczyk (red.), nr 3, t. X: Autoetnografiatechnika, metoda, nowy paradygmat?, s. 6-13.

Kacperczyk A. (red.) (2014), Autoetnografia - technika, metoda, nowy paradygmat?, „Przegląd Socjologii Jakościowej”, t. X, nr 3, s. 241.

Knowles J.G., Cole A.L. (red.) (2008), Handbook of the Arts in Qualitative Research, Sage Publications, Los Angeles-London-New Delhi-Singapore.

Korniłowicz K. (1976), Pomoc społeczno-kulturalna dla mlodzieży pracujacej $i$ dorostych: wybór pism, Zakład Narodowy im. Ossolińskich, Wrocław.

Krasoń K., Konieczna-Nowak L. (2016), Sztuka-terapia-poznanie. W strone podejścia indywidualizującego $w$ badaniach muzykoterapeutycznych, PWN, Warszawa.

Kubinowski D. (2013), Idiomatyczność - synergia - emergencja. Rozwój badań jakościowych w pedagogice polskiej na przetomie XX $i$ XXI wieku, Wydawnictwo „Makmed”, Lublin.

Kubinowski D. (2019), Metodologia badań pedagogicznych między normatywnościq a opisowościq, [w:] J. Piekarski, D. Urbaniak-Zając, S. Pasikowski (red.), Krytyka metodologiczna w praktyce tworzenia wiedzy, Wydawnictwo Uniwersytetu Łódzkiego, Łódź.

Leavy P. (2018), Metoda spotyka sztukę. Praktyki badawcze oparte na sztuce, tłum. K. Stanisz, J. Kucharska, Narodowe Centrum Kultury, Warszawa.

Lewin K. (1946), Action Research and Minority Problems, "Journal of Social Issues", vol. 2, s. 34-46.

Nowa encyklopedia powszechna PWN (1997), PWN, Warszawa.

Nowak S. (2012), Metodologia badań spolecznych, PWN, Warszawa.

Palka S. (1990), Ilościowo-jakościowe badania pedagogiczne, [w:] R. Schulz (red.), Metodologiczne i utylitarne aspekty badań pedagogicznych, Instytut Badań Pedagogicznych, Warszawa.

Palka S. (2006), Metodologia, badania, praktyka pedagogiczna, Gdańskie Wydawnictwo Psychologiczne, Gdańsk.

Stownik grecko-polski (2001), na podstawie słownika Zygmunta Węclewskiego opracował Oktawiusz Jurewicz, t. 1-2, Wydawnictwo Szkolne PWN, Warszawa.

Smolińska-Theiss B., Theiss W. (2013), Badanie i dziatanie w pedagogice spotecznej - między tradycja a wspótczesnymi zadaniami, [w:] H. Červinkova, B.D. Gołębniak (red.), Edukacyjne badania w działaniu, Wydawnictwo Naukowe Scholar, Warszawa.

Szwabowski O. (2019), Nekrofilna produkcja akademicka i pieśni partyzantów. Autoetnografia pracy akademickiej $i$ dydaktycznej w czasach zombie-kapitalizmu, Instytut Pedagogiki Uniwersytetu Wrocławskiego, Wrocław.

Telka L. (2009), Przeksztatcanie przestrzeni spolecznej placówki: studium spoteczno-pedagogiczne na przykładzie żłobków, Wydawnictwo Uniwersytetu Łódzkiego, Łódź.

Touraine A. (2010), Samotworzenie się spoleczeństwa, tłum. A. Karpowicz, Zakład Wydawniczy „Nomos”, Kraków. 


\title{
Problematyczność recepcji metody fenomenologicznej i jej stosowalności w badaniach pedagogicznych
}

\author{
Abstract \\ The problems of the reception \\ of the phenomenological method \\ and its applicability in pedagogical research
}

The nature of this paper is determined by three main theses that delineate the scope and boundaries of the title problem: 1. the method of phenomenological research is a method developed on the basis of philosophical discourse and it is based on the cognitive legitimacy of different varieties of phenomenological philosophy; 2. there is no obvious transition from the assumptions, methods and achievements of phenomenological philosophy to its reception and application on the pedagogical ground. Such concepts are always specific transpositions, adaptations and implementations that more or less abstract from the original intentions and intentions of phenomenology itself; 3 . the vast majority of pedagogical receptions of phenomenology take the form of referring to selected research results and the content of particular analyses. The attempts to apply the very method of phenomenological analysis, in a well-established, methodical and consistent way, are rare.

Keywords: pedagogical reception of phenomenology, phenomenological inspirations in pedagogy, methods of phenomenological research, epistemological and methodological basis of phenomenological research in pedagogy

Słowa kluczowe: pedagogiczna recepcja fenomenologii, fenomenologiczne inspiracje w pedagogice, metody badań fenomenologicznych, epistemologiczne i metodologiczne podstawy fenomenologicznych badań w pedagogice 
Stany rzeczy nie są od siebie niezależne. Przeciwnie, często jest tak, że jeśli pewien stan rzeczy istnieje, wtedy istnieje także inny. Świat może być pomyślany jako układ stanów rzeczy. Rzeczywiście, sam w sobie jest on kolosalnym, w najwyższym stopniu skomplikowanym stanem rzeczy, w którym wszystko, co jest i co może być połączone, jest nieskończoną siecią stosunków ze wszystkim innym (Bocheński 1993: 13-14).

Tendencje i zjawiska „kultury instant” (przybierające makrostrukturalną postać post-kultury, post-społeczeństwa, post-edukacji, post-nauki, post-uniwersytetu i post-człowieka) konfrontują nas i zarazem oswajają z podejściem, w ramach którego oczekujemy nieskomplikowanych, funkcjonalnych i wymiernych postaci określonych wytworów kultury (materialnych lub symbolicznych): w warstwie teoretycznej - prosto komunikowanych i szybko przyswajalnych (np. w formie przewodnika lub vademecum wiedzy, encyklopedycznego lub podręcznikowego zarysu), a w warstwie aplikacyjnej - egalitarnych i pragmatycznych w zastosowaniu (np. $\mathrm{w}$ formie instruktażowego sposobu niezawodnego postępowania, szkolenia lub kursu zawodowego).

$\mathrm{Na}$ „przeciwległym brzegu” różnych postaci społeczno-kulturowej „logiki/racjonalności instant” - ujmując rzecz metaforycznie - można usytuować takie podejścia i nastawienia, które wyrażają się w eksponowaniu nieredukowalności wielowarstwowości i wielopłaszczyznowości doświadczenia społeczno-kulturowego (w tym doświadczenia edukacyjnego jako formacji, formacyjnego wychowania/kształcenia - gr. paideia, niem. Bildung) oraz związanego z tym zakorzenienia/wykorzenienia jako doświadczenia, które w swej aporetyczności nie tylko współwystępuje, ale również nawzajem się dookreśla i współwarunkuje ${ }^{1}$. Takie podejście

1 Warto przywołać w tym miejscu pogląd zgodnie z którym czasy, w których żyjemy, stawiają przed współczesnym człowiekiem zadanie mające swą prometejską dramaturgię mierzenia się z systemowo konstruowanymi, redukcjonistycznymi tendencjami i zjawiskami technologicznej wykładni edukacji, wyrażającej się właśnie w „logice/racjonalności instant” - „odzyskania” autentycznej/humanistycznej tradycji wychowania/kształcenia. Natura ludzka wyraża się bowiem w byciu, które potrzebuje ogólnej (kulturowej/humanistycznej) formacji wychowania/kształtowania (Bildung). Taka formacja pozwala nabywać szczególny rodzaj dystansu (obycia, wyrobienia), w ramach którego człowiek jest zdolny do aprobaty/dezaprobaty przekonań i działań innych ludzi, kierując się nadrzędnym kryterium wiarygodności (Grondin 2015: 18, 20). „Zatem człowiek musi kształcić, doskonalić, rozwijać rozumowe zdolności" - stwierdza w swej hermeneutycznej wykładni Jean Grondin - „i wznieść się do pewnej ,uniwersalności’, ,ogólności’: musi uczyć się widzieć rzeczy w szerszej perspektywie. Bildung wydarza się 
wyraża się w afirmacji struktury doświadczenia społeczno-kulturowego człowieka, która - jak można to ująć - odzwierciedla humanistyczną intencję „logiki/racjonalności odysei” (długotrwałej, czasochłonnej, rozciągniętej w czasie oraz opartej na kolejnych przybliżeniach wędrówki i poszukiwań, co zarazem zakłada też introspekcję, retrospekcję i antycypację egzystencjalnych zasobów i horyzontów własnego doświadczenia) ${ }^{2}$, całkowicie różnej od technologicznej „logiki/racjonalności instant”.

To, co wiąże się z fenomenologiczną tradycją badawczą/fenomenologicznymi nastawieniami poznawczymi można rozpatrywać tylko i wyłącznie w trybie humanistycznych intencji „logiki/racjonalności odysei”3. Można zatem powiedzieć, że fenomenologiczna tradycja badawcza nie tylko jest „nieczytelna”, ale w ogóle staje się niedostępna/niezrozumiała w swych rozległych, złożonych i zróżnicowanych zasobach tradycji dla poznawczego zorientowania i zainteresowania, wyrażającego się w intencji technologicznej „logiki/racjonalności instant”. W takim trybie nie da się wyjaśniać, a tym bardziej rzetelnie przyswajać - opierając się na rozumiejącym wglądzie w zagadnienia i problemy, które określają swoistość przedmiotowego pola zainteresowania, historycznych lub współczesnych - zagadnień i problemów reprezentatywnych dla fenomenologii. Tu nie sposób czegokolwiek przyswoić i zastosować w sposób krytyczno-naukowy, bazując na podejściu, które jest wyrażane w technologicznej „logice/racjonalności instant”.

Fenomenologia - jak konstatował to już jej protoplasta wymaga „specjalnych i żmudnych studiów, jeśli mamy się nauczyć

głównie przez owo poszerzanie horyzontów: kształcenie kogoś oznacza włączenie do jego oglądu tak wielu różnych punktów widzenia jak to możliwe, a w ten sposób umożliwienie wzniesienia się danej osoby ponad jej własną partykularność oraz uczenia się patrzenia na własną szczególność w pewnej perspektywie” (Grondin 2015: 19; zob. także: Przanowska 2015: 39).

2 Reprezentatywnym przykładem takich przeciwległych nastawień i zorientowań poznawczych, w ramach aktualnie podejmowanego dyskursu w pedagogice polskiej, jest m.in. praca poświęcona fenomenowi marzeń, który ze swej natury jawi się jako uniwersalizm (nie)dokończenia (nie)miejsc i (nie)śladów na trajektorii egzystencjalnego doświadczenia (zakorzenienia/wykorzenienia) człowieka, jego rozwoju, biegu życia i losu (zob. Piasecka 2018; por. Gara 2019).

3 Ad marginam, co znamienne, ową sensotwórczą/kulturotwórczą figurę „odysei” w jej symbolicznym potencjale wykorzystał również, choć w innym kontekście problemowym, w swych fenomenologicznych deskrypcjach (socjologii fenomenologicznej) aporetycznych struktur doświadczenia świata życia codziennego Alfred Schütz (zob. Schütz 2012; por. Gara 2015). 
swobodnie poruszać w tym nastawieniu” (Husserl 1975: 6). Problematyka składająca się na epistemologiczne i metodologiczne pryncypia oraz rudymenty fenomenologii jest po prostu złożona lub wręcz niejednoznaczna ${ }^{4}$, oparta na rozległych studiach oraz dyskusji wokół odmiennych stanowisk lub reinterpretacji podstawowych fenomenologicznych zagadnień w jej historycznym rozwoju (por. Gniazdowski 2015).

\section{Kluczowe tezy \\ określające horyzont problematyzacji przedmiotowego pola zainteresowania}

Charakter niniejszego opracowania określany jest trzema zasadniczymi tezami, które zarazem wytyczają zakres i granice tytułowego problemu:

${ }^{4}$ Znamienne jest to, że już u samych początków rozwoju fenomenologii i tylko w odniesieniu do założycielskich studiów w tym względzie, a zatem studiów nie związanych jeszcze z wyodrębnianiem się odmiennych stanowisk i reinterpretacji podstawowych fenomenologicznych zagadnień w jej historycznym rozwoju, Edmund Husserl podkreślał, że kluczowych założeń i nastawień badań fenomenologicznych nie sposób prosto - bez uwzględnienia istotnych dystynkcji i kontekstów problemowych - scharakteryzować i wyjaśnić (por. Blaustein 2013: 226). Warto nadmienić w tym kontekście, że tylko seria „Husserliana”, krytycznego wydania dzieł wszystkich twórcy fenomenologii (obejmujących wznowienia dział wydanych za życia, ale przede wszystkim dzieła zredagowane na podstawie szkiców, zarysów, wykładów i manuskryptów za życia niepublikowanych) w 2014 roku liczyła 41 tomów, a nie były to jeszcze wszystkie działa (zob. Płotka 2014: 28-31). Daniel Roland Sobota wyróżnia też długą listę nieznanych szerzej fenomenologów, związanych tylko z początkowym stadium historycznego „ruchu fenomenologicznego". Niektóre zapiski tych fenomenologów często do dziś nie ukazały się drukiem. Dopiero współcześnie poddawane są też studiom archiwalnym, odkrywane i udostępniane szerszym kręgom czytelników. Przykładem tego jest twórczość jednego z najwybitniejszych i spektakularnych fenomenologów wczesnego „ruchu fenomenologicznego” - Johannesa Dauberta. Sam Husserl uznawał go za jednego z najzdolniejszych spośród swoich uczniów, choć nie tylko za życia nic nie opublikował, ale również nie dokończył rozprawy doktorskiej. Jego niepublikowane za życia prace (rękopisy) dopiero współcześnie poddawane są opracowywaniu i badaniu, ukazując tym samym nieznane dotychczas oblicza/ aspekty analiz fenomenologicznych. Jednym z pierwszych badaczy, który podjął się całościowych studiów nad wyodrębnieniem zasadniczego problemu fenomenologicznej twórczości tego nieznanego w szerszej percepcji filozofa jest polski filozof i fenomenolog nowego pokolenia Daniel R. Sobota (Sobota 2017; zob. także: Sobota [red.] 2018). 
1. Metoda badań fenomenologicznych - co oczywiście może brzmieć jak truizm - jest metodą wypracowaną na gruncie dyskursu filozoficznego (a następnie podlegającą transpozycji, adaptacji i implementacji w ramach innych dyskursów dyscyplinarnych, w szczególności socjologii, psychologii, prawa, teologii czy pedagogiki) i w sposób ścisły opiera się na uprawomocnieniach określonych założeń epistemologiczno-metodologicznych filozofii fenomenologicznej, wraz z jej różnymi reinterpretacjami, sposobami dookreślania lub recepcjami.

„Klasyczna” (wczesna) metoda badań fenomenologicznych przede wszystkim przybiera zaś postać rygoru drogi określonego sposobu myślenia/rozumowania w postaci kategorialnej ideacji oraz ejdetycznego uzmienniania (zob. Gara 2017). W tym znaczeniu fenomenologia jest swoistą praktyką myślenia ${ }^{5}$ i, co należy podkreślić, jest to praktyka na wskroś teoretyczna, analityczna oraz oparta na postawie refleksyjno-kontemplacyjnej (zob. Embree 2006; Krokos 1992), która dla potrzeb własnych badań zakłada metodyczne powstrzymywanie się od powodowanych logiką doraźności praktycznych i aplikacyjnych punktów odniesienia względem tego, co faktyczne (empiryczne) w swej czasowo-przestrzennej konstytucji (Bocheński 1993: 30, 31).

2. Nie ma prostego i oczywistego przejścia od założeń, metody i w ogóle dorobku filozofii fenomenologicznej do jego recepcji na gruncie pedagogicznym.

Recepcje problemów, metody, czy wyników badań filozofii fenomenologicznej na gruncie pedagogiki zawsze są swoistymi transpozycjami, adaptacjami i implementacjami, które w mniejszym lub większym stopniu abstrahują od pierwotnych intencji i zamierzeń samej fenomenologii w jej filozoficznych aspiracjach

5 W tym też kontekście należy stwierdzić za wybitnym filozofem, logikiem i metodologiem Janem Marią Bocheńskim, że metoda jako taka jest sposobem, w jaki musimy postępować w danej dziedzinie/sferze działania, by osiągnąć określone zamierzenie/cel, a metodologia jest teorią tak rozumianej metody. Starogreckie pojęcie méthodos ( $\mu \varepsilon \dot{\theta} \theta \delta \delta \varsigma$ ), wywodzone od słów $\mu \varepsilon \tau \alpha ́$, które oznacza

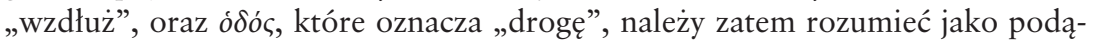
żanie, które określa metodyczny, tzn. przemyślany, zaplanowany i zoperacjonalizowany sposób naszego rozumowania i postępowania w postaci poprawnego „chodzenia-wzdłuż-drogi”. Każda zoperacjonalizowana metoda badawcza zawsze jest bowiem pochodną metody samego myślenia. W tym też kontekście będę się odwoływać do fenomenologii przede wszystkim jako metody myślenia, która wyrasta z właściwych sobie założeń epistemologiczno-metodologicznych (Bocheński 1993: 24, 29). 
problematyzacji poszczególnych zagadnień i teorematów; recepcje te są selektywne i koncentrują się na określonych aspektach lub motywach dorobku fenomenologicznego.

Każda recepcja fenomenologii na gruncie innych dyscyplin (socjologii, psychologii, prawa, teologii, czy pedagogiki) w mniej lub bardziej ugruntowany filozoficznie sposób nawiązuje jednak do określonego zestawu problemów oraz podstawowego lub rozszerzonego instrumentarium terminologicznego i badawczego filozofii fenomenologicznej.

3. Zdecydowana większość pedagogicznych recepcji fenomenologii, w próbie określania własnej paradygmatycznej tożsamości, przybiera postać odwoływania się do określonych wyników badań i treści fenomenologicznych analiz oraz ogólnych koncepcyjnych założeń. Do rzadkości zaś należą próby stosowania - w sposób studialnie ugruntowany, metodyczny i konsekwentny - samej metody analizy fenomenologicznej ${ }^{6}$.

Literalne i hasłowe odwołania do fenomenologicznych nastawień badawczych często pojawiają się natomiast $\mathrm{w}$ dyskursie pedagogicznym w sposób zapośredniczony i zredefiniowany ujęciami socjologicznymi i psychologicznymi, lub, co gorsza, nie wykazują związku ze zrozumieniem kluczowych zagadnień i problemów poszczególnych stanowisk filozofii fenomenologicznej zarówno tych określających jej podstawowe punkty wyjścia, jak i tych związanych z jej historycznym rozwojem i ewoluowaniem określonych ujęć, koncepcyjnych reprezentacji i zróżnicowań.

\section{„Co to jest fenomenologia” - współczesne horyzonty rozpatrywania i uprawiania fenomenologii}

Aby móc sensownie i rzeczowo przybliżyć kwestię problematyczności recepcji metody fenomenologicznej i jej stosowalności w badaniach pedagogicznych, należy najpierw choć w przybliżeniu spróbować odpowiedzieć na pytanie podstawowe, a mianowicie:

${ }^{6} \mathrm{~W}$ polskiej literaturze do udanych zastosowań warsztatu metody fenomenologicznej, które uwidaczniają „metodyczną” konsekwencję deskrypcji fenomenologicznej (w „klasycznym” znaczeniu deskrypcji fenomenologii ejdetycznej/„rdzennej”) na rzecz analizy i rozjaśniania wybranych problemów pedagogicznych/filozofii wychowania bez wątpienia należy zaliczyć tekst Jacka Filka (2001). 
„Co to jest fenomenologia?”" oraz do jakich horyzontów poznawczych współcześnie odsyła nas jej rozpatrywanie lub uprawianie. Siłą rzeczy ograniczę się jednak tylko do tych kwestii, które mają istotny walor różnicujący/dystynktywny i wprost przekładają się na epistemologiczną i metodologiczną problematyczność wpisywania się w zróżnicowaną - z pozycji współczesnego oglądu tradycję badań fenomenologicznych.

Kwestię poprawności lub niepoprawności, prawomocności lub nieprawomocności, konsekwencji lub niekonsekwencji wpisywania się w określoną tradycję fenomenologiczną (należy bowiem mówić o różnych modelach/ujęciach/odmianach uprawiania fenomenologii) sytuuję w kontekście podstawowej metodologicznej intencji posługiwania się określoną metodą w jej źródłowym, starogreckim znaczeniu, w myśl którego konsekwentne i prawomocne posługiwanie się metodą należy rozumieć jako celowe i zoperacjonalizowane podążanie zgodnie ze wzorem wyrażanym w metaforze poprawnego „chodzenia-wzdłuż-drogi”.

Samo pytanie o to, czym jest fenomenologia, ponawiane jest w szczególności przez filozofów, ale nie tylko - od samego początku istnienia tego ruchu filozoficznego aż do dzisiejszych czasów. Jest to pytanie wciąż aktualne w swej nieoczywistości i nadal wyłaniające nowe nierozpoznane obszary namysłu i dyskursu wśród współczesnych kontynuatorów, niezwykle rozległej i bogatej tradycji fenomenologicznej, która nieustannie podlegała różnym recepcjom na gruncie nauk humanistycznych i społecznych, w tym - co w tym miejscu istotne - również na gruncie myśli pedagogicznej.

Tożsamość różnych odmian i reprezentacji analiz fenomenologicznych - co należy podkreślić - nie jest jednak oparta ani na zgodności co do sposobu realizacji fenomenologicznej metody badań, ani na zgodności określonych wyników badań poszczególnych fenomenologów, a co za tym idzie wyprowadzanych na tej podstawie wniosków i koncepcyjnych modeli określonych aspektów i przejawów analizowanej rzeczywistości. Tożsamość ta oparta jest

7 Takie rudymentarne pytanie ponawiane jest od samego początku ukonstytuowania się fenomenologii i jej kolejnych koncepcyjnych reinterpretacji jako oryginalnego i wyrazistego paradygmatycznego nurtu myślowego, a co za tym idzie opartego na swoistym systemie właściwych sobie aksjomatów i założeń, specyficznym instrumentarium pojęciowym oraz metodzie rozjaśniania/ujmowania/opisu „rzeczy samych” tak, jak się one same ukazują (prezentują, zjawiają) w oglądzie podmiotu intencjonalnych aktów poznania (przypomnieniu, spostrzeżeniu, wyobrażeniu, czy antycypacji). 
na ogólnych założeniach/ideach (tj. uznanie intencjonalnej struktury świadomości, dezyderat powrotu do rzeczy samych „poprzez oddzielenie tego, co jest dane, od tego, co jest [teoretycznie - J.G.] skonstruowane" ${ }^{8}$, dowartościowanie źródłowego doświadczenia przedmiotu poznania, ujmowanie intencjonalnych treści jako przedmiotu poznania, koncentrowanie analizy na sposobach ukazywania się fenomenu, wyodrębnianie szczególnej klasy przedmiotów kategorialnych i kategorialnych stanów rzeczy), które w ujęciu różnych fenomenologów przybierają odmienną postać i prowadzą do różnych konsekwencji zarówno ontologicznych, epistemologicznych, jak i metodologicznych (por. Tatarkiewicz 2013: 70).

Samo pojęcie fenomenu w swoim podstawowym znaczeniu oznacza to, co jest dane w polu świadomości podmiotu poznania, innymi słowy, co się jawi/zjawia jako bezpośrednio dane świadomości. Tym samym „fenomenologiczne pole doświadczenia” określane jest przez sposób zjawiania się fenomenów w świadomości, tzn. przez uświadomienie sobie (w trybie spostrzeżenia, przypomnienia, wyobrażenia lub antycypacji) tego, co jest przedmiotem naszych przeżyć intencjonalnych (Husserl 1968: 279, 280, 282, 284; Sokolowski 2012: 77-84). W tym znaczeniu mówiąc o fenomenie nie mamy więc na myśli zjawisk fizycznych lub zjawisk psychicznych, ale określone dane świadomości. Sfera świadomości określa bowiem „pole badania”, w ramach którego odkrywane/odsłaniane są fenomeny jako dane świadomości (Rozkwitalski 2013: 593-595).

Fenomenologiczna perspektywa poznawcza koncentruje się na badaniu ogólnych związków strukturalnych tak, by „wykryć, jakie własności należą z konieczności do istoty danego przedmiotu bez względu na doświadczenie aktualne” (Kołakowski 1965: 278-279). Podejście fenomenologiczne - stwierdzał Roman Ingarden wymaga więc swoistych, ,uporządkowanych sposobów zachowania się” (Ingarden 1974: 71), „postępowania drogą” osobliwej procedury i osobliwych wysiłków; co więcej, wymusza niejako, by tę „drogę od pierwotnych danych źródłowych do określonych, naocznie rozumianych poglądów teoretycznych” (Ingarden 1974: 77)

8 W kontekście tego programowego dla fenomenologii postulatu - jak zauważył to również Władysław Tatarkiewicz - „badania fenomenologiczne korygują w tym względzie poglądy życia potocznego, a także nauki i filozofii, które niejednokrotnie uważają za dane, co nim bynajmniej nie jest, i, odwrotnie, przeoczają, co oczywiście jest dane" (Tatarkiewicz 2013: 66). 
w pełni przemierzyć samodzielnie. Tym samym fenomenologia zakłada metodyczny dystans wobec „naiwnej akceptacji wszystkiego”, co opiera się na oczywistościach naszego poznania ukonstytuowanego w trybie propozycjonalnym. Fenomenologia zawsze stawia przed sobą zadanie źródłowego rozjaśnienia przedmiotów poznania (zarówno w znaczeniu prawdy jako zgodności, jak i prawdy jako jawności) (Sokolowski 2012: 165-166) poprzez odwołanie się do doświadczenia sposobu ich bezpośredniego ukazywania się $\mathrm{w}$ aktach intencjonalnych podmiotu poznania.

W ten sposób fenomenolog, wychodząc od wstępnych danych poznania, zawsze staje przed zadaniem, które jest próbą źródłowego poznania rzeczy i stanów rzeczy, w taki sposób, w jaki one same się ukazują (prezentują/uobecniają) w naszym doświadczeniu intencjonalnego zorientowania na przedmiot poznania (zob. Husserl 2013: 48-64).

W opisie fenomenologicznym mamy do czynienia dokładnie z tym światem, z którym mamy do czynienia na co dzień - tyle że ujętym $\mathrm{z}$ innego punktu widzenia: $\mathrm{z}$ punktu widzenia sposobów zjawiania się, a nie tego, co się w nich zjawia. Fenomenologia jest w tym podobna do sztuki: i sztuka przecież pozwala nam spojrzeć innymi oczyma na to samo, co widzimy co dzień. I fenomenologia, i sztuka zakładają pewną swobodę, dystans wobec wszelkiego przedmiotu, pozwalającego na wydobycie na jaw tej myśli, która zwykle pozostaje w cieniu [...] Opis fenomenologiczny jest to więc opis sposobu, w jaki zjawia się rzeczywistość, opis projektu wszelkiego możliwego spotkania z tym, co jest, opis możliwości pojawienia się czegoś przed nami (Michalski 1998: 18-19)9 .

\section{Podstawowe przesłanki problematyczności współczesnego rozpatrywania fenomenologii i jej pedagogicznych recepcji}

Podstawowe przesłanki problematyczności współczesnego rozpatrywania fenomenologii i jej pedagogicznych recepcji należy sprowadzić do trzech zasadniczych kwestii:

9 Sam Husserl również odwoływał się expressis verbis do porównania podejścia fenomenologa i artysty: „Ogląd fenomenologiczny jest blisko spokrewniony z oglądem estetycznym, jaki ma miejsce w ,czystej' sztuce [...] Świat w oczach obserwującego go artysty staje się fenomenem, którego egzystencja jest dlań, tak jak i dla filozofa (w krytyce rozumu) obojętna” (Husserl 1996: 257). 
1. Koncepcyjnym punktem odniesienia studiów fenomenologicznych jest bogata zarówno ilościowo, jak i jakościowo twórczość jej intelektualnego protoplasty. Dorobek fenomenologiczny Husserla nie tylko bowiem ma swoje istotne koncepcyjne zwroty, rewizje i reinterpretacje (Ingarden 2013: 90-91), ale jest również obszerny i złożony z licznych drobiazgowych filozoficznych studiów, w których przede wszystkim podejmowane są zagadnienia natury epistemologicznej. W dorobku tym wyróżnia się również trzy zasadnicze okresy twórczości, którym towarzyszą odmienne założenia oraz związane z tym konsekwencje epistemologiczne i metodologiczne dla uprawiania/ujmowania samej fenomenologii.

Mówiąc w uproszczeniu, reprezentatywna dla pierwszego okresu twórczości Husserla konceptualizacja to fenomenologia ejdetyczna/,rdzenna” (kluczowe koncepcyjnie kategorie to: intencjonalność, ontologia części i całości, istota rzeczy, kategorialne stany rzeczy, naoczność kategorialna, deskrypcja, oczywistość), dla drugiego okresu - fenomenologia transcendentalna (kluczowe kategorie to: epoche, noemat i noeza, ja transcendentalne), a dla trzeciego okresu - fenomenologia świata życia codziennego (kluczowe kategorie to: dzieje, tradycja, intersubiektywność, doświadczenie przedpredykatywne, codzienna egzystencja, świat przeżywany, substrat doświadczenia/dokonań poznawczych). Taki jest historyczny punkt wyjścia, ukazujący złożoność i zróżnicowanie formowania się Husserlowskiej fenomenologii jako założycielskiej/ fundującej podstawy dalszego rozwoju fenomenologii.

2. Filozofia fenomenologiczna posiada własne specyficzne instrumentarium pojęciowe, a podstawowe kategorie i problemy, które określają tożsamość jej nastawień poznawczych - tj. intencjonalność, oczywistość, rzeczy same, redukcja ${ }^{10}$, przedmioty idealne, intuicja ejdetyczna, deskrypcja czy intersubiektywność podlegały krytycznej rewizji i ewolucji wśród samych fenomenologów, rodząc różne ich reinterpretacje i modyfikacje znaczeniowe, a co za tym idzie, zróżnicowane konsekwencje epistemologiczne i metodologiczne oraz różne odmiany samej fenomenologii.

${ }^{10} \mathrm{Na}$ marginesie, we wczesnej fenomenologii wyróżniano dwie podstawowe i niesprowadzalne do siebie redukcje: ejdetyczną i transcendentalną/fenomenologiczną epoche. Uznanie/nieuznanie uprawomocnień poznawczych drugiej z wskazanych redukcji określało też swoistą linię demarkacyjną pierwotnego zróżnicowania fenomenologii, związanego z jej realistycznym lub idealistycznym nurtem. Dalszy rozwój badań fenomenologicznych wprowadzi jeszcze inne „techniczne” redukcje, zakładane w ramach różnie dookreślanych zadań i celów analizy fenomenologicznej. 
3. Fenomenologiczny dorobek jest istotnie zróżnicowany zarówno pod względem konceptualizacji i operacjonalizacji metody fenomenologicznej, jak i konceptualizacji samych wyników badań i analiz fenomenologicznych (zob. Spiegelberg 1994; Embree [red.] 1997; Moran, Cohn [red.] 2012; Płotka [red.] 2014; Migasiński, Lorenc [red.] 2006; Lorenc, Salwa, Schollenberger [red.] 2012). Zasadniczy podział wczesnej fenomenologii związany był z jej dwoma odmiennymi orientacjami: realistyczną i idealistyczną. Nie we wszystkich wypadkach cały dorobek poszczególnych reprezentantów tego nurtu filozoficznego ma też w pełni, lub w ogóle, charakter fenomenologiczny, a co za tym idzie, nie może też być automatycznie klasyfikowany jako wyrażający programowe założenia fenomenologii.

3.1 Z konceptualizacjami odmiennych lub autorsko zróżnicowanych modeli zastosowania metody badań fenomenologicznych spotykamy się np. w: fenomenologii ejdetycznej, fenomenologii genetycznej, fenomenologii transcendentalnej (Edmund Husserl, Eugen Fink), fenomenologii fundamentalnej (Martin Heidegger), fenomenologii jako podstawowej nauce filozoficznej (Aleksander Pfänder), hermeneutyce fenomenologicznej (Hans-Georg Gadamer), fenomenologii hermeneutycznej (Paul Ricoeur), fenomenologii egzystencjalnej (Jean Paul Sartre, Karl Jaspers), fenomenologii asubiektywnej (Jan Patočka), fenomenologii personalistycznej (Edyta Stein, Karol Wojtyła), nowej fenomenologii (Hermann Schmitz), fenomenologii donacji (Jean-Luc Marion) czy fenomenologii życia (Michel Henry).

3.2 Sprofilowane koncepcyjnie wyniki uznanych analiz fenomenologicznych w ich autorskim ujęciu dotyczą zaś np.: fenomenologii czasu (Edmund Husserl), fenomenologii człowieka, wartości (Max Scheler), fenomenologii bycia/Dasein (Martin Heidegger), fenomenologii wspólnoty (Dietrich von Hildebrand), fenomenologii uczuć i doznań estetycznych (Moritz Geiger), fenomenologii woli i usposobień (Aleksander Pfäder), fenomenologii człowieka, dzieła sztuki, doświadczenia estetycznego (Roman Ingarden), fenomenologii prawa (Adolf Reinach), fenomenologii pytania (Johannes Daubert), fenomenologii wczucia (Edyta Stein), fenomenologii osoby (Edyta Stein, Karol Wojtyła, Robert Sokolowski), fenomenologii religii (Gerardus van der Leeuw), fenomenologii percepcji, fenomenologii ciała (Maurice Merleau-Ponty), fenomenologii świata życia codziennego (Edmund Husserl, Jan Patočka, Alfred Schütz, Maurice Merleau-Ponty) czy fenomenologii Innego (Emmanuel Levinas, Bernard Waldenfels). 


\section{Implikacje problemu zróżnicowania i wielości odmian filozofii fenomenologicznej dla pedagogicznych recepcji fenomenologii}

Implikacje problemu zróżnicowania i wielości odmian/stanowisk filozofii fenomenologicznej dla pedagogicznych recepcji fenomenologii (transpozycji, adaptacji i implementacji) znajdują swoje odzwierciedlenie przede wszystkim w kwestii merytorycznej poprawności lub niepoprawności, epistemologicznej prawomocności lub nieprawomocności oraz metodologicznej konsekwencji lub niekonsekwencji w nawiązywaniu do poszczególnych założeń, kategorii, konceptualizacji oraz stosowalności samej metody fenomenologicznej analizy intencjonalnej. Zarówno bowiem kwestia definiowania podstawowych pojęć fenomenologicznych i ich roli (np. fenomen, doświadczenie, redukcja, metoda, podmiot, przedmiot, poznanie, oczywistość, świat), uznania lub odrzucenia określonych założeń koncepcyjnych/ideowych, jak i dookreślanie celu i granic deskrypcji fenomenologicznej w poszczególnych modelach lub autorskich odmianach/stanowiskach ma nie tylko zróżnicowany charakter, ale nierzadko jest też zupełnie odmienne.

W świetle aktualnego stanu wiedzy oraz zaawansowania historycznych i współczesnych studiów fenomenologicznych nie sposób zatem kompetentnie odwoływać się do fenomenologii, nie wskazując zarazem do jakiej odmiany (modelu/ujęcia/szkoły) fenomenologii oraz stanowisk z tym związanych się odwołujemy. W tym też kontekście należy odnotować następujące krytyczno-naukowe przesłanki, które określają adekwatną świadomość epistemologiczną i metodologiczną pedagogicznych recepcji zarówno w odwoływaniu się do metody badań, wyników badań, jak i określonych idei i koncepcji fenomenologicznych:

1. Złożoność materii, która jest związana z kwestią zróżnicowania, rozwojem oraz ponad stu letnią historia tradycji fenomenologicznej wymaga nie tylko pewnego rozeznania, ale i respektowania/brania pod uwagę prymarnych rozróżnień lub przeciwstawień określonych założeń, pojęć i stanowisk, z którymi mamy do czynienia w poszczególnych ujęciach fenomenologii ${ }^{11}$

11 Brak zachowania prymarnych dystynkcji w ramach przywoływanych problemów i zagadnień określających tak samą tożsamość, jak i przedmiot zainteresowania fenomenologii, będąc wyrazem braku wystarczającego rozeznania i staranności $\mathrm{w}$ tym względzie, narusza też sam etos fenomenologii, który wyrasta 
oraz wynikających z nich implikacji ontologicznych, epistemologicznych i metodologicznych dla określonego dyskursu lub podejmowanej problematyki. Chodzi więc o to, by od strony merytorycznej nie dokonywać błędnych utożsamień określonych kwestii lub nie popadać w sprzeczność, odwołując się do określonych założeń, pojęć lub koncepcji.

2. Pedagogiczne recepcje fenomenologii, które w sposób paradygmatyczny lub koncepcyjny nawiązują do założeń tego filozoficznego nurtu myślowego, nie mogą tylko w sposób czysto hasłowy odwoływać się do kluczowych założeń, kategorii i problemów, bez jasnego ujmowania ich charakteru w ramach tradycji i studiów fenomenologicznych. Każda taka recepcja (transpozycja, adaptacja i implementacja) ma swoje specyficzne konteksty, ponieważ siłą rzeczy opiera się na określonej reprezentacji fenomenologii, w ramach której spotykamy się z klasycznym, reinterpretacyjnym lub rewizjonistycznym dookreślaniem i definiowaniem podstawowego instrumentarium celów i zadań badań fenomenologicznych.

3. W pedagogicznych recepcjach fenomenologii badacz, który w sposób krytyczno-naukowy kieruje się aspiracjami kompetencji i rzetelności, konfrontowany jest tym samym z następującymi zagrożeniami braku merytorycznej poprawności, epistemologicznej prawomocności lub metodologicznej konsekwencji:

a. Odwoływania się do uogólnionych/zgeneralizowanych założeń określających paradygmatyczną swoistość fenomenologii bez różnicowania ich złożoności oraz polemiki związanej z odmiennymi stanowiskami, jej historycznym rozwojem i koncepcyjnym ewoluowaniem;

b. Odwoływania się do wybranych motywów, problemów lub poszczególnych wyników/treści analiz bez całościowych prób sytuowania się $\mathrm{w}$ tradycji tychże stanowisk/ujęć fenomenologii oraz bez konsekwentnej operacjonalizacji źródłowych założeń i ich konsekwencji epistemologicznych i metodologicznych dla swych własnych dyscyplinarnych recepcji;

z metodycznie - skrupulatnie i precyzyjnie - dokonywanych analitycznych rozróżnień i porównań („metoda dystynkcji/rozróżnień”). Znamienna w tym kontekście jest zatem uwaga: „Dystynkcje - jak ujmuje to wybitny historyk filozofii nie są dla fenomenologii środkiem do konstrukcji i teorii, lecz celem same przez się. Jest wszakże wystarczającą zdobyczą poznawczą rozróżnienie tego, co nie było rozróżniane, a zatem było uważane za takie samo, nie będąc nim” (Tatarkiewicz 2013: 68-69). 
c. Odwoływania się do programowych idei fenomenologii np. problemów: metody, redukcji, rzeczy samych, świata życia codziennego, ja transcendentalnego czy intersubiektywności - bez sytuowania/uzgadniania ich w ramach określonych modeli/ujęć samej fenomenologii, jak i w kontekście dyscyplinarnego obszaru badań, którym ostatecznie służyć mają owe recepcje założeń, metody lub wyników badań fenomenologicznych.

4. W końcu, znajomość przedmiotowego obszaru zainteresowania wymaga odróżniania recepcji, które mają charakter paradygmatycznych transpozycji, aplikacji i implementacji fenomenologii, a raczej poszczególnych aspektów - założeń, kategorii lub rozstrzygnięć, na rzecz pedagogicznych badań i pedagogicznej teorii ${ }^{12}$ (w takim przypadku można mówić o: pedagogice fenomenologicznej, pedagogice o orientacji fenomenologicznej, pedagogice inspirowanej fenomenologicznie lub pedagogice w optyce myśli fenomenologicznej) od zwykłych, mniej lub bardziej obszernych odniesień do pojęć, treści lub koncepcyjnych motywów fenomenologii.

Recepcje, które mają charakter transpozycji, aplikacji i implementacji założeń ontologicznych, epistemologicznych i metodologicznych określają bowiem dopiero paradygmatyczną tożsamość danego dyskursu pedagogicznego. Konkludując, można zatem stwierdzić, że podobnie jak samo nawiązywanie do pozytywizmu, psychoanalizy lub posługiwanie się właściwymi im pojęciami nie czyni jeszcze z określonego autora pozytywisty lub psychoanalityka, tak nawiązywanie do określonych badań fenomenologicznych lub literalne posługiwanie się właściwymi im pojęciami nie czyni jeszcze z nikogo - w ścisłym tego słowa znaczeniu - fenomenologa lub przedstawiciela pedagogiki o orientacji/proweniencji fenomenologicznej.

12 W zasobach polskiej literatury przedmiotu (rodzimych lub zagranicznych autorów, wydanych przez krajowe wydawnictwa naukowe) - nie wdając się w szczegółowe odniesienia, charakterystykę i ocenę - można wskazać następujące pozycje monograficzne (przywołuję je w układzie chronologii czasowej), w których podejmowane są takie próby zróżnicowanych (częściowych, specyficznych) - kontekstowo lub aspektowo - recepcji (zob. Ablewicz 1994, Lippitz 2005, Ablewicz 2003, Przybylski 2007, Gara 2009, Sosnowska 2009, Pelcová 2014, Ryk 2015, Przanowska 2019). Wśród współczesnych autorskich podręczników akademickich, dostępnych w rodzimej literaturze, w których widoczne są określone elementy lub poszczególne nawiązania do tradycji fenomenologicznej w sposobie problematyzacji i systematyzacji zagadnień pedagogicznych, można odnotować dwie interesujące monografie (zob. Benner 2015, Kron 2012). 


\section{Bibliografia}

Ablewicz K. (1994), Hermeneutyczno-fenomenologiczna perspektywa badań $w$ pedagogice, Wydawnictwo Uniwersytetu Jagiellońskiego, Kraków.

Ablewicz K. (2003), Teoretyczne i metodologiczne podstawy pedagogiki antropologicznej, Wydawnictwo Uniwersytetu Jagiellońskiego, Kraków.

Benner D. (2015), Pedagogika ogólna. Wprowadzenie do myślenia i dziatania pedagogicznego w ujęciu systematycznym i historyczno-problemowym, tłum. D. Stępkowski, Wydawnictwo KSW, Warszawa.

Blaustein L. (2013), Edmund Husserl i jego fenomenologia, [w:] D. Bęben, M. Ples-Bęben (red.), Polska fenomenologia przedwojenna. Antologia tekstów, Wydawnictwo Uniwersytetu Śląskiego, Katowice.

Bocheński J.M. (1993), Wspótczesne metody myślenia, tłum. S. Judycki, Wydawnictwo „W drodze”, Poznań.

Embree L. (red.) (1997), Encyclopedia of Phenomenology, Kluwer Academic Publisher, Dordrecht-Boston-London.

Embree L. (2006), Analiza refleksyjna. Wprowadzenie do badań fenomenologicznych, tłum. A. Łagodzka, Wydawnictwo IFiS PAN, Warszawa.

Filek J. (2001), Fenomenologia wychowania, [w:] J. Filek, Filozofia jako etyka, Wydawnictwo Znak, Kraków.

Gara J. (2009), Od filozoficznych podstaw wychowania do ejdetycznej filozofii wychowania, Wydawnictwo APS, Warszawa.

Gara J. (2015), Egzystencjalny fenomen epizodów codzienności jako źródto antycypacji przysztości, „Studia z Teorii Wychowania”, nr 3, s. 29-48.

Gara J. (2017), Fenomenologia jako metoda myślenia - u podstaw warsztatu badań ejdetycznych, „Pedagogika Szkoły Wyższej”, nr 1, s. 9-24.

Gara J. (2019), Odyseja myśli poszukującej „życia utkanego z refleksyjności nad marzeniami”, „Przegląd Pedagogiczny”, nr 1, s. 251-259.

Gniazdowski A. (2015), Antynomie radykalizmu. Fenomenologia polityczna $w$ Niemczech 1914-1933, Wydawnictwo IFiS PAN, Warszawa.

Grondin J. (2015), Gadamera doświadczenie i teoria wychowania: uczenie się, że inny może mieć rację, „Kwartalnik Pedagogiczny”, nr 2, s. 11-29.

Husserl E. (1968), Phänomenologische Psychologie. Husserliana: Edmund Husserl. Gesammelte Werke, IX, Martinus Nijhoff, The Hague.

Husserl E. (1975), Idee czystej fenomenologii $i$ fenomenologicznej filozofii, księga pierwsza, tłum. Gierlunka G., PWN, Warszawa.

Husserl E. (1996), List do Hugo von Hofmannsthala, tłum. P. Bukowski. „Teksty Drugie", nr 2/3, 255-258.

Husserl E. (2013), Są $i$ doświadczenie, tłum. B. Baran, Fundacja Aletheia, Warszawa.

Ingarden R. (1974), Wstęp do fenomenologii Husserla, PWN, Warszawa.

Ingarden R. (2013), Edmund Husserl: Logische Untersuchungen, [w:] D. Bęben, M. Ples-Bęben (red.), Polska fenomenologia przedwojenna. Antologia tekstów, Wydawnictwo Uniwersytetu Śląskiego, Katowice.

Kołakowski L. (1965), Husserl - filozofia doświadczenia rozumiejacego, [w:] B. Baczka (red.), Filozofia i socjologia XX wieku, Wiedza Powszechna, Warszawa. 
Krokos J. (1992), Fenomenologia Edmunda Husserla, Aleksandra Pfändera, Maxa Schelera, Agencja Wydawnicza Katolików, Warszawa.

Kron F.W. (2012), Pedagogika. Kluczowe zagadnienia, tłum. E. Cieślik, Gdańskie Wydawnictwo Psychologiczne, Sopot.

Lippitz W. (2005), Różnica i obcość. Studia fenomenologiczne w obrębie nauki o wychowaniu, tłum. A. Mużyn, Oficyna Wydawnicza Impuls, Kraków.

Lorenc I., Salwa M., Schollenberger P. (red.) (2012), Fenomen i przedstawienie. Francuska estetyka fenomenologiczna. Zatożenia/zastosowanialkonteksty, Wydawnictwo IFiS PAN, Warszawa.

Michalski (1988), Heidegger i filozofia współczesna, PIW, Warszawa.

Migasiński J., Lorenc I. (red.) (2006), Fenomenologia francuska. Rozpoznania/rozwinięcialinterpretacje. Wybór tekstów, Wydawnictwo IFiS PAN, Warszawa.

Moran D., Cohn J. (red.) (2012), The Husserl Dictionary, Continuum International Publishing Group, London-New York.

Pelcová N. (2014), Człowiek i wychowanie w refleksji fenomenologicznej, tłum. A. Bystrzycka, Wydawnictwo Kardynała Stefana Wyszyńskiego, Warszawa.

Piasecka J. (2018), O uniwersalizmie (nie)dokończenia. Edukacyjne (nie)miejsca $i$ (nie)ślady, Wydawnictwo im. Stanisława Podobińskiego Uniwersytetu Humanistyczno-Przyrodniczego im. Jana Długosza w Częstochowie, Częstochowa.

Płotka W. (2014), Stowo wstępne, [w:] W. Płotka (red.), Wprowadzenie do fenomenologii. Interpretacje, zastosowania, problemy, t. I, Wydawnictwo IFiS PAN, Warszawa.

Płotka W. (red.) (2014), Wprowadzenie do fenomenologii. Interpretacje, zastosowania, problemy, t. I, II, Wydawnictwo IFiS PAN, Warszawa.

Przanowska A. (2019), Listening and Acouological Education, Wydawnictwa Uniwersytetu Warszawskiego, Warszawa.

Przanowska M. (2015), Pytanie o sens (w) edukacji. Od Grondinowskiej semantyki sensu $i$ jej pedagogicznych egzemplifikacji do antyredukcjonizmu hermeneutyki ksztatcenia, „Kwartalnik Pedagogiczny”, nr 2, s. 30-55.

Przybylski A. (2007), Dziatalność edukacyjna i myśl pedagogiczna św. Edyty Stein, Wydawnictwo WAM, Kraków.

Rozkwitalski J. (2013), Metoda fenomenologiczna, [w:] D. Bęben, M. Ples-Bęben (red.), Polska fenomenologia przedwojenna. Antologia tekstów, Wydawnictwo Uniwersytetu Śląskiego, Katowice.

Ryk A. (2015), W poszukiwaniu podstaw badań ejdetycznych w perspektywie fenomenologicznej. Na podstawie koncepcji Edmunda Husserla, Oficyna Wydawnicza Impuls, Kraków.

Schütz A. (2012), Powracający do domu, [w:] A. Schütz, O wielości światów. Szkice z socjologii fenomenologicznej, tłum. B. Jabłońska, Zakład Wydawniczy „Nomos”, Kraków.

Sobota D.R. (2017), Narodziny fenomenologii z ducha pytania. Johannes Daubert $i$ fenomenologiczny rozruch, Wydawnictwo IFiS PAN, Warszawa.

Sobota D.R. (red.) (2018), Wybrane problemy wczesnej fenomenologii. Antologia tekstów, Wydawnictwo IFiS PAN, Warszawa.

Sokolowski R. (2012), Wprowadzenie do fenomenologii, tłum. M. Rogalski, Wydawnictwo WAM, Kraków. 
Sosnowska P. (2019), Filozofia wychowania w perspektywie Heideggerowskiej różnicy ontologicznej, Wydawnictwa Uniwersytetu Warszawskiego, Warszawa. Spiegelberg H. (1994), The Phenomenological Movement. A Historical Introduction, Kluwer Academic Publishers, Dordrecht-Boston-London.

Tatarkiewicz W. (2013), Szkoła fenomenologów, [w:] D. Bęben, M. Ples-Bęben (red.), Polska fenomenologia przedwojenna. Antologia tekstów, Wydawnictwo Uniwersytetu Śląskiego, Katowice. 


\title{
Rozumienie jako przekład. Wokół koncepcji hermeneutyki George'a Steinera
}

\author{
Abstract \\ The understanding as a translation. \\ Around George Steiner's hermeneutics concept
}

The recently deceased George Steiner was one of the leading contemporary comparativists and philosophers of literature. One of the most important themes of his book from the 1970s, After Babel: Aspects of Language and Translation, is the claim about the identity of understanding and translation. The concept of the hermeneutic act as a translation, spokesmen for which are modern humanists and researchers, such as Steiner and also Hans-Georg Gadamer, Paul Ricoeur, Zygmunt Bauman or Jacques Derrida, in their various variants seems to have significant potential for general pedagogy and philosophy of education and generate interesting impulses for educational practice and education research. In the article, referring to the translational turn, the thought and tradition of Judaism and Steiner's original approach to understanding, I analyse and discuss the premises of his basic claim and study the consequences and draw conclusions from Steiner's concept for the theory and practice of education.

Keywords: translation, understanding, hermeneutics, George Steiner, translational turn, philosophy of education, Jewish philosophy

Słowa kluczowe: przekład, rozumienie, hermeneutyka, George Steiner, zwrot translacyjny, filozofia edukacji, filozofia żydowska 
Ttumacze to ludzie bladzacy po omacku we wspólnej mgle

George Steiner

Kto thumaczy dostownie, jest fatszerzem, a kto cokolwiek dodaje, bluźni i złorzeczy

Kidduszin 49,1

Podejście do aktu hermeneutycznego jako przekładu, za którego rzeczników można uznać takich współczesnych humanistów i badaczy jak George Steiner, Hans-Georg Gadamer, Paul Ricoeur, Zygmunt Bauman czy Jacques Derrida, w swych różnych wariantach zdaje się posiadać znaczący potencjał dla pedagogiki ogólnej i filozofii edukacji oraz generować interesujące impulsy dla praktyki edukacyjnej i badań nad edukacją. Przybliżając wstępnie zasadnicze założenie właściwe dla owej perspektywy, można odwołać się do twierdzenia Steinera, wyrażonego w pracy opublikowanej w połowie lat 70. XX w. Po wieży Babel. Problemy języka $i$ przektadu: „Każdy model komunikacji jest jednocześnie modelem trans-lacji, wertykalnego lub horyzontalnego transferu znaczenia" (Steiner 2000: 84). Eksploracja rozumienia jako przekładu stanowi merytoryczną oś organizującą treści przywołanego studium, a jednocześnie radykalne i zarazem budzące kontrowersje podejście do problematyki procesów myślowych. Być może spośród wymienionych filozofów w sposobie postrzegania oraz ujmowania rozumienia i przekładu Steiner posuwa się najdalej, jednak grupa przywołanych myślicieli swoim zainteresowaniem problematyką tłumaczenia wpisuje się w pewną ogólną tendencję zaistniałą w naukach humanistycznych, którą jako translational turn daje się śledzić od lat 80. XX w. Można zatem uznać, że zwrot translacyjny czy translatologiczny tworzy ważny kontekst dla rozpatrywania kwestii przekładu, a w tym teorii Steinera na gruncie pedagogiki. Ponadto podejście tego literaturoznawcy i komparatysty daje się rozpatrywać także na płaszczyźnie antropologii kulturowej, dostrzegając zakorzenienie jego przekonań i ustaleń w myśli oraz tradycji judaizmu. Rozwinięcie tego kontekstu koncepcji rozumienia Steinera pozwala uwyraźnić charakterystykę poszczególnych wariantów hermeneutyki filozoficznej, które dadzą się wyróżnić w obrębie wskazanej tendencji. W związku z powyższym zagadnienie rozumienia jako przekładu, podjęte tu w intencji inspiracji dla teorii i praktyki edukacyjnej, zostanie 
omówione i scharakteryzowane kolejno w czterech ujęciach: w kontekście zwrotu translacyjnego, myśli i tradycji judaizmu, Steinera koncepcji rozumienia oraz relacji teorii i działania.

\section{Wokół translational turn}

Wyznaczanie i określenie ważniejszych tendencji rozwojowych we współczesnych naukach humanistycznych i społecznych należy co prawda do zadań wymagających, ale systematycznie podejmowanych. W zależności od nomenklatury i perspektywy przyjętej przez danego badacza ich mapa kształtuje się z początku odmiennie, niemniej z czasem niektóre punkty orientacyjne zdaje się cechować względna stabilność. Do takich właśnie punktów należy już translational turn, który zdaniem Doris Bachmann-Medick daje się obserwować jako wyraźnie rysująca się od późnych lat 80. ubiegłego wieku tendencja wyrosła z badań nad przekładem (zob. Bachmann-Medick 2012: 282).

Wnikliwa, sięgająca fundamentów krytyka zachodniej humanistyki i nauk społecznych, która nabrała mocy wraz z wydarzeniami '68 (Burzyńska 2001: 77-274; Dosse 2007: 95-105), mocno określająca poststrukturalizm, przyniosła niecałe dwie dekady później liczne próby przełamania impasu. Na fali przemian inspirowanych poststrukturalistyczną, a także postmodernistyczną krytyką wyłoniły się obejmujące wiele dyscyplin naukowych oryginalne kierunki badań, koncentrujących się wokół takich zagadnień, jak m.in. interpretacja, performatyka, ciało, refleksyjność, miejsce, obraz, rzeczy, doświadczenie czy post-kolonializm. Jak mapowała ten stan orientacji z perspektywy kulturoznawstwa pierwszej dekady XXI wieku Bachmann-Medick:

na pierwszy plan wysuwają się samowykładnia i inscenizacja, cielesność i siła działania (Handlungsmacht), ale także polityka społecznych i interkulturowych różnic wraz $\mathrm{z}$ ich praktykami przekładu i negocjacji, ponadto wizualne wglądy, sposoby percepcji obrazów (Bildwahrnehmungen) i kultur spojrzenia (Kulturen des Blickes), a także przestrzenność i odniesienia przestrzenne działania społecznego, na koniec niewywiedlna z ogólnej podstawy (unhintergehbare) materialność doświadczenia i historii (Bachmann-Medick 2012: 4 - wyrażenia w języku niemieckim pochodzą od tłumacza).

Każde z tych szerokozakresowych zagadnień umożliwiało kompleksowe, a przy tym dobrze uzasadnione i świeże spojrzenie 
na rzeczywistość i zasoby teorii w humanistyce i naukach społecznych, a co ważniejsze - rozwinięcie odpowiadających danej perspektywie badań. Ich włączenie do sposobów uprawiania np. studiów kobiecych czy studiów nad Zagładą powodowało istotne zmiany $\mathrm{w}$ ich teorii $\mathrm{i}$ badawczej praktyce, prowadziło do obiecujących ustaleń, odsłaniania nowych i przemieszczania, oczyszczania, ustalonych horyzontów i pól problemowych. W konsekwencji rozbudowujące się wspólnoty interpretacyjne doprowadziły do utrwalenia całego wachlarza przenikających się tendencji w badaniach kultury i społeczeństwa (zob. Bachmann-Medick 2012: 3-63; „Zwroty” badawcze w humanistyce 2010; Zeidler-Janiszewska 2006). Niemniej ich oddziaływanie na poszczególne dyscypliny, ośrodki naukowe czy obszary językowe nie rozkłada się równomiernie, a zależne jest w dużej mierze od specyfiki oraz kontekstu funkcjonowania danych dyscyplin i ośrodków. Przykładowo, w polskich studiach edukacyjnych rozwinęła się pedagogika miejsca, zwrot postkolonialny realizowany jest w ramach pedagogiki międzykulturowej i krytycznej, aktualnie do głosu dochodzi pedagogika rzeczy, natomiast zainteresowanie zwrotem translacyjnym i jego problematyką można uznać za jedynie okazjonalne. Jeśli jednak wziąć pod uwage rozwój na gruncie polskim pedagogiki międzykulturowej, można oczekiwać, że różnojęzyczność i pluralizm kulturowy, które były jedną z inspiracji translational turn, przyczynią się do otwarcia się jej na problematykę przekładu. Jak przekonująco wskazuje bowiem Bachmann-Medick: „Stymulacja kulturowych procesów translacyjnych oraz ich analiza od niedawna stała się koniecznością, której nie sposób zignorować - obojętnie, czy dotyczy to kontaktu kulturowego, czy stosunków i konfliktów między religiami, czy też strategii integracyjnych w społeczeństwach wielokulturowych”, stąd „Przekład pojawia się jako nowe podstawowe pojęcie nauk społecznych i nauk o kulturze" (Bachmann-Medick 2012: 280-281).

Zogniskowanie prac badawczych w ramach translational turn wykracza daleko poza zainteresowanie kodowaniem i dekodowaniem informacji w różnych systemach znaków, zdolnością do przenoszenia sensu wypowiedzi mimo występujących znacznych różnic języków i ich kontekstów funkcjonowania, przestrzeni kontaktu kultur. Pozwala wyjść z pułapki kulturalizmu definiującego odrębne, przeciwległe tożsamości, a między nimi przestrzenie wymiany i porozumienia (zob. Bhabha 2010: 22-25), 
poza myślenie o przekładzie w kategoriach harmonii i równowagi w stronę dostrzegania pertraktacji, dynamiki globalizacji i potencjału cybernetyki. W stronę rozpoznania przymusu społecznego w translacji własnej perspektywy i stylu życia na dominujący idiom (zob. Bachmann-Medick 2012: 325). Biorąc pod uwagę te nieoczywiste konteksty funkcjonowania omawianego zjawiska, można uznać, że „Przekład oznacza [...] szeroki transfer obcych sposobów myślenia, obrazów świata i różnorodnych praktyk" (Bachmann-Medick 2012: 288). Postrzeganie człowieka i grupy społecznej w tej perspektywie daje podstawy do podważenia założenia o jednojęzyczności składających się nań podmiotów, jednojęzyczności „ja” i „Innego”. W konsekwencji zwrot translacyjny pozwala ujmować przekład jako podstawową praktykę kulturową, a szerzej - jako sposób bycia w świecie i działania, co otwiera pedagogice dostęp do nowych możliwości samorozumienia, obszarów badań i praktykowania edukacji. Zapowiedziana zwrotem translacyjnym zmiana $\mathrm{w}$ teorii i praktyce edukacji może okazać się atrakcyjna również dla metodologii badań i naukoznawstwa. Wydaje się, że Bachmann-Medick przeczuwa takie możliwości:

Czy przekład może w ogóle stać się specyficznym modelem łączenia dyscyplin? Kategoria przekładu mogłaby w takim razie okazać się również metodycznie bardzo pomocna czy to przy uzasadnianiu interdyscyplinarności, czy w pracy nad nową koncepcją komparatystyki, która ma do przemyślenia sposoby porównywania kultur w świetle procesów translacyjnych (Bachmann-Medick 2012: 286; por. Bachmann-Medick 2012: 307-313; Włodarczyk 2011),

ale także przy przenoszeniu pojęć czy metod między dyscyplinami oraz wewnątrz nich, pionowej i poziomej integracji wiedzy.

\section{Komentarz i czytanie bez końca}

„Komentarz nie ma końca” - takiego twierdzenia moglibyśmy szukać z powodzeniem u Koheleta. Jego intryga zawiązała się dawno, niepostrzeżenie i bez naszego udziału, a potencjał przekracza czas i możliwości pojedynczego człowieka. W myśli i tradycji judaizmu komentowany tekst to pierwotnie tekst Pięcioksięgu, Tory pisanej, jednak za modelowy przykład relacji między siecią komentarzy może posłużyć Talmud. Status Talmudów Jerozolimskiego i Babilońskiego w judaizmie jako źródeł wiedzy o objawieniu i woli Boga, która zobowiązuje osoby wierzące 
lub wiążące się z ortodoksyjnym judaizmem, dorównuje szerzej rozumianej Torze $\left(\mathrm{TaNaCh}^{1}\right)$, zawierającej w swej zredagowanej ostatecznie, kanonicznej postaci oprócz Pięcioksięgu Mojżeszowego także księgi objawień i dziejów proroków Izraela oraz inne pisma o szczególnym znaczeniu dla nauki, historii, autorytetu i praktyki judaizmu. W Talmudzie proroków Biblii Hebrajskiej zastępują uczeni w piśmie i to ich wiążące ustalenia oraz dyskusje wokół tradycji i praktyki judaizmu są przedmiotem zawartych $\mathrm{w}$ nim komentarzy oraz narosłych przez wieki komentarzy do komentarzy. Z kolei i ten spisany wielogłos podlega w każdym pokoleniu i miejscu diaspory ${ }^{2}$ wnikliwemu badaniu uczonych w piśmie, a część z tych midraszy okazuje się na tyle cenna, że swoim znaczeniem wykracza poza region i czas życia autora. W niejednym z nich po przytoczeniu ustępu z Miszny (zebranej i skodyfikowanej w Talmudzie przez uczonych żydowskich zwanych tanaitami tradycji ustnej, która stanowi kanoniczne uzupełnienie Tory pisanej) oraz z Gemary (części Talmudu, która zawiera dyskusje uczonych żydowskich zwanych amoraitami i dokonane przez nich rozszerzenia wcześniej uporządkowanej Miszny)

1 TaNaCh to akronim słów oznaczających trzy składowe Biblii hebrajskiej: Tora (Prawo), Newiim (Prorocy) oraz Ktuwim (Pisma). Kanon Biblii hebrajskiej i ostateczne brzmienie poszczególnych jego ksiąg, z których większość zapisana jest w języku hebrajskim i tylko niewielka część w aramejskim, ustalone zostały ok. I w. n.e. Natomiast ostateczne redakcje dwóch wariantów Talmudu, spisanych w języku hebrajskim, różnym od biblijnego oraz w dwóch dialektach aramejskiego z domieszkami słów łacińskich i greckich, są wynikiem trwających około 800 lat dyskusji uczonych żydowskich, które były prowadzone w środowiskach Babilonii i Palestyny. Wiedzę z zakresu przywoływanych w tym podrozdziale zagadnień w znacznym stopniu pozwalają pogłębić i uporządkować odpowiednie hasła opracowane [w:] Polski Stownik Judaistyczny (2003) i The Encyclopedia of Jewish Life and Thought (1996).

2 Podobnie jak oba warianty Talmudu są świadectwem kontaktu i wymiany wiedzy między środowiskami uczonych z Babilonii i Palestyny, życie Żydów w diasporze (od grec. rozproszenie) w wielu krajach osiedlenia, początkowo głównie imperium perskiego i macedońskiego, z czasem pozostałych kontynentów, sprzyjało kulturowym wpływom i wykorzystywaniu przy komentowaniu używanych tam języków. Diaspora żydowska już w okresie działania Pierwszej Świątyni była liczna, jej dynamiczny rozwój, przekraczający liczebnie populację żyjącą w Palestynie, nastąpił po niewoli babilońskiej (IV w. p.n.e.) i trwa do dziś. Ponadto, jej istotne znaczenie dla historii Żydów podkreśla pojęcie galut (od hebr. wygnanie, niewola), określające charakterystyczną kondycję narodu żydowskiego od czasu zburzenia Drugiej Świątyni (70 r. n.e.) po proklamację państwa Izrael w maju 1948 roku. 
następuje szeroko zakrojony komentarz własny autora, w którym to komentarzu w nawiązaniu do Biblii hebrajskiej, komentarzy zawartych w Talmudzie, spuścizny literackiej i kulturowej judaizmu badacz stara się, za pomocą często zaawansowanych technik hermeneutycznych, wiarygodnie dociec możliwego powiązania między sobą zgromadzonych w komentowanych fragmentach tekstu wypowiedzi, ich znaczenia i przesłania. Zasadniczo w ten sposób dyskusje nad problematyką halachy (zasad prawnych judaizmu) prowadzili już amoraici, pokolenia uczonych żydowskich działających, jak wspomniano powyżej, po ustaleniu ostatecznego kształtu Miszny, które nastąpiło około osiemnastu wieków temu - wychodząc od konkretnego przypadku, opinii, decyzji zaczerpniętej z Miszny, a dochodząc do generalnej zasady, która ostatecznie rozwiązywałaby złożony problem prawno-religijny, a w konsekwencji umożliwiałaby postępowanie na drodze ascezy religijnej zgodne z przykazaniami i normami judaizmu. Stąd George Steiner ${ }^{3}$ może nie bez racji twierdzić, że:

W judaizmie nie kończący się komentarz i komentarz komentujący komentarz ma zupełnie elementarne znaczenie. Talmudyczna egzegeza złuszcza się w kolejne warstwy nieprzerwanego studiowania i komentowania Talmudu. [...] Sądzę, że hermeneutyczna nieskończoność i przetrwanie na wygnaniu są sobie pokrewne. Tekst Tory, kanonu biblijnego i koncentrycznych sfer tekstów o tych tekstach zastępuje zburzoną Świątynię (Steiner 1997b: 37-38).

Tradycja w judaizmie nie zawiera w sobie zwieńczenia, choć możliwe, że je zapowiada. Sieć komentarzy to nieustająca wymiana zdań i opinii otwarta na tych, którzy dopiero mają dołączyć. $\mathrm{Z}$ zasady Tora, Tanach, czy też Talmud nie mogą być inaczej czytane, jak przy udziale innych uznanych tekstów, i poprzez te teksty można na podstawie tego, co zostało już powiedziane, twierdzić, że one same stanowią już kolejne stopnie nakładających się na siebie komentarzy, inkarnację idei dialogu. Badanie jest rozciągniętą w czasie i przestrzeni wielogłosową rozmową.

A zatem w jakimś sensie niemożliwe staje się niezapośredniczone podejście do tekstu. Podjęcie w lekturze zagadki słowa, wersetu, parszy bądź danej historii buduje związek pomiędzy

3 W poszczególnych fragmentach tego i kolejnych części artykułu odwołuję się i wykorzystuję ustalenia z prac: Włodarczyk 2009b: 136-152, 249-278; Włodarczyk 2009a: 85-94. 
odległymi wydarzeniami i dniem dzisiejszym, przeprowadzając go równocześnie przez liczne oddźwięki, jakie stały się udziałem członków wspólnot żydowskich w czasach ich działalności. Udzielone przez nich odpowiedzi - te utrwalane przez uczonych i te codzienne, dawane w toku zwykłej praktyki spotkań - nie mają charakteru absolutnego, wpisujący się w cykl komentarzy nie chce być ostatni, ale przedostatni, pamięta, że epoka mesjańska jest ciągle kwestią nieodgadnionej, choć spodziewanej, wyczekiwanej przyszłości, a zatem w międzyczasie przyjdą jeszcze inni komentatorzy, odsłonią inne oblicza i możliwości tekstu, kładąc przy tym nacisk na odmienne czy sprzeczne znaczenia właściwe ich czasom i sytuacji. Synteza jest wielką nadzieją czasów mesjańskich, kiedy to podług tradycji, jak przypomina Emmanuel Lévinas, „rozstrzygał będzie wszystkie antynomie prorok Eliasz” (Lévinas 1977: 53; zob. Lévinas 1988: 43-65).

Prawdziwym zagrożeniem nie jest zatem brak ostatecznych odpowiedzi, a zerwanie tradycji poszukiwań. Bowiem kiedy „w diasporze tekst jest ojczyzną. [...] Czytanie bez końca - pisze Steiner - jest największą gwarancją żydowskiej tożsamości” (Steiner 1997b: 38) ${ }^{4}$. Stąd też zlanie się komentarza z interpretacją, o ile ta miałaby oznaczać ostateczne ustalenie znaczenia, jego domknięcie przed czasem spełnienia, byłoby równoznaczne z tuszowaniem zasadniczego między nimi napięcia, które dobitnie zdaje się wyrażać stanowisko rabina Sachy Pecarica: „pojęcie interpretacji w tradycji tej [żydowskiej - R.W.] po prostu nie istnieje" (Pecaric 2002: 233) .

Zachowanie ciągłości pomimo różnic czasu, przestrzeni, warunków środowiskowych czy języka, skrupulatne przechowywanie i odnotowywanie glos w ich oryginalnej postaci dociekań, pytań, jak również hipotetycznych odpowiedzi każe zwrócić uwagę na jeszcze inny wymiar pulsowania dialogu i komentarza, wymiar wyodrębniony poprzez rytualizację trybu powszechnej lektury Księgi:

${ }^{4}$ O kryzysie wywołanym zerwaniem ciągłości mówi Steiner również w kontekście kultury zachodniej. Jak dowodzi, prawdziwym problemem dla czytelnika chcącego zrozumieć tekst może być właśnie utrata ciągłości tradycji (zob. Steiner 1997b: 47-112; Steiner 2004: 230-292).

5 Zakreślając różnice między tradycją scholastyczną a hermeneutyką żydowską, Steiner zwraca uwagę na paradygmatyczne znaczenie „apetytu na summę”, zwieńczenie, które według niego, choć w zmienionej postaci, przetrwało w tradycji zachodniej aż do współczesności (zob. Steiner 199b: 39-40). Steiner podkreśla związek summy z tendencją do tępienia herezji. 
W żydowskim świecie, w świecie Tory - pisze Pecaric - istnieje w pewnym sensie obowiązek tłumaczenia, ponieważ istnieje obowiązek wysiłku zrozumienia. Wypełnienie przykazania sznej mikra weechad targum [dwa razy Tora i raz przekład - R.W.] nakazuje dwukrotne odczytanie parszy [odcinka tekstu Tory - R.W.] przypadającej na dany tydzień po hebrajsku i raz targumu, czyli właśnie tłumaczenia. Lecz nie każdego. Nie stanowiłoby wypełnienia tej micwy [przykazania - R.W.] przeczytanie takiego przekładu, który oddaje tylko gramatyczno-semantyczne znaczenia słów hebrajskich użytych w Torze. [...] Żaden przekład żadnego tekstu siłą rzeczy nie jest odbiciem oryginału, lecz pierwszym stopniem jego rozumienia (Pecaric 2005: V-VI) .

Zagadnienie komentarza jako ogniwa czytania bez końca wprowadza nie tylko problematykę ciągłości tradycji żydowskiej, ale także jej wielojęzyczności, której rozumienie zakłada praktykę przekładu. Komentowaniu towarzyszy translacja z racji wielojęzyczności komentowanych i przywoływanych źródeł, z racji dystansu czasowego i różnic społeczno-kulturowych, z racji patrzenia na wybrane ogniwo przeplatających się, rozwarstwiających i rozczepiających łańcuchów tradycji przez pryzmat komentarzy. Można zaryzykować twierdzenie, że sam komentarz jako efekt pracy rozumienia wybranej treści tradycji stanowi jej przekład.

\section{George’a Steinera rozumienie przekładu}

Twierdzenie George'a Steinera wyrażone we wstępie do obszernego studium Po wieży Babel, „przekład jest pod względem formalnym i pragmatycznym obecny implicite w każdym akcie komunikacji, w emisji i recepcji każdego rodzaju znaczenia, czy to w najszerszym sensie semiotycznym, czy w bardziej konkretnych wymianach werbalnych" (Steiner 2000: 15-16), nie jest oczywiście oryginalne. W klasycznym artykule „O językoznawczych aspektach przekładu” opublikowanym w 1959 r. Roman Jakobson, polemizując z Bertrandem Russellem i w nawiązaniu do koncepcji Charlesa Sandersa Peirce'a, równie dobitnie wyraża podobne przekonanie: „Dla nas, zarówno językoznawców, jak i zwykłych użytkowników języka, znaczenie jakiegokolwiek znaku

${ }^{6}$ Chodzi tu o Targum Onkelos, przekład Tory na język aramejski, który powstał w wersji ustnej na terenie Palestyny w II w. n.e., a utrwalony został na piśmie w Babilonii ok. 500 r. n.e. Jego autorem był prozelita wywodzący się z rzymskiej arystokracji. Zob. także: hasło „targum” (Polski Stownik Judaistyczny 2003). 
językowego jest jego przekładem na inny, alternatywny znak" (Jakobson 2009: 43). Rozwijając tę myśl, Jakobson proponuje wyróżnić „trzy sposoby tłumaczenia znaku językowego: może on być przełożony na inne znaki tego samego języka, na inny język lub na inny, pozajęzykowy system symboli” (Jakobson 2009: 44). Stąd Jakobson wyróżnia trzy rodzaje przekładu: wewnątrzjęzykowe przeredagowanie (rewording), przekład międzyjęzykowy (translation proper) oraz przekład intersemiotyczny (transmutation) (Jakobson 2009: 44; zob. Steiner 2000: 359-361). A zatem różnice między wieloma idiomatycznymi językami, w środowisku których działamy i których używamy na co dzień, jak również różnice między porządkiem myślenia a porządkiem działania wymagają od nas opanowania i ciągłego rozwijania kompetencji translatorskich. Im częściej używamy jakiegoś języka i poszczególnych jego składników, tym łatwiej, sprawniej, a w konsekwencji automatycznie i niezauważalnie dla nas samych, przebiega proces przekładu. Tak też zdaniem Steinera:

Zrozumieć oznacza rozszyfrować. To znaczy, że zasadnicze środki strukturalne i formy wyrazu oraz problemy aktu przekładu są w pełni obecne w aktach mowy, pisania, obrazowego kodowania w obrębie każdego języka. Przekład między różnymi językami stanowi szczególne zastosowanie konfiguracji i modelu zasadniczego dla mowy ludzkiej, nawet jeśli ma ona charakter monoglotyczny (Steiner 2000: 16).

Innymi słowy, „wewnątrz języka lub między językami ludzka komunikacja musi oznaczać przekład" (Steiner 2000: 86-87 - wyróżnienie G.S.). Przy czym wybór odpowiedniego słowa, frazy na oddanie wyrażenia oryginału jest dla niego decyzją ujawniającą sposób rozumienia danego wyrażenia w całej jego złożoności i uchwytnym dla tłumacza w danym momencie horyzoncie jego kontekstu. Niemożliwe jest powtórzenie, proste przepisanie. Każdy przekład określa sobą indeks podobieństw i różnic, których redukcja oraz ponowne zespolenie jest dziełem tłumacza (zob. Steiner 2000: 405-554). Dziełem, którego zasadnicze znaczenie sprowadza się do próby zniesienia dystansu i odzyskania bliskości, wglądu. Przekład literacki jest tu tylko szczególnym przypadkiem. Autor Po wieży Babel podkreśla znaczenie społecznego różnicowania się obiegu komunikacji ze względu na istnienie nieredukowalnych różnic biologicznych i psychologicznych między podmiotami oraz praktykowanie tożsamości grupowych - w tym kontekście rozważa 
funkcjonowanie odrębnych języków, np. kobiet czy dzieci (zob. Steiner 2000: 70-84).

Dla Steinera owa nieprzystawalność światów jest wynikiem permanentnych zmian i przekształceń, ciągłego niezsynchronizowanego ruchu, tak w obrębie języka, jak i świata życia codziennego każdego podmiotu komunikacji. Jak zauważa: „W takim stopniu, w jakim każdy użytkownik języka posługuje się idiolektem, problem wieży Babel sprowadza się najzwyczajniej w świecie do kwestii indywidualizacji osoby ludzkiej" (Steiner 2000: 631). Zmiany te uszczuplają rezerwuar tego, co podzielane, poszerzając jednocześnie dystans między stronami możliwego dialogu, dystans obecny z racji źródłowej odrębności podmiotów, wzajemnego odseparowania, jak również stałej dyspozycji świadomości jednostki do koncentracji na sobie i własnych przeżyciach. A zatem akt przekładu to dla Steinera przede wszystkim codzienny mechanizm adaptacyjny, wyuczony i uwarunkowany kulturowo, którego sprawność z zasady umyka naszej uwadze:

Czas, odległość, zmiana wyglądu lub przyjętych odniesień może ten akt utrudnić. Kiedy stopień trudności jest wystarczająco wysoki, proces przekładu przeobraża się z działania instynktownego w świadomą technikę. Poczucie bliskości z kolei, czy to związane z nienawiścią, czy z miłością, sprzyja zdecydowanemu, niemal natychmiastowemu przekładowi (Steiner 2000: 85-86; zob. Włodarczyk 2016: 31-33).

Nieprzystawalność to nie tylko zwrócenie uwagi na niewspółmierność egzystencjalnej sytuacji jednostek w świecie społecznym, ale także na ontologiczny status języków. Jak zaznacza Steiner, mamy zbyt mało przekonujących dowodów, by uznać przesłankę pozwalającą nam rozpatrywać język jako system - jako coś posiadającego dające się ustalić granice, co mogłoby ułatwić ukonstytuowanie dogodnej perspektywy poznawczej - jak i zaakceptować tezę o symetryczności wewnętrznych architektonik poszczególnych z nich. Jego zdaniem „cywilizacja istnieje, ponieważ nauczyliśmy się przekładać, eliminując wpływ czasu” (Steiner 2000: 65). Co więcej, każdy język w swej temporalności posługuje się właściwą sobie topografią pamięci, w odmienny sposób odwzorowuje świat i wyznacza sobą inny zbiór rzeczywistości możliwych, dzięki zdolności do generowania zdań kontrfaktycznych. Ta ostatnia właściwość najmocniej uwyraźnia trudności i wyzwania społecznego pluralizmu, stanowi warunek przetrwania ludzkości. Jak podkreśla Steiner: 
Trwamy, trwamy twórczo dzięki naszej zdolności do rzucenia rzeczywistości słowa nie, dzięki skłonności do budowania fikcji ,uinnienia', do tworzenia wyśnionej lub wymuszonej siłą woli lub oczekiwanej ,inności', w której nasza świadomość przemieszkuje. W tym precyzyjnym sensie element utopijny lub mesjański należy do figur składni (Steiner 2000: 18; zob. Steiner 2004: 11-15; Steiner 2008: 166-171).

Tłumaczenie zdaje się przedkładać i eksponować interes teraźniejszości, danego momentu w czasie i tworzących go ludzi, nad trwałość form tego, co dziedziczone. Być może w ten właśnie sposób tworzy warunki możliwości dziedziczenia.

Zdolność rozumienia Innego byłaby pochodną kompetencji i doświadczeń translatorskich obejmujących również szeroką gamę gestów i zjawisk towarzyszących spotkaniu, wyczuleniu na kontekst, a każdy akt hermeneutyczny de facto wprawianiem się w dokonywaniu transferu znaczenia. Śledząc, jak to czyni autor Po wieży Babel, zapiski i notatki tłumaczy, ich decyzje translacyjne uwarunkowane każdorazowo określonymi możliwościami i ograniczeniami, możemy wiele dowiedzieć się o naturze i przebiegu rozumienia. Choć Steiner nie wyklucza przebłysku jego pełnego uzysku, to daleki jest od upatrywania w nim sedna naszej praktyki translatorskiej. Jak zaznacza: „W każdym podejściu do komunikacji w obrębie jednego języka i pomiędzy językami musi się pojawić świadomość istnienia różnych sposobów, przy pomocy których tekst potrafi ukryć więcej, niż pokazuje" (Steiner 2000: 105), a „każdy rzeczywisty akt przekładu jest, przynajmniej pod jednym względem, oczywistą niedorzecznością, próbą biegu pod prąd na ruchomych schodach czasu oraz odtworzenia wysiłkiem woli tego, co niegdyś powstało w spontanicznym odruchu ducha" (Steiner 2000: 117). I kontynuuje:

Nie w szyst ko da się przełożyć. Teologia i gnoza wyznaczają górną granicę możliwości. Istnieją tajemnice, które można - co najwyżej transkrybować, których transpozycja lub parafraza byłaby bluźnierstwem i skrajną nieścisłością. [...] Nie wszystko również można przełożyć t e r a z. Zagubiły się w przeszłości konteksty, układy odniesień, które niegdyś pozwalały zinterpretować tekst. [...] W sensie jeszcze trudniejszym do zdefiniowania istnieją teksty, których jeszcze nie potrafimy przełożyć (Steiner 2000: 346 - wyróżnienia G.S.).

Nasza nieporadność translatorska ujawnia się nie tylko w zetknięciu z nadmiarem, który jedynie przykrywa, a nie likwiduje ontologiczna obecność wersetu, frazy czy tekstu (argumenty 
w dyskusji wokół kwestii misreading inspirowane dekonstrukcją są szeroko znane, nie ma potrzeby ich powtarzaćp ${ }^{7}$. Dystans między językami pozostaje mocno zróżnicowany. Przykłady z obszaru transmutacji wskazują na kolejne ograniczenia. Według Steinera „Matematykę jako taką można przełożyć tylko na inną matematykę (jak w przypadku geometrii algebraicznej)” (Steiner 2016: 18), nie jest jednak pewne, czy komparatysta właściwie ocenił możliwości wirtualnej przestrzeni i języków programowania. Natomiast jeśli chodzi o muzykę, jego zdaniem "Jedyną jej znaczącą ,translację' czy parafrazę stanowi ruch cielesny”, w tym sensie „Muzyka przekłada się na taniec" (Steiner 2016: 16; zob. Steiner 2000: 566). Z tych i wielu innych względów musimy liczyć się z tym, że, jak powie Steiner, „Przekład jest jednocześnie możliwy i niemożliwy" (Steiner 2000: 108). I w innym miejscu, nawiązując do ciągle obecnych w tradycji judaizmu kontrowersji wokół tłumaczeń Tory, takich jak Targum Onkelos czy Septuaginta, „Sześć murów ze światła otacza Pismo Święte. Sześć murów: nakazu przekładu i zakazu przekładu” (Steiner 1997a: 21) ${ }^{8}$.

\section{Idea, wypowiedź, działanie. Praktyka jako komentarz}

Podejmując za Jakobsonem w ostatnim rozdziale Po wieży Babel zagadnienie transmutacji, przekładu między znakami werbalnymi i pozawerbalnymi, Steiner stawia pytanie „W jakim stopniu kultura jest przekładem i przeredagowaniem wcześniejszego znaczenia?" (Steiner 2000: 557) i proponuje, aby tego typu akty hermeneutyczne i ich efekty rozpatrywać w kategoriach

7 Zob. Dekonstrukcja w badaniach literackich 2000; Bloom 2002.

8 Tekst Steinera poświęcony jest przekładowi Biblii hebrajskiej autorstwa Martina Bubera i Franza Rosenzweiga na język niemiecki i potwierdza tezę ciągłego dialektycznego związku między pismem a mową w tradycji żydowskiej. Jak tłumaczy status Targumu Onkelosa Pecaric, autor przekładu Tory na język polski, „po dziś dzień zachowuje on charakter normatywny, natomiast Septuaginta, która powstała w III-II w. p.n.e., nie zyskała tego statusu i przez judaizm jest wręcz zapomniana. Co je różni? Otóż to właśnie, że Septuagintę można nazwać przekładem zmierzającym do dosłowności, podczas gdy targum Onkelosa jest z pewnością tłumaczeniem, według tradycji natchnionym i potwierdzonym przez rabiego Akibę oraz innych tanaitów, którego relacja do hebrajskiego oryginału polega na wyjaśnianiu, czynieniu zrozumiałym" (Pecaric 2005: V; Steiner 2000: 333). 
topologii, nawiązując do jednej z gałęzi matematyki, zajmującej się, jak zauważa, „tymi relacjami między punktami i tymi fundamentalnymi właściwościami figury, które nie ulegają zmianie po odkształceniu tej figury" (Steiner 2000: 569) ${ }^{9}$, jak w przypadku rozwinięcia trójkąta w stożek. Innymi słowy, zdaniem komparatysty „Relacje ,niezmienności w obrębie transformacji’ wiążą się nieodrodnie, w mniejszym lub większym stopniu, z przekłade m" (Steiner 2000: 570 - wyróżnienie G.S.). Interesują go środki wyrazu, jak parafraza, ilustracja graficzna, pastisz, kolaż, plagiat itd., które nie tyle stanowią tłumaczenia tekstów, co je współtworzą, jak w przypadku kombinacji języka i muzyki, ale także kwestie, które moglibyśmy umieścić pod kategorią „wykonanie utworu”. Jak sugestywnie pisze, odnosząc się do sfery działań artystycznych:

Każdy wybór ucieleśnia konkretny komentarz do tekstu, każdy realizuje szczególną formułę ożywienia tekstu. [...] Interesuje mnie taka ,interpretacja', która nadaje mowie życie wykraczające poza moment i miejsce bezpośredniej wypowiedzi czy transkrypcji. Francuskie słowo interprète skupia w sobie wszystkie istotne właściwości. Aktor jest interprète Racine'a; pianista daje une interprètation sonaty Beethovena. Angażując własną tożsamość, krytyk staje się un interprète dającym życie wykonawcą - Montaigne’a czy Mallarmégo. Angielski termin interpreter ma słabszy wydźwięk, ponieważ nie obejmuje świata aktora, a świat muzyka przywołuje jedynie poprzez analogię. Jednak jest współbieżny z pojęciem francuskim, kiedy sięga w innym ważnym kierunku. Pojęć interprète/interpreter powszechnie używa się w odniesieniu do tłu macza. I to, jak sądzę, stanowi punkt wyjścia. Kiedy czytamy czy słyszymy jakąś wypowiedź językową z przeszłości, czy to biblijną Księgę Kapłańską, czy zeszłoroczny bestseller, tłumaczymy. Czytelnik, aktor, redaktor są tłumaczami spoza czasu (Steiner 2000: 61-62 - wyróżnienia G.S.).

W swej refleksji nad rozumieniem jako przekładem Steiner daje nam w ten sposób również sposobność spojrzenia na działanie jako swoisty komentarz teorii. W oczywisty sposób podjęcie działania kierowanego określoną intencją jest przejawem jej rozumienia, jednak widzenie związków teorii i praktyki, jakich

9 Pojęcie topologii zdaje się stanowić nawiązanie do wprowadzonego przez Ludwiga Wittgensteina, ważnego dla Steinera filozofa, w Dociekaniach filozoficznych pojęcia „rodzinnego podobieństwa”. Szerokie zastosowanie myślenia topologicznego w badaniach kultury stanowi książka Steinera Gramatyki tworzenia (Steiner 2004). 
oczekujemy w edukacji, jako dwóch porządków, między którymi mediuje translacja, daje okazję do ich ponownego sproblematyzowania. W tym sensie myślenie, mowa, pismo, działanie są różnymi porządkami praktyki, odmiennymi od siebie formami ludzkiej ekspresji, a przez to wymagającymi przekładu. Interpretacja-komentarz zawsze zakłada podmiotowy udział w postaci twórczej inwencji. Domaganie się od „teoretyków” - tj. praktyków przekładu lektur i myśli - bezpośredniej aplikacji ich pracy w zasoby praktyki społecznej jest nie-po-rozumieniem, próbą przerzucenia na nich ciężaru przekładu-przekształcenia, którego i tak nie mogą dokonać za kogoś, kto podejmuje działanie, ale też ucieczką od odpowiedzialności za nieodłącznie związane z przekraczaniem porządków, trans-lacją, ryzyko.

Tekst i jego kontekst oraz ruch i jego uwarunkowania (zob. Bachmann-Medick 2012: 119-166) odsłaniają się tu jako należące do dwóch porządków językowych, w których ekspresja nie tylko przyjmuje odmienne postaci, ale opiera się na diametralnie różnych gramatykach. Co więcej, w przechodzeniu od substancji tekstu przez obraz jego znaczenia pozyskany w lekturze do aplikacji w wybrany obszar teorii czy praktyki edukacyjnej można wyodrębnić dwie płaszczyzny translacji: przekład tekstu na ideę i idei na działanie. Monitorowanie osiąganych efektów i informacji zwrotnych wymagać będzie z kolei utworzenia definicji sytuacji stanowiącej efekt translacji. Podobnie w przypadku prowadzenia badań edukacyjnych, zbieranie danych przez wywiad, ankietę czy obserwację wymaga ich tłumaczenia na pojęcia badacza, a następnie języki teorii. Z kolei uczenie się ich przez lektury opracowań pozwala ustalić właściwą im topologię, a ta daje się wykorzystać w metodyce, jeśli użyć symultanicznie na przykład prezentacji multimedialnej i będącego jej przekładem omówienia w kontekście przygotowanego na zajęcia przez uczących się tekstu. Doświadczane przez nich trudności z jego rozumieniem być może wskazują, że praktyka chronicznego korzystania z kserokopii, która w kształceniu akademickim wypiera robienie notatek z lektur, swego rodzaju codziennych, indywidualnych ćwiczeń $\mathrm{z}$ translacji, przyczynia się $\mathrm{w}$ dłuższym okresie czasu do regresu ich kompetencji. To tylko kilka przykładów prześwitów, w których wyraźniej widać momenty translacji w ujęciu pedagogicznym. Innymi słowy, jeśli przy całej wielojęzyczności teorii i praktyki edukacyjnej pozioma i pionowa integracja wiedzy $\mathrm{z}$ dyscyplin i subdyscyplin naukowych oznacza przekład, to perspektywa 
otwarta przez translational turn kieruje nas $\mathrm{w}$ stronę figury pedagoga poligloty. Tę perspektywę warto wypełnić treścią. Jak stwierdza Steiner,

Absurdem byłoby odrzucenie zasadności przekładu tylko dlatego, że nie zawsze jest możliwy, a zawsze niedoskonały. Natomiast rzeczywiście trzeba wyjaśnić, powtarzają tłumacze, w jakim stopniu należy w każdym wypadku dążyć do wierności, gdzie są granice tolerancji, na które - jak w każdej innej pracy - można sobie pozwolić. Przez całą historię i praktykę przekładu przebiega naszkicowana, lecz wyraźna granica (Steiner 2000: 349).

A zatem jeśli autor Po wieży Babel proponuje ogólną teorię rozumienia jako przekładu, to każda praktyka - od myślenia, przez mówienie, po działanie - w której rozpoznajemy udział rozumienia, ma ścisły związek z translacją, jej szczególnymi fakturami. Punktem wyjścia Steinera jest hermeneutyka literacka znana nie tylko Grekom sztuka rozumienia i interpretacji tekstów. Podobnie jak Friedrich Schleiermacher nie traci z pola widzenia Biblii Hebrajskiej, myśl i tradycja judaizmu są dla niego ważną inspiracją. Tak jak Wilhelm Dilthey wyciąga wnioski dla humanistyki z konstytuowania się podmiotu $\mathrm{w}$ aktach przeżywania sztuki. Ostatecznie dochodzi jednak za Martinem Heideggerem do hermeneutyki filozoficznej, dostrzegając w aktach przekładu sposób bycia człowieka w świecie ${ }^{10}$.

\section{Bibliografia}

Bachmann-Medick D. (2012), Cultural turns. Nowe kierunki w naukach o kulturze, tłum. K. Krzemieniowa, Oficyna Naukowa, Warszawa.

Bhabha H.K. (2010), Miejsca kultury, tłum. T. Dobrogoszcz, Wydawnictwo Uniwersytetu Jagiellońskiego, Kraków.

Bloom H. (2002), Lęk przed wplywem. Teoria poezji, tłum. A. Bielik-Robson, M. Szuster, Universitas, Kraków.

Burzyńska A. (2001), „Przeciw interpretacji”, czyli burzliwe lata 60, [w:] A. Burzyńska, Dekonstrukcja i interpretacja, Universitas, Kraków.

Dosse F. (2007), 1967-1968: Redakcyjne wrzenie, tłum. Ł. Chomyn, [w:] K. Liszka, R. Włodarczyk (red.), Lektury poststrukturalistyczne, Chiazm, Wrocław. Jakobson R. (2009), O językoznawczych aspektach przektadu, tłum. L. Pszczołowska, [w:] B. Bukowski, M. Heydel (red.), Wspótczesne teorie przekładu. Antologia, Znak, Kraków.

10 Zasadnicza część książki Steinera poświęconej myśli i dziełu Heideggera jest jego komentarzem do Bycia i czasu (zob. Steiner 1980). 
Lévinas E. (1977), Judaïsme et révolution, [w:] E. Lévinas, Du sacré au saint. Cinq nouvelles lectures talmudiques, Les Éditions de Minuit, Paris.

Lévinas E. (1988), La traduction de l'Écriture, [w:] E. Lévinas, À l'Heure des Nations, Les Éditions de Minuit, Paris.

Nycz R. (2000), Dekonstrukcja w badaniach literackich, słowo/obraz terytoria, Gdańsk.

Pecaric S. (2002), Wglad w Pieśń nad Pieśniami. Istota języka religijnego, [w:] S. Pecaric (red.), Hagada na Pesach i Pieśń nad Pieśniami, Fundacja Ronalda S. Laudera, Kraków.

Pecaric S. (2005), Wstęp. Mowa na pustyni, [w:] Tora. Ksiega czwarta Bemidbar, red. i przekł. S. Pecaric, Fundacja Ronalda S. Laudera, Kraków.

Polski Stownik Judaistyczny. Dzieje, kultura, religia, ludzie (2003), t. 1-2, oprac. Z. Borzymińska, R. Żebrowski, Prószyński i S-ka, Warszawa.

Steiner G. (1980), Martin Heidegger, Penguin Books, New York.

Steiner G. (1997a), „Aus Worten, nicht Wörtern”, tłum. A. i A. Klubowie, „Dekada Literacka”, nr 8-9.

Steiner G. (1997b), Rzeczywiste obecności, tłum. O. Kubińska, słowa/obraz terytoria, Gdańsk.

Steiner G. (2000), Po wieży Babel. Problemy jezyka i przekładu, tłum. O. i W. Kubińscy, Universitas, Kraków.

Steiner G. (2004), Gramatyki tworzenia, tłum. J. Łoziński, Zysk i S-ka, Poznań. Steiner G. (2008), Wydrażony cud, „Przegląd Polityczny”, nr 91/92.

Steiner G. (2016), Poezja myślenia. Od starożytnych Greków do Celana, tłum. B. Baran, Wydawnictwo Aletheia, Warszawa.

The Encyclopedia of Jewish Life and Thought (1996), C. Pearl (red.), Carta, Jerusalem.

Włodarczyk R. (2009a), Hermeneutyka przekladu - zasadniczy wymiar dialogu. Wokót koncepcji George’a Steinera, [w:] E. Dąbrowa, D. Jankowska, Pedagogika dialogu. Dialog w teorii i praktyce edukacyjnej, Wydawnictwo Akademii Pedagogiki Specjalnej, Warszawa.

Włodarczyk R. (2009b), Lévinas. W strone pedagogiki azylu, Wydawnictwa Uniwersytetu Warszawskiego, Warszawa.

Włodarczyk R. (2011), Transdyscyplinarność - transgresja - translacja, [w:] R. Włodarczyk, W. Żłobicki (red.), Interdyscyplinarność i transdycyplinarność pedagogiki - wymiary teoretyczny i praktyczny, Oficyna Wydawnicza Impuls, Kraków.

Włodarczyk R. (2016), Ideologia, teoria, edukacja. Myśl Ericha Fromma jako inspiracja dla pedagogiki wspótczesnej, Oficyna Wydawnicza Impuls, Kraków.

Zeidler-Janiszewska A. (2006), O tzw. zwrocie ikonicznym we współczesnej humanistyce. Kilka uwag wstępnych, „Dyskurs”, nr 4.

„Zwroty” badawcze w humanistyce. Konteksty poznawcze, kulturowe i spoleczno-instytucjonalne (2010), J. Kowalewski, W. Piasek (red.), Instytut Filozofii UWM, Olsztyn. 


\section{Stanowisko X Ogólnopolskiego Zjazdu Pedagogicznego wobec następstw zmian w oświacie}

My, zgromadzeni na X Ogólnopolskim Zjeździe Pedagogicznym, odbywającym się w Warszawie w dniach 18.09. 20.09.2019 r., przedstawiciele polskiej pedagogiki akademickiej zwracamy się do najwyższych władz Rzeczypospolitej Polskiej: Jej Parlamentu i Rządu z apelem o podjęcie działań uzdrawiających polską oświatę. Naszą wiedzę, wyniki badań oraz zaangażowanie w kształcenie i wychowanie na rzecz godności, zaufania, autonomii i wspólnotowości traktujemy jako podstawę uprawnienia do wyrażenia stanowiska wobec obecnego stanu polskiej edukacji.

Ostatni rok nasilił i pogłębił trudności występujące od lat w polskich szkołach. Zwracamy uwagę na te najważniejsze i palące. Zmiana struktury szkolnictwa wprowadzana bez porozumienia z samorządami, konsultacji z dyrektorami szkół i środowiskiem nauczycielskim oraz bez uwzględnienia opinii szeroko rozumianego środowiska ludzi nauki, ponadto bez czasu i środków finansowych na dostosowanie infrastruktury szkolnej, spowodowała kryzys w funkcjonowaniu szkół, szczególnie ponadpodstawowych. Niespójność podstaw programowych poszczególnych etapów kształcenia zaburza warunki zarówno rzetelnej nauki, jak i rozwijania zainteresowań i pasji uczniów oraz nauczycieli. Jest również źródłem bardzo złych doświadczeń obywatelskich. Uczniowie stają się świadkami i uczestnikami chaosu, złej organizacji i dysfunkcyjnych rozwiązań. W przepełnionych szkołach nie są w stanie otrzymać odpowiedniego wsparcia i pomocy psychologicznej i pedagogicznej w trudnych sytuacjach życiowych, a często nie mogą nawet liczyć na to, że ich problemy szkolne, rodzinne, zdrowotne zostaną zauważone. 
Drugim wymagającym natychmiastowego rozwiązania problemem, pogłębiającym kryzys szkolnictwa, jest sytuacja zawodowa polskich nauczycieli. Bardzo niskie, w porównaniu do innych grup zawodowych, zarobki nauczycieli, lekceważenie ich problemów i nie branie ich pod uwagę jako partnerów w naprawianiu polskiej oświaty powoduje stałe obniżanie nauczycielskiego autorytetu i prestiżu zawodu oraz ogólne zniechęcenie, osłabienie ich kreatywności i gotowości do wspólnotowego działania i rozwiązywania problemów szkolnych, a także odchodzenie z zawodu, które już teraz skutkuje brakiem nauczycieli w wielu szkołach.

Polska szkoła przeżywa także kryzys wspólnotowości i zaufania. Wprowadzone szybko i bez przygotowania reformy spowodowały, że nie była możliwa praca nad odpowiednimi rozwiązaniami w zespołach nauczycieli, rodziców, samorządowców i administracji oświatowej. Nauczycielom i rodzicom odebrano sprawczość i podmiotowość, która decyduje o sukcesie każdego działania. Oświata staje się miejscem erozji reguł demokratycznych. Podlega zawłaszczaniu przez doraźne interesy polityczne.

Apelujemy o zmianę języka w odniesieniu do nauczycieli i okazywanie szacunku ich pracy. Poniżanie nauczycieli to deprecjonowanie zadania, jakim jest wychowanie dzieci i młodzieży. Lekceważenie środowiska nauczycielskiego i akcelerowanie konfliktu rodziców i nauczycieli pogłębia kryzys zaufania, który, niestety, jest charakterystyczny dla polskiej szkoły i całego społeczeństwa.

Dla dobra polskiej szkoły i ratowania jej przed jeszcze głębszym kryzysem apelujemy o natychmiastowe podjęcie działań naprawczych we współpracy $\mathrm{z}$ innymi podmiotami odpowiedzialnymi za polską szkołę oraz ekspertami i środowiskiem naukowym. Apelujemy o podjęcie publicznej debaty nad edukacją oraz dialogu z samorządami, środowiskiem nauczycielskim oraz przedstawicielami nauki i wspólne określenie i zaplanowanie najpotrzebniejszych działań naprawczych.

Warszawa, 20 września 2019 r. 

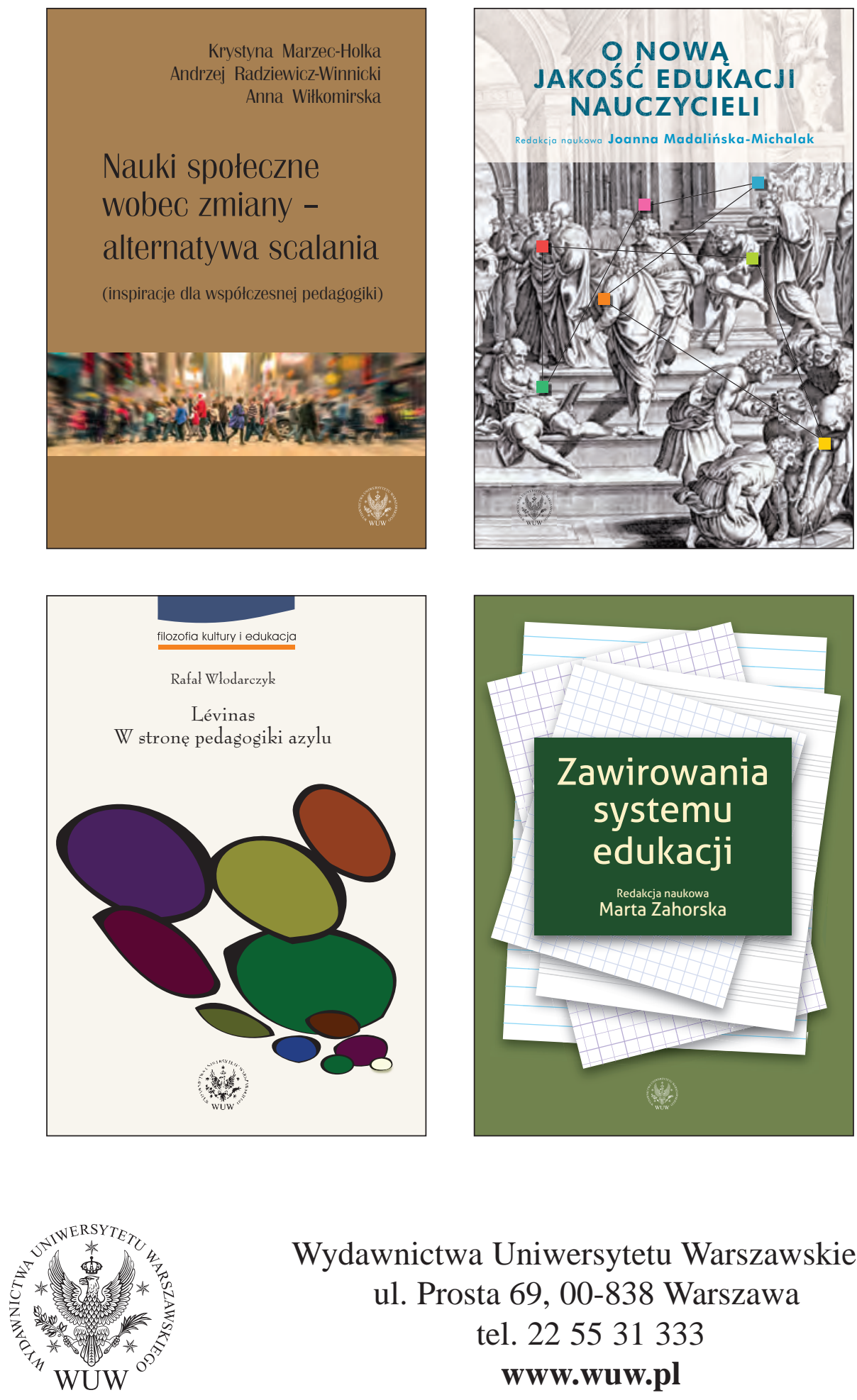

Wydawnictwa Uniwersytetu Warszawskiego ul. Prosta 69, 00-838 Warszawa tel. 225531333 wWw.WuW.pl 
Dbałość o budowanie społeczeństwa, w którym ludzie mogą wieść dobre życie i z którym chcą się identyfikować w wymiarze zarówno communitas, jak i societas, wymaga namysłu nad leżącymi u jego podstaw wartościami oraz rozpowszechniania w szerokich kręgach naukowych ustaleń dotyczących wychowania, kształcenia i uczenia.

Autorzy podejmują niezwykle ważne i aktualne problemy związane z pedagogiką i edukacją w obliczu coraz silniej zaznaczającego się kryzysu zaufania, wspólnotowości i autonomii w różnych sferach życia. Na podstawie badań, kierując się troską o polskie społeczeństwo, a zwłaszcza o młode pokolenie, które doświadcza życia w warunkach podziałów i destrukcji wspólnoty obywatelskiej, postulują podejmowanie działań na rzecz poprawy jej kondycji i jakości oraz rewitalizacji życia społeczno-edukacyjnego z wykorzystaniem kanonu wartości edukacyjnych, społecznych i kulturowych, a także regeneracji i wzmocnienia więzi społecznych.

Książka jest adresowana do odbiorców ze środowiska akademickiego i oświatowego, szczególnie do naukowców zajmujących się pedagogiką i naukami pokrewnymi, nauczycieli, dyrektorów szkół, studentów studiów pedagogicznych i nauczycielskich, oraz do przedstawicieli administracji rządowej i samorządowej. 